\title{
FADIGA TERMOMECÂNICA EM LIGAS DE FERRO FUNDIDO CINZENTO PARA DISCOS DE FREIO AUTOMOTIVOS
}

\section{OMAR MALUF}

Tese apresentada ao programa de Pós-Graduação Interunidades Ciência e Engenharia de Materiais, da Universidade de São Paulo, para obtenção do título de Doutor em Ciência e Engenharia de Materiais.

ORIENTADOR: Prof. Dr. DIRCEU SPINELLI 
"Se eu não for por mim, quem será?

Mas se eu for apenas por mim, o que serei eu? E se não agora, quando?"

Hillel

(modificado) 
Aos meus filhos Ana, Mario, Aline, Vivian, Felipe e Letícia, razões da minha vida, por sempre acreditarem incondicionalmente e à minha mulher Beth, minha fortaleza: rio afluente de mim, que me concede obstinação e força. 


\section{AGRADECIMENTOS}

- Ao Prof. Dr. Dirceu Spinelli pela clareza, objetividade e discernimento de sua orientação e, também, pela estima e consideração demonstradas durante o transcorrer deste trabalho de pesquisa. - Ao Prof. Dr. Waldek Wladimir Bose Filho, profissional competente e amigo presente nos momentos mais difíceis, sem cuja contribuição esta empreitada jamais teria sido possível.

- Aos demais professores do SMM-EESC-USP que de alguma maneira colaboraram com o trabalho. - Aos colegas pós-graduandos, meus amigos, sem o apoio dos quais este objetivo teria sido uma tarefa muito mais espinhosa. São eles: Danilo de Castro, Maurício Angeloni, Artur Malafaia, Roberto Piovato, Rosamel Riofano, Cristina Gatti, Cassius Ruckert, Marcelo Milan e particularmente a Luciana Sgarbi Rossino.

- Ao Edison Serbino pelas opiniões sempre importantes, principalmente quando o assunto é sistema de frenagem automotivo.

- A todos os funcionários e técnicos do SMM e de outros departamentos que colaboraram na execução das tarefas, especialmente o Eliezer (Tico), o Carlos Eduardo de Souza e o Carlos Bento.

- Às funcionárias da secretaria de pós-graduação da Interunidades, particularmente a Sra. Wladerez Caiado pela atenção e paciência.

- Ao Programa Interunidades em Ciência e Engenharia de Materiais que tornou possível, além do mestrado, este doutorado.

- À General Motors do Brasil (GMB), nas pessoas dos Srs. José Carlos dos Santos (Carlito) e Marco António Colósio, pelas profícuas discussões, além do apoio financeiro e logístico.

- À Fundação de Incremento à Pesquisa e Aperfeiçoamento Industrial - FIPAI pela viabilização do apoio financeiro.

- Aos amigos Marcos Mucheroni e Kleber Mendes de Figueiredo pelos exemplos de fé, garra e determinação e ao Mauro Thobias, também, pelas apreciações referentes à redação deste trabalho.

- Às minhas irmãs Esmeralda e Helena, aos meus irmãos Ricardo e Edmon, aos meus sobrinhos que sempre me incentivaram a chegar até aqui.

- Aos meus cunhados, sobretudo à Maria do Carmo, pela demonstração perene de carinho e amizade.

- Às empresas TRW, Look e Teksid pelo fornecimento dos materiais e componentes utilizados nos ensaios.

- Ao Prof. Dr. Elson Longo e ao Dr. Cristiano Morita, do LIEC-UFSCar, pela colaboração durante os ensaios de difusividade térmica.

- Ao Movimento dos Focolares por demonstrar que é o exemplo que arrasta.

- E principalmente a Ele, que nunca se deixa vencer em generosidade. 


\section{SUMÁRIO}

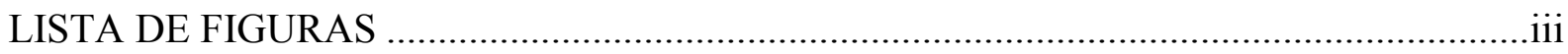

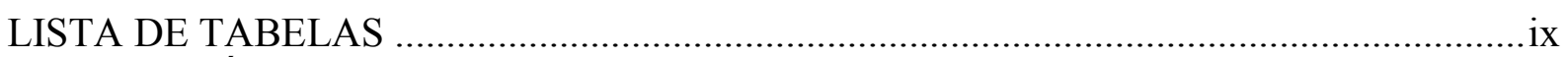

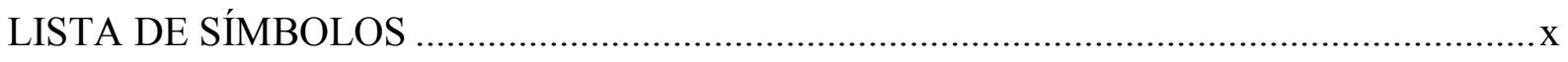

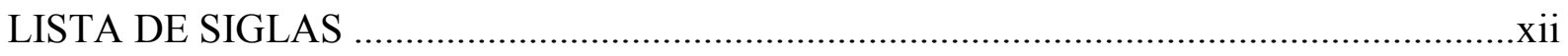

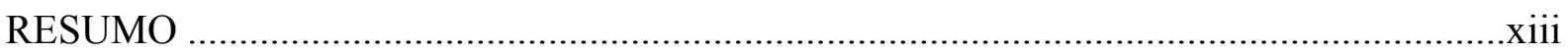

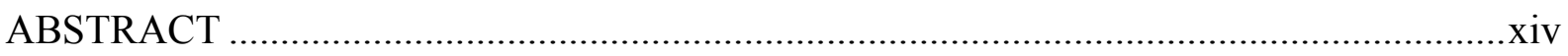

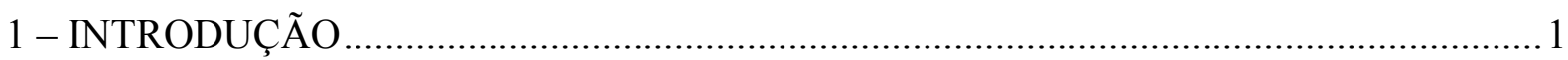

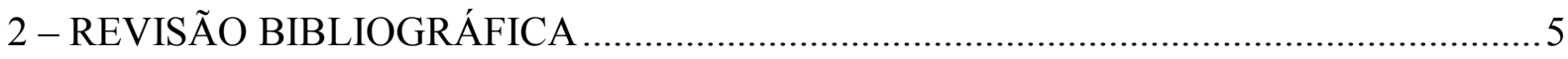

2.1 - Considerações Iniciais ............................................................................................ 5

2.2 - Efeito das Temperaturas Elevadas sobre os Materiais ................................................ 8

2.2.1 - Interação Fadiga-Fluência .......................................................................... 10

2.2.2 - Dano e Início de Trincas em Temperaturas Elevadas ........................................ 13

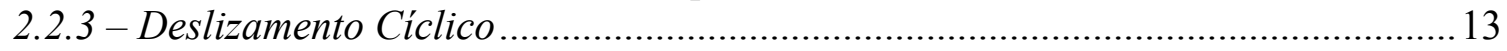

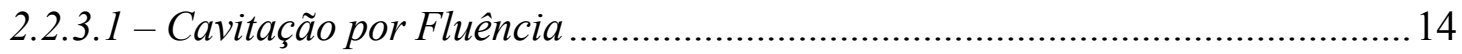

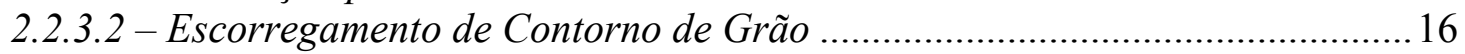

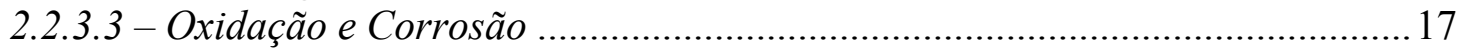

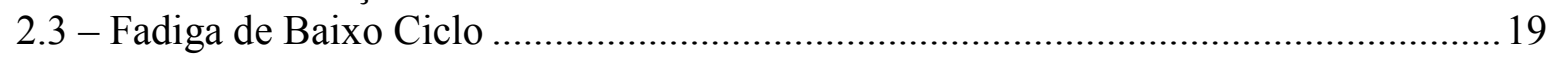

2.3.1 - Fadiga Isotérmica ..................................................................................... 24

2.3.2 - Fadiga Térmica e Termomecânica ......................................................................28

2.3.2.1 - Aspectos da Resposta Cíclica Tensão - Deformação ...................................... 32

2.3.2.2 - Fadiga Termomecânica (FTM) - Em Fase e Fora-de-Fase ............................ 37

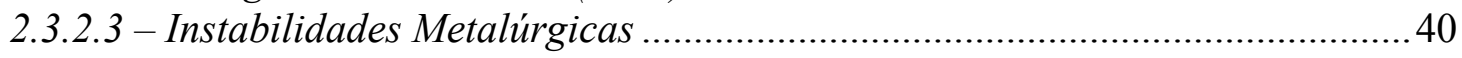

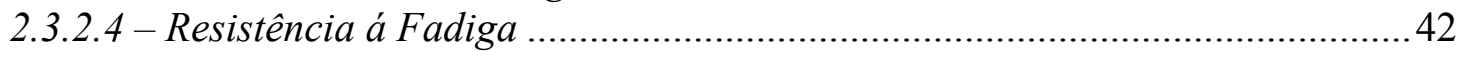

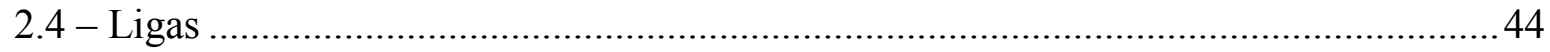

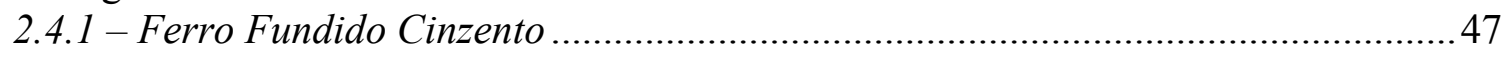

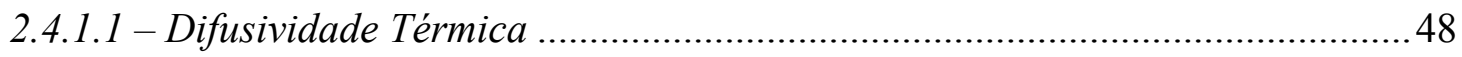

2.4.1.2 - Resistência à Abrasão e Propriedades Mecânicas .......................................51

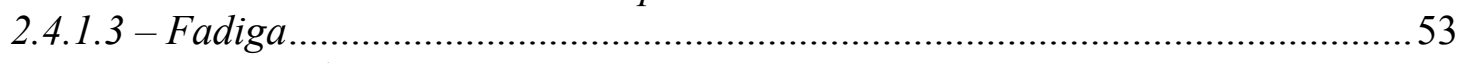

2.4.1.3.1 - Fadiga Térmica e Termomecânica ..................................................5 54

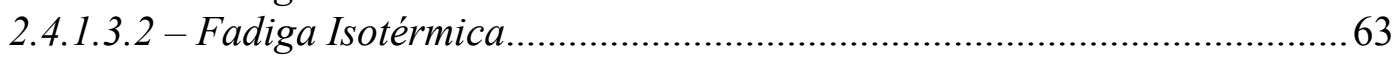

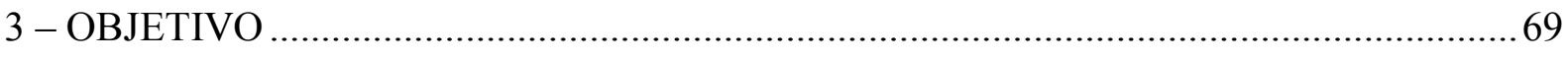

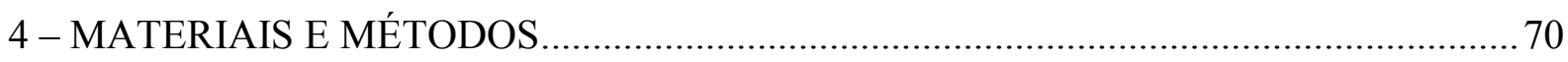

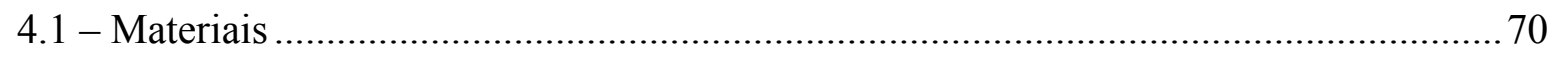

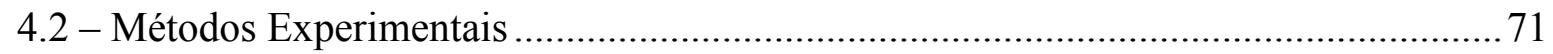

4.2.1 - Ensaios de Fadiga Termomecânica em Corpos de Prova .....................................73

4.2.2 - Ensaios de Fadiga Termomecânica em Componentes ......................................... 76

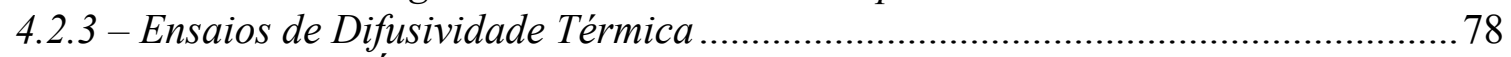

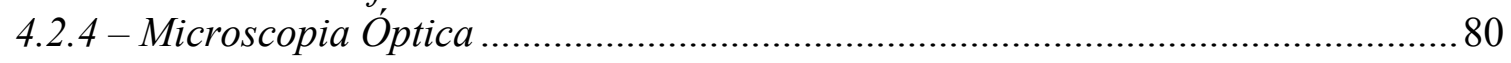

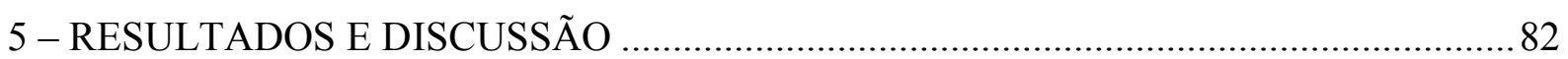

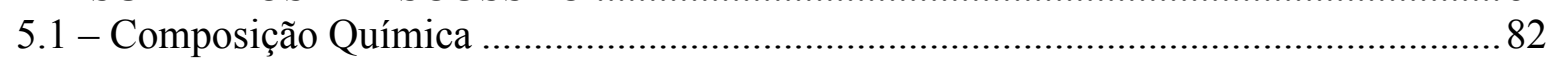

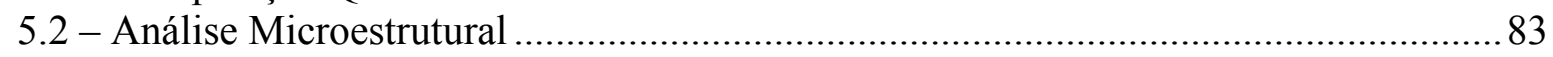

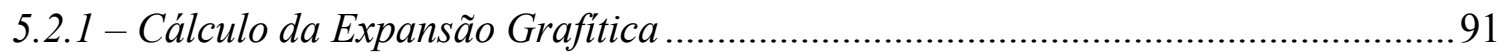

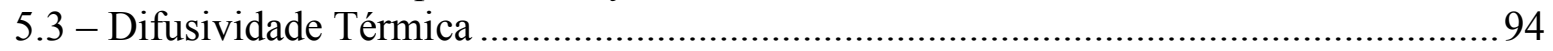

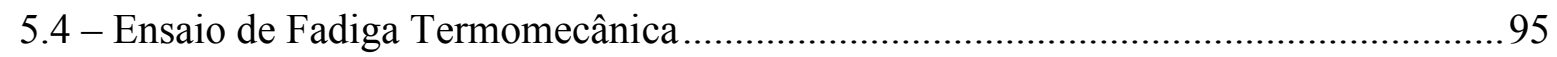

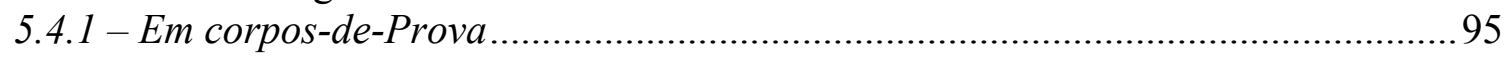


5.4.1.1 - Fadiga Termomecânica Em Fase e Fora de Fase ........................................95

5.4.1.2 - Comportamento Tensão x Deformação ........................................................ 99

5.4.1.3 - Comportamento Temperatura x Deformação................................................ 107

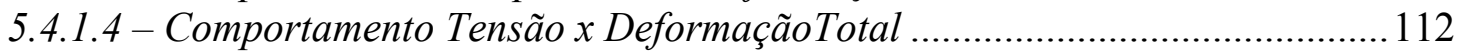

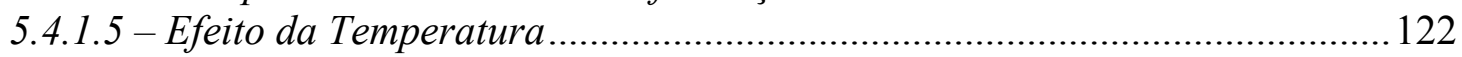

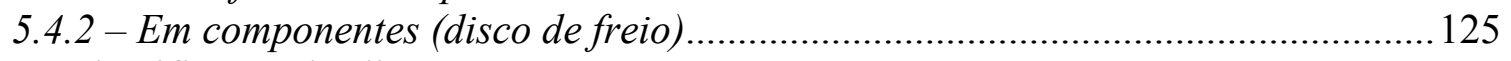

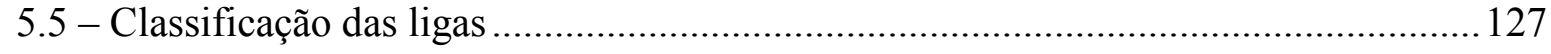

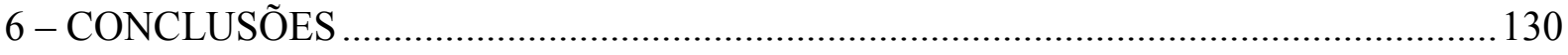

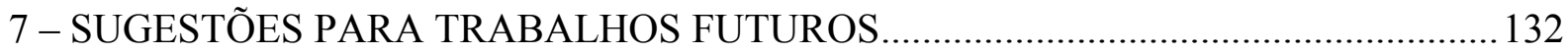

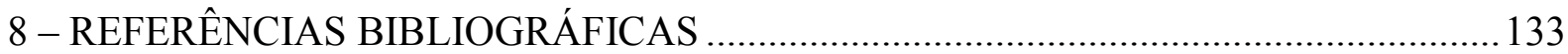

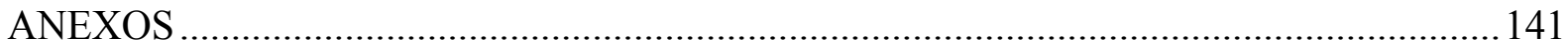




\section{LISTA DE FIGURAS}

Figura 2.1 - Falha no rotor de freio dianteiro de Ford F-250 Pickup. Podem ser observadas trincas que se propagaram radialmente do chapéu para o exterior do disco [Mackin, 2002].

Figura 2.2 - Influência da temperatura no limite de fadiga, para várias ligas metálicas [Fuchs, 1980].

Figura 2.3 - (a) Esquema de carregamento em fadiga balanceado, lento-rápido e rápidolento. (b) Mapa dos mecanismos de vida em fadiga como função da temperatura (para valores fixos de variação não linear de deformação e freqüência) para carregamento lento-rápido em fluência-fadiga [Riedel, 1987].

Figura 2.4 - Esquema do mecanismo de Fujita para nucleação de trincas por fadiga [Suresh, 1998]....

Figura 2.5 - Variação da deformação plástica em função da vida para liga AISI A286 em ar e vácuo com variação da freqüência e temperatura [Coffin, 1973].....

Figura 2.6 - Amplitude de deformação plástica em função do número de reversos, escala bilogarítmica [Dieter, 1981]

Figura 2.7 - Tensão verdadeira em função do número de reversos, em escala bilogarítmica [Dieter, 1981].

Figura 2.8 - Amplitude de deformação total em função do número de reversos para falhar, obtido da superposição da amplitude de deformação elástica e plástica em função do número de reversos para falhar [Suresh, 1998].

Figura 2.9 - Ciclo de histerese tensão-deformação ideal resultante de um ensaio de fadiga de baixo ciclo com deformação cíclica constante [Thomas, 1987]....................23

Figura 2.10 - Curva de fadiga isotérmica e termomecânica [Shi, 1998] ................................25

Figura 2.11 - Influência da temperatura na vida em fadiga [Srinivasan, 2003] ......................26

Figura 2.12 - Resposta da tensão cíclica em função da temperatura [Srinivasan, 2003].......27

Figura 2.13 - Comparação esquemática entre os ensaios de fadiga térmica e fadiga termomecânica [Engler-Pinto Jr., 1996] ........................................................... 30

Figura 2.14 - Exemplo de um ciclo de histerese anisotérmico fora de fase (Engler-Pinto Jr., 1996).

Figura 2.15 - Relação tensão-deformação para várias histórias de carregamento e tipos de ciclagem (a) deformação cíclica contínua (continuous strain cycling), (b) patamar de deformação (strain hold), (c) ciclo contínuo de tensão média (continuous mean stress cyclic), (d) patamar de tensão (stress hold), (e) limite de deformação-patamar de tensão (stress hold-strain limit (CP)), (f) situação termomecânica (mixed mechanical-thermal) [Fuchs, 1980].

Figura 2.16 - Curva de histerese para condições de deformação termomecânicas elásticas, para ciclagem em fase [Hetnarski, 1991].

Figura 2.17 - Curva de histerese para condições de deformação termomecânicas plásticas, para ciclagem em fase [Hetnarski, 1991].

Figura 2.18 - Curva de histerese para condições de deformação termomecânicas por fluência, para ciclagem em fase [Hetnarski, 1991].

Figura 2.19 - Variação térmica, mecânica e deformação total em função do tempo para fadiga termomecânica (a) fora-de-fase (b) em-fase [Cai, 1999].

Figura 2.20 - Tensão em função da Deformação para fadiga termomecânica: (a) fora-defase; e (b) em fase [Cai, 1999]. 
Figura 2.21 - Ciclo Temperatura - Deformação para diferentes testes de fadiga termomecânica $\left(\mathrm{T}_{\mathrm{u}}\right.$ - temperatura máxima, $\mathrm{T}_{1}$ - temperatura mínima) [Cai, 1999].

Figura 2.22 - Fadiga termomecânica em fase e fora-de-fase, para superliga de aço com e sem camada protetora, para temperatura entre 427 e $1038^{\circ} \mathrm{C}$ [Leverant, 1976].

Figura 2.23 - Fadiga isotérmica e fadiga termomecânica em fase e fora-de-fase, para temperatura entre 495 e $1000^{\circ} \mathrm{C}$ [Bill, 1984]

Figura 2.24 - Resistência à fadiga com o aumento da temperatura [Hetnarski, 1991] ..........43

Figura 2.25 - Curva deformação em função da vida, para diferentes temperaturas [Hetnarski, 1991].

Figura 2.26 - Comportamento do coeficiente de atrito com a variação na porcentagem de Titânio em liga de ferro fundido [Brembo, 1997].

Figura 2.27 - Ferro fundido cinzento apresentando veios de grafita em matriz perlítica, atacado com Nital 2\% [Milan, 2004]...

Figura 2.28 - Ferro fundido vermicular em matriz ferrítica, atacado com Nital 2\% [Milan, 2004].

Figura 2.29 - Ferro fundido nodular com matriz perlítica, mostrando a microestrutura conhecida por "olho de boi", que consiste em nódulos de grafita circundados por ferrita livre (branca), atacado com Nital 2\% [Milan, 2004].

Figura 2.30 - Micrografia de um ferro fundido cinzento mostrando trincas se propagando na matriz através dos veios de grafita [Milan, 2004].

Figura 2.31 - Aumento da difusividade térmica à temperatura ambiente em função do carbono equivalente (CE) [Hecht, 1996].

Figura 2.32 - Apresentação esquemática da caracterização da morfologia do veio de grafita através de programas computacionais, onde $P$ é o perímetro, $\mathrm{X}$ o eixo maior, Y o eixo menor, L o comprimento real e A a área [Hecht, 1996].

Figura 2.33 - Relação entre o número de ciclos térmicos para falha e a resistência à tração à temperatura ambiente e a $540^{\circ} \mathrm{C}$ [Gundlach, 1978].

Figura 2.34 - Relação entre o volume de grafita e medida do calor relativo após 500 ciclos. Um ciclo térmico consiste de 2 segundos a $450^{\circ} \mathrm{C}$ e 30 segundos à temperatura ambiente [Roehrig, 1978].

Figura 2.35 - Variação no número de ciclos térmicos para falha, no ciclo de máxima temperatura para ferros fundidos, cinzento e nodular, e aço. As composições dos ferros fundidos cinzentos estão na Tabela 2.3 [Gundlach, 1978].

Figura 2.36 - Comprimento total de seis trincas (as primeiras três trincas em cada um dos dois corpos de prova de cada ferro fundido) como função do número de ciclos térmicos entre 590 e $200^{\circ} \mathrm{C}$. As composições estão apresentadas na Tabela 2.4 [Gundlach, 1978].

Figura 2.37 - Profundidade das trincas resultantes do ciclo térmico nos ferros fundidos cinzentos entre $460^{\circ} \mathrm{C}$ e a temperatura ambiente [Roehrig, 1978].

Figura 2.38 - Relação entre o número de veios de grafita, razão de propagação da trinca e quantidade adicionada de níquel para as ligas A e B [Yamabe 2002].

Figura 2.39 - Relação entre o comprimento médio da trinca e o número de ciclos no teste simulado [Yamabe 2002].

Figura 2.40 - Relação entre o comprimento médio da trinca e o número de ciclos em teste de frenagem de alta velocidade no componente [Yamabe 2002].

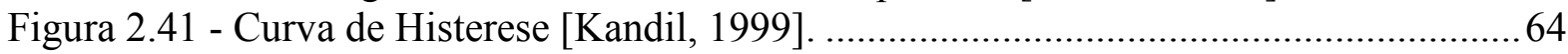

Figura 2.42 - Fadiga Isotérmica: Gráfico Comparativo da Amplitude de Deformação x Vida para temperatura de $25^{\circ} \mathrm{C}$ [Angeloni, 2005]. 
Figura 2.43 - Fadiga Isotérmica: Gráfico Comparativo da Amplitude de Deformação x Vida para temperatura de $300^{\circ} \mathrm{C}$ [Angeloni, 2005]....

Figura 2.44 - Fadiga Isotérmica: Gráfico Comparativo da Amplitude de Deformação x Vida para temperatura de $600^{\circ} \mathrm{C}$ [Angeloni, 2005]....

Figura 2.45 - Fadiga Isotérmica: Gráfico Comparativo da Amplitude de Tensão x Vida para temperatura de $25^{\circ} \mathrm{C}$ [Angeloni, 2005].

Figura 2.46 - Fadiga Isotérmica: Gráfico Comparativo da Amplitude de Tensão x Vida para temperatura de $300^{\circ} \mathrm{C}$ [Angeloni, 2005] .................................................67

Figura 2.47 - Fadiga Isotérmica: Gráfico Comparativo da Amplitude de Tensão x Vida para temperatura de $600^{\circ} \mathrm{C}$ [Angeloni, 2005] ....................................................6 68

Figura 4.48 - Bloco "Y”" segundo norma ASTM A476/476M. ............................................. 71

Figura 4.49 - Disco de freio aletado utilizado nos ensaios de fadiga termomecânica em componentes.

Figura 4.50 - Visão geral do aparato de ensaios mostrando o forno de indução e a máquina servo-hidráulica MTS 810.

Figura 4.51 - Detalhe do corpo de prova, da bobina de indução, do sistema de refrigeração auxiliar das garras e do extensômetro de hastes cerâmicas, para os ensaios de fadiga anisotérmica.

Figura 4.52 - Variação da deformação total com o tempo e a temperatura, em ciclos iniciais de ensaios de fadiga termomecânica da liga A, com controle de deformação mecânica $(0,10 \%)$, (a) em fase e (b) fora de fase.

Figura 4.53 - Temperatura em função do ciclo deformação total para um ensaio de fadiga termomecânica em fase.

Figura 4.54 - Temperatura em função do ciclo de deformação total para um ensaio de fadiga termomecânica fora de fase. .................................................................76

Figura 4.55 - Desenho de usinagem do corpo de prova para ensaio de fadiga.......................76

Figura 4.56 - Foto do corpo de prova utilizado nos ensaios de fadiga. ...................................76

Figura 4.57 - Vista do local de fixação do disco de freio no equipamento da TRW para o ensaio de fadiga termomecânica.

Figura 4.58 - Vista do equipamento de ensaio de fadiga termomecânica com o disco de freio já fixado.

Figura 4.59 - Foto do Laser Flash Apparatus onde foram realizadas as medições de difusividade térmica.

Figura 4.60 - Croquis de usinagem do conjunto de corpos de prova necessários para medição da difusividade em cada uma das ligas.

Figura 4.61 - Microscopia ótica com aquisição de imagens..................................................... 81

Figura 5.62 - Foto micrografia da liga A: (a) sem ataque. Podem-se observar veios de grafita do tipo VII, disposição C e tamanho 4, segundo a norma ASTM A 247; (b) a mesma região atacada com Nital 2\% apresentando matriz perlítica com algumas áreas de ferrita livre (branca).

Figura 5.63 - Foto micrografia da liga B: (a) sem ataque. Podem-se observar veios de grafita do tipo VII, disposição A e tamanho 4, segundo a norma ASTM A 247; (b) a mesma região atacada com Nital $2 \%$ apresentando matriz perlítica áreas de ferrita livre (branca).

Figura 5.64 - Foto micrografia da liga C: (a) sem ataque. Podem-se observar veios de grafita do tipo VII, disposição C e tamanho 4, segundo a norma ASTM A 247; (b) a mesma região atacada com Nital 2\% apresentando matriz totalmente perlítica. 
Figura 5.65 - Foto micrografia da liga E: (a) sem ataque. Podem-se observar veios de grafita do tipo VII, disposição C e tamanho 4, segundo a norma ASTM A 247; (b) a mesma região atacada com Nital $2 \%$ apresentando matriz perlítica.

Figura 5.66 - Gráfico mostrando o número de veios por $\mathrm{mm}^{2}$ para cada uma das quatro ligas estudadas. Os dados para a confecção do gráfico foram obtidos da Tabela 5.14.

Figura 5.67 - Gráfico mostrando o tamanho médio dos veios para cada uma das quatro ligas estudadas. Os dados para a confecção do gráfico foram obtidos da Tabela 5.14.

Figura 5.68 - Gráfico mostrando a percentagem de grafita em cada uma das quatro ligas estudadas. Os dados para a confecção do gráfico foram obtidos da Tabela 5.14.

Figura 5.69 - Difusividade Térmica em função da Temperatura para as ligas A, B, C e E....94

Figura 5.70 - Gráfico comparativo da amplitude de deformação mecânica das quatro ligas em função do número de reversos para falhar, em fase.

Figura 5.71 - Gráfico comparativo da amplitude de deformação mecânica em função do número de reversos para falhar, para as quatro ligas, fora de fase.

Figura 5.72 - Gráfico comparativo da amplitude de deformação mecânica em função do número de reversos para falhar, para as quatro ligas, em fase e fora de fase, suprimindo as amplitudes menores que $0,2 \%$.

Figura 5.73 - Curvas Tensão em função do Número de Ciclos para a liga A, ensaiada em fadiga termomecânica, em fase, sob amplitude de deformação mecânica de $0,2 \%$.

Figura 5.74 - Curvas Tensão em função do Número de Ciclos para a liga A, ensaiada em fadiga termomecânica, fora de fase, sob amplitude de deformação mecânica de $0,2 \%$.

Figura5.75 - Gráfico da tensão máxima em função do número de ciclos para a liga $\mathrm{A}$, para condição em fase e em vários níveis de amplitude de deformação mecânica.

Figura 5.76 - Gráfico da tensão máxima em função do número de ciclos para a liga $\mathrm{A}$, para condição fora de fase e em vários níveis de amplitude de deformação mecânica.

Figura 5.77 - Gráfico da tensão máxima em função do número de ciclos para a liga $\mathrm{B}$, para condição em fase e em vários níveis de amplitude de deformação mecânica.

Figura 5.78 - Gráfico da tensão máxima em função do número de ciclos para a liga $\mathrm{B}$, para condição fora de fase e em vários níveis de amplitude de deformação mecânica.

Figura 5.79 - Gráfico da tensão máxima em função do número de ciclos para a liga $\mathrm{C}$, para condição em fase e em vários níveis de amplitude de deformação mecânica.

Figura 5.80 - Gráfico da tensão máxima em função do número de ciclos para a liga $\mathrm{C}$, para condição fora de fase e em vários níveis de amplitude de deformação mecânica.

Figura 5.81 - Gráfico da tensão máxima em função do número de ciclos para a liga E, para condição em fase e em vários níveis de amplitude de deformação mecânica. 
Figura 5.82 - Gráfico da tensão máxima em função do número de ciclos para a liga $\mathrm{E}$, para condição fora de fase e em vários níveis de amplitude de deformação mecânica.

Figura 5.83 - Deformação térmica apresentada pelas ligas A, B, C e E, devido ao aumento da temperatura...

Figura 5.84 - Fadiga termomecânica em fase - Gráfico da Deformação em função da Temperatura, para amplitude de deformação mecânica de $0,1 \%$.

Figura 5.85 - Fadiga termomecânica fora de fase - Gráfico da Deformação em função da Temperatura, para amplitude de deformação mecânica de $0,1 \%$.

Figura 5.86 - Fadiga termomecânica em fase - Gráfico da Deformação em função da Temperatura, para amplitude de deformação mecânica de $0,3 \%$.

Figura 5.87 - Fadiga termomecânica fora de fase - Gráfico da Deformação em função da Temperatura, para amplitude de deformação mecânica de $0,3 \%$.

Figura 5.88 - Fadiga termomecânica em fase - Gráfico da Deformação em função da Temperatura, para amplitude de deformação mecânica de $0,4 \%$.

Figura 5.89 - Fadiga termomecânica fora de fase - Gráfico da Deformação em função da Temperatura, para amplitude de deformação mecânica de $0,4 \%$.

Figura 5.90 - Gráfico da Amplitude de Tensão em função da Amplitude de Deformação Total, para condição em fase da Liga A em amplitude de deformação mecânica de $0,1 \%$.

Figura 5.91 - Gráfico da Amplitude de Tensão em função da Amplitude de Deformação Total, para condição em fase da Liga A em amplitude de deformação mecânica de $0,2 \%$.

Figura 5.92 - Gráfico da Amplitude de Tensão em função da Amplitude de Deformação Total, para condição em fase da Liga A em amplitude de deformação mecânica de $0,3 \%$.

Figura 5.93 - Gráfico da Amplitude de Tensão em função da Amplitude de Deformação Total, para condição em fase da Liga A em amplitude de deformação mecânica de $0,4 \%$.

Figura 5.94 - Gráfico da Amplitude de Tensão em função da Amplitude de Deformação Total, para a condição fora de fase da Liga A, em amplitude de deformação mecânica de $0,1 \%$.....

Figura 5.95 - Gráfico da Amplitude de Tensão em função da Amplitude de Deformação Total, para a condição fora de fase da Liga A, em amplitude de deformação mecânica de $0,15 \%$.

Figura 5.96 - Gráfico da Amplitude de Tensão em função da Amplitude de Deformação Total, para a condição fora de fase da Liga A, em amplitude de deformação mecânica de $0,2 \%$.

Figura 5.97 - Gráfico da Amplitude de Tensão em função da Amplitude de Deformação Total, para a condição fora de fase da Liga A, em amplitude de deformação mecânica de $0,3 \%$.

Figura 5.98 - Gráfico da Amplitude de Tensão em função da Amplitude de Deformação Total, para a condição fora de fase da Liga A, em amplitude de deformação mecânica de $0,4 \%$.

Figura 5.99 - Gráfico comparativo da tensão máxima de ensaio em função da deformação mecânica para as ligas estudadas.

Figura 5.100 - Fadiga termomecânica - em fase e fora de fase. Gráfico comparativo dos níveis de tensão alcançados durante o ciclo final para as ligas $\mathrm{A}, \mathrm{B}, \mathrm{C}$ e E, sob amplitude de deformação mecânica de $0,1 \%$. 
Figura 5.101 - Fadiga termomecânica fora de fase. Gráfico comparativo dos níveis de tensão alcançados durante o ciclo final para as ligas A, B, C e E, sob amplitude de deformação mecânica de $0,2 \%$.

Figura 5.102 - Fadiga termomecânica - em fase e fora de fase. Gráfico comparativo dos níveis de tensão alcançados durante o ciclo final para as ligas A, B, C e E, sob amplitude de deformação mecânica de $0,3 \%$.

Figura 5.103 - Fadiga termomecânica - em fase e fora de fase. Gráfico comparativo dos níveis de tensão alcançados durante o ciclo final para as ligas $\mathrm{A}, \mathrm{B}, \mathrm{C}$ e E, sob amplitude de deformação mecânica de $0,4 \%$.

Figura 5.104 - Amplitude de Deformação em função do Número de Reversos para falhar para a liga A. Comparativo entre Fadiga Termomecânica, em fase e fora de fase, e Fadiga Isotérmica em $27^{\circ} \mathrm{C}, 300^{\circ} \mathrm{C}$ e $600^{\circ} \mathrm{C}$.

Figura 5.105 - Amplitude Deformação em função do Número de Reversos para falhar para a liga B. Comparativo entre Fadiga Termomecânica, em fase e fora de fase, e Fadiga Isotérmica em $27^{\circ} \mathrm{C}, 300^{\circ} \mathrm{C}$ e $600^{\circ} \mathrm{C}$

Figura 5.106 - Amplitude Deformação em função do Número de Reversos para falhar para a liga C. Comparativo entre Fadiga Termomecânica, em fase e fora de fase, e Fadiga Isotérmica em $27^{\circ} \mathrm{C}, 300^{\circ} \mathrm{C}$ e $600^{\circ} \mathrm{C}$.

Figura 5.107 - Amplitude Deformação em função do Número de Reversos para falhar para a liga E. Comparativo entre Fadiga Termomecânica, em fase e fora de fase, e Fadiga Isotérmica em $27^{\circ} \mathrm{C}, 300^{\circ} \mathrm{C}$ e $600^{\circ} \mathrm{C}$.

Figura 5.108 - Disco com composição química similar à da liga A após ensaio de fadiga termomecânica e líquidos penetrantes. Falhou após 250 ciclos. Aprovado..... 125

Figura 5.109 - Disco com composição química similar à da liga B após ensaio de fadiga termomecânica e líquidos penetrantes. Não falhou até 400 ciclos. Aprovado. 125

Figura 5.110 - Disco com composição química similar à da liga $\mathrm{E}$ (primeiro ensaio) após ensaio de fadiga termomecânica e líquidos penetrantes. Aprovado. 


\section{LISTA DE TABELAS}

Tabela 2.1 - Composições químicas nominais usadas pela General Motors do Brasil, \% em peso (GME-05002).

Tabela 2.2 - Efeito endurecedor dos elementos de liga em solução sólida na ferrita [Milan, 2004].

Tabela 2.3 - Composições químicas (\% em peso) dos ferros fundidos cinzentos da Figura 2.35 [Gundlach, 1978].

Tabela 2.4 - Composições químicas (\% em peso) dos ferros da Figura 2.36 [Gundlach,

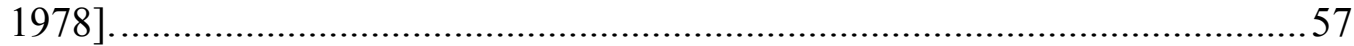

Tabela 2.5 - Composição química de ligas de ferro fundido (\% peso) [Yamabe 2002].........60

Tabela 2.6 - Propriedades físicas e mecânicas das ligas A e B [Yamabe 2002] ......................60

Tabela 2.7 - Parâmetros microestruturais das ligas A e B [Yamabe 2002] .............................60

Tabela 2.8 - Composições químicas nominais (\% em peso) especificadas para as sete ligas [Angeloni, 2005] .............................................................................6 63

Tabela 4.9 - Composições químicas nominais especificadas. ............................................... 70

Tabela 4.10 - Classificação comparativa das sete ligas de ferro fundido cinzento

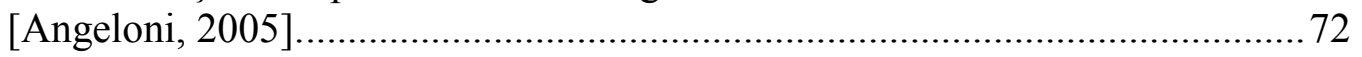

Tabela 4.11 - Parâmetros para ensaio de fadiga (discos de freio). ........................................78

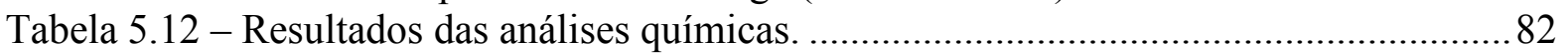

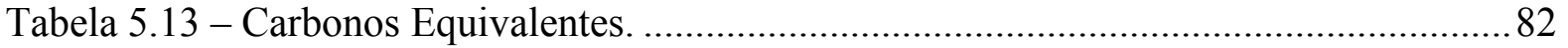

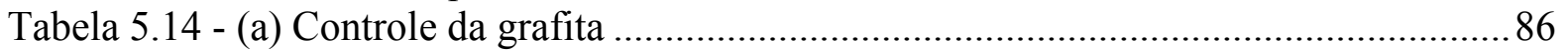

Tabela 5.15 - Controle da grafita em corpos de prova ensaiados em fadiga termomecânica

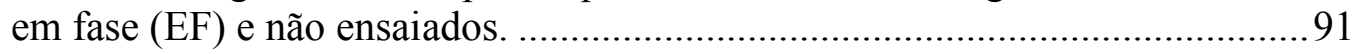

Tabela 5.16 - Tabela de deformação total em função da tensão.............................................93

Tabela 5.17 - Comparação dos resultados das ligas A, B, C e E segundo o critério de classificação adotado. 


\section{LISTA DE SÍMBOLOS}

A Área da grafita

ac Distância que corresponde às amplitudes de deformação total (horizontal) e de tensão (vertical).

Al Alumínio

b Expoente de resistência à fadiga

C Carbono

C Capacidade térmica

CE Carbono equivalente

Ce Césio

Cr Cromo

$\mathrm{Cu}$ Cobre

c Expoente de ductilidade de fadiga

D Difusividade térmica

$\mathbf{D}_{\mathbf{b}} \quad$ Coeficiente de difusão do contorno de grão

db Distância que corresponde à amplitude de deformação plástica

dg Tamanho de grão

$\boldsymbol{d p} \quad$ Tamanho médio das partículas

E Módulo de Young ou de Elasticidade

$\mathbf{E}_{1} \quad$ Módulo de elasticidade no descarregamento trativo

$\mathbf{E}_{2} \quad$ Módulo de elasticidade no descarregamento compressivo

E(T) Módulo de elasticidade em função da temperatura instantânea

$\mathbf{F e}_{3} \mathbf{C} \quad$ Cementita

fb Fração em volume de partículas nucleadoras de cavidade no contorno de

K Condutividade térmica

$\boldsymbol{k} \quad$ Constante de Boltzman

$\boldsymbol{L} \quad$ Espessura

L Comprimento real da grafita

Mn Manganês

Mo Molibdênio

N Nitrogênio

Ni Níquel

Nf Número de ciclos em fadiga para falhar

2Nf Número de reversos em fadiga para falhar (vida em fadiga)

P Fósforo

$\boldsymbol{P} \quad$ Perímetro da grafita

$\mathbf{Q} / \Delta \mathbf{T} \quad$ Energia transferida

S Enxofre

Si Silício

T Temperatura

$\boldsymbol{T}_{\boldsymbol{a m b}} \quad$ Temperatura ambiente

$\mathbf{T}_{\mathbf{f}} \quad$ Temperatura de fusão

$\boldsymbol{T}(\boldsymbol{t}) \quad$ Ciclo de temperatura em função do tempo

$\mathbf{T}_{\mathbf{u}} \quad$ Temperatura máxima

$\mathbf{T}_{\mathbf{l}} \quad$ Temperatura mínima

V Vanádio

$\mathbf{V}_{\mathbf{e}} \quad$ Volume da esfera 


\begin{tabular}{|c|c|}
\hline$\alpha(T)$ & Coeficiente de dilatação térmica \\
\hline$\varepsilon$ & Deformação total \\
\hline$\varepsilon_{c r}$ & Taxa de deformação crítica \\
\hline$\varepsilon_{\mathrm{e}}$ & Deformação elástica \\
\hline$\varepsilon f$ & Coeficiente de ductilidade verdadeiro \\
\hline$\varepsilon f^{\prime}$ & Coeficiente de ductilidade de fadiga \\
\hline$\varepsilon_{\mathrm{fl}}$ & Deformação de fluência \\
\hline$\varepsilon_{\text {in }}$ & Deformação inelástica \\
\hline$\varepsilon_{\mathrm{m}}$ & Deformação mecânica imposta pela máquina de ensaio \\
\hline$\varepsilon_{\mathrm{p}}$ & Deformação plástica \\
\hline$\varepsilon(t)$ & Deformação em função do tempo \\
\hline$\varepsilon_{\text {th }}$ & Deformação térmica (dilatação térmica) \\
\hline$\varepsilon_{\text {tot }}$ & Deformação total medida durante um ensaio de fadiga anisotérmica \\
\hline$\varepsilon \times 2 \mathbf{N}_{\mathrm{f}}$ & Curvas de amplitude de Deformação-Vida \\
\hline$\sigma_{\mathrm{a}}$ & Amplitude de tensão \\
\hline$\sigma_{\mathrm{c}}$ & Tensão compressiva \\
\hline of' & Coeficiente de resistência à fadiga \\
\hline$\sigma_{\mathbf{y}}$ & Limite de escoamento \\
\hline $\boldsymbol{\sigma}-\mathbf{N}$ & Curva tensão-vida em fadiga \\
\hline$\Delta T$ & Diferença de temperaturas \\
\hline$\Delta \varepsilon$ & Variação da deformação \\
\hline$\Delta \varepsilon_{\mathrm{p}}$ & Variação da deformação plástica \\
\hline$\rho$ & Densidade \\
\hline$v_{c}$ & Freqüência \\
\hline$\Omega$ & Volume atômico \\
\hline
\end{tabular}




\section{LISTA DE SIGLAS}

AISI American Iron and Steel Institute

ASM American Society of Metals

ASTM American Society for Testing Materials

DEMAA (SMM) Departamento de Engenharia de Materiais, Aeronáutica e Automobilística

EESC Escola de Engenharia de São Carlos

EF $\quad$ Em fase

FF $\quad$ Fora de fase

FIPAI Fundação de Incentivo a Pesquisa e ao Aperfeiçoamento Industrial

FIT Fadiga Isotérmica

FT Fadiga Térmica

FTM Fadiga Termomecânica

GME General Motors European

GMB General Motors do Brasil

LFA Laser Flash Apparatus

LIEC Laboratório Interdisciplinar de Eletroquímica e Cerâmica

MFLE Mecânica da Fratura Elasto-Plástica

NEMAF Núcleo de Ensaios de Materiais e Análise de Falhas

UFSCar Universidade Federal de São Carlos

USP Universidade de São Paulo 


\section{RESUMO}

Os discos de freio, durante a frenagem, são submetidos a tensões térmicas e mecânicas que podem ser relativamente altas quando muito bruscas (frações de segundo), situação em que a temperatura pode chegar a valores próximos de $600^{\circ} \mathrm{C}$. Esta variação de temperatura provoca choques térmicos que podem gerar trincas e/ou uma grande quantidade de deformação plástica no disco. A proposta deste trabalho foi a de investigar, através de experimentos, o comportamento mecânico e físico em quatro ligas de ferro fundido cinzento (A, B, C e E), utilizadas para produzir discos de freio de veículos automotivos. Para tanto, foram realizados ensaios termomecânicos de baixo ciclo em corpos de prova, entre $300^{\circ} \mathrm{C}$ e $600^{\circ} \mathrm{C}$, nas condições em fase e fora de fase, adotando o critério de falha em $50 \%$ da tensão máxima (ASTM E-606) e em componentes (discos), além daqueles de difusividade térmica desde a temperatura ambiente até $600^{\circ} \mathrm{C}$. As curvas deformação em função da vida $(\boldsymbol{\varepsilon}-\mathbf{N})$ foram obtidas e analisadas segundo norma ASTM E 466/468. A análise microestrutural nos corpos de prova e peças, após os ensaios de fadiga, serviu para revelar a influência da morfologia e quantidade de grafita e da matriz sobre as propriedades mecânicas. A medição das difusividades térmicas teve como objetivo a verificação da influência do carbono equivalente e dos elementos de liga sobre esta propriedade física. Observou-se que, durante os ensaios de fadiga termomecânica em fase, em função da decomposição de parcela da cementita da perlita, houve, nos materiais, a chamada expansão grafítica, que teve influência na parte trativa do ciclo, diminuindo as tensões necessárias para se alcançar determinadas amplitudes de tensão mecânica. Pelos gráficos de amplitude de deformação mecânica em função do número de reversos para falhar, sob fadiga termomecânica em fase e fora de fase, observou-se que a melhor liga de ferro fundido cinzento foi a liga E. Esta constatação implicará em uma significativa redução dos custos de produção dos discos de freio, pois se poderá prescindir do elemento de liga Molibdênio, extremamente caro. Comparando-se os resultados de fadiga termomecânica com os de fadiga isotérmica a $25^{\circ} \mathrm{C}, 300^{\circ} \mathrm{C}$ e $600^{\circ} \mathrm{C}$, pôde-se verificar que os ensaios mais críticos foram os fora de fase, pois conduziram, comparativamente, a vidas menores.

Palavras-chave: Fadiga Termomecânica. Elementos de Liga. Ferro Fundido Cinzento. Difusividade Térmica. Discos de Freio. 


\begin{abstract}
Brake discs are submitted to thermal and mechanical stress that can be relatively high during abrupt braking action happens (fractions of seconds), causing the temperature to reach values as high as $600^{\circ} \mathrm{C}$. This temperature variation results in thermal shocks that can generate cracks and/or a large amount of plastic deformation in the disk. The main aim of this work was to investigate, through experiments, the mechanical and physical behavior of four alloys of gray cast iron (A, B, C and $\mathbf{E}$ ), used to produce brake discs of automotives vehicles. Low cycle thermomechanical fatigue tests were carried out in components (discs) and in test specimens, between $300^{\circ} \mathrm{C}$ and $600^{\circ} \mathrm{C}$, in the conditions in-phase and out-of-phase, adopting the failure criterion of $50 \%$ drop of the maximum tensile stress (ASTM E - 606). Thermal diffusivity values were measured from room temperature up to $600^{\circ} \mathrm{C}$ in order to analyze the effects of carbon content and alloying elements in physical properties. Curves $\boldsymbol{\varepsilon}-\mathbf{N}$ were obtained and analyzed according to ASTM E 466/468 standard. Microstructural analysis was employed to reveal the influence of the matrix and morphology/amount of graphite on the mechanical properties. It was observed that, during in-phase thermomechanical fatigue tests, the volume expansion due to cementite decomposition into graphite and ferrite caused a decrease in the tensile stress necessary to achieve the mechanical strain imposed during tests. From $\Delta \varepsilon_{M} / \mathbf{2} \times \mathbf{2} \mathbf{N}_{\mathbf{f}}$ graphs it was inferred that alloy $\mathbf{E}$ presented the best performance both in in-phase and out-of phase tests. The lack of $\mathbf{M o}$ in this alloy implies in a significant reduction of cost production of the brake discs, due to the high cost of such alloying element. Out-ofphase thermomechanical fatigue tests resulted in shorter lives compared to isothermal fatigue tests carried out at $25^{\circ} \mathrm{C}, 300^{\circ} \mathrm{C}$ and $600^{\circ} \mathrm{C}$.
\end{abstract}

Key-words: Thermomechanical Fatigue. Alloy Elements. Gray Cast Iron. Thermal Difusivity. Brake Discs. 


\section{1 - INTRODUÇÃO}

No final do século XIX, com o transporte ferroviário e início da fabricação dos automóveis, tornaram-se necessários novos materiais de base tecnológica para sistemas de freio que permitissem frear de maneira eficaz veículos transportando grandes cargas a velocidades consideráveis. Estes dispositivos são utilizados para desacelerar os veículos pelo atrito, transformando a maior parte da energia cinética em energia térmica, dissipada pelo sistema de freio durante o processo de frenagem [Iombriller, 2002].

Muitas são as partes que contribuem ativa ou passivamente para que um veículo tenha um desempenho satisfatório, mas a segurança está intimamente ligada à eficiência do sistema de freio, submetido a tensões térmicas e mecânicas relativamente altas durante o ato regular de frenagem. Assim, é de fundamental importância a precisão da análise e desenvolvimento do sistema de freio, considerando todos os aspectos envolvidos em seu comportamento térmico e dinâmico [Mazur, 2005].

Durante severa desaceleração por frenagem (em fração de segundos), a temperatura do sistema de freio pode chegar a valores próximos a $650^{\circ} \mathrm{C}$ e o superaquecimento do disco de freio pode provocar sérias conseqüências, que reduzem a segurança do veículo [Iombriller, 2002]. Esta variação de temperatura provoca choques térmicos e pontos de aquecimentos localizados, mudando o comportamento do metal devido a transformações metalúrgicas, causando o surgimento de trincas no disco em virtude do escoamento plástico do metal da superfície e induzindo tensões após o resfriamento [Mazur, 2005]. Mesmo desconsiderando a presença de choques térmicos, ainda sim, uma pequena quantidade de ciclos de frenagem com desaceleração brusca é o suficiente para causar pequenas trincas na parte útil dos discos de freio.

As tensões cíclicas resultantes do uso contínuo dos veículos podem causar fadiga, propagar trincas e provocar a quebra do componente de freio [Iombriller, 2002]. Este tipo de mecanismo pode resultar em falha progressiva do material quando este estiver sujeito a deformações cíclicas repetitivas. Como nos discos de freio as condições de carregamento cíclico são principalmente induzidas por um gradiente de temperatura, os ensaios programados para este trabalho foram essencialmente controlados por deformação. Desta maneira, fica claro que o trincamento em discos de freio deve ser considerado como um problema de fadiga térmica, isotérmica e termomecânica de baixo ciclo. 
A fadiga isotérmica consiste na imposição de uma deformação mecânica variável, com a temperatura mantida constante. Tem como vantagem principal a simplicidade de execução e o baixo custo dos ensaios, quando comparado aos ensaios anisotérmicos (termomecânicos). Esses que são caracterizados pela variação simultânea de temperatura e deformação mecânica, originada pelas restrições externas aplicadas no material. Já a fadiga térmica envolve ciclos térmicos sem carregamento externo, em que as tensões são originadas por gradientes abruptos de temperatura no componente, ou por restrições internas, tais como orientações de grãos diferentes ao nível microscópico ou anisotropia do coeficiente de expansão térmica de certos cristais.

Até recentemente, a resistência à fadiga de materiais em alta temperatura era estimada através de testes de fadiga isotérmica na temperatura máxima esperada no ciclo de fadiga térmica. Porém, este procedimento revelou-se insuficiente em função de que a resistência dos materiais em fadiga termomecânica é significativamente menor que aquela esperada com relação à estimativa baseada na fadiga isotérmica. Isso ocorre devido a mecanismos possivelmente ativados durante a ciclagem térmica, característica da fadiga termomecânica, que não ocorrem na fadiga isotérmica em que a temperatura é mantida constante.

Hoje em dia existem dois tipos principais de sistemas de freio: a tambor e a disco. Nos últimos anos vem se tornando cada vez mais comum a utilização do freio a disco em veículos pesados substituindo os tambores de freio. Isso se deve principalmente à busca de maior eficiência na frenagem, já que os freios a disco suportam temperaturas superiores às que suportam os freios a tambor [Boiocchi, 1999]. Entretanto, observa-se que a simples troca do sistema tambor/lona pelo sistema disco/pastilha não é suficiente, tornando-se necessário a análise do sistema de freio como um todo, bem como sua influência no desempenho do veículo e na segurança veicular.

Em muitas das aplicações de alta responsabilidade - como é o caso dos discos de freio - para caracterizar os materiais usados em componentes, não basta apenas conhecer os resultados de ensaios de tração, impacto e dureza. Isso porque estes resultados podem não fornecer os subsídios necessários que permitam prever, de maneira confiável, o comportamento dos componentes sob condições reais de trabalho. Idealmente, os materiais a serem utilizados em sistemas de frenagem devem possuir algumas propriedades tais como boa condutividade térmica, boa resistência à corrosão, baixo peso, longa durabilidade, atrito estável, baixa taxa de desgaste e boa relação custo/benefício [Weintraub, 1998]. Também, a forma e a composição química dos discos influem na durabilidade, pois afetam o fluxo de 
calor, a capacidade de amortecer vibrações, a perda de material durante a frenagem e o nível de ruído [Metzler, 1990; Rhee, 1972].

Portanto, para atender às propriedades requeridas por um sistema de freio, muitas vezes é necessário combinar muitos materiais com diversas formas e dimensões. A história registra, já no final do século retrasado o uso, em conjunto, de materiais diferentes, como por exemplo, madeira e couro nos freios de vagões de trem. Durante as últimas décadas, uma grande atenção tem sido voltada à melhoraria do desempenho dos discos de freio no que diz respeito a seu comportamento em relação ao atrito com as pastilhas de freio. Esse grande esforço levou ao desenvolvimento de materiais tais como ligas não ferrosas de cobre, compósitos de matriz alumínio e, atualmente, os compósitos de carbono [Rhee, 1970; Wycliffe, 1993]. No entanto, o ferro fundido cinzento continua sendo o material mais usado em discos de freio automotivos, pois, além de apresentar boas propriedades físicas e mecânicas, é de fácil fabricação e baixo custo. Faz-se necessário, no entanto, uma caracterização mais minuciosa das ligas de ferro fundido cinzento mais utilizadas para a finalidade em questão. E isso se faz mister principalmente no que se refere à resistência à fadiga, para determinar qual delas é mais adequada, visto que, com a melhoria no desempenho dos caminhões e veículos de passeio, há um crescente aumento na demanda por melhoria tecnológica nos discos de freio.

Como, talvez, a parte mais importante de um sistema de freio a disco seja o próprio disco de freio, o material com o qual este é produzido deve ser caracterizado, dentre outros, em ensaios de fadiga: térmica, isotérmica e termomecânica (em fase ou fora de fase). Particularmente, a mais importante, por melhor representar a realidade das solicitações a que o disco é submetido durante o processo de frenagem, é a fadiga termomecânica.

No entanto, as montadoras ainda especificam os materiais para fabricação de discos de freio com base apenas em resultados de ensaios convencionais à temperatura ambiente, que não representam, de fato, a totalidade das solicitações a que o componente é submetido, pois não conseguem reproduzir os carregamentos cíclicos. Em função da existência desta deficiência de controle, optou-se por dar seqüência a um estudo preliminar que realizou, a temperaturas ambiente de $300^{\circ} \mathrm{C}$ e $600^{\circ} \mathrm{C}$, testes convencionais e de fadiga isotérmica nas sete ligas de ferro fundido cinzento mais utilizadas pelas montadoras, identificadas pelas letras A, B, C, D, E, F e G. Analisando-se os resultados encontrados, buscou-se, considerando a influencia das composições químicas sobre as propriedades mecânicas, selecionar quatro delas. Para tanto, adotou-se o critério de classificá-las, com colocações da $1^{\text {a }}$ até, no máximo, a $7^{\mathrm{a}}$, de acordo com os resultados obtidos nos diversos tipos de ensaio. 
Extraindo-se a média aritmética do somatório dos resultados de classificação de cada uma das ligas, foram consideradas as melhores aquelas quatro que apresentaram os menores valores médios.

Com elas, identificadas pelas letras $\mathbf{A}, \mathbf{B}, \mathbf{C}$ e $\mathbf{E}$, foi dado início ao presente estudo que teve por objetivo estudá-las sob ensaios de fadiga termomecânica, que, como já visto, melhor representa as condições operacionais. Os ensaios de fadiga anisotérmica (termomecânica), em fase e fora de fase, foram realizados entre $300^{\circ} \mathrm{C}$ e $600^{\circ} \mathrm{C}$, para determinação das propriedades de fadiga de baixo ciclo. Foram executados, também, ensaios de fadiga termomecânica em componentes (disco) do tipo "passa não passa", com o intuito de comparar estes resultados com aqueles obtidos em laboratório. Os ensaios de difusividade térmica desde a temperatura ambiente até aproximadamente $600^{\circ} \mathrm{C}$ serviram para analisar o efeito dos elementos de liga e do carbono equivalente sobre esta propriedade física nos ferros fundidos cinzentos.

Análises microestruturais nos corpos de prova ensaiados revelaram a influência da morfologia e quantidade de grafita e da matriz nas propriedades mecânicas. Os resultados do conjunto de ensaios propiciaram o estabelecimento de um banco de dados relativo às propriedades das ligas mais empregadas pelo mercado. Este trabalho, em função de seu ineditismo, não encontra similar na literatura, pois se propôs estudar a fundo o comportamento mecânico e físico de algumas ligas ferrosas usadas em discos de freio, que é um dos principais itens de segurança existentes nos automóveis.

A contrapartida foi que, com os subsídios obtidos, conseguiu-se aumentar o conhecimento a respeito do assunto e, conseqüentemente, a segurança veicular. A escolha de uma das ligas como a melhor de todas, trouxe benefícios comerciais importantes pelo ganho na economia de escala ao permitir que se eliminasse a variedade de itens normalmente em estoque. Além disso, a economia das montadoras com a eliminação do elemento molibdênio, da composição química dos discos de freio automotivos, certamente será bastante significativa. 


\section{2 - REVISÃO BIBLIOGRÁFICA}

\section{1 - Considerações Iniciais}

Vários componentes utilizados em sistemas de freio de veículos automotores, como os discos, estão sujeitos a variações de temperatura durante sua utilização. O gradiente térmico induzido nas diversas regiões da peça durante a frenagem pode provocar a ocorrência de tensões internas, e a repetição destes ciclos térmicos pode causar a nucleação e a propagação de trincas por fadiga, conforme pode ser visto na Figura 2.1 [Mackin, 2002]. O estudo do comportamento mecânico e dos mecanismos de fratura destes materiais é essencial para possibilitar a elaboração de projetos e a utilização racional destes componentes.

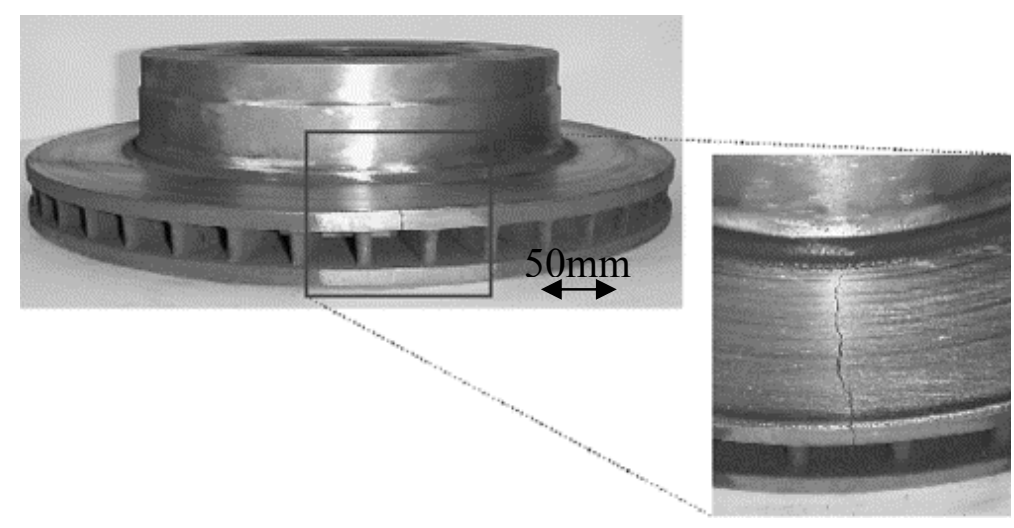

Figura 2.1 - Falha no rotor de freio dianteiro de Ford F-250 Pickup. Podem ser observadas trincas que se propagaram radialmente do chapéu para o exterior do disco [Mackin, 2002].

A fadiga corresponde a um mecanismo de falha progressivo, em que os materiais podem estar sujeitos a deformações cíclicas repetitivas. Para o assunto que +está sendo tratado, as três principais formas de fadiga a ocorrer serão: Térmica, em que apenas ocorrem variações de temperatura sem que haja qualquer carregamento; Isotérmica, na qual a temperatura é mantida constante e o carregamento é variável e Termomecânica, em que tanto a temperatura quanto o carregamento são variáveis.

Quando a deformação é altamente localizada e detectável somente em escala microscópica (regime de deformação elástica), serão necessários muitos ciclos $\left(\mathbf{N}_{\mathrm{f}}>\mathbf{5} \times \mathbf{1 0}^{\mathbf{5}}\right.$ ) para a iniciação e propagação de uma trinca em escala macroscópica (alto ciclo). Se a deformação inelástica é grande o suficiente, e homogeneamente distribuída, em escala macroscópica (regime de deformação plástica), a vida do material é drasticamente reduzida, e 
poucos ciclos $\left(\mathbf{1 0}^{\mathbf{2}}<\mathbf{N}_{\mathrm{f}}<\mathbf{1 0}^{\mathbf{5}}\right)$ irão causar a falha do material. Este último é denominado de regime de fadiga de baixo ciclo [Bannantine, 1990; Hetnarski, 1991].

A fadiga isotérmica de baixo ciclo é resultado de altas deformações aplicadas de maneira constante em temperatura elevada. Por sua vez, a fadiga térmica corresponde à fonte de deformação cíclica imposta como resultado da restrição da expansão térmica diferencial no sólido causado pelo gradiente de temperatura. Este é induzido durante aquecimento e resfriamento alternado, que proporciona diminuição na resistência em estruturas utilizadas em condições de temperaturas elevadas variantes [Hetnarski, 1991].

A fadiga térmica de baixo ciclo é o modo de falha predominante em componentes estruturais sujeitos a alta temperatura. $\mathrm{O}$ custo da prevenção e substituição de componentes que falham devido a este tipo de fadiga é tão alto que se torna inviável, sendo estimado em bilhões de dólares apenas nos Estados Unidos da América. Assim, um melhor entendimento deste processo de falha [Hetnarski, 1991] é vital para o aumento tanto da segurança quanto da relação benefício/custo. Ênfase está sendo dada à busca de ligas mais resistentes e, conseqüentemente, de componentes mais eficientes quando submetidos à solicitação. Para tanto, entender como se processa a fadiga térmica de baixo ciclo é imprescindível.

Seria razoavelmente simples entender estes processos se os mecanismos de deformação cíclica fossem independentes da temperatura e se a ciclagem térmica não alterasse o estado metalúrgico dos materiais. Mas como na maior parte dos casos, nenhuma dessas condições existe, o problema se agrava [Hetnarski, 1991].

Até recentemente, a resistência à fadiga térmica de materiais era estimada através de testes de fadiga isotérmica de baixo ciclo na temperatura máxima esperada no ciclo de fadiga térmica. As correlações e aproximações de engenharia se tornaram ingredientes necessários para determinar a resposta dos materiais sob fadiga térmica através de dados da fadiga isotérmica. Dessa maneira, efeitos provocados por oxidação, corrosão térmica e fluência, devido a longos tempos de exposição do material a altas temperaturas, podiam ser avaliados em experiências de simulação de laboratório relativamente simples, o que aumentou a base de dados de fadiga isotérmica através dos anos [Hetnarski, 1991].

As mais simples e mais comuns aproximações de engenharia necessárias para predizer o comportamento de materiais sob fadiga anisotérmica (fadiga térmica e fadiga termomecânica) através de dados de fadiga isotérmica são: (a) assumir que a resistência à fadiga isotérmica na máxima temperatura representa a resistência à fadiga térmica, (b) assumir que a mais baixa resistência à fadiga isotérmica dentro da faixa de temperatura do 
ciclo térmico é uma das usadas na resistência à fadiga térmica, e (c) utilizar as médias ou integrais algébricas equivalentes entre as duas temperaturas extremas [Hetnarski, 1991].

Porém, o uso de dados de fadiga isotérmica para predizer o desempenho do material sob fadiga termomecânica tem demonstrado possuir algumas desvantagens. Os resultados de fadiga de baixo ciclo isotérmica em altas temperaturas geralmente são conservativos. Esforços estão sendo feitos para relacionar crescimento de trincas sob fadiga termomecânica com o crescimento de trincas sob fadiga isotérmica usando conceitos de Mecânica da Fratura Linear Elástica, mas são necessários refinamentos adicionais incorporando conceitos da Mecânica da Fratura Elasto-Plástica. Muitos dos modelos existentes não contam com as interações entre deformação mecânica e a temperatura, que é bastante complexa e ainda não está bem entendida. Como conseqüência, as comparações dos resultados de fadiga termomecânica com fadiga isotérmica têm revelado grandes discrepâncias principalmente pelo fato de que a resistência dos materiais em fadiga termomecânica é, significativamente, menor que aquela esperada com relação à estimativa baseada em fadiga isotérmica. Isso porque podem existir mecanismos que são possivelmente ativados durante a ciclagem térmica e não durante a fadiga isotérmica, o que dificultaria a predição da resposta de materiais e componentes sujeitos à fadiga anisotérmica de baixo ciclo a partir de dados obtidos através da fadiga isotérmica [Hetnarski, 1991].

Assim, o estudo do comportamento em fadiga e predição de vida é extremamente mais complicado em altas temperaturas do que na temperatura ambiente, pois envolvem interações complexas entre processos dependentes do tempo e aqueles ativados termicamente. Isso inclui o ambiente, relaxação/fluência e aspectos metalúrgicos em ação conjunta com mecanismos de fadiga mecânica. Fatores tais como: freqüência, forma de onda e relaxação/fluência, pouco significativos na temperatura ambiente, têm muita importância em alta temperatura [Fuchs, 1980].

Atualmente, como as técnicas e equipamentos de testes controlados por computador evoluíram, a possibilidade de realizar ensaios mais precisos de fadiga termomecânica cresceu [Hetnarski, 1991].

Será discutido, a seguir, o efeito das altas temperaturas sobre os processos de fadiga isotérmica, térmica e termomecânica, bem como aspectos característicos deste processo de falha em baixo ciclo. O enfoque será sobre fadiga de baixo ciclo, pois é como ocorre a fadiga térmica, devido principalmente á baixa resistência em ciclagem térmica de muitas estruturas de engenharia [Hetnarski, 1991]. 


\section{2 - Efeito das Temperaturas Elevadas sobre os Materiais}

As peças utilizadas em temperaturas elevadas são submetidas a numerosos problemas, dos quais os principais são: fluência, oxidação (ou corrosão) e fadiga. Esses mecanismos de dano podem agir independentemente ou em conjunto (o que traz maior complexidade ao estudo do dano em temperatura elevada), de acordo com as variáveis dos materiais e condições de operação, tais como a temperatura máxima e mínima, a faixa de temperatura, a faixa da deformação mecânica, taxa de deformação (em fase ou fora de fase) ou fatores ambientais [Cai, 1999]. Segundo Engler-Pinto Jr (1996), a combinação do dano provocado por estes fatores está na origem da nucleação de trincas que irão propagar-se e provocar a ruptura por fadiga. Porém, à medida que a temperatura é elevada bem acima da temperatura ambiente, torna-se importante o fenômeno de fluência e - a temperaturas ainda mais altas (aproximadamente em temperaturas superiores à metade do ponto de fusão) — esta será a causa principal da fratura.

Como o que é considerado alta temperatura para um material pode não o ser para outro, esta é muitas vezes expressa em temperatura homóloga, isto é: a razão entre a temperatura do ensaio e a de fusão do metal em questão, ambas em escala absoluta (Kelvin). Segundo Dieter (1981), de uma maneira geral, a fluência atinge significância na engenharia para temperatura homóloga superior a 0,5 .

Em geral, a resistência mecânica dos metais diminui com o aumento da temperatura acima da ambiente (Figura 2.2). Isto se deve principalmente ao aumento da mobilidade dos átomos com o aumento da temperatura. 


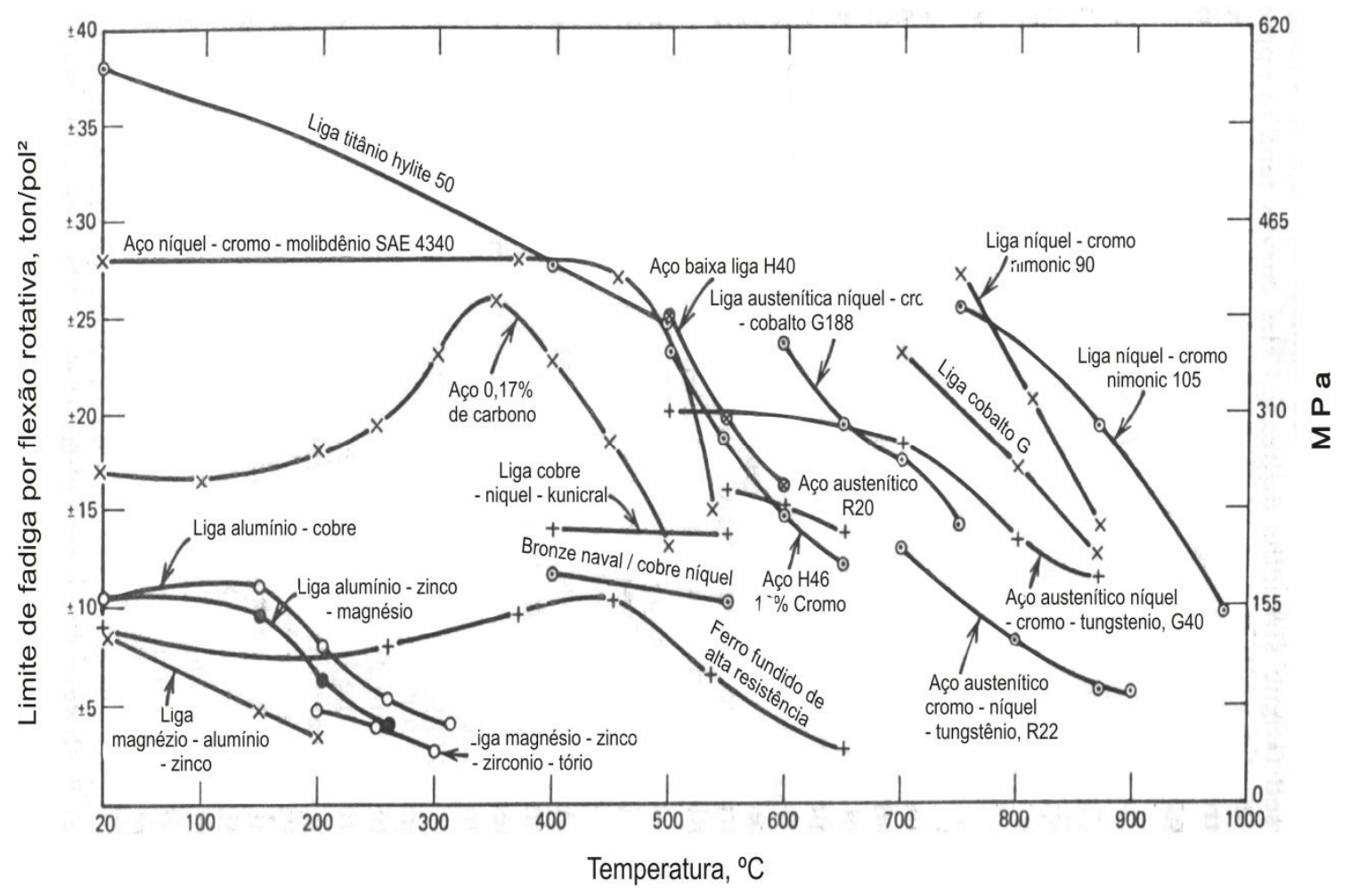

Figura 2.2 - Influência da temperatura no limite de fadiga, para várias ligas metálicas [Fuchs, 1980].

Desse modo, os processos controlados por difusão exercem um efeito muito significativo sobre as propriedades mecânicas em temperaturas elevadas. Altas temperaturas também resultam em uma maior mobilidade das discordâncias devido ao mecanismo de escalagem, que se torna importante devido à maior facilidade de difusão, e também porque a concentração de lacunas em equilíbrio aumenta com o aumento da temperatura. Além disso, novos mecanismos de deformação podem tornar-se operativos. Em alguns metais, o sistema de deslizamento muda, ou são introduzidos sistemas de deslizamento adicionais. A deformação nos contornos de grãos torna-se uma possibilidade adicional na deformação dos metais em temperatura elevada. Outro fator importante a se considerar é o efeito da exposição prolongada de ligas e metais em temperatura elevada com relação a suas estabilidades metalúrgicas. Os metais trabalhados a frio irão se recristalizar e experimentar crescimento de grãos, enquanto que ligas endurecidas por envelhecimento podem sofrer superenvelhecimento e perder resistência à medida que as partículas de segunda fase crescem. A interação do metal com o meio ambiente, ou seja, a oxidação também é um fator importante a ser considerado [Dieter, 1981].

Consiste em uma característica importante o fato de que as propriedades mecânicas em temperaturas elevadas devem sempre ser consideradas em relação a alguma escala de 
tempo. As propriedades mecânicas em temperatura ambiente da maioria dos metais de engenharia são, para fins práticos, independentes do tempo. No entanto, em temperaturas elevadas, a resistência torna-se muito dependente tanto da taxa de deformação como do tempo de exposição. Sob estas condições, vários metais se comportam em muitos aspectos como materiais viscoplásticos.

Fluência ou crescimento de trincas pode ocorrer quando os materiais estão sujeitos a condições de tensão constante, resultando em uma mudança da resposta de deformação do material. Um metal submetido a uma carga trativa constante, a uma temperatura elevada, irá fluir e experimentar um aumento de comprimento que depende do tempo. Sobre condições de deformação constante, relaxação pode ocorrer, resultando em uma mudança da tensão que o material sofre. Esta dependência entre propriedades mecânicas com o tempo em temperaturas elevadas varia de material para material, e está relacionada com a temperatura a qual o material está exposto [Fuchs, 1980]. Assim, em seguida, serão discutidos alguns fatores importantes que devem ser considerados quando os materiais estão sofrendo fadiga em altas temperaturas.

\subsection{1 - Interação Fadiga-Fluência}

Componentes que estejam em estado permanente de carregamento cíclico em temperaturas elevadas podem estar sujeitos a interação fadiga-fluência, já que podem sofrer danos micro-estruturais por fluência. Portanto, a resistência à fadiga de baixo ciclo e o domínio do processo de interação fadiga-fluência são importantes critérios para o desenvolvimento de componentes que trabalham sob condições limite. Por isso, é necessário um entendimento da deformação cíclica e comportamento da fratura nos materiais, em vários níveis de carregamento a altas temperaturas [Srinivasan, 2003].

O fenômeno da fluência pode ser definido como a deformação em materiais sólidos que ocorre com o decorrer do tempo, quando estão submetidos a uma carga ou tensão constante em temperaturas elevadas, que eventualmente pode levar a fratura. Embora essa deformação possa ocorrer em todas as temperaturas, considera-se significativa aquela que corresponde a $30 \%$ do ponto de fusão para metais puros e $40 \%$ para ligas metálicas [Seco, 2001; Es-Souni, 2001a; Langdon, 2002].

A transição da falha por fadiga para falha por fluência com o aumento da temperatura resultará, quase sempre, em uma mudança no tipo de fratura que passará de transgranular 
característico da fadiga, para a falha intergranular por fluência [Fuchs, 1980]. A oxidação local dos contornos de grão pode contribuir significativamente para o início da trinca. Segundo Dieter (1981), a quantidade de fluência aumenta com a tensão média para qualquer temperatura. Os materiais ferrosos, que, normalmente, apresentam um limite de fadiga pronunciado nos ensaios à temperatura ambiente, não têm o mesmo desempenho quando ensaiados a temperaturas acima de aproximadamente $420^{\circ} \mathrm{C}$. Os ensaios de fadiga a altas temperaturas dependerão também da freqüência de aplicação da tensão. É comum nos referirmos ao tempo total necessário à fratura, da mesma forma que ao número de ciclos.

Em geral, quanto maior a resistência à fluência de um material, maior será sua resistência à fadiga em altas temperaturas. No entanto, o tratamento metalúrgico que produz as melhores propriedades de fadiga em altas temperaturas não resulta necessariamente nas melhores propriedades de fluência. Isso foi mostrado por Toolin e Mochell apud Dieter (1981) em ensaios a altas temperaturas de várias superligas. Em geral, para baixas temperaturas, quanto menor for o tamanho de grão, melhor será o desempenho em fadiga do metal. À medida que a temperatura de ensaio é aumentada, a diferença no desempenho em fadiga entre um material de granulação fina e grosseira diminui até que para temperaturas bastante elevadas, em que predomina a fluência, o material de tamanho de grão grande apresenta maior resistência. Geralmente, as ligas previamente trabalhadas mecanicamente apresentam resistência à fadiga um pouco superior, enquanto que os materiais fundidos são freqüentemente mais resistentes à fluência. As soluções que obtêm sucesso na redução das falhas por fadiga em temperatura ambiente podem não ser efetivas em temperaturas elevadas. As tensões residuais compressivas, por exemplo, podem ser aliviadas antes que a temperatura de operação seja atingida.

A nucleação de trincas por fadiga é um fenômeno basicamente superficial. Em contraposição, o dano por fluência se manifesta tanto na superfície quanto no interior do material. Desta forma, o fenômeno de fluência pode influenciar tanto a iniciação quanto o crescimento da trinca (Sarabanda, 1991). Segundo Wareing (1983), o dano por fluência se manifesta pela nucleação de cavidades nos contornos de grãos devido ao coalescimento de vacâncias, empilhamento de discordâncias e deslizamento de contornos de grãos. O mesmo pode ocorrer junto às partículas de segunda fase. O subseqüente crescimento destas cavidades conduz ao trincamento do contorno de grão e fratura intergranular. Sob aplicação de carregamento estático, a falha é estabelecida por fratura catastrófica quando se verifica o coalescimento das cavidades. Em fadiga de baixo ciclo com superposição de patamares de 
carregamento em temperaturas elevadas, a fratura ocorre quando as cavidades alcançam uma configuração geométrica crítica.

O dano por fluência pode ter origem a partir de uma tensão residual trativa originada de uma deformação em compressão seguida da reversão desta deformação. Em ambos os casos, a deformação inelástica se dá sob deformação total nula, diferindo, entretanto, no sinal da tensão residual. Outros carregamentos envolvendo deformações inelásticas, encontradas em componentes submetidos à fadiga térmica, são passíveis de serem simulados nos ensaios mecânicos (Wareing, 1983; Skelton, 1983; Hales, 1983). O tempo de patamar sob determinado nível de tensão ou deformação é outra variável independente, podendo variar desde segundos até horas.

As retenções verificadas em tração são, geralmente, mais danosas do que as retenções em compressão quando aplicadas separadamente. Ao se aplicar um carregamento com retenção em tração e, logo em seguida, um carregamento com retenção em compressão, verifica-se que o dano é menor do que no caso da aplicação isolada do primeiro. Segundo Wareing (1983), isto é devido a um efeito de "aniquilamento" (healing), no meio-ciclo compressivo, de parte das cavidades formadas durante a retenção no meio-ciclo trativo. $\mathrm{O}$ fenômeno é complexo e requer um conhecimento do mecanismo de formação de danos microestruturais por fluência. Entretanto, alguns efeitos secundários devido à transformação de energia elástica em deformação inelástica estão presentes mesmo na ausência de danos microestruturais. O mais importante efeito é o de causar uma alteração da tensão média devido à deformação inelástica para materiais com elevada resistência à fluência. Para ciclos com reversão total, um patamar no meio-ciclo trativo conduz a uma tensão média compressiva e para patamar no meio-ciclo compressivo a tensão média se desloca no sentido trativo. Neste último caso, há uma redução da vida em fadiga como conseqüência de tensões trativas mais elevadas e não propriamente devido à deformação inelástica [ASM, 1985].

Outro fenômeno que pode ocorrer nos materiais é o processo de relaxação por fluência. A relaxação da tensão ocorre geralmente em peças juntadas por parafusos (flanges), ou montagens ajustadas a quente, quando tais componentes estão em serviço em alta temperatura, podendo tornar frouxas tais junções e produzir desconexão entre as peças devido ao alongamento excessivo dos parafusos ou rotação dos flanges. A relaxação consiste na redução da carga (tensão) aplicada a um corpo de prova com o tempo, quando a deformação é mantida constante. A constância da deformação é obtida diminuindo a carga ou a tensão com o tempo ou parando a movimentação dos cabeçotes da máquina, anotando a carga em função do tempo na posição fixa dos cabeçotes. Como habitualmente a temperatura é alta, têm-se 
condições de fluências nestes casos. A deformação total, $\varepsilon$, é igual à soma da deformação elástica, $\boldsymbol{\varepsilon}_{\mathbf{e}}$, com a deformação plástica (deformação por fluência), $\boldsymbol{\varepsilon}_{\mathbf{p}}$. Para que a deformação $\varepsilon$ permaneça constante, é preciso que a deformação elástica diminua com o tempo e a deformação plástica cresça proporcionalmente, e, como conseqüência, a tensão necessária para se ter $\boldsymbol{\varepsilon}$ constante deve diminuir com o aumento da fluência. $\mathrm{O}$ aumento de $\boldsymbol{\varepsilon}_{\mathbf{e}}$ é igual ou menor que o aumento de $\boldsymbol{\varepsilon}_{\mathbf{p}}$ [Souza, 1982].

\subsection{2 - Dano e Início de Trincas em Temperaturas Elevadas}

Nucleação de trinca por fadiga em ligas à temperatura elevada é influenciada por diferentes processos microscópicos que dependem da temperatura, do nível de tensão e do meio ambiente. Os mecanismos responsáveis pelo início das trincas de fadiga podem ser geralmente agrupados nas seguintes categorias: (i) trinca induzida por deslizamento cíclico, (ii) cavitação de contorno de grão por fluência, (iii) escorregamento de contorno de grão e o desenvolvimento de trincas em cunha, (iv) nucleação e crescimento de vazios a partir de inclusões e precipitados, e (v) oxidação e corrosão.

\subsection{3- Deslizamento Cíclico}

A natureza do deslizamento cíclico é afetada pela temperatura. As observações seguintes fornecem uma ilustração do papel da temperatura sobre o fenômeno.

1. Em temperaturas superiores à metade da temperatura homóloga, a maioria dos materiais começa a exibir características de deslizamento alternado. Nas ligas com solução sólida, a energia de falha de empilhamento geralmente aumenta com o aumento da temperatura. A ativação térmica também permite o movimento de discordâncias por escalagem e deslizamento cruzado.

2. A irreversibilidade cinemática do deslizamento cíclico é aumentada por oxidação e/ou difusão de gás em temperaturas elevadas.

3. A tendência para deslizamento alternado pode ser contraposta, em alguns materiais, pelo envelhecimento por deformação dinâmica que favorece o deslizamento planar.

4. O processo de movimento de discordâncias por escalagem é dependente do tempo, o que torna a deformação em temperaturas elevada sensível à taxa de deformação. 
5. A estabilidade microestrutural, na maioria dos materiais de engenharia, diminui em temperaturas elevadas. Alterações microestruturais ativadas termicamente podem surgir como resultado de envelhecimento por deformação, recuperação ou precipitação. Essas alterações microestruturais podem ser benéficas ou nocivas à resistência a fadiga; em outro caso elas modificam consideravelmente as características tensão-deformação cíclicas.

\subsubsection{1 - Cavitação por Fluência}

Segundo Suresh [Suresh, 1998], em temperaturas entre 1/3 e 2/3 do ponto de fusão e baixas tensões impostas, a maioria dos metais, ligas e cerâmicas exibem deformação por fluência através da cavitação nos contornos de grãos. Estas cavidades nucleiam em pontos triplos de contornos de grão, em partículas no contorno de grão ou em saliências nas facetas intergranulares. Em muitas ligas de engenharia, cavidades de fluência nucleiam bem abaixo da tensão nominal de $100 \mathrm{MPa}$, e sua nucleação ocorre continuamente sobre fração substancial da vida em fluência [Riedel, 1987]. O escorregamento cisalhante das faces de contornos de grão também auxilia a nucleação de cavidades. Um aspecto particularmente interessante da cavitação de fluência sob carregamento cíclico é que o grau da cavitação é fortemente afetado pela forma de onda da tensão. Taxas de deformação lenta em tração e rápida em compressão, isto é, forma de onda com longos períodos em tensão de tração, exibe uma maior propensão para cavitação que ciclos de carregamento balanceados em que a magnitude da parte de carregamento em tração varia de maneira idêntica à fase de compressão, Figura 2.3 [Majumdar, 1980; Baik, 1982]. 

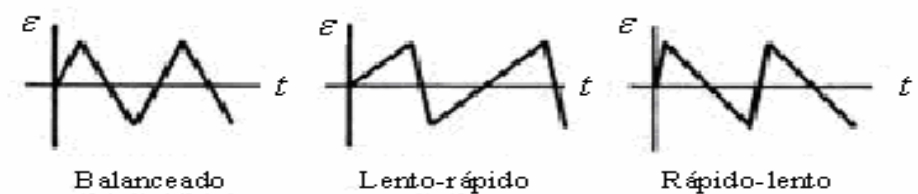

(a)

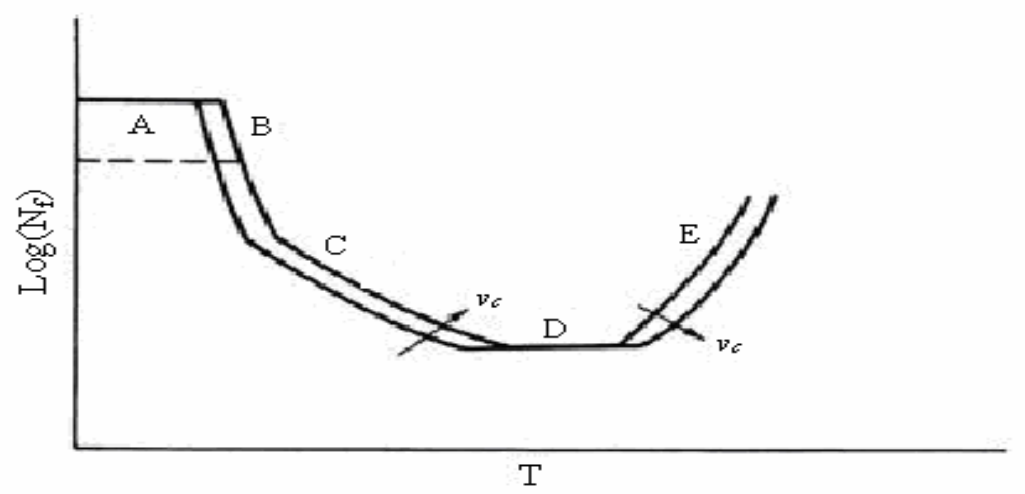

(b)

Figura 2.3 - (a) Esquema de carregamento em fadiga balanceado, lento-rápido e rápido-lento. (b) Mapa dos mecanismos de vida em fadiga como função da temperatura (para valores fixos de variação não linear de deformação e freqüência) para carregamento lento-rápido em fluência-fadiga [Riedel, 1987].

Riedel (1987) considerou várias teorias diferentes para cavitação de fluência para carregamento lento e rápido de fadiga e apresentou um mapa de mecanismos para vida em fadiga como função da temperatura, para valores fixos de variação da deformação, $\Delta \varepsilon$, e freqüência de teste.

Em temperaturas intermediárias representadas pelo regime $\mathrm{C}$, ocorre crescimento de cavidade por difusão, na qual as cavidades nucleiam continuamente por todo teste de fluênciafadiga. Para baixos valores de deformação acumulada $2 \Delta \varepsilon N f$, o efeito da freqüência $v_{\mathrm{c}}$ e temperatura $\mathbf{T}$ no regime $\mathbf{C}$ são descritos pela relação $N f \alpha\left(v_{\mathbf{c}} \mathbf{T} / \boldsymbol{\delta}_{\mathrm{g}} \mathbf{D}_{\mathbf{b}}\right)^{2 / 5}$, na qual $\mathbf{D}_{\mathbf{b}}$ é o coeficiente de difusão do contorno de grão. Para maiores valores de $N f$, regime $\mathbf{B}$, a deformação acumulada é tão grande que a densidade de cavidades satura cedo na vida em fadiga. Para este caso, $\boldsymbol{N f} \alpha \boldsymbol{v}_{\mathbf{c}} \mathbf{T} / \boldsymbol{\delta}_{\mathbf{g}} \mathbf{D}_{\mathbf{b}}$. Para temperaturas baixas representada pela região $\mathbf{A}, o$ crescimento plástico de cavidades é postulado para ser o mecanismo dominante. Este processo é independente da freqüência se a formação de cavidades superficiais é completamente irreversível.

Para temperaturas superiores, região $\mathbf{D}$, as cavidades crescem tão rápido que a taxa de deformação imposta, a qual é assumida constante dentro do quadro da Figura $2.3 b$, pode não acomodar por muito tempo volume da cavidade. Conseqüentemente, o crescimento da 
cavidade no modo de carregamento lento-rápido torna-se restringido. Para temperaturas ainda mais elevadas, região $\mathbf{E}$, o crescimento de cavidades restringidas ocorre no segmento de compressão rápido. Uma vez que as taxas de difusão são altas nestas temperaturas, o crescimento de cavidades começa a ser restringida tanto na tração como na compressão. Isso resulta em crescimento de cavidade zero, melhorando a vida em fadiga.

\subsubsection{2 - Escorregamento de Contorno de Grão}

Muitos estudos experimentais [Driver, 1971; Min, 1979] mostraram que o escorregamento de contorno de grão tem um papel importante na nucleação de cavidades intergranulares em fadiga-fluência. Este processo é também uma das considerações mecanísticas no particionamento empírico da variação da deformação inelástica no cálculo da vida em fadiga-fluência. Sobre a suposição de que o escorregamento de contorno de grão (rate-limiting step) é o fator limitante na nucleação de trincas na junção tripla e que elas não ocorrem acima de um valor crítico da taxa de deformação imposta $\dot{\mathcal{E}}_{c r} r$, Min \& Raj (1979) desenvolveram o seguinte modelo apresentado na Equação (2.1):

$$
\dot{\varepsilon}_{c r}=\frac{8 \sigma_{y} \Omega \delta_{g} D_{b}}{k T d_{g} f_{b} d_{p}^{2}}
$$

na qual $\sigma_{\mathbf{y}}$ é a tensão limite de escoamento do material, $\boldsymbol{\Omega}$. é o volume atômico, $\boldsymbol{k}$ é a constante de Boltzman, $\mathbf{T}$ é a temperatura absoluta $(\mathrm{K}), \boldsymbol{d} \boldsymbol{g}$ é o tamanho de grão, $\boldsymbol{f} \boldsymbol{b}$ é a fração em volume de partículas nucleadoras de cavidade no contorno de grão, $\boldsymbol{d} \boldsymbol{p}$ é o tamanho médio das partículas e os termos restantes serão definidos na seção seguinte.

De acordo com esta teoria, se o formato da onda é tal que as taxas de deformação na tração e compressão estão abaixo de um valor crítico, nenhum dano líquido é produzido, desde que o escorregamento de contorno de grão ocorra igualmente na direção de carregamento avançado e reverso. Com o carregamento lento-rápido e taxa de deformação na

fase de compressão maior que $\dot{\varepsilon}_{c r}$ é produzido dano máximo. Embora esse modelo seja uma simplificação do processo de escorregamento de grão, ele oferece entendimento dos efeitos de forma de onda em fadiga em temperatura elevada em muitas ligas.

A cavitação de contorno de grão pode ser afetada por variações relativas de temperatura e tensão com o tempo. Experimentos de Fujino \& Taira (1980), sobre aço 
inoxidável AISI 304 mostraram que a fadiga termomecânica em-fase produz maior dano que quando o carregamento ocorre na situação fora-de-fase e que este tipo de fadiga termomecânica resulta em menor tempo de vida para o componente se comparada com fadiga isotérmica. Esta variação da resistência à fadiga termomecânica para diferentes condições de carregamento aparenta exibir uma correlação com a quantidade de escorregamento de contorno de grão.

Nucleação de trincas sub-superficiais por fadiga pode ocorrer em temperaturas elevadas pela decoesão de inclusões e partículas de segunda fase com a matriz. Em algumas ligas de alumínio, a nucleação de vazios ao redor de precipitados no contorno de grão causam cavitação mesmo em temperaturas baixas [Vasudevan, 1987]. Além disso, o aumento da precipitação durante o processo de fadiga em temperatura elevada produz um grande número de sítios de nucleação de vazios.

\subsubsection{3 - Oxidação e Corrosão}

A presença de meio-ambiente oxidante ou agressivo pode influenciar os mecanismos de nucleação de trincas por fadiga, em temperaturas elevadas, das seguintes maneiras:

1. impedindo a sinterização ou fechamento de cavidades em temperaturas elevadas;

2. sob a influência de uma tensão-aplicada, cavidades são iniciadas ao redor de precipitados no contorno de grão [Wells, 1979]. Além disso, a precipitação de gases residuais pode proporcionar núcleos para cavidades, com a pressão interna do gás acelerando o crescimento das cavidades. O gás oxigênio ou outra espécie de fragilizante pode difundir ao longo do seu contorno e reagir com precipitados ali presentes se os contornos de grão perto da superfície não estiverem protegidos por uma camada de óxido.

3. A combinação de difusão superficial e oxidação, durante os estágios de deslizamento, promovem aumento cinemático do deslizamento cíclico, o que resulta em nucleação de trincas por fadiga (Figura 2.4). Este processo é comumente conhecido como mecanismo de Fujita [Fujita, 1963].

4. Oxidação preferencial em certos sítios microestruturais, tais como a intersecção do contorno de grão com a superfície livre, causa concentradores de tensão (entalhes) microscópios. Os micro entalhes elevam a tensão local e promovem nucleação de trincas [Duquette, 1979]. 
5. Cargas repetidas rompem o filme de óxido protetor sobre a superfície do material. A ausência do filme protetor proporciona um caminho ativo para ataque químico. Além disso, o trincamento do filme frágil do óxido, por si mesmo, pode levar a um crescimento de uma falha catastrófica de fadiga [Wells, 1979].

Para muitos materiais, a deterioração da resistência à fadiga em temperaturas elevadas é meramente uma conseqüência das interações com o meio-ambiente. A base experimental para esta inferência está ilustrada pelos resultados de Coffin (1973) para a liga ferrosa AISI A286 (Figura 2.5).

Aqui a variação da deformação plástica $\Delta \boldsymbol{\varepsilon p}$ com o número de ciclos para falhar $\mathbf{N}_{\mathbf{f}}$ não é afetada pela temperatura ou freqüência no vácuo. Contudo, abaixando-se a freqüência de teste a vida em fadiga de baixo ciclo é reduzida severamente em temperaturas elevadas no ar.
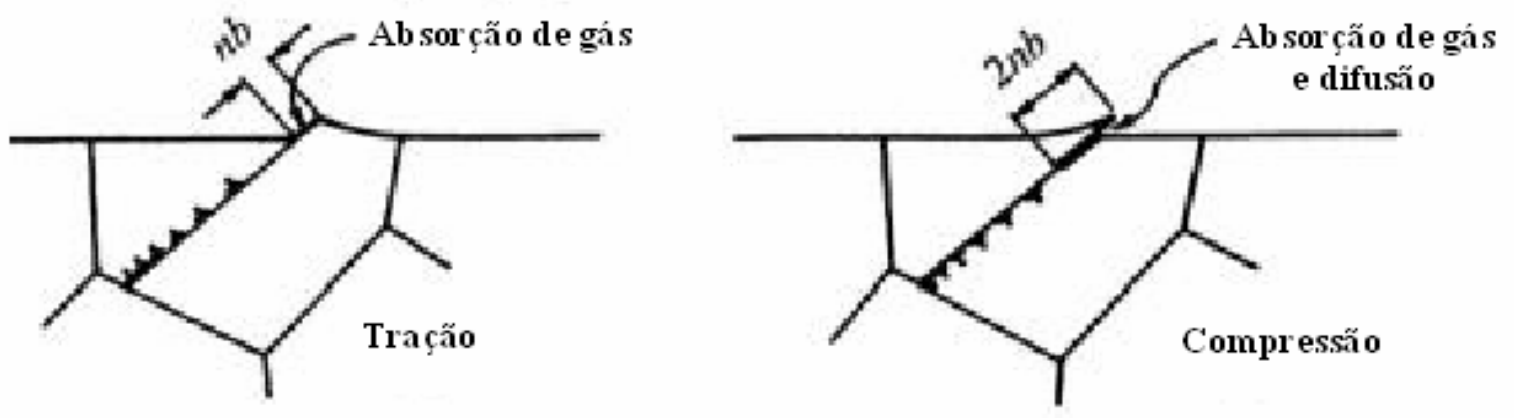

Figura 2.4 - Esquema do mecanismo de Fujita para nucleação de trincas por fadiga [Suresh, 1998].

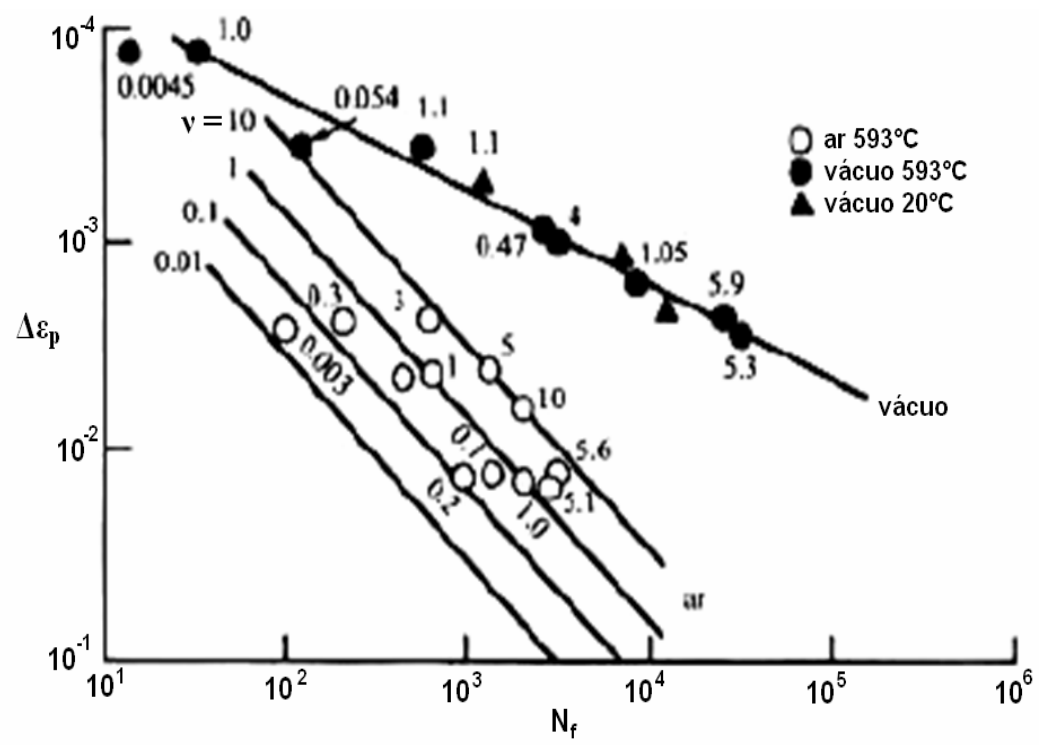

Figura 2.5 - Variação da deformação plástica em função da vida para liga AISI A286 em ar e vácuo com variação da freqüência e temperatura [Coffin, 1973]. 


\section{3 - Fadiga de Baixo Ciclo}

Como já visto, o ensaio de fadiga consiste na aplicação de carga cíclica em corpo de prova apropriado e padronizado segundo o tipo de ensaio a ser realizado. Os materiais metálicos, quando submetidos a tensões flutuantes ou repetitivas, isto é, quando sob a ação de esforços cíclicos, rompem-se a tensões muito inferiores àquelas determinadas nos ensaios de tração e compressão. A ruptura que ocorre nessas condições dinâmicas de aplicação de esforços é conhecida como ruptura por fadiga. Este fenômeno ocorre após um tempo considerável a que o material é submetido a esforços. À medida que o desenvolvimento tecnológico, por exigência da indústria (ex: aeronáutica e automobilística), incorporou novos componentes e equipamentos, submetidos continuamente a esforços dinâmicos e vibrações, o fenômeno de fadiga passou a ser a causa de mais de $90 \%$ das falhas de componentes metálicos em serviço. A falha em fadiga é particularmente imprevisível, pois acontece sem que haja qualquer aviso prévio.

Por volta de 1871, o engenheiro alemão A. Wöhler realizou a primeira investigação sistemática do comportamento à fadiga dos eixos ferroviários. Realizou ensaios de fadiga em modelos de tamanho natural e, também, em corpos de prova pequenos submetidos a carregamentos cíclicos de flexão, torção e tração-compressão, utilizando vários tipos de materiais. Os resultados foram registrados em termos da tensão convencional ( $\boldsymbol{\sigma})$ em função do logaritmo do número de ciclos $(\mathbf{N})$, o qual se tornou conhecido como curva $\boldsymbol{\sigma}-\mathbf{N}$ ou curva de Wöhler. A curva $\boldsymbol{\sigma}$-N é geralmente determinada utilizando-se determinadas quantidades de corpos de prova segundo recomendações das normas ASTM E466 (1996), ASTM E468 e ASTM E739 (1991). Estas recomendam, dentre outras coisas, uma quantidade mínima de corpos de prova para cada nível de tensão ensaiado, que é determinado pelo grau de precisão exigido do ensaio.

O método de tensão-vida $(\boldsymbol{\sigma}-\mathbf{N})$ foi a primeira metodologia usada em uma tentativa de entender e de quantificar a fadiga de metais. Esta metodologia é extensivamente utilizada em aplicações de projetos em que a tensão aplicada se encontra predominantemente dentro do regime elástico do material e a vida resultante (ciclos para falhar) é longa, sendo as tensões e deformações linearmente relacionadas, determinada de fadiga de alto ciclo. Conseqüentemente, neste intervalo, os resultados de ensaios sob controle de carga ou de deformação são equivalentes, mas as curvas $\sigma-\mathbf{N}$ são geradas por ensaios sob controle de carga. Porém, o método de tensão-vida não é adequado em aplicações de baixo-ciclo, em que 
deformações aplicadas têm uma componente plástica significativa. Neste caso, uma metodologia baseada em deformação é mais apropriada [Bannantine, 1990].

Assim, fadiga de baixo ciclo está relacionada com condições de serviço nas quais as falhas ocorrem para tensões relativamente altas, e baixos números de ciclos para falha (menores que $10^{5}$ ). As condições para que ocorra fadiga de baixo ciclo são freqüentemente criadas quando as tensões repetidas são de origem térmica. Como as tensões térmicas devemse à expansão ou contração térmica do material, a fadiga resulta de deformação cíclica em vez de tensão cíclica. Também, segundo Suresh (1998), informações derivadas de análises em tensão cíclica baseadas na mecânica do contínuo dizem respeito principalmente à deformação elástica sem restrição mecânica. Em muitas aplicações práticas, componentes de engenharia geralmente sofrem certo grau de restrição estrutural e deformação plástica localizada, particularmente em regiões de concentração de tensões. Este tipo de problema deve ser considerado nos projetos de vasos de pressão para indústria nuclear, componentes de turbinas a vapor, motores aeronáuticos e em muitos outros tipos de equipamentos e máquinas, como discos de freio, por exemplo [Dieter, 1981].

Os ensaios de fadiga de baixo ciclo são realizados com controle de deformação e os resultados obtidos são registrados em gráficos como logaritmo de deformação em função do logaritmo do número de reversos $\left(\mathbf{2 N}_{\mathbf{f}}\right)$.

Coffin e Manson apud Suresh [Suresh, 1998], trabalharam independentemente em problemas de fadiga térmica, e propuseram a caracterização da vida em fadiga com base na amplitude de deformação plástica. Eles observaram uma relação linear (equação (2.2)) entre o logaritmo da amplitude de deformação plástica e o logaritmo do número de reversos para falhar em materiais metálicos.

$$
\frac{\Delta \varepsilon_{p}}{2}=\varepsilon_{f}^{\prime}(2 N)^{c}
$$

onde $\boldsymbol{\varepsilon f}$ ' é o coeficiente de ductilidade de fadiga e $c$ é o expoente de ductilidade de fadiga. Em geral $\boldsymbol{\varepsilon} \boldsymbol{f}$ 'é aproximadamente igual ao coeficiente de ductilidade verdadeiro, $\boldsymbol{\varepsilon} f$, em tração e $c$ está dentro da faixa de $-0,5$ a $-0,7$ para a maioria dos metais.

Em escala bilogarítmica, a relação da equação (2.2) pode ser relacionada por uma reta, como mostra a Figura 2.6. 
A amplitude de deformação total de um ensaio com amplitude de deformação constante pode ser escrita como a soma das amplitudes de deformação elástica e plástica, como segue na equação (2.3):

$$
\frac{\Delta \varepsilon}{2}=\frac{\Delta \varepsilon_{e}}{2}+\frac{\Delta \varepsilon_{p}}{2}
$$

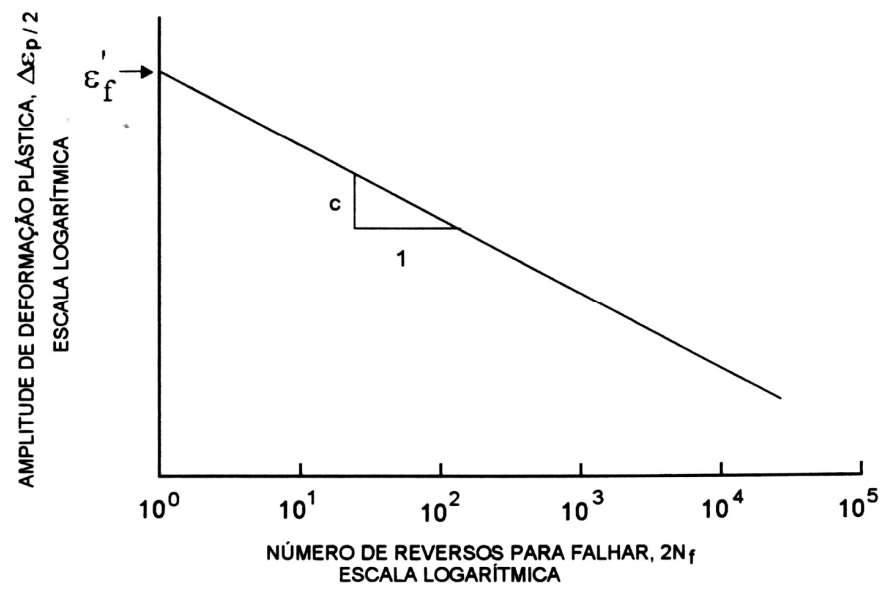

Figura 2.6 - Amplitude de deformação plástica em função do número de reversos, escala bilogarítmica [Dieter, 1981].

Utilizando a equação 2.4 de Basquin apud Suresh (1998), para relacionar a amplitude de tensão (Figura 2.7):

$$
\frac{\Delta \sigma}{2}=\sigma_{f}^{\prime}(2 N)^{b}
$$

onde $\sigma f^{\prime}$ é o coeficiente de resistência à fadiga e $\frac{\Delta \sigma}{2}$ corresponde à amplitude de tensão $\sigma_{\mathrm{a}}$. O coeficiente de resistência à fadiga, of', e o expoente de resistência à fadiga, b, são propriedades de fadiga dos materiais. O valor de $\mathbf{b}$ varia entre -0.05 e -0.12 , e para muitos metais of' é aproximadamente igual à tensão real na fratura, determinada no ensaio de tração.

Observando a equação (2.5):

$$
\frac{\Delta \varepsilon_{e}}{2}=\frac{\Delta \sigma}{2 E}=\frac{\sigma_{f}^{\prime}}{E}\left(2 N_{f}\right)^{b}
$$


onde $\boldsymbol{E}$ é o módulo de Young, pode-se reescrever a equação (2.3) como indicado na equação (2.6):

$$
\frac{\Delta \varepsilon}{2}=\frac{\sigma_{f}{ }^{\prime}}{E}(2 N)^{b}+\varepsilon_{f}^{\prime}(2 N)^{c}
$$

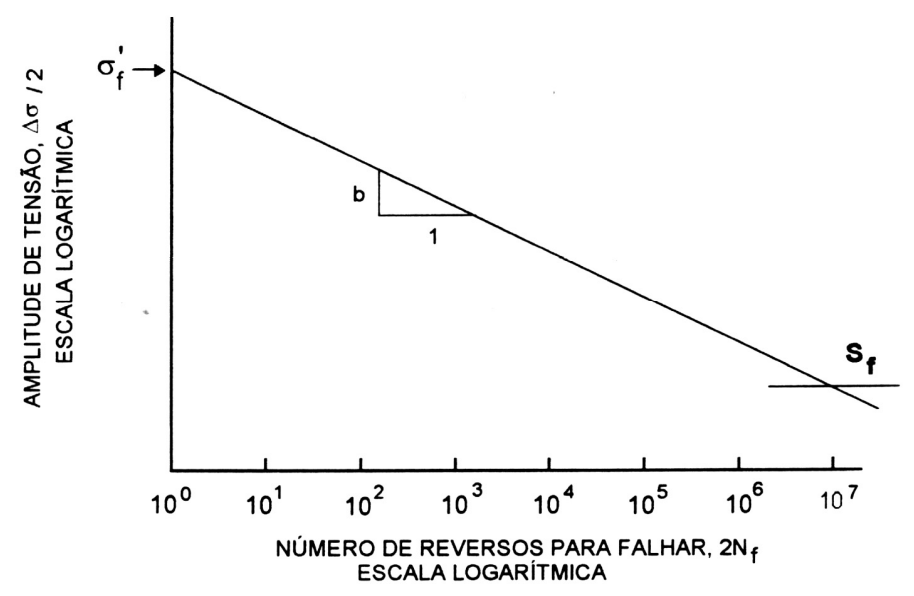

Figura 2.7 - Tensão verdadeira em função do número de reversos, em escala bilogarítmica [Dieter, 1981].

As amplitudes de deformação total, plástica e elástica são apresentadas no gráfico da Figura 2.8 como função do número de reversos para falhar $(2 N)$. Pode-se definir uma transição entre fadiga de baixo e alto ciclo no ponto em que as amplitudes de deformação plástica e elástica são iguais $(\mathbf{2 N t})$. Segundo Suresh (1998), para fadiga de baixo ciclo $(\mathbf{2 N}<$ 2Nt) a deformação plástica é mais dominante que a elástica e a resistência à fadiga é controlada pela ductilidade do material. Já para fadiga de alto ciclo $(2 N>2 N t)$, a deformação elástica é mais significante que a plástica e a vida é controlada pela resistência do material. Para Mitchell [Mitchell, 1974], a otimização das propriedades de fadiga leva a um balanço entre resistência e ductilidade de um material. 


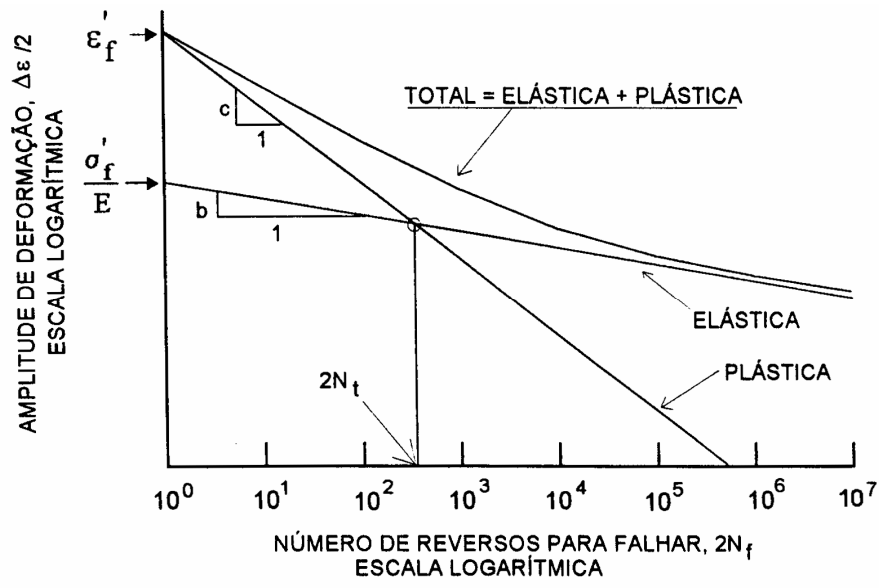

Figura 2.8 - Amplitude de deformação total em função do número de reversos para falhar, obtido da superposição da amplitude de deformação elástica e plástica em função do número de reversos para falhar [Suresh, 1998].

Os ensaios de fadiga de baixo ciclo geralmente são realizados sob controle de deformação. A Figura 2.9 apresenta um ciclo de tensão-deformação ideal resultante de um ensaio de fadiga de baixo ciclo onde a deformação cíclica é mantida constante.

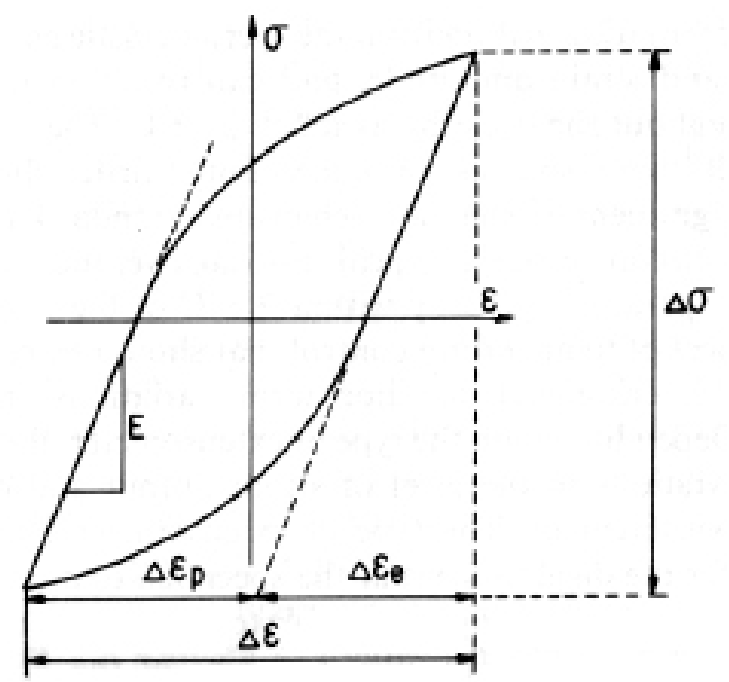

Figura 2.9 - Ciclo de histerese tensão-deformação ideal resultante de um ensaio de fadiga de baixo ciclo com deformação cíclica constante [Thomas, 1987].

Durante o carregamento e o descarregamento, desenvolve-se um ciclo de histerese que tem suas dimensões descritas por sua largura $\Delta \varepsilon$, o intervalo total de deformação, e por sua altura $\Delta \sigma$, que é o intervalo de tensões. O intervalo total de deformação $\Delta \varepsilon$ consiste em um componente de deformação elástica $\Delta \boldsymbol{\varepsilon}_{\mathrm{e}},=\Delta \sigma / \boldsymbol{E}$ mais um componente de deformação plástica 
$\Delta \boldsymbol{\varepsilon}_{\mathrm{p}}$. A largura do ciclo de histereses dependerá do nível de deformação cíclica; com um nível pequeno, o ciclo de histereses torna-se muito estreito.

Para os ensaios realizados sob $\Delta \varepsilon$ constante, o intervalo de tensãọ $\Delta \sigma$ normalmente varia com o aumento do número de ciclos. Os materiais recozidos experimentam endurecimento cíclico, o que significa que $\Delta \sigma$ aumenta com o númerọ de ciclos até atingir a saturação após cerca de 100 ciclos de deformação. O aumento no intervalo de tensões será maior quanto maior for o valor de $\Delta \varepsilon$. Os materiais que previamente sofreram trabalho a frio experimentam amolecimento cíclico, isto é, $\Delta \sigma$ decresce com o aumento do número de ciclos de deformação. Então, a maneira usual de apresentação dos resultados dos ensaios de fadiga de baixo-ciclo consiste no. lançamento em gráfico da amplitude de deformação $\Delta \varepsilon / 2$ contra o número dẹ reversos para falhar, $\mathbf{2} \boldsymbol{N}_{f}$.

Normalmente a fadiga de baixo ciclo aparece identificada como fadiga isotérmica de baixo ciclo, fadiga térmica de baixo ciclo ou fadiga termomecânica de baixo ciclo. A fadiga de baixo ciclo pode ser identificada por dois caminhos: (1) ciclagem de alta deformação quando a faixa de deformação inelástica no ciclo excede a faixa de deformação elástica e (2) quando as deformações inelásticas são de magnitude tal que se espalham uniformemente pela microestrutura. Danos de fadiga a elevadas temperaturas desenvolvem-se como resultado destas deformações inelásticas quando as mesmas não são recuperáveis. Nos casos de baixos ciclos, o material sofre danos após um pequeno número de ciclos. Fadiga termomecânica é geralmente uma resultante de fadiga de baixo ciclo. Por exemplo, em motores a jato os maiores gradientes e transientes térmicos ocorrem durante a partida e desligamento. O número total de decolagens e pousos durante a vida de uma aeronave é menor que 30.000 ciclos. Neste caso, em laboratório, as investigações são conduzidas sob condições de baixo ciclo e podem ser concluídas em curto espaço de tempo.

\subsection{1 - Fadiga Isotérmica}

O ensaio de fadiga isotérmico consiste na imposição de uma deformação mecânica variável, mantendo a temperatura constante. Este tipo de ensaio tem sido muito utilizado a partir da década de 70, com o surgimento de máquinas de ensaio que funcionam em ciclo fechado. Tem como vantagem principal a simplicidade de execução e o baixo custo quando comparado aos ensaios anisotérmicos, sendo que resultados para diversos materiais podem ser encontrados na literatura (Coffin Jr., 1954). 
Observações feitas por vários pesquisadores mostraram que a vida encontrada em fadiga isotérmica é maior que aquela encontrada para fadiga anisotérmica [Hetnarski, 1991; Shi, 1998]. Isto pode ser verificado pelo estudo realizado por Shi et al [Shi, 1998], e ilustrado na Figura 2.10, com uma liga de molibdênio que contém 0,5\% de Ti, 0,08\% de $\mathrm{Zr}$ e Carbono na faixa de 0,01 a $0,04 \%$.

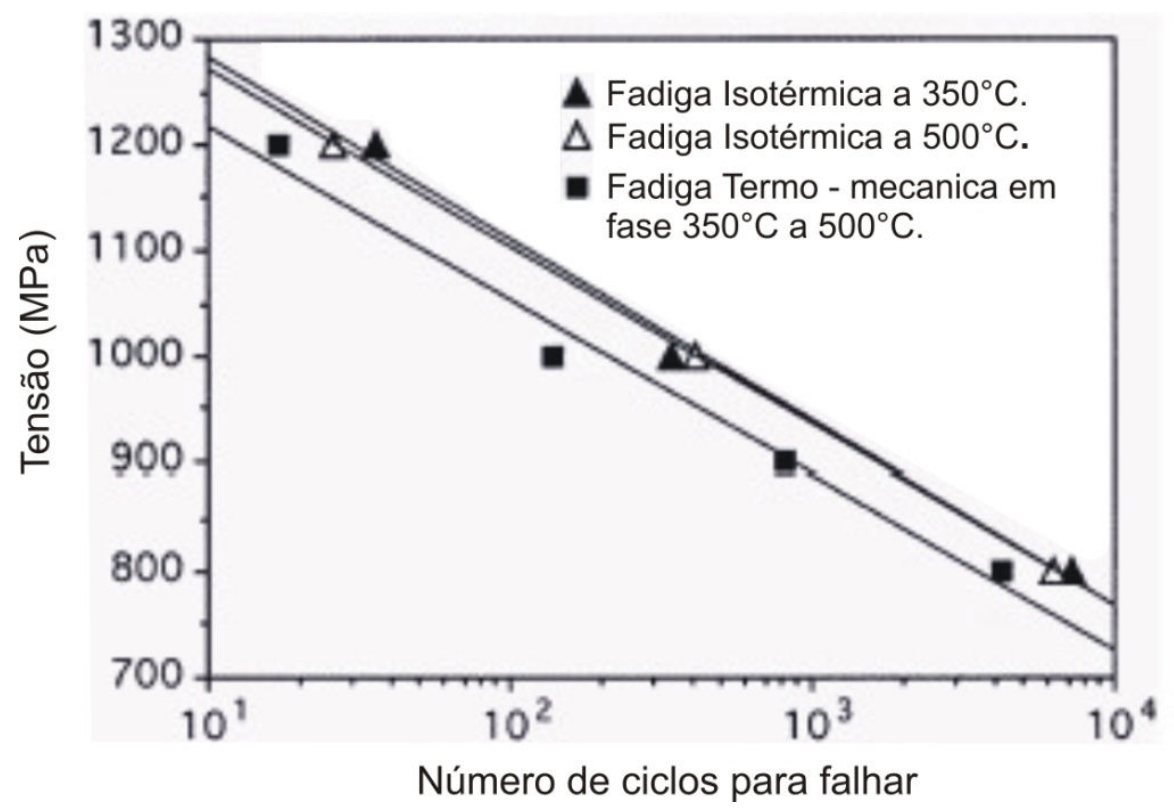

Figura 2.10 - Curva de fadiga isotérmica e termomecânica [Shi, 1998].

As vidas obtidas em ensaios de fadiga isotérmica para dois níveis de temperatura estudados $\left(350^{\circ} \mathrm{C}\right.$ e $\left.500^{\circ} \mathrm{C}\right)$ foram maiores, em ambos os casos, quando comparadas com a vida encontrada em fadiga termomecânica em fase para a faixa de temperatura de $350^{\circ} \mathrm{C}$ a $500^{\circ} \mathrm{C}$, demonstrando que a variação da temperatura produz um grande dano no material. Porém, entre os dois tipos de experimentos isotérmicos analisados, não se observou nenhuma diferença obvia quanto ao número de ciclos para falha do corpo de prova, certificando que nesta faixa de temperatura o material mantém uma boa resistência. Então, projetos baseados somente em resultados de fadiga isotérmica em componentes que trabalham em altas temperaturas não são confiáveis, sendo necessário um estudo mais aprofundado do comportamento dos materiais sujeitos a este fenômeno, incluindo ensaios em intervalos de temperaturas diferentes (fadiga anisotérmica), e faixas de tensão e deformação variáveis.

A Figura 2.11 mostra que a maior vida em fadiga isotérmica ocorre em uma faixa intermediária da temperatura aplicada. Nesta faixa, a menor vida encontrada para o aço 
inoxidável austenítico $316 \mathrm{~L}(\mathrm{~N})$ sob fadiga isotérmica ocorreu à temperatura ambiente $\left(25^{\circ} \mathrm{C}\right)$, onde a deformação induziu a formação da martensita.

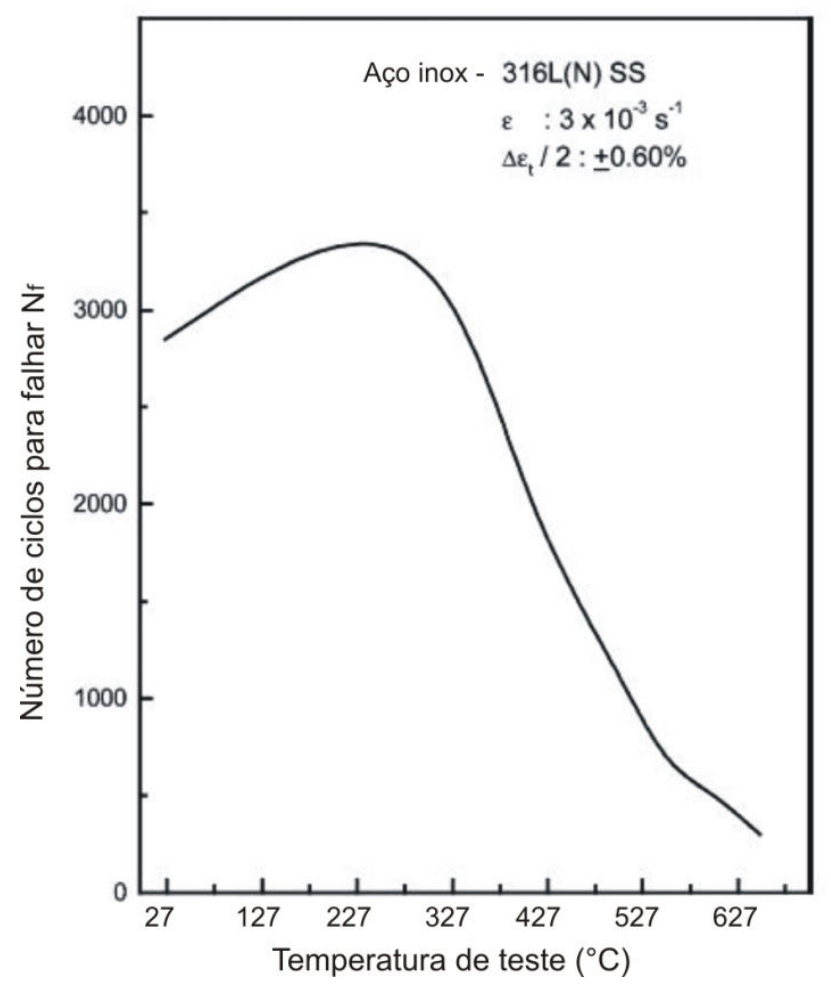

Figura 2.11 - Influência da temperatura na vida em fadiga [Srinivasan, 2003].

Já para $573 \mathrm{~K}\left(300^{\circ} \mathrm{C}\right)$ ocorreu uma recuperação sub-estrutural do material que foi responsável pelo aumento na vida. A redução na vida com a continuidade do aumento da temperatura é atribuída a diversos efeitos da deformação dinâmica, como, por exemplo, a concentração de tensões provocada em locais de empilhamento de discordâncias quando se atinge a tensão máxima do ciclo, causando um aumento na taxa de crescimento da trinca. Isto fica bem nítido para temperaturas maiores que $873 \mathrm{~K}\left(600^{\circ} \mathrm{C}\right)$, em que a vida foi significantemente reduzida pela oxidação [Srinivasan, 2003].

Outro aspecto a ser observado em fadiga isotérmica com controle de deformação é o comportamento da tensão cíclica em função da vida. Para aço inoxidável austenítico 316L $(\mathrm{N})$, o comportamento do material foi acompanhado por quatro estágios, conforme pode ser visto na Figura 2.12 [Srinivasan, 2003].

A liga exibiu um curto período de endurecimento cíclico, atingindo uma tensão máxima no estágio inicial da vida. Então, observa-se que acontece um amolecimento cíclico antes que o regime estável seja atingido. No período anterior à fratura, a amplitude de tensão 
decresce rapidamente, indicando a formação de uma macro-trinca e sua subseqüente propagação. $\mathrm{Na}$ mesma figura, pode-se observar que a amplitude do pico de tensão desenvolvido aumenta com o aumento na temperatura, para a faixa de 573 a $873 \mathrm{~K}$, [Srinivasan, 2003] e, também, que alguns fatores contribuem para a queda na resistência do material com o aumento na temperatura. São eles: taxa anormal de endurecimento cíclico e redução na amplitude de deformação plástica na vida intermediária à fratura, e aumento na taxa da tensão máxima nos primeiros ciclos com aumento na temperatura, desenvolvida devida à interação indutiva entre os solutos de difusão e mobilidade das discordâncias durante a deformação. Todos estes fenômenos são considerados processos de manifestação do período de deformação dinâmica.

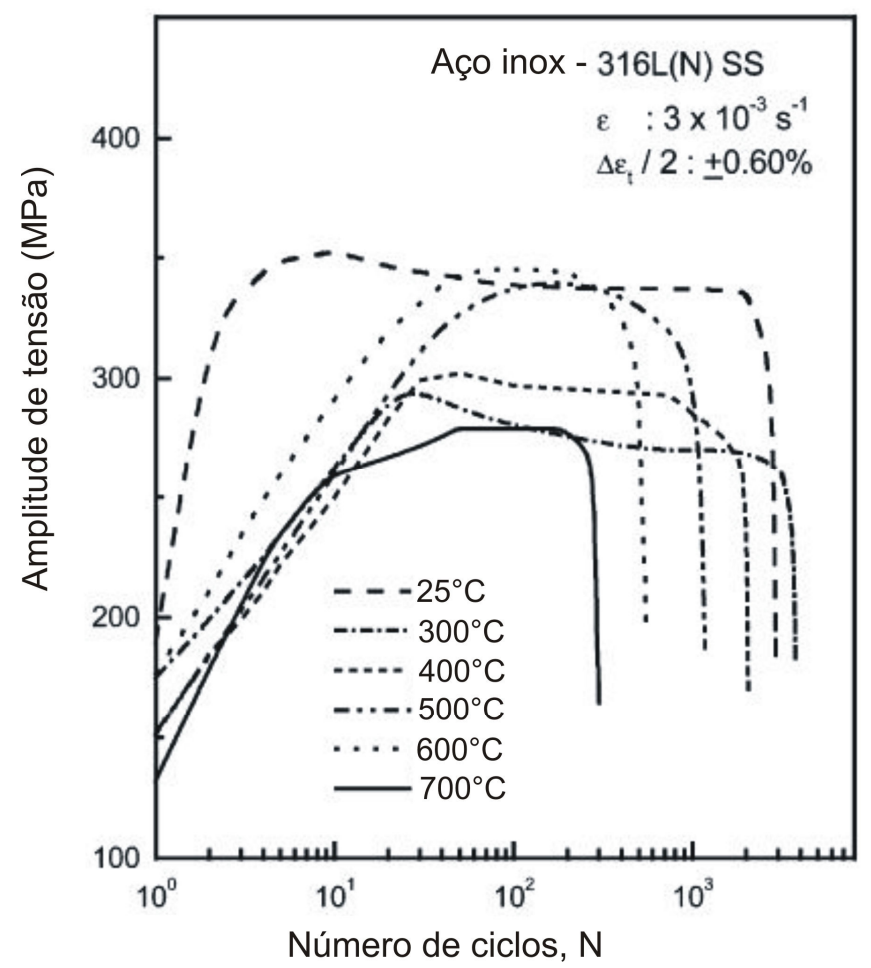

Figura 2.12 - Resposta da tensão cíclica em função da temperatura [Srinivasan, 2003].

Uma discussão mais aprofundada das comparações entre fadiga isotérmica e anisotérmica será feita no próximo item. 


\subsection{2 - Fadiga Térmica e Termomecânica}

Vários componentes estão sujeitos a uma variedade de carregamentos térmicos e termomecânicos devido a variações de temperatura durante o período de funcionamento. As condições de carregamento cíclico induzido pelo gradiente de temperatura são essencialmente carregamentos limitados pela deformação. Então, os estudos laboratoriais de fadiga térmica são geralmente limitados pelo controle de deformação em testes de fadiga de baixo ciclo [Hetnarski, 1991]. O estudo do comportamento mecânico e dos mecanismos de fratura destes materiais é essencial para possibilitar melhoria do projeto e utilização racional destes componentes.

Se as tensões em um componente se desenvolvem sob ciclos térmicos sem carregamento externo, o termo fadiga térmica (FT) é utilizado. Este processo pode ser causado por gradientes abruptos de temperatura em um componente, ou através de uma seção, e pode ocorrer em um material perfeitamente homogêneo e isotrópico. Por exemplo, quando uma superfície é aquecida, ela é comprimida pelo material mais frio abaixo da superfície e assim a superfície é submetida a tensões compressivas. Sob resfriamento, a deformação está na direção contrária, e tensões de tração podem se desenvolver. Sob ciclos de aquecimento e resfriamento, a superfície irá sofrer danos por FT. Exemplos clássicos de FT são encontrados em rodas de composições ferroviárias sujeitas a ação de sapatas de freios, que geram gradientes de temperaturas e, conseqüentemente, tensões internas [Sehitoglu, 1996].

Por outro lado, FT pode se desenvolver em corpos de prova mesmo sob condições de temperatura uniforme, causada por restrições internas, tais como orientação de grãos diferentes ao nível microscópico ou anisotropia do coeficiente de expansão térmica de certos cristais (não cúbicos). As deformações e tensões internas podem ser de magnitude suficiente para causar aumento, distorção, e irregularidades superficiais no material. Conseqüentemente, ciclos térmicos resultam em danos e deterioração da microestrutura. Este comportamento tem sido observado em metais puros como urânio, estanho, e ligas a base de cádmio e em aços duplex com microestrutura formada de ferrita e martensita.

O termo fadiga termomecânica (FTM) descreve a fadiga sob variação simultânea de temperatura e deformação mecânica. A deformação mecânica é determinada pela subtração da deformação térmica da deformação total, a qual deve ser uniforme em todo corpo de prova. A deformação mecânica origina-se das restrições externas ou carregamentos aplicados externamente. Por exemplo, se um corpo de prova é mantido entre duas paredes rígidas e submetido à ciclagem térmica (sem permitir expansão), ele sofrerá deformação mecânica 
compressiva "externa". Exemplos de FTM podem ser encontrados em vasos de pressão e tubulações, na indústria de geração de energia elétrica, onde estruturas sofrem carregamentos de pressão e transientes térmicos com gradientes de temperaturas na direção da espessura, e na indústria aeronáutica, onde pás e discos de turbinas sofrem gradientes de temperaturas sobrepostas a tensões devido à rotação.

Segundo Sehitoglu [Sehitoglu, 1996], a fadiga termomecânica pode envolver vários mecanismos adicionais ao dano "puro" por fadiga, incluindo fluência a temperaturas elevadas e oxidação, as quais contribuem diretamente ao dano. Estes mecanismos diferem-se, dependendo do histórico da deformação e temperatura. Eles são diferentes dos previstos por testes de fluência (sem reversos) e por testes de oxidação sem tensões (ou de tensões constantes). A degradação microestrutural pode ocorrer sob FTM na forma de (1) superenvelhecimento, tais como coalescimento de precipitados e lamelas; (2) envelhecimento por deformação no caso de sistemas endurecidos por solução sólida; (3) precipitação de partículas de segunda fase; e (4) transformação de fase dentro da temperatura limite do ciclo. Variações nas propriedades mecânicas ou no coeficiente de expansão térmica entre matriz e precipitados (presentes em muitas ligas), também resultam em tensões locais e trincas. Estes mecanismos influenciam as características de deformação do material, as quais inevitavelmente associam-se com os processos de dano.

Por esta razão, técnicas mais avançadas de ensaios a temperaturas variáveis foram desenvolvidas, tais como, os ensaios de fadiga térmica (FT) e fadiga termomecânica (FTM), cujas diferenças principais são mostradas esquematicamente na Figura 2.13 [MeyerOlbersleben, 1995; Engler-Pinto Jr., 1994].

O ensaio de FT consiste em submeter um corpo de prova, de geometria similar ao do componente a ser estudado, a ciclos alternados de aquecimento e resfriamento. As tensões, de origem interna, são conseqüências da geometria do corpo de prova, das velocidades de aquecimento e de resfriamento e das propriedades do material. É um ensaio de cunho mais tecnológico, já que seus resultados possibilitam uma aplicação imediata em projeto, pois determinam a vida útil de um corpo de prova com geometria semelhante ao componente estudado e servem para comparar diferentes tipos de materiais de maneira confiável. Por outro lado, apresenta o inconveniente de não permitir que sejam realizadas medições diretas de deformação e de tensão, que devem ser calculados, por exemplo, através do método de elementos finitos. Para tanto, segundo Mallet et al. (1995), é necessário utilizar algum modelo matemático para que o comportamento mecânico do material seja equacionado. $\mathrm{O}$ ensaio de FTM, entretanto, é caracterizado pela superposição, de maneira independente e simultânea, de 
um ciclo de deformação em função do tempo, $\boldsymbol{\varepsilon}(\boldsymbol{t})$, a um ciclo de temperatura em função do tempo, $T(t)$, segundo uma história termomecânica previamente estabelecida. A deformação externa é imposta por uma máquina de ensaios especialmente adaptada e informatizada, substituindo a deformação interna do ensaio de FT. O ensaio é uniaxial e deve ser realizado a freqüências baixas, de modo que sejam evitados gradientes de temperatura ao longo do corpo de prova, permitindo que a parte útil do corpo-de-prova ensaiado esteja sujeito a uma variação uniforme da temperatura, tensão e deformação. Assim, todas as variáveis macroscópicas podem ser medidas ou controladas, o que não é possível de ser realizado na fadiga térmica [Fuchs, 1980].

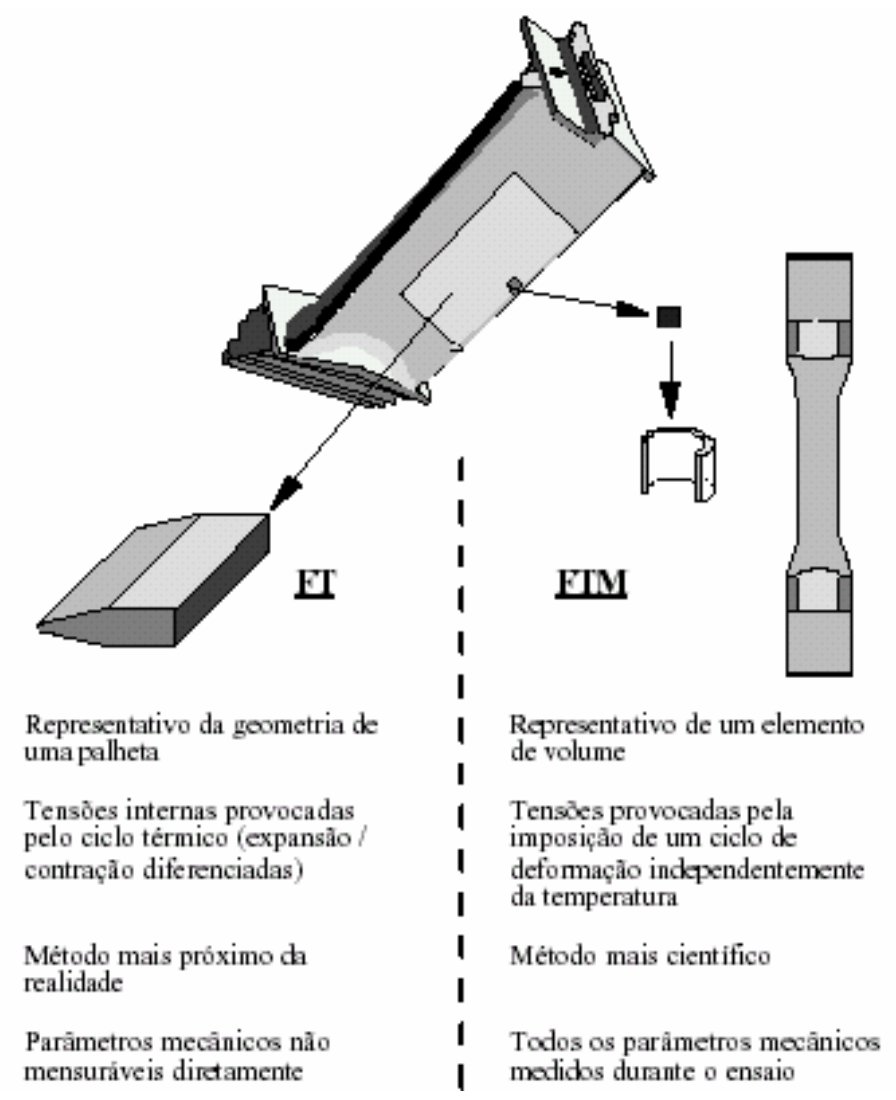

Figura 2.13 - Comparação esquemática entre os ensaios de fadiga térmica e fadiga termomecânica [Engler-Pinto Jr., 1996].

Apesar da complexidade e do custo elevado, o ensaio FTM é mais científico, já que todos os parâmetros influentes são controlados pelo pesquisador. É útil para que seja determinado, em condições anisotérmicas, mais próximas da realidade, o comportamento mecânico dos materiais e, deste modo, auxilia o desenvolvimento e possibilita a verificação 
dos modelos matemáticos utilizados no cálculo de tensões e deformações de componentes reais ou de corpos de prova de FT [Mallet,1995].

Segundo Sehitoglu [Sehitoglu, 1996], uma distinção importante deve ser feita entre FTM e choque térmico. Choque térmico envolve uma variação muito rápida na temperatura (devido ao aquecimento da superfície ou geração interna de calor), e as tensões resultantes são geralmente diferentes daquelas produzidas por condições de aquecimento e resfriamento lentos (ou seja, quase-estático). Propriedades físicas, tais como calor específico e condutividade (as quais não aparecem em casos de baixa taxa de deformação), aparecem claramente em casos de choque térmico. A taxa de deformação influencia na resposta do material e deve ser considerada na análise de danos devido ao choque térmico ou na seleção de materiais para melhor resistência ao choque térmico.

Sehitoglu [Sehitoglu, 1996] e Sarabanda [Sarabanda, 1991] afirmaram que se um corpo é submetido a condições de ciclagem térmica com uma superimposição de cargas na seção, o componente sofrerá fluência térmica cíclica (thermal ratcheting), que é a acumulação gradual de ciclos de deformação inelástica. Este tipo de falha envolve mecanismos de fadiga e rompimento dúctil que às vezes ocorre sem intenção em ensaios de FTM quando uma região do corpo de prova está mais quente que as vizinhanças, resultando em uma saliência na região quente.

O evento de iniciação de trinca em fadiga térmica é uma função decrescente da distância da superfície do sólido, devido ao campo temperatura-deformação-tensão gerada nas regiões superficiais em componentes estruturais. Por isso, a força dirigente para se propagar uma trinca térmica é freqüentemente decrescente com o crescimento da trinca, já que quanto mais longe a trinca está do campo de temperatura-deformação-tensão gerada, menos esta será influenciada pela fadiga térmica, sendo menor, portanto, a sua propagação. Porém, para testes de fadiga isotérmica ou termomecânica, onde os componentes estão sob condições de temperatura uniformes, a trinca, ao crescer em direção ao interior do material, atinge um campo de tensão-deformação mais severo, já que a área da seção transversal do componente é reduzida pelo crescimento da trinca [Hetnarski,1991]. 


\subsubsection{1 - Aspectos da Resposta Cíclica Tensão-Deformação}

A terminologia utilizada para ensaios à temperatura ambiente não é sempre adequada para ensaios a temperaturas elevadas. O limite de elasticidade, por exemplo, é muito difícil de ser definido para temperaturas superiores a $\mathbf{0 , 4} \mathbf{T}_{\mathbf{f}}$, onde $\mathbf{T}_{\mathbf{f}}$ é a temperatura de fusão. No caso de ensaios de fadiga anisotérmica, a situação é ainda mais complicada devido à ausência de normatização, sendo que uma comissão internacional continua trabalhando na elaboração de uma norma para este tipo de ensaio. Assim sendo, serão definidos alguns termos utilizados em um ciclo de histerese anisotérmico, como apresentado na Figura 2.14.

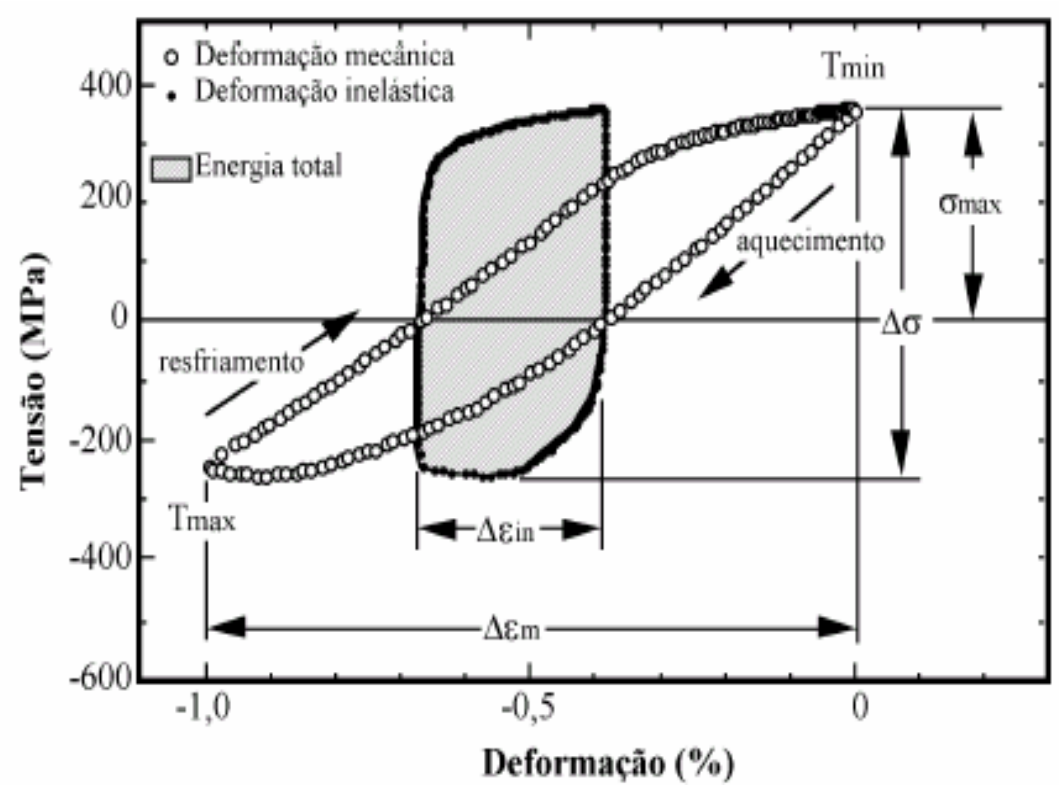

Figura 2.14 - Exemplo de um ciclo de histerese anisotérmico fora de fase (Engler-Pinto Jr., 1996).

A deformação total $\left(\varepsilon_{\text {tot }}\right)$ medida durante um ensaio de fadiga anisotérmica é a soma da deformação mecânica $\left(\varepsilon_{\mathbf{m}}\right)$, imposta pela máquina de ensaio, com a deformação térmica (ou dilatação térmica, $\boldsymbol{\varepsilon}_{\text {th }}$ ), resultante da variação de temperatura (equação (2.7)):

$$
\varepsilon_{t o t}=\varepsilon_{m}+\varepsilon_{b}
$$

A deformação térmica em um corpo sem restrições não provoca tensões e pode ser determinada pela relação apresentada na equação (2.8): 


$$
\varepsilon_{\mathrm{f}}=\alpha(T)\left(T-T_{a m b}\right)
$$

onde $\alpha(\boldsymbol{T})$ é o coeficiente de dilatação térmica, $\boldsymbol{T}$ é a temperatura e $\boldsymbol{T}_{\boldsymbol{a} \boldsymbol{}}$ é a temperatura ambiente.

Por outro lado, a deformação mecânica pode ser decomposta (equação (2.9)) em deformação elástica $\left(\varepsilon_{\mathrm{e}}\right)$ e deformação inelástica $\left(\boldsymbol{\varepsilon}_{i n}\right)$ :

$$
\varepsilon_{m}=\varepsilon_{e}+\varepsilon_{i}
$$

e o termo $\varepsilon_{\mathrm{e}}$ é obtido pela lei de Hooke (equação (2.10)):

$$
\varepsilon_{e}=\sigma / E(T)
$$

onde $\sigma$ é a tensão e $\mathbf{E}(\mathbf{T})$ é o módulo de elasticidade em função da temperatura instantânea.

Além disso, $\boldsymbol{\varepsilon}_{\text {in }}$ é formada por dois componentes distintos em temperaturas elevadas: deformação plástica $\left(\varepsilon_{\mathrm{p}}\right)$, provocada pelas tensões superiores ao limite de elasticidade do material, e deformação de fluência $\left(\boldsymbol{\varepsilon}_{\mathrm{fl}}\right)$, devido à ativação térmica.

Coffin tem sumarizado a relação básica de tensão - deformação para vários ciclos e histórias de aquecimento, como ilustrados na Figura 2.15.

Pode ser visto que a curva de histerese é totalmente complexa e descontínua, explicando, então, a grande dificuldade na predição da vida em fadiga dos componentes que trabalham em altas temperaturas [Fuchs, 1980].

A fadiga térmica é vista como um processo não balanceado de repetição, ou seja, a resposta da metade do ciclo trativo difere da resposta da metade do ciclo compressivo, sendo uma função da temperatura. Existem três aspectos básicos do comportamento tensão deformação que são importantes em mecanismos cíclicos não balanceados: elástico, plástico e fluência [Hetnarski, 1991].

- ELÁSTICO - A resposta tensão-deformação elástica de um sólido é função da temperatura, já que o módulo de elasticidade decresce invariavelmente com o aumento da temperatura. Então, um ciclo termomecânico elástico em fase exibe uma resposta não linear, 
já que o sólido é endurecido na temperatura mais baixa do ciclo, e mais concordante para a temperatura mais alta. A resposta tensão-deformação cíclica elástica está ilustrada na Figura 2.16, e exibe uma curvatura côncava-declinante. O ciclo mostrado é completamente reverso em termos da deformação, mas não reverso com respeito à tensão. Pode-se observar que a tensão trativa é menor que a tensão compressiva, que corresponde à diferença de valores do módulo de elasticidade em temperaturas elevadas. Então, a diferença de tensão em desequilíbrio é uma função direta da faixa e do nível de temperatura [Hetnarski, 1991].

- PLÁSTICO - Se for considerada uma deformação termomecânica suficientemente alta, o material sofrerá deformação plástica. Isto acarretará uma resposta da tensão trativa versus tensão compressiva não linear e não balanceada (Figura 2.17). Tipicamente, o limite de elasticidade decresce com o aumento da temperatura, tendo então uma resposta de tensão mais baixa para a temperatura mais alta. Haverá também uma mudança leve na deformação elástica e plástica, embora a deformação total seja completamente reversa [Hetnarski, 1991].

- FLUÊNCIA - O pico da tensão máxima é menor em um teste termomecânico com uma baixa taxa de deformação, onde a fluência é favorecida, que em um teste com uma taxa de deformação maior, devido ao fato que a fluência reduz a resistência do material. (Figura 2.18). A resposta do pico de tensão para a temperatura mais baixa será essencialmente independente da taxa de deformação. Portanto, a metade do ciclo referente à temperatura mais alta se torna cada vez mais não balanceada com relação à metade do ciclo referente à temperatura mais baixa, com o decréscimo na taxa de ciclagem ou com o aumento na temperatura máxima do ciclo, que são fatores que favorecem o processo da fluência [Hetnarski, 1991]. 


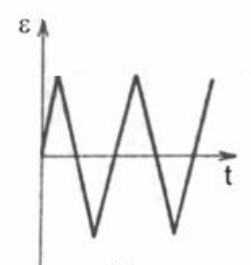

(a)

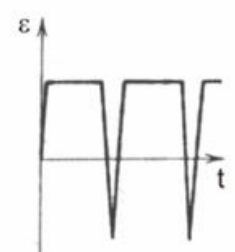

(b)

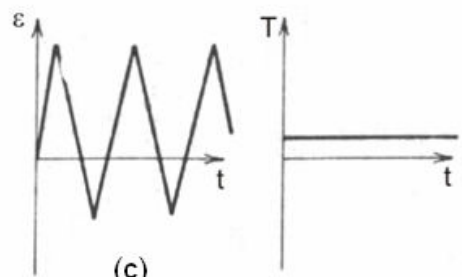

(c)
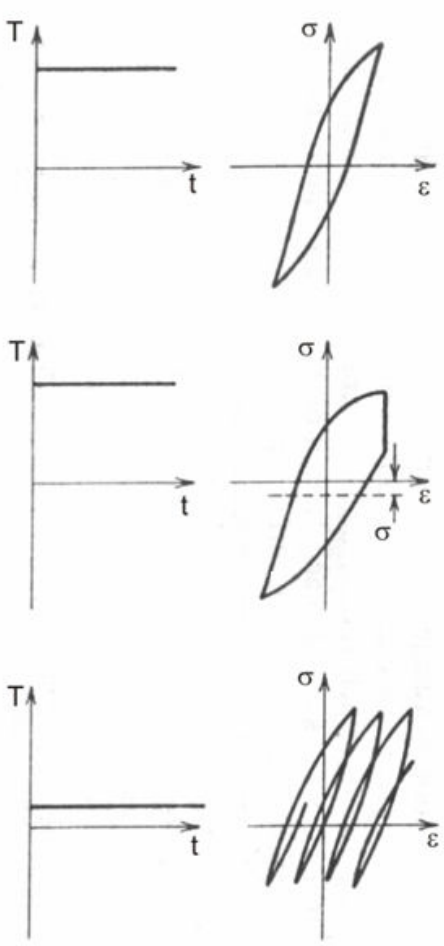
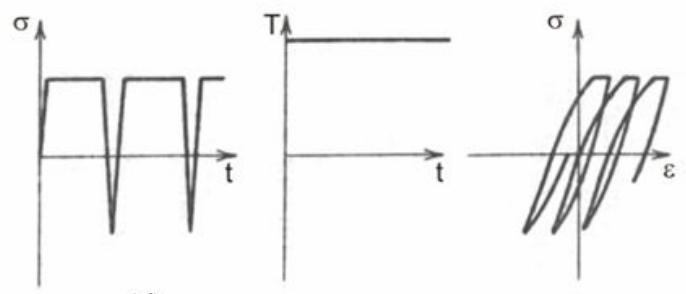

(d)
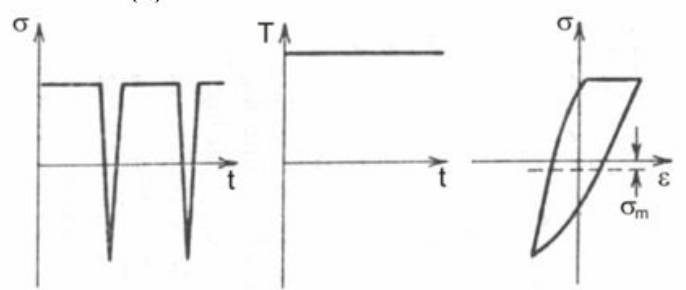

(e)

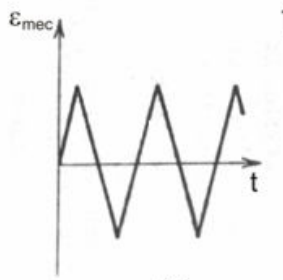

(f)

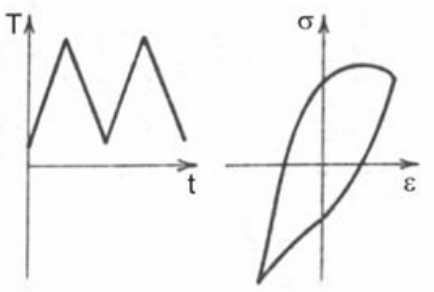

Figura 2.15 - Relação tensão-deformação para várias histórias de carregamento e tipos de ciclagem (a) deformação cíclica contínua (continuous strain cycling), (b) patamar de deformação (strain hold), (c) ciclo contínuo de tensão média (continuous mean stress cyclic), (d) patamar de tensão (stress hold), (e) limite de deformação-patamar de tensão (stress holdstrain limit (CP)), (f) situação termomecânica (mixed mechanical-thermal) [Fuchs, 1980].

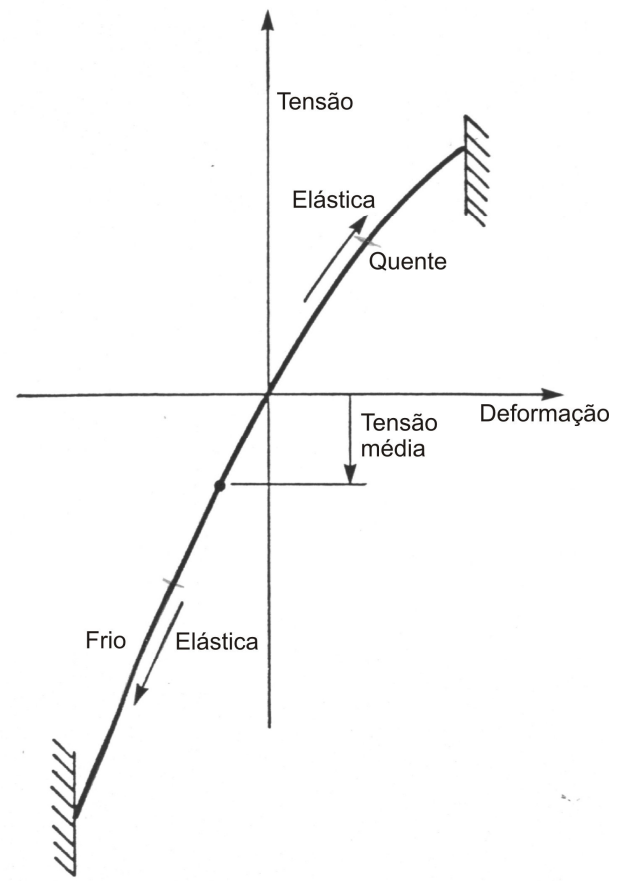

Figura 2.16 - Curva de histerese para condições de deformação termomecânicas elásticas, para ciclagem em fase [Hetnarski, 1991]. 


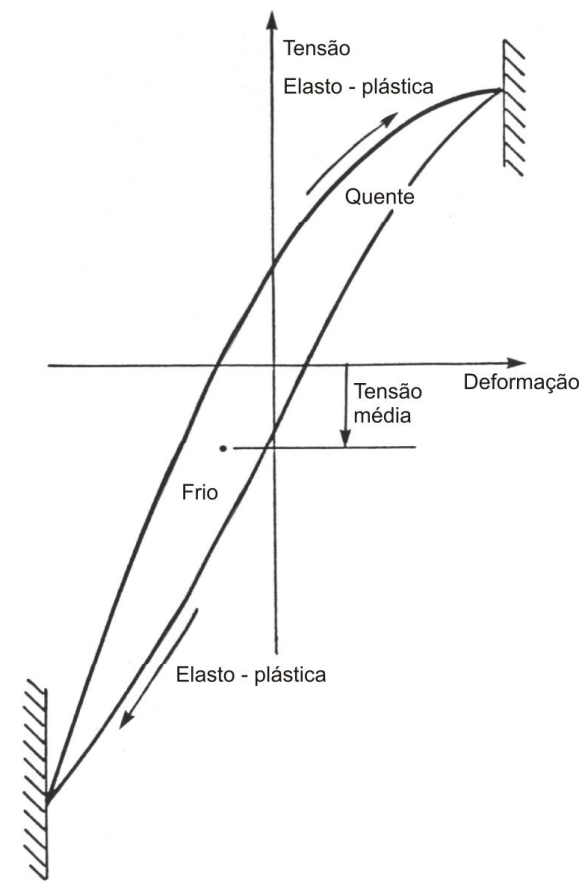

Figura 2.17 - Curva de histerese para condições de deformação termomecânicas plásticas, para ciclagem em fase [Hetnarski, 1991].

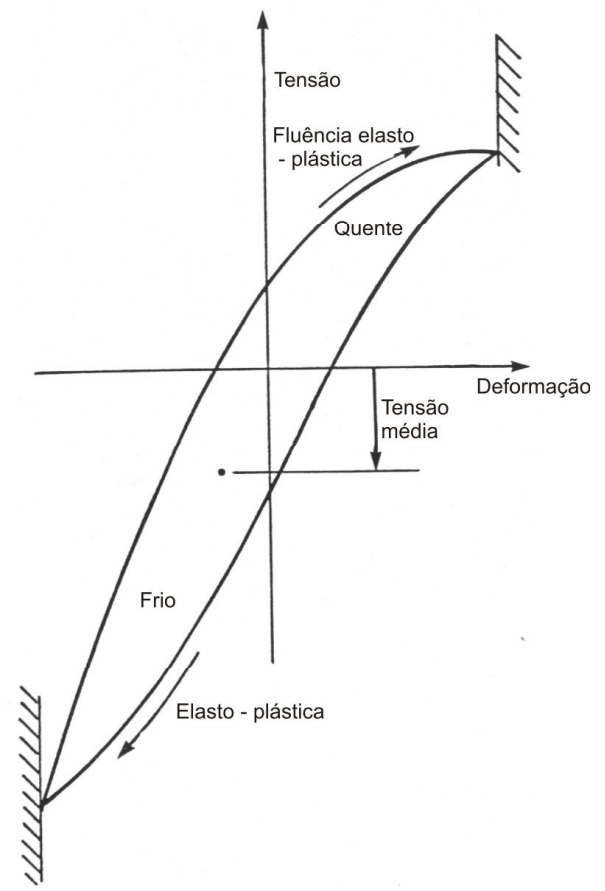

Figura 2.18 - Curva de histerese para condições de deformação termomecânicas por fluência, para ciclagem em fase [Hetnarski, 1991]. 


\subsubsection{2 - Fadiga Termomecânica (FTM) - Em Fase e Fora-de-Fase}

Os ensaios de FTM são classificados de acordo com a relação de fase entre a deformação mecânica e a temperatura. No ensaio de FTM em-fase (in-phase), a deformação mecânica máxima coincide com a temperatura máxima do ciclo. Já no ensaio de FTM forade-fase (out-of-phase), a deformação mecânica máxima coincide com a temperatura mínima do ciclo. A Figura 2.19 ilustra a variação térmica, mecânica e deformação total com o tempo para estes dois tipos de fase. $\mathrm{O}$ esquema do comportamento tensão-deformação correspondentes a estes dois casos está ilustrado na Figura 2.20, onde se pode observar que a tensão média do ciclo é trativa no caso de FTM fora-de-fase, e compressiva para o caso FTM em fase. Estes dois tipos de fase reproduzem muitos dos mecanismos que se desenvolvem na FTM [Cai, 1999].

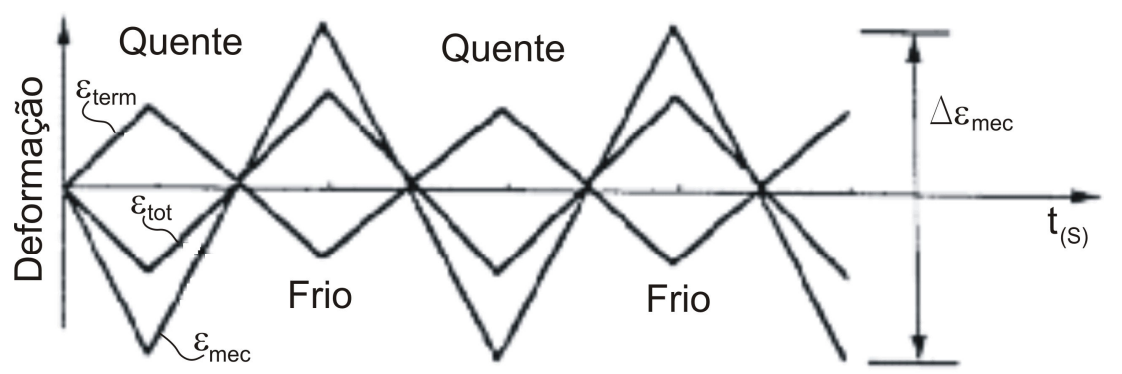

(a)

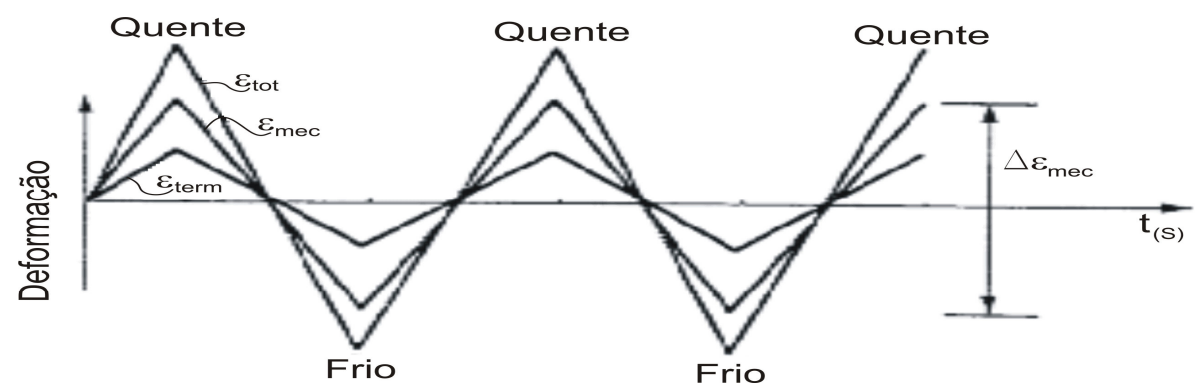

(b)

Figura 2.19 - Variação térmica, mecânica e deformação total em função do tempo para fadiga termomecânica (a) fora-de-fase (b) em-fase [Cai, 1999].

No entanto, análises térmicas e mecânicas mais recentes demonstraram que os elementos críticos de palhetas de turbinas apresentam valores máximo e mínimo de deformação em temperaturas intermediárias do ciclo, conforme mostra o ciclo tipo “diamante", ilustrado na Figura 2.21 [Sehitoglu, 1996]. Pode-se notar que é na temperatura 
intermediária que são alcançadas as mais altas deformações trativas e compressivas, enquanto que na maior e menor temperatura a deformação é zero [Cai, 1999].

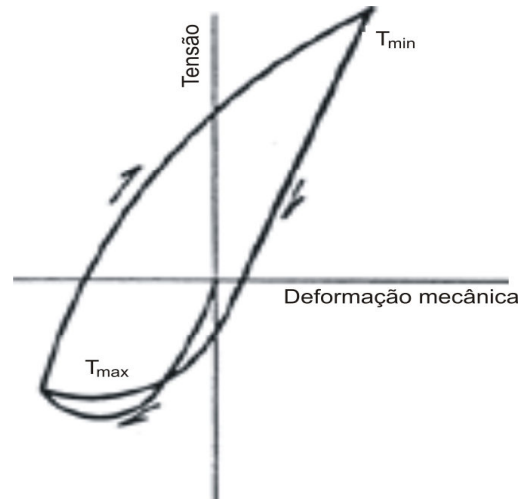

(a)

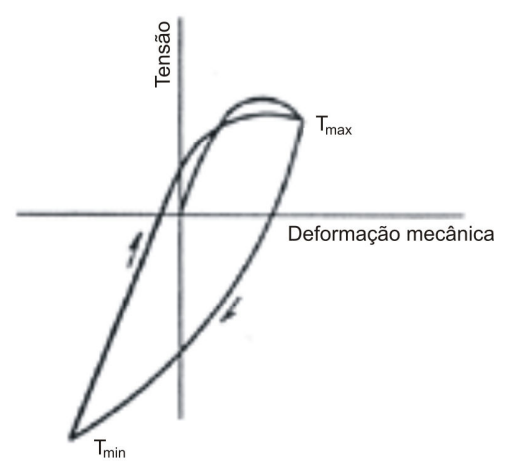

(b)

Figura 2.20 - Tensão em função da Deformação para fadiga termomecânica: (a) fora-de-fase; e (b) em fase [Cai, 1999].

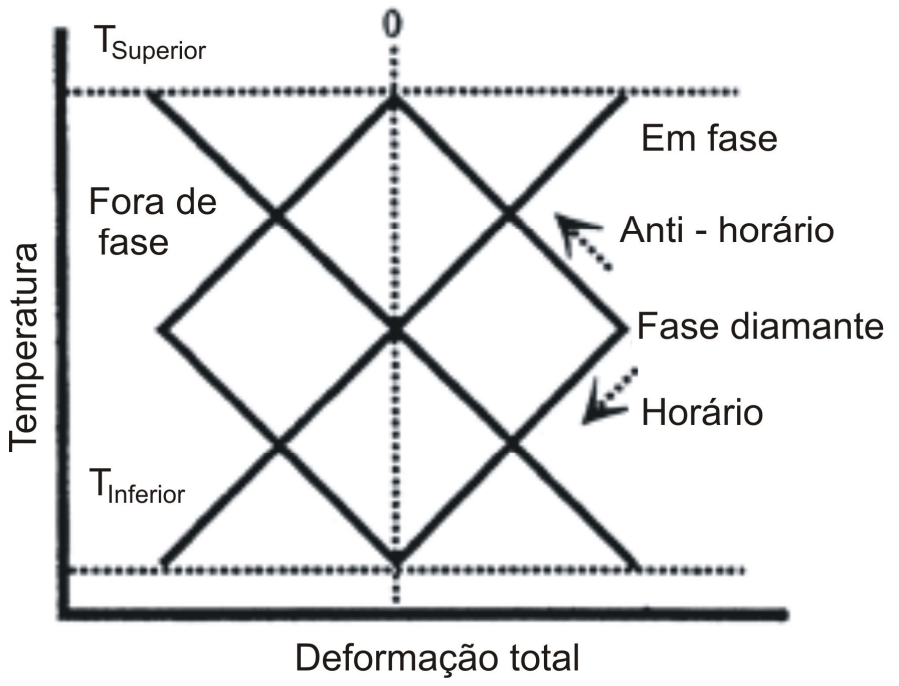

Figura 2.21 - Ciclo Temperatura - Deformação para diferentes testes de fadiga termomecânica ( $\mathbf{T}_{\mathbf{u}}-$ temperatura máxima, $\mathbf{T}_{\mathbf{l}}-$ temperatura mínima) [Cai, 1999].

Leverant et al. [Leverant, 1976] observou em seus ensaios, usando uma superliga de aço, com e sem camada protetora, que ambas não falharam quando os ensaios termomecânicos foram realizados na condição em fase. Naquele com a camada protetora as trincas não progrediram para falhas em função de que as condições do ensaio não causaram queda de ductilidade e, também, porque a máxima tensão foi aplicada na máxima temperatura. Já para ensaios de fadiga termomecânica fora-de-fase, houve falha apenas do material que possuía a camada protetora, pois esta foi trincada ao atingir a temperatura mais baixa do ciclo, devido à queda da sua ductilidade e às tensões trativas a que o material estava sujeito nesta condição de ensaio (Figura 2.22). 
Assim, pode-se observar que os mecanismos e a vida após a iniciação de uma trinca dependem tanto das propriedades do material quanto das condições de carregamento.

A relação entre temperatura e deformação durante a fadiga anisotérmica pode produzir combinações incomuns de mecanismos micro-estruturais. Em um estudo do comportamento sob fadiga termomecânica de uma superliga a base de níquel, MAR M-200, Bill et al. [Bill, 1984] observaram uma diferença significativa na resistência em fadiga termomecânica, dependendo do tipo de ciclagem imposta (Figura 2.23). Durante a ciclagem em fase, o pico de tensão trativa e a máxima deformação do material ocorrem simultaneamente ao pico da máxima temperatura. Neste caso, as trincas prematuras aparecem preenchidas de óxidos, o que não ocorre para a ciclagem fora-de-fase, pois a tensão compressiva fecha as trincas quando estas atingem a temperatura máxima, retardando o processo de oxidação. Então, ficou claro que a ciclagem fora-de-fase foi menos danosa que a ciclagem em fase. Além disso, estes dois tipos de condições de fadiga produzem diferentes modos de crescimento de trinca interna, já que a ciclagem em fase produz trincamento na interface carbeto-matriz, enquanto a ciclagem fora-de-fase causa fratura do próprio carbeto. Observa-se, também, na Figura 2.23 que, comparativamente, o material submetido à fadiga isotérmica apresentou maior vida que quando submetido a fadiga termomecânica tanto em fase como fora-de-fase.

Solidificação direcionada Mar M 200

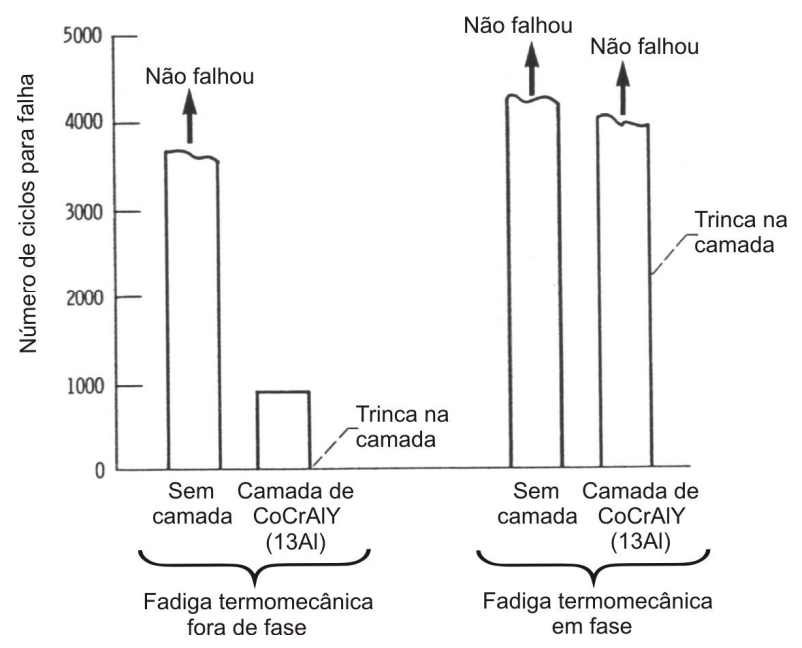

Figura 2.22 - Fadiga termomecânica em fase e fora-de-fase, para superliga de aço com e sem camada protetora, para temperatura entre 427 e $1038^{\circ} \mathrm{C}$ [Leverant, 1976]. 
Porém, Rau et al. (1973) encontrou em seus experimentos para uma superliga a base de cobalto MAR-M-509, recoberta através do tratamento superficial a plasma PWA 45, que a taxa de crescimento da trinca foi maior para a fadiga termomecânica fora-de-fase do que para a fadiga termomecânica em fase. Os autores explicam este comportamento devido à maior deformação produzida na ponta da trinca quando esta é comprimida em altas temperaturas, já que altas temperaturas produzem maiores deformações inelásticas.

Policristalino Mar M 200

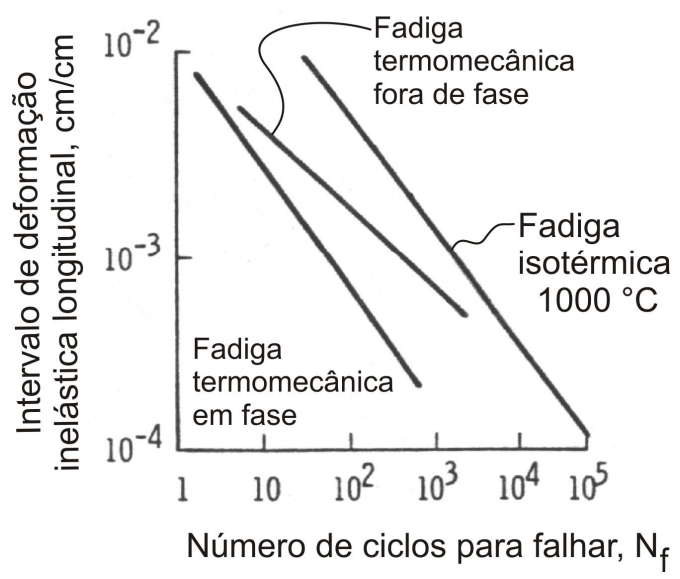

Figura 2.23 - Fadiga isotérmica e fadiga termomecânica em fase e fora-de-fase, para temperatura entre 495 e $1000^{\circ} \mathrm{C}$ [Bill, 1984].

Assim, pode-se observar que as fases do carregamento e temperatura podem produzir um significante efeito na ponta da trinca, dependendo do grau do carregamento, da quantidade da deformação, da tensão local, da exposição da ponta da trinca a ambientes oxidantes, e fluência local [Rau, 1973].

\subsubsection{3 - Instabilidades Metalúrgicas}

Sabe-se que materiais sujeitos a certos níveis de tensão e de deformação, quando expostos a determinadas condições ambientais tais como alta temperatura e gases reativos, podem produzir instabilidades metalúrgicas, desenvolvendo precipitados que alteram a deformação e características de resistência dos materiais [Hetnarski, 1991].

As mudanças na microestrutura do material (tamanho e orientação do grão cristalino, endurecimento por trabalho, precipitação de partículas de segunda fase, etc) são refletidas no 
"flow stress" cíclico, mudando a curva de histerese mecânica. Porém, a constatação de sua influência na resistência do material é difícil de ser analisada. Embora somente certas ligas sofram grandes e instáveis mudanças em suas propriedades, todos os materiais experimentam mudanças microestruturais em fadiga térmica diferentemente da esperada sob fadiga isotérmica. Então, na fadiga anisotérmica, a combinação das mudanças microestruturais causam alterações na resposta cíclica da tensão quando comparada com fadiga isotérmica, pois o material experimenta um endurecimento ao atingir o ciclo de tensão na temperatura mais baixa, tornando-o mais resistente na sua parte cíclica referente à maior temperatura, o que não acontece em fadiga isotérmica [Hetnarski, 1991].

Manson et al. [Manson, 1971] observaram em seus ensaios isotérmicos para uma superliga a base de cobalto L-605 que, em taxas reduzidas de deformação, reações metalúrgicas podem ocorrer, já que o material estará exposto à alta temperatura por mais tempo. O carbono, em solução sólida com a matriz, precipita formando carbeto do tipo $\mathbf{M}_{23} \mathbf{C}_{6}$. Como os carbetos aumentam em número e tamanho devido à continuidade do carregamento, a resposta tensão-deformação da liga muda drasticamente.

Ao analisar as causas da falha de uma palheta de turbina de Monel 738 LC, observouse que ocorreu a formação de trincas em cavidades mais frias a $0,4 \mathrm{~mm}$ de profundidade, que se propagaram em direção ao substrato, seguindo a trajetória da fronteira dos grãos (intergranular). A iniciação e propagação de trincas na matriz foram facilitadas devido à fragilização intergranular causada pela formação de um filme contínuo de carbeto nesta região. A análise metalográfica da microestrutura da palheta revelou que ela é formada por grãos equi-axiais de fase $\gamma$ e partículas finas de precipitados $\gamma^{\prime}$ dentro da matriz, com partículas dispersas de carbeto na fronteira do grão com o interior da matriz. O tamanho de grão foi de $365 \mu \mathrm{m}$. Porém, a microestrutura da fronteira de grão muda em serviço devido à instabilidade da fase $\gamma^{\prime}$. Esta mudança se dá como resultado da transformação de carbetos do tipo $\mathbf{M C}$ para carbetos do tipo $\mathbf{M}_{23} \mathbf{C}_{6}+\gamma^{\prime}$, devido á alta temperatura de operação em que a palheta se encontrava, formando um filme contínuo de carbeto ao longo da fronteira de grão, resultando em uma liga mais frágil. Esta densa e contínua ligação do carbeto formada reduz a ductilidade e resistência da liga em 30\% do valor inicial e facilita a iniciação e propagação de trincas, o que conduz a uma redução na vida do equipamento. A média do tamanho das partículas formadas nas zonas de aquecimento foi de 33\% a $89 \%$ maiores que aquelas da fase inicial e a média do alongamento da fase formada foi de $8 \%$ a $50 \%$ maior que a fase inicial. Também, observou-se que a iniciação e propagação de trincas foram derivadas de 
mecanismos mistos de fadiga e fluência. A iniciação da trinca na camada superficial ocorreu provavelmente devida à tensões desenvolvidas por causa do mecanismo de fadiga térmica, como resultado de alto carregamento e do transiente térmico, e a propagação no substrato se deu por fluência, como mostram os vazios de fluência encontrados na análise microestrutural [Mazur, 2005].

\subsubsection{4 - Resistência á Fadiga}

A variação da resistência à fadiga com a temperatura é de extraordinária importância na fadiga térmica e termomecânica, já que estes casos envolvem a exposição de um material a um espectro de temperatura em cada ciclo de carregamento. Com poucas exceções, a resistência à fadiga dos materiais decresce com o aumento na temperatura devido a mecanismos de dano como a fluência e oxidação (Figura 2.24) [Hetnarski, 1991].

A mudança na resistência à fadiga da liga depende de vários fatores, como por exemplo, da deformação imposta, do tempo de exposição da liga à alta temperatura, e da temperatura a qual a liga está exposta, como mostra a Figura 2.25.

Portanto, a resistência à fadiga torna-se dependente da história cíclica imposta, e não mais somente do nível de carregamento imposto. Isto foi observado considerando dois níveis de temperatura diferentes para o mesmo carregamento em fadiga para uma superliga a base de cobalto L-605 [Manson, 1971]. Na temperatura mais baixa, ocorreu a geração de discordância, mas não se observou a precipitação de carbetos. Já na temperatura mais elevada, ocorreu a geração de discordância e precipitação de carbetos. Quando a liga é ciclada entre estas duas temperaturas, o efeito endurecedor que ocorre na temperatura mais elevada irá afetar o comportamento do material quando este atingir a temperatura mais baixa. Assim, a vida em fadiga térmica será diferente da vida em fadiga isotérmica onde, o efeito metalúrgico não é sinergístico como no caso da fadiga térmica. 


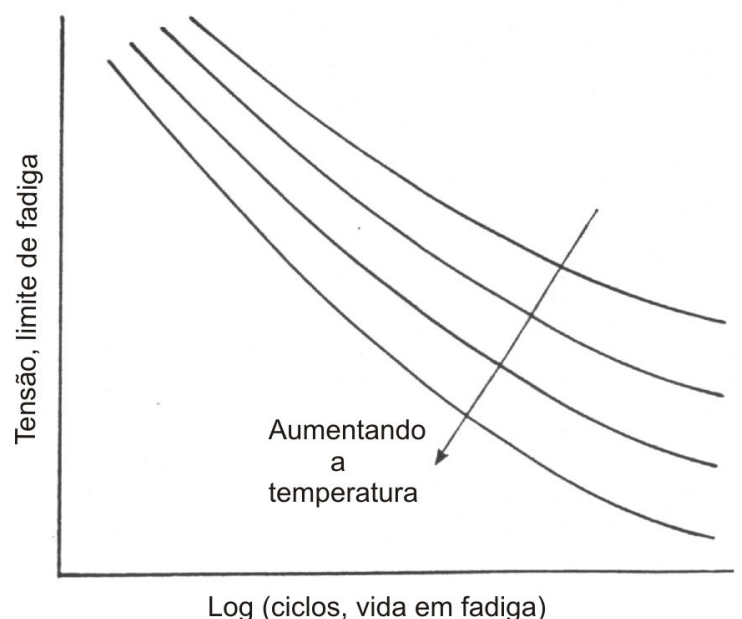

Figura 2.24 - Resistência à fadiga com o aumento da temperatura [Hetnarski, 1991].

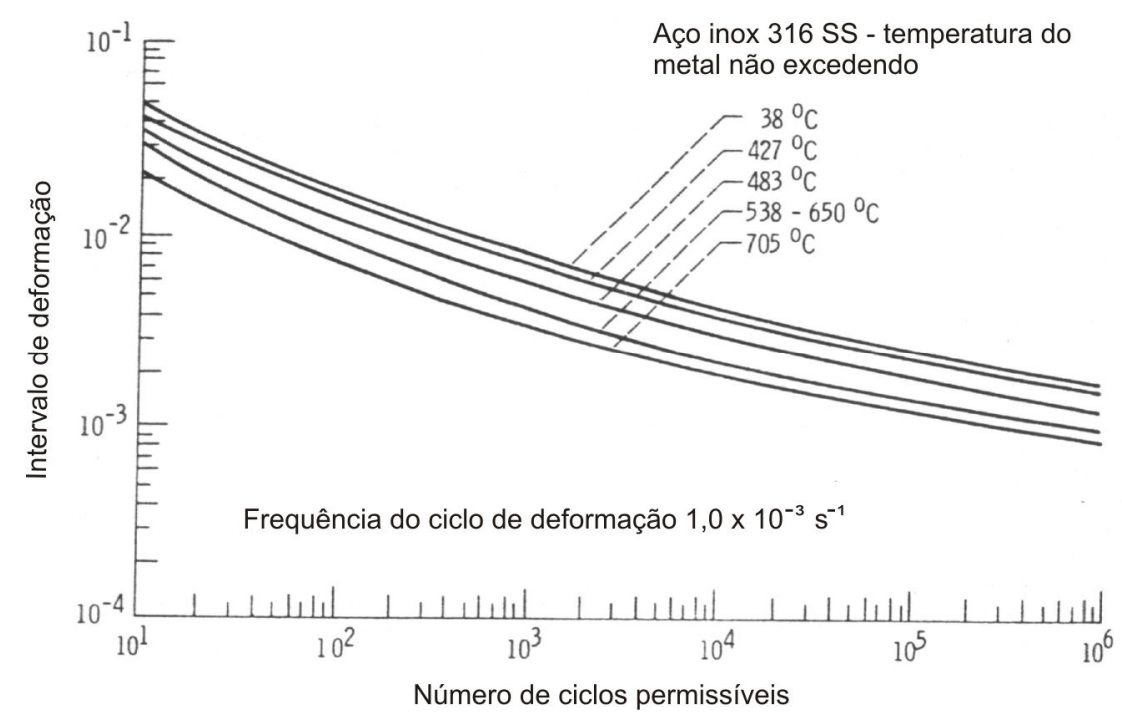

Figura 2.25 - Curva deformação em função da vida, para diferentes temperaturas [Hetnarski, 1991].

Outro exemplo do efeito da história de carregamento na resistência em fadiga para temperaturas elevadas foi observado por Leverant et al. (1976), enquanto estudavam o efeito da camada protetora superficial no comportamento da fadiga termomecânica. A fadiga termomecânica pode introduzir mecanismos de dano não encontrados na fadiga isotérmica. Enquanto em altas temperaturas a camada protetora é eficaz contra a oxidação superficial do material e resistente à fadiga devido à sua ductilidade, em baixas temperaturas esta pode se tornar dura, dependendo de sua composição. Então, se a ciclagem térmica for imposta de tal modo a produzir uma tensão trativa na temperatura mais baixa, trincas podem ser produzidas 
na camada protetora, comprometendo sua durabilidade cíclica, o que não ocorreria nos casos de fadiga isotérmica em altas temperaturas. Assim, testes de fadiga isotérmica não são suficientes para determinar as propriedades dos materiais quando estes estão expostos a altas temperaturas, nem determinam com clareza os mecanismos de dano aos quais os materiais estão sujeitos nestas condições.

\section{4 - Ligas}

Como já visto, as duas principais funções de um disco de freio são a transmissão de uma considerável força mecânica e a dissipação do calor produzido na operação. Para carros de passeio, a temperatura de trabalho, dependendo da severidade e do número de frenagens, pode estar situada entre a ambiente e, em alguns casos, chega a $700^{\circ} \mathrm{C}$. Esta grande variação acaba por gerar altos gradientes de temperatura no disco, o que ocasiona problemas de fadiga térmica. No entanto, o componente também está sujeito à ação de uma carga mecânica cíclica aplicada pela pastilha durante a frenagem, contribuindo para o desgaste do mesmo. Portanto, em condições reais de trabalho, o disco está sujeito a uma solicitação de fadiga termomecânica e não apenas térmica [Mackin, 2002].De um ponto de vista teórico, vários materiais seriam capazes de atender a estas solicitações. No entanto, por razões de comportamento mais estável, menor custo da matéria prima e facilidade comparativa de produção, o ferro fundido é o material mais usado [Brembo, 1997].

Usam-se outros tipos de materiais para frenagens nas quais o componente é submetido a altíssimas temperaturas. Por exemplo, materiais compósitos com matriz de carbono são empregados na produção de discos de freio para carros de competição e aeronaves. Apresentam excelente desempenho a quente, mas o custo de fabricação e a forma de utilização os inviabiliza para uso em veículos automotivos comuns. Outro exemplo são os discos de freio de ferro fundido ligado ao titânio, elemento que aumenta a resistência do componente, mas diminui o valor do coeficiente de atrito, o que causa um grande problema quando se tem uma curta distância de frenagem. A Figura 2.26 ilustra a queda no coeficiente de atrito com o aumento da porcentagem de titânio na liga [Brembo 1997]. Ligas de alumínio contendo carbeto de silício também podem ser usadas em discos de freio, pois possuem baixa densidade. No entanto, apesar do menor peso, estas ligas não dissipam tão bem o calor como, por exemplo, o ferro fundido cinzento. Para utilizá-las, a saída seria aumentar a área 
superficial do componente o que, no mínimo, reduziria a vantagem de seu menor peso [Mackin 2002].

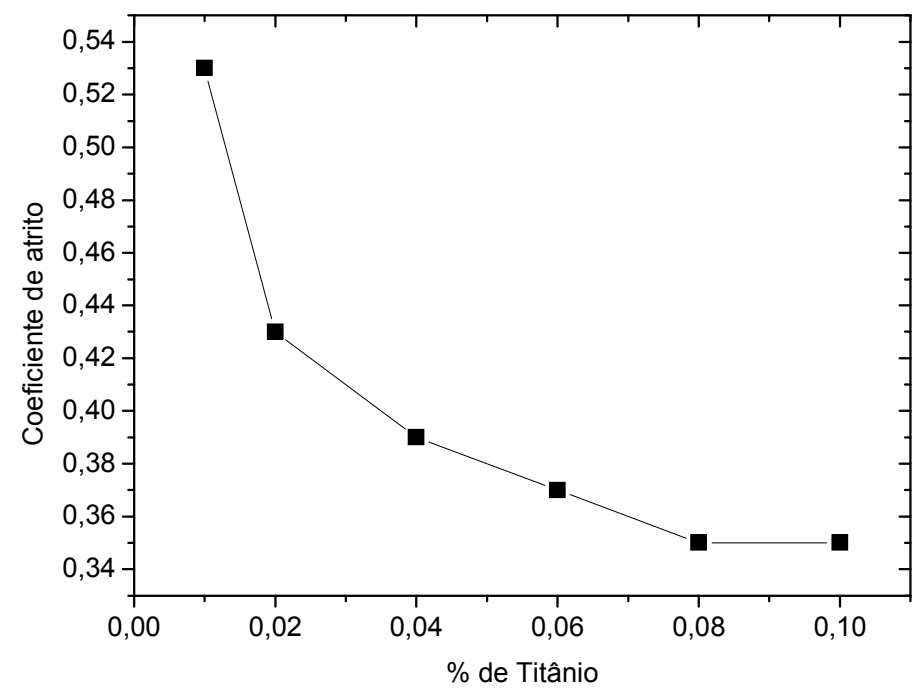

Figura 2.26 - Comportamento do coeficiente de atrito com a variação na porcentagem de Titânio em liga de ferro fundido [Brembo, 1997].

Portanto, comparativamente, os ferros fundidos são os materiais preferidos na confecção de componentes dos sistemas de frenagem e são classificados, geralmente, da seguinte maneira: grafíticos (cinzentos, nodulares, maleáveis) e brancos. Nas Figuras de 2.27 a 2.29 ver-se-ão as microestruturas de três tipos de ferros fundidos grafíticos [Milan, 2004].

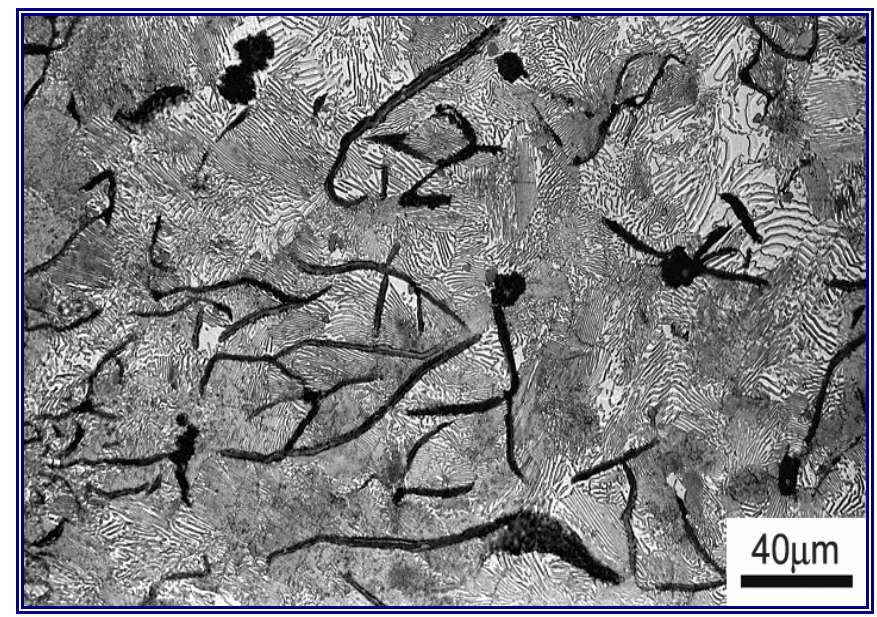

Figura 2.27 - Ferro fundido cinzento apresentando veios de grafita em matriz perlítica, atacado com Nital 2\% [Milan, 2004]. 


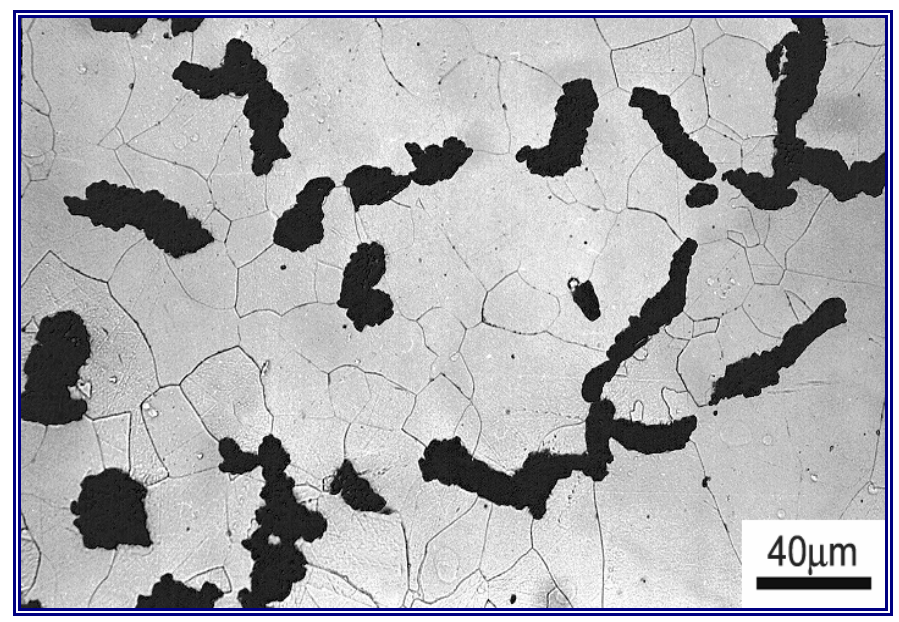

Figura 2.28 - Ferro fundido vermicular em matriz ferrítica, atacado com Nital 2\% [Milan, 2004].

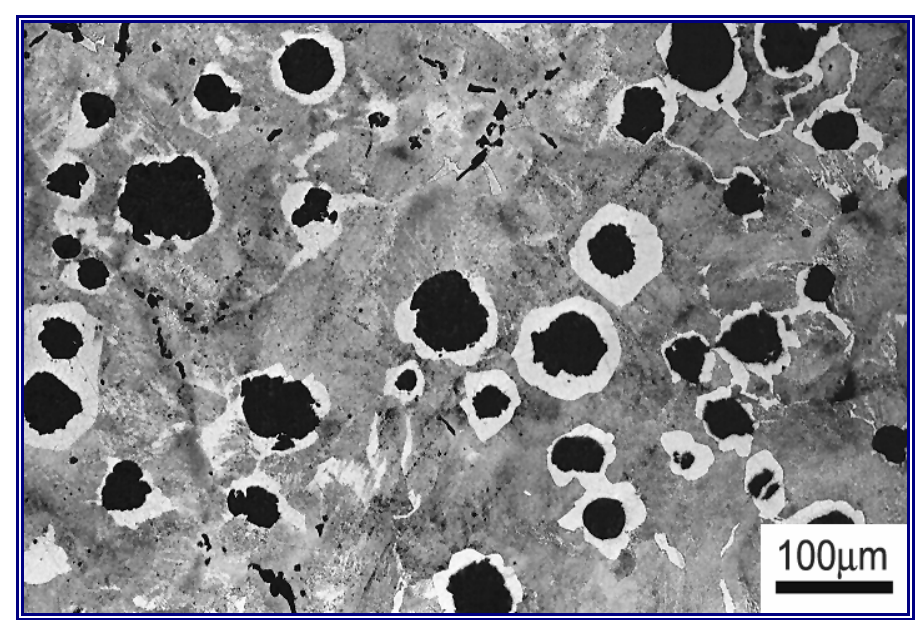

Figura 2.29 - Ferro fundido nodular com matriz perlítica, mostrando a microestrutura conhecida por "olho de boi", que consiste em nódulos de grafita circundados por ferrita livre (branca), atacado com Nital 2\% [Milan, 2004].

As ligas mais usadas para fabricação de discos de freio pela General Motors do Brasil são ferros fundidos cinzentos, com ou sem adição de alguns elementos químicos, conforme pode ser observado na Tabela 2.1. Estas ligas que dependendo da composição química e da velocidade de resfriamento, apresentam o carbono na forma de veios (grafita) sobre matrizes que podem ser ferríticas, ferríticas-perlíticas ou perlíticas, continuam apresentando a melhor relação custo/benefício para uso em discos de freio automotivos. 
Tabela 2.1 - Composições químicas nominais usadas pela General Motors do Brasil, \% em peso (GME-05002).

\begin{tabular}{|c|c|c|c|c|}
\hline Elementos / Ligas & A & B & C & D \\
\hline \% C & $3,20-3,60$ & $3,20-3,60$ & $3,60-3,80$ & $3,70-3,90$ \\
\hline \% Si & $1,90-2,40$ & $1,90-2,40$ & $1,80-2,20$ & $1,75-1,95$ \\
\hline \% Mn & $0,60-0,90$ & $0,60-0,90$ & $0,60-0,80$ & $0,50-0,80$ \\
\hline$\% \mathbf{P}$ & Máx. 0,20 & Máx. 0,10 & Máx. 0,12 & Máx. 0,10 \\
\hline \% S & Máx. 0,12 & Máx. 0,10 & Máx. 0,12 & Máx. 0,13 \\
\hline \% Cr & - & $0,25-0,40$ & $0,10-0,25$ & Máx. 0,20 \\
\hline \% Mo & - & $0,40-0,50$ & $0,30-0,60$ & Máx. 0,10 \\
\hline$\% \mathbf{C u}$ & - & - & $0,30-0,45$ & Máx. 0,40 \\
\hline
\end{tabular}

\subsection{1 - Ferro Fundido Cinzento}

O ferro fundido cinzento é o mais antigo e comum dos tipos de ferro, possuindo teores de carbono e silício variando entre 2,5 e 4,0\%, e 1,0 e 3,0\%, respectivamente [Callister Jr., 2002]. O nome foi atribuído, pois sua fratura exibe um tom acinzentado, devido ao carbono na forma de veios de grafita. A fluidez do ferro fundido cinzento e sua baixa contração durante a solidificação, fazem deste o metal ideal para produção econômica de peças de geometrias complexas, livres de rechupes, como os blocos de motores de combustão interna.

A grafita na forma de veios, como apresentada na Figura 2.27, funciona como um intensificador de tensões, provocando a nucleação prematura de trincas nas suas extremidades (Figura 2.30).

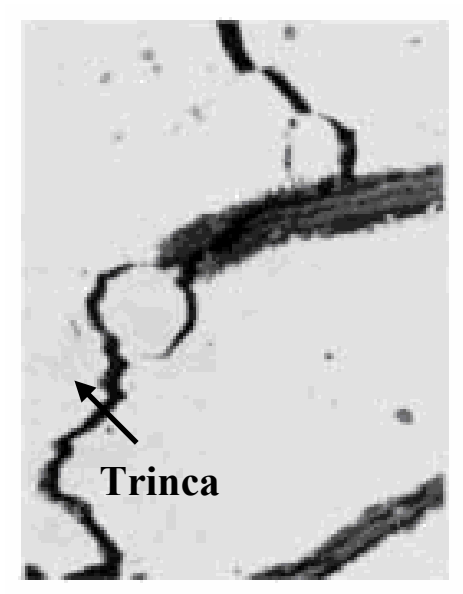

Figura 2.30 - Micrografia de um ferro fundido cinzento mostrando trincas se propagando na matriz através dos veios de grafita [Milan, 2004]. 
Esta característica faz com que o ferro fundido cinzento não apresente, quando solicitado em tração, o regime de proporcionalidade entre a tensão e a deformação, ou seja, a lei de Hooke não se aplica. Entretanto, apesar da grafita na forma de veios apresentar acúmulo de tensões nas extremidades dos mesmos, proporciona ao material excelente difusividade térmica, maior resistência à fricção, boa usinabilidade e capacidade de amortecer vibrações e auto-lubrificação.

A seguir, serão apresentadas algumas propriedades físicas e mecânicas do ferro fundido cinzento, relevantes a este estudo.

\subsubsection{1 - Difusividade Térmica}

Os ferros fundidos são materiais indicados para a produção de discos de freio porque, além do baixo custo de produção, possuem excelente condutividade térmica, o que facilita a dissipação do calor gerado pela fricção da pastilha de freio contra si durante a frenagem, e capacidade de amortecer vibrações, características primordiais para este tipo de componente.

O calor é normalmente conduzido por átomos que se chocam uns contra os outros e, nos metais, os elétrons também se somam a esse fluxo de calor, o que explica os metais serem bons condutores de calor. A medida de quão bom um material é para conduzir calor é conhecida como condutividade térmica. Esta pode ser definida como a quantidade de energia transportada por unidade de tempo através de uma área perpendicular para um gradiente de temperatura unitário ou como a taxa que o calor flui através de uma determinada área de um corpo [Callister Jr., 2002]. A direção do escoamento de calor vai da região mais quente para a mais fria, ou seja, desce ao longo do gradiente de temperatura, ou seja, diminui na medida em que a temperatura se eleva devido à maior distância entre os elementos condutores de calor (átomos e elétrons). Existe equação que utiliza a difusividade térmica para calcular a condutividade térmica, pois esta é diretamente proporcional a aquela.

Uma das maneiras de melhorar a propriedade do material em transferir calor é aumentar sua difusividade térmica. Esta descreve a taxa de propagação do calor durante o processo transiente, e também é um parâmetro fundamental para o projeto de freios. A difusividade térmica pode ser usada para calcular a condutividade térmica, que é uma medida intrínseca da capacidade do material transmitir calor. Discos de freio com condutividade térmica melhorada apresentam aumento na resistência a trincas térmicas [Jimbo, 1990], possibilitando aumento no seu tempo de vida útil, ou seja, se a característica do ferro fundido 
cinzento em transportar calor puder ser aumentada sem sacrificar outros critérios objetivos, o desempenho do disco pode ser melhorado.

Os principais fatores que influenciam a transferência de calor nos ferros fundidos são a distribuição, o tamanho e a morfologia da fase grafita, pois os veios de grafita possuem condutividade térmica muito maior que as matrizes. A condutividade térmica do ferro fundido é tanto maior quanto maior for a razão entre a área superficial da grafita e seu respectivo volume [Hecht, 1996]. Portanto, ferros fundidos com grafita na forma de nódulos são piores condutores do que aqueles com a grafita em forma de vermículos, que por sua vez são piores que aqueles com a grafita na forma de veios.

Em 1990, Jimbo et al. descrevem o beneficio de usar ferro fundido com alta condutividade térmica em discos de freio. No entanto, a mudança nas características de fricção, tais como o valor do coeficiente de atrito e a quantidade de partículas geradas pela fricção, avaliadas como uma função da microestrutura do ferro cinzento tem sido pouco discutida na literatura. Em particular, sobre a correlação entre a quantidade relativa de fases no ferro cinzento e o desempenho sob fricção pouca atenção tem sido dada.

Em 1999, Hecht et al. observaram que a difusividade térmica do ferro fundido cinzento é influenciada por uma sutil mudança na composição química e apresentaram uma relação linear entre difusividade térmica e carbono equivalente (ou comprimento máximo dos veios de grafita), conforme pode ser visto na Figura 2.31. Ela mostra que, tanto para amostras tiradas do componente (disco) como para aquelas obtidas a partir dos blocos padrões fundidos, existe um ponto positivo que é a dependência quase linear da difusividade térmica com o aumento do carbono equivalente (CE), calculado conforme equação (2.11).

A dependência linear era esperada, pois aumentar o $\mathbf{C E}$ é a maneira mais rápida de melhorar a grafitização no ferro fundido cinzento. Em amostras de disco de freio acorreu um aumento de 25\% na difusividade com um aumento de 0,40\% no CE [Jimbo, 1990; Okamoto, 1983; Hecht, 1996].

A taxa de solidificação influi na morfologia dos veios de grafita, portanto diferentes configurações nos moldes de fundição, tais como número de machos, tipo de areia de moldagem e processo ou novo projeto do componente pode resultar em modificação, ainda que pequena, na morfologia dos veios de grafita. Sabendo como a morfologia da grafita influi na transferência de calor, pode-se avaliar como uma variação de processo durante a fundição dos discos pode alterar seus desempenhos, pois como já foi visto uma propriedade tridimensional importante para a transferência de calor é a relação área superficial da grafita/volume. Hoje em dia existem programas de computador, que através da analise de 
imagens bidimensionais são capazes de medir os parâmetros morfológicos dos veios de grafita, dividindo o perímetro $(\boldsymbol{P})$ pela área $(\mathbf{A})$ por ela encerrada, como pode ser visto na Figura 2.32.

$$
C E=\% C+\frac{1}{3}(\% S i+\% P)
$$

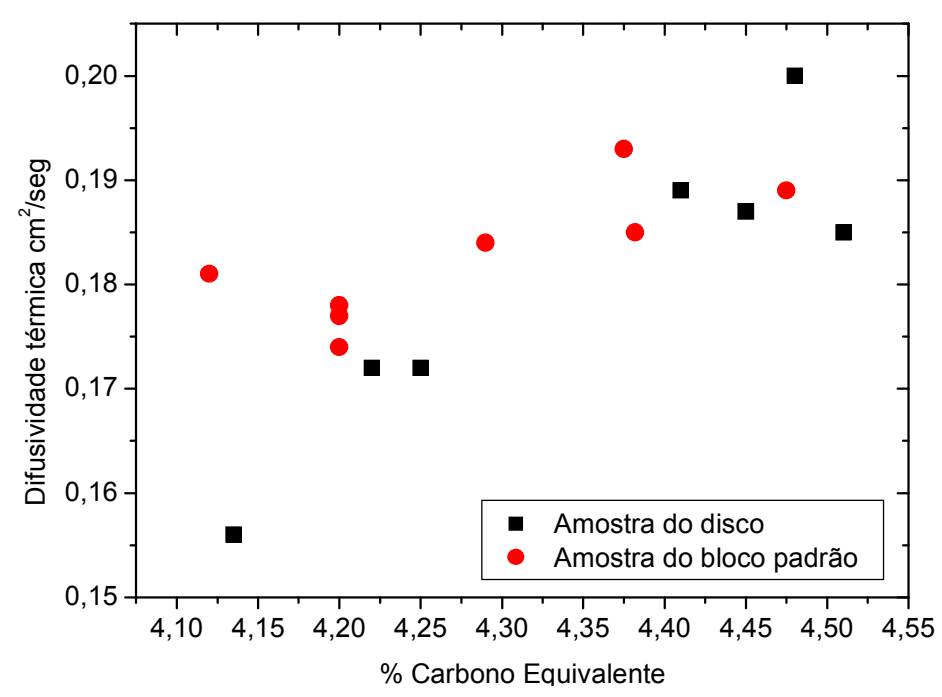

Figura 2.31 - Aumento da difusividade térmica à temperatura ambiente em função do carbono equivalente (CE) [Hecht, 1996].

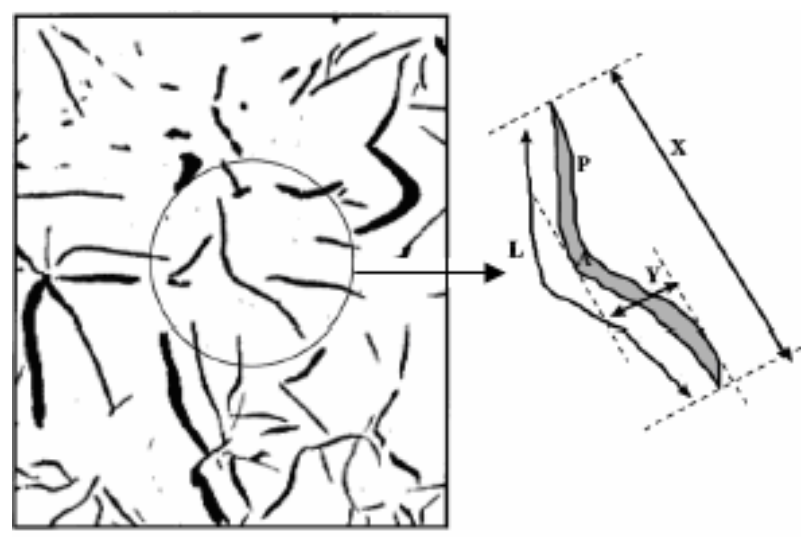

Figura 2.32 - Apresentação esquemática da caracterização da morfologia do veio de grafita através de programas computacionais, onde $P$ é o perímetro, $\mathbf{X}$ o eixo maior, $\mathbf{Y}$ o eixo menor, L o comprimento real e A a área [Hecht, 1996].

Notaram também que em ferros fundidos cinzentos a difusividade diminui com o aumento da temperatura até $500^{\circ} \mathrm{C}$ e que acima desta temperatura, diminui a diferença 
observada na difusividade das ligas que apresentaram valores similares em $500^{\circ} \mathrm{C}$. Estes dados sugerem que difusividades altas e benefícios térmicos podem ser alcançados através do controle do processo de fundição de discos de freio em ferro fundido cinzento, com veios de grafita mais longos e que quanto maior o comprimento dos veios, maior a difusividade e a condutividade [Okamoto, 1983; Yamada, 1998].

\subsubsection{2 - Resistência à Abrasão e Propriedades Mecânicas}

O valor da difusividade da fase ferrita é maior que o da microestrutura perlítica. Desta maneira, com o que já foi visto, se poderia concluir que a melhor liga de ferro fundido para a produção de discos de freio seria aquela de ferro fundido cinzento que apresentasse veios de grafita mais longos sobre uma matriz ferrítica. Porém isto não é verdade, pois além do tipo da matriz influenciar pouco a difusividade [Palmer, 1960; Fitzgeorge, 1959], o disco tem que apresentar, para a função a que se destina, uma boa resistência mecânica, principalmente à abrasão. Por esse motivo, a maioria dos discos de freio usados nos chamados carros de passeio é produzida com ferros fundidos cuja microestrutura apresenta veios de grafita sobre matriz perlítica. A perlita, por ser composta de lamelas da fase ferrita intercaladas com lamelas da fase cementita $\left(\mathrm{Fe}_{3} \mathrm{C}\right)$ muito dura, é um micro-constituinte que confere à matriz maior dureza e ao componente, por conseqüência, maior resistência mecânica [Palmer, 1960; Omerod, 1978].

Para evitar que componentes produzidos a partir de ligas de ferro fundido cinzento, com composições químicas idênticas, apresentem propriedades mecânicas diferentes é necessário que a taxa de solidificação seja a mesma, de forma que não se altere a microestrutura. Para tanto, os parâmetros de moldagem, fusão e vazamento devem ser rigorosamente controlados a cada nova produção. Caso as composições químicas venham a ser alteradas através da adição de elementos de liga, modificar-se-ão as propriedades mecânicas. Resumindo, para se alterar as propriedades mecânicas, dois fatores são de vital importância: velocidade de resfriamento e composição química.

Apesar de ser possível produzir ferros fundidos de boa qualidade sem adição de elementos de liga, apenas controlando com rigor o carbono livre e combinado, os teores de silício e manganês e a técnica de fabricação, é usual a adição de elementos de liga para a obtenção não só de maiores resistências com o carbono equivalente mais elevado, como também porque as microestruturas resultantes são menos susceptíveis à variação da espessura 
das peças. Praticamente todos os elementos de liga tendem a aumentar a resistência à tração e a dureza, sendo os mais eficientes, nesse sentido, para o ferro fundido cinzento, o manganês (Mn), o vanádio (V), o molibdênio (Mo), o cromo $(\mathbf{C r})$ e o cobre $(\mathbf{C u})$. O Mn promove a formação de microestrutura perlítica, aumentando a resistência mecânica e a dureza; o $\mathbf{V}$ é forte formador de perlita e refinador de grafita; o Mo aumenta a resistência mecânica a quente, à fluência e à corrosão; o $\mathbf{C r}$ aumenta a resistência à abrasão e à corrosão e o $\mathbf{C u}$ é um forte estabilizador da perlita.

O efeito de endurecimento provocado por elementos de liga em solução sólida na ferrita pode ser visto na Tabela 2.2 [Milan 2004]. Observa-se que apesar de todos os elementos aumentarem a dureza da liga, aqueles que formam soluções sólidas intersticiais têm este efeito mais pronunciado que os substitucionais.

Além da forma direta, através de formação de solução sólida e de precipitados de segunda fase, os elementos de liga podem atuar indiretamente no aumento da resistência através do refino de grão, dessulfurando ou globulizando sulfetos, estabilizando carbonetos, desgaseificando e, ainda, aumentando a temperabilidade do material.

Em 1972, Rhee et al. [Rhee, 1972a] mostraram que a mudança na composição química do disco afetou fortemente as propriedades mecânicas e a taxa de desgaste da pastilha de freio e do disco, sugerindo que o disco foi quimicamente ativado pelo revestimento durante a frenagem.

Libsch e Rhee, em 1979, relataram os efeitos da variação na composição química sobre o desgaste do disco. Mostraram que pequenas mudanças no nível dos elementos de liga mudaram o nível de desgaste do revestimento e do disco.

Em 1992, Anderson relatou que veios de grafita finos reduzem o desgaste do disco e do revestimento.

No ano de 1993, Zhang et al. estudaram as propriedades tribológicas do ferro fundido em termos da concentração de fósforo e morfologia da grafita e observaram que um ferro fundido contendo fósforo e com morfologia da grafita compacta (vermicular), apresentou alto coeficiente de atrito e baixa perda de massa por desgaste.

Em 2003, Cho et al. investigaram as características do ferro fundido cinzento em relação às quantidades de fase, grafita e ferrita, e do micro-constituinte perlita, controlando a microestrutura pela variação na quantidade de carbono (carbono equivalente) e velocidade de resfriamento. Eles notaram que a quantidade de ferrita livre e de perlita no disco de ferro cinzento não afeta o coeficiente de atrito. E mais, observaram um aumento do coeficiente de atrito com o aumento percentual da área de grafita. 
Tabela 2.2 - Efeito endurecedor dos elementos de liga em solução sólida na ferrita [Milan, 2004].

\begin{tabular}{|l|l|}
\hline Elemento & Efeito endurecedor \\
\hline $\mathbf{C}, \mathbf{N}$ & \\
\hline $\mathbf{P}$ \\
\hline $\mathrm{Si}$ \\
\hline $\mathrm{Ti}$ \\
\hline $\mathrm{Al}$ \\
\hline $\mathrm{Cu}$ \\
\hline $\mathrm{Mn}$ \\
\hline $\mathrm{Mo}$ \\
\hline $\mathrm{V}$ \\
\hline $\mathrm{Ni}$ \\
\hline $\mathrm{Cr}$ \\
\hline
\end{tabular}

\subsubsection{3 - Fadiga}

Sobre fadiga térmica em ferro fundido cinzento, até que existe razoável quantidade de literatura à disposição. No entanto, quando se trata de isotérmica e termomecânica, a situação é incipiente.

Devido à importância do componente disco de freio na indústria da mobilidade, procura-se suprir esta lacuna buscando incentivos para projetos sobre os temas. Resultados positivos nesta linha de raciocínio foram os dois projetos para os quais se conseguiu patrocínio da General Motors do Brasil (GMB), que foram desenvolvidos no Departamento de Engenharia de Materiais, Aeronáutica e Automobilística da Escola de Engenharia de São Carlos - EESC - USP. O primeiro deles de mestrado intitulado "Fadiga Isotérmica em Ligas de Ferro Fundido Cinzento para Discos de Freio Automotivos”, concluído em 2005, estudou as sete ligas de ferro fundido cinzento usadas pelo mercado, na confecção do componente, e identificou as quatro delas que tiveram o melhor desempenho comparativo no conjunto dos seguintes quesitos: ensaios de tração; impacto; fadiga isotérmica e relação benefício/custo. As quatro ligas selecionadas serviram como subsídios (estado da arte) para este que é o segundo projeto em nível de doutorado, intitulado "Fadiga Termomecânica em Ligas de Ferro Fundido Cinzento para Discos de Freio Automotivos", que está agora sendo concluído. A seguir estão 
informações sobre fadiga térmica, termomecânica e isotérmica, especificamente em ligas de ferro fundido cinzento. Vale lembrar que, no que diz respeito à fadiga isotérmica, todos os dados foram obtidos da dissertação de mestrado [Angeloni, 2005], citada anteriormente.

\subsubsection{1 - Fadiga Térmica e Termomecânica}

A utilização de ferro fundido cinzento em aplicações como componentes de freio, dutos de ar quente, lingoteiras e moldes para vidro, requerem que o mesmo resista a variações de temperatura e a altos gradientes térmicos [Roehrig, 1978; Burgess, 1939]. A restrição à contração e à expansão térmica durante o ciclo térmico induz tensões no ferro que resultam tipicamente em rachaduras ou em uma rede de trincas superficiais, que podem crescer e conectar-se de modo a, eventualmente, danificar o componente.

Variações no ciclo térmico,determinado pela diferença de temperatura, temperatura máxima e taxas de aquecimento/resfriamento, influenciam o tipo de ferro fundido a ser selecionado [Roehrig, 1978]. Para boa resistência à fadiga térmica, ferros fundidos cinzentos devem possuir alta condutividade térmica, baixo módulo de elasticidade, alta resistência mecânica tanto a temperatura ambiente como a altas temperaturas e, para temperaturas acima de $500^{\circ} \mathrm{C}$, resistência à oxidação e a mudanças microestruturais [Roehrig, 1978]. A Figura 2.33 mostra a influência da temperatura sobre a resistência a tração de um ferro fundido cinzento e a relação entre o número de ciclos térmicos para a falha e a resistência a tração à temperatura ambiente e à $540^{\circ} \mathrm{C}$.

Ferros fundidos que possuem elevada resistência à tração, tanto à temperatura ambiente quanto a temperaturas elevadas, são geralmente ligados e apresentam altíssima resistência à fadiga térmica (Figura 2.34).

No entanto, outras propriedades, juntamente com a resistência mecânica, influenciam o comportamento em fadiga térmica. Como apresentado na Figura 2.34, a resistência à fadiga térmica de um ferro fundido cinzento não ligado aumenta com o aumento do volume de grafita [Roehrig, 1978]. Esta melhora ocorre em função de dois efeitos benéficos da grafita: a diminuição no módulo de elasticidade, e o aumento na condutividade térmica que reduz o gradiente de temperatura entre a superfície e o interior do componente. A morfologia da grafita também afeta a fadiga térmica. Por exemplo, a fadiga térmica pode ser menor com grafita do tipo A do que com a do tipo D (ASTM A247). Os resultados indicam que ferros fundidos com baixo carbono equivalente apresentam grafita do tipo A mais curta, e que, 
quando submetidos a um severo ciclo térmico $\left(650\right.$ a $\left.200^{\circ} \mathrm{C}\right)$, apresentam um desempenho um pouco melhor que o mesmo material contendo grafita do tipo A mais longa, e são consideravelmente melhores quando comparados a ligas que apresentam em sua microestrutura grafita do tipo D [Rostoker, 1969].

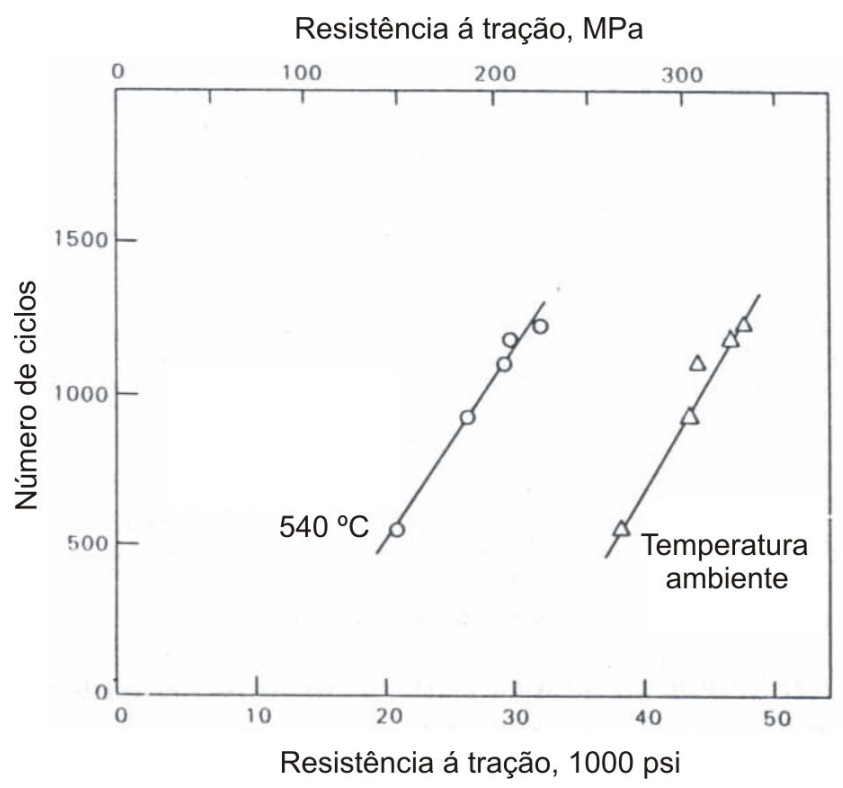

Figura 2.33 - Relação entre o número de ciclos térmicos para falha e a resistência à tração à temperatura ambiente e a $540^{\circ} \mathrm{C}$ [Gundlach, 1978].

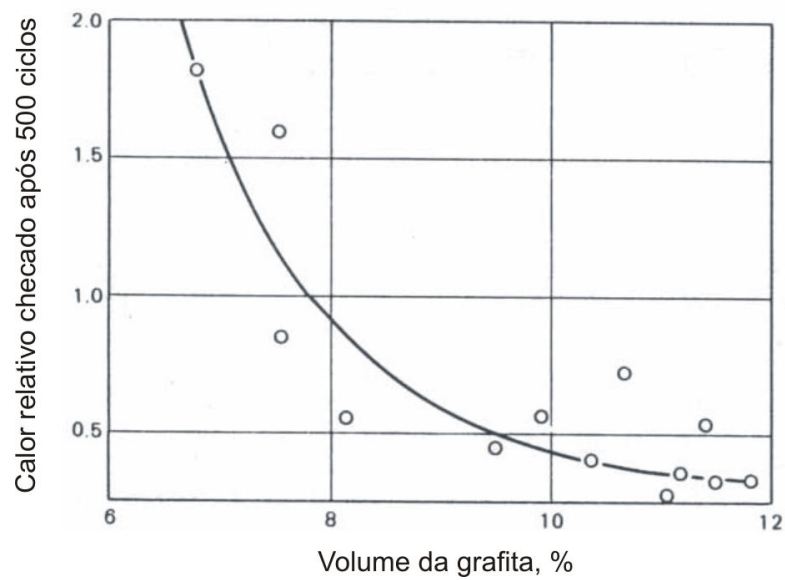

Figura 2.34 - Relação entre o volume de grafita e medida do calor relativo após 500 ciclos. Um ciclo térmico consiste de 2 segundos a $450^{\circ} \mathrm{C}$ e 30 segundos à temperatura ambiente [Roehrig, 1978].

Testes [Rostoker, 1969] com um ciclo térmico mais suave $\left(600\right.$ a $\left.480^{\circ} \mathrm{C}\right)$, proporcionaram novos resultados utilizando um ferro fundido cinzento com grafita do tipo A fina. A melhoria na resistência à fadiga térmica que esses ferros fundidos apresentaram foi 
observada em todas as temperaturas de teste, e o motivo foi atribuído à habilidade da grafita de absorver a expansão da matriz e deste modo reduzir a deformação superficial. Também, deve ser notado que enquanto a resistência à tração de ferros fundidos contendo quantidade de grafita e carbono equivalente elevados, à temperatura ambiente, é menor que de outros estudados, a suposta diminuição da resistência à tração, em temperaturas altas, não apresenta efeitos adversos na resistência ao trincamento, conforme pode ser visto na Figura 2.35 (Tabela 2.3). Outro trabalho indicou que células eutéticas muito finas proporcionam melhoria na resistência à fadiga térmica [Llinskii, 1971].

A faixa de temperatura na qual ocorre a ciclagem é um dado muito importante, uma vez que ela é que determina as mudanças estruturais e o tipo do dano a ser esperado. Com respeito aos ferros fundidos totalmente perlíticos, a resistência à fadiga térmica é melhor naqueles que contém grandes quantidades de grafita. Para quantidades de grafita equivalentes, contudo, aqueles ferros que tem maior porcentagem de perlita proporcionam melhor resistência à fadiga térmica, particularmente a temperaturas mais altas [Roehrig, 1978]. A adição de elementos de liga que refinam a perlita e aumentam a resistência sem afetar significativamente o módulo de elasticidade ou a condutividade térmica, proporcionam um aumento na resistência à fadiga térmica.

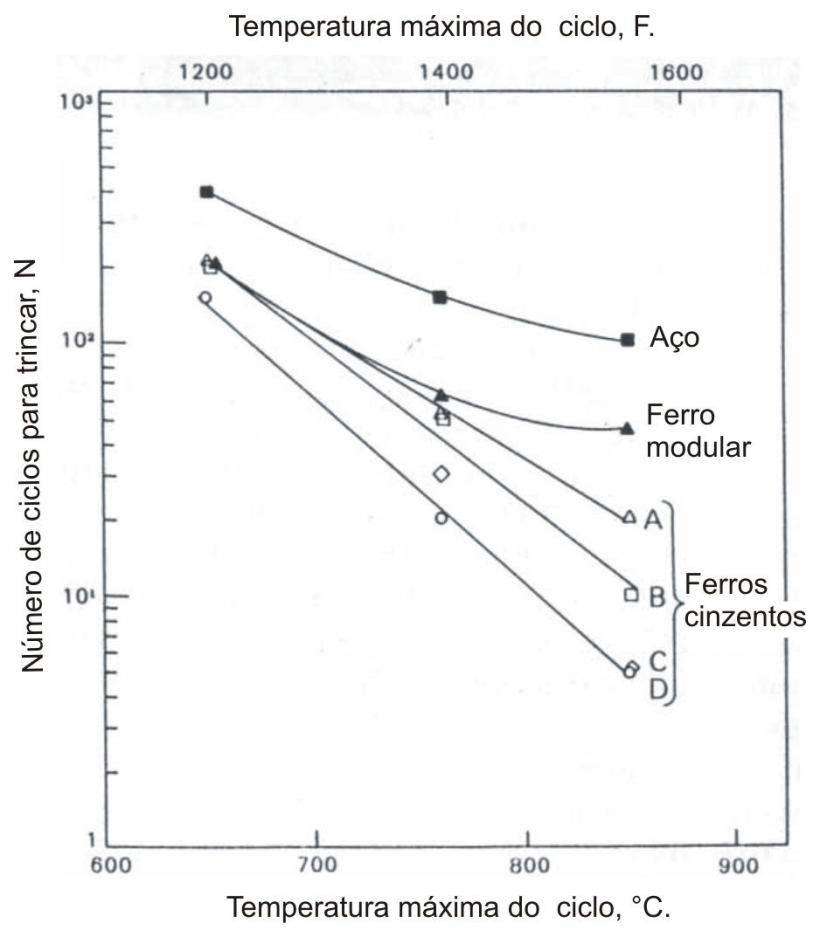

Figura 2.35 - Variação no número de ciclos térmicos para falha, no ciclo de máxima temperatura para ferros fundidos, cinzento e nodular, e aço. As composições dos ferros fundidos cinzentos estão na Tabela 2.3 [Gundlach, 1978]. 
Tabela 2.3 - Composições químicas (\% em peso) dos ferros fundidos cinzentos da Figura 2.35 [Gundlach, 1978].

\begin{tabular}{|c|c|c|c|c|c|c|}
\hline Ligas / Elementos & $\mathbf{C}$ & $\mathbf{S i}$ & $\mathbf{M n}$ & $\mathbf{C r}$ & Mo & Outros \\
\hline $\mathbf{A}$ & 3,43 & 2,37 & 0,78 & 0,22 & 0,32 & $0,21 \mathrm{Sn}$ \\
\hline $\mathbf{B}$ & 3,49 & 2,37 & 0,84 & 0,24 & 0,22 & - \\
\hline $\mathbf{C}$ & 3,48 & 2,60 & 0,88 & 0,23 & 0,20 & $2,37 \mathrm{Al}$ \\
\hline $\mathbf{D}$ & 3,60 & 2,38 & 0,83 & 0,30 & 0,77 & $1,61 \mathrm{Cu}$ \\
\hline
\end{tabular}

A Figura 2.36 apresenta os resultados dos ensaios de fadiga térmica em vários ferros fundidos cinzentos que tem aproximadamente os mesmos teores de carbono e silício (Tabela 2.4), módulos de elasticidade e condutividades térmicas e, além disso, microestruturas das matrizes totalmente perlíticas [Gundlach, 1978].

Tabela 2.4 - Composições químicas (\% em peso) dos ferros da Figura 2.36 [Gundlach, 1978].

\begin{tabular}{|c|c|c|c|c|c|c|c|c|}
\hline $\begin{array}{c}\text { Aços / } \\
\text { Elementos }\end{array}$ & $\mathrm{C}$ & $\mathrm{Si}$ & $\mathrm{Mn}$ & $\mathrm{Cr}$ & $\mathrm{Mo}$ & $\mathrm{Ni}$ & $\mathrm{Cu}$ & $\mathrm{Sn}$ \\
\hline $\mathrm{A}$ & 3,43 & 1,65 & 0,57 & - & - & - & - & - \\
\hline $\mathrm{B}$ & 3,45 & 1,74 & 0,59 & 0,49 & - & 0,60 & 0,59 & - \\
\hline $\mathrm{C}$ & 3,45 & 1,68 & 0,63 & 0,30 & 0,30 & 0,97 & 0,87 & - \\
\hline $\mathrm{D}$ & 3,44 & 1,69 & 0,58 & 0,21 & 0,38 & - & 0,30 & 0,077 \\
\hline $\mathrm{E}$ & 3,43 & 1,66 & 0,58 & 0,50 & 0,39 & - & - & - \\
\hline
\end{tabular}




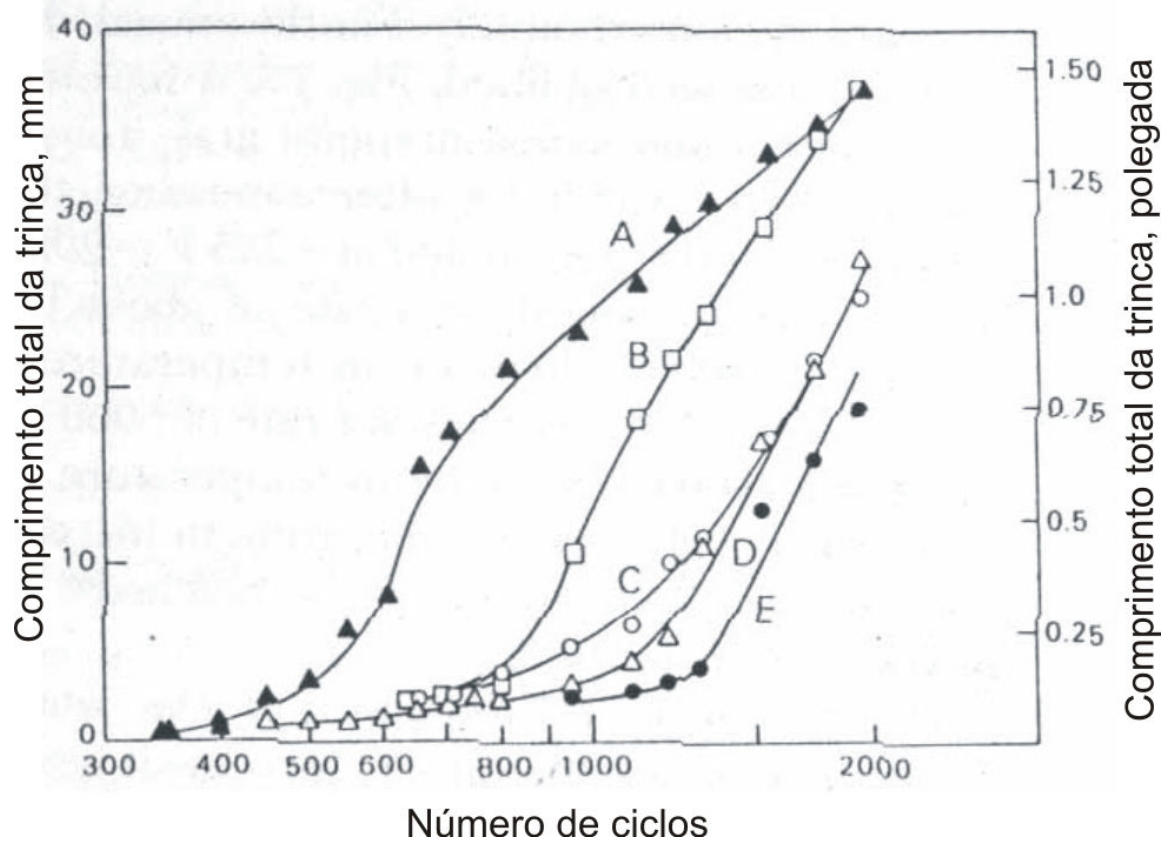

Figura 2.36 - Comprimento total de seis trincas (as primeiras três trincas em cada um dos dois corpos de prova de cada ferro fundido) como função do número de ciclos térmicos entre 590 e $200^{\circ}$ C. As composições estão apresentadas na Tabela 2.4 [Gundlach, 1978].

Elementos de liga como molibdênio e cromo proporcionam aumento na resistência à fadiga térmica de ferros fundidos cinzentos, se comparados com outros ferros que contém outros elementos de liga, ou que não são ligados. Nesse caso, a melhora da resistência à fadiga térmica pode estar diretamente relacionada com a maior resistência à tração em temperaturas elevadas (Figura 2.37) e com a melhor estabilidade dos ferros fundidos cinzentos cromomolibdênio. No entanto, deve ser lembrado que este ganho está relacionado, e depende do ciclo de temperatura e da composição química do ferro fundido [Roehrig, 1978], como mostrado na Figura 2.36.

Os discos de freio sujeitos a elevadas tensões térmicas, como o caso dos caminhões, requerem materiais que ofereçam maiores resistências à fadiga térmica. Nestes casos, ferros fundidos cinzentos contendo níquel, cromo e molibdênio têm sido usados [Yamabe 2002], por exemplo, pela Mitsubishi Motors, cujo material apresenta $12 \%$ de níquel, mais cromo e molibdênio [Sakamoto 1993]. Todavia a desvantagem do uso destas ligas é, sem duvida, o alto custo. 


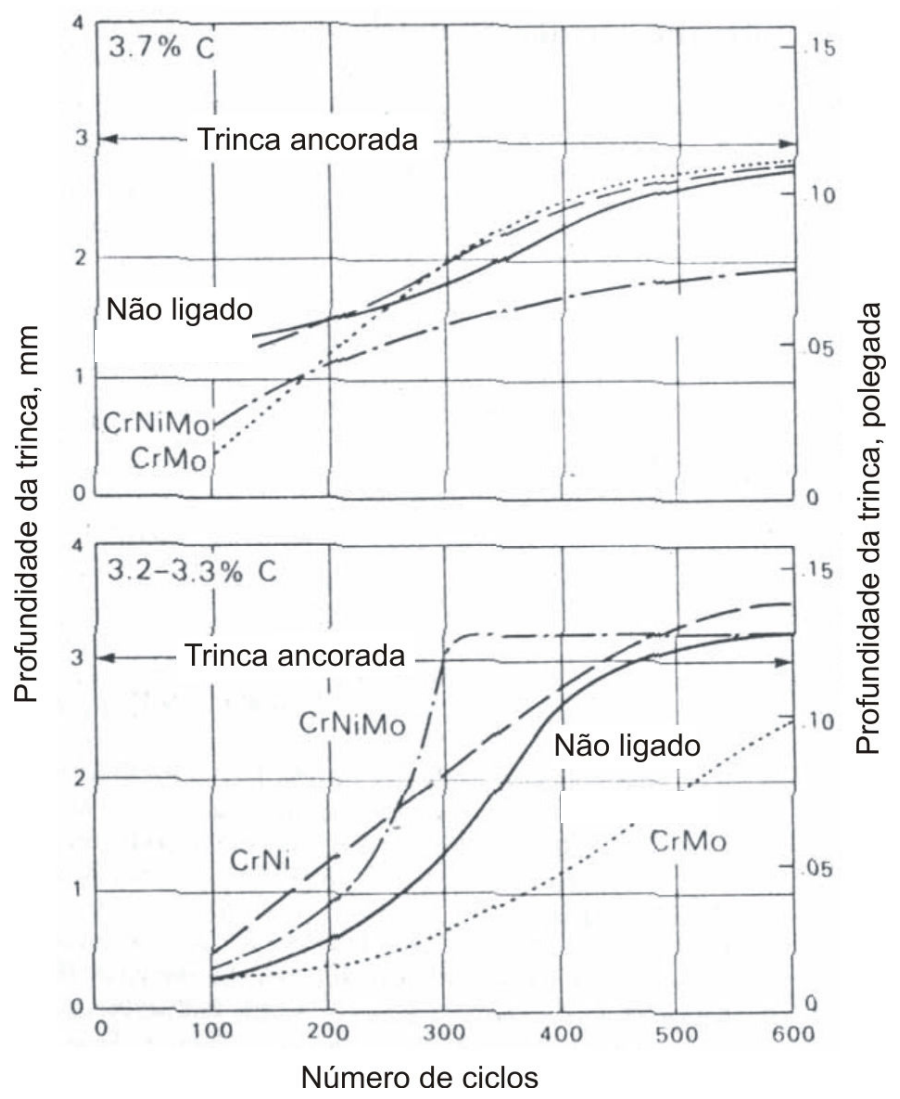

Figura 2.37 - Profundidade das trincas resultantes do ciclo térmico nos ferros fundidos cinzentos entre $460^{\circ} \mathrm{C}$ e a temperatura ambiente [Roehrig, 1978].

Em 2002, J. Yamabe et al. estudaram a possibilidade de produzir discos de caminhões com uma liga de ferro fundido de menor custo e alta resistência à fadiga térmica. Utilizaram protótipos de diferentes ligas com quantidades variáveis de elementos, sendo em alguns casos adicionado cério à liga. Verificaram a relação entre a resistência à fadiga térmica do material, suas propriedades físicas e mecânicas e a correspondente microestrutura. Notaram que a razão de propagação da trinca é menor quanto maior for a quantidade de grafita distribuída em uma matriz com grãos refinados, e que o número de veios de grafita na microestrutura aumenta com a adição de níquel e alguma inoculação de cério. Observaram também que o limite de fadiga térmica de um disco de freio não é muito afetado pelo número de ciclos antes da iniciação da trinca, mas sim depois do seu início. A partir deste estudo foi desenvolvida uma liga para disco de freio de baixo custo (B) equivalente ao da liga atualmente usada (A) [Yamabe, 2002].

Nas Tabelas de 2.5 a 2.7, e Figuras de 2.38 a 2.40, encontram-se os resultados obtidos por J. Yamabe et al. (2002). Nota-se que na Tabela 2.5, o teor de níquel da liga B é menor que 
na liga $\mathrm{A}$, o que faz com que a liga desenvolvida tenha um custo mais baixo em função do altíssimo preço deste elemento.

Tabela 2.5 - Composição química de ligas de ferro fundido (\% peso) [Yamabe 2002].

\begin{tabular}{|c|c|c|c|c|c|c|c|c|}
\hline Aços / Elementos & $\mathbf{C}$ & $\mathbf{S i}$ & $\mathbf{N i}$ & $\mathbf{C r}$ & $\mathbf{M o}$ & $\mathbf{C u}$ & $\mathbf{S}$ & $\mathbf{C e}$ \\
\hline $\mathbf{A}$ & 3,35 & 2,16 & 1,25 & 0,32 & 0,30 & 0,32 & 0,023 & - \\
\hline $\mathbf{B}$ & 3,36 & 1,92 & 0,58 & 0,50 & 0,37 & 0,50 & 0,050 & 0,023 \\
\hline
\end{tabular}

O efeito do Cério pode ser observado na Tabela 2.6, onde o valor da resistência à tração da liga desenvolvida (B) é quase 52\% maior do que a liga usual (A), sem prejuízo para os valores de condutividade e expansão térmica.

Tabela 2.6 - Propriedades físicas e mecânicas das ligas A e B [Yamabe 2002].

\begin{tabular}{|c|c|c|c|}
\hline & & A & B \\
\hline Resistência à tração $\mathbf{( M P a )}$ & $\begin{array}{c}\mathrm{Amb} . \\
500^{\circ} \mathrm{C}\end{array}$ & 290 & 440 \\
205 & 320 \\
\hline Condutividade térmica $\left(\mathbf{W} / \mathbf{m}^{* \mathbf{0}} \mathbf{C}\right)$ & $\begin{array}{c}\mathrm{Amb} . \\
500^{\circ} \mathrm{C}\end{array}$ & $\begin{array}{c}45,8 \\
37,2\end{array}$ & $\begin{array}{c}43,8 \\
37,2\end{array}$ \\
\hline Coef. Expansão térmica $\left(\mathbf{1 0}^{-\mathbf{5}} /{ }^{\circ} \mathbf{C}\right)$ & $100 \sim$ & 1,32 & 1,33 \\
& $500^{\circ} \mathrm{C}$ & & \\
\hline
\end{tabular}

$\mathrm{Na}$ Tabela 2.7, observa-se que o único valor cuja diferença é significativa é a dureza da matriz, em que o da liga $\mathbf{B}$ é bem maior do que o da $\mathbf{A}$, confirmando inclusive a tendência apresentada na resistência à tração.

Tabela 2.7 - Parâmetros microestruturais das ligas A e B [Yamabe 2002].

\begin{tabular}{|c|c|c|}
\hline & A & B \\
\hline Dureza da Matriz (HV) & 301 & 394 \\
\hline Número de células Eutéticas $/ \mathbf{c m}^{\mathbf{2}}$ & 318 & 288 \\
\hline Comprimento médio da trinca $(\boldsymbol{\mu m})$ & 53 & 57 \\
\hline$\%$ de área de grafita & 21,6 & 19,9 \\
\hline Número de veios de grafita/mm $\mathbf{m}^{\mathbf{2}}$ & 200 & 153 \\
\hline
\end{tabular}


Na Figura 2.38, é possível observar que, quanto maior o número de veios de grafita, menor é taxa de propagação da trinca; e que, quanto maior a adição de níquel, maior o número de veios de grafita tanto para a liga sem inoculação de cério como para aquela inoculada.

A taxa de propagação da trinca no material desenvolvido, para um determinado número de ciclos, é praticamente a mesma que para o material usual, como pode ser observado nas Figuras 2.38 e 2.39 .

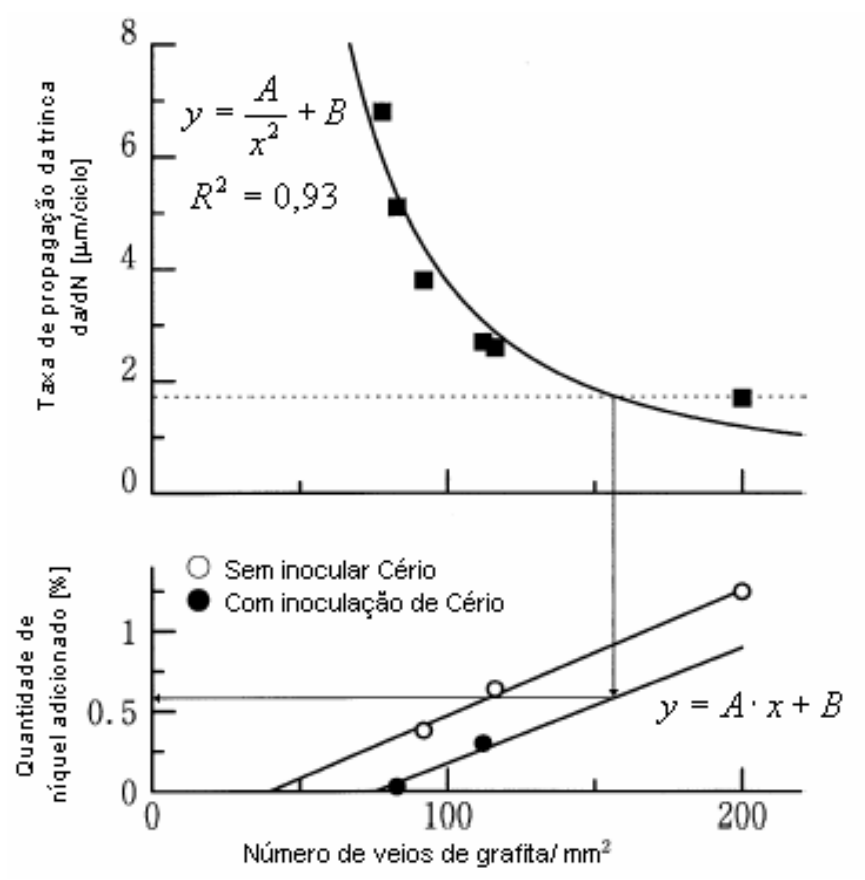

Figura 2.38 - Relação entre o número de veios de grafita, razão de propagação da trinca e quantidade adicionada de níquel para as ligas A e B [Yamabe 2002].

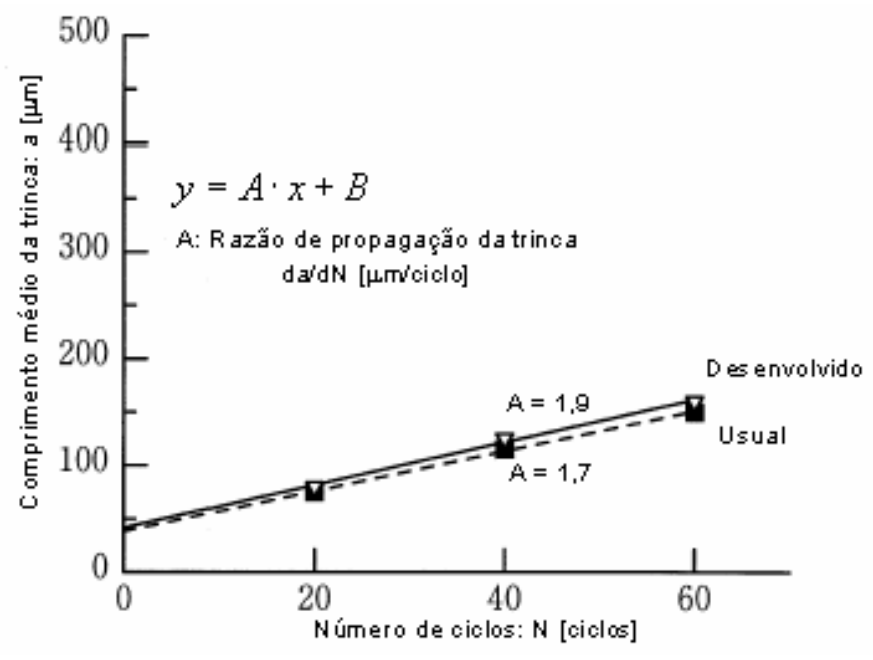

Figura 2.39 - Relação entre o comprimento médio da trinca e o número de ciclos no teste simulado [Yamabe 2002]. 
Com esses resultados, torna-se evidente que quanto maior o carbono equivalente e mais refinados os grãos, menor é a razão de propagação da trinca. Observa-se, na Figura 2.40 também que a razão de propagação da trinca foi praticamente a mesma para os dois materiais, o que viabiliza o material de baixo custo.

Foram realizadas análises em sistemas de freios automotivos, mostrando que os componentes falharam em conseqüência de fadiga termomecânica de baixo ciclo [Yamabe, 2001; Manson, 1953]. Análises na dinâmica dos veículos foram usadas para determinar a equação do fluxo térmico causado pela força de frenagem. A equação de fluxo térmico foi também usada em análises de elementos finitos para determinar o perfil de temperatura no freio. Depois que o perfil foi determinado, uma análise simplificada de ajuste de contração foi usada para estimar as tensões que surgiram durante a frenagem brusca. Essa aproximação mostra que a deformação plástica ocorre devido a grande deformação térmica associada com a frenagem brusca. A amplitude de deformação calculada foi usada como base para a lei de Coffin-Manson, utilizada para prever qual o número de ciclos de frenagem necessário para causar falha. Os ensaios realizados têm confirmado a precisão da teoria proposta.

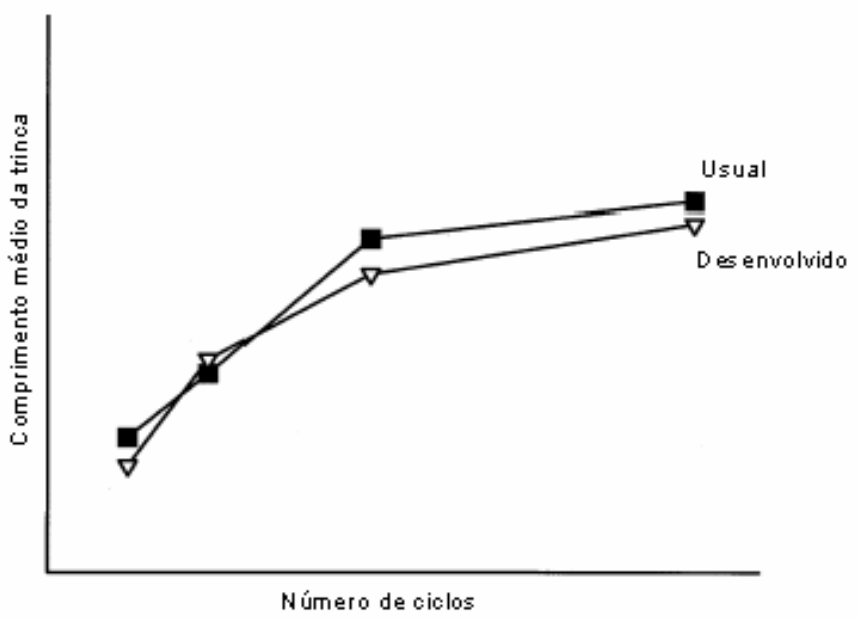

Figura 2.40 - Relação entre o comprimento médio da trinca e o número de ciclos em teste de frenagem de alta velocidade no componente [Yamabe 2002].

Com relação à fadiga termomecânica em ferros fundidos usados na fabricação de componentes de freio, a importância do estudo dos mecanismos de falha está ligada ao fato de que o problema está essencialmente relacionado á trincas decorrentes do processo de fadiga termomecânica [Mackin, 2002]. 


\subsubsection{2 - Fadiga Isotérmica}

Maurício Angeloni [Angeloni, 2005] realizou ensaios de fadiga isotérmica em sete diferentes ligas de ferro fundido cinzento, que são usadas pelo mercado na produção de discos de freio de veículos automotivos, com o intuito de identificar aquelas que apresentassem melhor comportamento quando submetidas à fadiga isotérmica. As composições químicas nominais de cada uma delas estão apresentadas na Tabela 2.8.

Tabela 2.8 - Composições químicas nominais (\% em peso) especificadas para as sete ligas [Angeloni, 2005].

\begin{tabular}{|c|c|c|c|c|c|c|c|}
\hline \multirow[b]{2}{*}{ Elementos } & \multicolumn{7}{|c|}{ Ligas Metálicas } \\
\hline & $\begin{array}{c}\text { A } \\
\text { Luk }\end{array}$ & $\begin{array}{c}\text { B } \\
\text { Teksid }\end{array}$ & $\begin{array}{c}\text { C } \\
\text { Teksid }\end{array}$ & $\begin{array}{c}\text { D } \\
\text { TRW }\end{array}$ & $\begin{array}{c}\text { E } \\
\text { TRW }\end{array}$ & $\begin{array}{c}\text { F } \\
\text { TRW }\end{array}$ & $\begin{array}{c}\text { G } \\
\text { TRW }\end{array}$ \\
\hline \multirow{2}{*}{$\% \mathrm{C}$} & 3,20 & 3,20 & 3,60 & 3,70 & 3,20 & 3,35 & 3,35 \\
\hline & 3,60 & 3,60 & 3,80 & 3,90 & 3,50 & 3,42 & 3,70 \\
\hline \multirow{2}{*}{$\% \mathbf{S i}$} & 1,90 & 1,90 & 1,80 & 1,75 & 1,70 & 1,80 & 2,20 \\
\hline & 2,40 & 2,40 & 2,20 & 1,95 & 2,10 & 2,00 & 2,60 \\
\hline \multirow{2}{*}{$\% \mathbf{M n}$} & 0,60 & 0,60 & 0,60 & 0,50 & 0,50 & 0,45 & 0,80 \\
\hline & 0,90 & 0,90 & 0,80 & 0,80 & 0,80 & 0,65 & 1,10 \\
\hline \multirow{2}{*}{$\% \mathbf{P}$} & Max & Max & Max & Max & Max & 0,015 & Max \\
\hline & 0,20 & 0,10 & 0,10 & 0,10 & 0,12 & 0,080 & 0,05 \\
\hline \multirow{2}{*}{$\% \mathrm{~S}$} & Max & Max & Max & Max & Max & 0,06 & Max \\
\hline & 0,12 & 0,10 & 0,12 & 0,13 & 0,12 & 0,12 & 0,60 \\
\hline \multirow{2}{*}{$\% \mathrm{Cr}$} & \multirow{2}{*}{ - } & 0,25 & 0,10 & Max & 0,25 & Max & 0,05 \\
\hline & & 0,40 & 0,25 & 0,20 & 0,40 & 0,10 & 0,25 \\
\hline \multirow{2}{*}{ \%Мо } & \multirow{2}{*}{ - } & 0,40 & 0,30 & Max & \multirow{2}{*}{ - } & \multirow{2}{*}{-} & Max \\
\hline & & 0,50 & 0,60 & 0,10 & & & 0,15 \\
\hline \multirow{2}{*}{$\% \mathrm{Cu}$} & \multirow{2}{*}{ - } & \multirow{2}{*}{-} & 0,30 & Max & 0,40 & 0,50 & 0,45 \\
\hline & & & 0,45 & 0,40 & 0,60 & 0,60 & 0,65 \\
\hline
\end{tabular}

Como o ferro fundido cinzento possui comportamento compressivo muito diferente do trativo, devido ao fato de que os veios de grafita se comportam como micro trincas, o método convencional de cálculo das componentes plástica e elástica da deformação não pôde ser 
usado. Isso porque forneceria valores incorretos, uma vez que a tangente do descarregamento trativo poderia, dependendo da histerese, encontrar valores de deformação plástica negativos. Em virtude disto a extensão da histerese de meia vida foi determinada pela tensão média, como pode ser visto na Figura 2.41 [Kandil, 1999].

Na Figura 2.41 observa-se que a distancia db corresponde a amplitude de deformação plástica, a distancia ac, na horizontal, a amplitude de deformação total e a distancia ac na vertical corresponde a amplitude de tensão; $\mathbf{E}_{\mathbf{1}}$ é o módulo de elasticidade no descarregamento trativo e $\mathbf{E}_{\mathbf{2}}$ o modulo de elasticidade no descarregamento compressivo.

Pode-se observar, através dos gráficos de Amplitude de Deformação - Vida $\left(\boldsymbol{\varepsilon} \mathbf{x} \mathbf{2 N}_{\mathbf{f}}\right)$ (Figuras 2.42 a 2.44), que houve algumas diferenças significativas na vida encontrada para as sete ligas em estudo (Tabela 2.8), para as temperaturas de $25^{\circ} \mathrm{C}, 300^{\circ} \mathrm{C}$ e $600^{\circ} \mathrm{C}$. Isto ocorre para todos os níveis de deformação estudados, $0,2 \%, 0,3 \%, 0,4 \%$ e $0,5 \%$, devido à baixa ductilidade das ligas estudadas, observando-se nestes casos que o CE parece não exercer qualquer influência sobre a vida em fadiga, para cada temperatura de teste. Porém, pode-se notar que a vida encontrada para a liga B aumenta com o aumento da temperatura, que se deve à presença de elementos de liga como molibdênio e cromo, demonstrando que estes elementos aumentam a resistência mecânica à quente dos materiais.

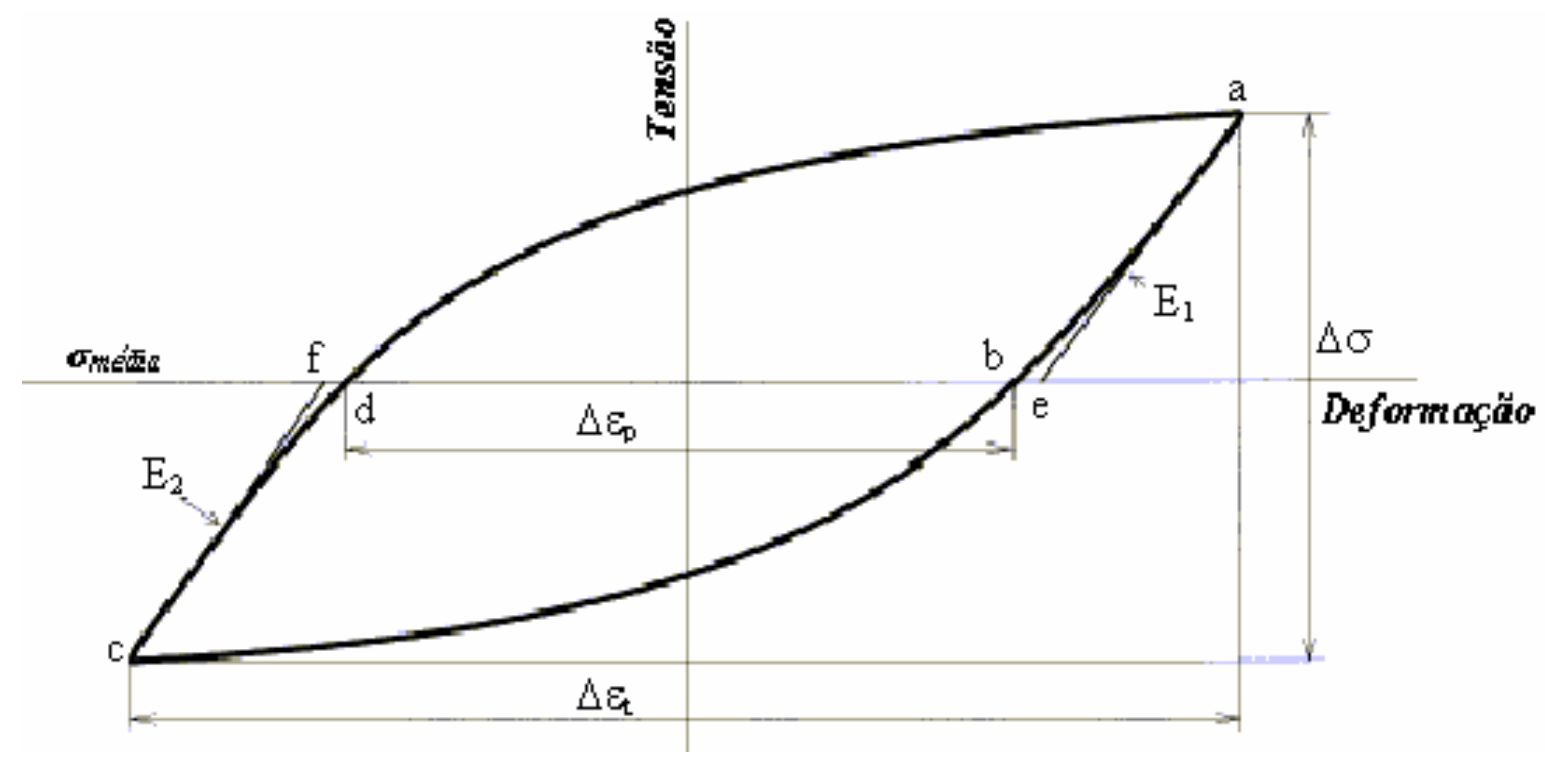

Figura 2.41 - Curva de Histerese [Kandil, 1999].

As ligas com maior resistência mecânica necessitam de uma maior tensão para serem deformados. Então, analisando-se o comportamento das sete ligas estudadas através dos gráficos Amplitude de Tensão - Vida para as temperaturas de $25^{\circ} \mathrm{C}$ e $300^{\circ} \mathrm{C}$ (Figuras 2.45 e 
2.46), pode-se observar que não houve uma diminuição significativa na amplitude de tensão para as sete ligas.

No entanto, quando a temperatura chega em torno de $600^{\circ} \mathrm{C}$ (Figura 2.47), há uma diminuição mais acentuada na amplitude de tensão para as ligas que contem pouco ou nenhum molibdênio, deixando claro sua relação com o aumento na resistência a altas temperaturas. Assim, pode-se observar que as ligas mais resistentes à diminuição das propriedades mecânicas com a temperatura, ligas $\mathbf{B}, \mathbf{E}, \mathbf{A}$ e $\mathbf{F}$, apresentam melhores desempenhos quanto à vida em fadiga isotérmica.

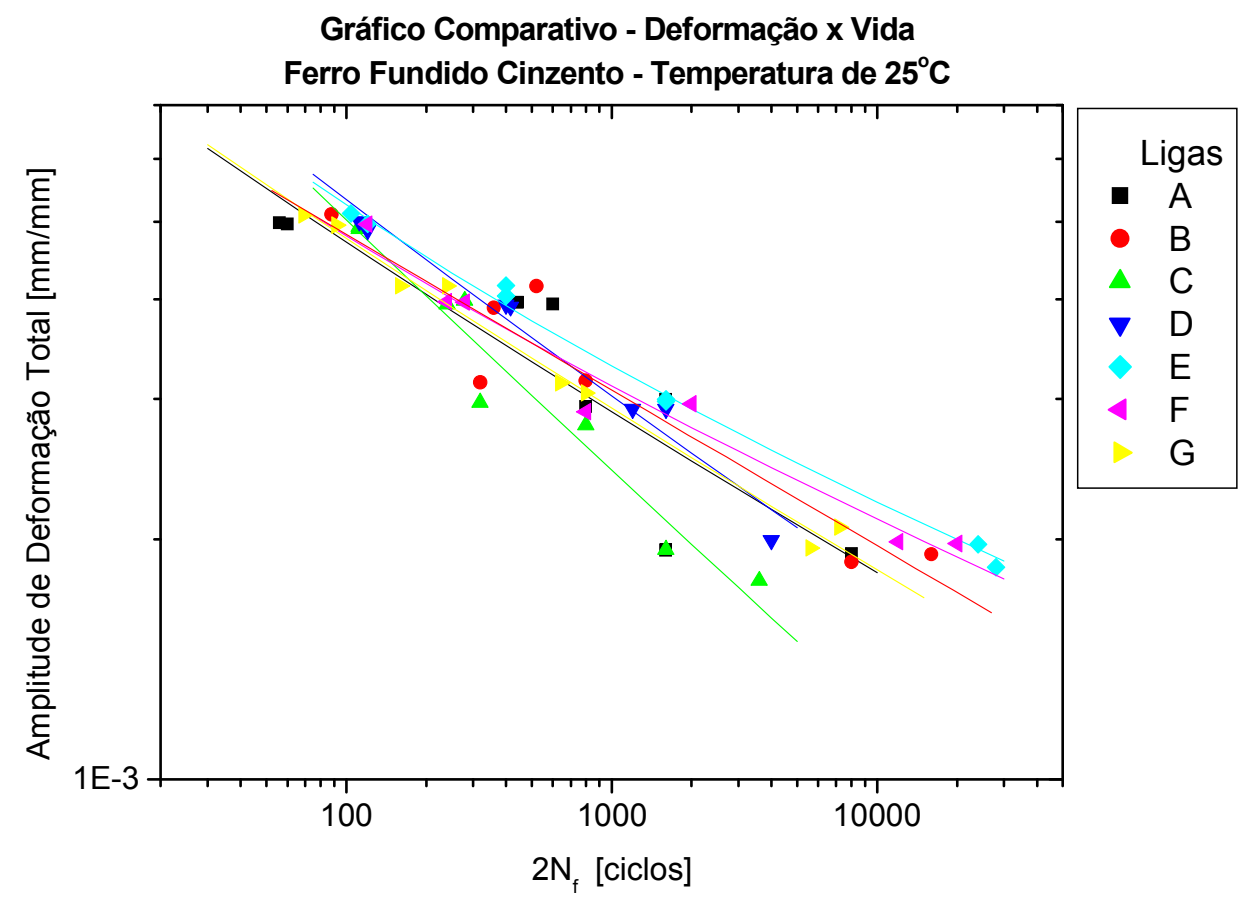

Figura 2.42 - Fadiga Isotérmica: Gráfico Comparativo da Amplitude de Deformação x Vida para temperatura de $25^{\circ} \mathrm{C}$ [Angeloni, 2005]. 


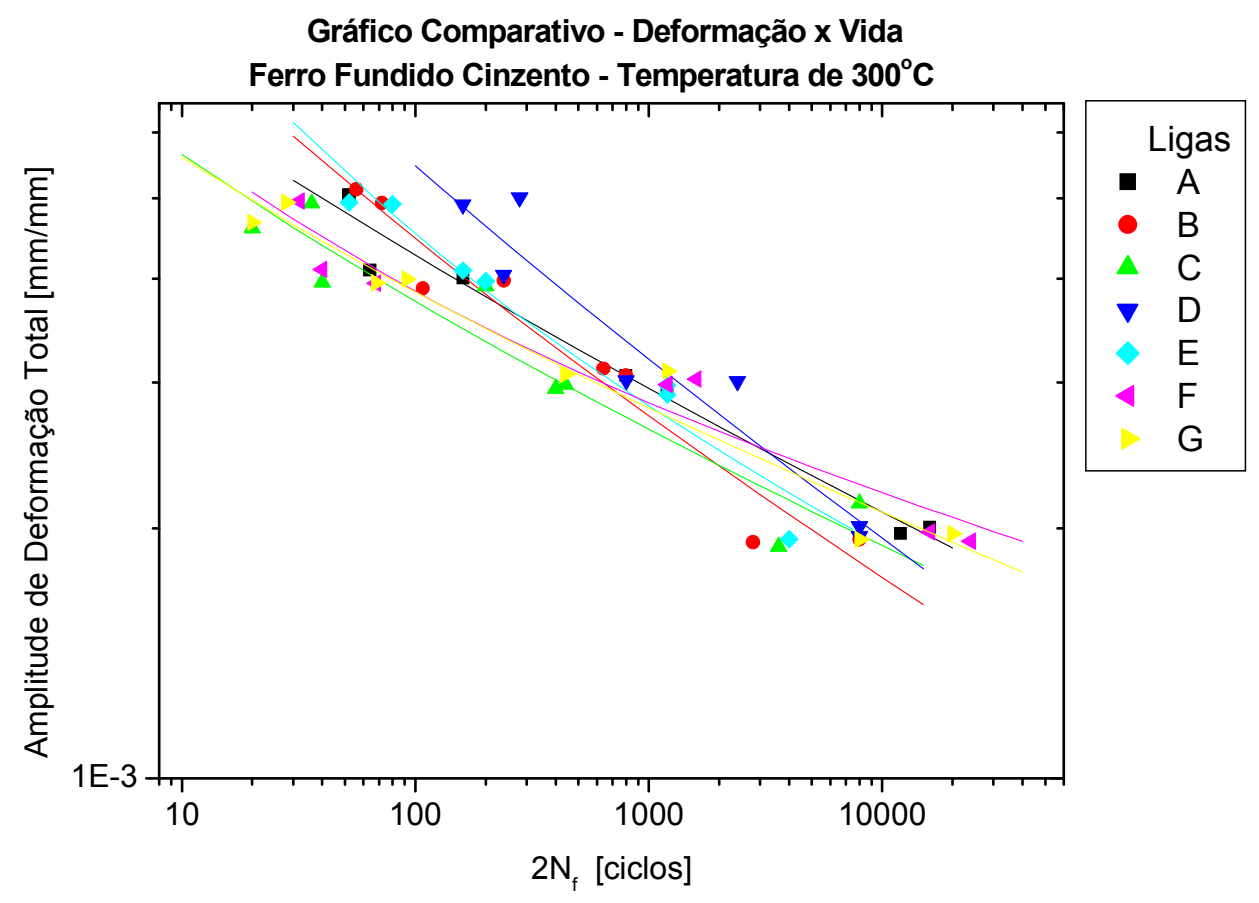

Figura 2.43 - Fadiga Isotérmica: Gráfico Comparativo da Amplitude de Deformação x Vida para temperatura de $300^{\circ} \mathrm{C}$ [Angeloni, 2005].

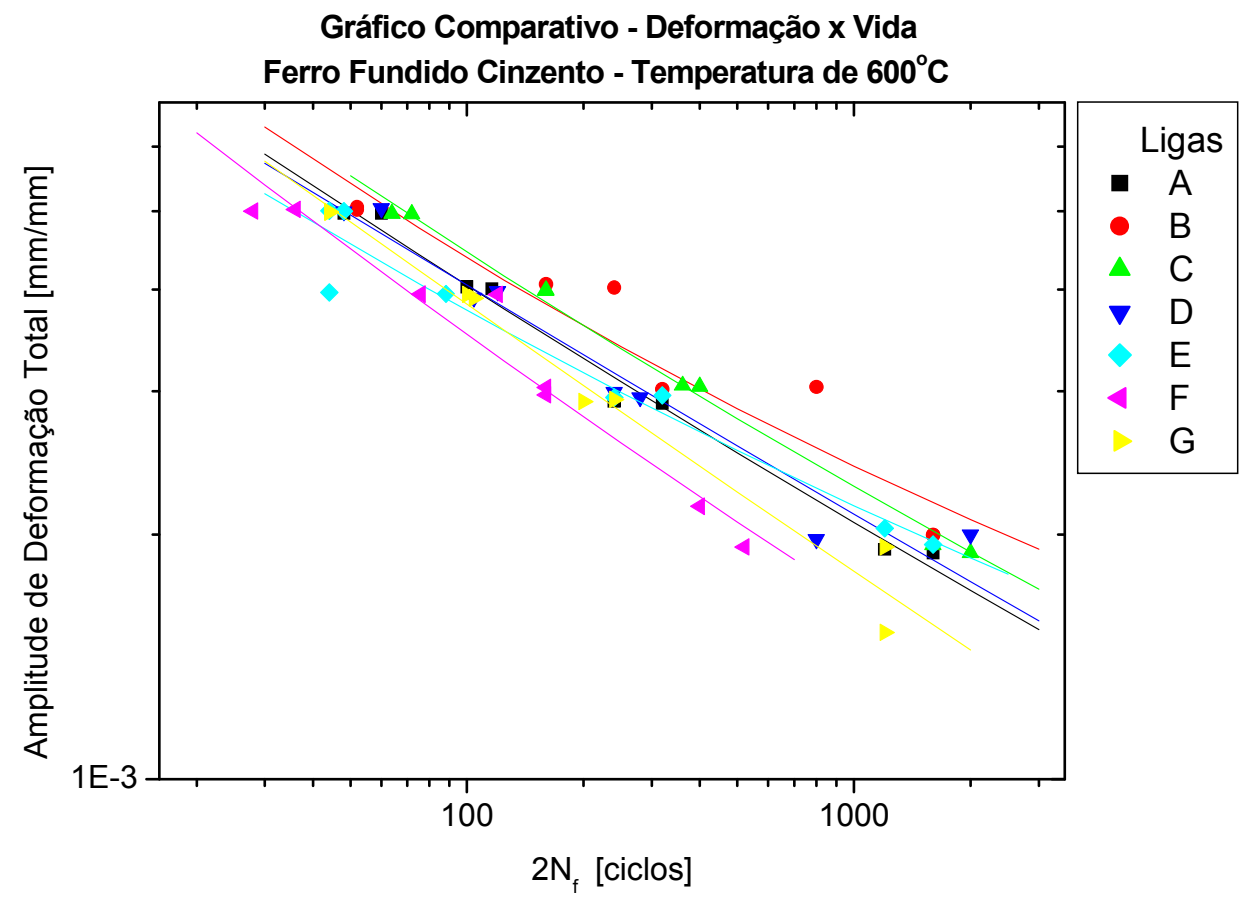

Figura 2.44 - Fadiga Isotérmica: Gráfico Comparativo da Amplitude de Deformação x Vida para temperatura de $600^{\circ} \mathrm{C}$ [Angeloni, 2005]. 


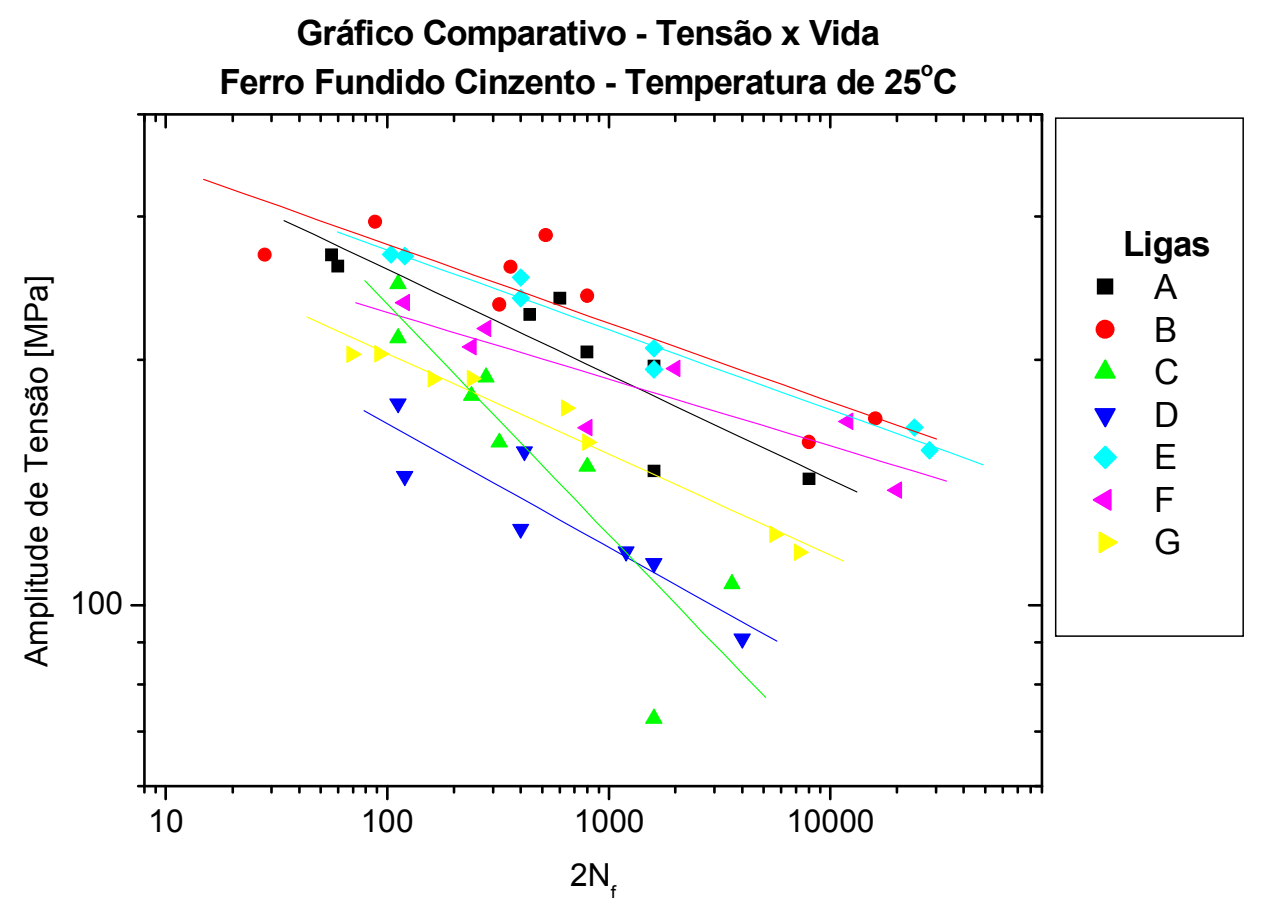

Figura 2.45 - Fadiga Isotérmica: Gráfico Comparativo da Amplitude de Tensão x Vida para temperatura de $25^{\circ} \mathrm{C}$ [Angeloni, 2005].

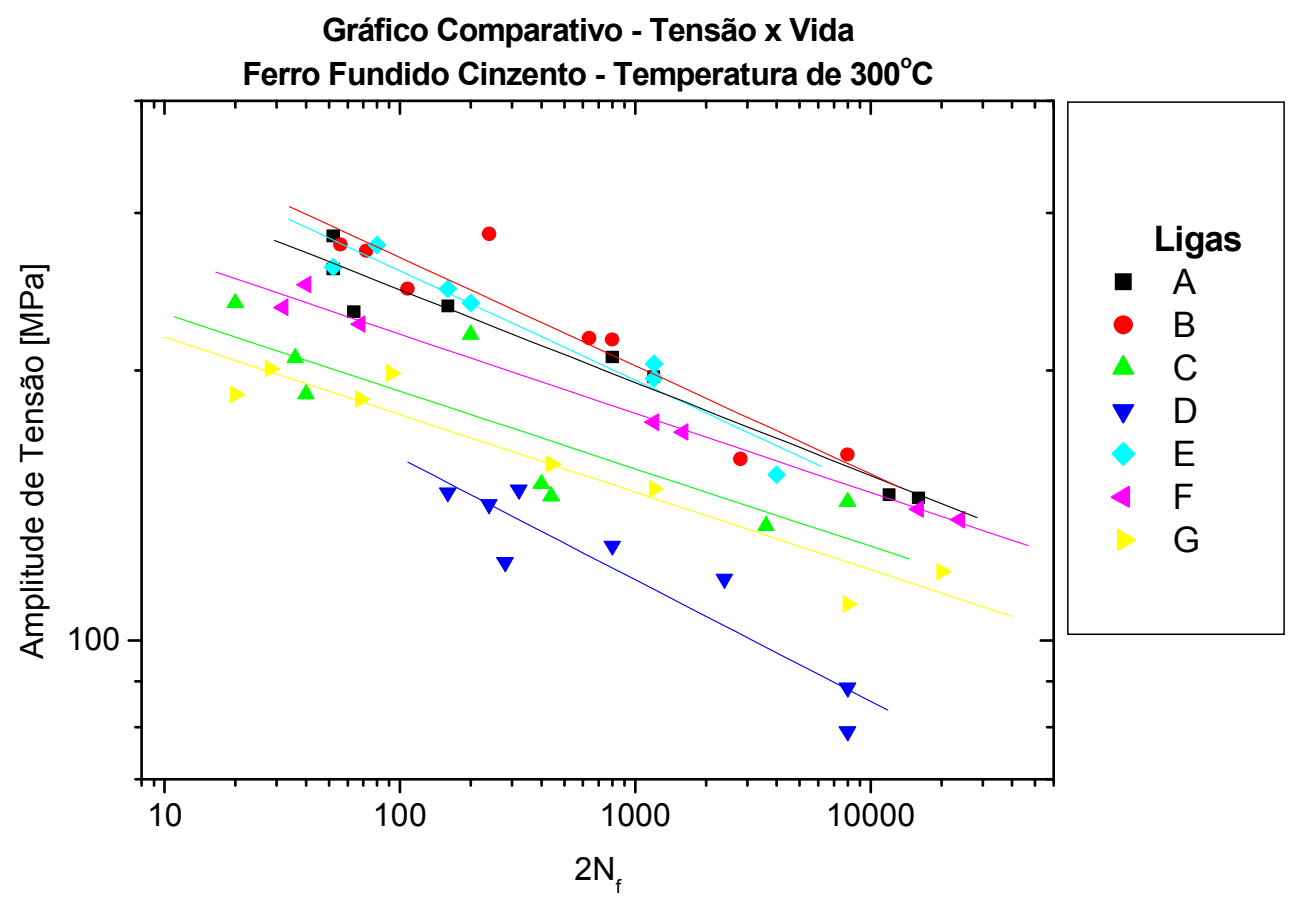

Figura 2.46 - Fadiga Isotérmica: Gráfico Comparativo da Amplitude de Tensão x Vida para temperatura de $300^{\circ} \mathrm{C}$ [Angeloni, 2005]. 


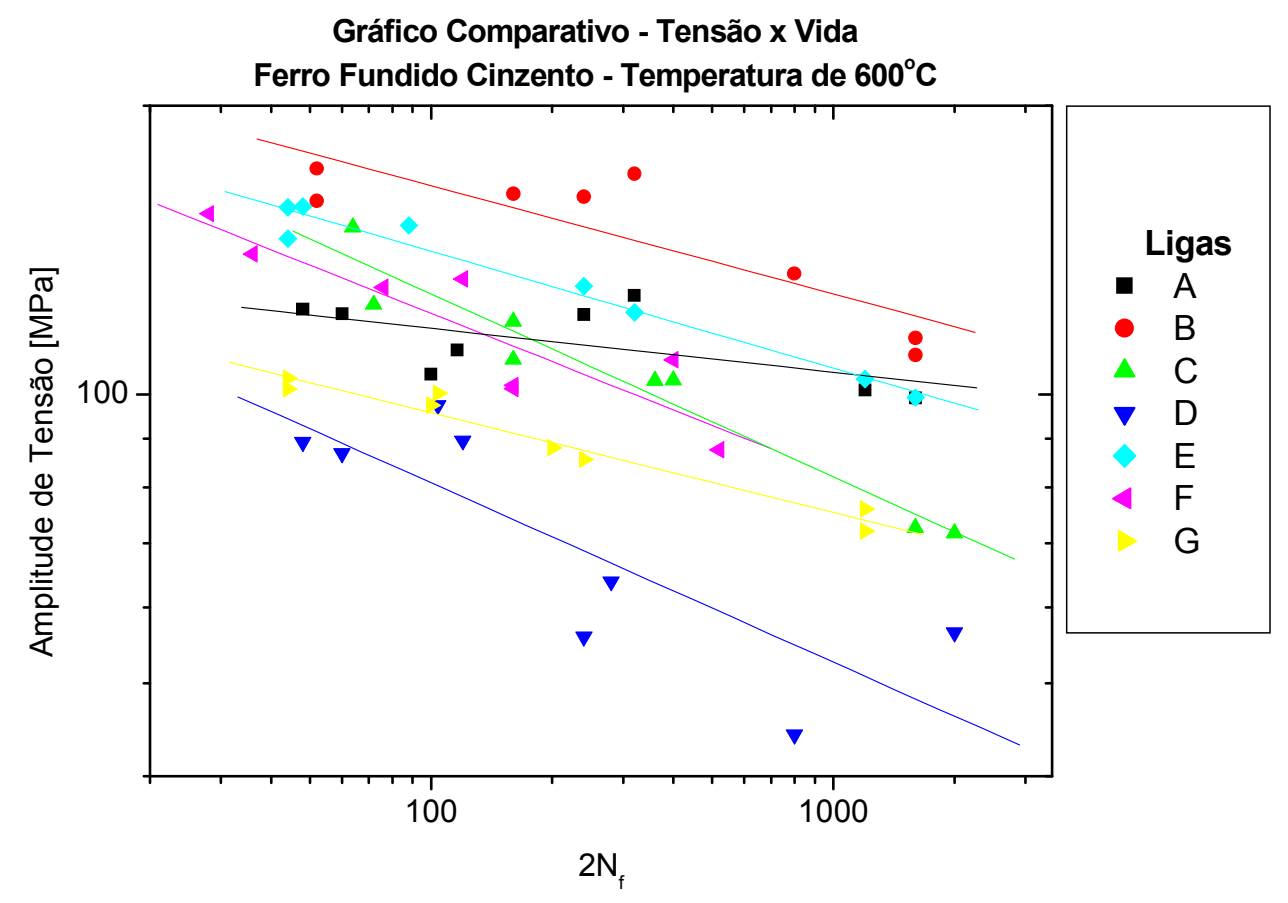

Figura 2.47 - Fadiga Isotérmica: Gráfico Comparativo da Amplitude de Tensão x Vida para temperatura de $600^{\circ} \mathrm{C}$ [Angeloni, 2005]. 


\section{3 - OBJETIVO}

O objetivo deste trabalho é o de estudar o comportamento de algumas ligas de ferro fundido cinzento usadas na produção de discos de freio, nas condições as mais próximas possíveis daquelas encontradas pelo componente durante a operação, isto é, sob fadiga termomecânica de baixo ciclo. Para tanto, curvas de vida em fadiga, em controle de deformação, foram determinadas por meio de ensaios de fadiga anisotérmicos em corpos de prova e componentes. Observações por microscopia óptica também foram efetuadas de modo a verificar o efeito que eventuais modificações microestruturais tiveram sobre o comportamento mecânico. Também foram realizados ensaios de difusividade térmica, com o intuito de avaliar a influencia da temperatura e dos elementos de liga sobre esta propriedade física e verificar qual a real importância desta sobre a performance dos discos de freio. 


\section{4 - MATERIAIS E MÉTODOS}

Na Tabela 4.9, estão especificadas as faixas de composição química para as quatro ligas de ferro fundido cinzento utilizadas na produção de discos de freio automotivos, que foram estudadas neste trabalho.

Tabela 4.9 - Composições químicas nominais especificadas.

\begin{tabular}{|c|c|c|c|c|}
\hline \multirow{2}{*}{ Elementos } & \multicolumn{4}{|c|}{ Ligas Metálicas } \\
\cline { 2 - 5 } & $\mathbf{A}$ & $\mathbf{B}$ & $\mathbf{C}$ & $\mathbf{E}$ \\
Luk & Teksid & Teksid & TRW \\
\hline \%C & $3,20-3,60$ & $3,20-3,60$ & $3,60-3,80$ & $3,20-3,50$ \\
\hline $\mathbf{\% S i}$ & $1,90-2,40$ & $1,90-2,40$ & $1,80-2,20$ & $1,70-2,10$ \\
\hline$\% \mathbf{M n}$ & $0,60-0,90$ & $0,60-0,90$ & $0,60-0,80$ & $0,50-0,80$ \\
\hline $\mathbf{\% P}$ & $0,20 \mathrm{Max}$. & $0,10 \mathrm{Max}$ & $0,10 \mathrm{Max}$ & $0,12 \mathrm{Max}$ \\
\hline $\mathbf{\% S}$ & $0,12 \mathrm{Max}$ & $0,10 \mathrm{Max}$ & $0,12 \mathrm{Max}$ & $0,12 \mathrm{Max}$ \\
\hline $\mathbf{\% C r}$ & - & $0,25-0,40$ & $0,10-0,25$ & $0,25-0,40$ \\
\hline $\mathbf{\% M o}$ & - & $0,40-0,50$ & $0,30-0,60$ & - \\
\hline $\mathbf{\% C u}$ & - & - & $0,30-0,45$ & $0,40-0,60$ \\
\hline
\end{tabular}

Após a seleção destas quatro ligas, foram realizados ensaios de fadiga termomecânica de baixo ciclo em corpos de prova, em fase e fora de fase, e em componentes, além de testes de difusividade.

\section{1 - Materiais}

A Figura 4.48 mostra o formato dos blocos de prova, doados por fornecedores da General Motors do Brasil (GMB), Luk, Teksid e TRW, que foram entregues, no estado bruto de solidificação, com composição química de acordo com o apresentado na Tabela 4.9. Vale salientar que foram utilizados tanto no trabalho anterior (Angeloni) quanto neste de fadiga termomecânica. 


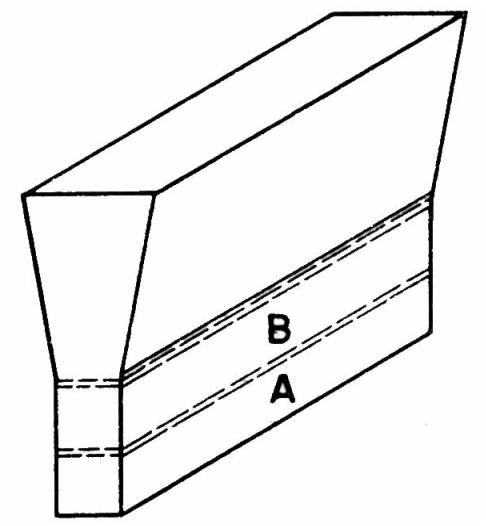

Figura 4.48 - Bloco "Y" segundo norma ASTM A476/476M.

Um dos fornecedores, a TRW, além dos blocos Y também disponibilizou discos de freio com composições químicas similares àquelas das ligas $\mathbf{A}, \mathbf{B}$ e E, para que fosse possível comparar o desempenho funcional de algumas ligas selecionadas. A Figura 4.49 mostra fotografia do disco no qual foram realizados os ensaios de fadiga termomecânica.

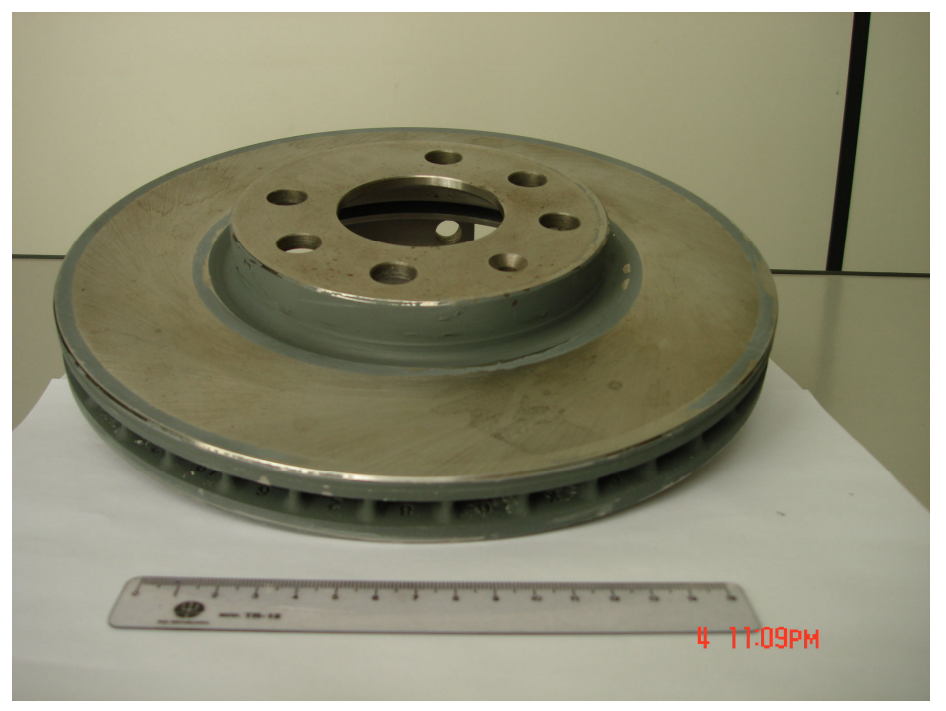

Figura 4.49 - Disco de freio aletado utilizado nos ensaios de fadiga termomecânica em componentes.

\section{2 - Métodos Experimentais}

Conforme já visto, o objetivo principal deste estudo foi o de pesquisar o comportamento mecânico e físico de quatro ligas de ferro fundido cinzento, usadas pelas montadoras para produzir discos de freio automotivos, quando submetidas a ensaios de fadiga termomecânica de baixo ciclo, em fase e fora de fase, na faixa de temperatura compreendida 
entre $300^{\circ} \mathrm{C}$ e $600^{\circ} \mathrm{C}$ e sob controle de deformação. Vale salientar que se adotou, de acordo com a norma ASTM E 606, o critério de falha de 50\% da tensão máxima, ou seja, toda vez que a tensão do ensaio cair para valor de $50 \%$ da maior tensão detectada no ensaio, este deve ser interrompido, e considera-se que o corpo de prova falhou.

As ligas $\mathrm{A}, \mathrm{B}, \mathrm{C}$ e $\mathrm{E}$, foram escolhidas por terem sido aquelas que, em um universo de sete (A, B, C, D, E, F e G) usadas na confecção de discos de freio automotivos de ferro fundido cinzento, apresentaram os melhores resultados comparativos em ensaios de tração, impacto, fadiga isotérmica e relação custo/benefício, conforme mostra a Tabela 4.10. Nela as ligas são tão melhores, em termos de propriedades, ou mais baratas por quilo de carga metálica, quanto menores os números a elas atribuídos.

Tabela 4.10 - Classificação comparativa das sete ligas de ferro fundido cinzento [Angeloni, 2005].

\begin{tabular}{|c|c|c|c|c|c|c|c|c|}
\hline & LIGA & A & B & C & D & E & F & G \\
\hline \multirow{2}{*}{ TRAÇÃO } & $25^{\circ} \mathrm{C}$ & 3 & 1 & 4 & 6 & 2 & 4 & 5 \\
\hline & $300^{\circ} \mathrm{C}$ & 2 & 1 & 3 & 5 & 4 & 4 & 5 \\
\cline { 2 - 10 } & $600^{\circ} \mathrm{C}$ & 2 & 1 & 3 & 6 & 4 & 4 & 5 \\
\hline \multirow{2}{*}{ IMPACTO } & $25^{\circ} \mathrm{C}$ & 3 & 1 & 3 & 6 & 2 & 4 & 5 \\
\hline & $400^{\circ} \mathrm{C}$ & 4 & 1 & 3 & 5 & 2 & 4 & 5 \\
\cline { 2 - 10 } & $600^{\circ} \mathrm{C}$ & 3 & 1 & 2 & 5 & 2 & 4 & 4 \\
\hline \multirow{2}{*}{ FADIGA } & $25^{\circ} \mathrm{C}$ & 2 & 1 & 3 & 6 & 2 & 4 & 5 \\
\hline & $3^{\circ} 0^{\circ} \mathrm{C}$ & 2 & 1 & 4 & 6 & 2 & 3 & 5 \\
\cline { 2 - 10 } & $600^{\circ} \mathrm{C}$ & 2 & 1 & 2 & 5 & 2 & 3 & 4 \\
\hline PREÇO* & $\mathbf{k g}$ & 1 & 6 & 7 & 2 & 4 & 3 & 5 \\
\hline MÉDIA & & 2,4 & 1,5 & 3,2 & 5,2 & 2,6 & 3,7 & 4,8 \\
\hline POSIÇÃO & & $2^{\circ}$ & $1^{\circ}$ & $4^{\circ}$ & $7^{\circ}$ & $3^{\circ}$ & $5^{\circ}$ & $6^{\circ}$ \\
\hline
\end{tabular}

Os ensaios de fadiga termomecânica em altas temperaturas e as microscopias ópticas foram realizados nos laboratórios do Departamento de Engenharia de Materiais, Aeronáutica e Automobilística da Escola de Engenharia de São Carlos (EESC) - USP.

Já os ensaios de fadiga termomecânica em componentes (discos de freio), cujas composições químicas são similares àquelas das ligas $\mathbf{A}, \mathbf{B}$ e $\mathbf{E}$, foram realizados nas dependências da própria empresa TRW, na cidade de Limeira-SP. Os valores de difusividade 
térmica de cada uma das ligas foram realizados no Laboratório Interdisciplinar de Eletroquímica e Cerâmica (LIEC) do Departamento de Química da Universidade Federal de São Carlos (UFSCar).

\subsection{1 - Ensaios de Fadiga Termomecânica em Corpos de Prova}

Os ensaios de fadiga termomecânica foram realizados em uma máquina servohidráulica MTS 810 com capacidade para $250 \mathrm{kN}$, equipada com controlador MTS Micro Console 458.20 (Figura 4.50). Os corpos de prova foram ensaiados, em fase e fora de fase, sob controle de deformação mecânica $(0,10 \%, 0,20 \%, 0,30 \%$ e $0,40 \%)$ com a utilização de um extensômetro MTS, modelo 632.54F14, para altas temperaturas, constituído de duas hastes de cerâmica de $2 \mathrm{~mm}$ de diâmetro. O sistema de garras hidráulicas utilizado foi o MTS modelo 680.01B, próprio para altas temperaturas.

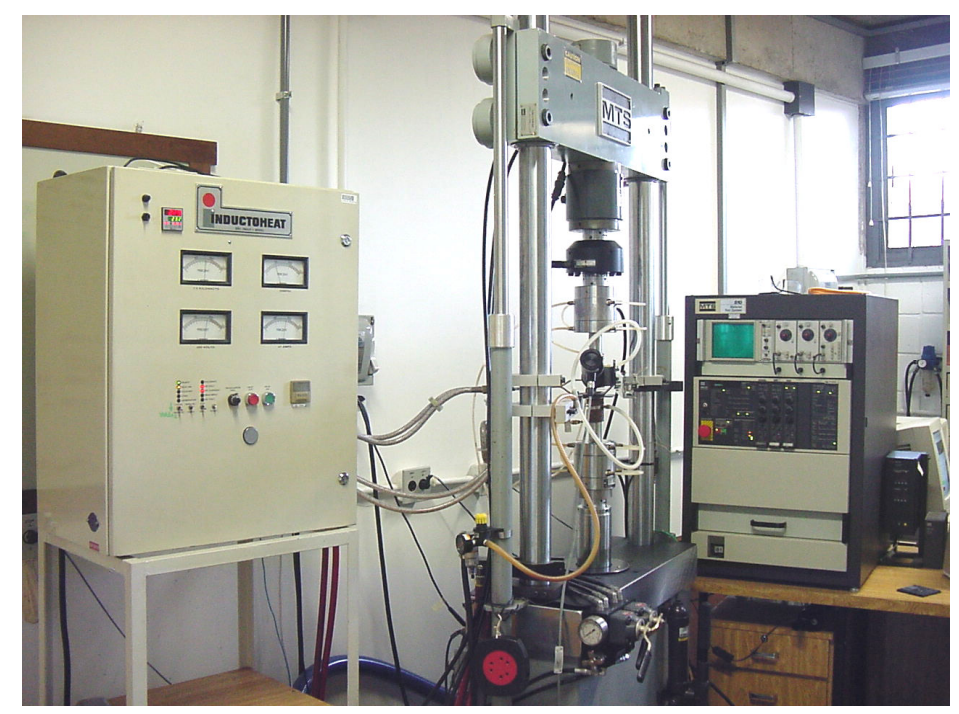

Figura 4.50 - Visão geral do aparato de ensaios mostrando o forno de indução e a máquina servo-hidráulica MTS 810.

Os corpos de prova foram aquecidos por um forno à indução elétrica, marca Inductoheat, e a medição da temperatura executada por um pirômetro fixo equipado com mira a laser. O sistema de resfriamento auxiliar das garras para os ensaios de fadiga termomecânica é composto por duas serpentinas confeccionadas com tubos de cobre, por onde circula água refrigerada, e por duas mangueiras de ar comprimido acopladas às extremidades, superior e 
inferior das garras. A Figura 4.51 uma visão localizada da região de fixação do corpo de prova durante um ensaio de fadiga termomecânica.

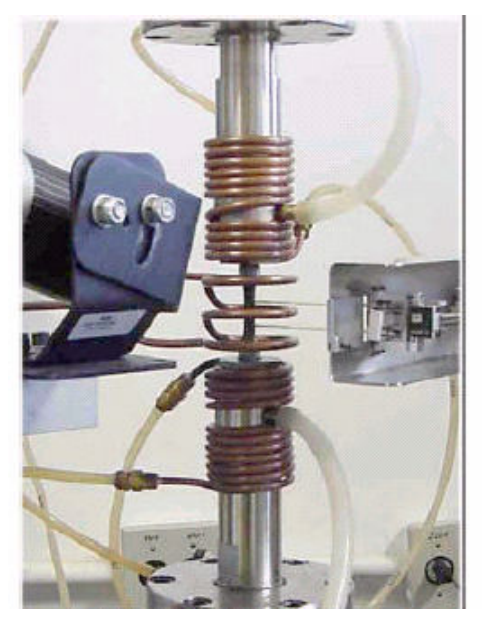

Figura 4.51 - Detalhe do corpo de prova, da bobina de indução, do sistema de refrigeração auxiliar das garras e do extensômetro de hastes cerâmicas, para os ensaios de fadiga anisotérmica.

Os ensaios de FTM foram realizados em ciclos de 120 segundos, tempo mínimo para permitir o resfriamento do corpo de prova de ferro fundido cinzento de maneira estável e para manter a sincronia entre os ciclos térmicos e mecânicos, e razão de carga, $\mathrm{R}=-1$, como ilustram as Figuras 4.52(a)e 4.5(b).

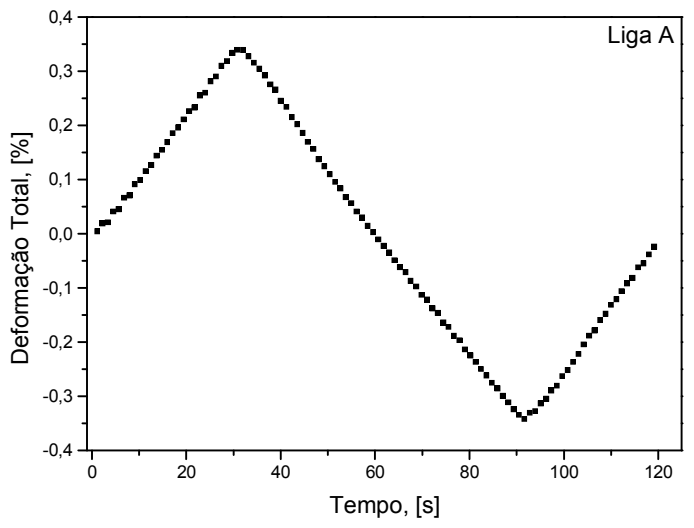

(a)

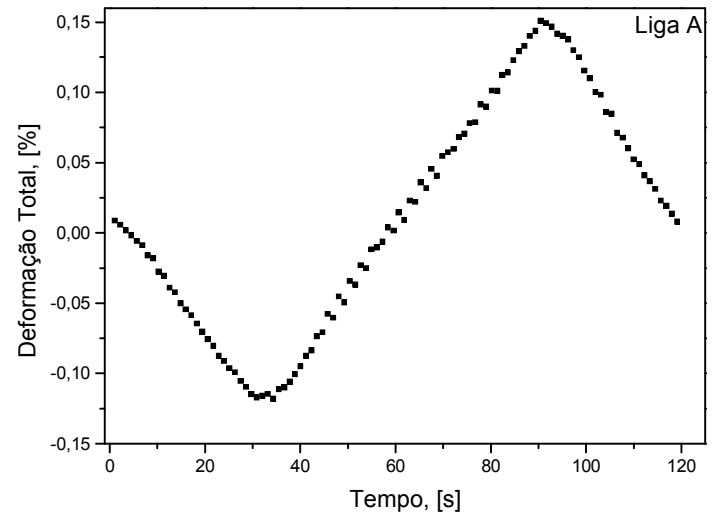

(b)

Figura 4.52 - Variação da deformação total com o tempo e a temperatura, em ciclos iniciais de ensaios de fadiga termomecânica da liga $\mathrm{A}$, com controle de deformação mecânica $(0,10 \%),(a)$ em fase e (b) fora de fase.

Os ensaios de fadiga termomecânica em fase e fora de fase foram realizados na faixa de temperatura de $300^{\circ} \mathrm{C}$ a $600^{\circ} \mathrm{C}$. Para a fadiga termomecânica em fase, a deformação 
positiva corresponde à máxima temperatura do ciclo, e a deformação negativa corresponde à mínima temperatura do ciclo, sendo a deformação nula para a temperatura de $450^{\circ} \mathrm{C}$, como ilustra a Figura 4.53.

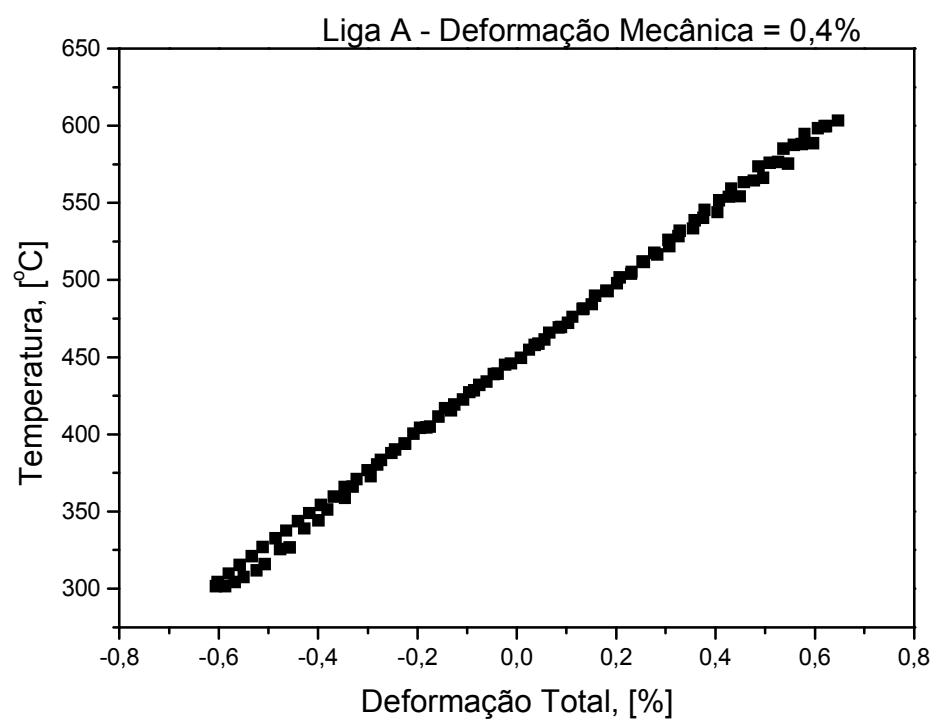

Figura 4.53 - Temperatura em função do ciclo deformação total para um ensaio de fadiga termomecânica em fase.

Já para a fadiga termomecânica fora de fase, a deformação positiva corresponde à mínima temperatura do ciclo, e a deformação negativa à máxima temperatura do ciclo, sendo a deformação nula para a temperatura de $450^{\circ} \mathrm{C}$, como ilustra a Figura 4.54 . Inicialmente, o corpo de prova, sem nenhum carregamento, foi aquecido até $450^{\circ} \mathrm{C}$, e os valores de deformação (térmica) zerados. Foi, então, realizado um ciclo térmico de ensaio, entre $300^{\circ} \mathrm{C}$ e $600^{\circ} \mathrm{C}$, ainda sem carregamento, para a obtenção da deformação térmica ao longo do referido ciclo. O passo seguinte foi a realização do ensaio até a fratura, ou até a queda de $50 \%$ da carga aplicada no quinto ciclo, adotado como critério de falha. A deformação fornecida pelo equipamento, através da histerese, corresponde à deformação total sofrida pelo material, composta pela deformação mecânica (pré-estabelecida) mais a térmica, determinada pelas propriedades físicas do material.

Da parte útil dos blocos padrões, foram retiradas 24 amostras para usinagem dos corpos de prova para os ensaios de fadiga termomecânica (ASTM E466), conforme desenho da Figura 4.55. A Figura 4.56 mostra a foto de um corpo de prova de fadiga usinado e já recoberto com tinta refratária, que tem a função de aumentar a emissividade do material. 


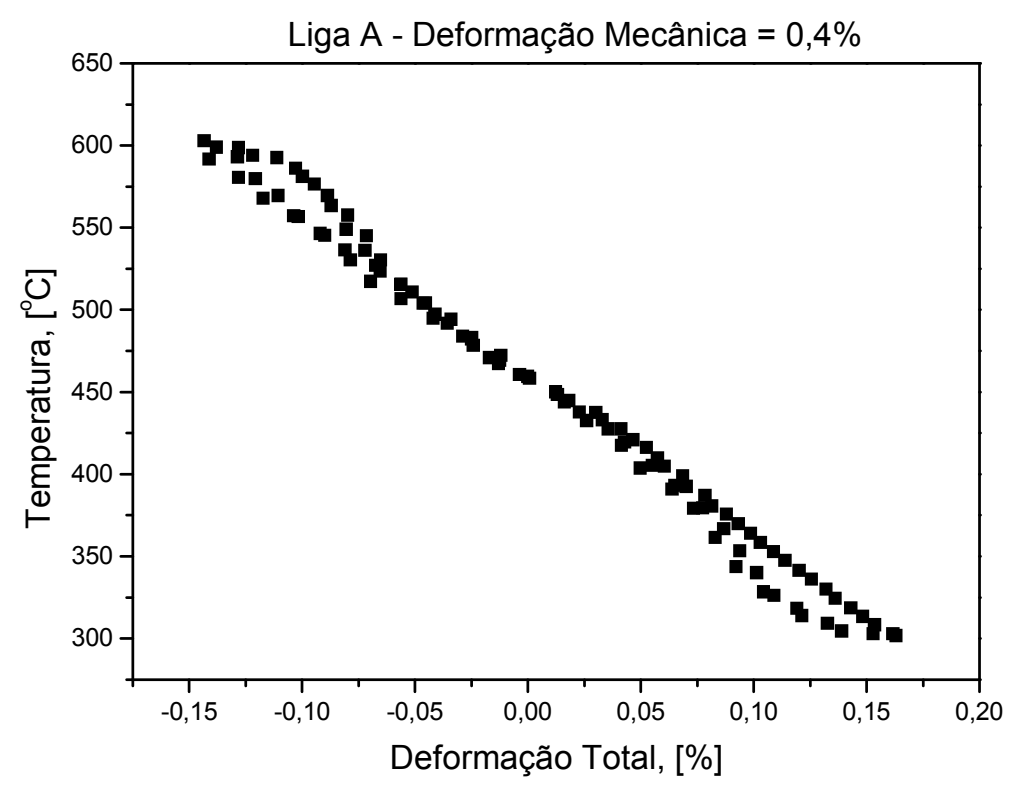

Figura 4.54 - Temperatura em função do ciclo de deformação total para um ensaio de fadiga termomecânica fora de fase.

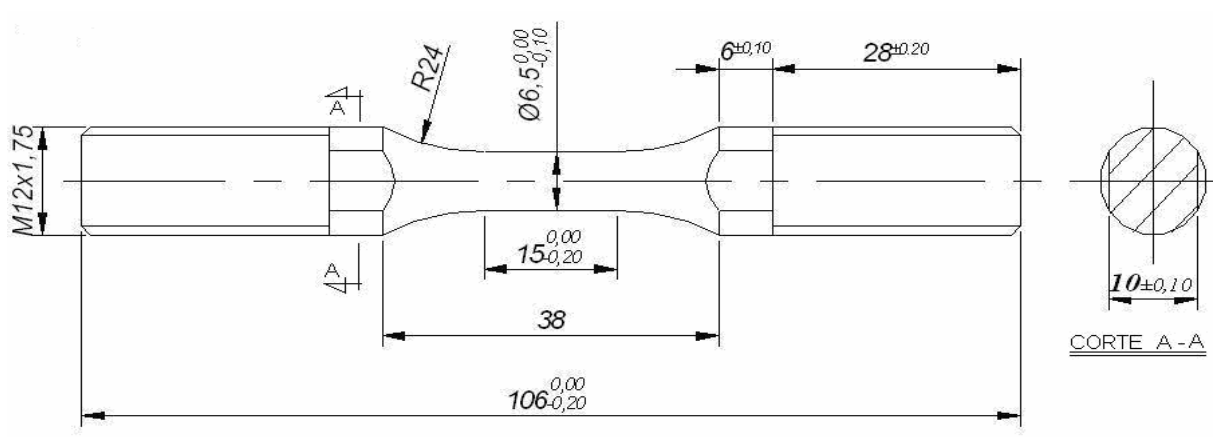

Figura 4.55 - Desenho de usinagem do corpo de prova para ensaio de fadiga.

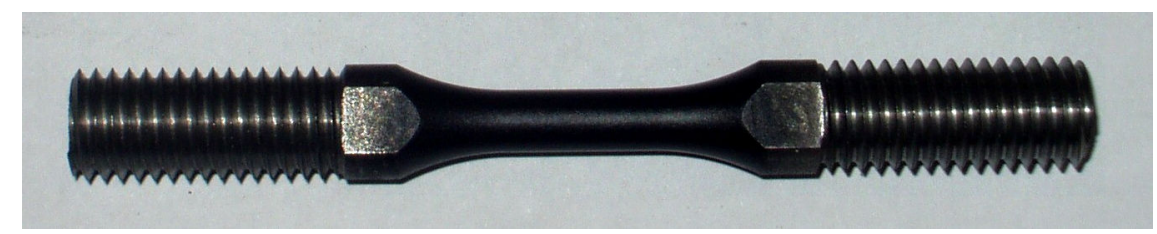

Figura 4.56 - Foto do corpo de prova utilizado nos ensaios de fadiga.

\subsection{2 - Ensaios de Fadiga Termomecânica em Componentes}

Os ensaios de fadiga termomecânica em componentes foram realizados na TRW, empresa multinacional, especializada em sistemas de freio para veículos automotores, que abastece montadoras no Brasil e no exterior. O aparato utilizado, que pode ser visto na Figura 
4.57 e Figura 4.58, é equipado com dinamômetro e próprio para ensaios de frenagem em componentes.

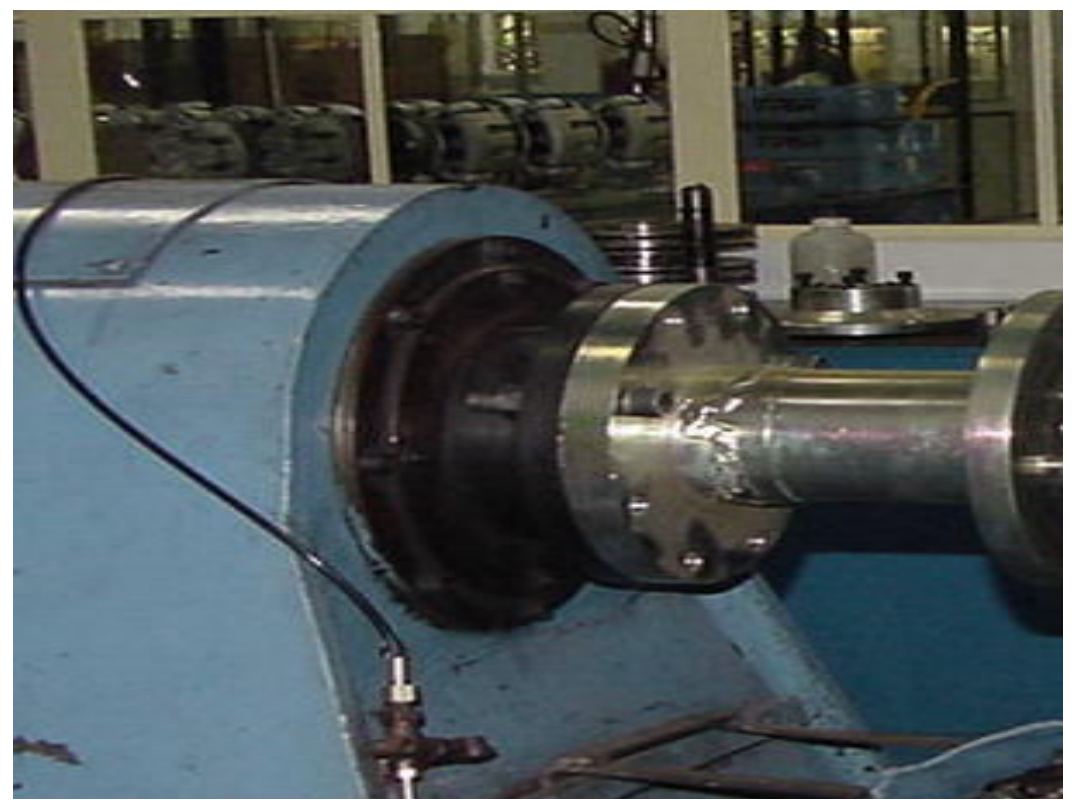

Figura 4.57 - Vista do local de fixação do disco de freio no equipamento da TRW para o ensaio de fadiga termomecânica.

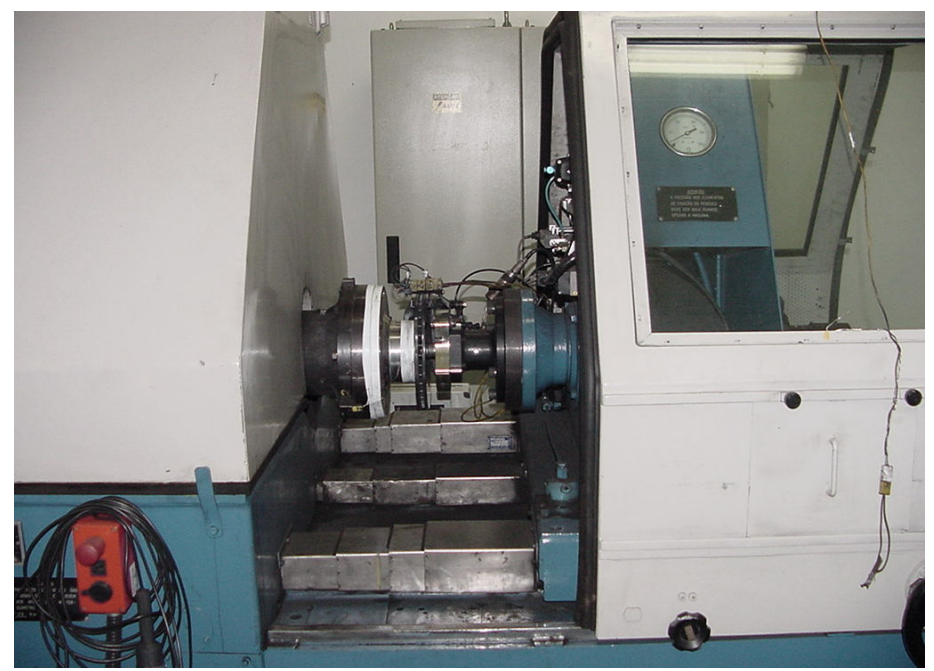

Figura 4.58 - Vista do equipamento de ensaio de fadiga termomecânica com o disco de freio já fixado.

O disco de freio, à temperatura ambiente, é instalado na máquina, que nada mais é que um completo sistema de frenagem similar aos existentes nas rodas de um automóvel que, após atingir a velocidade estabelecida, é freado quase que instantaneamente por pastilha de freio. Cada grupo de quatro frenagens consecutivas, com controle de temperatura, é considerado um 
ciclo e o ciclo seguinte se inicia tão logo a temperatura do componente caia para $100^{\circ} \mathrm{C}$. Normalmente o disco para ser aprovado não pode apresentar trincas passantes antes de 240 ciclos. É uma avaliação de desempenho do tipo "passa - não passa" cuja profundidade de trincas após os ensaios pode ser observada "a olho nu" ou com o auxílio de líquidos penetrantes. Para realizar esse teste, são necessárias informações sobre o veículo onde o disco vai ser utilizado, e essas informações são, por exemplo, a velocidade máxima que pode atingir e o peso. Conhecendo-se, por exemplo, o peso do carro utilizam-se contrapesos para simular o efeito da inércia no processo de frenagem. A TRW produziu e disponibilizou 12 discos de freio, 03 de cada uma das quatro ligas selecionadas para este estudo. Para execução dos experimentos desse trabalho, foram pré-estabelecidos os parâmetros da Tabela 4.11.

Tabela 4.11 - Parâmetros para ensaio de fadiga (discos de freio).

\begin{tabular}{|c|c|}
\hline Parânmetros & Valores utilizados \\
\hline Peso total (contrapeso) - kg & 1605 \\
\hline Balanceamento - \% & 76,2 \\
\hline Velocidade máxima - km/h & 175 \\
\hline Velocidade de ensaio ( $85 \%$ da máxima) & 148 \\
\hline Desaceleração - $\mathbf{m} \mathbf{s}^{2}$ & 8 \\
\hline Total de ciclos- cada ciclo 4 frenagens & 240 \\
\hline Temperatura primeira frenagem $-{ }^{\circ} \mathrm{C}$ & 100 \\
\hline Temperatura - quarta frenagem - ${ }^{\circ} \mathrm{C}$ & 400 \\
\hline Pressão-bar & 100 \\
\hline Torque - N.m & 1400 \\
\hline
\end{tabular}

\subsection{3 - Ensaios de Difusividade Térmica}

Os ensaios de medição da difusividade térmica, desde a temperatura ambiente até $600^{\circ}$ $\mathrm{C}$, em cada uma das 4 ligas de ferro fundido cinzento identificadas pelas letras $\mathbf{A}, \mathbf{B}, \mathbf{C}$ e $\mathbf{E}$, foram realizados, conforme a norma ASTM C 1113, no Laboratório Interdisciplinar de Eletroquímica e Cerâmica - LIEC da UFSCar, em um Laser Flash Apparatus (LFA - 427) da NETZSCH, mostrado na Figura 4.59. O equipamento consiste em uma fonte de laser, com a qual é possível controlar a duração e a potência do pulso que será incidido na face de uma amostra cilíndrica em estado estacionário de temperatura. Ao mesmo tempo, na face oposta da 
amostra, o aumento da temperatura em função do tempo é medido por um sensor infravermelho resfriado por nitrogênio líquido, que é acionado no mesmo instante do disparo do laser. O resultado obtido do aparelho é a resposta do detector que mostra o transiente de temperatura pelo tempo, em que a difusividade é calculada levando em conta a espessura da amostra, e o tempo necessário para que o aumento da temperatura na parte posterior da amostra atinja metade de seu valor máximo. Através das curvas obtidas para cada uma das ligas se obtém os valores das difusividades térmicas (D), que descrevem as taxas de propagação do calor durante o processo transiente, que podem ser utilizadas, se for o caso, para calcular as condutividades térmicas $\mathbf{k}$, equações 4.1 e 4.2 , que são medidas que bem mostram a capacidade de os materiais conduzirem calor.

$$
\begin{gathered}
k=D \cdot \rho \cdot C \\
\frac{Q}{\Delta t}=K \times A \times\left(\frac{\Delta T}{L}\right)
\end{gathered}
$$

onde: $\mathbf{k}$ é a condutividade térmica, $\mathbf{D}$ a difusividade térmica, $\boldsymbol{\rho}$ a densidade, $\mathbf{C}$ a capacidade térmica, $\mathbf{Q} / \Delta \mathbf{T}$ energia transferida, como calor, por segundo $(\mathbf{J} / \mathbf{s}), A=$ área $\left(\mathbf{m}^{2}\right)$, $\Delta \boldsymbol{T}=$ diferença de temperaturas $(\mathbf{K}), \boldsymbol{L}=$ espessura $(\mathbf{m})$.

Com estas medidas, poder-se-á verificar a validade da afirmação de que quanto maior o carbono equivalente melhor a difusividade térmica do material.

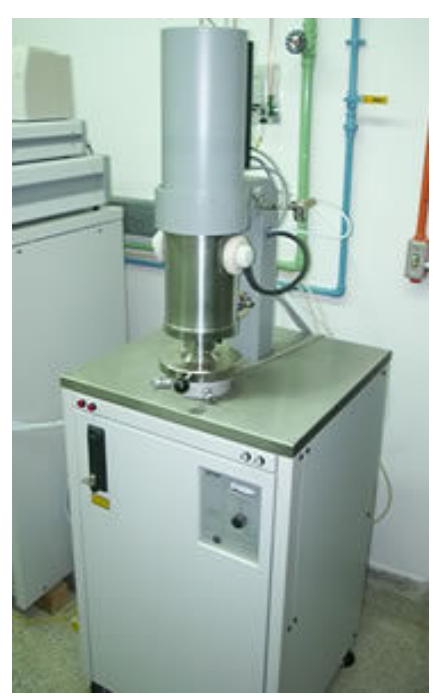

Figura 4.59 - Foto do Laser Flash Apparatus onde foram realizadas as medições de difusividade térmica. 
Dos blocos de prova, foram retiradas e usinadas as amostras de cada uma das ligas estudadas, de maneira a se obter, para cada liga, um jogo de 7 pequenas bolachas com mesmo diâmetro e espessuras diversas, para a determinação da difusividade térmica de cada material. O desenho utilizado para a usinagem das mesmas pode ser visto na Figura 4.60.

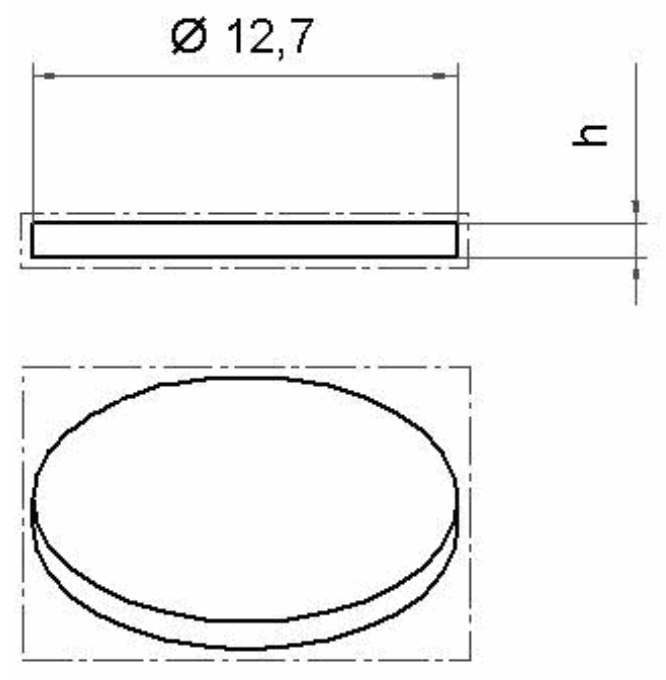

\begin{tabular}{|c|c|}
\hline $\mathrm{Cp} \mathrm{n}^{\mathbf{0}}$ & $\mathrm{h}[\mathrm{mm}]$ \\
\hline 1 & 1,50 \\
\hline 2 & 1,80 \\
\hline 3 & 2,10 \\
\hline 4 & 2,40 \\
\hline 5 & 2,70 \\
\hline 6 & 3,00 \\
\hline 7 & 3,18 \\
\hline
\end{tabular}

Figura 4.60 - Croquis de usinagem do conjunto de corpos de prova necessários para medição da difusividade em cada uma das ligas.

\subsection{4- Microscopia Óptica}

As amostras para análises metalográficas foram retiradas no sentido perpendicular ao comprimento de corpos de prova de fadiga termomecânica. Preparadas conforme norma ASTM E 3[95], embutidas em baquelite, lixadas utilizando, seqüencialmente, lixas de grana 220, 320, 400, 600 e 1000, e depois polidas na seguinte ordem: óxido de cromo 10,0 $\mu \mathrm{m}$, diamante $6,0 \mu \mathrm{m}$, diamante $3,0 \mu \mathrm{m}$, diamante $1,0 \mu \mathrm{m}$ e diamante $0,25 \mu \mathrm{m}$. A microestrutura do material foi revelada após ter sido submetida ao ataque do reagente químico (ASTM E 407) Nital 2\% (Ácido Nítrico 2\% + Etanol 98\%).

Para todas as análises metalográficas e quantitativas, utilizou-se um sistema de aquisição de imagens composto por um microscópio óptico ZEISS AXIOTECH equipado com uma câmera SONY DXC-151A, acoplado a um micro-computador MACINTOSH (Figura 4.61). Nas amostras sem ataque químico, observou-se o tamanho, distribuição e forma dos veios de grafita. Nas que foram atacadas com Nital $2 \%$, foi possível observar as 
microestruturas das matrizes e possíveis mudanças de fases. Os percentuais de microconstituintes, a distribuição e o tamanho dos veios foram obtidos utilizando o programa GRAFFITEK de análises de imagens.

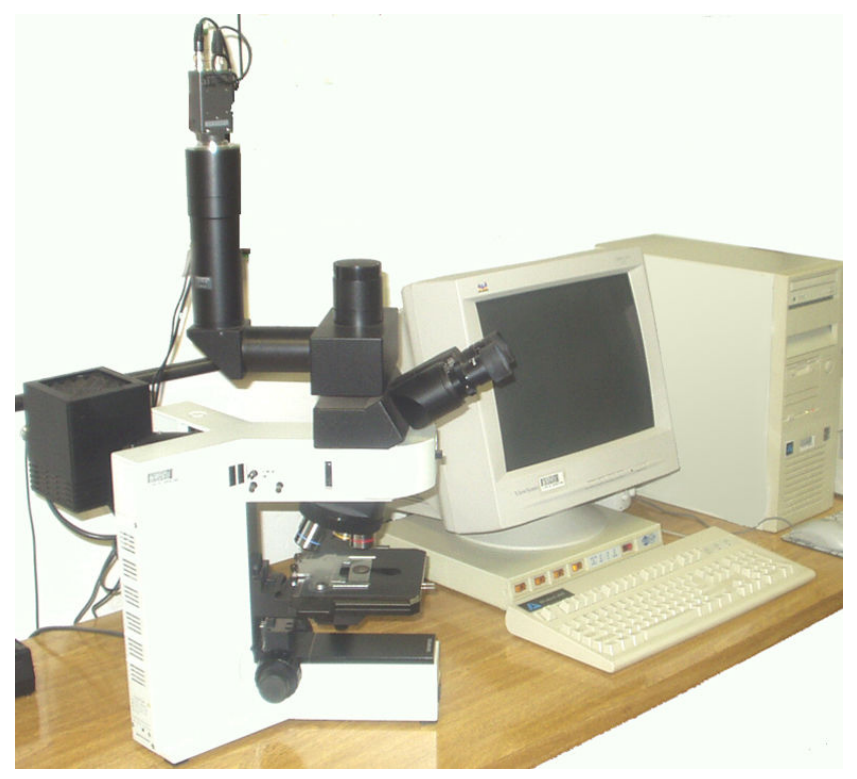

Figura 4.61 - Microscopia ótica com aquisição de imagens. 


\section{5 - RESULTADOS E DISCUSSÃO}

\section{1 - Composição Química}

A Tabela 5.12 traz o resultado das análises químicas realizadas. Observa-se que todos os elementos estão rigorosamente dentro das faixas de composições químicas estabelecidas para cada uma das ligas estudadas, apresentadas na Tabela 4.9. Os carbonos equivalentes de cada uma das ligas, calculados substituindo os valores percentuais de Carbono e Silício na equação $\mathbf{C E}=\%$ Carbono+1/3\% Silício, estão mostrados na Tabela 5.13.

Tabela 5.12 - Resultados das análises químicas.

\begin{tabular}{|c|c|c|c|c|}
\hline \multirow{2}{*}{ Elementos } & \multicolumn{4}{|c|}{ Ligas } \\
\cline { 2 - 5 } & $\begin{array}{c}\mathrm{A} \\
\text { Luk }\end{array}$ & $\begin{array}{c}\text { B } \\
\text { Teksid }\end{array}$ & $\begin{array}{c}\mathrm{C} \\
\text { Teksid }\end{array}$ & $\begin{array}{c}\mathrm{E} \\
\text { TRW }\end{array}$ \\
\hline$\% \mathrm{C}$ & 3,36 & 3,45 & 3,71 & 3,49 \\
\hline$\% \mathrm{Si}$ & 2,07 & 2,11 & 2,0 & 1,87 \\
\hline$\% \mathrm{Mn}$ & 0,63 & 0,71 & 0,69 & 0,53 \\
\hline$\% \mathrm{P}$ & 0,03 & 0,068 & 0,059 & 0,03 \\
\hline$\% \mathrm{~S}$ & 0,06 & 0,05 & 0,052 & 0,11 \\
\hline$\% \mathrm{Cr}$ & 0,16 & 0,30 & 0,19 & 0,29 \\
\hline$\% \mathrm{Mo}$ & 0,06 & 0,41 & 0,42 & - \\
\hline$\% \mathrm{Cu}$ & 0,08 & 0,10 & 0,40 & 0,52 \\
\hline
\end{tabular}

Tabela 5.13 - Carbonos Equivalentes.

\begin{tabular}{|c|c|c|c|c|}
\hline \multirow{2}{*}{} & \multicolumn{4}{|c|}{ Ligas } \\
\cline { 2 - 5 } & $\mathbf{A}$ & $\mathbf{B}$ & $\mathbf{C}$ & $\mathbf{E}$ \\
& Luk & Teksid & Teksid & TRW \\
\hline \%CE & 4,05 & 4,18 & 4,40 & 4,12 \\
\hline
\end{tabular}




\section{2 - Análise Microestrutural}

Quanto maior o carbono equivalente, maior deveria ser o comprimento dos veios. Não foi exatamente isso que aconteceu quando foram observadas as metalografias das ligas $\mathbf{A}, \mathbf{B}$, C e E, apresentadas, respectivamente, nas Figuras de 5.62 a 5.65. Por este critério, as microestruturas deveriam ter apresentado comprimento de veios crescentes na seguinte ordem, liga A, liga $\mathbf{E}$, liga $\mathbf{B}$ e liga $\mathbf{C}$, e, no entanto, a seqüência foi $\mathbf{E}, \mathbf{A}, \mathbf{C}$ e $\mathbf{B}$. Esta discrepância, no entanto, não é suficiente para derrubar o conceito que relaciona carbono equivalente com comprimento de veios, porque os ferros fundidos não sendo materiais homogêneos, apresentam microestruturas e percentagens de fases diferentes dependendo do campo visual analisado.

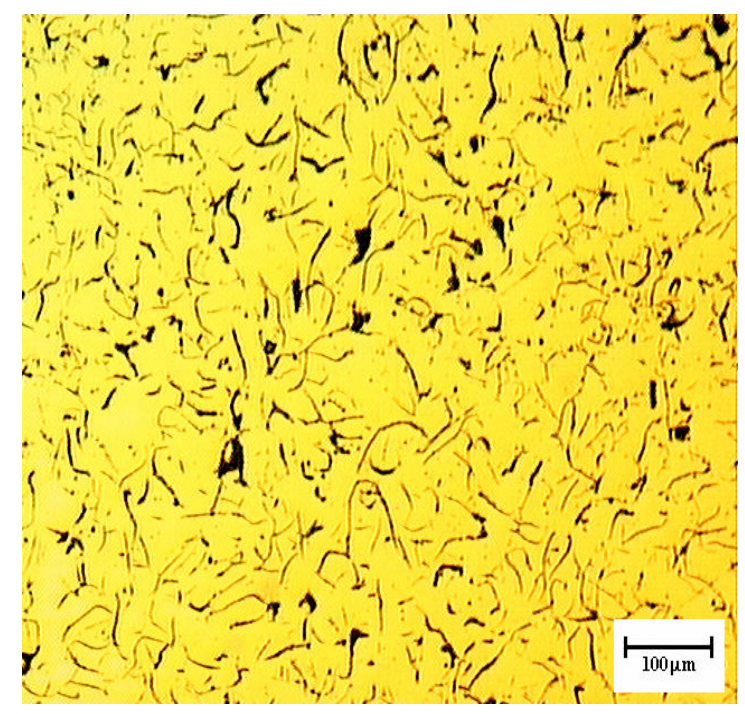

(a)

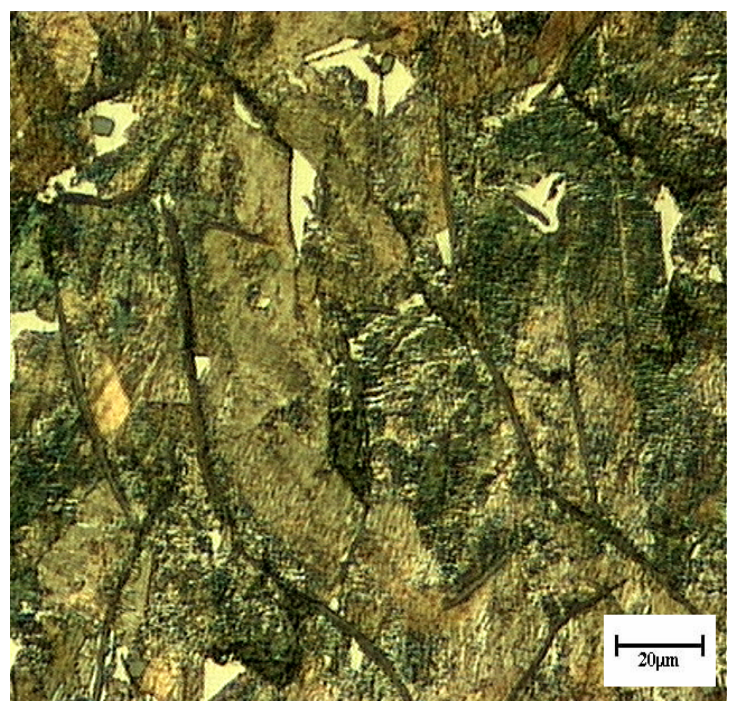

(b)

Figura 5.62 - Foto micrografia da liga A: (a) sem ataque. Podem-se observar veios de grafita do tipo VII, disposição C e tamanho 4, segundo a norma ASTM A 247; (b) a mesma região atacada com Nital 2\% apresentando matriz perlítica com algumas áreas de ferrita livre (branca). 


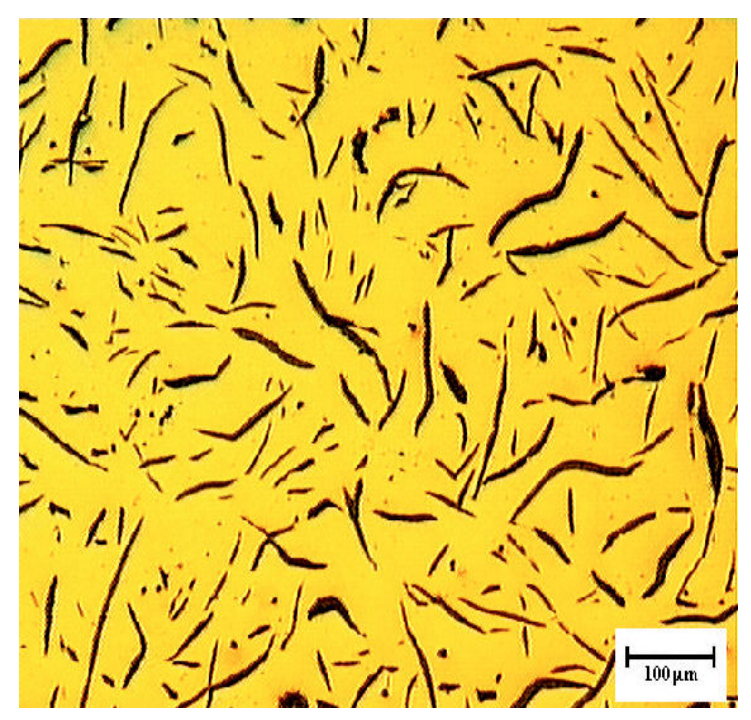

(a)

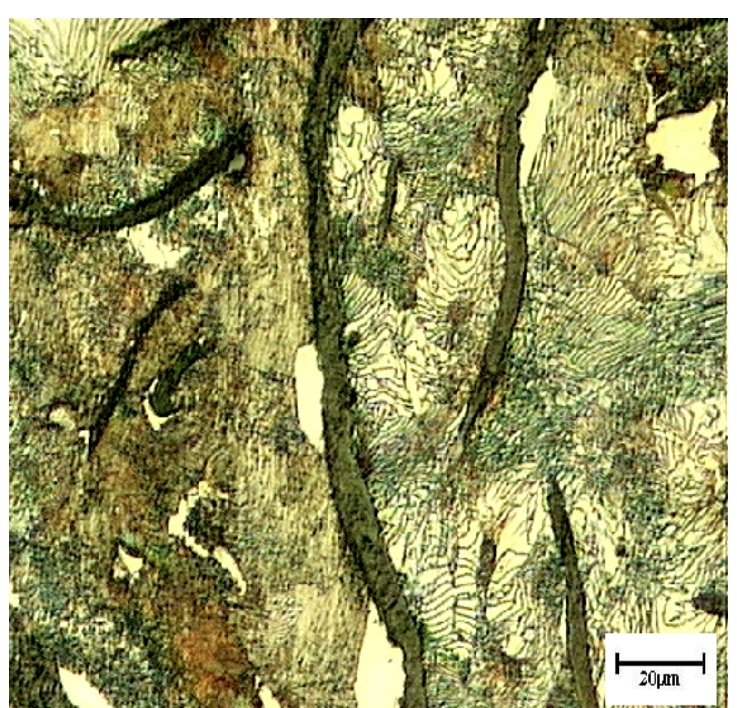

(b)

Figura 5.63 - Foto micrografia da liga B: (a) sem ataque. Podem-se observar veios de grafita do tipo VII, disposição A e tamanho 4, segundo a norma ASTM A 247; (b) a mesma região atacada com Nital $2 \%$ apresentando matriz perlítica áreas de ferrita livre (branca).

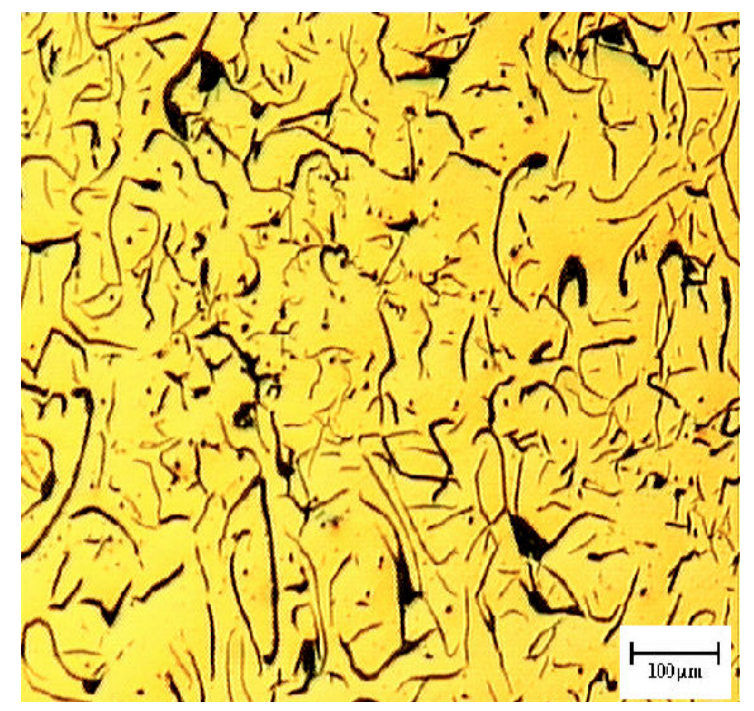

(a)

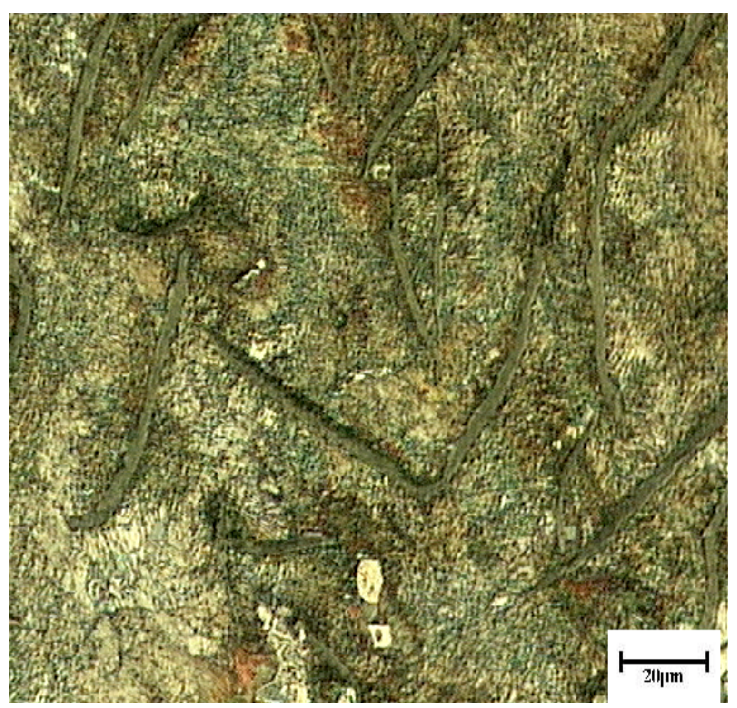

(b)

Figura 5.64 - Foto micrografia da liga C: (a) sem ataque. Podem-se observar veios de grafita do tipo VII, disposição C e tamanho 4, segundo a norma ASTM A 247; (b) a mesma região atacada com Nital $2 \%$ apresentando matriz totalmente perlítica. 


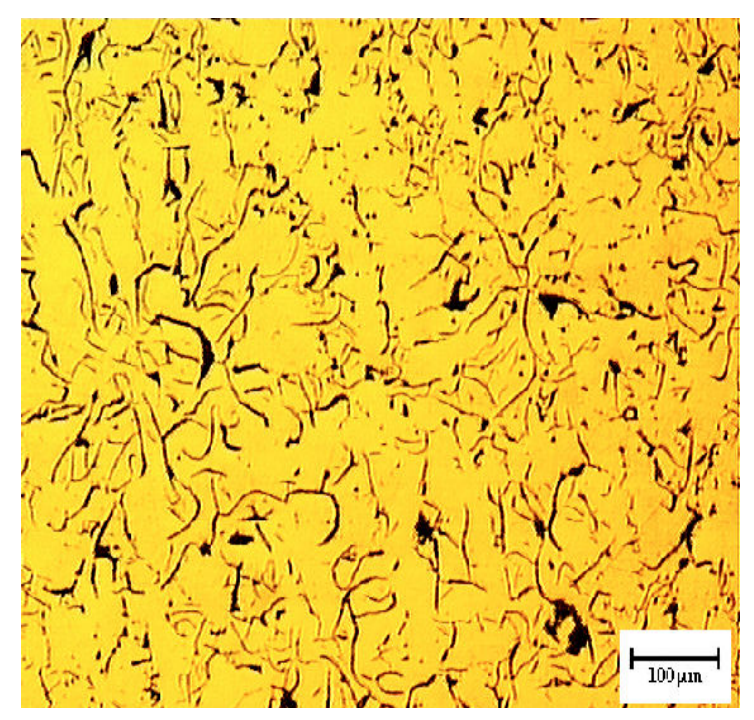

(a)

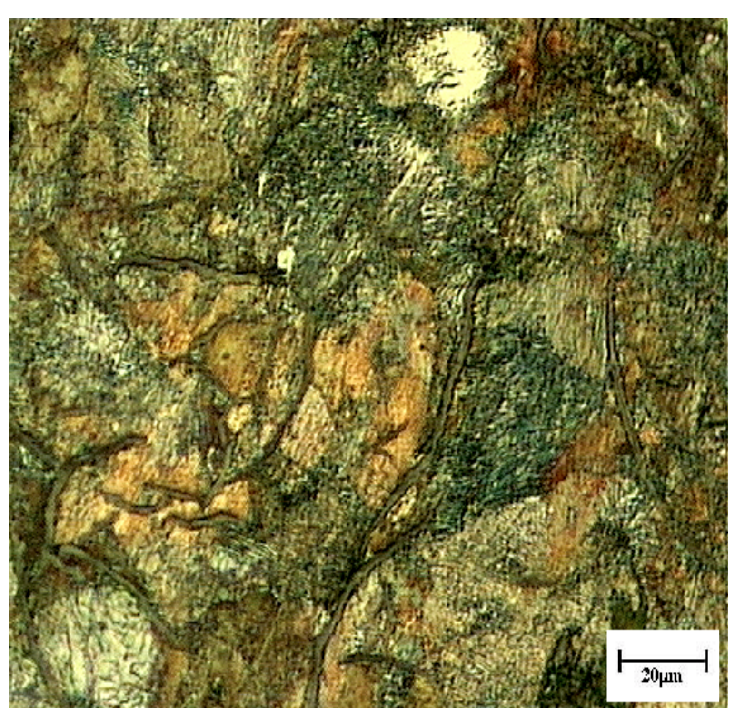

(b)

Figura 5.65 - Foto micrografia da liga E: (a) sem ataque. Podem-se observar veios de grafita do tipo VII, disposição C e tamanho 4, segundo a norma ASTM A 247; (b) a mesma região atacada com Nital $2 \%$ apresentando matriz perlítica.

Para validar as observações metalográficas realizadas em apenas um campo visual das amostras obtidas de corpos de prova de fadiga não ensaiados, buscou-se analisar quatro campos visuais de cada uma e, através de um programa de aquisição de imagens, realizar um controle mais preciso da grafita. Os resultados deste controle, nas quatro ligas estudadas, estão na Tabela 5.14 (a e b) e nos gráficos de barra das Figuras 5.66, 5.67 e 5.68. 
Tabela 5.14 - (a) Controle da grafita

\begin{tabular}{|c|c|c|c|c|c|c|c|c|c|c|}
\hline Amostra & \multicolumn{3}{|c|}{ Números de veios } & \multicolumn{3}{|c|}{ Tamanho dos veios } & \multirow[b]{2}{*}{$\begin{array}{l}\text { Desvio } \\
\text { padrão }\end{array}$} & \multicolumn{3}{|c|}{ Áreas e porcentagem de grafita } \\
\hline A25 & $\begin{array}{c}\text { Veios } \\
\text { detectados }\end{array}$ & $\begin{array}{c}\text { Veios na } \\
\text { borda }\end{array}$ & Veios $/ \mathrm{mm}^{2}$ & $\begin{array}{l}\text { Veio de A.mín. } \\
\qquad\left(\mathrm{mm}^{2}\right)\end{array}$ & $\begin{array}{l}\text { Veio de A.máx. } \\
\qquad\left(\mathrm{mm}^{2}\right)\end{array}$ & A. méd. $\left(\mathrm{mm}^{2}\right)$ & & $\begin{array}{c}\text { Áreas dos } \\
\text { veios }\left(\mathrm{mm}^{2}\right)\end{array}$ & $\mathrm{A}_{\text {total }}\left(\mathrm{mm}^{2}\right)$ & $\%$ da área \\
\hline Foto1 & 1084,00 & 46,00 & 2192,95 & 6,30 & 1010,23 & 56,94 & 92,24 & 61725,20 & 484156,00 & 12,75 \\
\hline Foto2 & 1047,00 & 47,00 & 2115,53 & 6,30 & 989,75 & 51,14 & 81,10 & 53547,20 & 484156,00 & 11,06 \\
\hline Foto3 & 1003,00 & 41,00 & 2030,65 & 6,30 & 747,04 & 45,36 & 68,53 & 45493,70 & 484156,00 & 9,40 \\
\hline Foto4 & 1148,00 & 39,00 & 2332,14 & 6,30 & 1275,01 & 41,67 & 81,77 & 47841,90 & 484156,00 & 9,88 \\
\hline Média & 1070,50 & 43,25 & 2167,81 & & 1005,51 & 48,78 & & 52152,00 & 484156,00 & 10,77 \\
\hline B25 & $\begin{array}{c}\text { Veios } \\
\text { detectados }\end{array}$ & $\begin{array}{c}\text { Veios na } \\
\text { borda }\end{array}$ & Veios $/ \mathrm{mm}^{2}$ & $\begin{array}{l}\text { Veio de A.min. } \\
\qquad\left(\mathrm{mm}^{2}\right)\end{array}$ & $\begin{array}{c}\text { Veio de A.máx. } \\
\left(\mathrm{mm}^{2}\right)\end{array}$ & A.méd. $\left(\mathrm{mm}^{2}\right)$ & $\begin{array}{l}\text { Desvio } \\
\text { padrão }\end{array}$ & $\begin{array}{c}\text { Áreas dos } \\
\text { veios }\left(\mathrm{mm}^{2}\right)\end{array}$ & $\mathrm{A}_{\text {total }}\left(\mathrm{mm}^{2}\right)$ & $\%$ da área \\
\hline Foto1 & 367,00 & 47,00 & 711,02 & 6,30 & 2769,08 & 200,69 & 340,48 & 73652,60 & 484156,00 & 15,21 \\
\hline Foto2 & 375,00 & 48,00 & 726,54 & 6,30 & 2613,06 & 195,46 & 316,22 & 73298,00 & 484156,00 & 15,14 \\
\hline Foto3 & 338,00 & 45,00 & 653,12 & 6,30 & 9043,25 & 264,58 & 631,88 & 89428,60 & 484156,00 & 18,47 \\
\hline Foto4 & 284,00 & 45,00 & 541,59 & 6,30 & 8433,33 & 288,29 & 682,91 & 81873,10 & 484156,00 & 16,91 \\
\hline Média & 341,00 & 46,25 & 658,07 & & 5714,68 & 237,25 & & 79563,08 & 484156,00 & 16,43 \\
\hline
\end{tabular}

(b) Controle da grafita (continuação). 


\begin{tabular}{|c|c|c|c|c|c|c|c|c|c|c|}
\hline Amostra & \multicolumn{3}{|c|}{ Números de veios } & \multicolumn{3}{|c|}{ Tamanho dos veios } & & \multicolumn{3}{|c|}{ Áreas e porcentagem de grafita } \\
\hline $\mathrm{C} 25$ & $\begin{array}{c}\text { Veios } \\
\text { detectados }\end{array}$ & $\begin{array}{c}\text { Veios na } \\
\text { borda }\end{array}$ & Veios $/ \mathrm{mm}^{2}$ & $\begin{array}{c}\text { Veio de A.mín. } \\
\left(\mathrm{mm}^{2}\right)\end{array}$ & $\begin{array}{l}\text { Veio de A.máx. } \\
\qquad\left(\mathrm{mm}^{2}\right)\end{array}$ & A. méd. $\left(\mathrm{mm}^{2}\right)$ & $\begin{array}{l}\text { Desvio } \\
\text { padrão }\end{array}$ & $\begin{array}{c}\text { Áreas dos } \\
\text { veios }\left(\mathrm{mm}^{2}\right)\end{array}$ & $\mathrm{A}_{\text {total }}\left(\mathrm{mm}^{2}\right)$ & $\%$ da área \\
\hline Foto1 & 520,00 & 61,00 & 1013,03 & 6,30 & 4140,23 & 177,12 & 388,22 & 92101,60 & 484156,00 & 19,02 \\
\hline Foto2 & 428,00 & 58,00 & 826,01 & 6,30 & 5317,52 & 216,21 & 504,45 & 92539,70 & 484156,00 & 19,11 \\
\hline Foto3 & 460,00 & 65,00 & 885,11 & 6,30 & 10067,70 & 212,55 & 615,10 & 97772,10 & 484156,00 & 20,19 \\
\hline Foto4 & 632,00 & 68,00 & 1237,36 & 6,30 & 5722,56 & 158,40 & 469,79 & 100111,00 & 484156,00 & 20,68 \\
\hline Média & 510,00 & 63,00 & 990,38 & & 6312,00 & 191,07 & & 95631,10 & 484156,00 & 19,75 \\
\hline E25 & $\begin{array}{c}\text { Veios } \\
\text { detectados }\end{array}$ & $\begin{array}{c}\text { Veios na } \\
\text { borda }\end{array}$ & Veios $/ \mathrm{mm}^{2}$ & $\begin{array}{l}\text { Veio de A.mín. } \\
\qquad\left(\mathrm{mm}^{2}\right)\end{array}$ & $\begin{array}{l}\text { Veio de A.máx. } \\
\qquad\left(\mathrm{mm}^{2}\right)\end{array}$ & A. méd. $\left(\mathrm{mm}^{2}\right)$ & $\begin{array}{l}\text { Desvio } \\
\text { padrão }\end{array}$ & $\begin{array}{c}\text { Áreas dos } \\
\text { veios }\left(\mathrm{mm}^{2}\right)\end{array}$ & $\mathrm{A}_{\text {total }}\left(\mathrm{mm}^{2}\right)$ & $\%$ da área \\
\hline Foto1 & 1115,00 & 65,00 & 2237,98 & 6,30 & 1424,73 & 53,44 & 95,76 & 59589,70 & 484156,00 & 12,31 \\
\hline Foto2 & 1051,00 & 48,00 & 2122,79 & 6,30 & 1434,19 & 58,33 & 99,07 & 61301,20 & 484156,00 & 12,66 \\
\hline Foto3 & 1108,00 & 56,00 & 2232,52 & 6,30 & 1421,58 & 53,34 & 94,55 & 59096,40 & 484156,00 & 12,21 \\
\hline Foto4 & 1230,00 & 58,00 & 2482,50 & 6,30 & 1172,57 & 46,27 & 77,67 & 56907,30 & 484156,00 & 11,75 \\
\hline Média & 1126,00 & 56,75 & 2268,95 & & 1363,27 & 52,84 & & 59223,65 & 484156,00 & 12,23 \\
\hline
\end{tabular}


Veios de Grafita por $\mathrm{mm}^{2}$

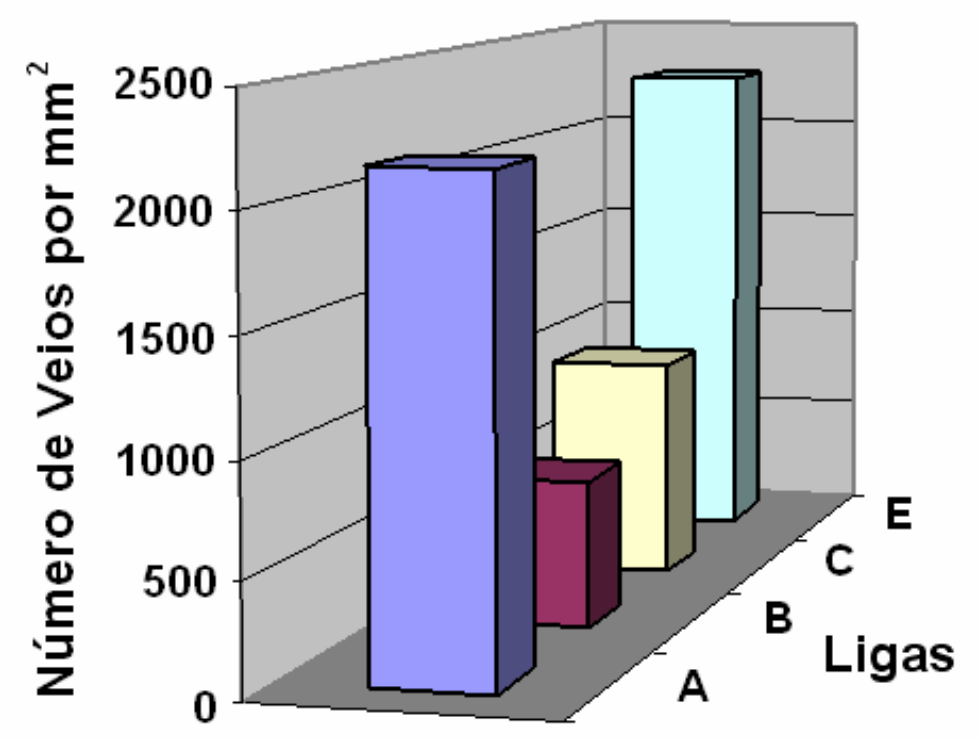

Figura 5.66 - Gráfico mostrando o número de veios por $\mathrm{mm}^{2}$ para cada uma das quatro ligas estudadas. Os dados para a confecção do gráfico foram obtidos da Tabela 5.14.

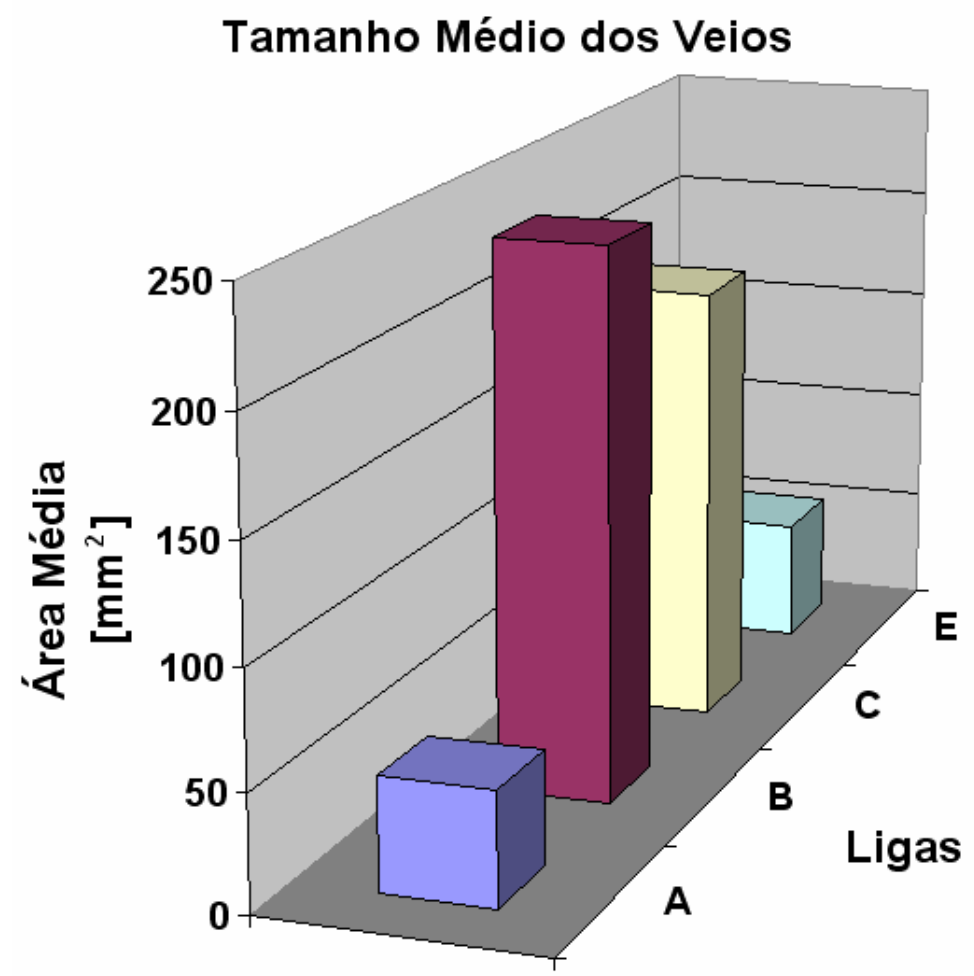

Figura 5.67 - Gráfico mostrando o tamanho médio dos veios para cada uma das quatro ligas estudadas. Os dados para a confecção do gráfico foram obtidos da Tabela 5.14. 


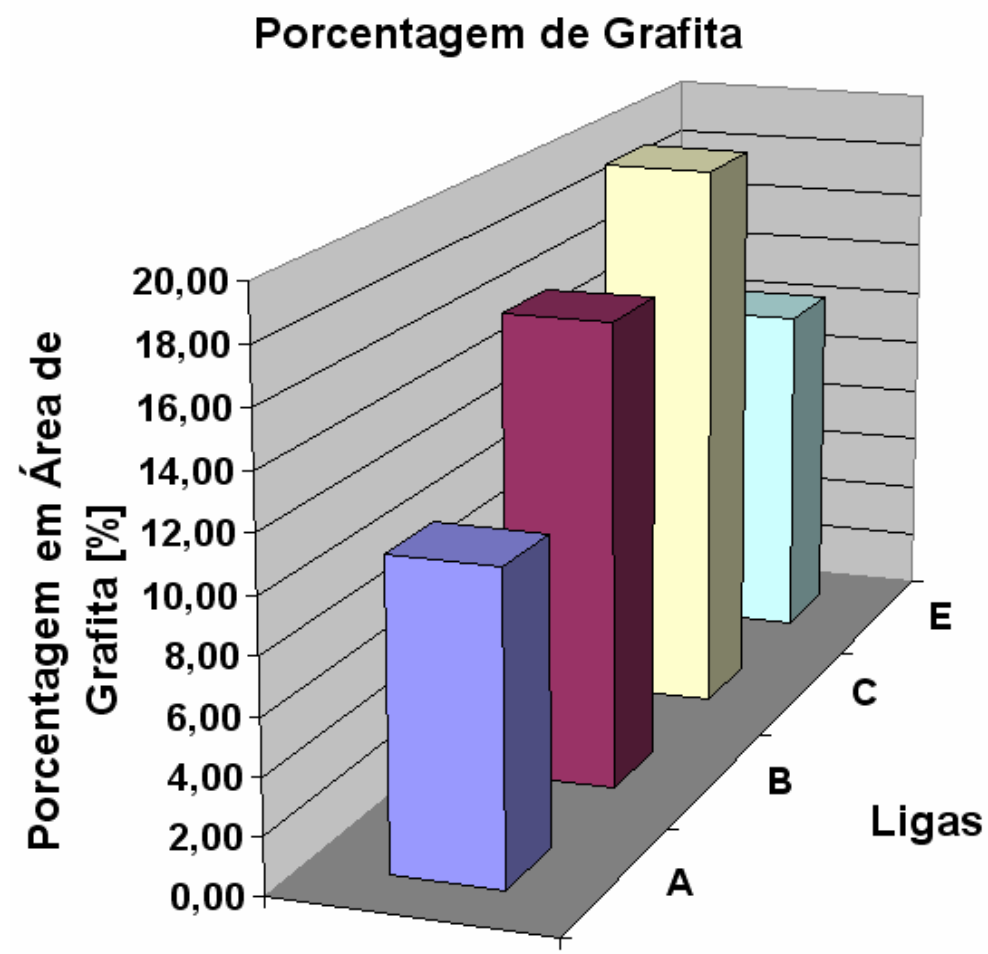

Figura 5.68 - Gráfico mostrando a percentagem de grafita em cada uma das quatro ligas estudadas. Os dados para a confecção do gráfico foram obtidos da Tabela 5.14.

Observa-se que a percentagem de grafita presente nas quatro ligas estudadas confirma a regra que associa carbono equivalente com percentagem de grafita, ou seja, quanto maior o carbono equivalente presente na liga, maior a percentagem de carbono livre. Deve ser lembrado que os principais fatores que influenciam a transferência de calor nos ferros fundidos são a distribuição, o tamanho e a morfologia da fase grafita, que possui difusividade térmica muito maior que a matriz. No entanto, para se obter o melhor desempenho do disco, quando este for solicitado mecanicamente, outros fatores devem ser levados em conta. Por exemplo: as extremidades dos veios de grafita funcionam como intensificadores de tensão facilitando a nucleação e a propagação de trincas e, por conseqüência, diminuem sensivelmente as propriedades mecânicas. Desta maneira, para que um ferro fundido cinzento seja adequado para uso em discos de freio de automóveis, não basta apenas apresentar elevada difusividade térmica, é necessário apresentar também boa resistência ao desgaste que ocorre durante a frenagem.

Nos ensaios de fadiga isotérmica [Maurício Angeloni], as ligas que apresentaram melhor desempenho foram por ordem decrescente as B, E, A e C. Este comportamento no caso das ligas $\mathbf{E}$ e $\mathbf{A}$ é explicado pelos menores carbonos equivalentes desses ferros fundidos 
cinzentos não ligados, o que implica em veios de menor comprimento (maior quantidade de veios por $\mathrm{mm}^{2}$ ) e maiores resistências mecânicas, seja à tração, ao impacto ou à fadiga isotérmica em todas as temperaturas estudadas. A liga $\mathbf{B}$, apesar do $\mathbf{C E}$ um pouco mais elevado, contou com o elemento de liga molibdênio para apresentar as melhores propriedades dentre todas as estudadas em qualquer condição de ensaio. É interessante notar que no material identificado pela letra $\mathbf{C}$, os elementos de liga, mesmo em maior quantidade que na liga B, não foram suficientes para eliminar os efeitos deletérios de um carbono equivalente tão elevado sobre as propriedades mecânicas.

Outro aspecto a ser analisado foi o comportamento das fases e microestruturas das ligas estudadas quando submetidas, durante os ensaios termomecânicos, a condições variáveis de carregamento e temperatura. Para tanto, selecionaram-se dois corpos de prova de fadiga termomecânica da liga $\mathbf{B}$ para análises metalográficas. Da área útil de cada um deles, um não ensaiado e outro após ensaio termomecânico em fase, foram retiradas as amostras a serem observadas. Naquela não ensaiada foram observados dez campos visuais e, na outra, ensaiada em fase, 20. Em cada um deles, com a ajuda de programas de aquisição de imagens, buscouse determinar os tamanhos dos veios e as percentagens de grafita existentes, para em seguida calcular-se a média aritmética. O motivo de observar um bom número de campos visuais foi diminuir a probabilidade de erro em função da falta de homogeneidade microestrutural, característica dos ferros fundidos cinzentos. A verificação estatística da análise do carbono livre da liga B, apresentada no Anexo III, demonstrou que o método utilizado foi correto, pois apresentou alta confiabilidade. Os resultados obtidos podem ser vistos na Tabela 5.15.

Observando os resultados das médias das percentagens da grafita, fica claro que houve um aumento desta fase quando se compara o valor do corpo de prova não ensaiado com aquele ensaiado em fase. Este aumento só pôde ter como causa a decomposição da cementita $\left(\mathbf{F e}_{3} \mathbf{C}\right)$ da perlita em ferrita $(\mathbf{3 F e})$ e grafita $(\mathbf{C})$. Como esta "quebra" de microestrutura só deveria ocorrer acima de $723^{\circ} \mathrm{C}$, conforme o diagrama ferro-carbono [Callister Jr., 2002], e os ensaios atingiram, no máximo, $600^{\circ} \mathrm{C}$, como isto se explica? A resposta é que durante o ensaio de fadiga termomecânica, em fase, associa-se máxima temperatura com máximo carregamento trativo, que pelo sentido de aplicação da tensão, facilita o fenômeno da expansão volumétrica, que acontece quando a cementita é decomposta, denominada expansão grafítica. Os cálculos que demonstram haver expansão quando há decomposição da $\mathrm{Fe}_{3} \mathrm{C}$, são apresentados a seguir. 
Tabela 5.15 - Controle da grafita em corpos de prova ensaiados em fadiga termomecânica em fase (EF) e não ensaiados.

\begin{tabular}{|c|c|c|c|c|}
\hline Liga B 100X & C.P & Grafita & Média & Desvio Padrão \\
\hline \multirow{2}{*}{ Não ensaiado } & \multirow{3}{*}{30} & Veio Tam Max & 0,345 & 0,098 \\
\cline { 3 - 5 } & & Veio Tam Min & 0,002 & 0,000 \\
\cline { 3 - 5 } & & Veio Tam Méd & 0,031 & 0,004 \\
\cline { 3 - 5 } & & \%eio grafita & $\mathbf{1 6 , 2 7}$ & 2,41 \\
\hline \multirow{3}{*}{$\begin{array}{c}\text { Ensaiado EF a 0,10\% } \\
\text { (vinte campos visuais) }\end{array}$} & \multirow{2}{*}{29} & Veio Tam Min & 0,002 & 0,000 \\
\cline { 3 - 5 } & & Veio Tam Méd & 0,034 & 0,006 \\
\cline { 3 - 5 } & & $\%$ grafita & $\mathbf{1 8 , 3 7}$ & 3,08 \\
\hline
\end{tabular}

\subsection{1 - Cálculo da Expansão Grafítica}

A comprovação matemática de que ocorre expansão volumétrica quando da decomposição da cementita em ferrita e grafita será apresentada na seqüência.

$$
\mathrm{Fe}_{3} \mathrm{C} \rightarrow 3 \mathrm{Fe}+\mathrm{C}
$$

Como a massa molar da ferrita é $56 \mathrm{~g} / \mathrm{mol}$ e a do carbono $12 \mathrm{~g} / \mathrm{mol}$, tem-se:

$$
3 * 56 \mathrm{~g} / \mathrm{mol}+1 * 12 \mathrm{~g} / \mathrm{mol} \rightarrow 168 \mathrm{~g} / \mathrm{mol}+12 \mathrm{~g} / \mathrm{mol} \quad=180 \mathrm{~g} / \mathrm{mol}
$$

Dividindo, o peso molar da ferrita e da grafita por 180, serão obtidos os pesos molares de cada uma das fases existentes em um grama de $\mathrm{Fe}_{3} \mathrm{C}$, ou seja:

$$
1 g F e 3 C \rightarrow \frac{168 g F e}{180 g}+\frac{12 g C}{180 g}=0,933 g \text { Fe }+0,067 g \mathrm{C}
$$


Para se obter os volumes ocupados por um grama tanto da cementita quanto do produto de sua decomposição, dividiu-se cada um dos pesos molares pela densidade das respectivas fases.

$$
\frac{1 \mathrm{gFe} 3 \mathrm{C}}{7,66 \mathrm{~g} / \mathrm{cm}^{3}} \rightarrow \frac{0,933 \mathrm{gFe}}{7,86 \mathrm{~g} / \mathrm{cm}^{3}}+\frac{0,067 \mathrm{gC}}{2,25 \mathrm{~g} / \mathrm{cm}^{3}}
$$

Assim, tem-se:

$$
\begin{gathered}
0,1305 \mathrm{~cm}^{3}\left(\mathrm{Fe}_{3} \mathrm{C}\right) \rightarrow 0,1187 \mathrm{~cm}^{3}(\mathrm{Fe})+0,0298 \mathrm{~cm}^{3}(\mathrm{C}) \\
0,1305 \mathrm{~cm}^{3}\left(\mathrm{Fe}_{3} \mathrm{C}\right) \rightarrow 0,1485 \mathrm{~cm}^{3}(\mathrm{Fe}+\mathrm{C})
\end{gathered}
$$

Nota-se que o volume de 1 grama de cementita $\left(0,1305 \mathrm{~cm}^{3}\right)$ é menor que a soma dos volumes das fases resultantes de sua decomposição $\left(0,1485 \mathrm{~cm}^{3}\right)$. Fazendo a diferença volumétrica, tem-se $0,018 \mathrm{~cm}^{3}$, o que corresponde a uma expansão volumétrica de $13,80 \%$. O passo seguinte foi determinar qual a expansão linear que se verifica quando da decomposição de um grama de cementita, pois, na realidade, é o que mais importa para os ensaios realizados. Para tanto, utilizou-se a fórmula de cálculo do volume da esfera, através da qual foi possível determinar os diâmetros de duas esferas, a primeira de $\mathrm{Fe}_{3} \mathrm{C}$ e a segunda com a cementita já decomposta em ferrita e grafita.

$\mathbf{V}_{\mathrm{e}}=\boldsymbol{\pi}^{*} \mathbf{d}^{\mathbf{3}} / \mathbf{6}$, o que implica que $\mathbf{d}^{3}=\mathbf{V}_{\mathrm{e}} * \mathbf{6} / \boldsymbol{\pi}$, onde $\mathbf{d}$ é o diâmetro da esfera e $\mathbf{V}_{\mathrm{e}} \mathrm{o}$ volume da esfera. Para a amostra não ensaiada e que não apresentou decomposição da cementita:

$$
\mathrm{d}^{3}\left(\mathrm{Fe}_{3} \mathrm{C}\right)=0,1305 \mathrm{~cm}^{3} * 6 / \pi \rightarrow \mathrm{d}\left(\mathrm{Fe}_{3} \mathrm{C}\right)=0,63 \mathrm{~cm}
$$

Para aquela ensaiada em fadiga termomecânica que apresentou cementita decomposta em ferrita e grafita:

$$
\mathrm{d}^{3}(\mathrm{Fe}+\mathrm{C})=0,1485 \mathrm{~cm}^{3} .6 / \pi \rightarrow \mathrm{d}\left(\mathrm{Fe}_{+} \mathrm{C}\right)=0,66 \mathrm{~cm}
$$

Na seqüência, para se obter a percentagem de expansão linear, faz-se: 


$$
\frac{\mathrm{d}(\mathrm{Fe}+\mathrm{C})-\mathrm{d}(\mathrm{Fe} 3 \mathrm{C})}{\mathrm{d}(\mathrm{Fe} 3 \mathrm{C})} \times 100=\frac{0,0277}{0,63} \times 100=4,40 \%
$$

Portanto, a percentagem de expansão linear, que acontece quando um grama de cementita é totalmente decomposto em ferrita e grafita, é 4,40\%. Restava agora avaliar quanto da cementita existente na microestrutura perlítica teria sido decomposta durante os ensaios de fadiga termomecânica, em fase. Para tanto, utilizou-se a seguinte expressão:

$$
\sigma_{c}=E . \varepsilon
$$

onde $\sigma_{\mathrm{c}}$ é a tensão compressiva, $\mathbf{E}$ corresponde ao Módulo de Young e $\boldsymbol{\varepsilon}$ a deformação total. Para que se possa avaliar o comportamento da deformação total em função da tensão compressiva durante o ensaio de fadiga termomecânica em fase, confeccionou-se a Tabela 5.16, utilizando a equação $\varepsilon=\sigma_{\mathrm{c}} / \mathbf{E}$, para $\mathbf{E}$ igual a $80 \mathrm{GPa}$ e determinando os valores das tensões.

\begin{tabular}{|c|c|}
\hline Deformação Total (E) - \% & Tensão Compressiva $\left(\sigma_{c}\right)-$ MPa \\
\hline 0,03125 & -25 \\
\hline 0,0625 & -50 \\
\hline 0,09375 & -75 \\
\hline 0,12500 & -100 \\
\hline 0,15625 & -125 \\
\hline 0,1875 & -150 \\
\hline 0,21875 & -175 \\
\hline 0,25000 & -200 \\
\hline 0,28125 & -225 \\
\hline
\end{tabular}

Tabela 5.16 - Tabela de deformação total em função da tensão.

Para uma tensão compressiva de, por exemplo, -50 MPa tem-se:

$$
\varepsilon=\frac{\sigma_{c}}{E}=\frac{-50}{80000} \times 100=0,0625 \%
$$

Então, efetuando uma regra de três simples, tem-se:

$4,40 \%$ linear $\rightarrow 100 \%$ de decomposição da cementita em 3Fe $+\mathrm{C}$

0,0625\% linear $-\mathbf{X} \%$ de decomposição necessária para $-50 \mathrm{MPa}$. 
Portanto $X=\mathbf{1 , 4 2 \%}$.

\section{3 - Difusividade Térmica}

Os resultados dos ensaios de difusividade térmica para as quatro ligas estudadas, desde a temperatura ambiente até pouco mais de $600^{\circ} \mathrm{C}$, estão apresentados graficamente nas curvas da Figura 5.69. Nota-se, como era de se esperar, que a difusividade diminui com o aumento da temperatura de todas as ligas. É interessante observar que as curvas de difusividades das ligas se apresentam relativamente bem separadas até aproximadamente $400^{\circ} \mathrm{C}$, a partir de onde começam se aproximar. Isto indica que todas elas têm, praticamente, a mesma difusividade térmica acima de $400^{\circ} \mathrm{C}$.

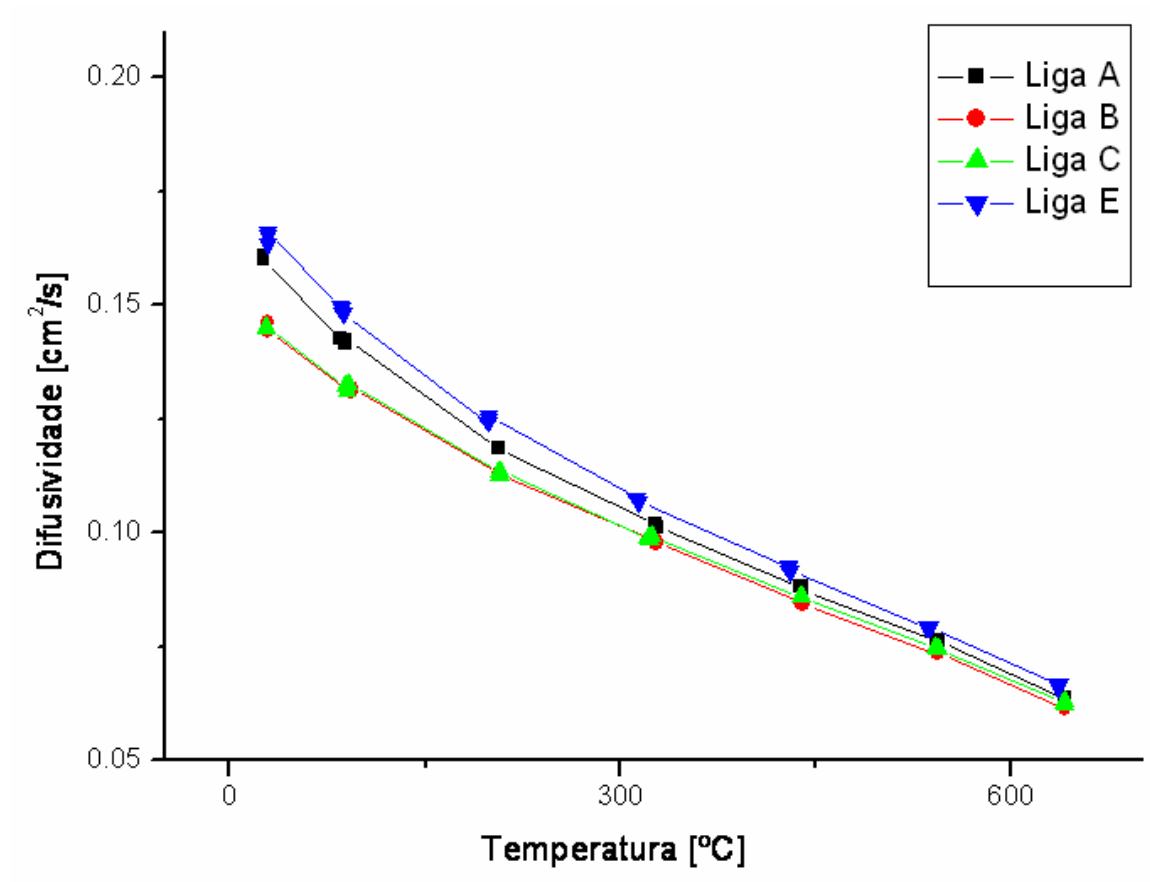

Figura 5.69 - Difusividade Térmica em função da Temperatura para as ligas A, B, C e E.

Esperava-se encontrar os valores das difusividades tanto maiores quanto maior fosse o carbono equivalente da liga, ou seja, por ordem decrescente: $\mathbf{C}, \mathbf{B}, \mathbf{E}$ e $\mathbf{A}$. As ligas $\mathbf{C}$ e B, apesar dos altos carbonos equivalentes, como continham molibdênio, apresentaram, comparativamente, os piores resultados de difusividade térmica, em função, provavelmente, da formação de carbetos de molibdênio que, em solução sólida na matriz, prejudicam o fluxo de calor. Já os materiais identificados pelas letras $\mathbf{E}$ e A, pelos 
resultados de difusividade, confirmaram as expectativas, que foram determinadas pelo carbono equivalente, da liga $\mathbf{E}$ apresentar maior difusividade que a liga $\mathbf{A}$. Vale observar o que aconteceu com a liga $\mathbf{E}$ que, apesar de apresentar um dos carbonos equivalentes mais baixos, foi a melhor no quesito difusividade térmica porque o elemento cobre, em solução sólida, com certeza contribuiu positivamente para a transferência de calor.

A afirmação de que quanto maior o carbono equivalente maior a difusividade térmica só é válida para ferros fundidos cinzentos não ligados, pois os elementos de liga, de uma maneira geral, e também as impurezas agem como barreiras, reduzindo a eficiência do movimento dos elétrons [Callister Jr., 2002]. Exceção se faz a elementos de liga, como o cobre, que são bons condutores e formam solução sólida com a matriz.

\section{4 - Ensaio de Fadiga Termomecânica}

\subsection{1 - Em corpos-de-Prova}

\subsubsection{1 - Fadiga Termomecânica Em Fase e Fora de Fase}

O comportamento do Número de Ciclos para Falha em função da Deformação Total foi observado para as ligas $\mathbf{A}, \mathbf{B}, \mathbf{C}$ e $\mathbf{E}$ sob várias condições de deformação, no ciclo térmico entre $300^{\circ} \mathrm{C}$ e $600^{\circ} \mathrm{C}$. Pode-se notar que, no geral, quanto maior a deformação aplicada, menor a vida do material, o que ocorre devido ao aumento na tensão necessária para se alcançar maiores deformações. Como já visto, o critério de falha adotado foi o de $50 \%$ da tensão máxima.

A Figura 5.70 mostra, no gráfico Amplitude de Deformação em função do Número de Reversos para Falhar $\left(2 \mathrm{~N}_{\mathrm{f}}\right)$, o comportamento das quatro ligas ensaiadas em fase. Nota-se que, neste gráfico, para amplitudes de deformação mecânica de $0,10 \%$, em fase, houve um comportamento anômalo de todas as ligas, que falharam prematuramente, pelo critério adotado de decréscimo de $50 \%$ da tensão máxima trativa. Ou seja, apresentaram um número de reversos para falhar inferior ao das amplitudes de deformação mecânicas maiores. Isto provavelmente aconteceu em função da chamada expansão grafítica, oriunda da decomposição de parcela da fase cementita, existente no microconstituinte perlita que se 
transforma em ferrita e grafita. A expansão grafítica acarreta indiretamente uma diminuição na componente da amplitude de deformação mecânica, produzindo abaixamento rápido da tensão de tração aplicada em função do número de reversos para falhar. Isto provoca a não validação do critério de $50 \%$ da tensão máxima, como um critério de falha para a condição de amplitude de deformação mecânica muito baixa. Desta maneira, como os resultados para a amplitude de deformação de $0,1 \%$ não estão conformes, foram deixados de lado no momento da construção das curvas da Figura 5.70.

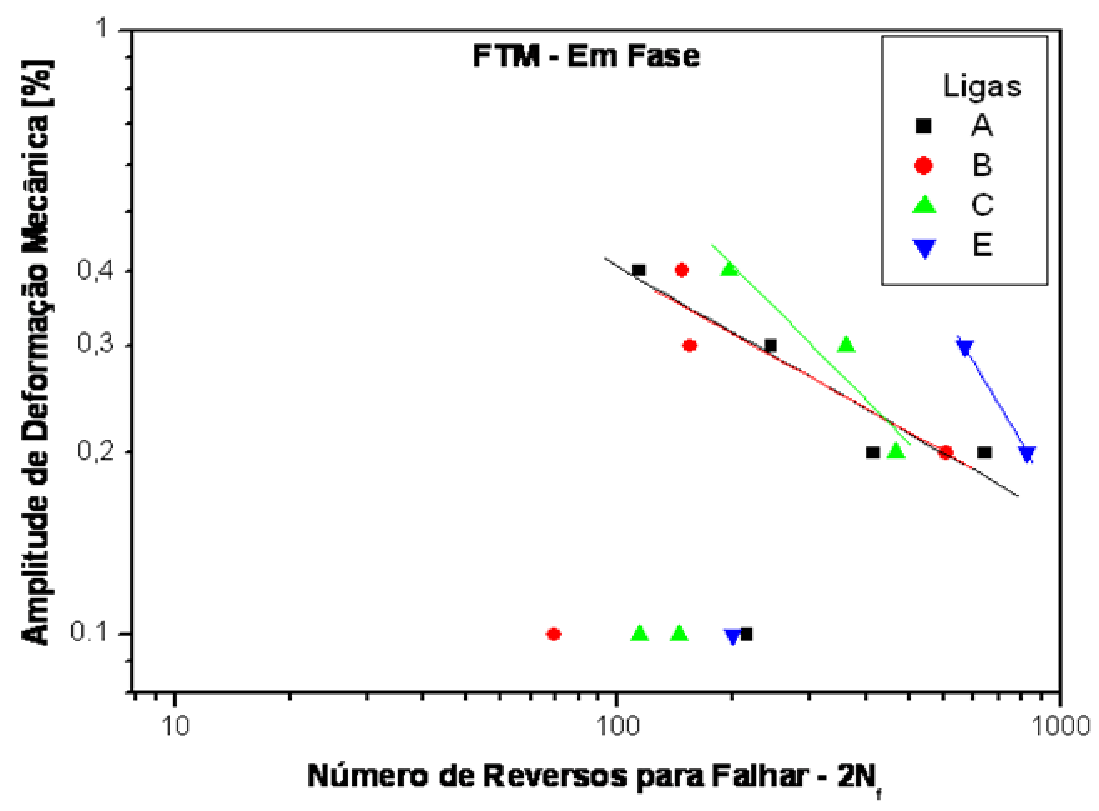

Figura 5.70 - Gráfico comparativo da amplitude de deformação mecânica das quatro ligas em função do número de reversos para falhar, em fase.

Observam-se nas curvas dos ensaios, em fase, que os comportamentos das ligas de ferro fundido cinzento $\mathrm{A}, \mathrm{B}$ e $\mathrm{C}$ foram muito parecidos, em termos de número de reversos para falhar, para amplitudes de deformação mecânica de $0.2 \%, 0,3 \%$ e $0,4 \%$. Ou seja, as três apresentaram praticamente a mesma vida em fadiga termomecânica, em fase, para deformações mecânicas iguais ou maiores que $0,2 \%$.

Conforme pôde ser visto no gráfico acima, a liga $\mathbf{E}$ foi a que apresentou a melhor performance sob fadiga termomecânica em fase para qualquer amplitude de deformação utilizada. Ficou claro, então, que para as ligas de ferro fundido cinzento estudadas neste trabalho, o melhor desempenho coube àquela com carbono equivalente relativamente baixo e com os elementos de liga cromo e cobre. Apenas cromo e cobre, sem molibdênio. Estas 
conclusões foram baseadas nos resultados de FTM, em fase, onde a liga A, apesar de não possuir nenhum elemento de liga especial, apresentou comportamento similar tanto ao da liga $\mathbf{C}$ quanto ao da liga $\mathbf{B}$, que são as mais ligadas.

Na Figura 5.71 pode-se observar que os comportamentos das quatro ligas sob fadiga termomecânica, fora de fase, foram semelhantes, indicando que, nesta condição de ensaio, os elementos de liga, bem como o carbono equivalente, tiveram pouca ou nenhuma influência na resistência dos materiais.

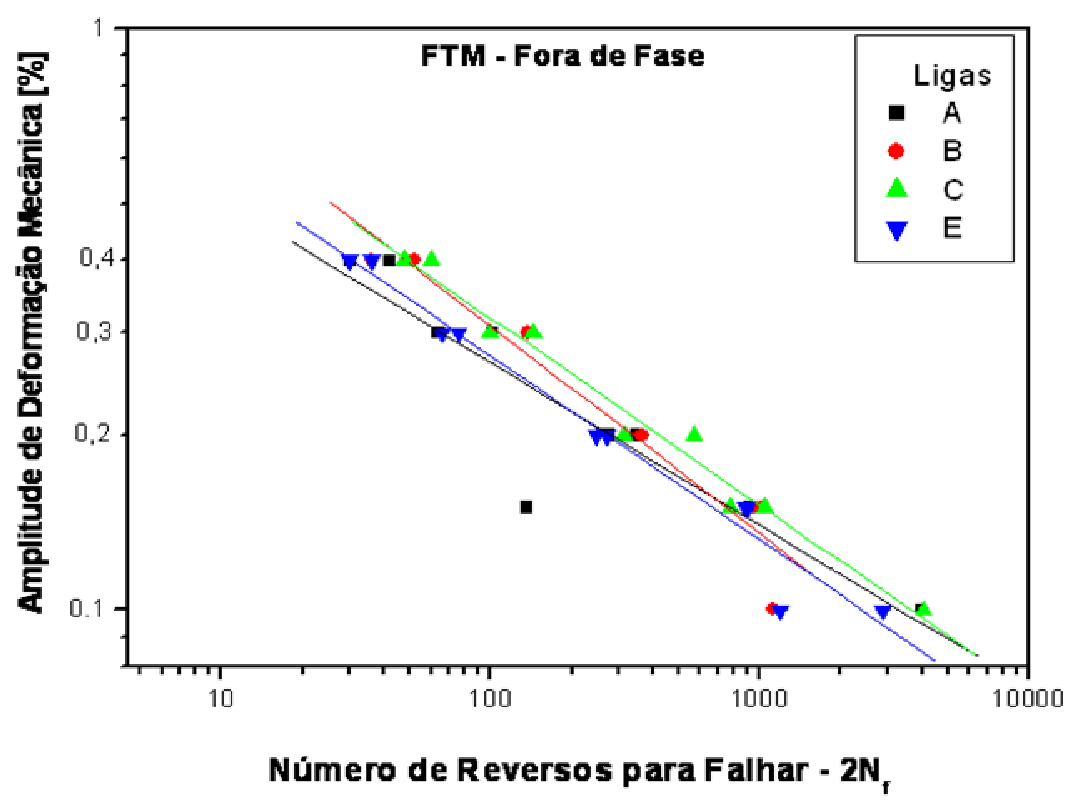

Figura 5.71 - Gráfico comparativo da amplitude de deformação mecânica em função do número de reversos para falhar, para as quatro ligas, fora de fase.

Diferente do que aconteceu na condição em fase, sob fadiga termomecânica fora de fase, todas as ligas tiveram comportamento normal; ou seja, quanto maior a deformação aplicada menor a vida. Isto permitiu construir o gráfico Amplitude de Deformação em função da Vida, com amplitudes de deformação, abrangendo desde 0,1\% até 0,4\% (Figura 5.71). Para a condição em fase, em função da anomalia a $0,1 \%$, optou-se pela abrangência de 0,2 até 0,4\% (Figura 5.70).

Para facilitar a comparação dos resultados dos comportamentos das ligas sob as duas condições de fadiga termomecânica, optou-se por plotá-los em um mesmo gráfico, mas sem considerar as amplitudes de deformação mecânica menores que $0,2 \%$. Com este artifício, foi possível visualizar, de maneira mais nítida, a performance das ligas (Figura 5.72). 


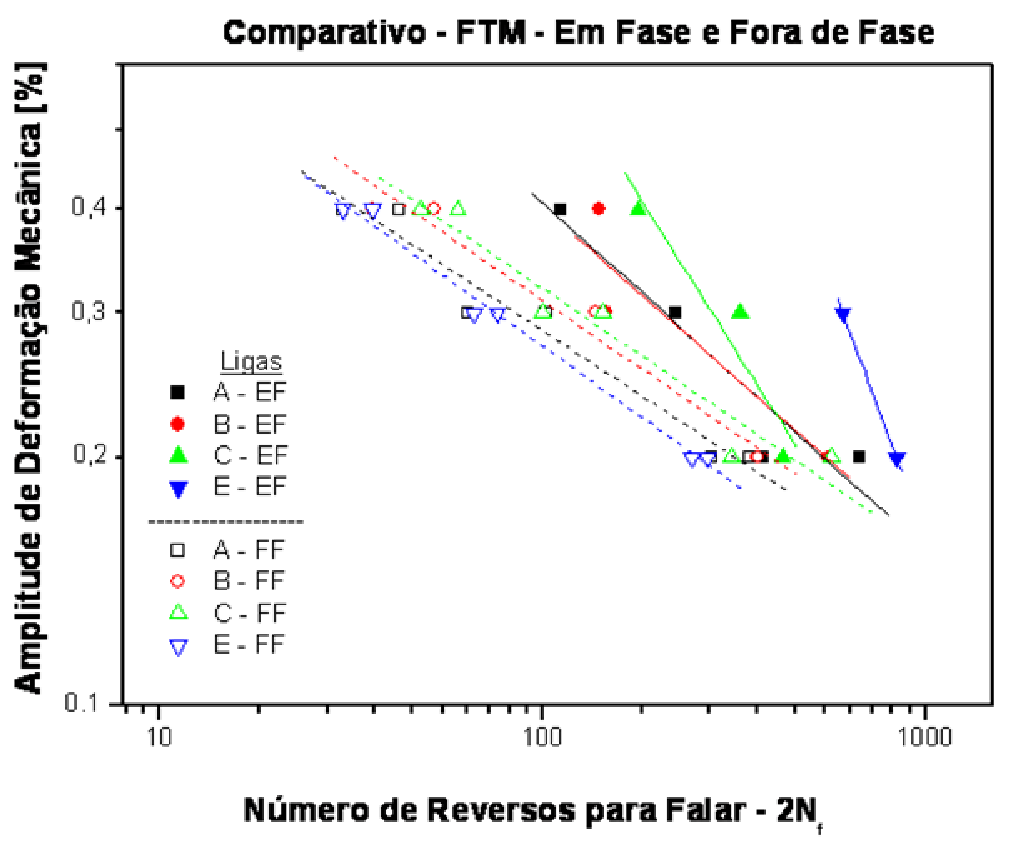

Figura 5.72 - Gráfico comparativo da amplitude de deformação mecânica em função do número de reversos para falhar, para as quatro ligas, em fase e fora de fase, suprimindo as amplitudes menores que $0,2 \%$.

Com base nas curvas da Figura 5.72, pode-se afirmar que dentre os ensaios de fadiga termomecânica de baixo ciclo, realizados em corpos de prova de diversas ligas de ferro fundido cinzento, aqueles realizados na condição fora de fase foram os mais críticos, pois levaram à falha em um menor número de reversos. Esta maior severidade dos ensaios fora de fase se justifica, pois nesta condição de ensaio as tensões trativas são aplicadas nas temperaturas mais baixas do ciclo, nas quais o material é mais resistente e, portanto, exige, para se deformar mecanicamente, tensões mais elevadas do que seriam as necessárias para deformá-lo em temperaturas mais elevadas. O mesmo tipo de raciocínio, com relação à temperatura, pode ser usado para estudar o comportamento das tensões compressivas. O efeito da condição de ensaio na aplicação das tensões pôde ser facilmente observado pelo comportamento das curvas de tensão média, nos ensaios de fadiga termomecânica de baixo ciclo. As referidas curvas foram negativas para a condição de ensaio em fase e positivas para fora de fase. 


\subsubsection{2 - Comportamento Tensão x Deformação}

Observando as tensões necessárias para se alcançar as deformações mecânicas préestabelecidas nos ensaios de fadiga termomecânica em fase, notou-se que as tensões médias de todos os ensaios, para todas as ligas, foram sempre negativas, o que demonstrou que os corpos de prova estavam sujeitos a maiores períodos de tensões compressivas que trativas. Como em fase as tensões trativas são aplicadas nas temperaturas mais altas do ensaio, o material se deforma mais facilmente, alcançando a deformação desejada com menores tensões. Já os valores das tensões compressivas são maiores, pois tem que ser suficientes para proporcionar a deformação mecânica desejada nas temperaturas mais baixas do ciclo, em que os materiais são, comparativamente, mais resistentes. Este comportamento do material causou um desbalanceamento na relação tensão trativa x tensão compressiva que pode ser observado, claramente, na Figura 5.73, que apresenta, como exemplo, um ensaio da liga A, sob amplitude de deformação de $0,2 \%$.

Outro fator que cooperou para que fossem reduzidas as tensões trativas — necessárias para alcançar amplitude pré-determinada de deformação mecânica, na condição em fase - foi o fenômeno da expansão grafítica, que, como já visto no último parágrafo da página 95, é o resultado da decomposição da cementita da perlita em ferrita e grafita. Esta expansão atuou como uma componente aditiva da deformação total aplicada, fazendo assim com que o valor da tensão necessária para atingir a deformação total no ciclo trativo decrescesse constantemente produzindo um efeito conhecido como amolecimento cíclico, somente no ciclo trativo. 


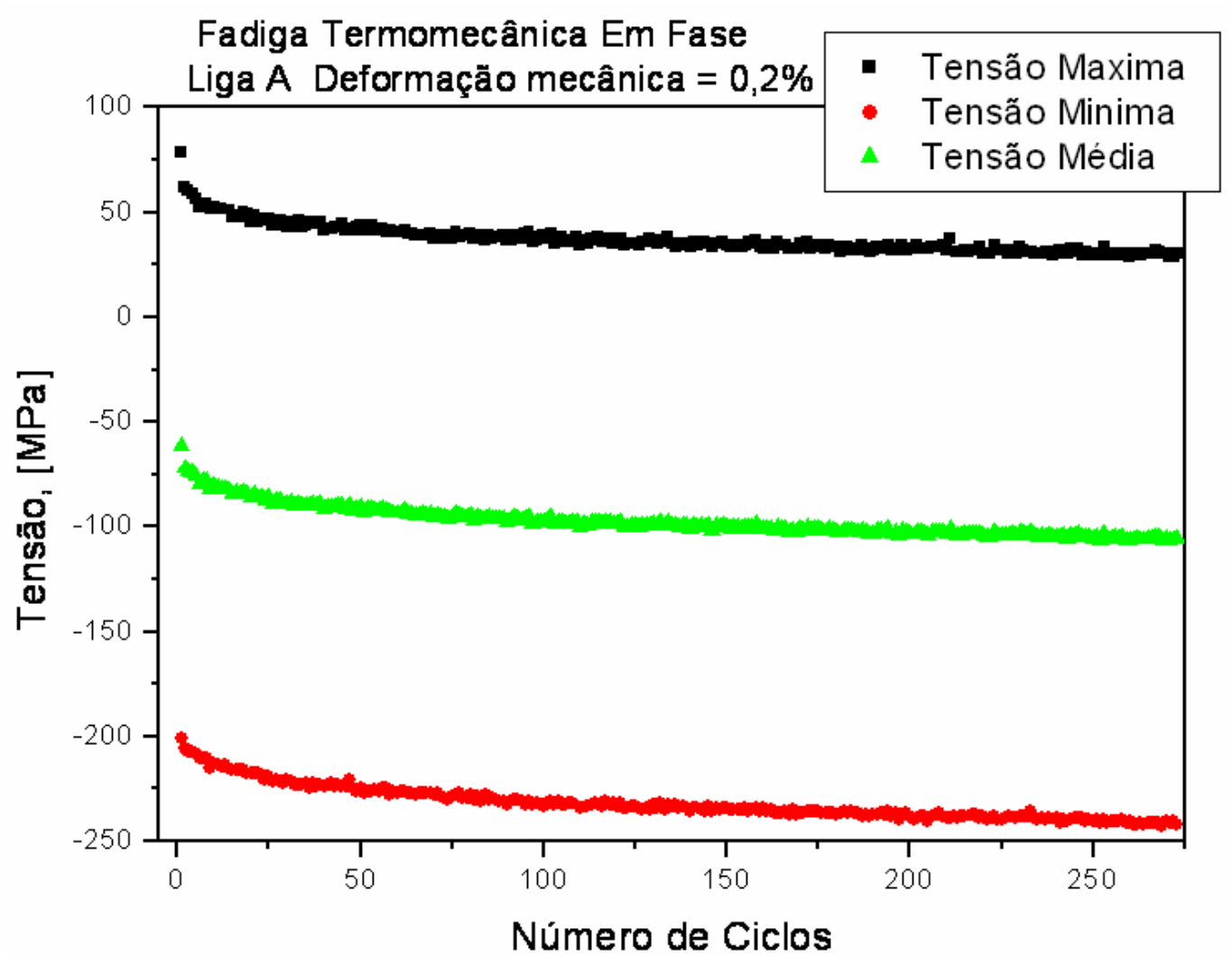

Figura 5.73 - Curvas Tensão em função do Número de Ciclos para a liga A, ensaiada em fadiga termomecânica, em fase, sob amplitude de deformação mecânica de $0,2 \%$.

Já nos ensaios de fadiga termomecânica fora de fase, em que o pico de temperatura coincide com a máxima tensão compressiva aplicada, a tensão média foi sempre positiva, pois as tensões trativas são aplicadas na parte do ciclo de deformação no qual as temperaturas são menores e, consequentemente, onde o material é mais resistente à deformação. A Figura 5.74 mostra o comportamento trativo-compressivo típico das tensões desenvolvidas no ferro fundido cinzento usando como exemplo a liga $\mathbf{A}$, ensaiada em fadiga termomecânica fora de fase, sob amplitude de deformação mecânica de $0,2 \%$. 


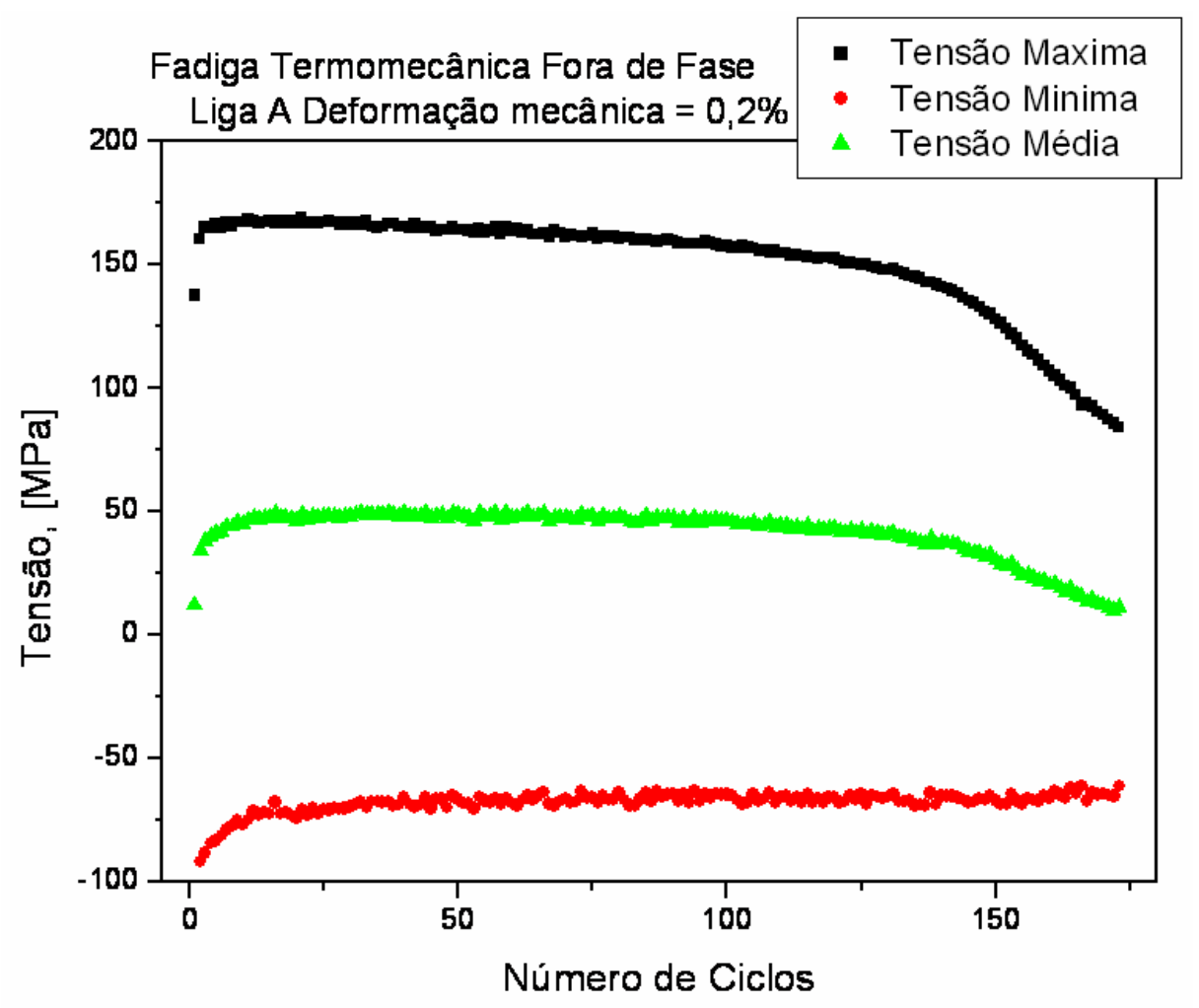

Figura 5.74 - Curvas Tensão em função do Número de Ciclos para a liga A, ensaiada em fadiga termomecânica, fora de fase, sob amplitude de deformação mecânica de $0,2 \%$.

Nas Figuras de 5.75 a 5.82, estão apresentados os gráficos das tensões máximas em função do número de ciclos, para as várias deformações mecânicas, nas condições de fadiga termomecânica em fase e fora de fase para as quatro ligas estudadas. Para os ensaios realizados na condição fora de fase, apresentados nas Figuras 5.76, 5.78, 5.80 e 5.82, observaram-se, como era de se esperar, que quanto maiores as deformações mecânicas impostas, maiores foram as tensões máximas necessárias para atingir tais deformações. Este comportamento das curvas aconteceu porque na condição fora de fase os carregamentos trativos acontecem nas temperaturas mais baixas do ensaio nas quais o material é mais resistente e também porque em baixas temperaturas não ocorrem transformações de fase e interações entre os mecanismos de falha por fadiga e por fluência, que diminuem as tensões trativas máximas.

No entanto, quando se observam os comportamentos dos ensaios realizados em fase, Figuras 5.75, 5.77, 5.79 e 5.81, a situação é muito mais complexa. Como as tensões trativas são aplicadas nas temperaturas mais altas do ciclo nas quais o material é menos resistente, seus valores são muito menores do que seriam em temperaturas mais baixas. Outro fator importante é que o carregamento trativo, realizado em temperaturas mais elevadas, facilita a 
transformação de fase; ou seja, a decomposição da cementita da perlita, em ferrita e grafita, resultando em diminuição da dureza e, consequentemente, na dimuição da resistência mecânica da matriz e facilita, também, a expansão grafítica.

Além disso, a condição de deformação em fase propicia boas condições para a ocorrência da interação fadiga-fluência. Os fenômenos de expansão grafítica e a interação fadiga-fluência, atuando separada ou conjuntamente, facilitam a deformação mecânica dos corpos de prova, pois como o ensaio é realizado sob controle da deformação total, o extensômetro computa este aumento como sendo uma componente da deformação mecânica, diminuindo assim o valor da tensão necessária para atingir o nível da deformação total préestabelecida. Desta maneira, estes fenômenos, que só ocorrem na condição em fase, resultam em uma diminuição das tensões necessárias para causar as deformações mecânicas impostas durante o ensaio.

A tensão máxima atingida durante os ensaios realizados em fase é função de um equilíbrio entre a deformação imposta, carbono equivalente e teor de elementos de liga do material. Maiores valores de deformação mecânica e de carbono equivalente tendem a reduzir os valores das tensões máximas atingidas nos ciclos de fadiga, pois favorecem um maior volume de transformação grafítica. Além disso, maiores valores de deformação mecânica aumentam a probabilidade da ocorrência de nucleação de danos na microestrutura, diminuindo os valores de tensão máxima no ciclo. Por outro lado, maiores teores de elementos de liga, como o molibdênio, tendem a elevar os valores de tensão máxima devido ao aumento de resistência mecânica a quente. Desta forma, dependendo da liga analisada, os valores de tensão máxima atingidos podem aumentar ou diminuir com o nível de amplitude de deformação mecânica aplicada. Como exemplo, pode ser citado o caso do comportamento apresentado pela liga $\mathbf{C}$ que mostrou valores de tensão máxima menores à medida que se aumenta a deformação total aplicada. Por outro lado, a liga $\mathbf{B}$, que apresenta teores similares de elementos de liga, mas menor carbono equivalente apresenta tendência inversa; ou seja, quanto maior a deformação total aplicada, maiores foram os valores da tensão máxima atingida. 


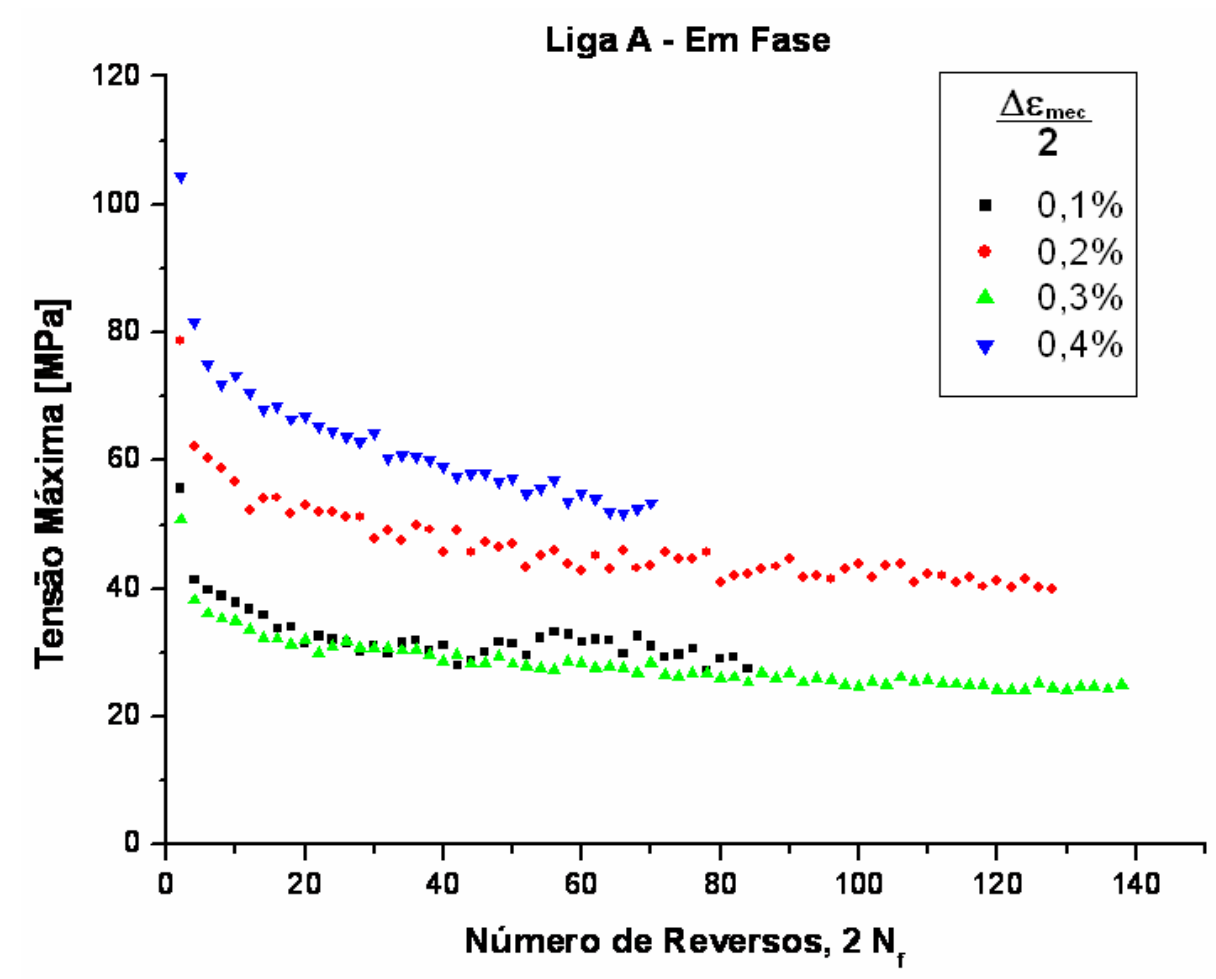

Figura 5.75 - Gráfico da tensão máxima em função do número de ciclos para a liga $\mathrm{A}$, para condição em fase e em vários níveis de amplitude de deformação mecânica.

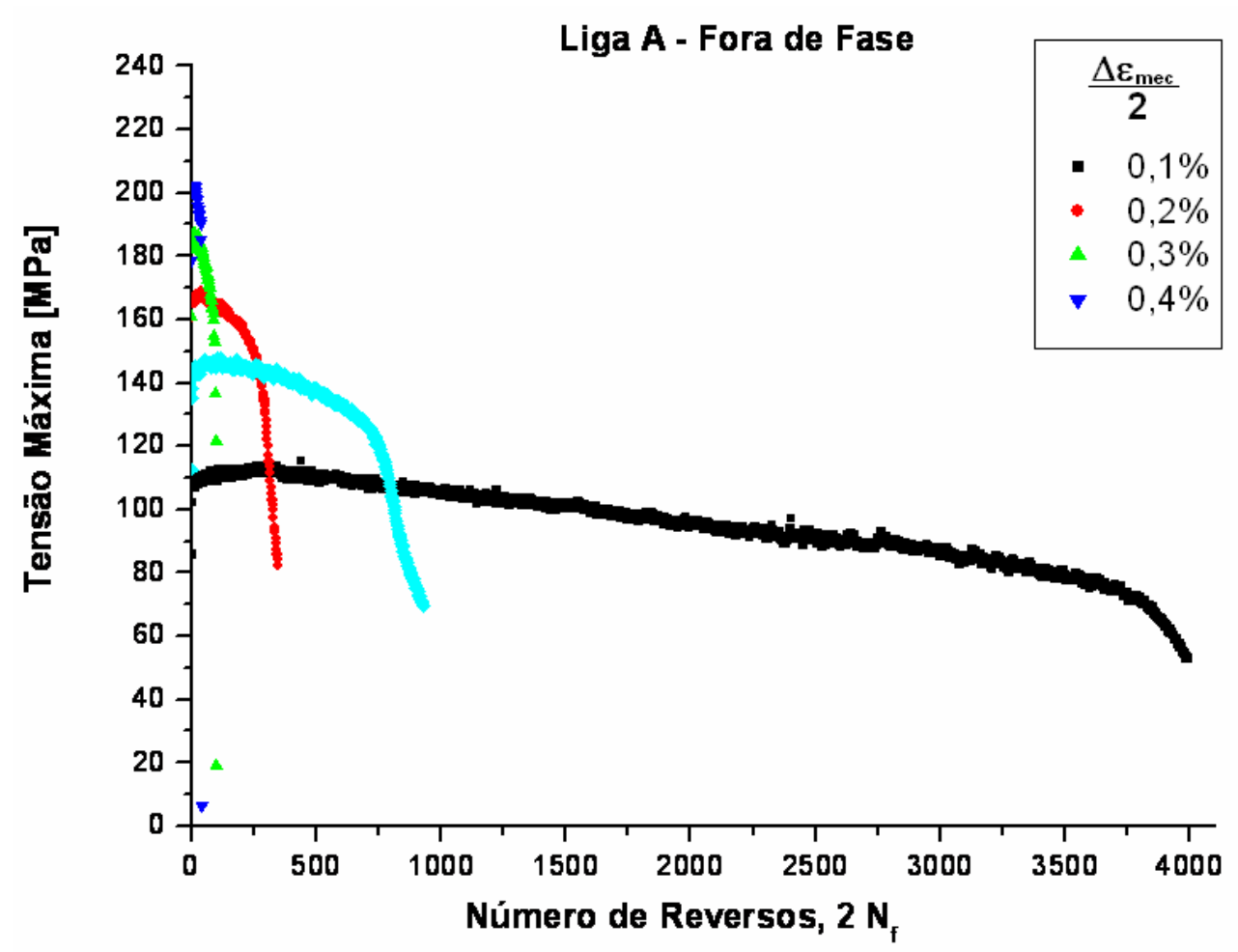

Figura 5.76 - Gráfico da tensão máxima em função do número de ciclos para a liga A, para condição fora de fase e em vários níveis de amplitude de deformação mecânica. 


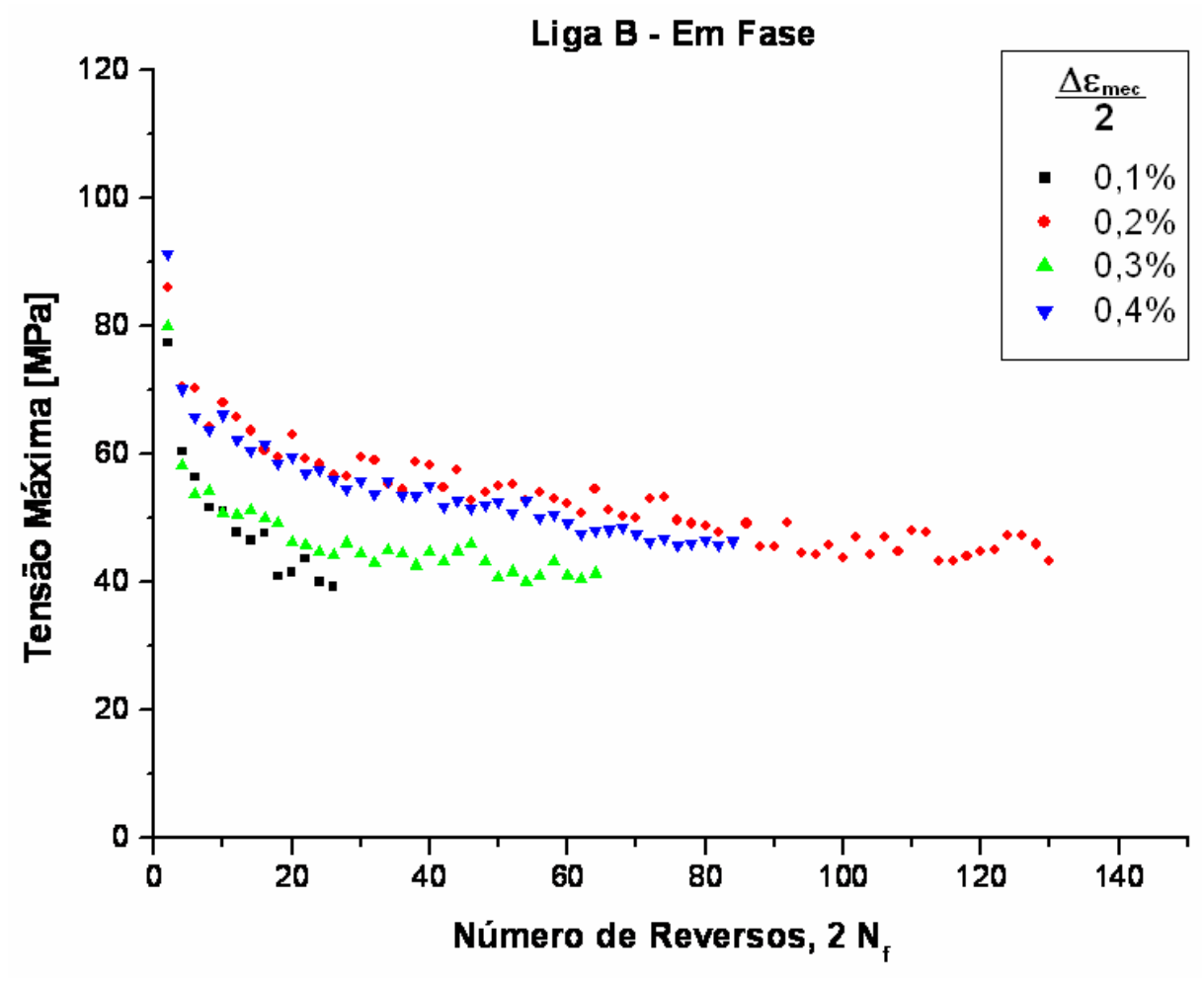

Figura 5.77 - Gráfico da tensão máxima em função do número de ciclos para a liga $\mathrm{B}$, para condição em fase e em vários níveis de amplitude de deformação mecânica.

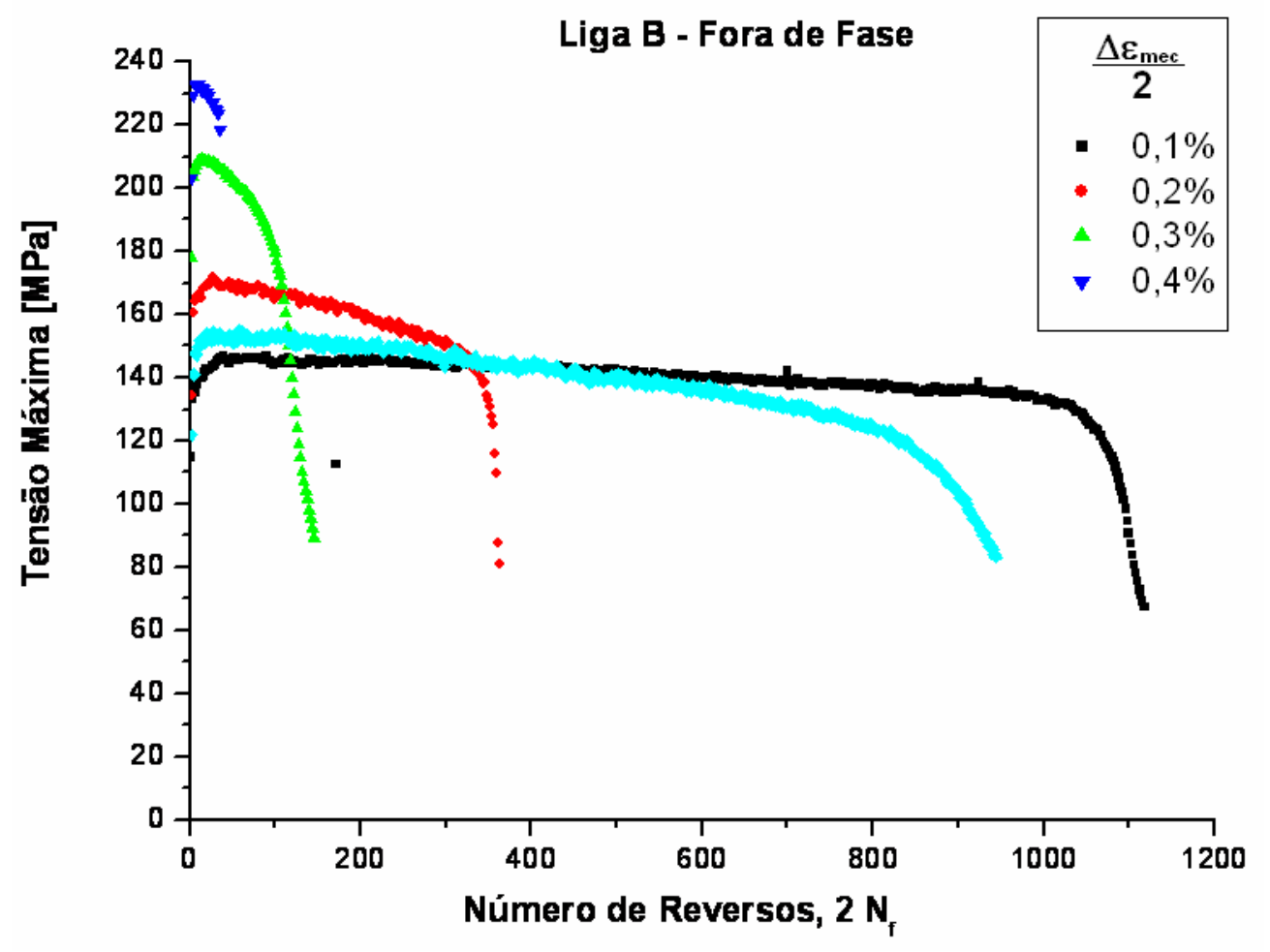

Figura 5.78 - Gráfico da tensão máxima em função do número de ciclos para a liga $\mathrm{B}$, para condição fora de fase e em vários níveis de amplitude de deformação mecânica. 


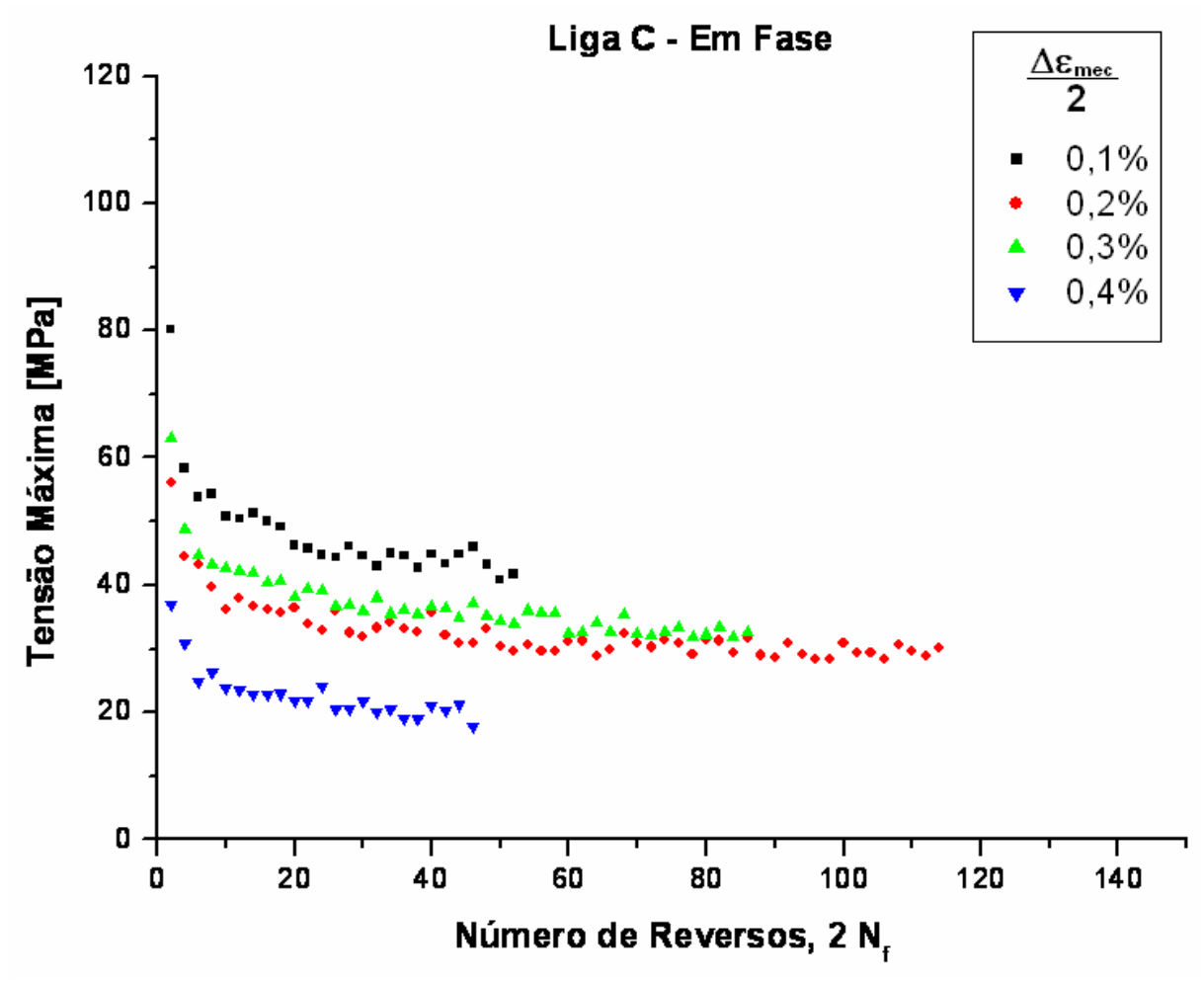

Figura 5.79 - Gráfico da tensão máxima em função do número de ciclos para a liga $\mathrm{C}$, para condição em fase e em vários níveis de amplitude de deformação mecânica.

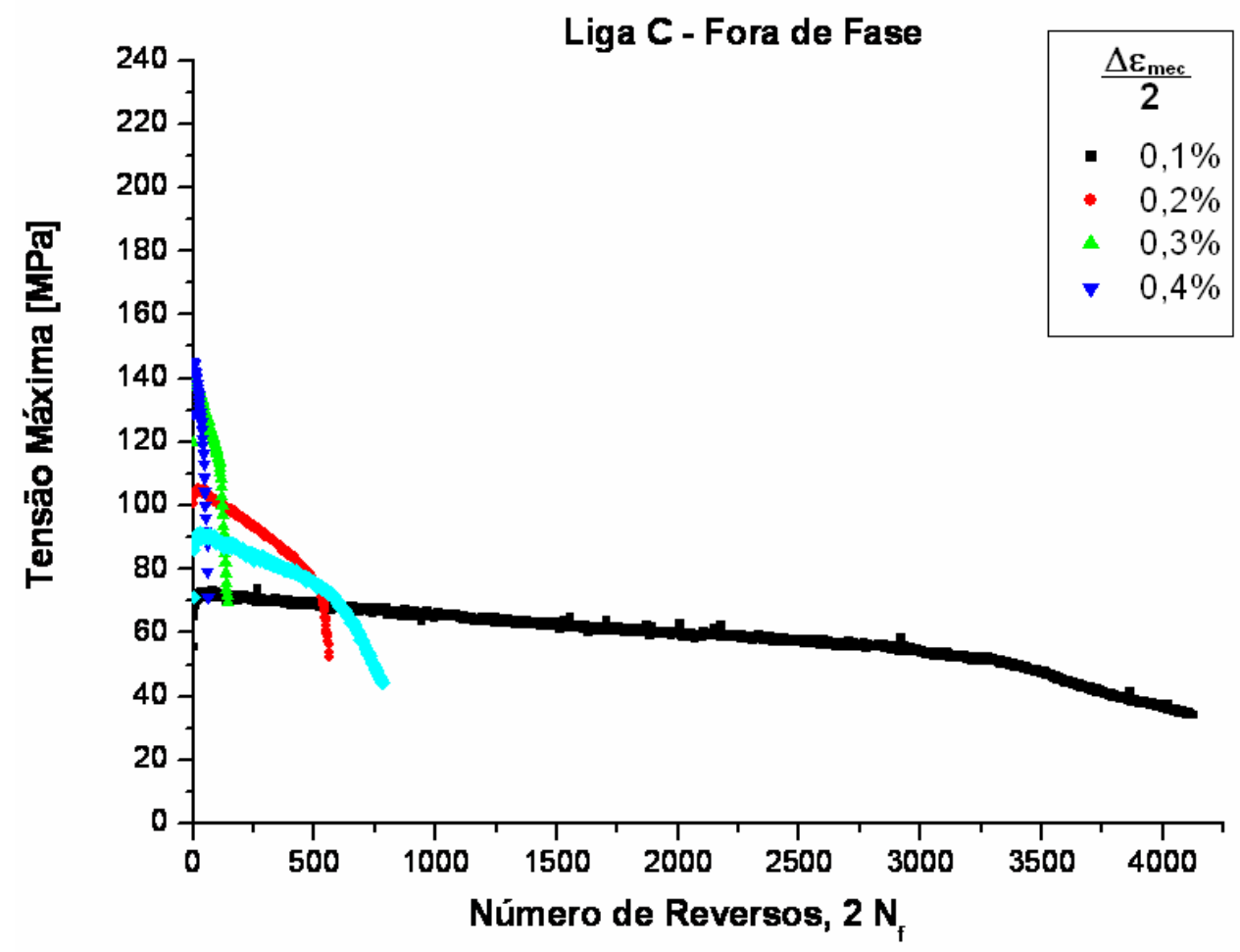

Figura 5.80 - Gráfico da tensão máxima em função do número de ciclos para a liga $\mathrm{C}$, para condição fora de fase e em vários níveis de amplitude de deformação mecânica. 


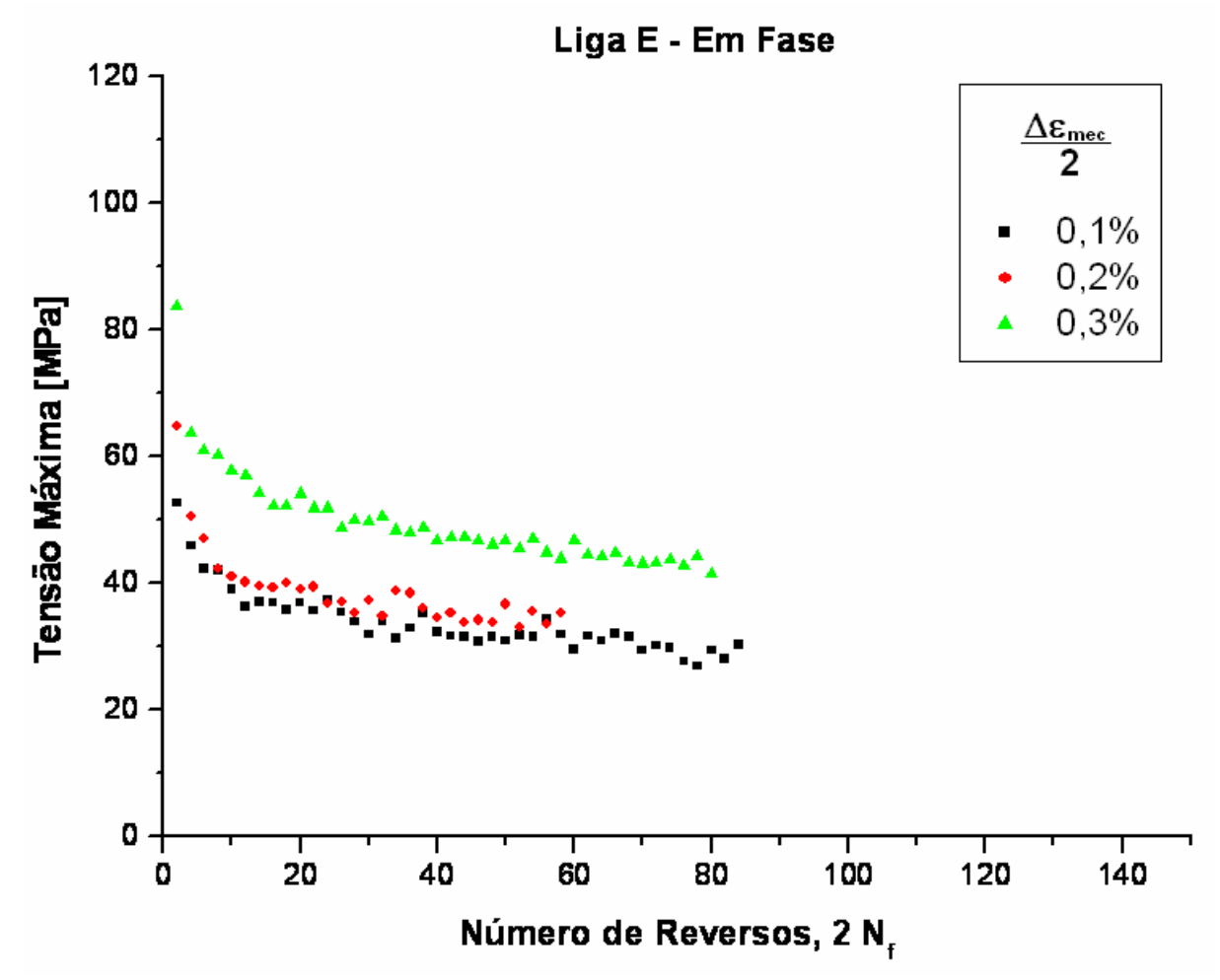

Figura 5.81 - Gráfico da tensão máxima em função do número de ciclos para a liga $\mathrm{E}$, para condição em fase e em vários níveis de amplitude de deformação mecânica.

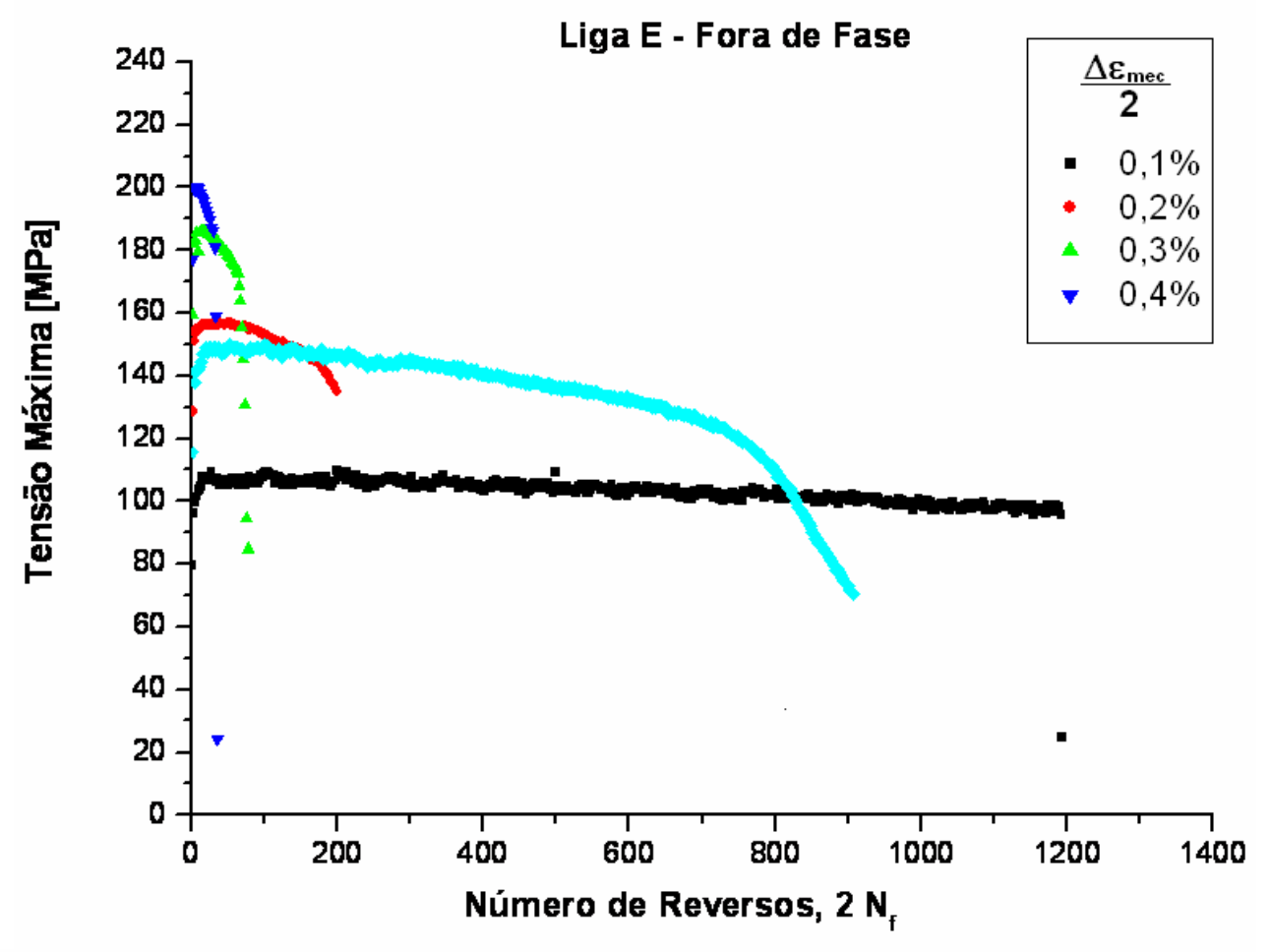

Figura 5.82 - Gráfico da tensão máxima em função do número de ciclos para a liga $\mathrm{E}$, para condição fora de fase e em vários níveis de amplitude de deformação mecânica. 


\subsubsection{3 - Comportamento Temperatura x Deformação}

A amplitude de deformação total que acontece em um ensaio de fadiga termomecânica é a soma da amplitude de deformação mecânica, pré-determinada, com a amplitude de deformação térmica, que é característica de cada material submetido a variação de temperatura.

O ciclo térmico aplicado antes do início do ensaio é utilizado para verificar quanto o material expande com o aumento da temperatura. Na Figura 5.83, estão as expansões (deformações térmicas) para as quatro ligas estudadas, e pode-se observar que os comportamentos não foram muito diferentes. Adotou-se, por critério, que a deformação térmica tivesse sinal negativo na temperatura de $300^{\circ} \mathrm{C}$ e positivo em $600^{\circ} \mathrm{C}$. Em módulo, a percentagem da deformação térmica foi de $0,24 \mathrm{em} 300^{\circ} \mathrm{C}$ e $0,27 \mathrm{em} 600^{\circ} \mathrm{C}$. Para ensaios de fadiga termomecânica em fase, a deformação mecânica é trativa $(+) \mathrm{em} 600^{\circ} \mathrm{C}$ e compressiva (-) em $300^{\circ} \mathrm{C}$. Logo, em fase, a deformação total é uma soma de deformações com o mesmo sinal. Nos ensaios de fadiga termomecânica fora de fase, a deformação mecânica é compressiva (-) em $600^{\circ} \mathrm{C}$ e trativa $(+) \mathrm{em} 300^{\circ} \mathrm{C}$. Assim, para ensaios de fadiga fora de fase, a deformação total é uma soma de deformações com sinais diferentes, já que ambas possuem sinais opostos nos picos de temperatura do ensaio, o que acarreta, para se obter a deformação total, uma subtração entre as deformações mecânica e térmica.

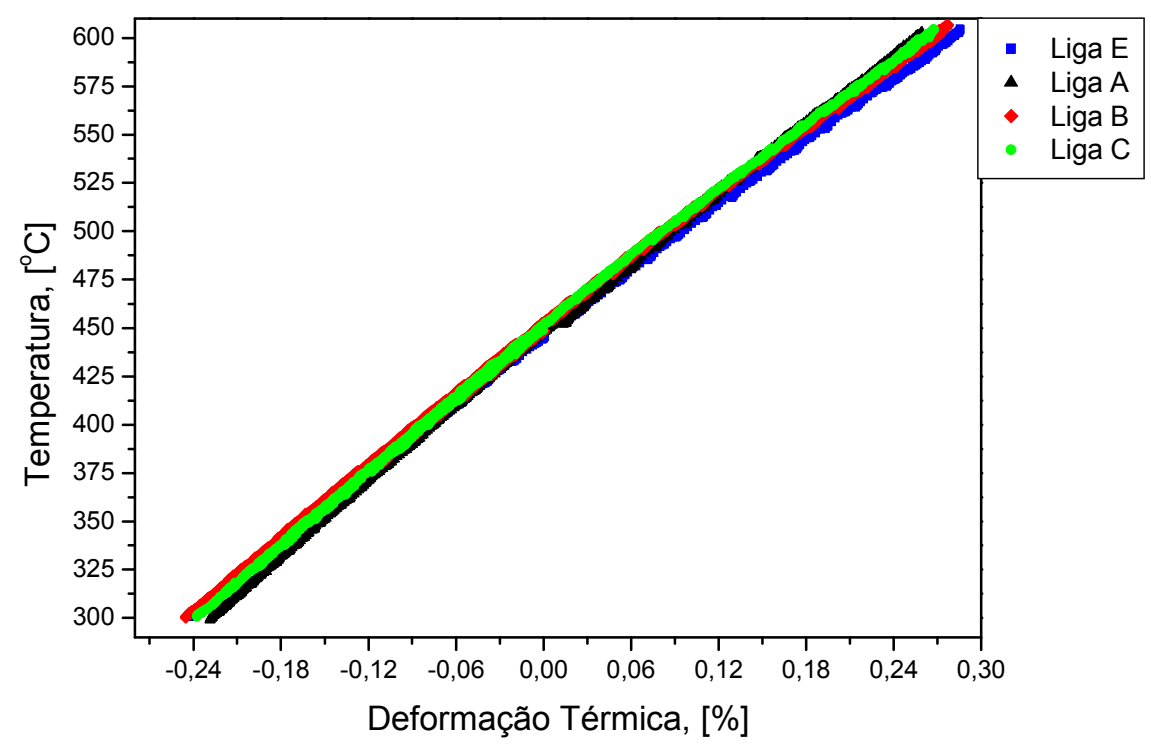

Figura 5.83 - Deformação térmica apresentada pelas ligas A, B, C e E, devido ao aumento da temperatura. 
Então, o tamanho e a direção das histereses, que ilustram o comportamento do material durante o ciclo, são influenciados pela característica do ensaio e pela maior deformação dentre as duas existentes: térmica e mecânica.

A amplitude de deformação térmica para as quatro ligas foi de aproximadamente 0,3\%, maior, portanto, que as amplitudes de deformações mecânicas de $0,1 \%$ e $0,2 \%$, o que a fez influenciar sobremaneira no tamanho e na direção das histereses. As Figuras 5.84 e 5.85 mostram o comportamento da liga $\mathbf{A}$, quando submetida a ensaios termomecânicos de baixo ciclo, em fase e fora de fase, com controle de amplitude de deformação mecânica de $0,1 \%$. Fica claro na 5.84 (em fase) que a deformação total, fruto da soma da deformação térmica e mecânica, foi maior que cada uma das duas separadamente e as histereses tiveram todas a mesma tendência de direção.

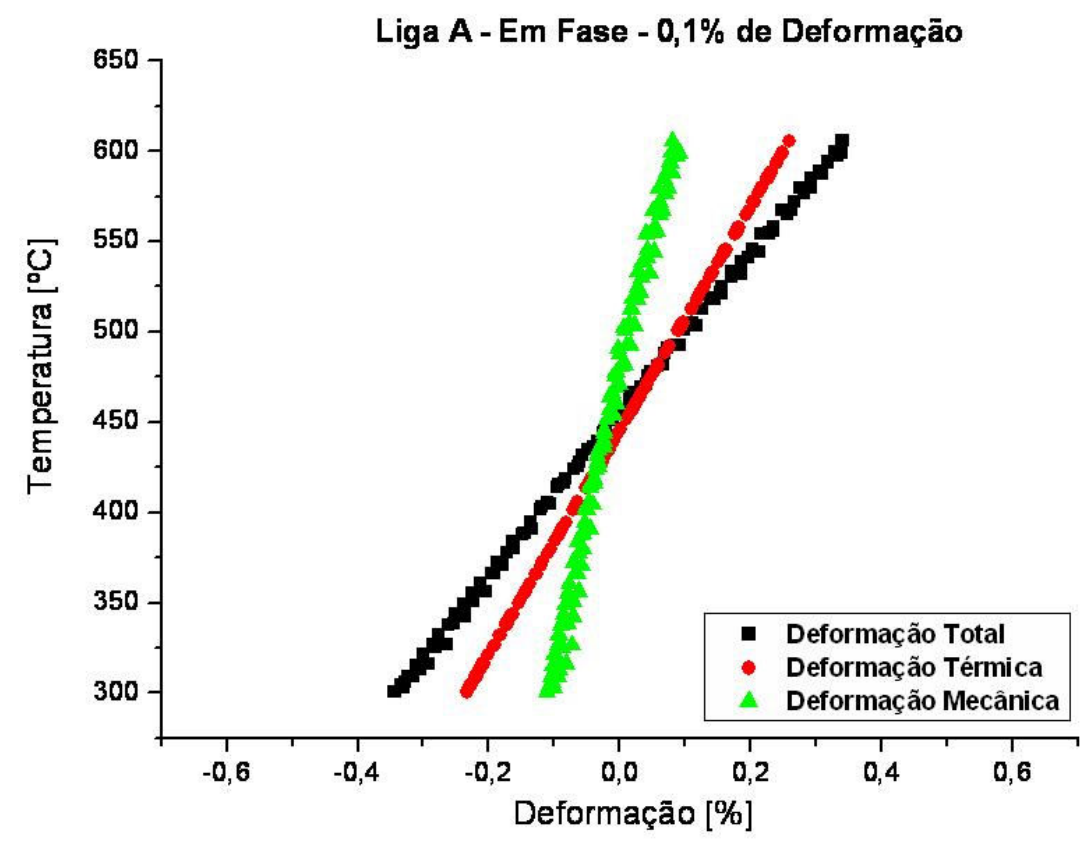

Figura 5.84 - Fadiga termomecânica em fase - Gráfico da Deformação em função da Temperatura, para amplitude de deformação mecânica de $0,1 \%$.

Não é o que ocorre para uma situação fora de fase (Figura 5.85), em que a deformação total foi menor que a térmica e maior que a mecânica. Neste caso, as histereses da deformação total e da térmica tiveram a mesma tendência de direção.O comportamento das histereses verificado para a liga $\mathbf{A}$ sob fadiga termomecânica, em fase e fora de fase, para qualquer nível de deformação mecânica, foi similar àqueles das outras três ligas estudadas. 


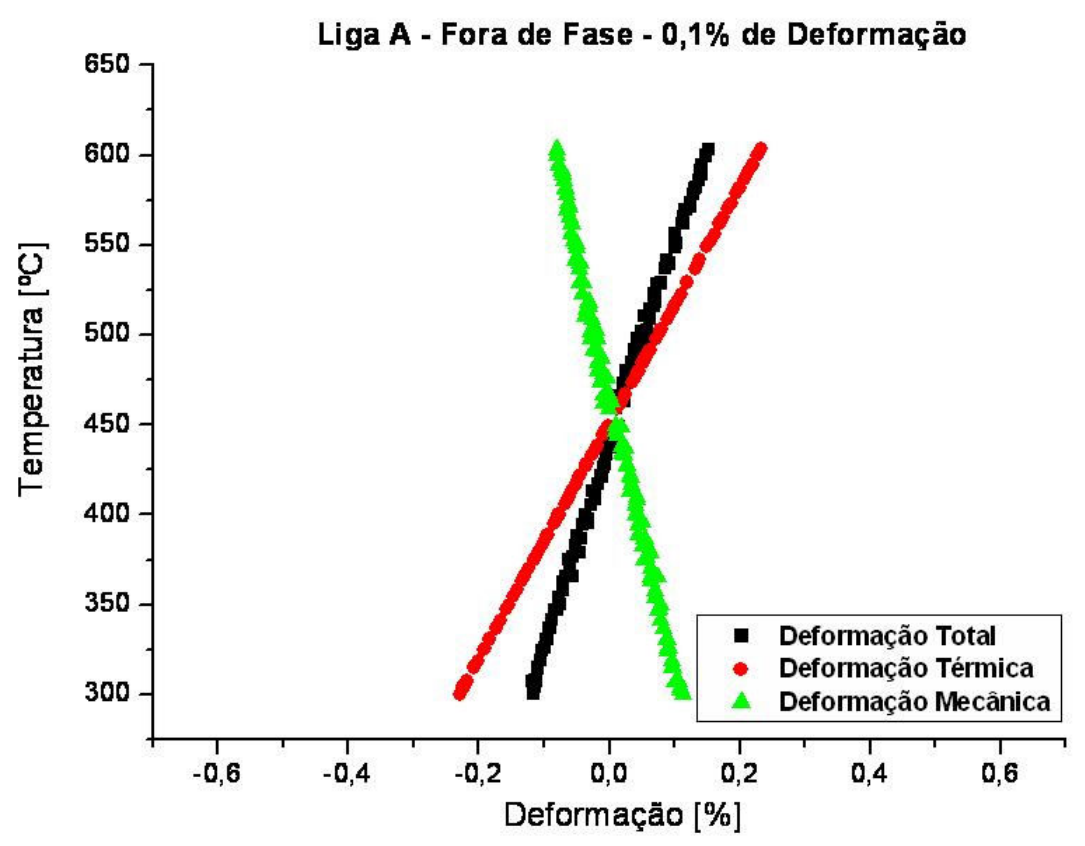

Figura 5.85 - Fadiga termomecânica fora de fase - Gráfico da Deformação em função da Temperatura, para amplitude de deformação mecânica de $0,1 \%$.

Para uma amplitude de deformação mecânica de 0,3\%, como a amplitude de deformação térmica, também é de aproximadamente $0,3 \%$, a histerese da deformação total para o ensaio em fase (Figura 5.86) representou a soma das duas deformações e teve a mesma tendência de direção que elas.

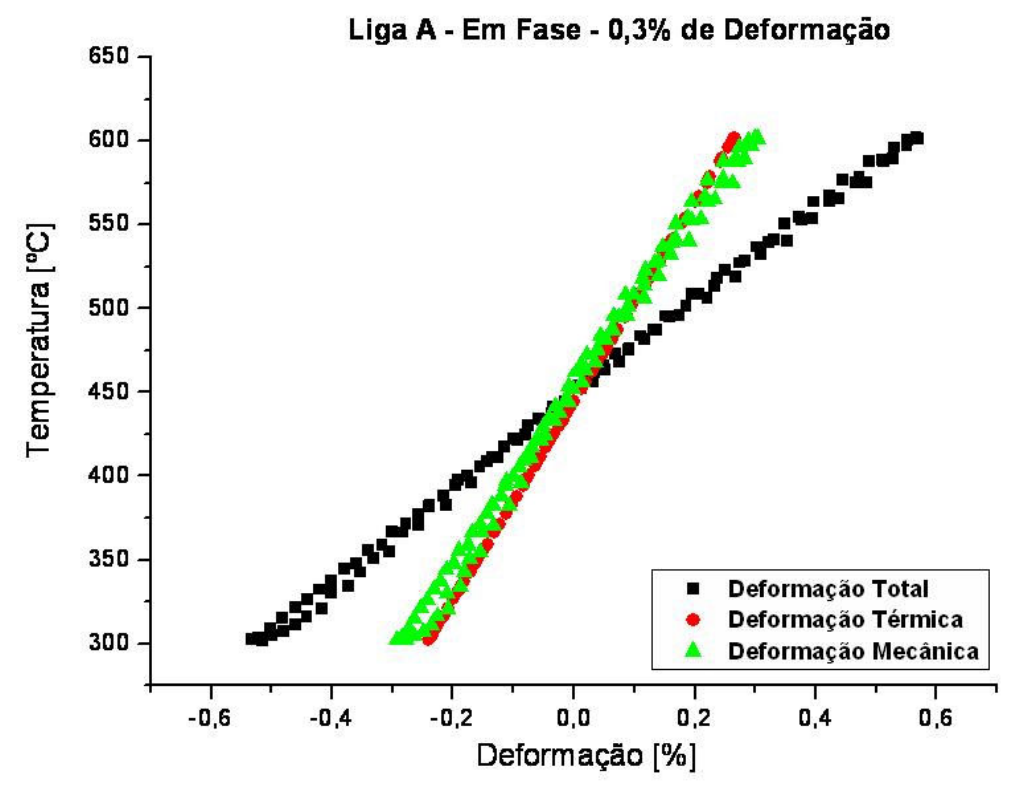

Figura 5.86 - Fadiga termomecânica em fase - Gráfico da Deformação em função da Temperatura, para amplitude de deformação mecânica de $0,3 \%$. 
Já para a fadiga termomecânica, fora de fase (Figura 5.87), com amplitude de deformação mecânica também de $0,3 \%$, a curva de histerese que representa a deformação total ficou com valores muito próximos de zero e na direção perpendicular ao eixo da deformação.

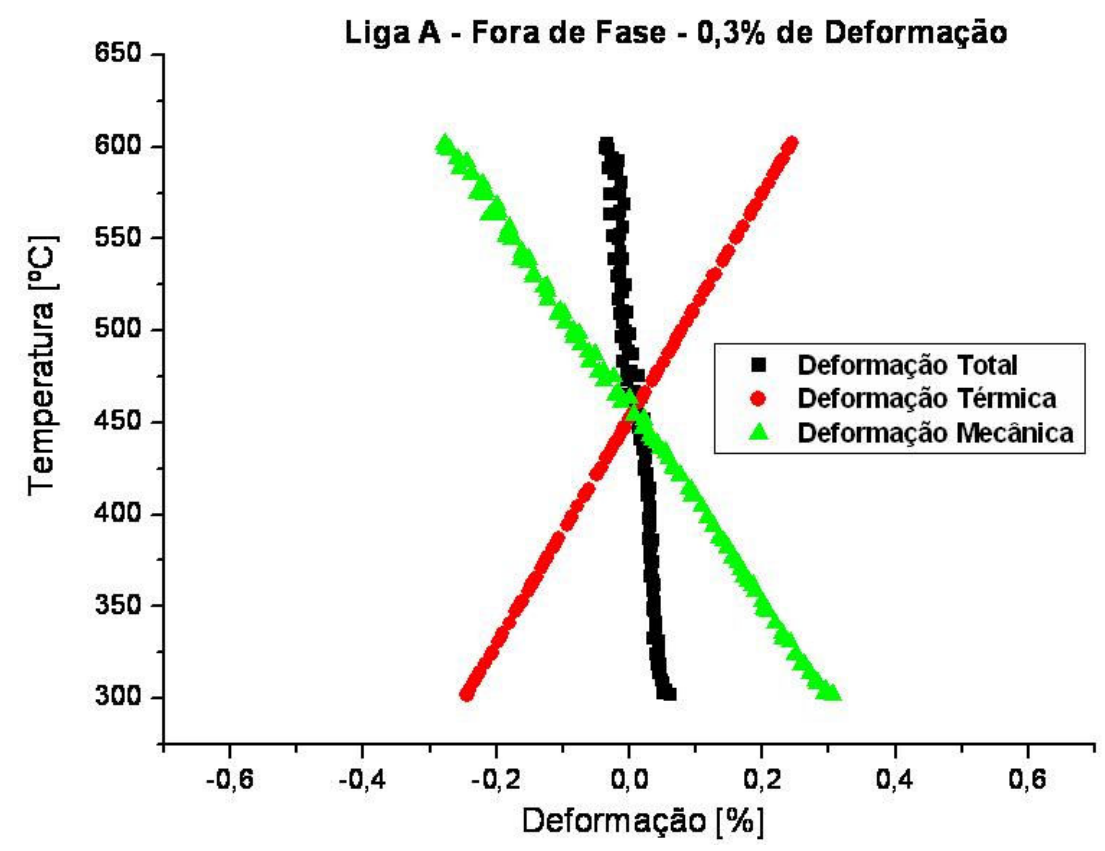

Figura 5.87 - Fadiga termomecânica fora de fase - Gráfico da Deformação em função da Temperatura, para amplitude de deformação mecânica de $0,3 \%$.

No ensaio de fadiga termomecânica, também da liga $\mathbf{A}$, quando a amplitude de deformação mecânica é de $0,4 \%$, portanto maior que a amplitude de deformação térmica, o comportamento da histerese de deformação total está mostrado nas Figuras 5.88 e 5.89. Quando o ensaio transcorreu na condição em fase, a amplitude de deformação total foi o resultado da soma das amplitudes de deformação térmica e mecânica, portanto maior que cada uma das duas separadamente e as três histereses tiveram a mesma tendência de direção. No entanto, quando o ensaio foi realizado fora de fase, a amplitude de deformação total foi menor que as outras e sua histerese teve a mesma tendência de direção que a da amplitude de deformação mecânica, que foi a maior. 


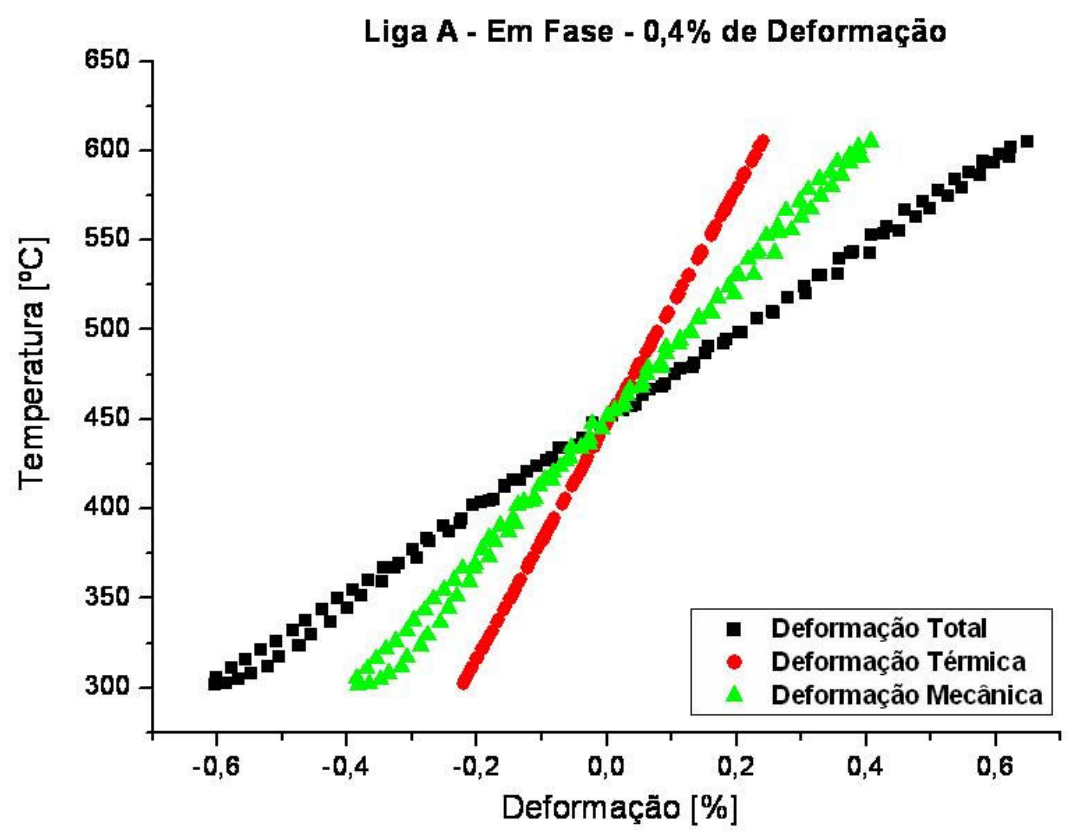

Figura 5.88 - Fadiga termomecânica em fase - Gráfico da Deformação em função da Temperatura, para amplitude de deformação mecânica de $0,4 \%$.

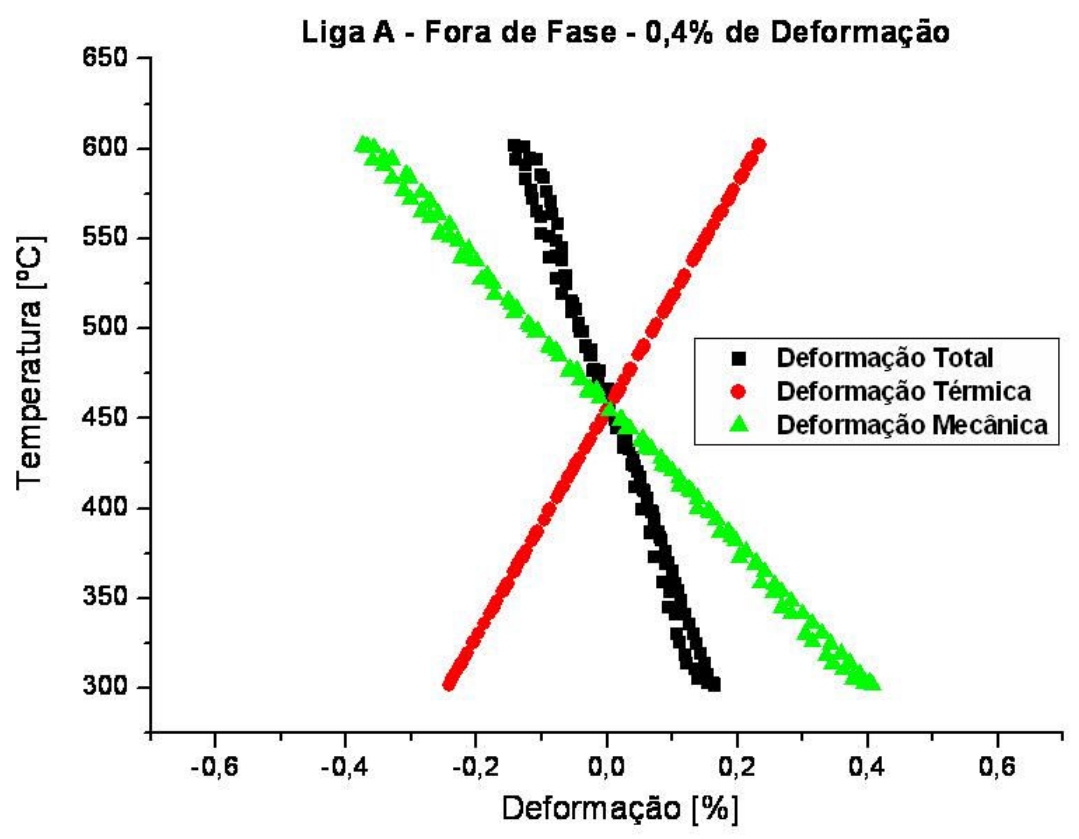

Figura 5.89 - Fadiga termomecânica fora de fase - Gráfico da Deformação em função da Temperatura, para amplitude de deformação mecânica de $0,4 \%$.

Vale salientar que as histereses de ensaios de fadiga termomecânica são mais largas quando a condição de ensaio ocorrer em fase, pois a deformação total é resultado de uma soma de deformações, ao contrário da condição fora de fase que resulta de uma subtração. 


\subsubsection{4-Comportamento Tensão x DeformaçãoTotal}

Analisando o comportamento das histereses iniciais, de meia vida e das que representam o final do ensaio, quando as tensões caíram para $50 \%$ da tensão máxima, observou-se que, para deformações mecânicas de 0,1 e $0,2 \%$, em fase, as curvas de histerese se deslocaram para baixo, na direção de valores compressivos maiores. Isso pode ser visto nas Figuras 5.90 e 5.91 para a liga A, mas este comportamento foi similar para todas as ligas estudadas neste trabalho. Este fenômeno pôde ser explicado pelo fato de que materiais expostos a temperaturas elevadas deformam mais facilmente e, também, devido à influência da expansão grafítica, aumento de volume resultante da decomposição da cementita da perlita, em ferrita e grafita. Este aumento interno de volume provoca, indiretamente, um amolecimento do material, diminuindo assim, o nível de tensão necessário para atingir o valor da deformação total imposta no ensaio. Vale salientar que esta decomposição ocorre normalmente em temperatura acima de $723^{\circ} \mathrm{C}$, mas a presença de tensão trativa aplicada no mesmo sentido potencializa essa expansão favorecendo termodinamicamente a transformação grafítica, mesmo em temperaturas menores que $600^{\circ} \mathrm{C}$.

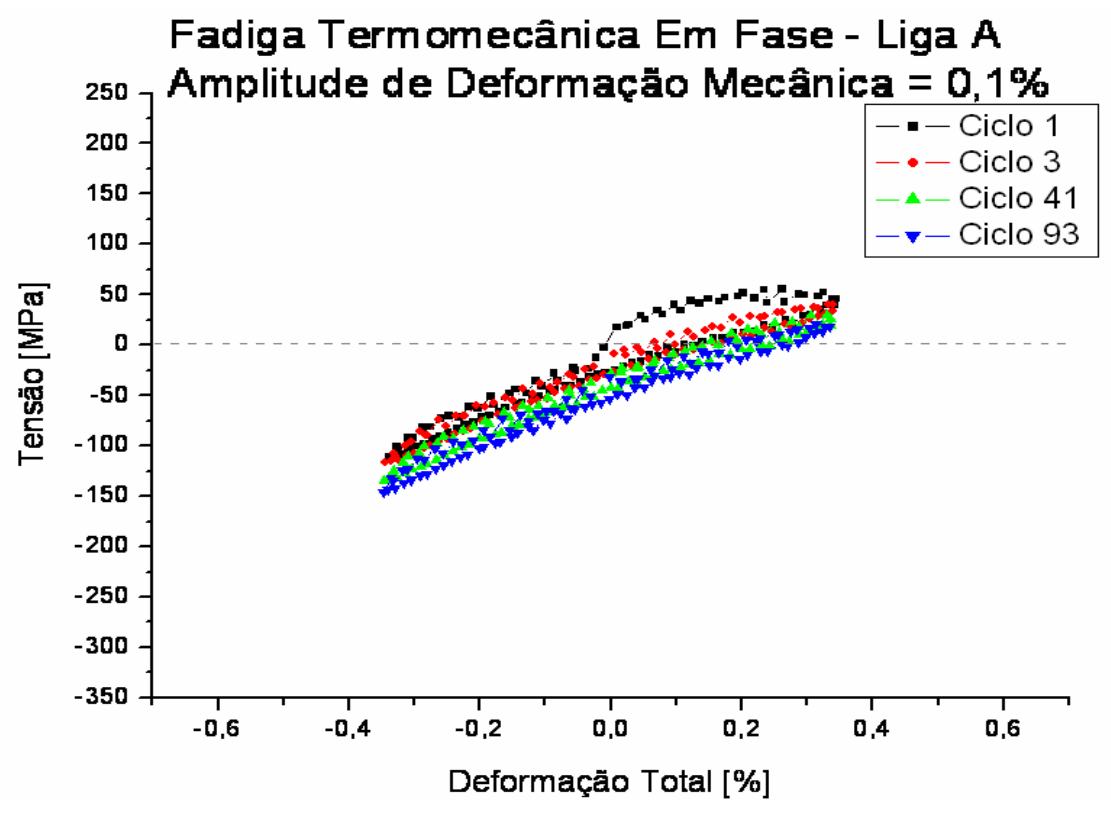

Figura 5.90 - Gráfico da Amplitude de Tensão em função da Amplitude de Deformação Total, para condição em fase da Liga A em amplitude de deformação mecânica de $0,1 \%$. 


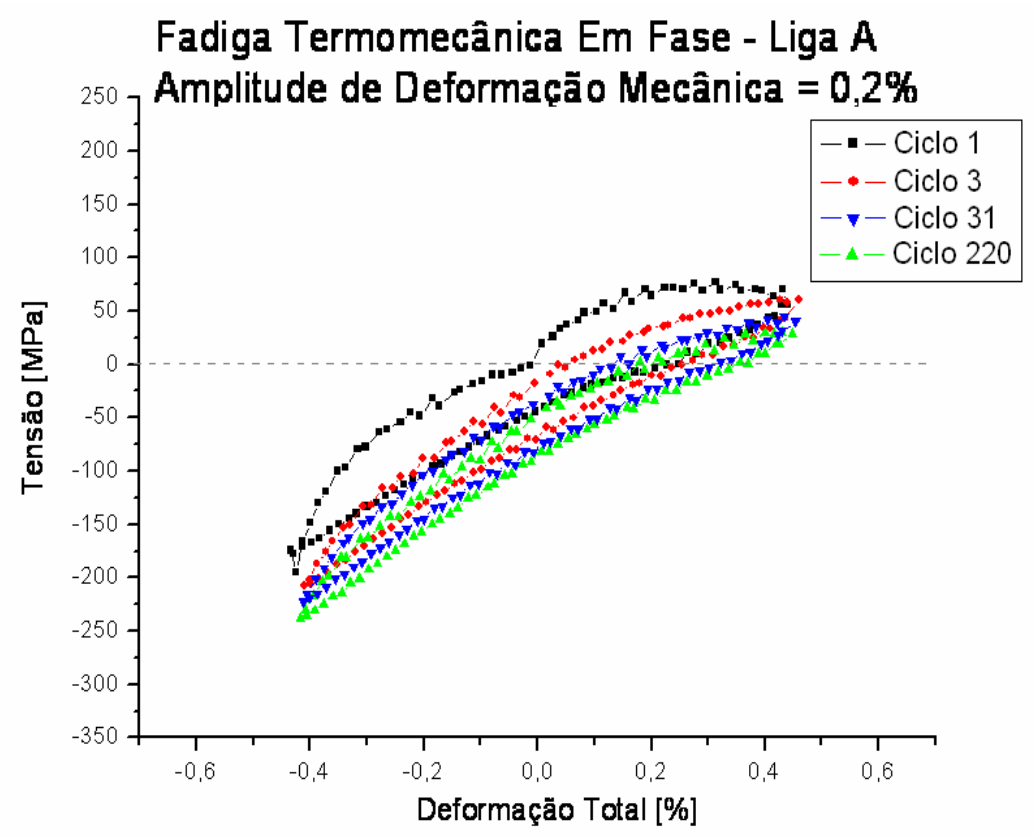

Figura 5.91 - Gráfico da Amplitude de Tensão em função da Amplitude de Deformação Total, para condição em fase da Liga A em amplitude de deformação mecânica de 0,2\%.

Para amplitudes de deformações mecânicas maiores, tais como 0,3\% e 0,4\%, nos ensaios realizados em fase, as histereses, como mostradas nas Figuras 5.92 e 5.93, somente se deslocaram para baixo nos ciclos trativos.

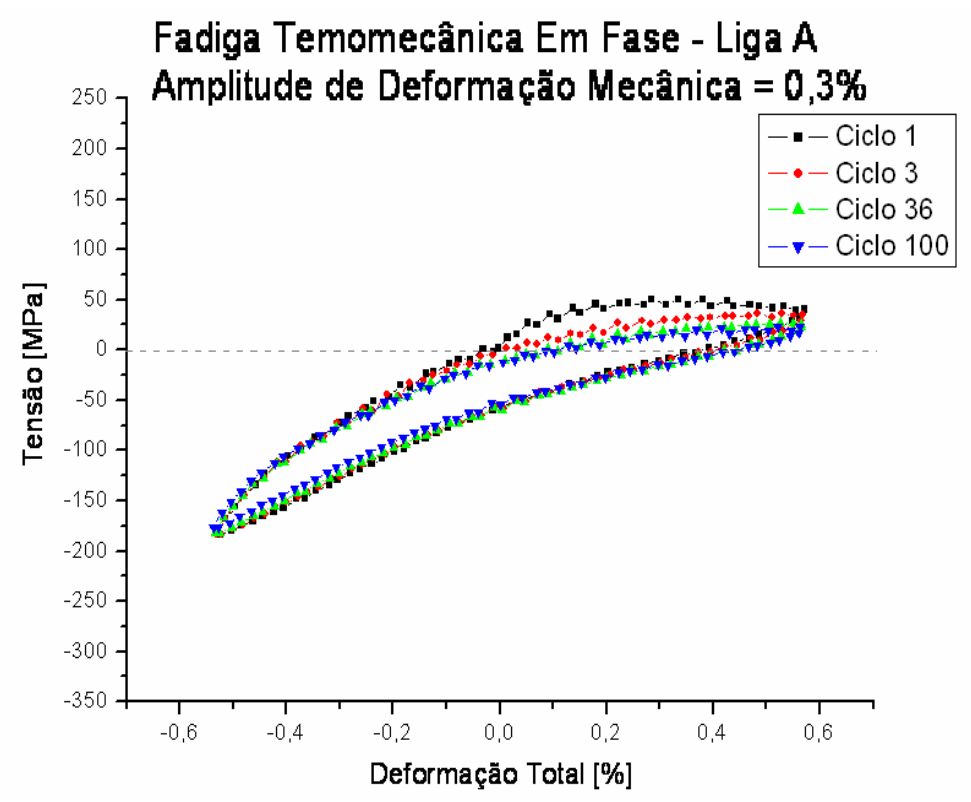

Figura 5.92 - Gráfico da Amplitude de Tensão em função da Amplitude de Deformação Total, para condição em fase da Liga A em amplitude de deformação mecânica de $0,3 \%$. 


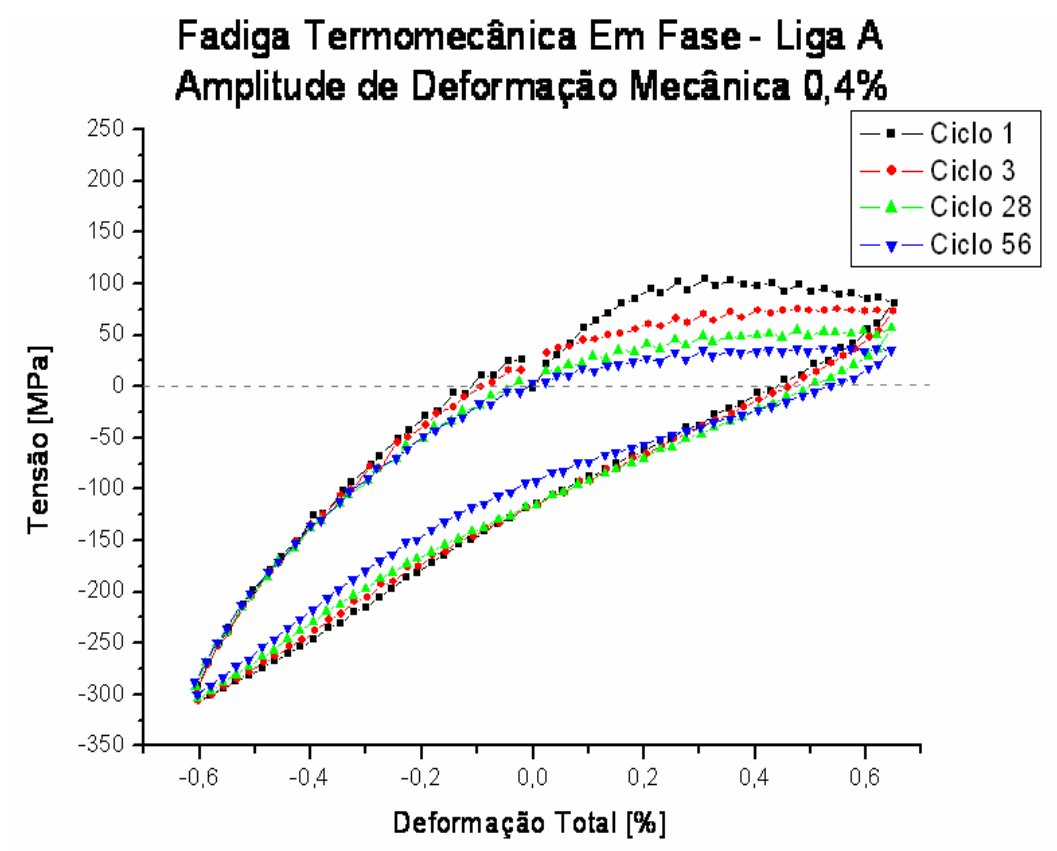

Figura 5.93 - Gráfico da Amplitude de Tensão em função da Amplitude de Deformação Total, para condição em fase da Liga A em amplitude de deformação mecânica de $0,4 \%$.

Este comportamento pôde ser explicado pelos maiores níveis de deformações mecânicas aplicados, suficientemente altos para permitirem a propagação de trincas que nucleiam a partir dos veios de grafita existentes na microestrutura do material. A forma geométrica lamelar dos veios produz um acúmulo de concentração de tensões em suas extremidades, o que facilita a propagação de trincas pelo mecanismo de fadiga. Vale salientar que o tamanho e a quantidade dos veios de grafita afetam, sobremaneira, a resistência mecânica dos ferros fundidos cinzentos.

O trincamento gerado no ciclo trativo diminuiu a secção resistente do corpo de prova, provocando assim uma diminuição da tensão com o crescimento do número de ciclos. Por outro lado, na região compressiva do ciclo ocorre o fechamento das trincas e, como conseqüência, as tensões máximas compressivas não variaram com o aumento do número de ciclos. Vale salientar que isto aconteceu para deformações altas $(0,3 \%$ e $0,4 \%)$ em que as velocidades de crescimento das trincas, a partir dos veios de grafita, são maiores. Resumindo, as curvas de histerese tensão-deformação mostraram, no decorrer do ensaio, uma diminuição dos picos das tensões trativas e valores das tensões compressivas praticamente constantes.

Como nos ensaios de fadiga termomecânica, realizados na condição fora de fase, os corpos de prova sofrem compressão na temperatura máxima do ciclo, a expansão grafítica não deve ocorrer devido ao carregamento em sentido contrário. Portanto, não colabora para baixar 
as curvas de histerese como um todo, no transcorrer do ensaio. Apesar da necessidade da aplicação de tensões trativas cada vez maiores à medida que as amplitudes de deformações mecânicas são aumentadas, observou-se, na condição fora de fase, o mesmo comportamento das histereses que na em fase para maiores deformações mecânica $(0,3 \%$ e $0,4 \%)$. As curvas de histerese acusaram, com o decorrer do ensaio, uma diminuição significativa das tensões trativas e quase nenhuma diminuição das tensões compressivas, indicando que sob fadiga termomecânica fora de fase, como as tensões necessárias são maiores, aconteceram nucleações de trincas para todas as deformações mecânicas pré-estabelecidas. Sob tensões trativas as trincas se abrem diminuindo as tensões necessárias para determinada deformação mecânica. No entanto, como sob tensões compressivas as trincas se fecham, as tensões praticamente permanecem as mesmas. Este comportamento para a liga A, típico a todas as ligas, é mostrado nas Figuras de 5.94 a 5.98.

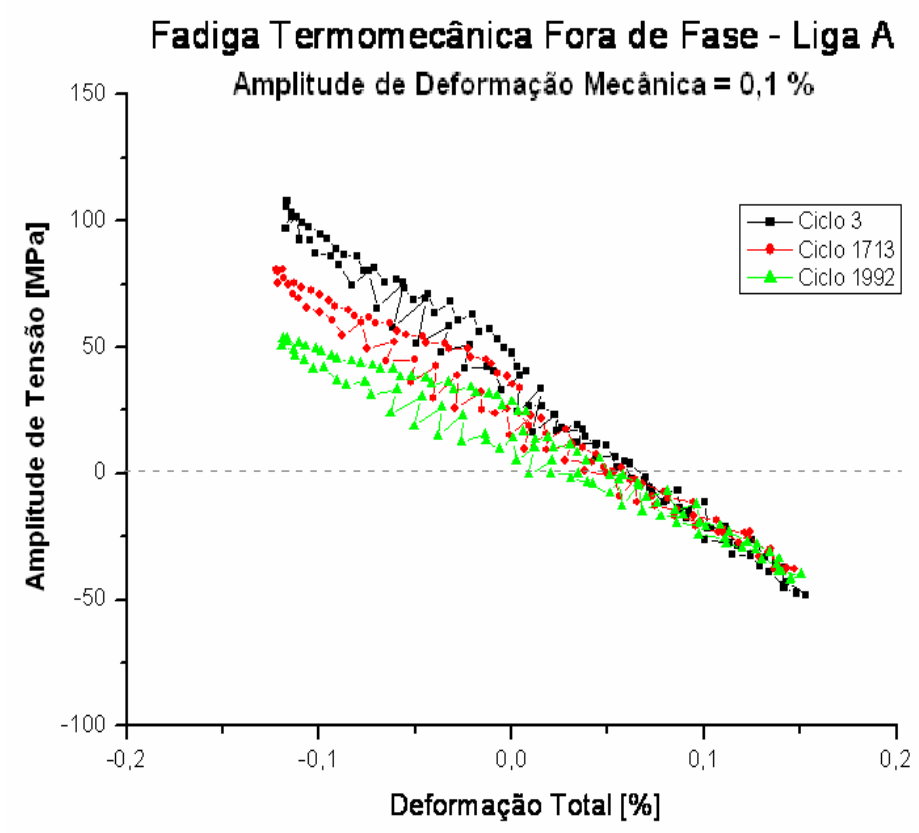

Figura 5.94 - Gráfico da Amplitude de Tensão em função da Amplitude de Deformação Total, para a condição fora de fase da Liga $\mathrm{A}$, em amplitude de deformação mecânica de $0,1 \%$ 


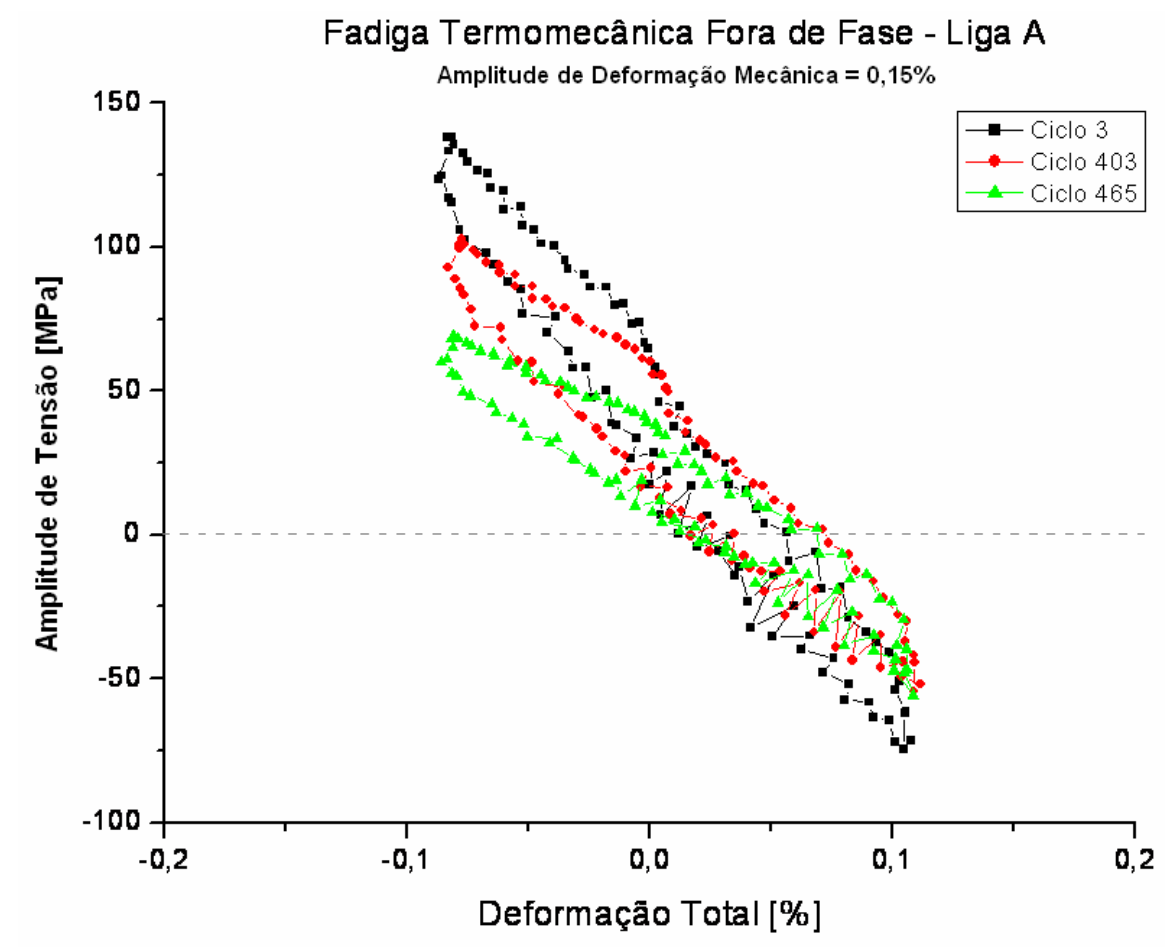

Figura 5.95 - Gráfico da Amplitude de Tensão em função da Amplitude de Deformação Total, para a condição fora de fase da Liga A, em amplitude de deformação mecânica de $0,15 \%$

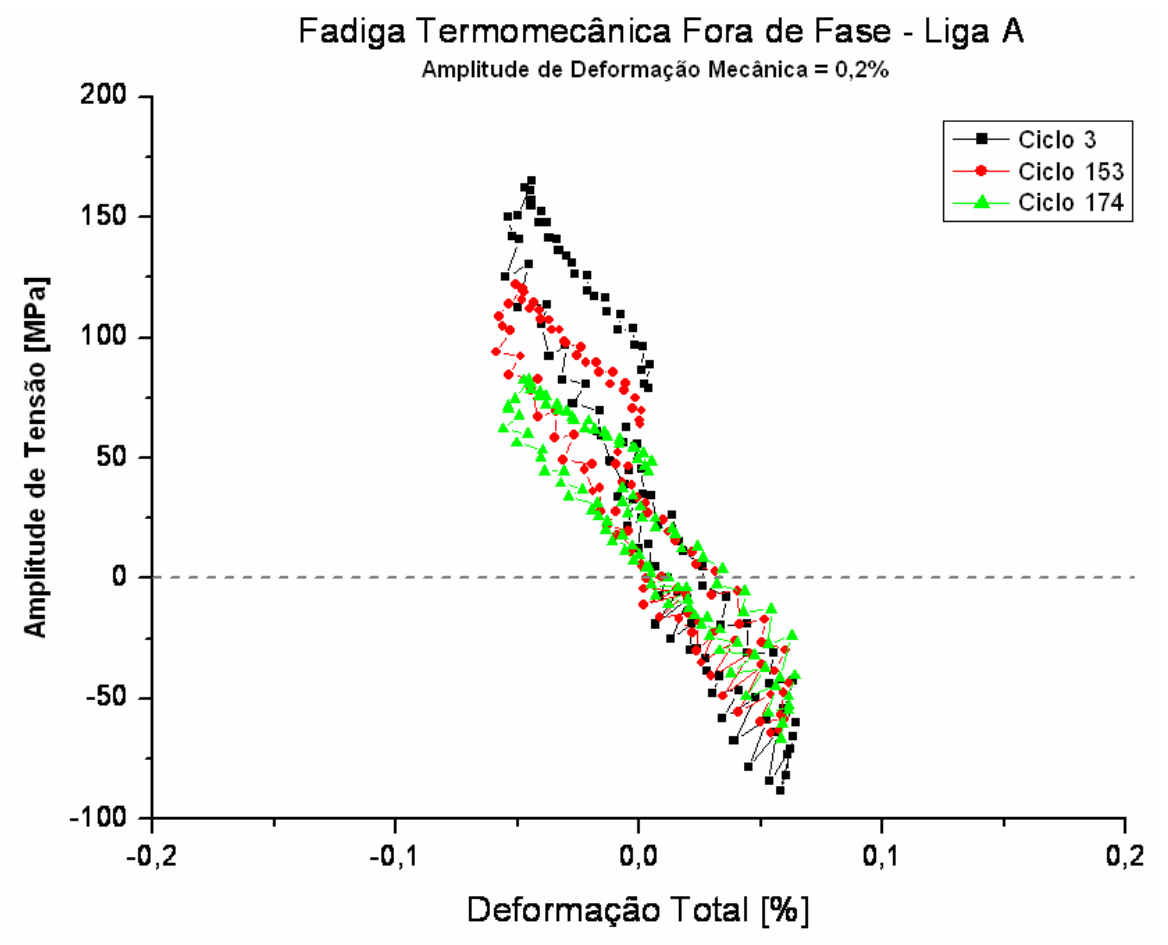

Figura 5.96 - Gráfico da Amplitude de Tensão em função da Amplitude de Deformação Total, para a condição fora de fase da Liga A, em amplitude de deformação mecânica de $0,2 \%$ 


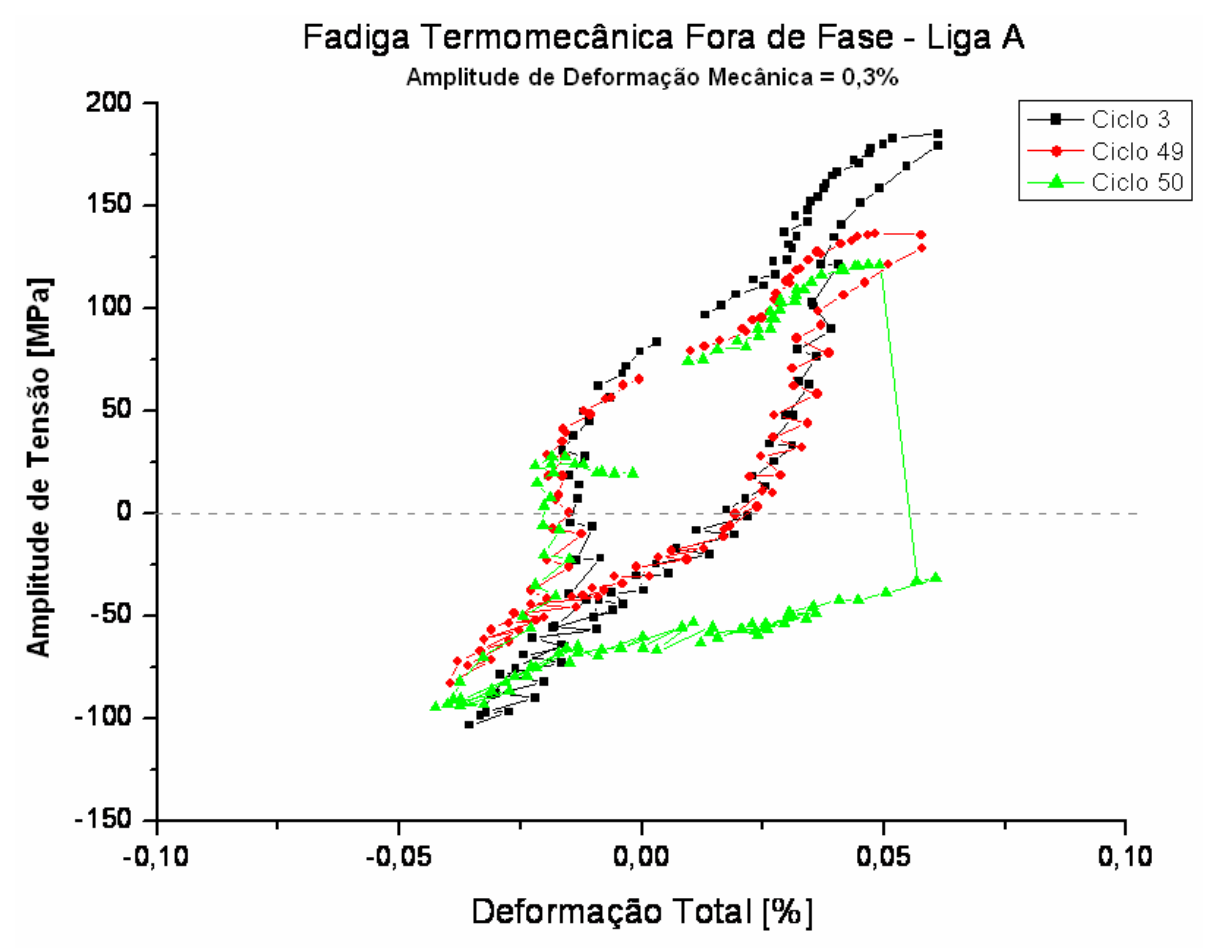

Figura 5.97 - Gráfico da Amplitude de Tensão em função da Amplitude de Deformação Total, para a condição fora de fase da Liga A, em amplitude de deformação mecânica de $0,3 \%$.

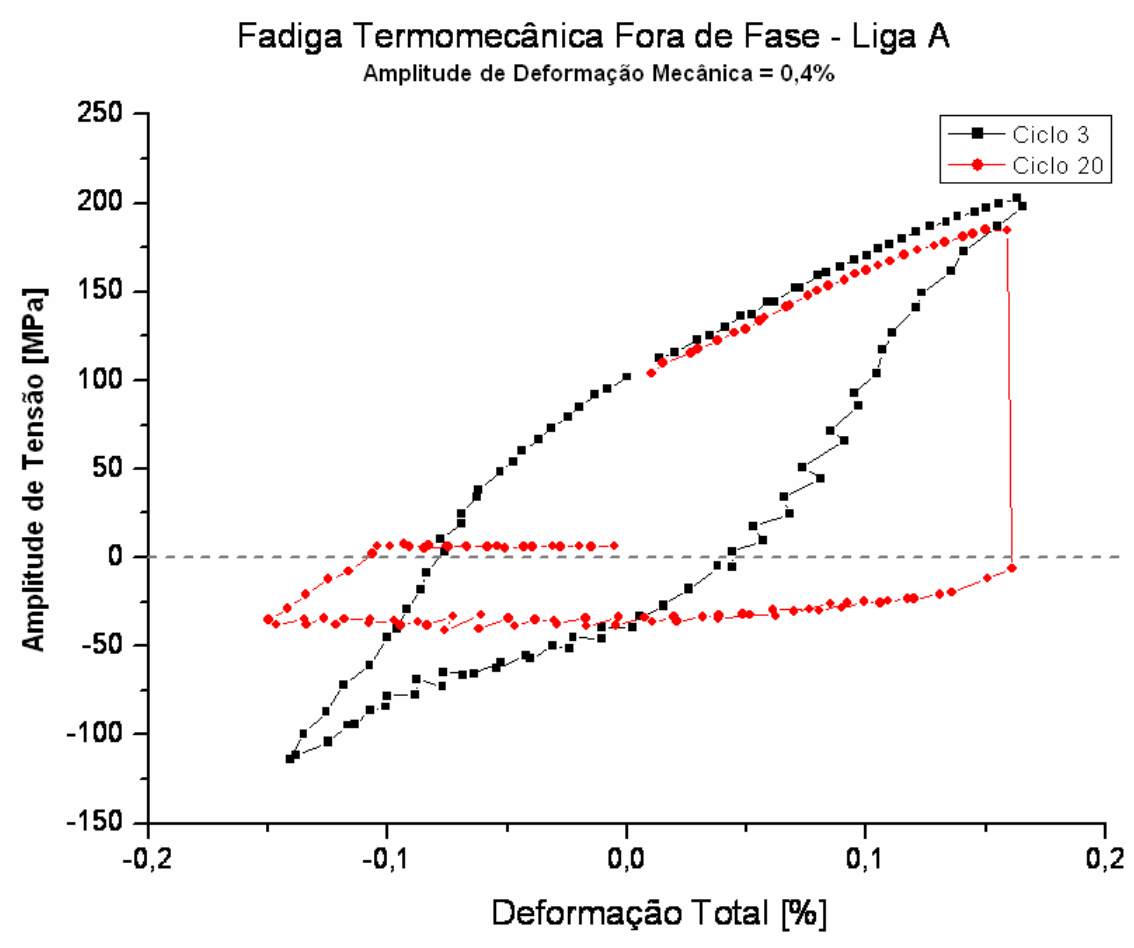

Figura 5.98 - Gráfico da Amplitude de Tensão em função da Amplitude de Deformação Total, para a condição fora de fase da Liga A, em amplitude de deformação mecânica de $0,4 \%$.

A Figura 5.99 apresenta um gráfico que compara os resultados das tensões máximas trativas do ensaio em função das deformações mecânicas para as quatro ligas, em fase e fora 
de fase. Comprovou-se o que já havia sido dito, ou seja, que os valores das tensões trativas máximas, responsáveis pela nucleação e crescimento de trincas, foram muito maiores nos ensaios de fadiga termomecânica fora de fase do que naqueles em fase. A liga $\mathbf{B}$ foi a que exigiu maiores tensões para atingir as diversas deformações (140 a 240MPa), seguida pelas ligas A e E (130 a 200MPa). Já a liga $\mathbf{C}$ foi aquela que mais facilmente se deformou, tendo exigido tensões menores ( 80 a $140 \mathrm{MPa}$ ). Na condição em fase, os valores das tensões necessárias para atingir as deformações foram, comparativamente, baixos, muito próximos e variaram muito pouco.

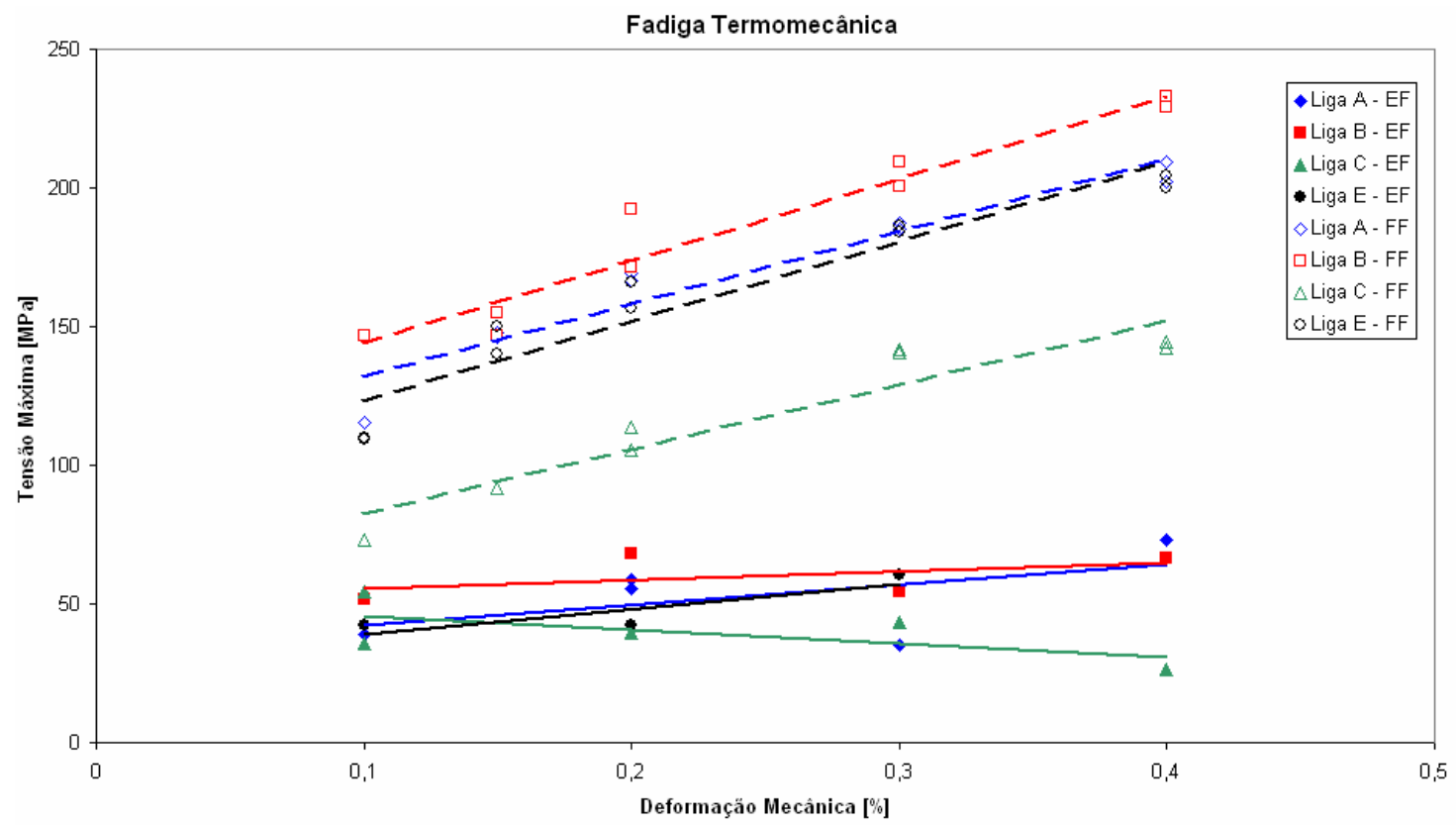

Figura 5.99 - Gráfico comparativo da tensão máxima de ensaio em função da deformação mecânica para as ligas estudadas.

Analisando os gráficos de tensão em função do tempo de cada uma das ligas, no ciclo final de ensaio, em fase e fora de fase, para amplitudes de deformação de $0,1 \%, 0,2 \%, 0,3 \%$ e 0,4\%, ilustrados nas Figuras de 5.100 a 5.103, observou-se que nas condições fora de fase as ligas apresentaram, na parte trativa do ciclo, tensões relativamente bem diferenciadas de uma para outra. Já durante toda a parte compressiva do ciclo os valores das tensões das ligas foram muito próximos. A justificativa principal para esta variação de comportamento baseia-se no fato de que a resistência mecânica dos materiais é maior em temperaturas mais baixas e, desta maneira, na parte trativa, houve valores de tensões trativas mais significativos e com possibilidades de, graficamente, estarem mais espaçados. $\mathrm{Na}$ parte compressiva, como os 
materiais estavam, comparativamente, em temperaturas mais altas, puderam ser deformados com maior facilidade, ou seja, com baixas tensões compressivas. Daí a proximidade entre as curvas das diversas ligas, quase que se sobrepondo umas sobre as outras.

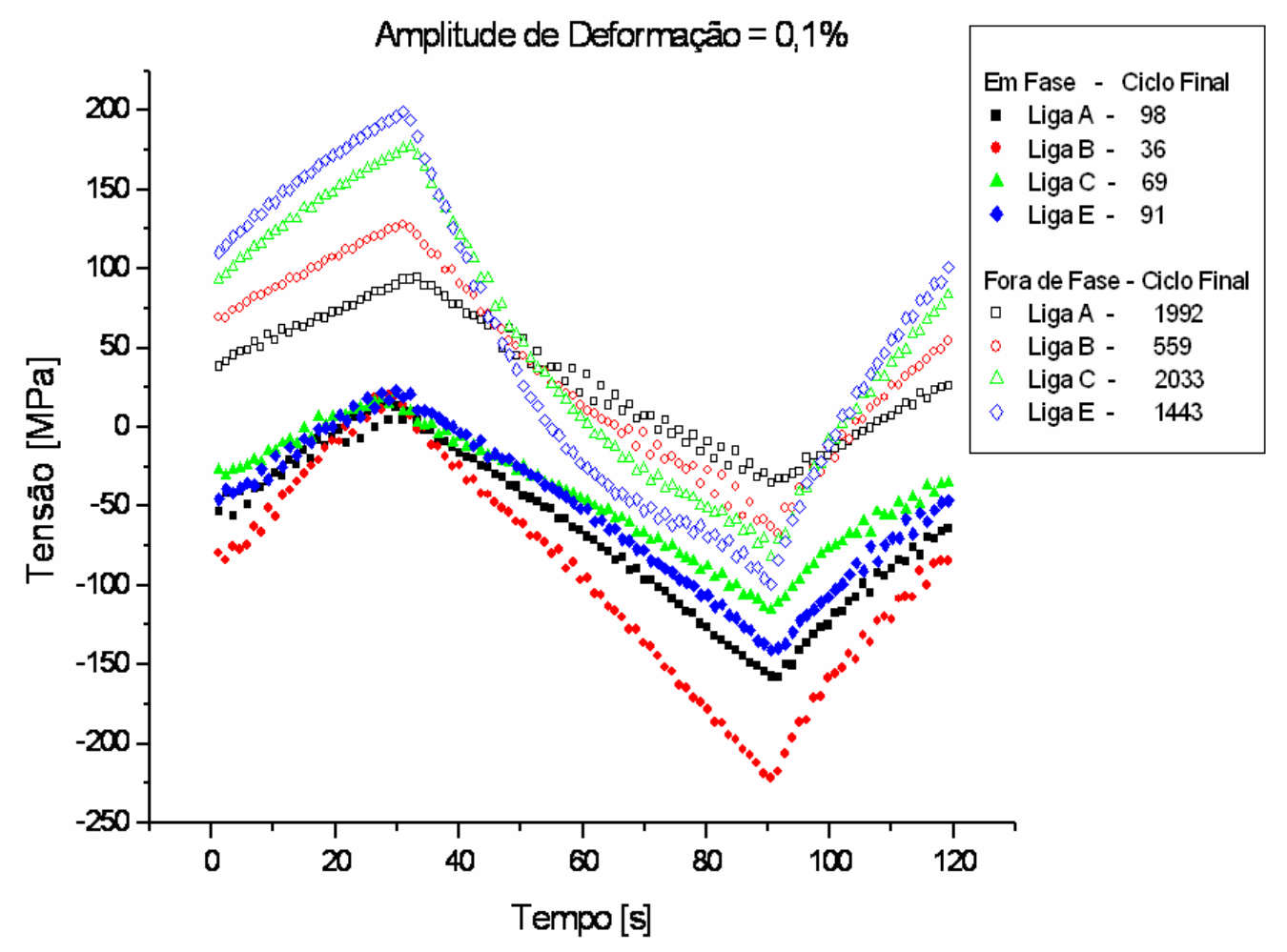

Figura 5.100 - Fadiga termomecânica - em fase e fora de fase. Gráfico comparativo dos níveis de tensão alcançados durante o ciclo final para as ligas A, B, C e E, sob amplitude de deformação mecânica de $0,1 \%$. 


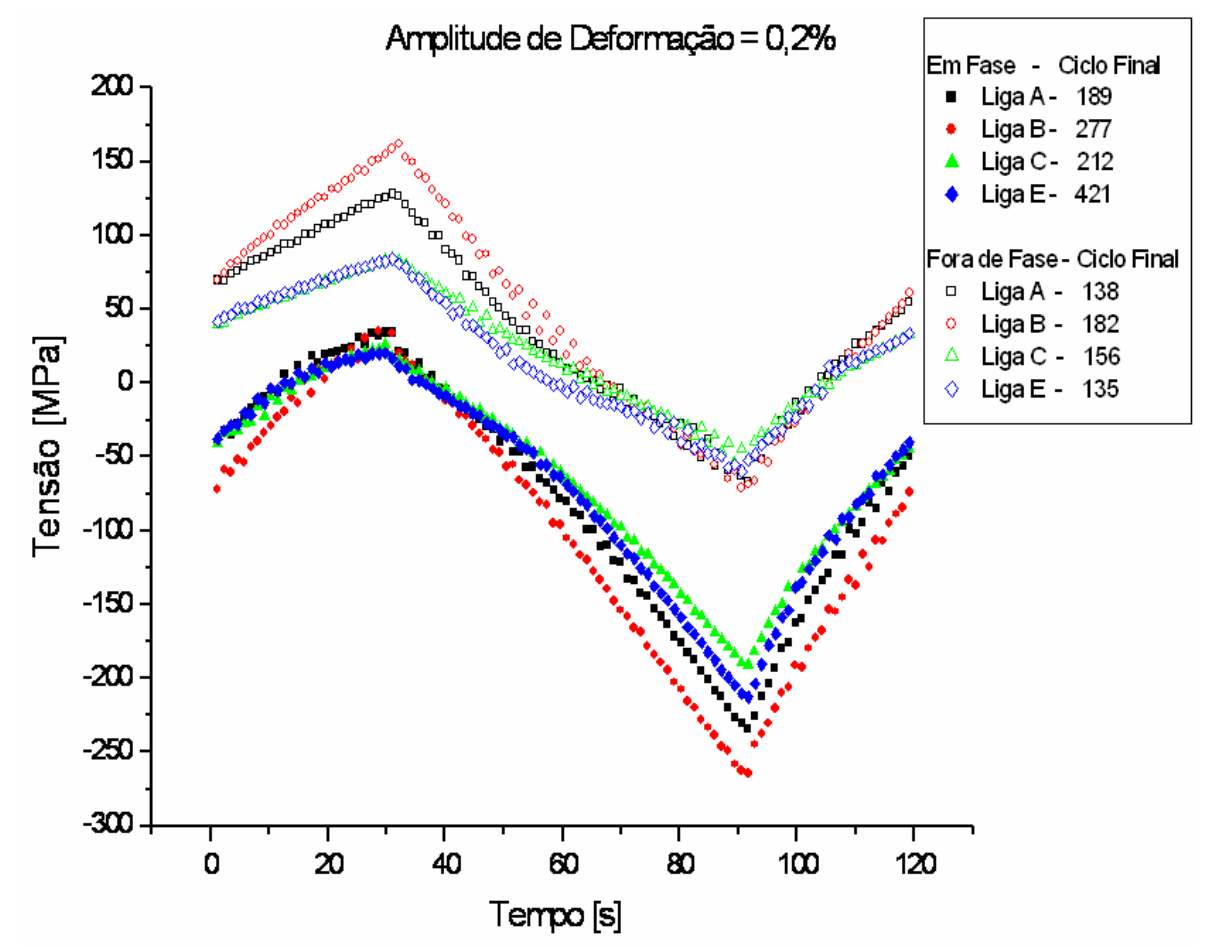

Figura 5.101 - Fadiga termomecânica fora de fase. Gráfico comparativo dos níveis de tensão alcançados durante o ciclo final para as ligas A, B, C e E, sob amplitude de deformação mecânica de $0,2 \%$.

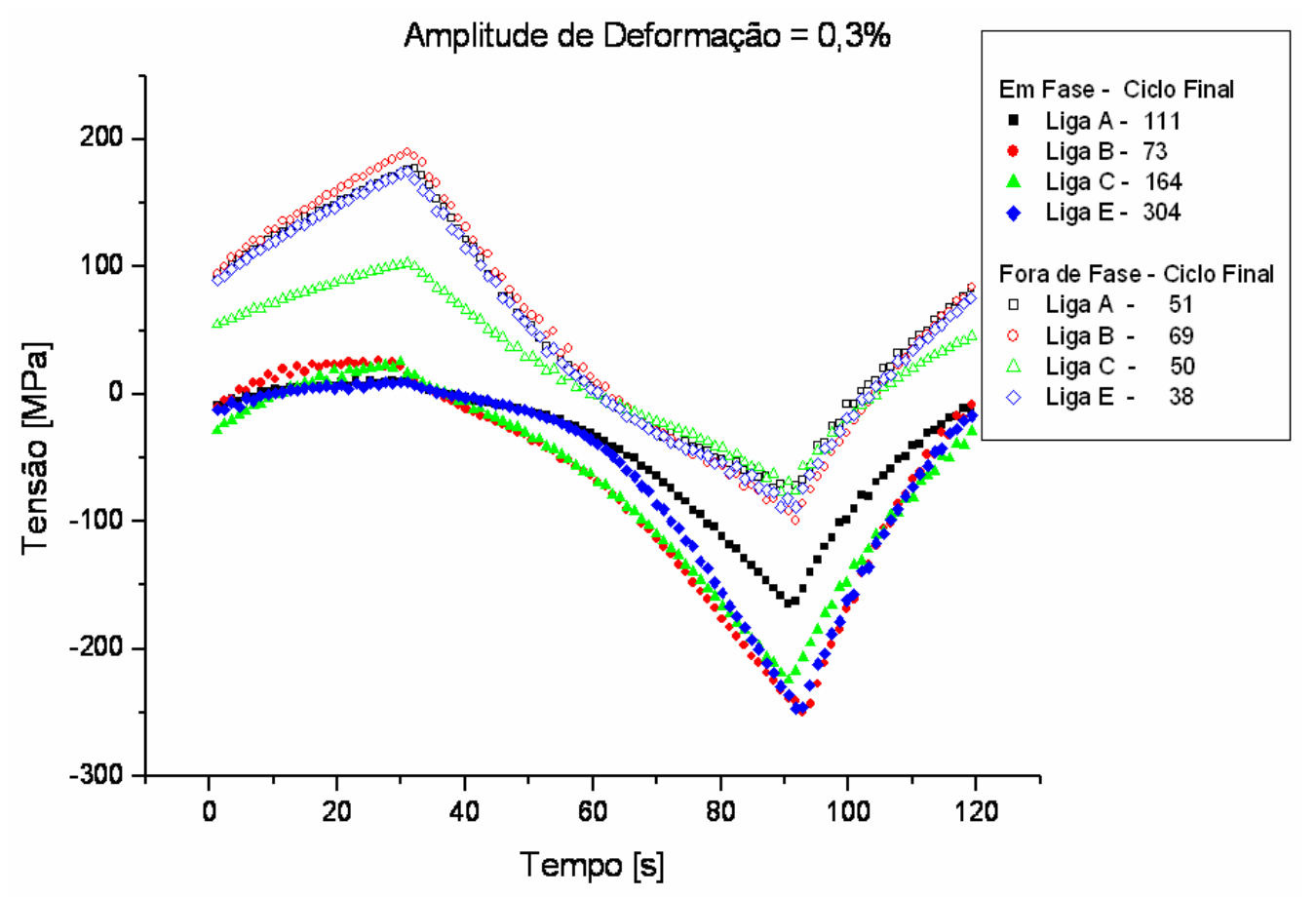

Figura 5.102 - Fadiga termomecânica - em fase e fora de fase. Gráfico comparativo dos níveis de tensão alcançados durante o ciclo final para as ligas A, B, C e E, sob amplitude de deformação mecânica de $0,3 \%$. 


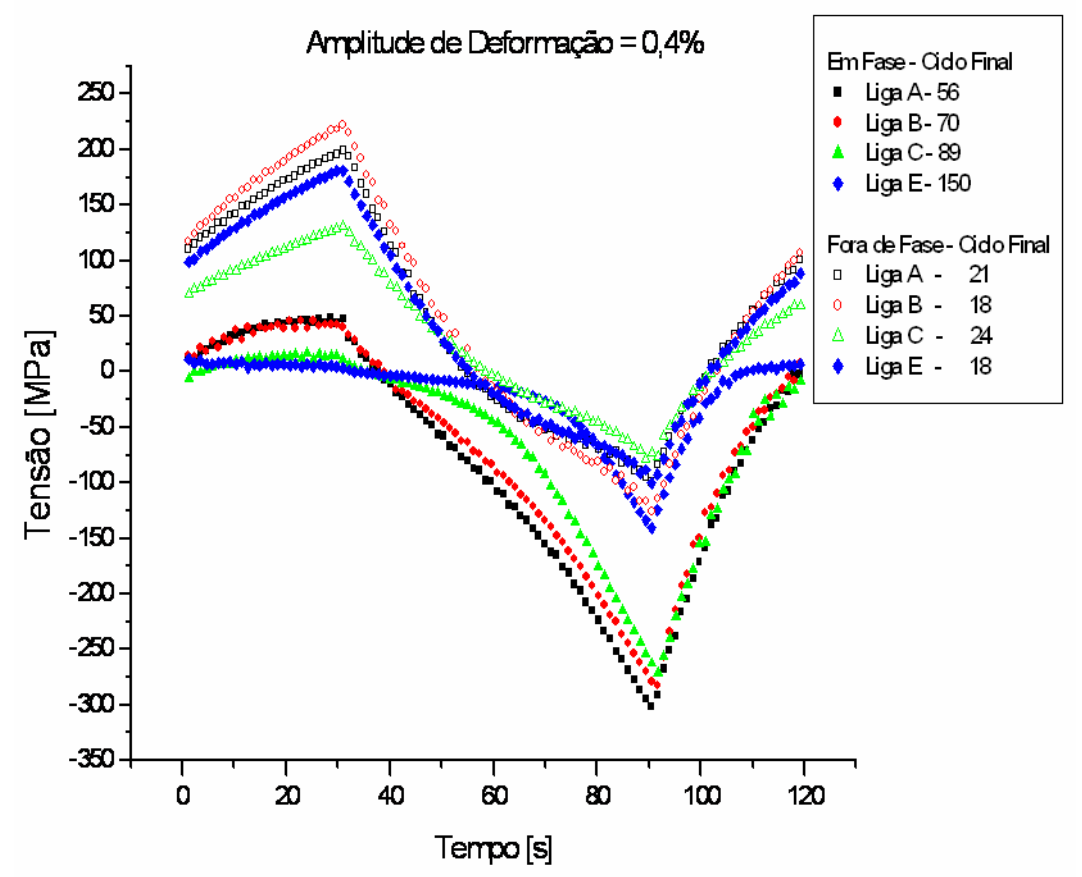

Figura 5.103 - Fadiga termomecânica - em fase e fora de fase. Gráfico comparativo dos níveis de tensão alcançados durante o ciclo final para as ligas A, B, C e E, sob amplitude de deformação mecânica de $0,4 \%$.

Observando-se, agora, o comportamento das ligas na condição em fase, verifica-se que ao contrário da condição fora de fase, as curvas das diversas ligas se aproximam na parte trativa do ciclo e se distanciam na compressiva. O motivo para isto, conforme já foi visto, foi a temperatura na qual as deformações mecânicas foram aplicadas e a participação, quando em fase, da expansão grafítica. A partir disso, na parte compressiva, as ligas se comportaram de maneira diferente em termos das tensões máximas necessárias para alcançar a deformação desejada. Ao contrário da situação fora de fase, aqui as tensões trativas são menores, pois o material, nesta temperatura, é menos resistente. Além disso, conforme já discutido, as condições são propícias para a ocorrência da expansão grafítica.

Nota-se que, fora de fase, para deformações maiores que 0,1\%, a liga $\mathbf{B}$ apresentava, no momento da falha, de maneira geral, maiores tensões tanto trativas quanto compressivas. $\mathrm{Na}$ condição em fase, o comportamento da liga B foi basicamente o mesmo que apresentou fora de fase, apenas as tensões trativas foram comparativamente menores. Este comportamento não significa que sob fadiga termomecânica a liga $\mathbf{B}$ tenha sido a melhor, e sim que este material apresentava maior resistência mecânica no ciclo em que houve a falha, em função de possuir na composição química elementos de liga que aumentaram sua resistência mecânica e a oxidação em altas temperaturas. Pelos valores das tensões 
apresentadas pela liga $\mathbf{C}$, no momento da falha, em comparação com a liga $\mathbf{B}$, pode-se avaliar o forte efeito deletério que o carbono teve sobre a resistência mecânica. As outras ligas praticamente se equivaleram, pois foram, ora uma ora outra, um pouco mais resistentes dependendo da amplitude de deformação desejada e da temperatura do ciclo.

\subsubsection{5 - Efeito da Temperatura}

Para que se pudesse verificar se os ensaios de fadiga isotérmica poderiam ser utilizados, como usualmente se faz, para prever o comportamento em fadiga termomecânica, foram lançadas nos mesmos gráficos de amplitude de deformação em função do número de reversos, as curvas de fadiga isotérmica e de fadiga termomecânica das quatro ligas estudadas. Pode-se observar nos gráficos das Figuras de 5.104, 5.105, 5.106 e 5.107 que as ligas estudadas $\mathbf{A}, \mathbf{B}, \mathbf{C}$ e $\mathbf{E}$, quando submetidas à fadiga isotérmica em qualquer das temperaturas, $27^{\circ} \mathrm{C}, 300^{\circ} \mathrm{C}$ e $600^{\circ} \mathrm{C}$, apresentaram vidas maiores que em fadiga termomecânica fora de fase, revelando um aumento da severidade do ensaio com a variação da temperatura.

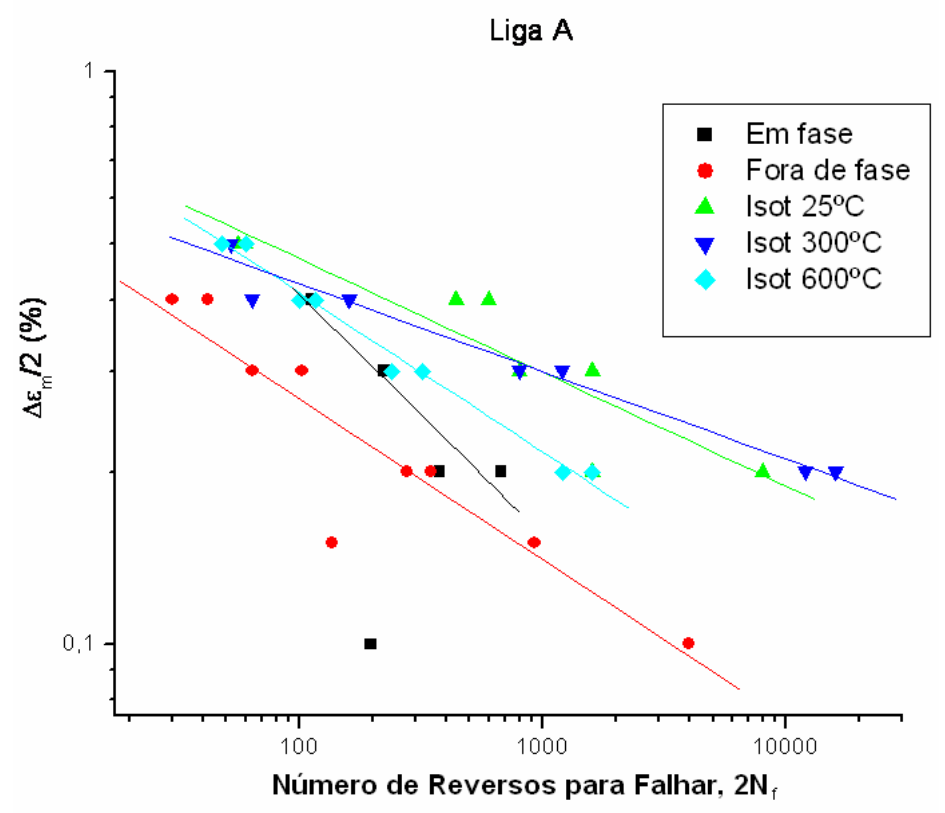

Figura 5.104 - Amplitude de Deformação em função do Número de Reversos para falhar para a liga A. Comparativo entre Fadiga Termomecânica, em fase e fora de fase, e Fadiga Isotérmica em $27^{\circ} \mathrm{C}, 300^{\circ} \mathrm{C}$ e $600^{\circ} \mathrm{C}$. 
Liga B

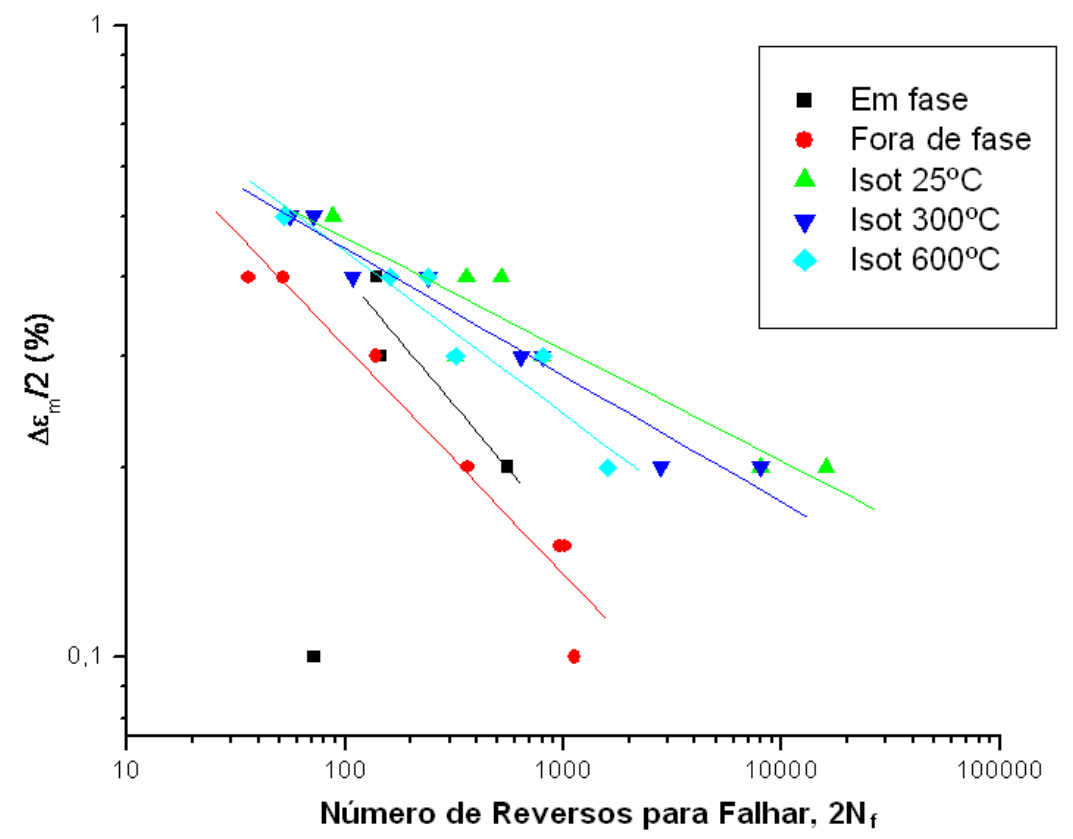

Figura 5.105 - Amplitude Deformação em função do Número de Reversos para falhar para a liga B. Comparativo entre Fadiga Termomecânica, em fase e fora de fase, e Fadiga Isotérmica em $27^{\circ} \mathrm{C}, 300^{\circ} \mathrm{C}$ e $600^{\circ} \mathrm{C}$.

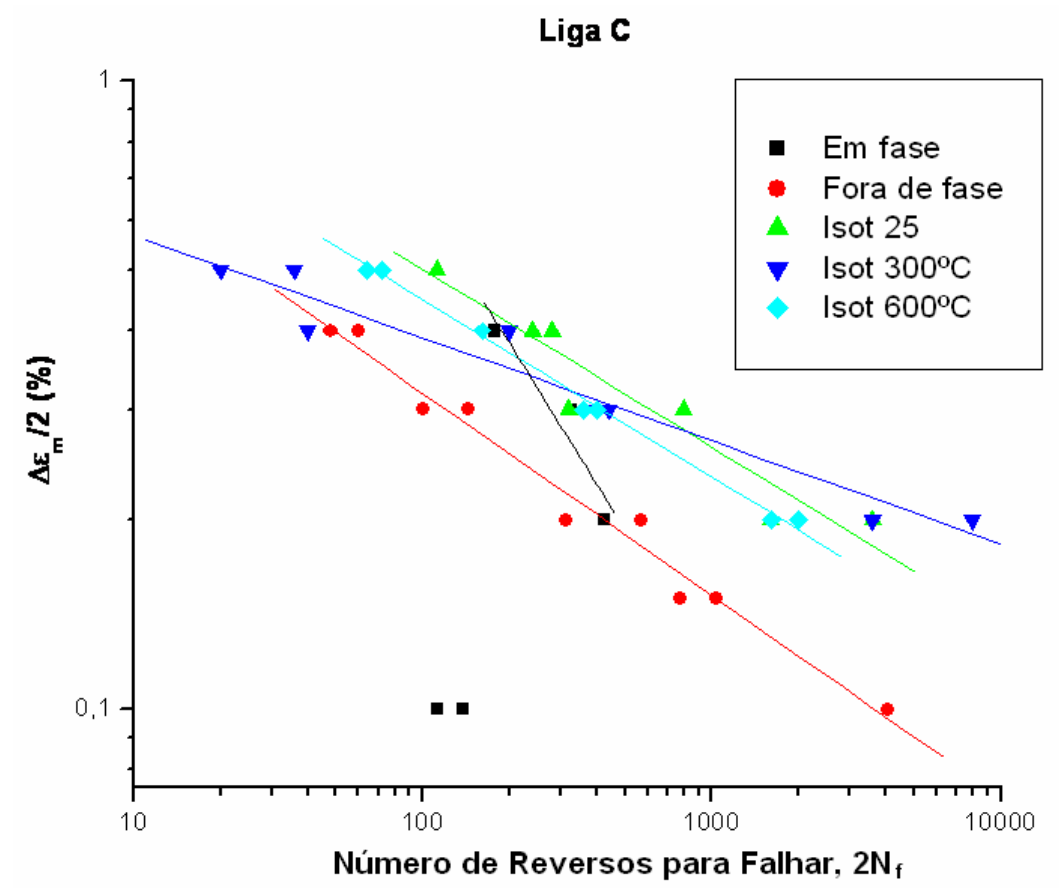

Figura 5.106 - Amplitude Deformação em função do Número de Reversos para falhar para a liga C. Comparativo entre Fadiga Termomecânica, em fase e fora de fase, e Fadiga Isotérmica em $27^{\circ} \mathrm{C}, 300^{\circ} \mathrm{C}$ e $600^{\circ} \mathrm{C}$. 


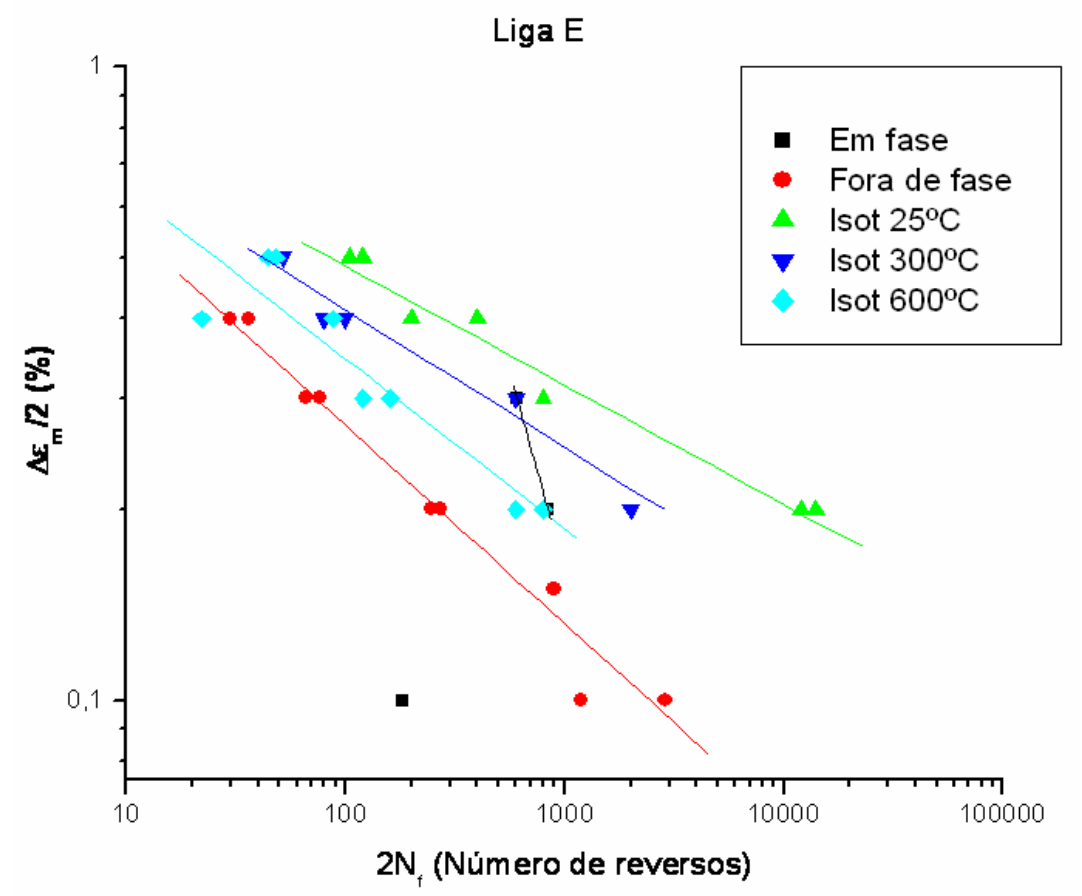

Figura 5.107 - Amplitude Deformação em função do Número de Reversos para falhar para a liga E. Comparativo entre Fadiga Termomecânica, em fase e fora de fase, e Fadiga Isotérmica em $27^{\circ} \mathrm{C}, 300^{\circ} \mathrm{C}$ e $600^{\circ} \mathrm{C}$.

Resumindo, pode-se considerar, com certeza, que a severidade dos ensaios aumenta e, portanto, a vida diminui na seguinte seqüência: fadiga isotérmica a $27^{\circ} \mathrm{C}$, fadiga isotérmica a $300^{\circ} \mathrm{C}$, fadiga isotérmica a $600^{\circ} \mathrm{C}$ e fadiga termomecânica fora de fase. Isto deixa claro que usar ensaios de fadiga isotérmica para prever comportamentos sob fadiga termomecânica não é correto, pelo menos para o material estudado.

A precisão da direção a ser considerada para as curvas de fadiga termomecânica, em fase, principalmente para a liga $\mathbf{E}$, foi prejudicada, pois os resultados para amplitude de deformação mecânica de $0,1 \%$, em função dos resultados anômalos, não foram considerados. Em função deste fato evitou-se analisá-las em termos de severidade. De uma maneira geral, e afora anomalias, quanto menores as deformações mecânicas pré-estabelecidas, maiores as durações dos ensaios de fadiga termomecânica e, então, fenômenos tais como fluência e oxidação têm oportunidade de atuar, reduzindo a vida. 


\subsection{2 - Em componentes (disco de freio)}

Foram ensaiados componentes das ligas de ferro fundido cinzento com composições químicas similares àquelas identificadas pelas letras A, B e E. As Figuras 5.108 e 5.109 mostram os discos de freio que, após terem sido ensaiados em fadiga por, no mínimo 250 ciclos de quatro frenagens, não apresentaram trinca passante na área de trabalho e, portanto, foram aprovados.

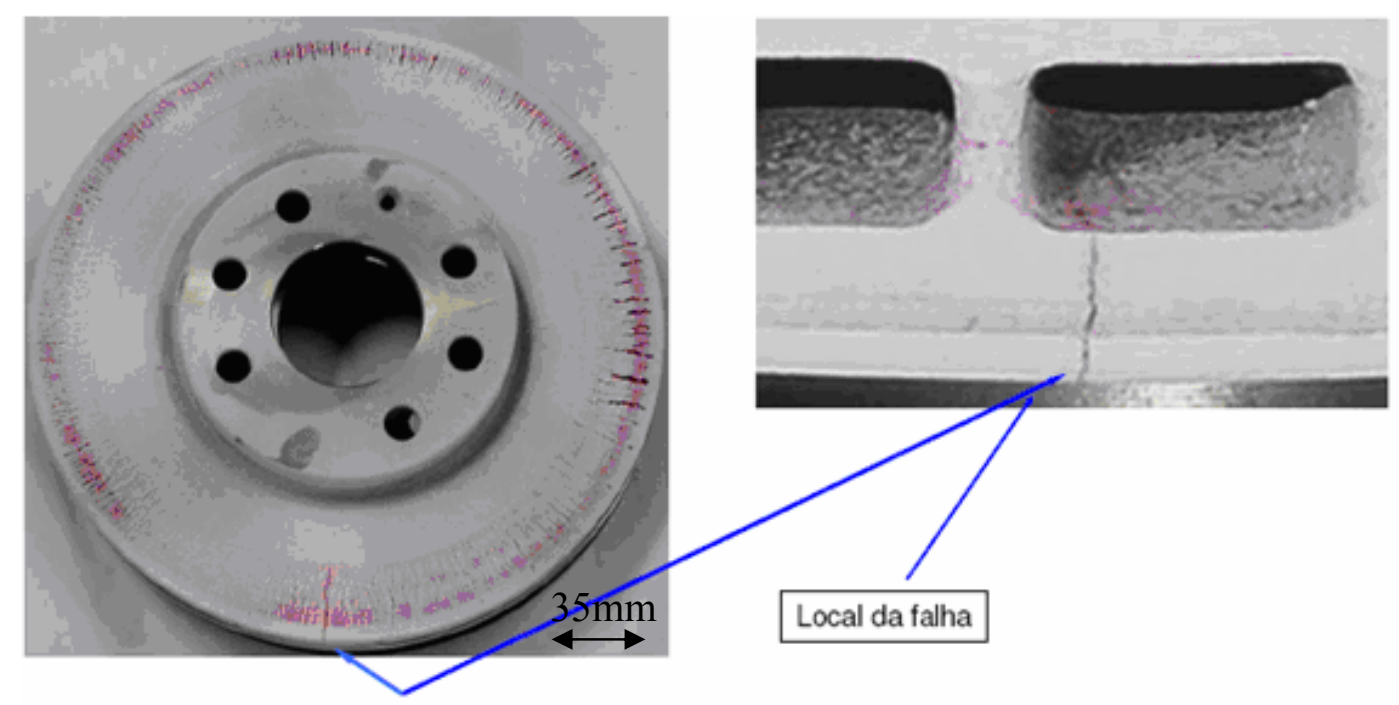

Figura 5.108 - Disco com composição química similar à da liga A após ensaio de fadiga termomecânica e líquidos penetrantes. Falhou após 250 ciclos. Aprovado.

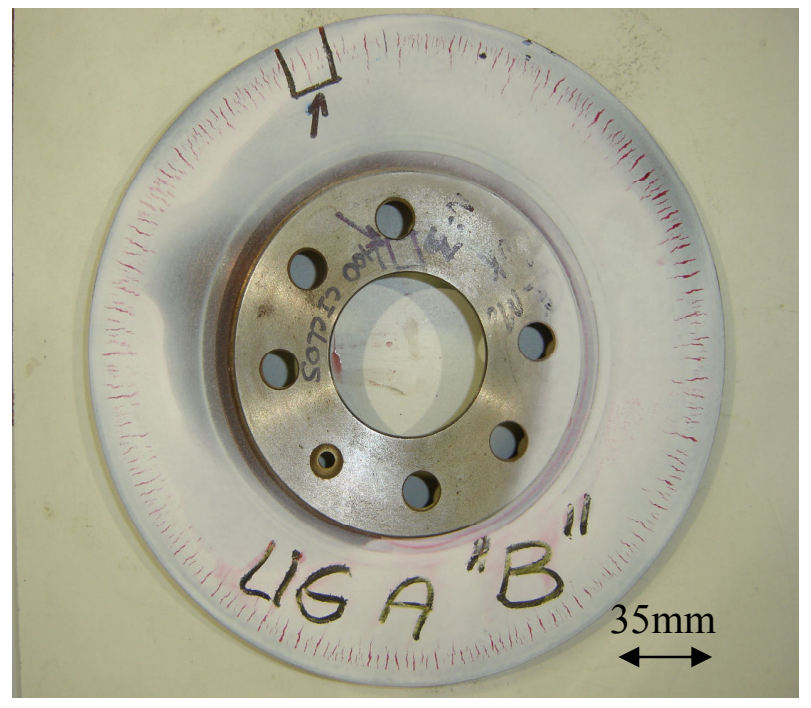

Figura 5.109 - Disco com composição química similar à da liga B após ensaio de fadiga termomecânica e líquidos penetrantes. Não falhou até 400 ciclos. Aprovado. 
Apresentaram, sim, um grande número de trincas por toda a extensão da área útil, mas nenhuma atravessava a espessura de um lado para outro. Para a liga E, como na época havia disponibilidade do equipamento de ensaio, foram realizados dois ensaios. A Figura 5.110 mostra do primeiro disco, uma vista após 160 ciclos, em que não houve trincas proibidas, e outra vista do ciclo número 342 , em que ocorreu uma trinca passante.

\section{DISCO NUM 14 "LIGA "E”}

\section{Após 160 ciclos}

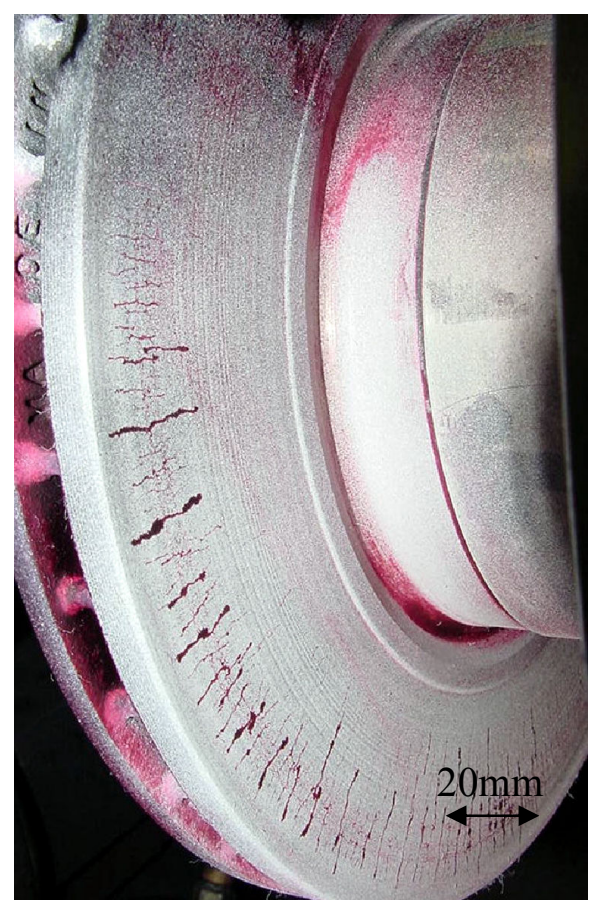

Após 342 ciclos (falha)

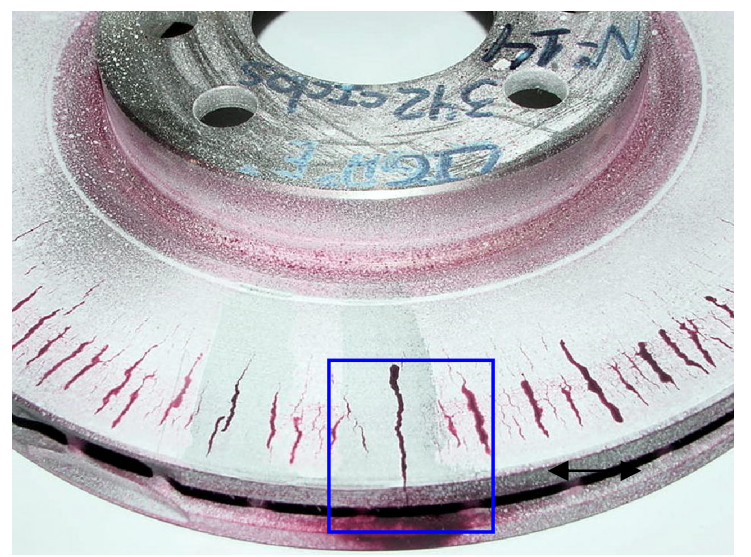

Figura 5.110 - Disco com composição química similar à da liga $\mathrm{E}$ (primeiro ensaio) após ensaio de fadiga termomecânica e líquidos penetrantes. Aprovado. 


\section{5 - Classificação das ligas}

Para facilitar uma visão do comportamento das ligas nos diversos ensaios, optou-se por construir a Tabela 5.18, que classifica os desempenhos. O critério de classificação utilizado foi considerar as ligas tão melhores, em termos de propriedades, quanto menores forem os números a elas atribuídos. Vale salientar que este expediente não tem qualquer valor científico, objetivando apenas facilitar a análise dos resultados. Analisando a Tabela em questão, os ensaios de fadiga termomecânica demonstraram que a liga $\mathbf{E}$ apresentou desempenho muito melhor que as outras, tanto em fase quanto fora de fase, em praticamente todas as deformações consideradas. Apresentou, também, os melhores resultados de difusividade térmica em todas as temperaturas consideradas. Foi considerada a segunda melhor nos ensaios de fadiga termomecânica em componente por ter alcançado 340 ciclos sem trincas passantes, enquanto que a liga $\mathbf{B}$ alcançou 400. No entanto, vale salientar que o componente é considerado aprovado quando supera 240 ciclos sem trincas passantes. Em seguida aparecem pela ordem, com comportamentos muito semelhantes entre si, as ligas $\mathbf{A}, \mathbf{B}$ e C.

O melhor desempenho da liga $\mathbf{E}$ em todos os ensaios deste trabalho, com certeza, se deu em função de a mesma possuir os elementos de liga cromo e cobre, associados a um carbono equivalente relativamente baixo. Comparando-a com a liga $\mathbf{A}$, que, apesar de ter apresentado um desempenho inferior ao da liga $\mathbf{E}$, é a segunda melhor e tem quase que o mesmo carbono equivalente. Percebe-se que o diferencial, como o teor de cromo é semelhante, foi o elemento de liga cobre. Foi uma grande surpresa, pois este elemento é conhecido principalmente como perlitizante e refinador da perlita.

Esperava-se muito do molibdênio, em função de sua característica de melhorar tanto a resistência mecânica quanto a oxidação em altas temperaturas. A expectativa não se concretizou nas ligas estudadas, para os ensaios de fadiga termomecânica em fase e fora de fase, levando a concluir que a adição deste elemento não tem efeitos práticos na melhoria do comportamento de ligas de ferro fundido cinzento submetidas à fadiga anisotérmica. 
Tabela 5.17 - Comparação dos resultados das ligas A, B, C e E segundo o critério de classificação adotado.

\begin{tabular}{|c|c|c|c|c|c|}
\hline & LIGA & $\mathbf{A}$ & B & $\mathbf{C}$ & $\mathbf{E}$ \\
\hline \multirow{3}{*}{$\begin{array}{c}\text { FADIGA } \\
\text { ISOTÉRMICA }\end{array}$} & $25^{\circ} \mathrm{C}$ & 3 & 2 & 4 & 1 \\
\hline & $300^{\circ} \mathrm{C}$ & 2 & 2 & 3 & 1 \\
\hline & $600^{\circ} \mathrm{C}$ & 2 & 1 & 1 & 3 \\
\hline SUBTOTAL 1 & & 7 & 5 & 8 & 5 \\
\hline \multirow{3}{*}{$\begin{array}{c}\text { FTM - FF - C.P } \\
\text { Def x Vida }\end{array}$} & $0,2 \%$ & 1 & 1 & 1 & 1 \\
\hline & $0,3 \%$ & 1 & 1 & 1 & 1 \\
\hline & $0,4 \%$ & 1 & 1 & 1 & 1 \\
\hline \multirow{3}{*}{$\begin{array}{c}\text { FTM - EF - CP } \\
\text { Def x Vida }\end{array}$} & $0,2 \%$ & 3 & 2 & 4 & 1 \\
\hline & $0,3 \%$ & 3 & 4 & 2 & 1 \\
\hline & $0,4 \%$ & 4 & 3 & 2 & 1 \\
\hline FTM - COMPONENTE & & 3 & 1 & - & 2 \\
\hline \multirow{6}{*}{ DIFUSIVIDADE } & $27^{\circ} \mathrm{C}$ & 2 & 3 & 3 & 1 \\
\hline & $85^{\circ} \mathrm{C}$ & 2 & 3 & 3 & 1 \\
\hline & $200^{\circ} \mathrm{C}$ & 2 & 3 & 3 & 1 \\
\hline & $300^{\circ} \mathrm{C}$ & 2 & 3 & 3 & 1 \\
\hline & $450^{\circ} \mathrm{C}$ & 2 & 3 & 3 & 1 \\
\hline & $550^{\circ} \mathrm{C}$ & 2 & 3 & 3 & 1 \\
\hline SUBTOTAL 2 & & 28 & 31 & 29 & 14 \\
\hline TOTAL & & 35 & 36 & 37 & 19 \\
\hline MÉDIA & & 2,06 & 2,12 & 2,18 & 1,12 \\
\hline COLOCAÇÃO & & $2^{a}$ & $3^{a}$ & $4^{a}$ & $1^{\mathrm{a}}$ \\
\hline
\end{tabular}

Como o intuito deste trabalho foi selecionar dentre as diversas ligas de ferro fundido cinzento, usadas pelo mercado, aquela que tivesse o melhor desempenho para o devido fim, ou seja, para a fabricação de discos de freio de veículos automotores, resolveu-se utilizar todos os resultados disponíveis, inclusive aqueles de fadiga isotérmica a $25^{\circ} \mathrm{C}, 300^{\circ} \mathrm{C}$ e $600^{\circ}$ C, de outro estudo (Angeloni, 2005).

Desta maneira, em função de sua boa resposta em praticamente todos os ensaios, a liga E deve ser considerada como a melhor dentre as quatro ligas ensaiadas e recomendada para o 
uso em discos de freio. Em seguida viriam, selecionadas pelo mesmo critério, quase que no mesmo nível as ligas $\mathbf{A}, \mathbf{B}$ e $\mathbf{C}$.

Vale salientar que o uso da liga $\mathbf{E}$ na produção de discos de freio, em substituição a outras que contém o elemento de liga molibdênio, certamente implicará em uma grande economia para as montadoras. 


\section{6 - CONCLUSÕES}

- As análises microestruturais revelaram a veracidade da afirmação de que quanto maior o carbono equivalente maior a percentagem de grafita, independentemente dos elementos de liga presentes.

- Por meio de análise de imagens micrográficas, conseguiu-se observar que, durante os ensaios de fadiga termomecânica em fase, diminuiu a temperatura para a decomposição de parte da fase cementita existente no microconstituinte perlita.

- Ficou claro, para as ligas estudadas, que os ensaios de fadiga isotérmica foram menos críticos que os de fadiga termomecânica fora de fase.

- Considerando todos os ensaios de fadiga realizados, a liga $\mathbf{E}$ demonstrou ser a recomendada para o uso em discos de freio automotivos.

- $\mathrm{O}$ elemento de liga molibdênio presente nas ligas $\mathbf{B}$ e $\mathbf{C}$ não atendeu às expectativas de torná-las mais resistentes a altas temperaturas.

- Ao contrário do cobre, elementos de liga como o molibdênio prejudicam a difusividade.

- As ligas de ferro fundido cinzento estudadas apresentaram resultados de difusividade térmica diferentes apenas em temperaturas abaixo de $400^{\circ} \mathrm{C}$.

- A liga com maior difusividade térmica foi a melhor sob fadiga apesar de não apresentar o maior carbono equivalente. 
- A caracterização apenas da morfologia, tamanho e distribuição da grafita e sua percentagem, considerada indispensável na análise de propriedades mecânicas e físicas de ferros fundidos, não foram suficientes para avaliar o comportamento das ligas sob fadiga. Foi necessário conhecer, também, a composição química base e a presença ou não de elementos de liga, bem como quais deles e em que quantidades.

- A substituição de ligas de ferro fundido cinzento que contém molibdênio pela liga E certamente resultará em uma grande economia para a industria automobilística, pois o custo da carga metálica praticamente será reduzido pela metade. 


\section{7 - SUGESTÕES PARA TRABALHOS FUTUROS}

- Utilizar amplitudes de deformações mecânicas maiores para analisar as ligas sob condições de fadiga termomecânica mais críticas.

- $\quad$ Submeter as ligas a ensaios de desgaste e corrosão para comparar seus desempenhos. 


\section{8 - REFERÊNCIAS BIBLIOGRÁFICAS}

ANDERSON, A. E., "Friction and wear of automotive brakes". Materials Park, OH: ASM Handbook, Vol. 18, 1992.

ANGELONI, M. "Fadiga Isotérmica em Ligas de Ferro Fundido Cinzento para Discos de Freios Automotivos". Dissertação (mestrado em Ciência e Engenharia de Materiais), São Carlos: USP - Universidade de São Paulo, p. 140, 2005.

AMERICAN SOCIETY FOR METALS - ASM. Metals Handbook - Mechanical Testing. 9ed. Ohio, v.8, 1985.

AMERICAN SOCIETY FOR TESTING AND MATERIALS - ASTM, Standard Test Method for Evaluating the Microstructure of Graphite in Iron Castings. Philadelphia, v.01.02, 1998.

ASTM A 476 - 98. AMERICAN SOCIETY FOR TESTING AND MATERIALS - Standard Specification for Ductile Irons Castings for Paper Mill Dryer Rolls. Philadelphia, v.01.02, 1998.

ASTM E 3 - 95. AMERICAN SOCIETY FOR TESTING AND MATERIALS - Standard Practice for Preparation of Metallographic Specimens. Philadelphia, v.03.01, 1995.

ASTM E 466 - 96. AMERICAN SOCIETY FOR TESTING AND MATERIALS - Standard Practice for Conducting Force Controlled Constant Amplitude Axial Fatigue Tests of Metallic Materials. Philadelphia, v.03.01, 1996.

ASTM E 468 - 98. AMERICAN SOCIETY FOR TESTING AND MATERIALS - Standard Practice for Presentation of Constant Amplitude Fatigue Test Results for Metallic Materials. Philadelphia, v.03.01, 1998.

ASTM E 606 - 98. AMERICAN SOCIETY FOR TESTING AND MATERIALS - Standard Practice for Strain-Controlled Fatigue Testing. Philadelphia, v.03.01, 1998. 
ASTM E 739 - 98. AMERICAN SOCIETY FOR TESTING AND MATERIALS - Standard Practice for Statistical Analysis of Linear or Linearized Stress-Life (S-N) and Srain-Life ( $\boldsymbol{\varepsilon}-\mathbf{N})$ Fatigue Data. Philadelphia, v.03.01, 1998.

ASTM C 1113 - 04. AMERICAN SOCIETY FOR TESTING AND MATERIALS Standard Test Method for Thermal Conductivity of Refractories by Hot Wire (Platinum Resistance Thermometer Technique). Philadelphia, v.03.01, 2004.

BAIK, S., RAJ, R. Metallurgical Transactions A (Physical Metallurgy and Materials Science), vol.13A, N.7, p.1207-1214, 1982.

BANNANTINE, J. A., COMER, J. J., HANDROCK, J., “Fundamentals of Metal Fatigue Analysis", Prentice Hall, New Jersey, p. 273, 1990.

BILL, R. C., VERRILLI, M. J., MCGAW, M. A., HALFORD, G. R., "Preliminary Study of Thermomechanical Fatigue of Polycrystalline MAR-M 200”, NASA-TP 2280, 1984.

BOIOCCHI, T., "Technological Differences between Tractors, Trailers and Impact in the Safety and Drivability", in Coloquium Internacional de Freios, 4, Caxias do Sul, p. 23 - 28, 1999.

BREMBO, I., “Manual del Disco Freno”, Capítulo 2, 1997.

BURGESS, C. O., "Influence of Chromium on the Oxidation Resistance of Cast Iron", Proceedings of American Society for Testing Materials, Volume 39, 1939, p.604.

CAI, C., LIAW, P. K., YE, M., YU, J., "Recent Developments in the Thermomechanical Fatigue Life Prediction of Superalloys", JOM-e, V. 51 (4), p. 1 - 19, 1999.

CALLISTER Jr, W. D. “Ciência e Engenharia de Materiais: Uma Introdução". 5 ed., Rio de Janeiro: LTC, 2002. 
CHO, M. H., KIM, S. J., BASCH, R. H., FASH, J. W. E JANG, H., “Tribological study of gray cast iron with automotive brake linings: The effect of rotor microstructure". Tribology International, 36, 2003, 537-545.

COFFIN, L. F., "Fatigue at high temperatures". In: Fatigue at elevated temperatures, Especial Technical Publication, 520, Philadelphia, ASTM, p.5 - 36, 1973.

COFFIN Jr., L.F., "A study of the effects of cyclic thermal stresses on a ductile metal", Transactions of the ASME, ${ }^{\circ}$ 53-A76, p. 931 - 949, 1954.

DIETER, G. E., "Metalurgia Mecânica”, Guanabara Dois, Segunda edição, Rio de Janeiro RJ, 1981.

DRIVER, J. H., "The effect of boundary precipitates on the high temperature fatigue strength of austenitic stainless steels", Metal Science, V. 5, p. 47 - 50, 1971.

DUQUETTE, D. J., "Enviromental effects I - general fatigue resistance and crack nucleation in metals and alloys". In: Fatigue and Microstructure, Metals Park, ASM, p.335 - 369, 1979.

ENGLER-PINTO JR., C. C., RÉZAÏ-ARIA, F., ILSCHNER, B., “Comportamento em fadiga termo-mecânica de superligas à base de níquel", $11^{\circ}$ CBECIMAT - Congresso Brasileiro de Engenharia e Ciência dos Materiais, Águas de São Pedro, 11-14 de dezembro de 1994, p. 167-169, 1994.

ENGLER-PINTO JR, C. C., "Étude de l'endommagement en fatigue thermomécanique de superlliages à base de nickel'. Tese de Doutorado, École Politechinique Fedérale de Lausanne, Lousane, 1996.

ES-SOUNI, M., “Creep behavior and creep microstructures of a high-temperature titanium alloy Ti-5.8-Al-4.0Sn-3.5Zr-0.7Nb-0.35Si-0.06C (Timetal 834) Part I. primary and steadystate creep". Materials Characterization, Vol.46, p.365-379,2001a.

FITZGEORGE, D. E., POPE, J. A., "Transactions of the North East Coast Institution of Engineers and Shipbuilders", Vol. 75, 1959, 284. 
FUCHS, H. O., STEPHENS, R. I., Metal Fatigue in Engineering, Wiley-Interscience, p. 319, 1980.

FUJINO, S., TAIRA, S. "Effect of thermal cycle on low cycle fatigue of steels and grain boundary characteristics". In: Mechanical behavior of materials, Vol.II, p.49 - 58, 1980.

FUJITA, F. E., "Oxidation and dislocation mechanisms in fatigue crack formation. Fracture of Solids". New York, Interscience, p.657-670, 1963.

GUNDLACH, R. B., “Elevated Temperature Properties of Alloyed Gray Irons for Diesel Engine Components", AFS Transactions, Volume 86, 1978, p.55.

HALES, R. S., "Fatigue testing methods at elevated temperatures". In: Fatigue at high temperature. Skelton, R.P. ed. Elsevier, London, 1983.

HETCH, R. L., DINWIDDIE, R. B., PORTER, W. E , WANG, H., SAE Technical Paper Series, 962126, 1996.

HETNARSKI, R. B. "Mechanics and Mathematical Methods - Thermal Stress II", NorthHolland, Oxford, $2^{\text {nd }}$ Series, V. 2, 1991.

IOMBRILLER, S. F. “Análise térmica e dinânica do Sistema de Freio a Disco de Veículos Comerciais Pesados”. Dissertação (doutorado em Engenharia Mecânica), São Carlos: USP Universidade de São Paulo, p. 177, 2002.

JIMBO, Y., MIBE, T., AKIYAMA, K, MATSUI, H., YOSHIDA, M. E OZAWA, A., SAE International, 1990, Vol. 22.

KANDIL, F.A., Potential ambiguity in the determination of the plastic strain range component in LCF testing, International Journal of Fatigue, Vol. 21, p.1013-1018, 1999.

LANGDON, T. G., "Creep at Low Stresses: An Evaluation of Diffusion Creep and HarperDorn Creep as Viable Creep Mechanisms". Metallurgical and Materials Transactions. Vol. 33A. p. 249-259, 2002. 
LEREVANT, G. R., STRANGMAN, T. E., LANGER, B. S., "Parameters Controlling the Thermal Fatigue Properties of Conventionally-Cast and Directionally-Solidified Turbine Alloys", Metallurgy \& Manufacture, p. 285 - 295, 1976.

LIBSCH, T. A., RHEE, S. K., "The effects of compositional variations in heavy truck rotors upon rotor and pad wear". Wear of Materials, 1979; 34:3-350.

LLINSKII, V. A., "The Ability of Cast Iron to Resist the Development of Thermal Fatigue Cracks", Russian Castings Productions, January, 1971, p. 39.

MACKIN, T.J., “Thermal cracking in disc brakes", Engineering Failure Analysis, February 2002, Vol. 9, no. 1, pp. 63-76(14).

MAJUMDAR, S., MAIYA, P. S. "Mechanistic model for time-dependent fatigue". Journal Engineering Materials Technology, p.159, 1980.

MALLET, O., ENGLER-PINTO JR., C. C., RÉZAÏ-ARIA, F., SKELTON, R. P., NIKBIN, K., WEBSTER, G. A. "Influence of material stress-strain characteristics on thermomechanical fatigue analysis of IN100 superalloy. Materials at High Temperatures", Vol. 13, n.1, pp. 47-54, 1995.

MANSON, S. S., "Behavior of materials under conditions of thermal stress" (Technical Report), no 2933, NACA, July 1953.

MANSON, S. S., HALFORD, G. R., SPERA, D. A. "The Role of Creep in High Temperature Low-Cycle Fatigue", In: Advances in Creep Design, A. I. Smith and A. M. Nicolson (Eds) (Halstered Press, 1971) Ch. 12, p. 229 - 249, 1971.

MAZUR, Z., LUNA-RAMÍZES, A., JUÁREZ-ISLAS, J. A., CAMPOS-AMEZCUA, A. "Failures Analysis of a Gas Turbine Blade made of Inconel 738 LC Alloy", Engineering Failures Analysis, Elsevier, V. 12, p. 474 - 486, 2005.

METZLER, H., "The brake rotor-friction partner of brake linings", SAE Technical Papers, $1990 ; 900847$. 
MEYER-OLBERSLEBEN, F., ENGLER-PINTO, Jr., C. C., RÉZAÏ-ARIA, F. “On thermal fatigue of nickel-based superalloys". In: Thermomechanical Fatigue Behavior of Materials, ASTM STP 1263. Philadelphia, V. 2, Verrilli, M.J and Castelli, M.G., ASTM, 1995.

MILAN, M., MALUF, O., SPINELli, D., BOSE FILHO, W. W., "Metais - Uma visão objetiva", São Carlos, Brasil, 2004.

MIN, B. K., RAJ, R. “A mechanism for intergranular fracture during high temperature fatigue". In: FATIGUE MECHANISMS, STP 675, Philadelphia. ASTM, p.569 - 591, 1979. OKAMOTO, T., KAGAWA, A., KAMEI, K., MATSUMOTO, H., “Effects of graphite shape on thermal conductivity, electrical resistivity, damping capacity and Young's Modulus of cast iron below 500 deg. C'. Journal of the Japanese Foundrymen's Society, 1983; 55:32-6.

OMEROD, J., TAYLOR, R. E., EDWARDS, R. J., “Met. Tech. Abril, (1978) 109.

PALMER, K. B., BCIRA, J., 8 (540) (1960) 266.

RAU, C. A., GEMMA, A. E., LEVERANT, G. R. "Thermal-Mechanical Fatigue Crack Propagation in Nickel and Cobalt-Base Superalloy under Various Strain-Temperature Cycles", Fatigue at Elevated Temperature, ASTM STP 520, p. 166 - 178, 1973.

RHEE, K., TURAK, J.L., SPURGEON, W.M., “An inertial dynamometer evaluation of three alloys for automotive brake drums", SAE Technical Papers, 1970; 700138.

RHEE, S.K., DUCHARME, R.T., SPURGEON, W.M., “Characterization of cast iron friction surfaces", SAE Technical Papers, 1972; 720056.

RHEE. S.K., THESIER, P.A., "Effects of surface roughness of brake drum on coefficient of friction and lining wear", SAE Technical Papers, 1972; 720449.

RIEDEL HERMANN. "Fracture at high temperatures". Berlin; New York: SpringerVerlag, 1987. 
ROEHRIG, K., “Thermal Fatigue of Gray and Ductile Irons", AFS Transactions, Volume 86, 1978, p.75.

ROSTOKER, W. "Thermal Fatigue Resistance of Gray Cast Iron", Journal of Metals, Volume 4, N.o 4, December, 1969, p. 909.

SAKAMOTO, H., et al., "Heavy-duty brake disk for high speed trains(in Japanese with English summary)". Technical Report of Sumitomo Metal Industries, Ltd., Vol. 45, No. 6, pp. $11-29$ (1993).

SARABANDA, J.V.L. "Estudo de fadiga sob controle de deformação de duas ligas de alumínio empregadas em pistões de motores diesel". Dissertação de Mestrado, Escola Politécnica - USP, São Paulo, 1991.

SECO, F. J.; IRISARRI, A. M. “Creep failure mechanisms of a Ti-6Al-4V thick plate”. p. 741-750, 2001.

SEHITOGLU, H. "Thermal and thermomechanical fatigue of structural alloys". In: ASM HANDBOOK - Fatigue and Fracture. Ohio, V.9, 1996.

SHI, H-J., KORN, C., PLUVINAGE, G., "High Temperature Isothermal and Thermomechanical Fatigue on a Molybdenum-Based Alloy", Materials Science and Engineering, A247, p. 180 - 186, 1998.

SKELTON, R.P. "Crack initiation and growth in simple metal components during thermal cicling”. In: Fatigue at High Temperature, SKELTON, R.P., Elsevier, London., 1983.

SOUZA, S.A. "Ensaios Mecânicos de Materiais Metálicos: Fundamentos Teóricos e Práticos". 5ํe․ edão Paulo: Edgar Blucher, 1982.

SRINIVASAN, V.S., VALSAN, M., RAO, B. S., MANNAN, S.L., RAJ, B. “Low Cycle Fatigue and Creep-Fatigue Interaction Behavior of 316L(N) Stainless and Life Prediction by Artificial Neural Network Approach", International Journal of Fatigue, V. 25, p. 1327 1338, 2003.

SURESH, S., “Fatigue of Materials”. Cambridge University Press. Cambridge, 1998. 
VASUDEVAN, A. K., DOHERT, R. "Grain boundary ductile fracture in precipitation hardened aluminum alloys". Acta Metallurgica, V. 35, p.1193 - 1219, 1987.

WAREING, J., "Mechanisms of high temperature fatigue and creep-fatigue failure in engineering materials". In: Fatigue at high temperature, Skelton, R.P. ed. Elsevier, London, 1983.

WEINTRAUB, M., “Brake additives consultant”, Private Communication, 1998.

WELLS, C. H., "High-temperature fatigue". In: Fatigue and microstructure. Metals Park, ASM, p.307 - 331, 1979.

WYCLIFFE, P., "Friction and wear of Duralcan reinforced aluminum composites in automotive braking systems", SAE Technical Papers, 1993; 930187.

J.YAMABE et al., "Development of Disc Brake Rotors for Trucks with High Thermal Fatigue Strength", SAE of Japan, June, 2001, p. 105-112.

YAMABE, J., TAKAGI, M., MATSUI, T., KIMURA, T. E SASAKI, M., “Development for disc brake rotors for trucks with high thermal fatigue strength", JSAE Review, 23, 2002, pp.105-112.

YAMADA, S. E KURIKUMA, T., Paper F98T683, "Proceedings form 1998 FISITA World Automotive Congress", Paris, September-October, 1998.

ZHANG, Y., CHEN, Y., HE, R. E SHEN, B., “Investigation of tribological properties of brake shoe materials-phosphorous cast irons with different graphite morphologies". Wear, 1993, 166:179-86. 
ANEXOS 


\section{ANEXO I}

TÓPICOS MAIS UTILIZADOS

DA DISSERTAÇÃO DE MESTRADO DE MAURÍCIO ANGELONI 
O estudo do comportamento mecânico em fadiga a altas temperaturas de sete ligas de ferro fundido cinzento, sendo quatro fornecidas pela General Motors do Brasil, através das empresas TRW, Teksid e Luk (ligas A, B, C e D), e as outras três (ligas E, F e G), que não são utilizadas pela GMB, mas estão no mercado nacional, de maneira a englobar todas as ligas utilizadas no mercado, foram submetidas à ensaios de tração, impacto e fadiga isotérmica de baixo ciclo às temperaturas de $25^{\circ} \mathrm{C}, 300^{\circ} \mathrm{C}$ e $600^{\circ} \mathrm{C}$, com o objetivo principal de avaliar a influência da composição química no comportamento mecânico do material nas temperaturas estudadas.

Então, após a caracterização das sete ligas estudadas, e comparando-se seus resultados de comportamento mecânico, as quatro ligas que apresentaram os resultados mais promissores, levando em conta o custo/benefício, foram submetidas a ensaios de fadiga termomecânica de baixo ciclo.

Na Tabela AI.1 estão apresentados os valores de dureza médios e os respectivos desvio padrão, obtidos dos valores medidos em cinco pontos distintos dos corpos de prova submetidos a ensaios de impacto para cada uma das sete ligas estudadas. Observa-se que quanto maior o carbono equivalente no ferro fundido cinzento, menor é a dureza do material, dado que a grafita é mais mole do que a matriz perlítica. Por outro lado, pode-se observar o efeito de endurecimento por solução sólida e precipitação de carboneto devido principalmente ao elemento $\mathrm{Cr}$, que é maior nas liga $\mathrm{B}$ e $\mathrm{E}$.

Tabela AI.1 - Média das medições de dureza [Angeloni, 2005]

\begin{tabular}{|c|c|c|c|c|c|c|c|}
\hline Liga Metálica & $\begin{array}{c}\text { A } \\
\text { Luk }\end{array}$ & $\begin{array}{c}\text { B } \\
\text { Teksid }\end{array}$ & $\begin{array}{c}\text { C } \\
\text { Teksid }\end{array}$ & $\begin{array}{c}\text { D } \\
\text { TRW }\end{array}$ & $\begin{array}{c}\text { E } \\
\text { TRW }\end{array}$ & $\begin{array}{c}\text { F } \\
\text { TRW }\end{array}$ & $\begin{array}{c}\text { G } \\
\text { TRW }\end{array}$ \\
\hline Dureza (HB) & 203,44 & 222,36 & 184,28 & 137,37 & 206,0 & 189,03 & 197,52 \\
\hline Desvio Padrão & 2,49 & 6,60 & 5,45 & 4,63 & 1,53 & 3,37 & 2,88 \\
\hline
\end{tabular}




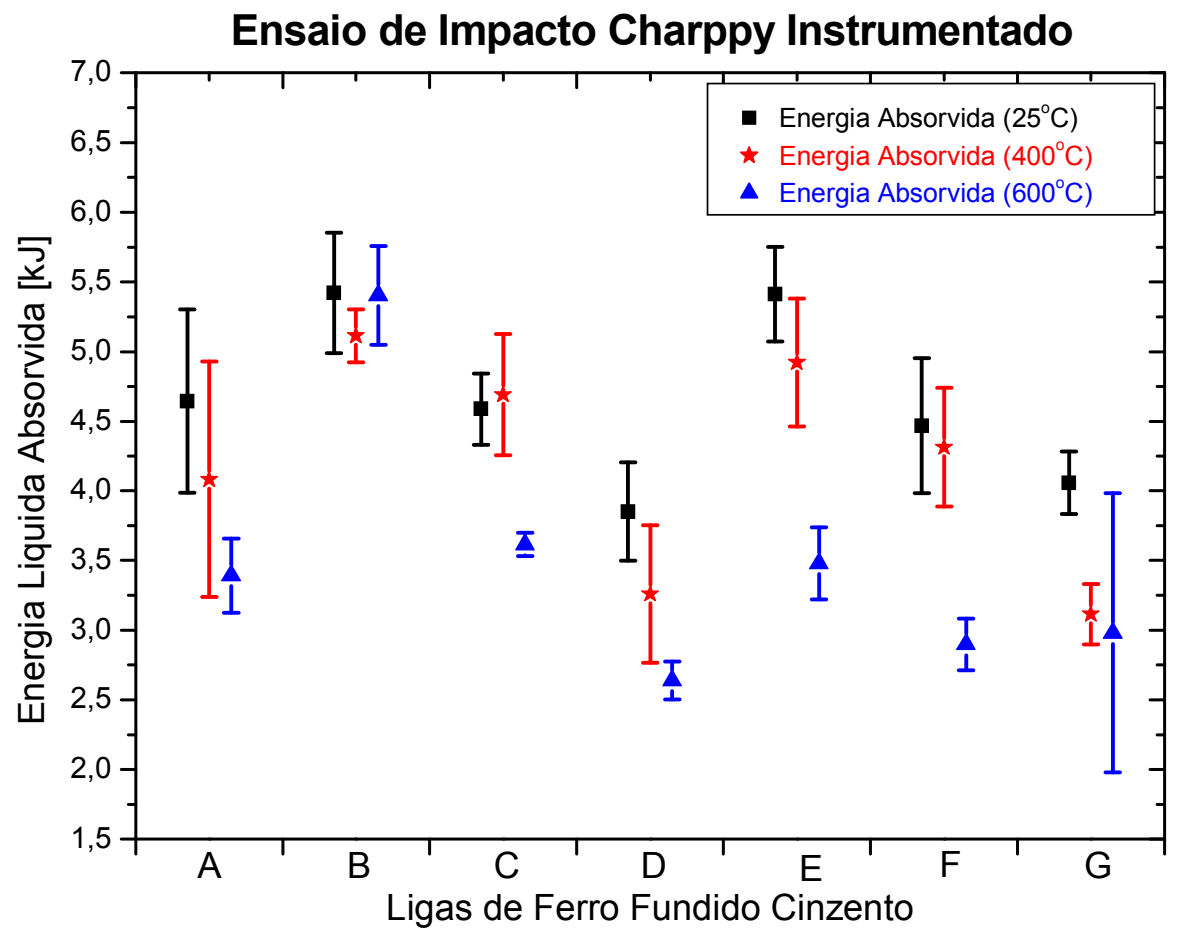

Figura AI.1 - Gráfico comparativo de Impacto das sete ligas de ferro fundido cinzento [Angeloni, 2005].

Na Figura AI.1 estão os dados referentes aos resultados dos ensaios de impacto para as sete ligas nas temperaturas de $25^{\circ} \mathrm{C}, 400^{\circ} \mathrm{C}$ e $600^{\circ} \mathrm{C}$. De modo geral, para uma mesma temperatura de ensaio, quanto maior o $\mathrm{CE}$, menor a tenacidade ao impacto (liga D). Isto se explica pelo fato de ferros fundidos de menor CE apresentarem tamanhos de veios menores, as quais se comportam como defeitos que facilitam a propagação das trincas e, então, quanto menores os veios (defeitos), maior a resistência mecânica do material. Em materiais de comportamento totalmente frágil submetidos a ensaios de impacto, a maior absorção de energia ocorrerá para os materiais de maior resistência mecânica. Para valores similares de $\mathrm{CE}$, observa-se que a presença do $\mathrm{Cr}$ melhorou as propriedades de impacto a temperatura ambiente e a $400^{\circ} \mathrm{C}$ (ligas B e E). A presença do Mo melhora acentuadamente as propriedades de impacto a $600^{\circ} \mathrm{C}$, mas quando o CE é elevado seu efeito é reduzido (liga C).

Nas Figuras AI.2, AI.3 e AI.4 são apresentados os gráficos das curvas de tensãodeformação das sete ligas estudadas neste projeto para as temperaturas de $25^{\circ} \mathrm{C}, 300^{\circ} \mathrm{C}$ e $600^{\circ} \mathrm{C}$. Observa-se que há uma queda na tensão com o aumento de temperatura para todas as ligas. Esta diminuição no valor da tensão é menos acentuada nas ligas B e C, que contém altos teores de molibdênio. No entanto, o comportamento da liga $\mathrm{A}$, que não contém o elemento, é similar, o que pode ser explicado pelo carbono equivalente comparativamente mais baixo. 


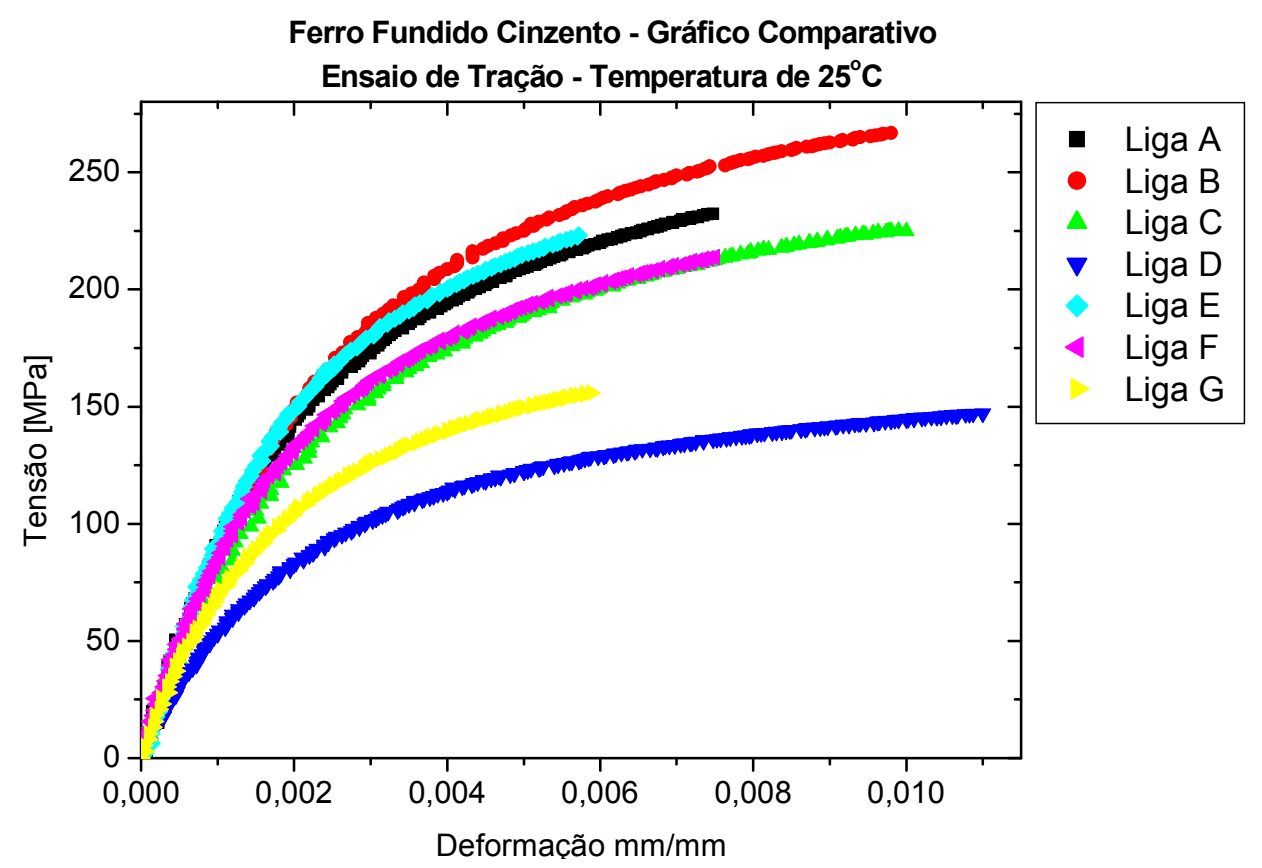

Figura AI.2 - Gráfico Comparativo dos Ensaios de Tração a $25^{\circ} \mathrm{C}$ [Angelloni, 2005].

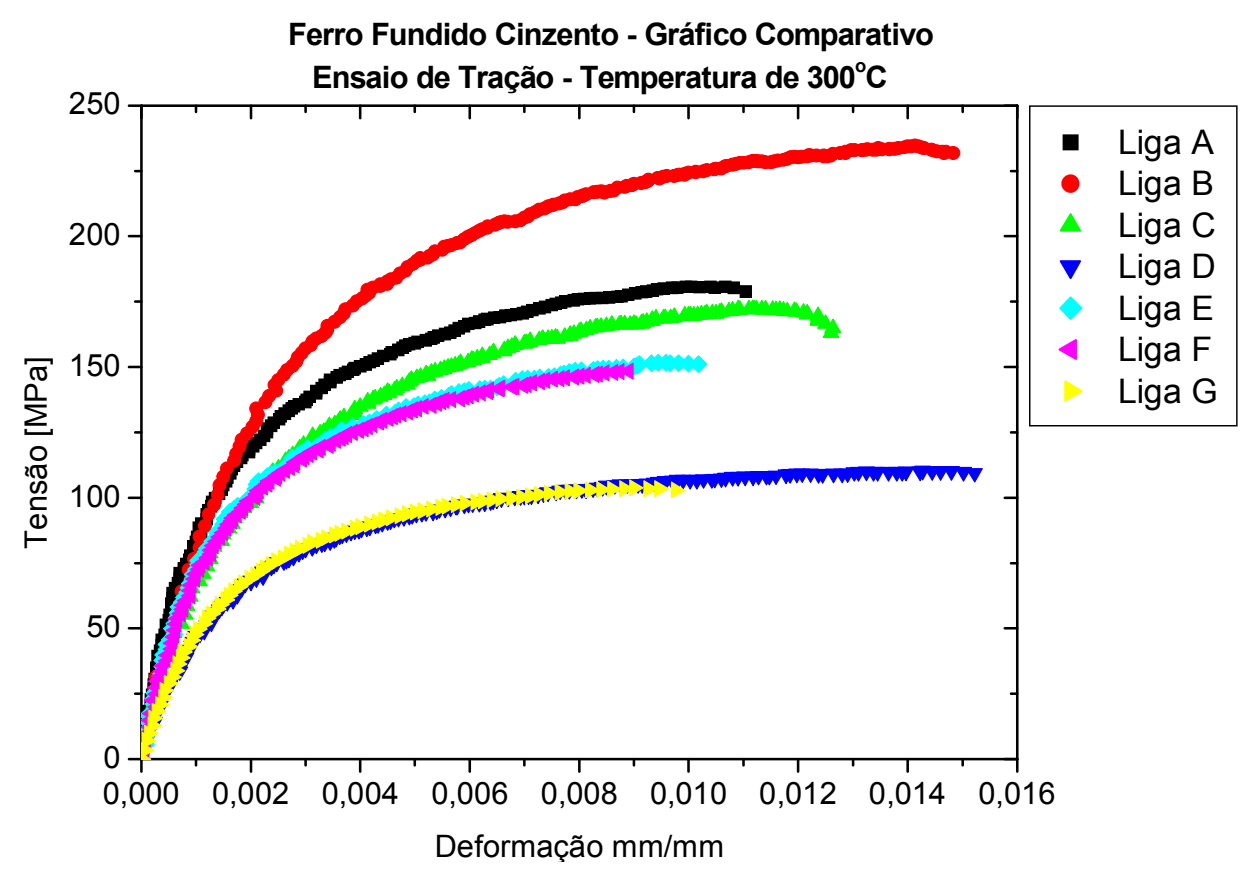

Figura AI.3 Gráfico Comparativo dos Ensaios de Tração a 300 C [Angelloni, 2005]. 


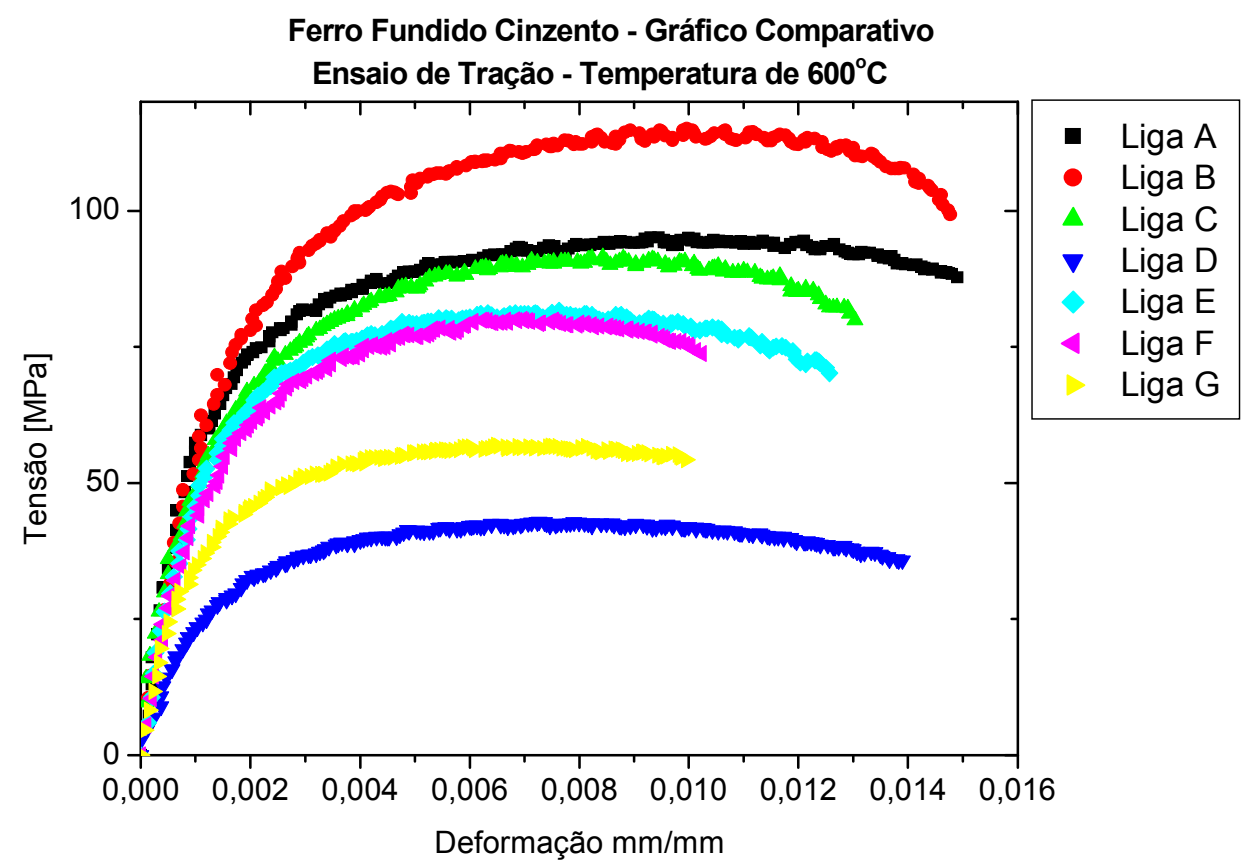

Figura AI.4 Gráfico Comparativo dos Ensaios de Tração a $600^{\circ} \mathrm{C}$ [Angelloni, 2005].

Observa-se que com relação aos ensaios de tração as ligas são formadas basicamente por três grupos, independente da temperatura. O primeiro grupo formado pela liga $\mathrm{B}(\mathrm{Cr}, \mathrm{Mo}$ e baixo $\mathrm{CE}$ ) apresenta o mais alto nível de resistência. O segundo grupo formado pelas ligas $\mathrm{A}$, C, E e F apresentam níveis de resistência intermediários. A liga A apesar de possuir somente uma adição moderada de $\mathrm{Cr}$, apresenta o mais baixo $\mathrm{CE}$. A liga $\mathrm{C}$ possui adições de $\mathrm{Cr}$, Mo e $\mathrm{Cu}$, mas alto $\mathrm{CE}$ o que contrapõe a melhoria por solução sólida. As ligas E e F possuem um baixo $\mathrm{CE}$ e alto teor de $\mathrm{Cu}$. $\mathrm{O}$ terceiro grupo formado pelas ligas $\mathrm{G}$ e $\mathrm{D}$ que possuem apenas $\mathrm{Cu}$ e alto CE [Angeloni, 2005].

Assim pode-se concluir que a adição de $\mathrm{Cr}$ e Mo associada a um baixo CE fornece as melhores propriedades mecânicas, enquanto que alto $\mathrm{CE}$ associado a um alto teor de $\mathrm{Cu}$ resulta em baixa resistência mecânica [Angelloni, 2005].

A Figura AI.5 ilustra o gráfico da variação da tensão de escoamento influenciada pelo CE e pelo aumento da temperatura nas ligas de ferro fundido. Observa-se que com o aumento da temperatura a tensão de escoamento diminui para todas as ligas. Já com o aumento do carbono equivalente nota-se uma diminuição generalizada da $\sigma_{\mathrm{E}}$, exclusive para as ligas $\mathrm{B}, \mathrm{C}$ e E que, sob influência dos elementos de liga $\mathrm{Mo}, \mathrm{Cr}$ e $\mathrm{Cu}$, tiveram seus resultados mascarados. 


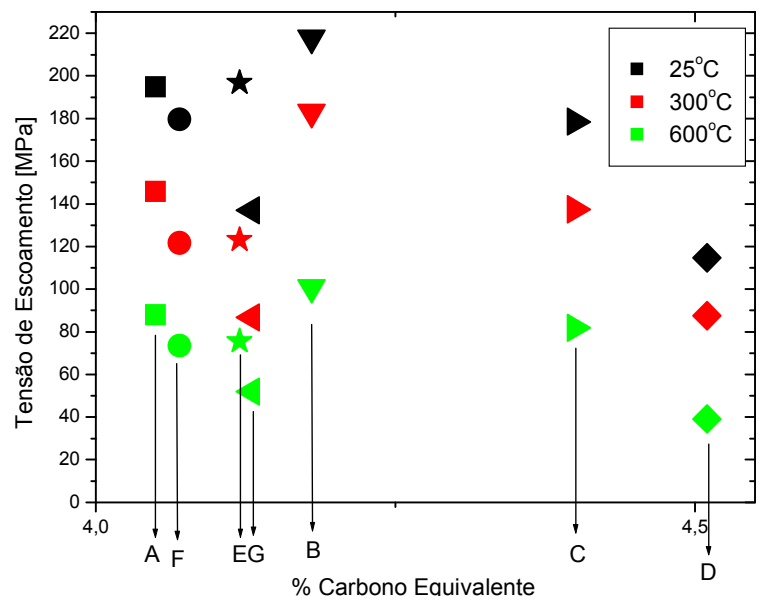

Figura AI.5 - Gráfico comparativo de $\sigma_{\mathrm{E}}$ versus CE das sete ligas de ferro fundido cinzento para as três temperaturas [Angeloni, 2005].

Analisando a influência do carbono equivalente nas propriedades do material, pode-se observar na Figura AI.6 que, como ambas as ligas possuem praticamente a mesma quantidade de carbono equivalente $\left(\mathrm{CE}_{\mathrm{F}}=0,02+\mathrm{CE}_{\mathrm{A}}\right)$, o comportamento delas em fadiga é semelhante à temperatura ambiente. No entanto, para a temperatura de $600^{\circ} \mathrm{C}$, a liga A tem uma queda menos acentuada na amplitude de tensão do que a liga $F$, sugerindo que em altas temperaturas, mesmo uma pequena diferença no $\mathrm{CE}$ pode ser significativa. Esta tendência aumenta com o aumento na quantidade de CE [Angeloni, 2005]. Então, quanto maior o carbono equivalente, melhor a condutividade térmica do material e pior a resistência mecânica da liga. Para temperaturas de até $300^{\circ} \mathrm{C}$ pequenas diferenças no $\mathrm{CE}$ não afetaram, de maneira significativa, o comportamento em fadiga [Angeloni, 2005].

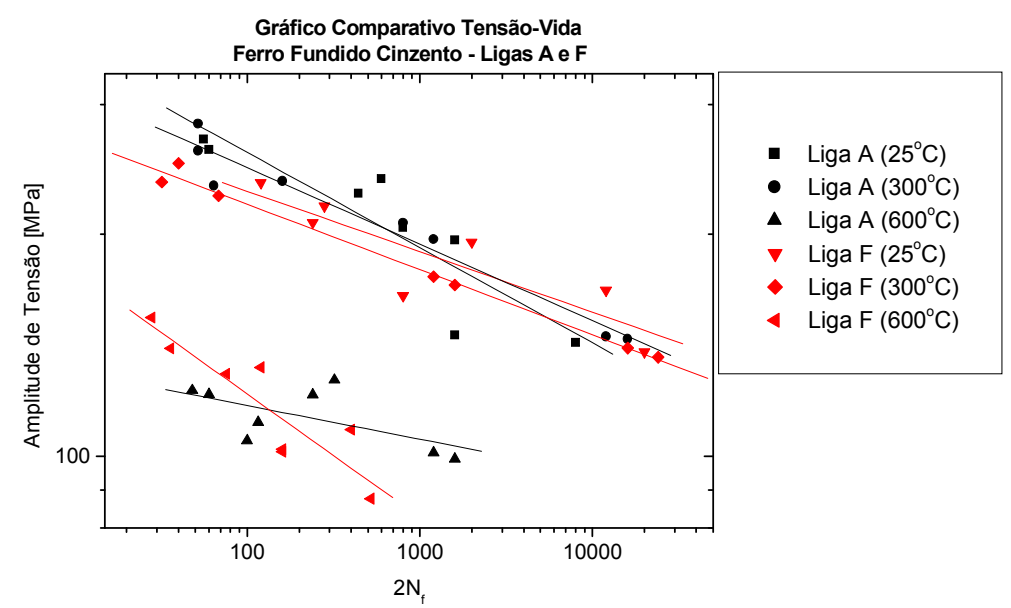

Figura AI.6 - Gráfico Comparativo da Amplitude de Tensão - Vida para as Ligas A e F 
A Tabela AI.2 apresenta um resumo das propriedades mecânicas das sete ligas de ferro fundido cinzento nas temperaturas de $25^{\circ} \mathrm{C}, 300^{\circ} \mathrm{C}$ e $600^{\circ} \mathrm{C}$.

Tabela AI.2 - Propriedades mecânicas das sete ligas de ferro fundido cinzento, nas temperaturas de $25^{\circ} \mathrm{C}, 300^{\circ} \mathrm{C}$ e $600^{\circ} \mathrm{C}$ [Angeloni, 2005].

\begin{tabular}{|c|c|c|c|c|c|}
\hline Ligas & Temperaturas & E (GPa) & $\sigma_{E}(\mathbf{M P a})$ & $\sigma_{\mathrm{R}}(\mathrm{MPa})$ & $\begin{array}{c}\text { Deformação } \\
\text { Total } \\
(\mathbf{m m} / \mathbf{m m})\end{array}$ \\
\hline \multirow{3}{*}{$\mathbf{A}$} & $25^{\circ} \mathrm{C}$ & 129,20 & 194,86 & 232,27 & 0,0074 \\
\hline & $300^{\circ} \mathrm{C}$ & 106,90 & 106,90 & 178,78 & 0,0110 \\
\hline & $600^{\circ} \mathrm{C}$ & 65,27 & 65,27 & 87,69 & 0,0149 \\
\hline \multirow{3}{*}{ B } & $25^{\circ} \mathrm{C}$ & 88,88 & 217,70 & 266,83 & 0,0098 \\
\hline & $300^{\circ} \mathrm{C}$ & 72,65 & 183,04 & 231,85 & 0,0148 \\
\hline & $600^{\circ} \mathrm{C}$ & 50,26 & 100,72 & 99,25 & 0,0148 \\
\hline \multirow{3}{*}{$\mathbf{C}$} & $25^{\circ} \mathrm{C}$ & 73,45 & 178,41 & 224,82 & 0,0100 \\
\hline & $300^{\circ} \mathrm{C}$ & 57,50 & 137,45 & 163,04 & 0,0126 \\
\hline & $600^{\circ} \mathrm{C}$ & 34,13 & 81,92 & 79,86 & 0,0130 \\
\hline \multirow{3}{*}{ D } & $25^{\circ} \mathrm{C}$ & 48,76 & 114,63 & 147,21 & 0,0110 \\
\hline & $300^{\circ} \mathrm{C}$ & 44,23 & 87,59 & 109,47 & 0,0152 \\
\hline & $600^{\circ} \mathrm{C}$ & 23,88 & 39,10 & 35,76 & 0,0139 \\
\hline \multirow{3}{*}{$\mathbf{E}$} & $25^{\circ} \mathrm{C}$ & 126,94 & 196,79 & 223,07 & 0,0057 \\
\hline & $300^{\circ} \mathrm{C}$ & 96,18 & 123,02 & 151,16 & 0,0102 \\
\hline & $600^{\circ} \mathrm{C}$ & 41,8 & 75,57 & 70,11 & 0,0126 \\
\hline \multirow{3}{*}{$\mathbf{F}$} & $25^{\circ} \mathrm{C}$ & 82,96 & 179,67 & 213,67 & 0,0075 \\
\hline & $300^{\circ} \mathrm{C}$ & 78,59 & 121,64 & 148,39 & 0,0089 \\
\hline & $600^{\circ} \mathrm{C}$ & 39,04 & 73,49 & 73,73 & 0,0102 \\
\hline \multirow{3}{*}{$\mathbf{G}$} & $25^{\circ} \mathrm{C}$ & 68,82 & 136,87 & 155,87 & 0,0059 \\
\hline & $300^{\circ} \mathrm{C}$ & 48,43 & 86,60 & 102,94 & 0,0097 \\
\hline & $600^{\circ} \mathrm{C}$ & 31,63 & 51,96 & 54,24 & 0,0099 \\
\hline
\end{tabular}


Para compensar a menor resistência mecânica causada pela maior quantidade de carbono equivalente, é comum a adição dos elementos de liga $\mathrm{Mo}, \mathrm{Cr}$ e $\mathrm{Cu}$. Na Figura AI.7, nota-se o efeito dos elementos $\mathrm{Mo}$ e $\mathrm{Cr}$ presentes na liga $\mathrm{B}$ que, por possuir carbono equivalente maior, deveria apresentar valores de resistência mecânica comparativamente menores que os da liga A. No entanto, a presença de Mo e Cr aumenta tanto a resistência a quente da liga $\mathrm{B}$, que na temperatura de $600^{\circ} \mathrm{C}$ ela apresenta limites de resistência melhores que os da liga A, cujo CE é menor.

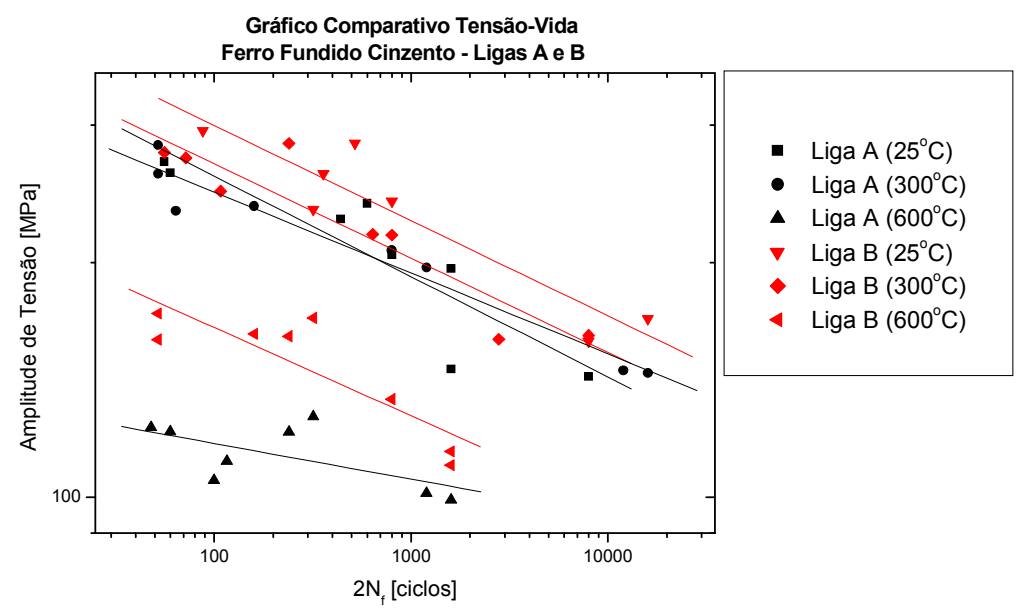

Figura AI.7 - Gráfico Comparativo da Amplitude de Tensão - Vida para as Ligas A e B [Angeloni, 2005].

Na Figura AI.8 pode ser observado o efeito do Mo e do $\mathrm{Cu}$ presentes na liga C. Pela Tabela AI.3 nota-se que o $\mathrm{CE}_{\mathrm{C}}>\mathrm{CE}_{\mathrm{A}}$ e, portanto, esperava-se que a resistência da liga $\mathrm{A}$ fosse bem maior, em virtude da grande diferença no carbono equivalente entre elas. No entanto, os elementos $\mathrm{Mo} \mathrm{e} \mathrm{Cu}$ tiveram por finalidade melhorar a resistência da liga C. Nas temperaturas de $25^{\circ} \mathrm{C}$ e $300^{\circ} \mathrm{C}$ a presença dos elementos de liga não resultou num aumento significativo de resistência da liga $\mathrm{C}$, e já na temperatura de $600^{\circ} \mathrm{C}$, a atuação deles se deu de maneira mais acentuada, tornando a liga $\mathrm{C}$ semelhante à liga $\mathrm{A}$ em termos de propriedades mecânicas.

Tabela AI.3 - Carbonos equivalentes

\begin{tabular}{|c|c|c|c|c|c|c|c|}
\hline \multirow{2}{*}{ Elementos } & \multicolumn{7}{|c|}{ Ligas metálicas } \\
\cline { 2 - 8 } & $\begin{array}{c}\text { A } \\
\text { Luk }\end{array}$ & $\begin{array}{c}\text { B } \\
\text { Teksid }\end{array}$ & $\begin{array}{c}\text { C } \\
\text { Teksid }\end{array}$ & $\begin{array}{c}\text { D } \\
\text { TRW }\end{array}$ & $\begin{array}{c}\text { E } \\
\text { TRW }\end{array}$ & $\begin{array}{c}\text { F } \\
\text { TRW }\end{array}$ & $\begin{array}{c}\text { G } \\
\text { TRW }\end{array}$ \\
\hline CE & 4,05 & 4,18 & 4,40 & 4,51 & 4,12 & 4,07 & 4,13 \\
\hline
\end{tabular}




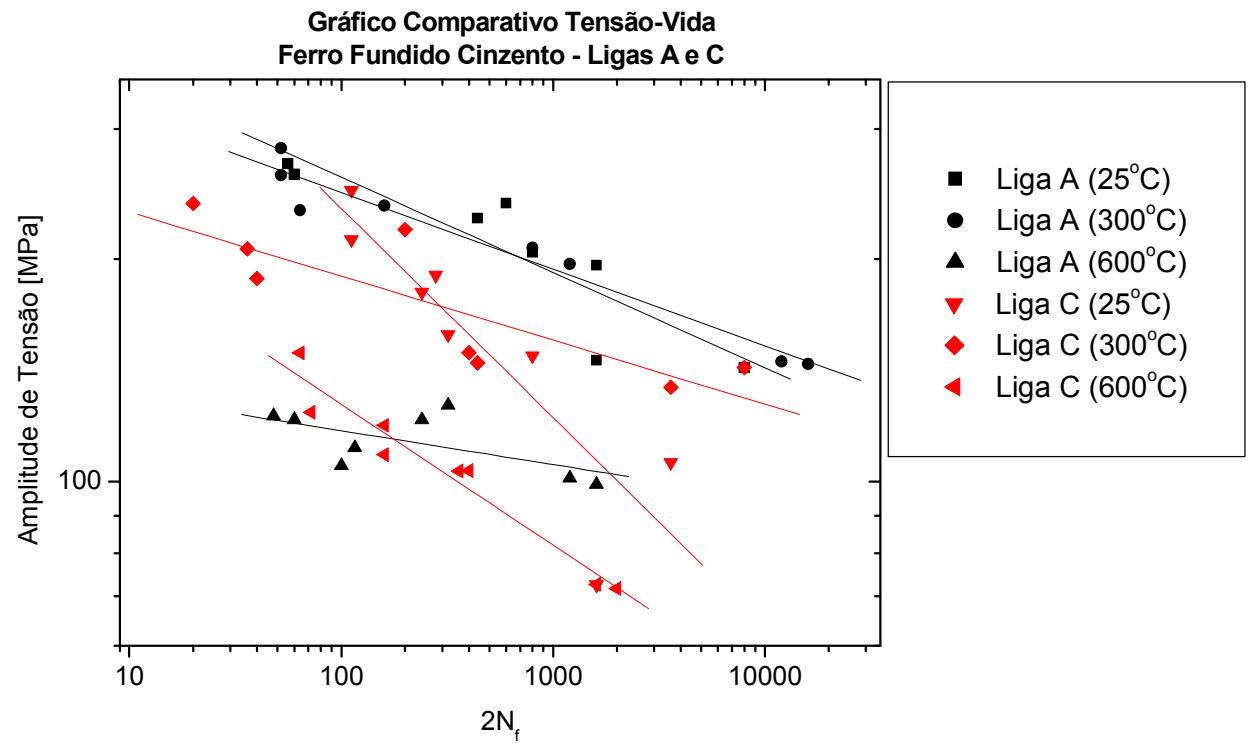

Figura AI.8 - Gráfico Comparativo da Amplitude de Tensão - Vida para as Ligas A e C [Angeloni, 2005].

Na Figura AI.9 nota-se o efeito do $\mathrm{Cr}$ presente em maior quantidade na liga E. Conforme observado na Tabela AI.3, o CE é praticamente o mesmo para ambas as ligas, portanto esperava-se, grosso modo, um comportamento similar em termos resistência mecânica. No entanto, o Cromo atuou de maneira significativa, aumentando a resistência da liga $\mathrm{E}$ tanto à temperatura ambiente como a $300^{\circ} \mathrm{C}$ e a $600^{\circ} \mathrm{C}$.

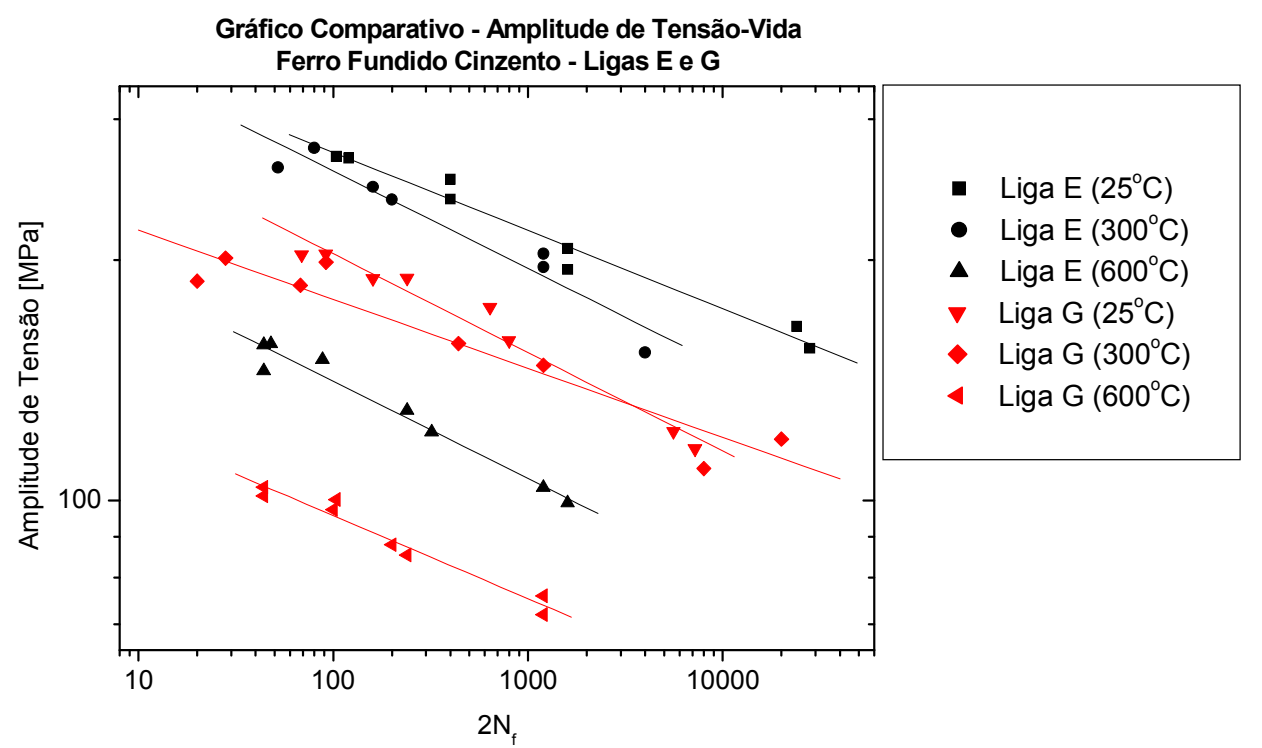

Figura AI.9 - Gráfico Comparativo da Amplitude de Tensão - Vida para as Ligas E e G [Angeloni, 2005].

Com base na análise dos resultados dos ensaios de tração, impacto, fadiga isotérmica e das medidas de dureza realizadas nos corpos de prova nas temperaturas ambiente, de $300^{\circ} \mathrm{C}$ e $600^{\circ} \mathrm{C}$, e levando-se também em consideração o custo de fabricação de cada uma das ligas 
levantado junto as fornecedoras LUK, TRW e Teksid, foi construída uma tabela (Tabela AI.4) de classificação do desempenho das sete ligas de ferro fundido estudadas no presente trabalho. Quanto menor os números, melhores as propriedades mecânicas e menor o custo por quilo. Então, observa-se que a liga que obteve o melhor comportamento foi a liga B seguida da A, E e C.

Tabela AI.4 Classificação das sete ligas de ferro fundido cinzento [Angeloni, 2005].

\begin{tabular}{|c|c|c|c|c|c|c|c|c|}
\hline & LIGA & A & B & C & D & E & F & G \\
\hline TRAÇÃO & $25^{\circ} \mathrm{C}$ & 3 & 1 & 4 & 6 & 2 & 4 & 5 \\
\hline \multirow{2}{*}{ IMPACTO } & $300^{\circ} \mathrm{C}$ & 2 & 1 & 3 & 5 & 4 & 4 & 5 \\
\cline { 2 - 10 } & $600^{\circ} \mathrm{C}$ & 2 & 1 & 3 & 6 & 4 & 4 & 5 \\
\hline & $400^{\circ} \mathrm{C}$ & 4 & 1 & 3 & 5 & 2 & 4 & 5 \\
\cline { 2 - 10 } & $600^{\circ} \mathrm{C}$ & 3 & 1 & 2 & 5 & 2 & 4 & 4 \\
\hline FADIGA & $25^{\circ} \mathrm{C}$ & 2 & 1 & 3 & 6 & 2 & 4 & 5 \\
\hline & $300^{\circ} \mathrm{C}$ & 2 & 1 & 4 & 6 & 2 & 3 & 5 \\
\cline { 2 - 10 } & $6000^{\circ} \mathrm{C}$ & 2 & 1 & 2 & 5 & 2 & 3 & 4 \\
\hline PREÇO* & $\mathrm{kg}^{*}$ & 1 & 6 & 7 & 2 & 4 & 3 & 5 \\
\hline MÉDIA & & 2,4 & 1,5 & 3,2 & 5,2 & 2,6 & 3,7 & 4,8 \\
\hline POSIÇÃO & & $2^{\circ}$ & $1^{\circ}$ & $4^{\circ}$ & $7^{\circ}$ & $3^{\circ}$ & $5^{\circ}$ & $6^{\circ}$ \\
\hline
\end{tabular}

*preço por quilo de carga metálica.

Assim, foram utilizadas as ligas A, B, C e E para o desenvolvimento do presente trabalho. 
ANEXO II

LIGAS A, B, C e E

1) Ensaios de Fadiga termomecânica

Gráficos: Tensão $x$ Vida

2) Ensaios de Fadiga termomecânica

Gráficos: Tensão x Deformação Total

3) Ensaios de Fadiga termomecânica

Gráficos: Temperatura $x$ Deformação Mecânica 


\section{1) GRÁFICOS TENSÃO X VIDA}

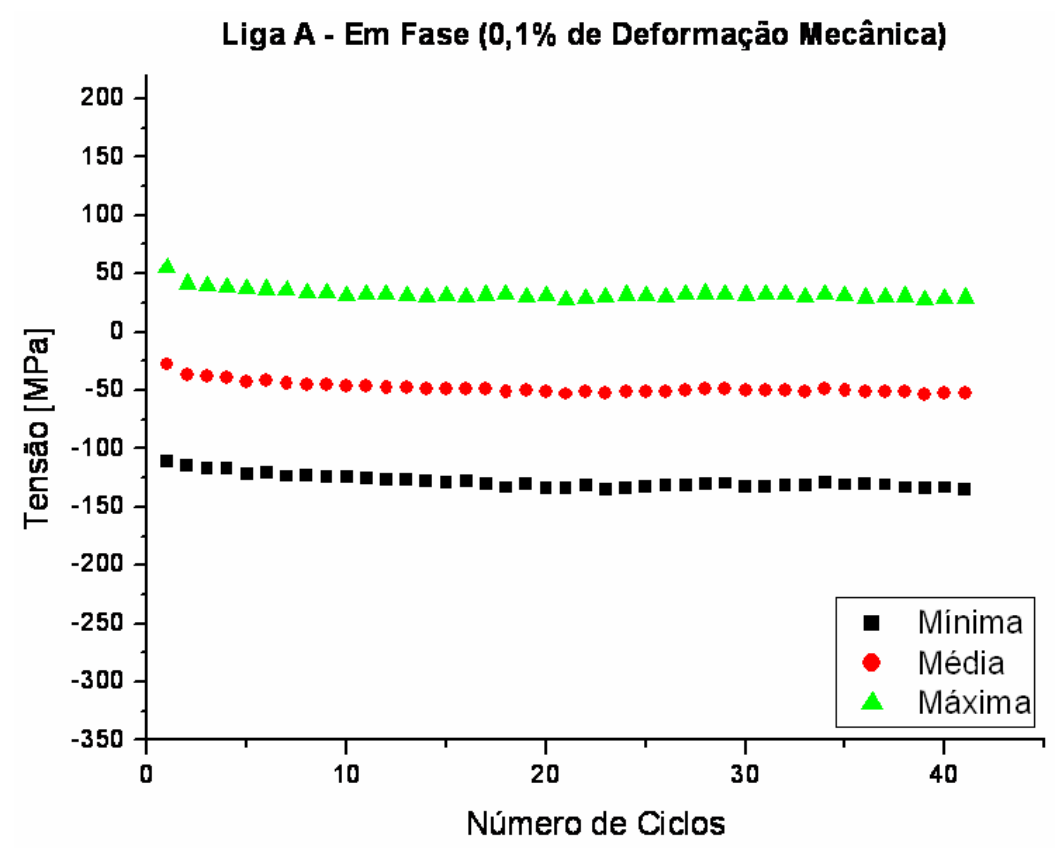

Figura AII.1 - Curvas Tensão em função do Número de Ciclos para a Liga A, ensaiada em fadiga termomecânica, em fase, sob amplitude de deformação mecânica de $0,1 \%$.

Liga A - Em Fase (0,2\% de Deformação Mecânica)

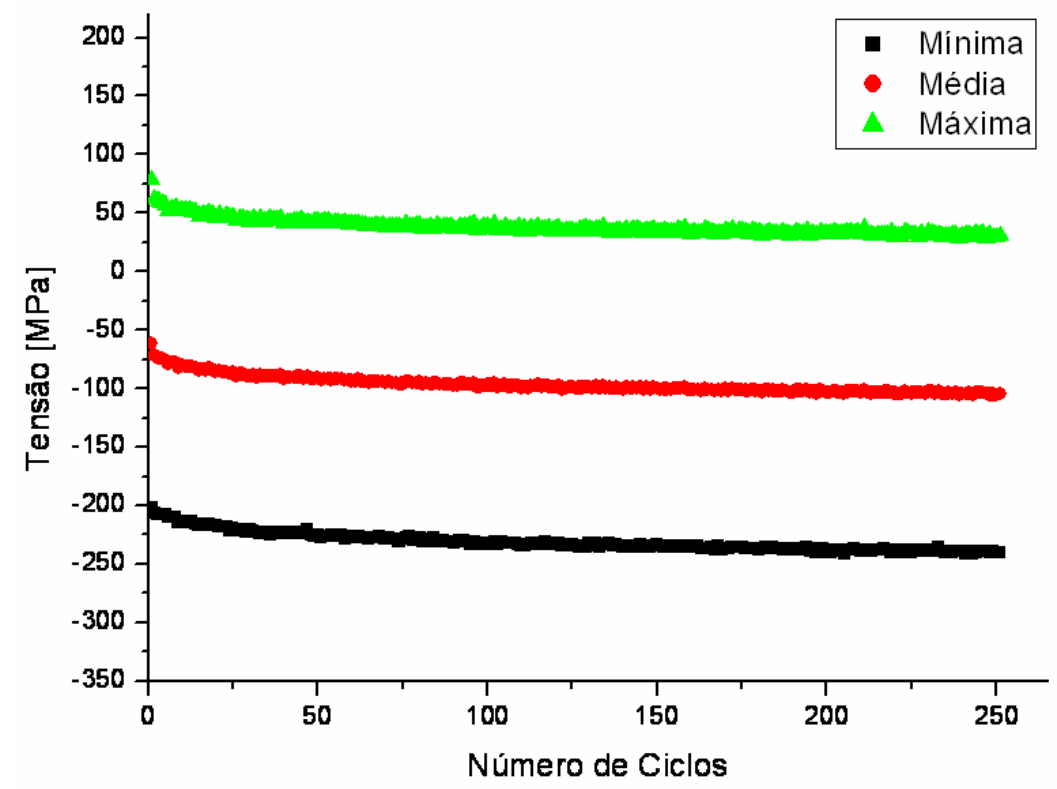

Figura AII.2 - Curvas Tensão em função do Número de Ciclos para a Liga A, ensaiada em fadiga termomecânica, em fase, sob amplitude de deformação mecânica de 0,2\%. 
Liga A - Em Fase (0,3\% de Deformação Mecânica)

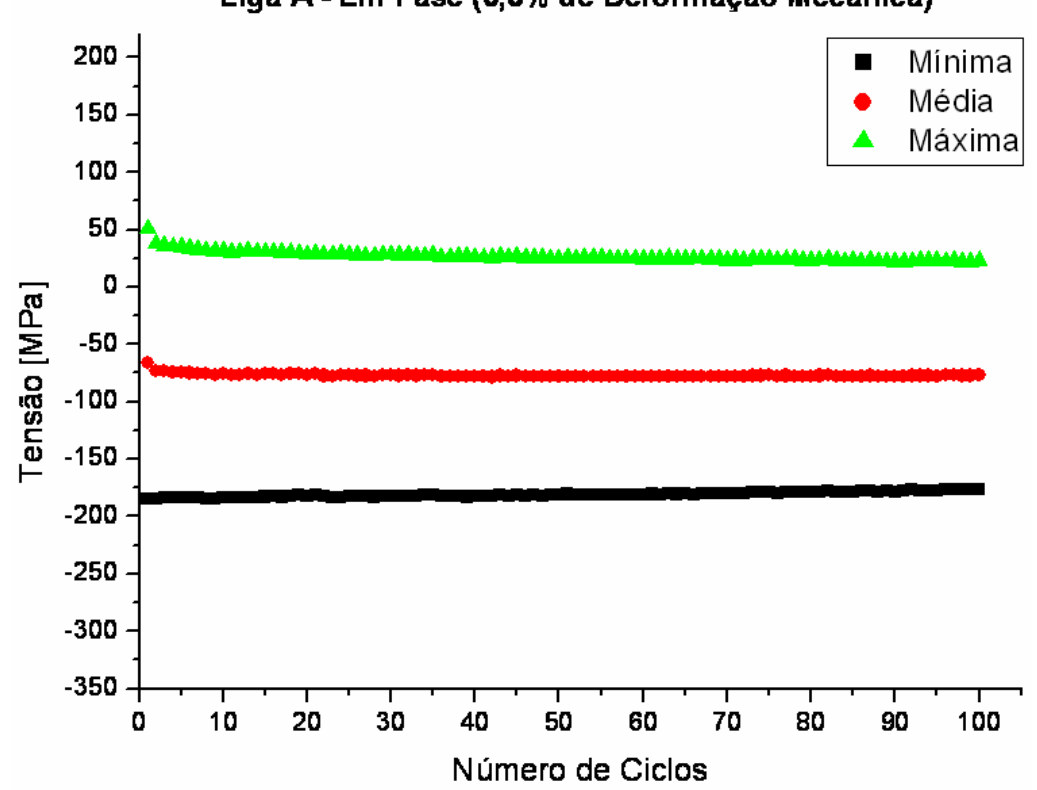

Figura AII.3 - Curvas Tensão em função do Número de Ciclos para a Liga A, ensaiada em fadiga termomecânica, em fase, sob amplitude de deformação mecânica de $0,3 \%$.

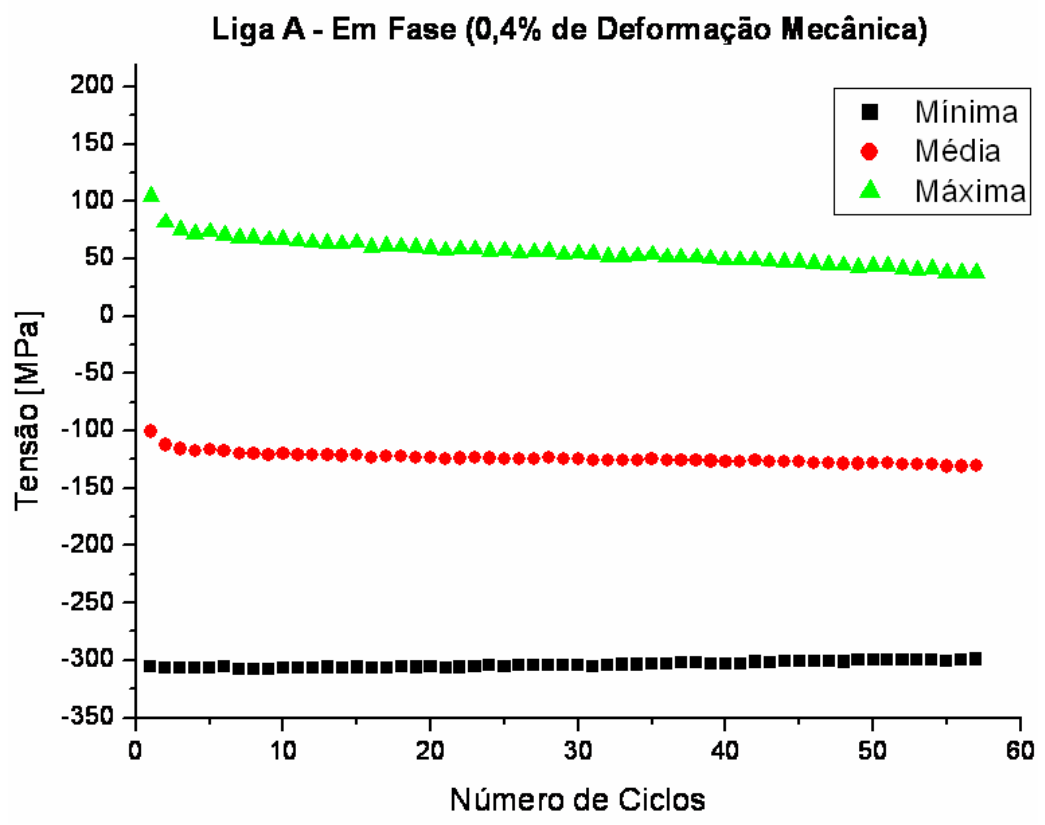

Figura AII.4 Curvas Tensão em função do Número de Ciclos para a Liga A, ensaiada em fadiga termomecânica, em fase, sob amplitude de deformação mecânica de 0,4\%. 


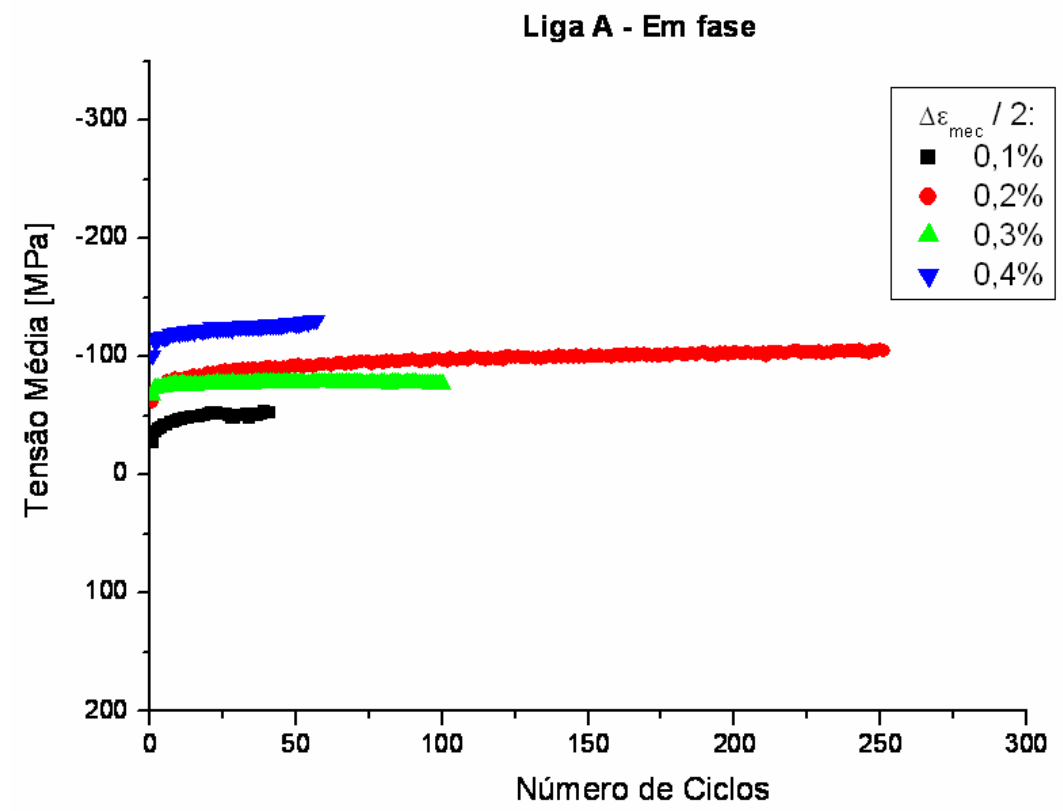

Figura AII.5 - Curvas Tensão em função do Número de Ciclos para a Liga A, em fase, comparando as quatro deformações mecânicas.

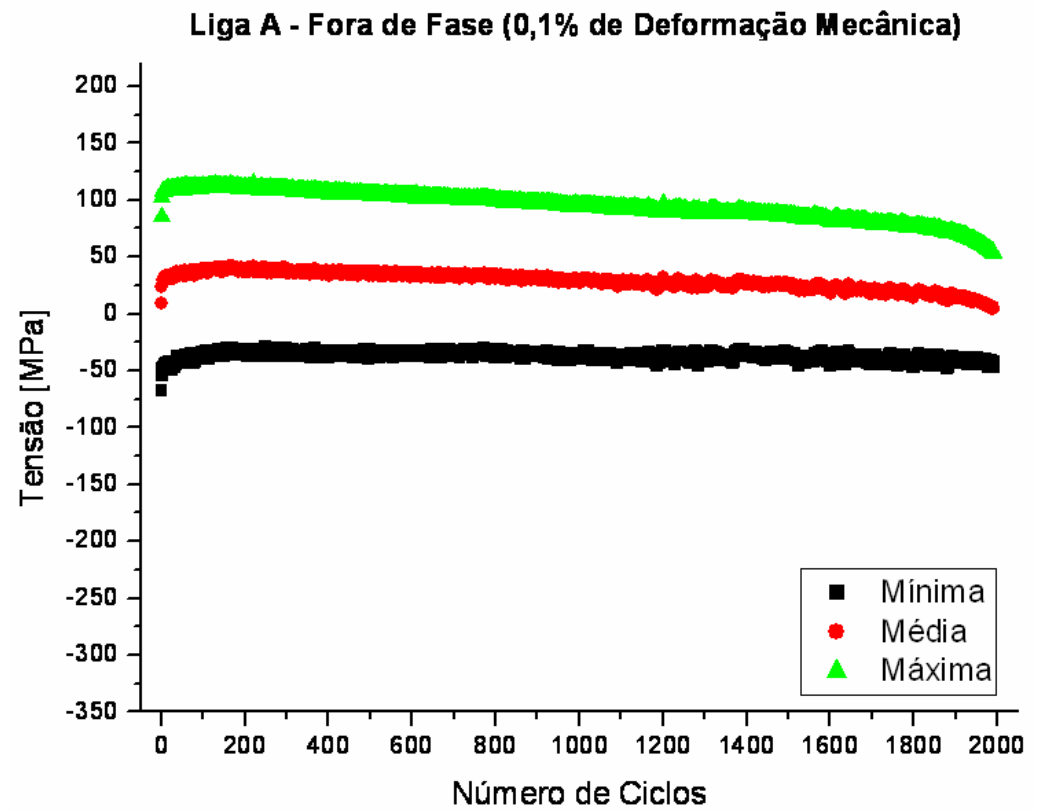

Figura AII.6 - Curvas Tensão em função do Número de Ciclos para a Liga A, ensaiada em fadiga termomecânica, fora de fase, sob amplitude de deformação mecânica de $0,1 \%$. 


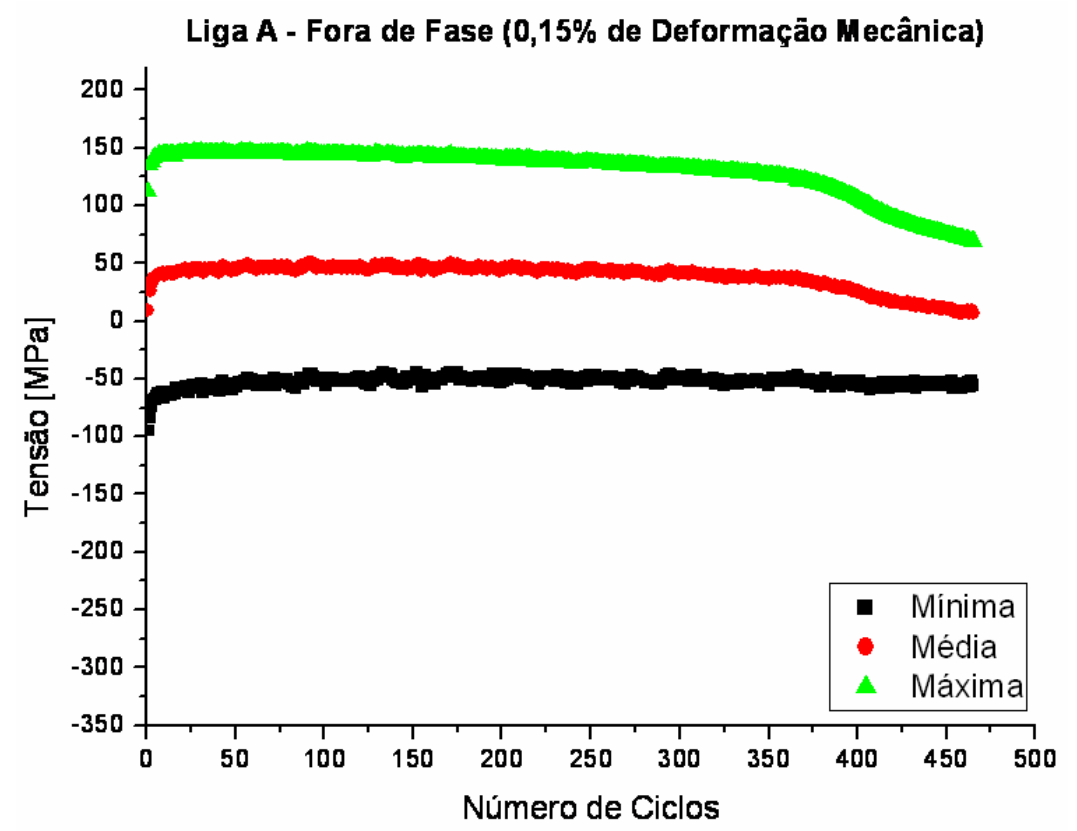

Figura AII.7 - Curvas Tensão em função do Número de Ciclos para a Liga A, ensaiada em fadiga termomecânica, fora de fase, sob amplitude de deformação mecânica de 0,15\%.

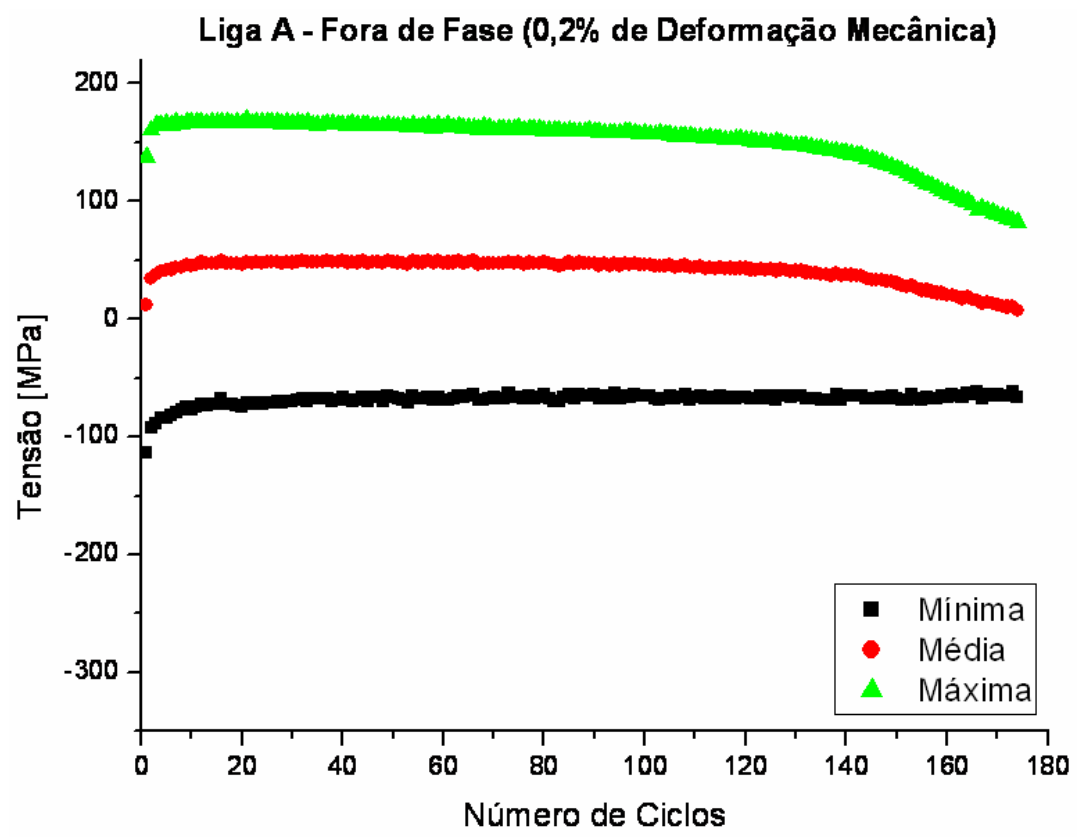

Figura AII.8 - Curvas Tensão em função do Número de Ciclos para a Liga A, ensaiada em fadiga termomecânica, fora de fase, sob amplitude de deformação mecânica de $0,2 \%$. 


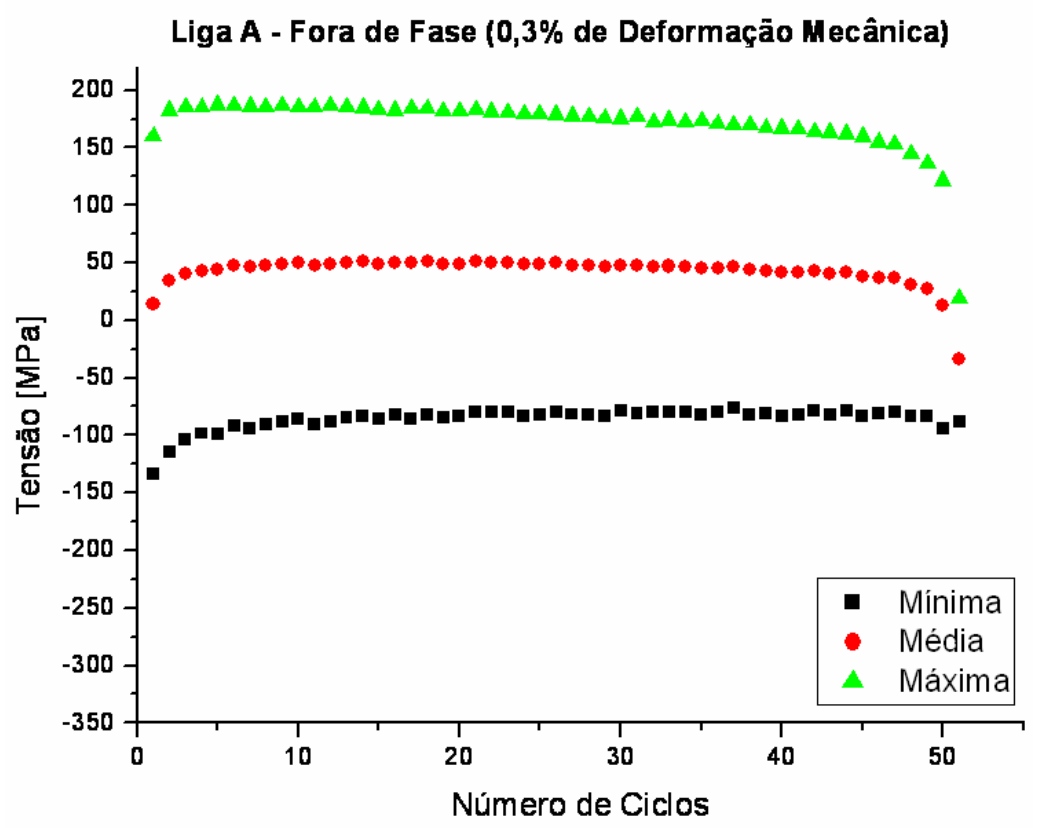

Figura AII.9 - Curvas Tensão em função do Número de Ciclos para a Liga A, ensaiada em fadiga termomecânica, fora de fase, sob amplitude de deformação mecânica de $0,3 \%$.

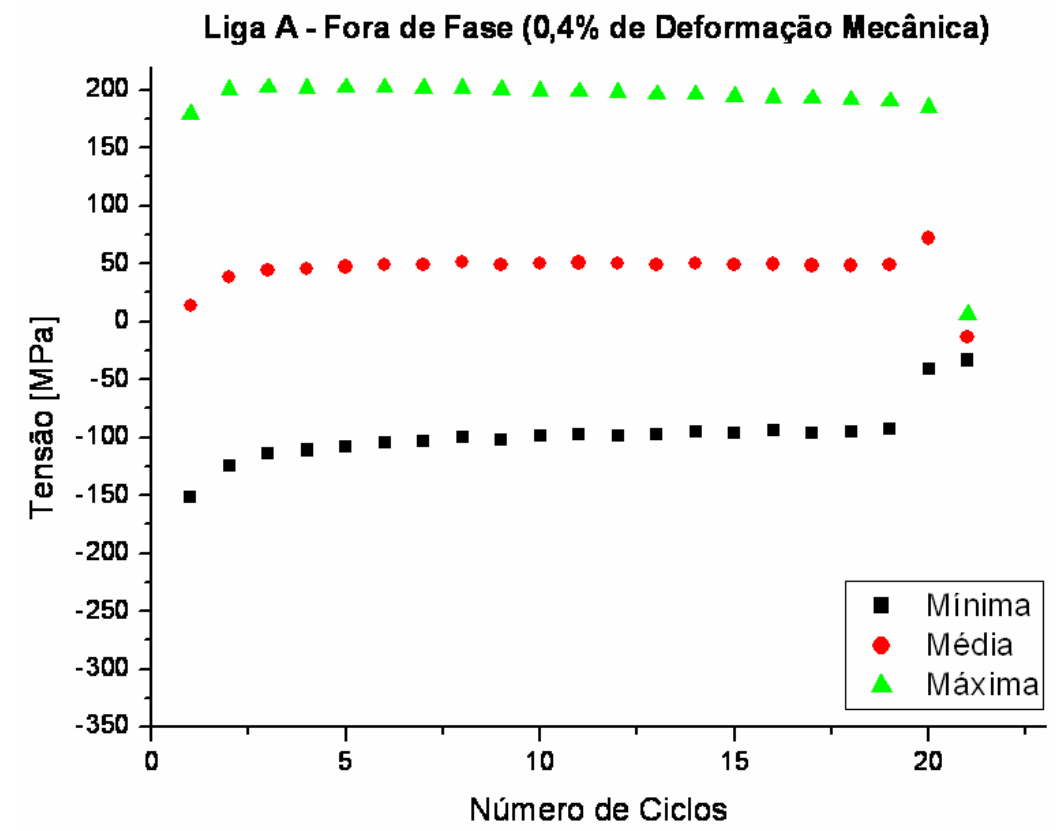

Figura AII.10 - Curvas Tensão em função do Número de Ciclos para a Liga A, ensaiada em fadiga termomecânica, fora de fase, sob amplitude de deformação mecânica de $0,4 \%$. 


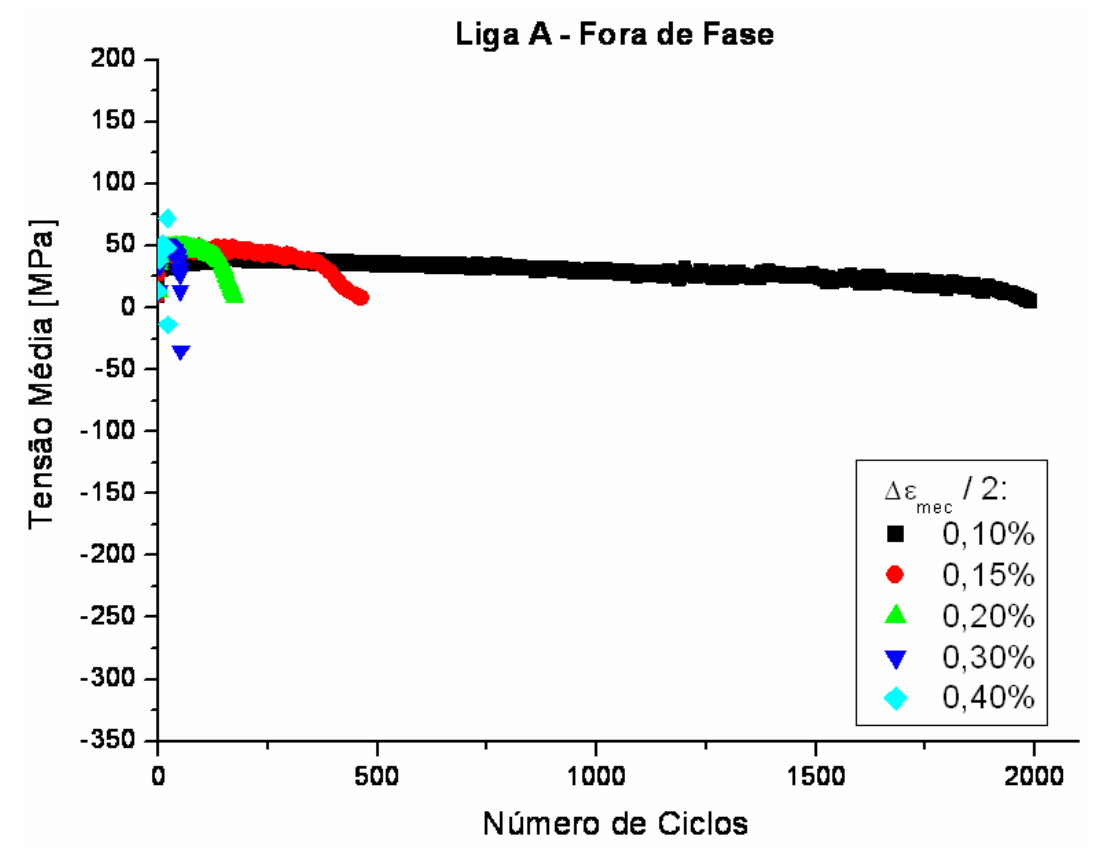

Figura AII.11 - Curvas Tensão em função do Número de Ciclos para a Liga A, fora de fase, comparando as cinco deformações mecânicas.

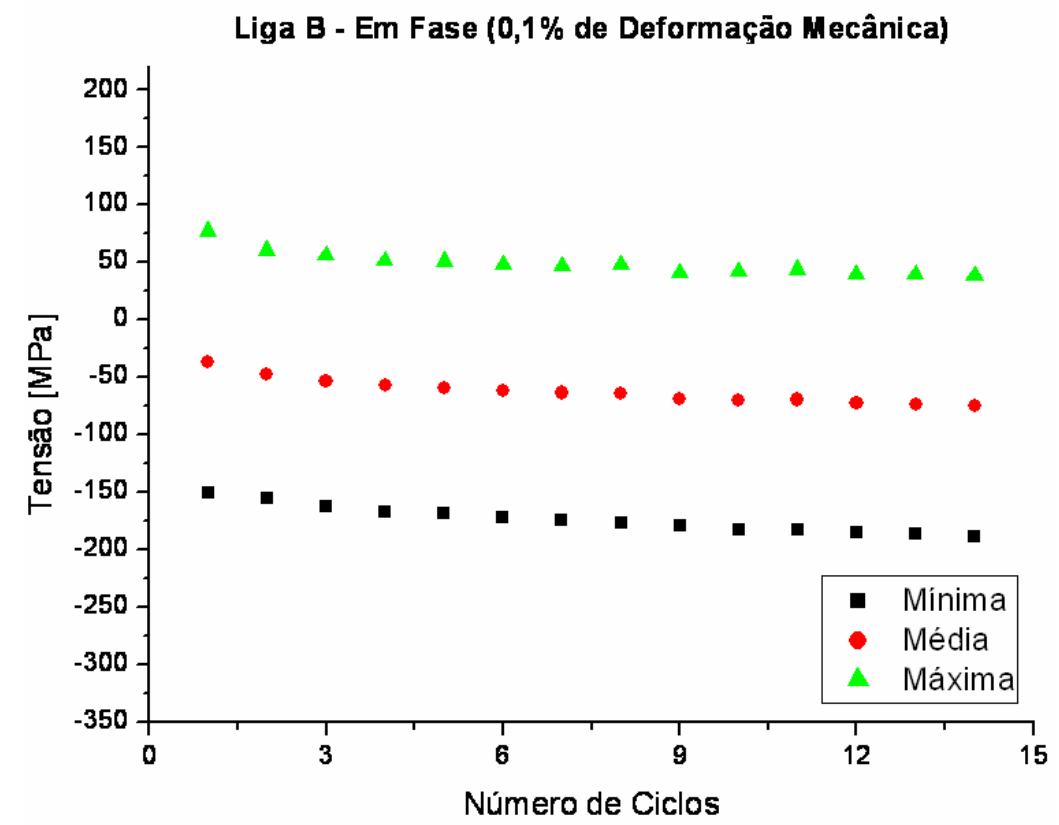

Figura AII.12 - Curvas Tensão em função do Número de Ciclos para a Liga B, ensaiada em fadiga termomecânica, em fase, sob amplitude de deformação mecânica de 0,1\%. 
Liga B - Em Fase (0,2\% de Deformação Mecânica)

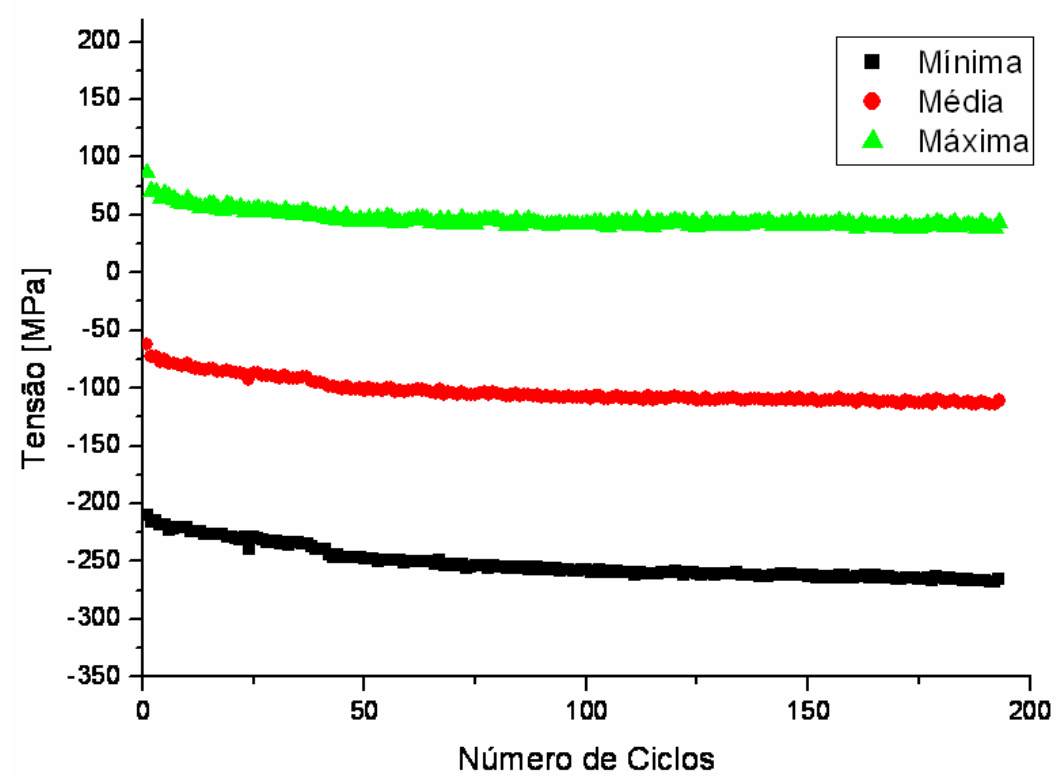

Figura AII.13 - Curvas Tensão em função do Número de Ciclos para a Liga B, ensaiada em fadiga termomecânica, em fase, sob amplitude de deformação mecânica de 0,2\%.

Liga B - Em Fase (0,3\% de Deformação Mecânica)

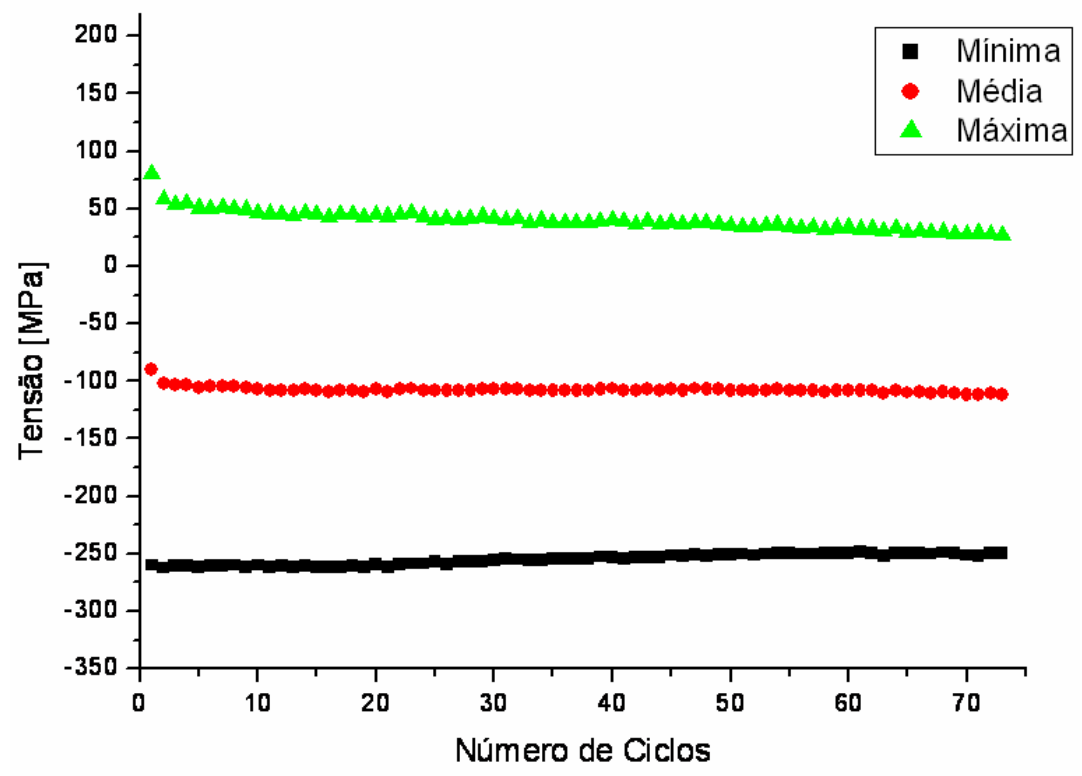

Figura AII.14 - Curvas Tensão em função do Número de Ciclos para a Liga B, ensaiada em fadiga termomecânica, em fase, sob amplitude de deformação mecânica de 0,3\%. 
Liga B - Em Fase (0,4\% de Deformação Mecânica)

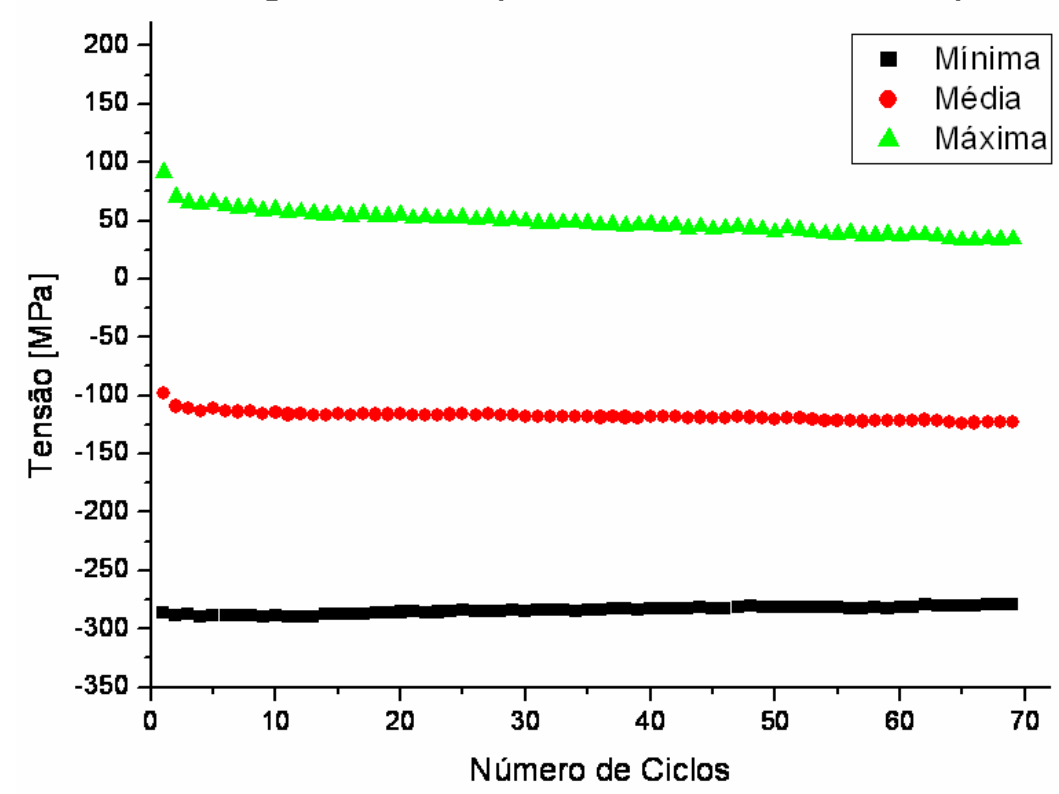

Figura AII.15 - Curvas Tensão em função do Número de Ciclos para a Liga B, ensaiada em fadiga termomecânica, em fase, sob amplitude de deformação mecânica de $0,4 \%$.

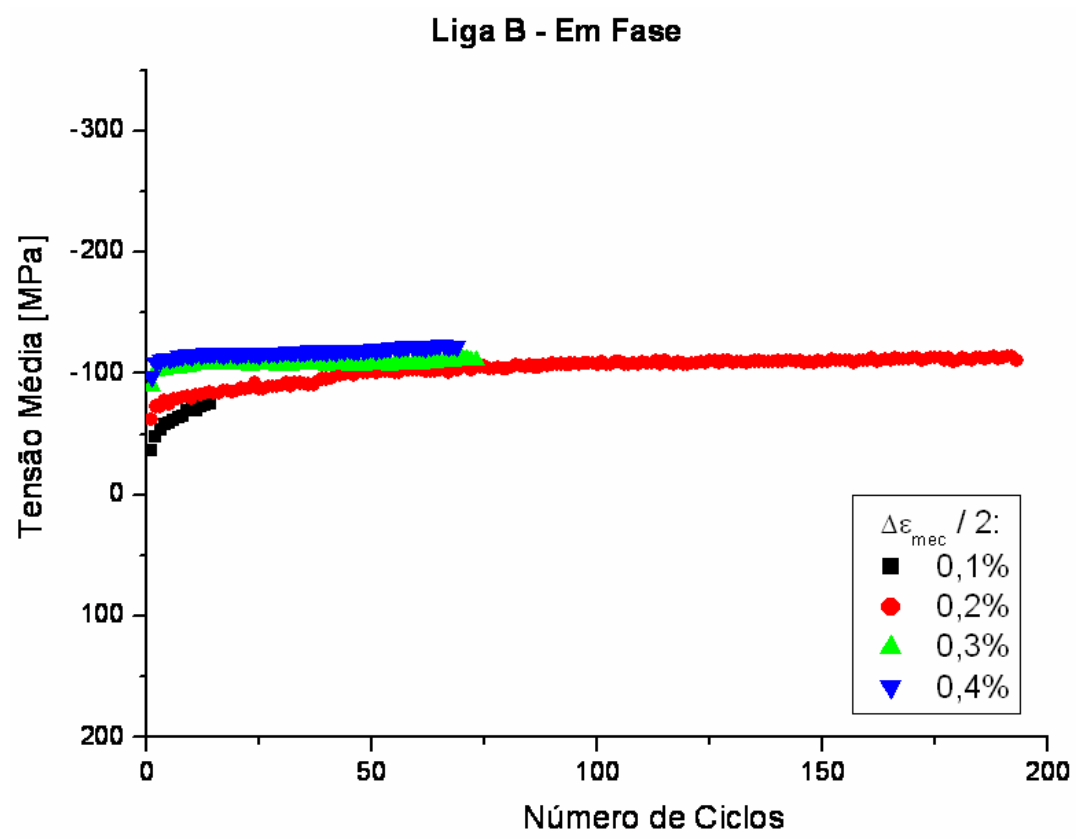

Figura AII.16 - Curvas Tensão em função do Número de Ciclos para a Liga B, em fase, comparando as quatro deformações mecânicas. 
Liga B - Fora de Fase (0,1\% de Deformação Mecânica)

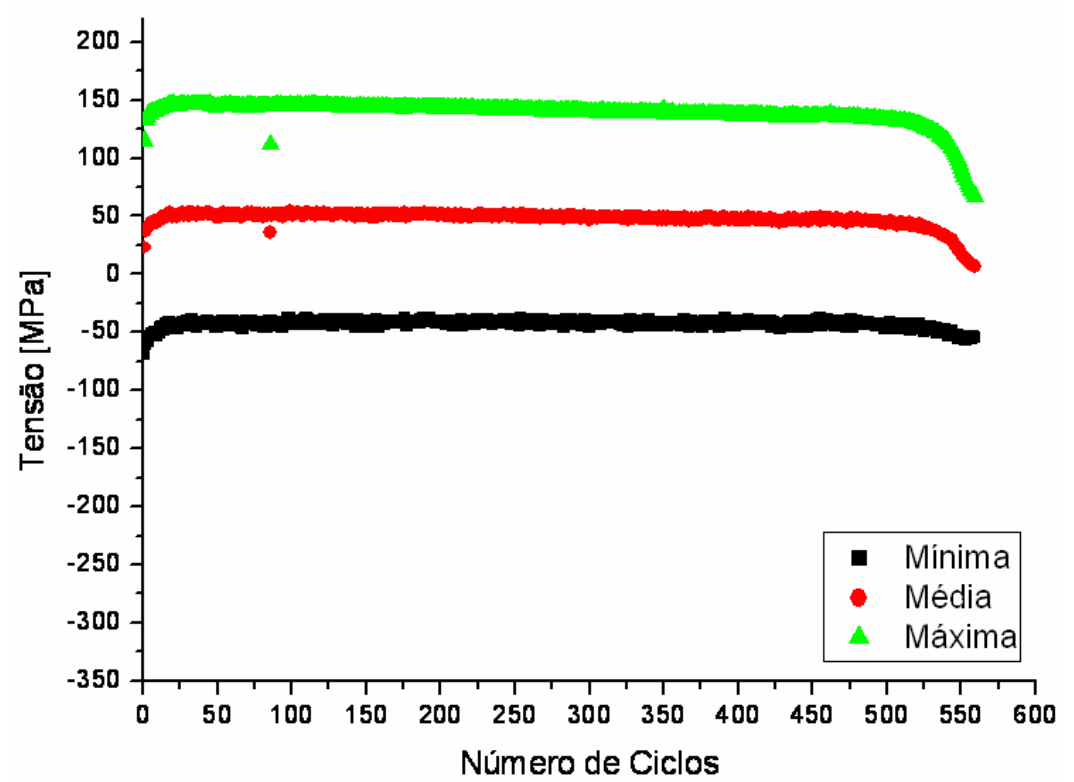

Figura AII.17 - Curvas Tensão em função do Número de Ciclos para a Liga B, ensaiada em fadiga termomecânica, fora de fase, sob amplitude de deformação mecânica de $0,1 \%$.

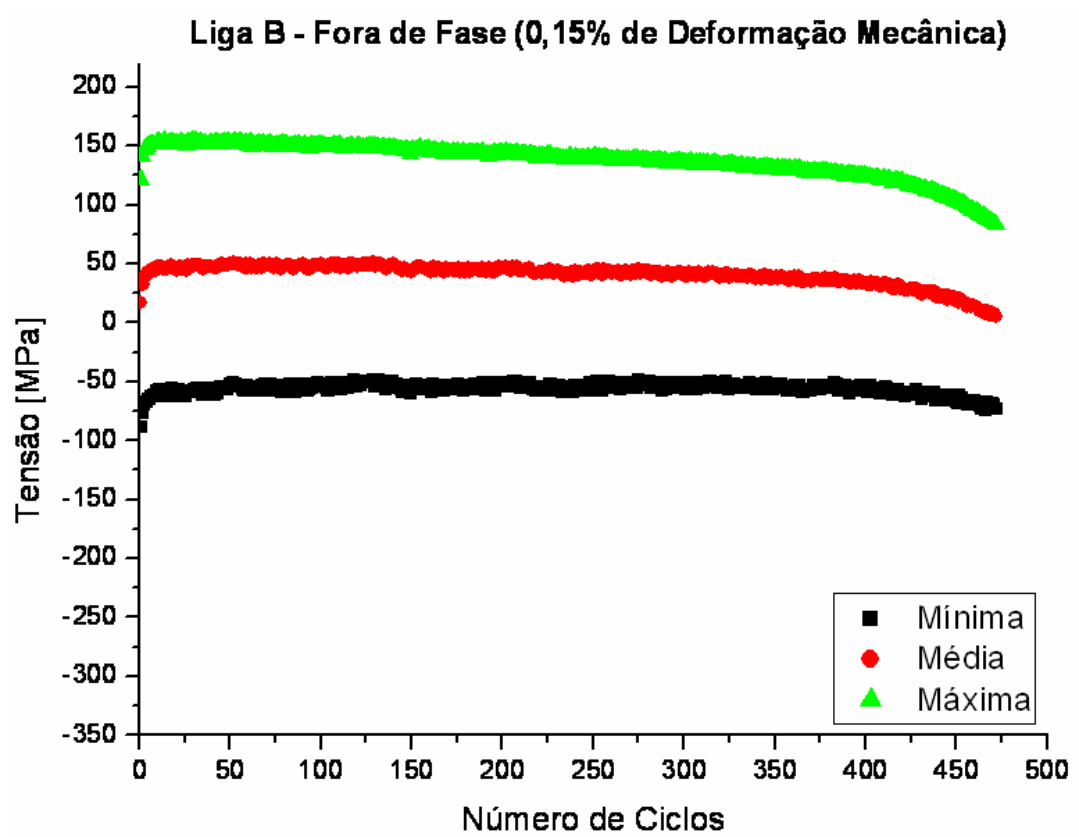

Figura AII.18 - Curvas Tensão em função do Número de Ciclos para a Liga B, ensaiada em fadiga termomecânica, fora de fase, sob amplitude de deformação mecânica de 0,15\%. 


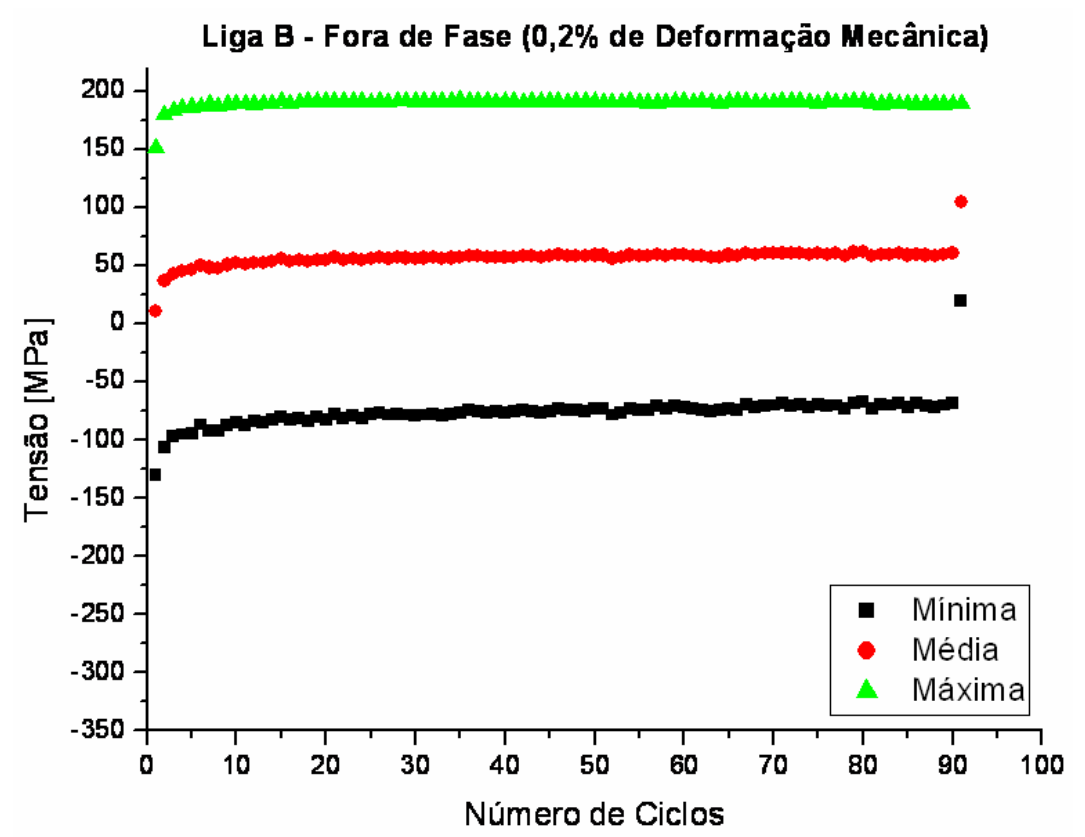

Figura AII.19 - Curvas Tensão em função do Número de Ciclos para a Liga B, ensaiada em fadiga termomecânica, fora de fase, sob amplitude de deformação mecânica de $0,2 \%$.

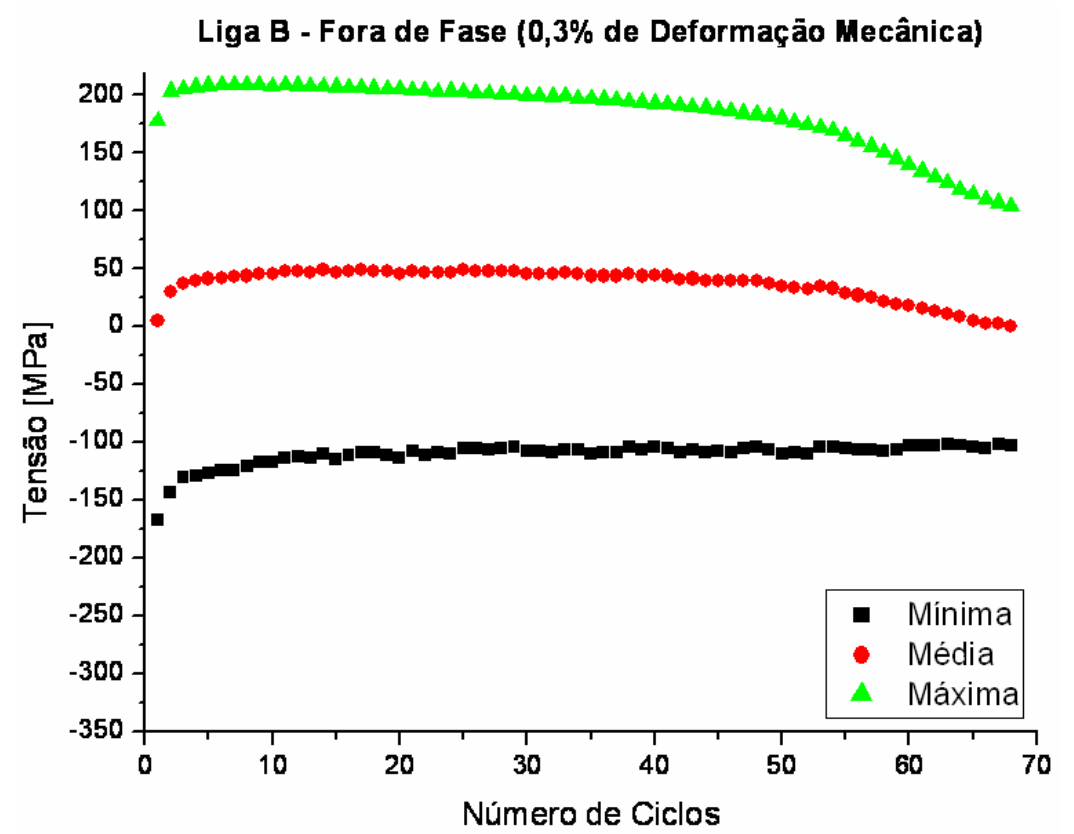

Figura AII.20 - Curvas Tensão em função do Número de Ciclos para a Liga B, ensaiada em fadiga termomecânica, fora de fase, sob amplitude de deformação mecânica de $0,3 \%$. 


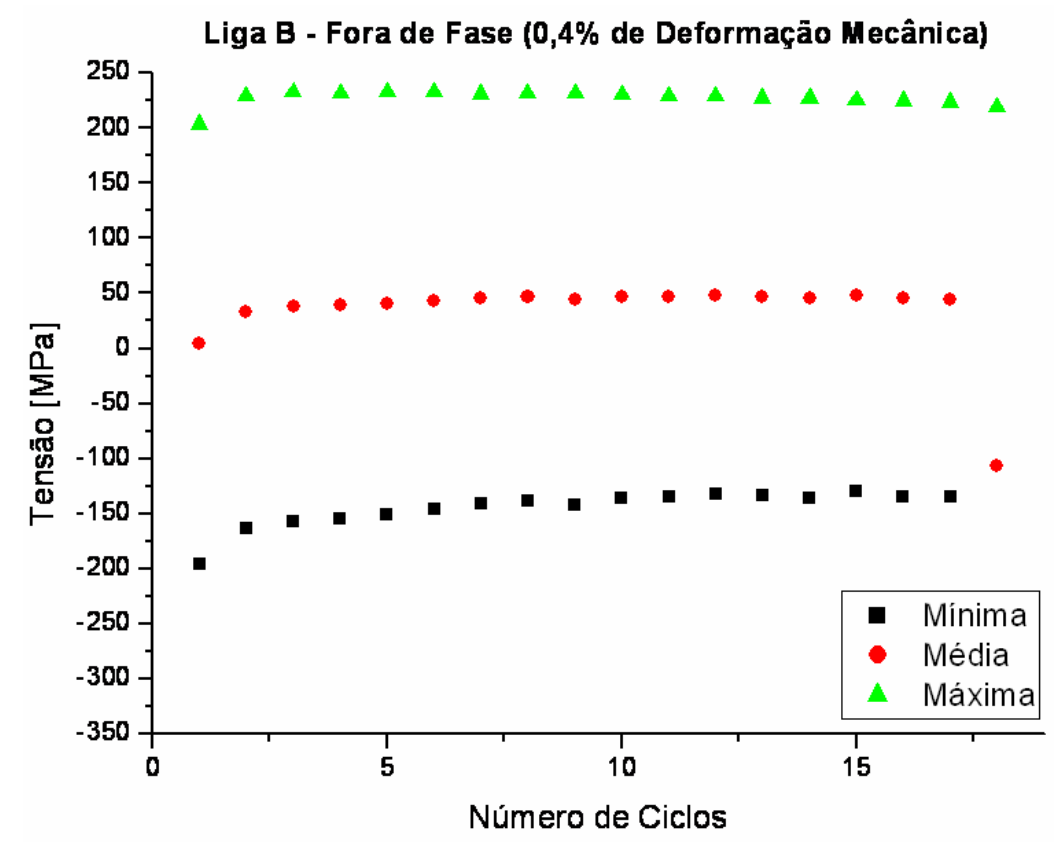

Figura AII.21 - Curvas Tensão em função do Número de Ciclos para a Liga B, ensaiada em fadiga termomecânica, fora de fase, sob amplitude de deformação mecânica de $0,4 \%$.

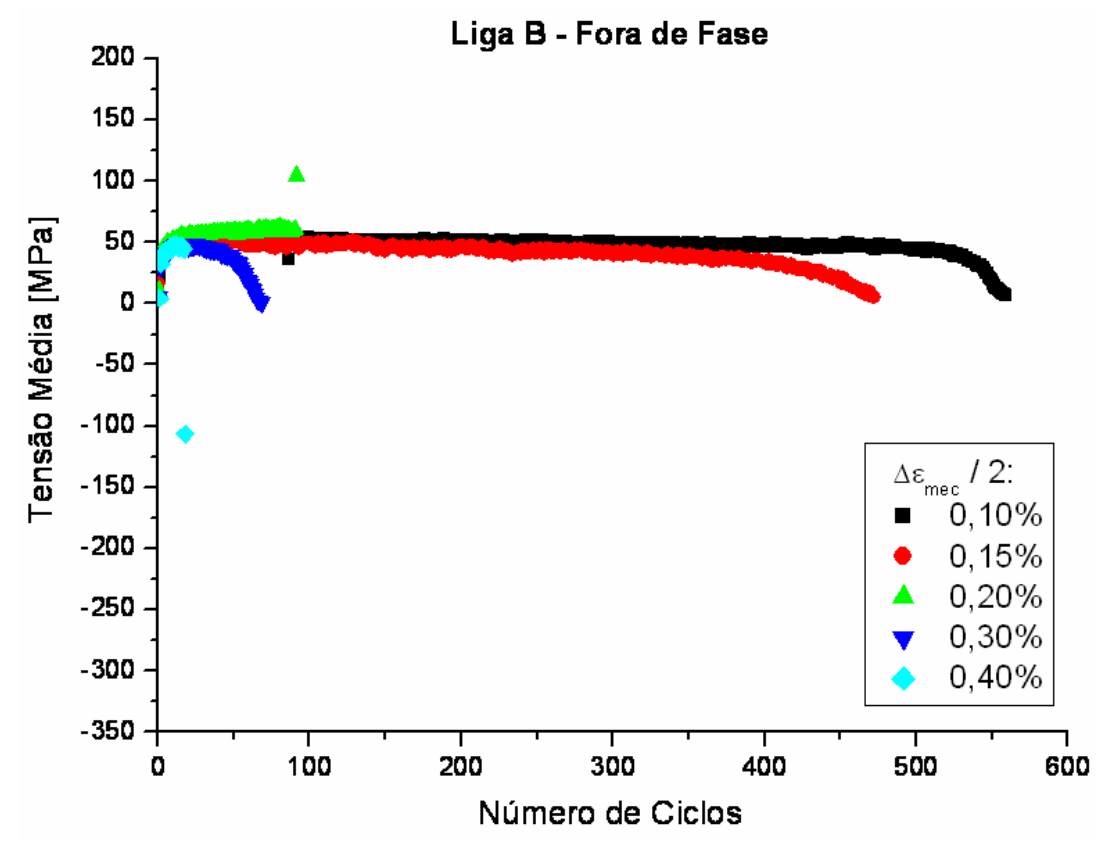

Figura AII.22 - Curvas Tensão em função do Número de Ciclos para a Liga B, fora de fase, comparando as cinco deformações mecânicas. 


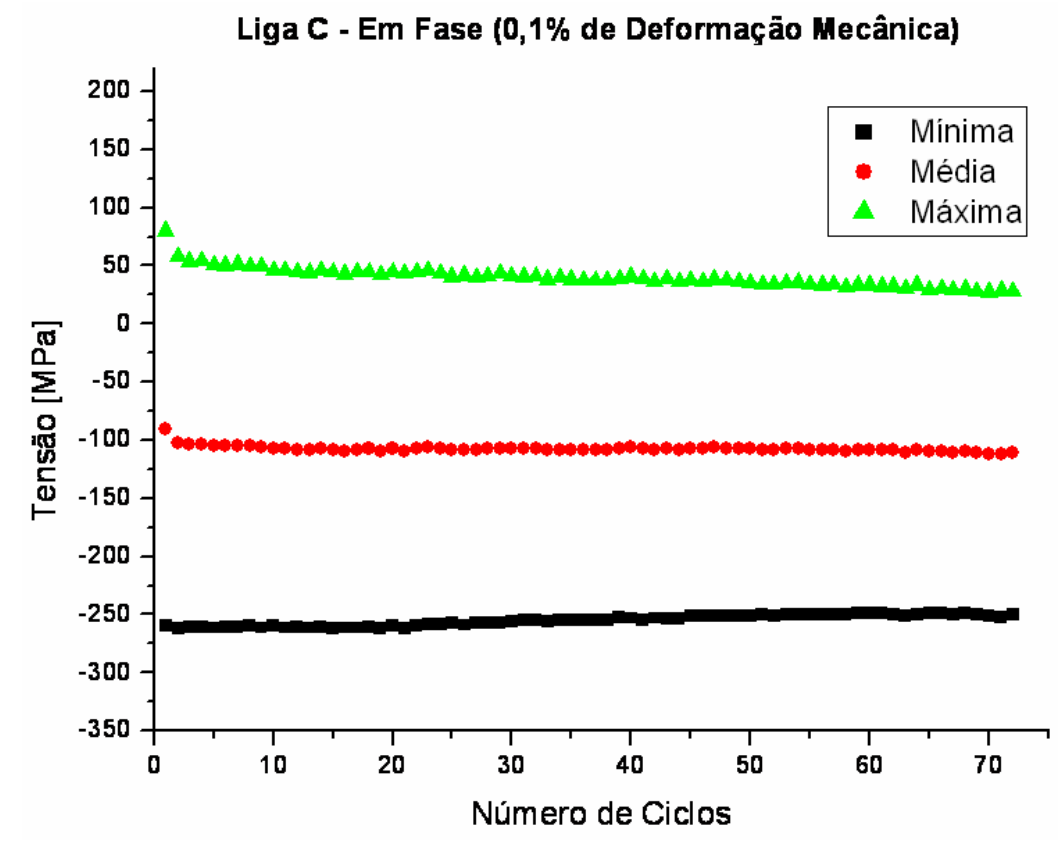

Figura AII.23 - Curvas Tensão em função do Número de Ciclos para a Liga C, ensaiada em fadiga termomecânica, em fase, sob amplitude de deformação mecânica de 0,1\%.

Liga C - Em Fase (0,2\% de Deformação Mecânica)

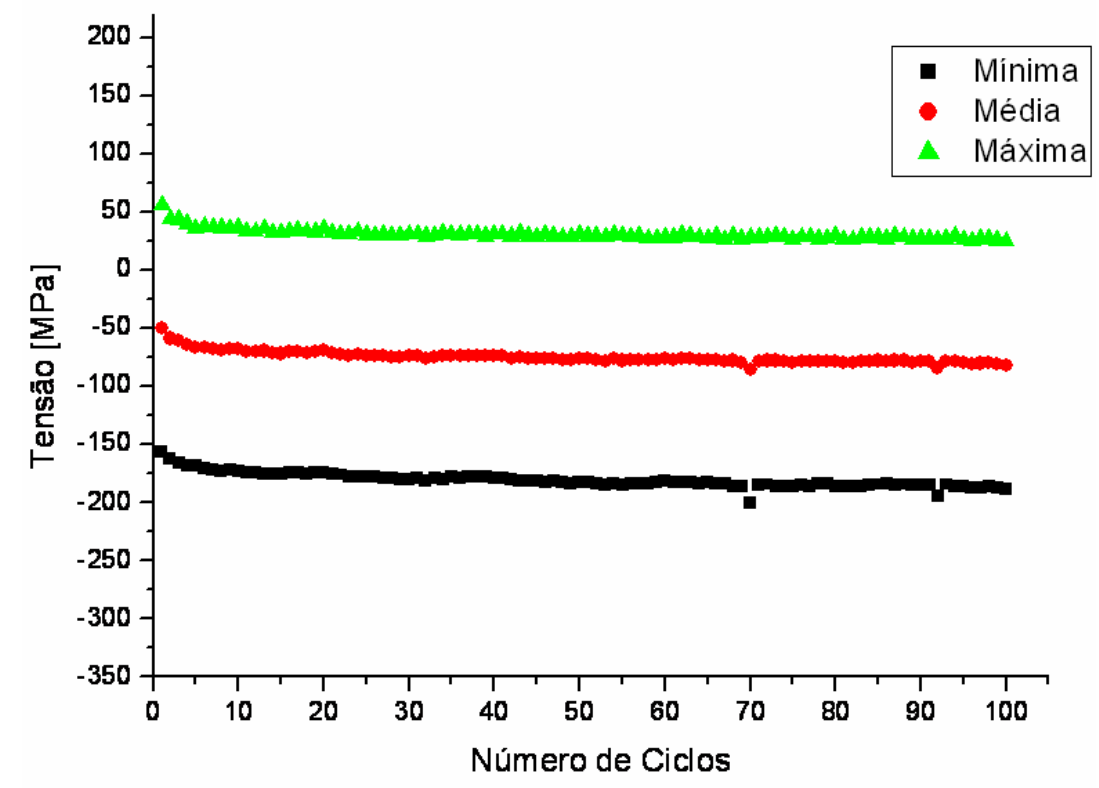

Figura AII.24 - Curvas Tensão em função do Número de Ciclos para a Liga C, ensaiada em fadiga termomecânica, em fase, sob amplitude de deformação mecânica de 0,2\%. 
Liga C - Em Fase (0,3\% de Deformação Mecânica)

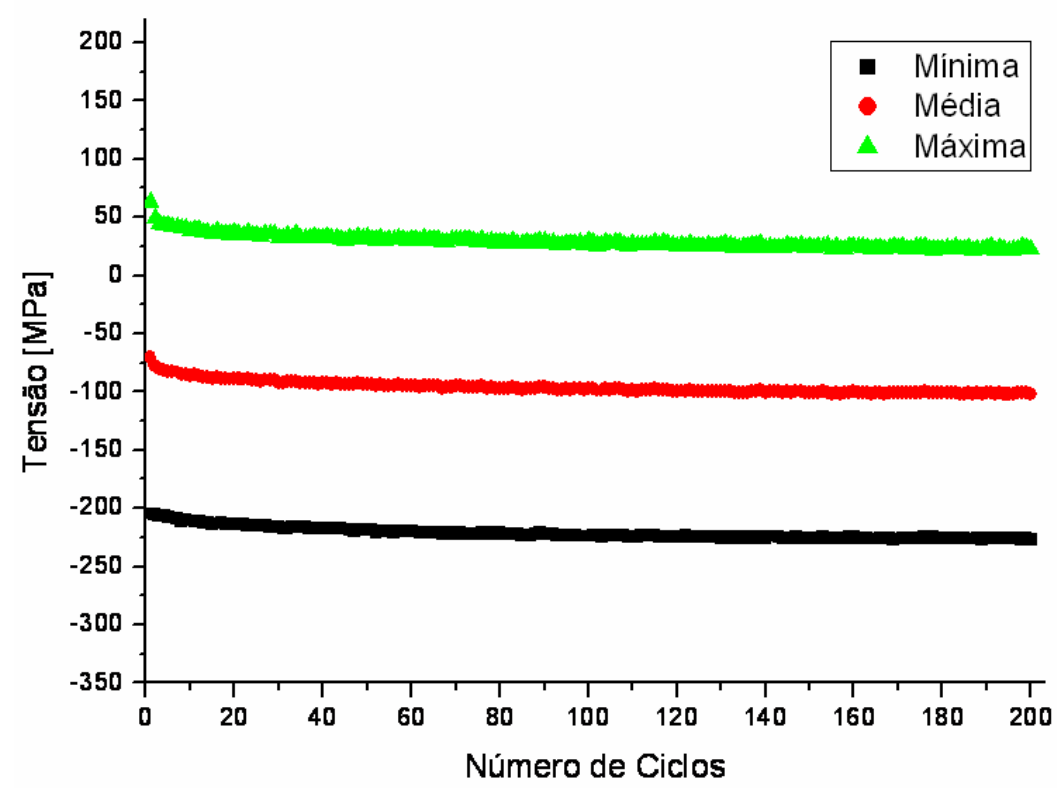

Figura AII.25 - Curvas Tensão em função do Número de Ciclos para a Liga C, ensaiada em fadiga termomecânica, em fase, sob amplitude de deformação mecânica de $0,3 \%$.

Liga C - Em Fase (0,4\% de Deformação Mecânica)

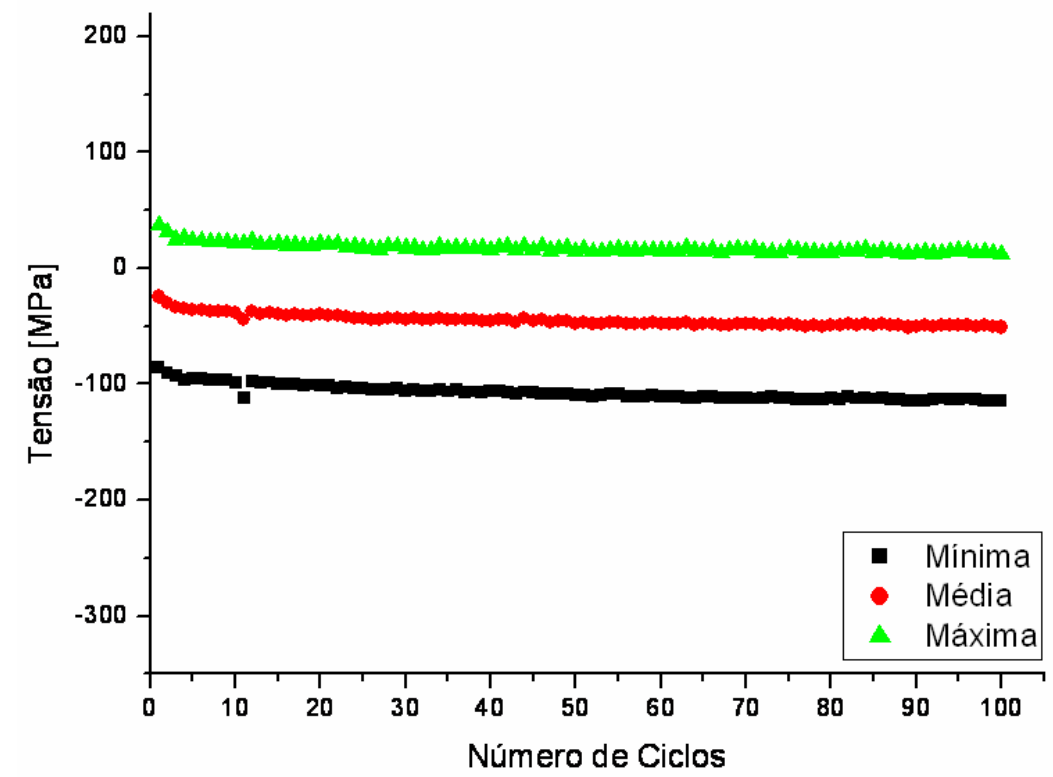

Figura AII.26 - Curvas Tensão em função do Número de Ciclos para a Liga C, ensaiada em fadiga termomecânica, em fase, sob amplitude de deformação mecânica de $0,4 \%$. 


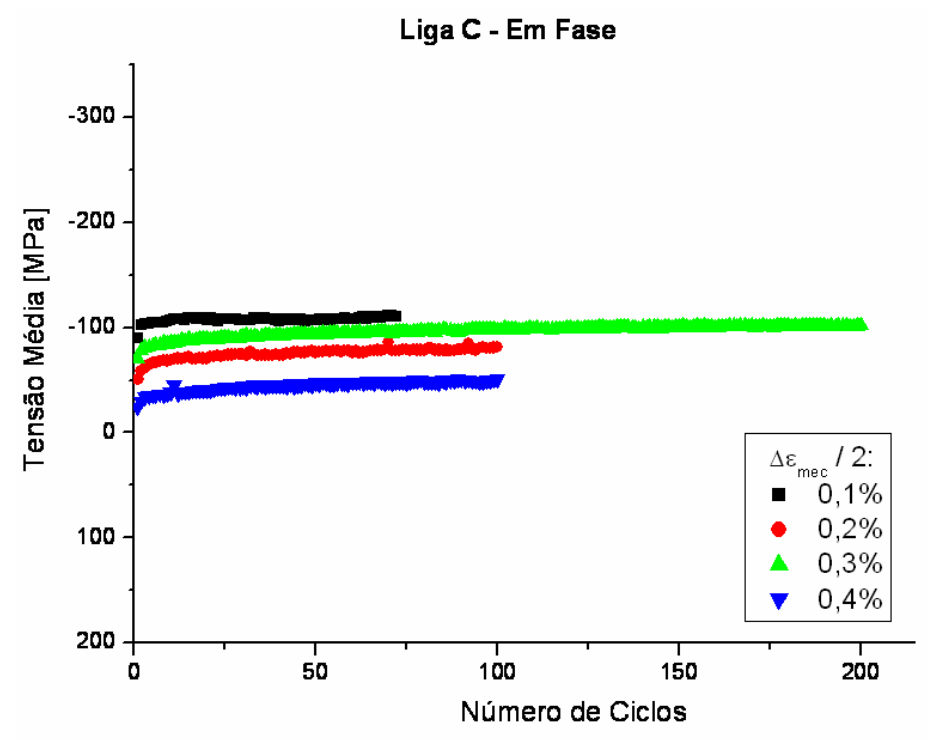

Figura AII.27 - Curvas Tensão em função do Número de Ciclos para a Liga C, em fase, comparando as quatro deformações mecânicas.

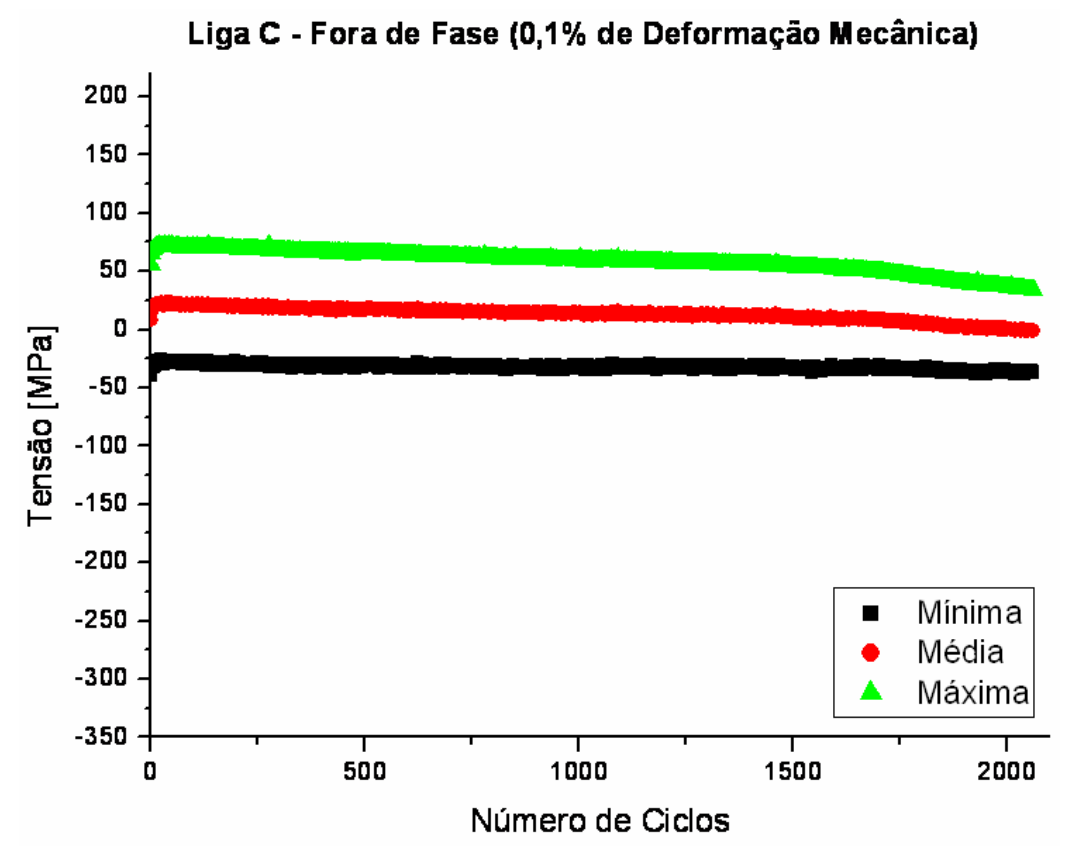

Figura AII.28 - Curvas Tensão em função do Número de Ciclos para a Liga C, ensaiada em fadiga termomecânica, fora de fase, sob amplitude de deformação mecânica de $0,1 \%$. 


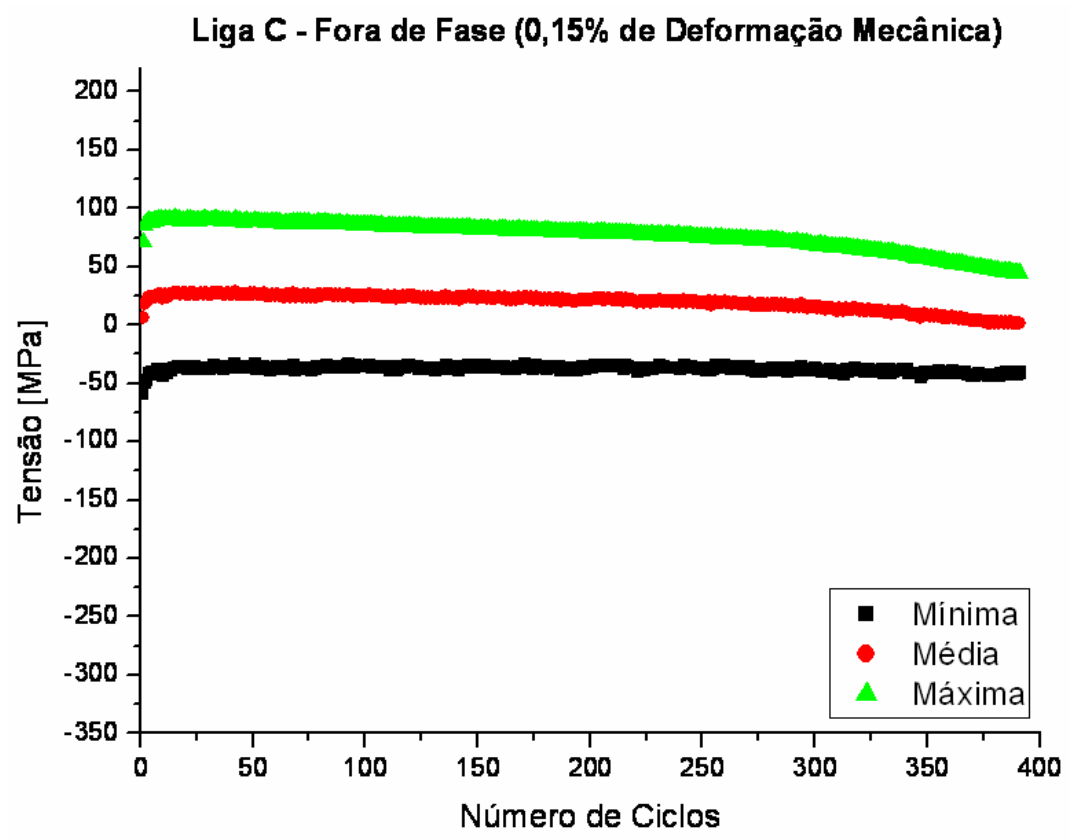

Figura AII.29 - Curvas Tensão em função do Número de Ciclos para a Liga C, ensaiada em fadiga termomecânica, fora de fase, sob amplitude de deformação mecânica de 0,15\%.

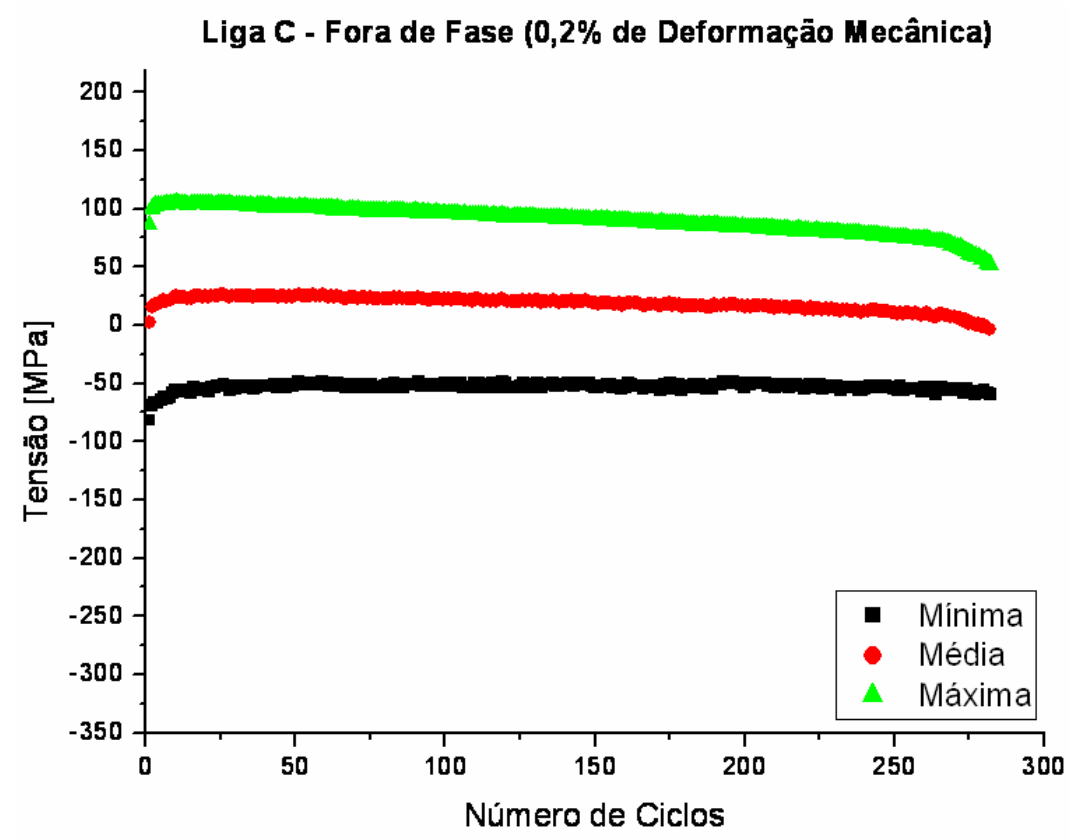

Figura AII.30 - Curvas Tensão em função do Número de Ciclos para a Liga C, ensaiada em fadiga termomecânica, fora de fase, sob amplitude de deformação mecânica de $0,2 \%$. 
Liga C - Fora de Fase (0,3\% de Deformação Mecânica)

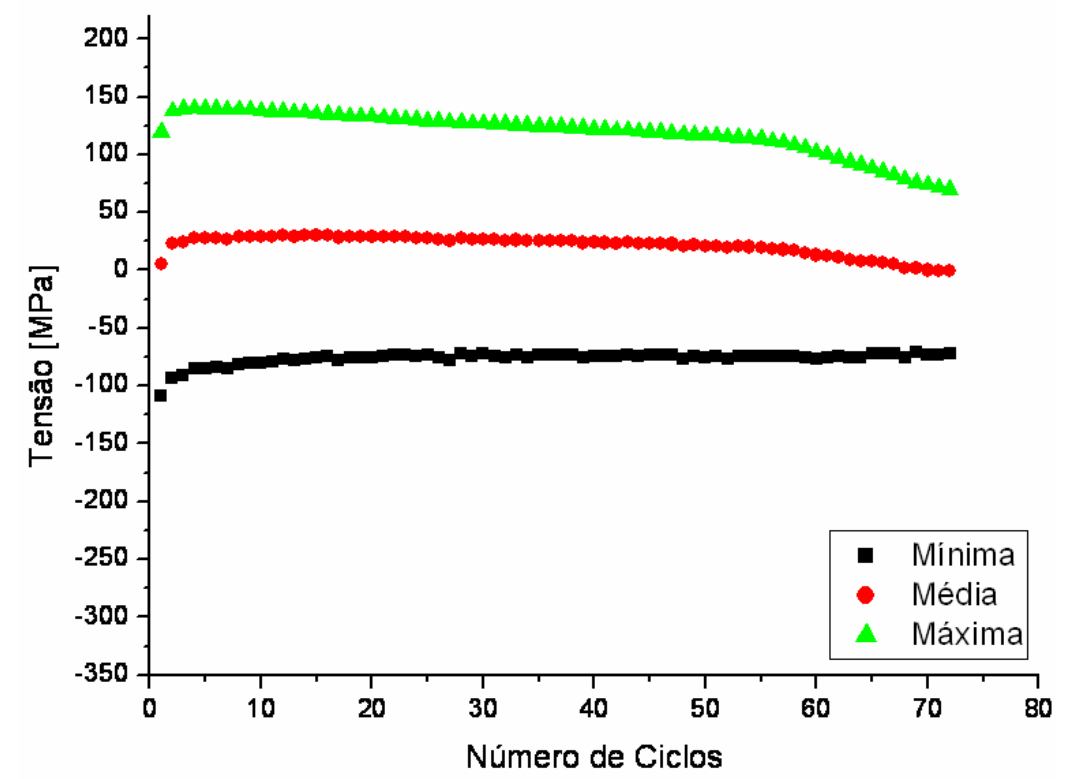

Figura AII.31 - Curvas Tensão em função do Número de Ciclos para a Liga C, ensaiada em fadiga termomecânica, fora de fase, sob amplitude de deformação mecânica de $0,3 \%$.

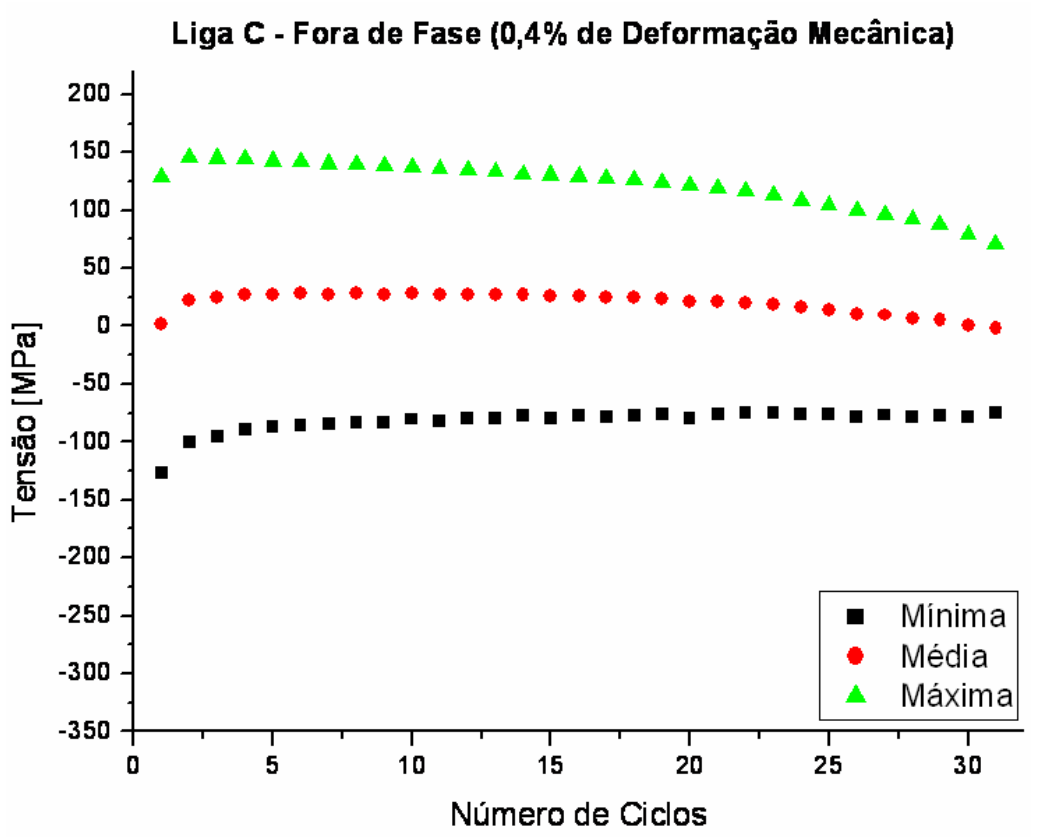

Figura AII.32 - Curvas Tensão em função do Número de Ciclos para a Liga C, ensaiada em fadiga termomecânica, fora de fase, sob amplitude de deformação mecânica de $0,4 \%$. 


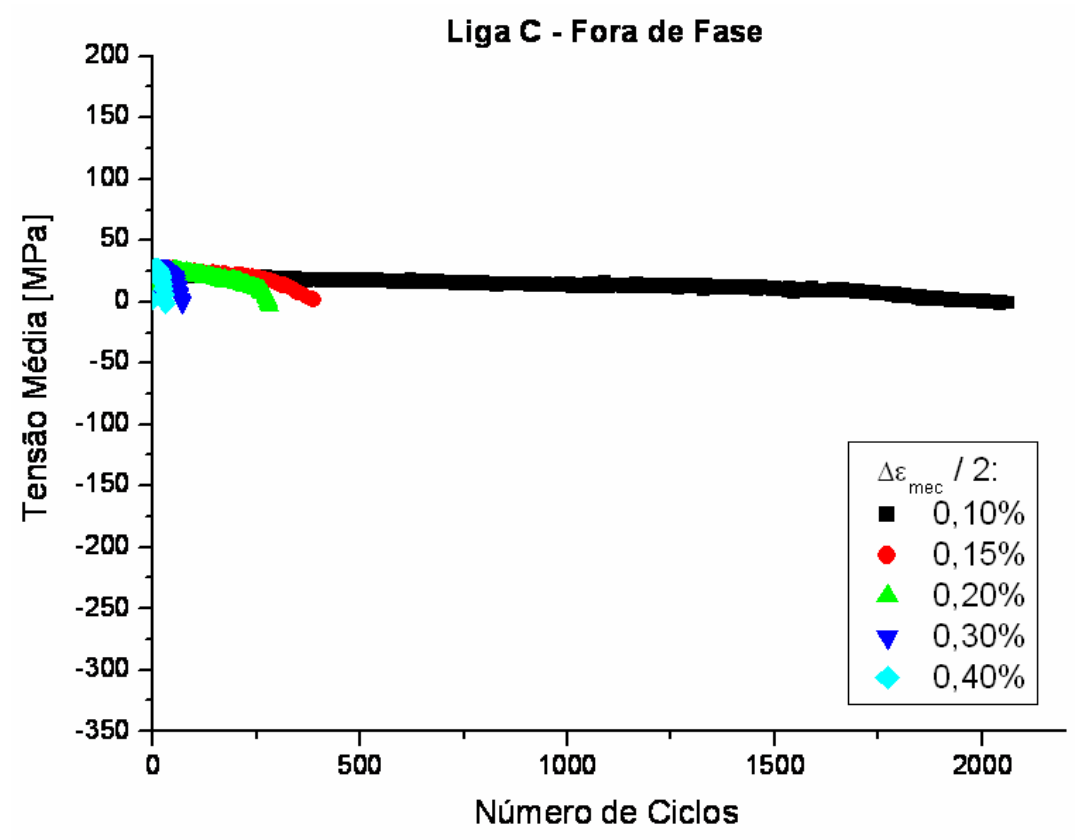

Figura AII.33 - Curvas Tensão em função do Número de Ciclos para a Liga C, fora de fase, comparando as cinco deformações mecânicas.

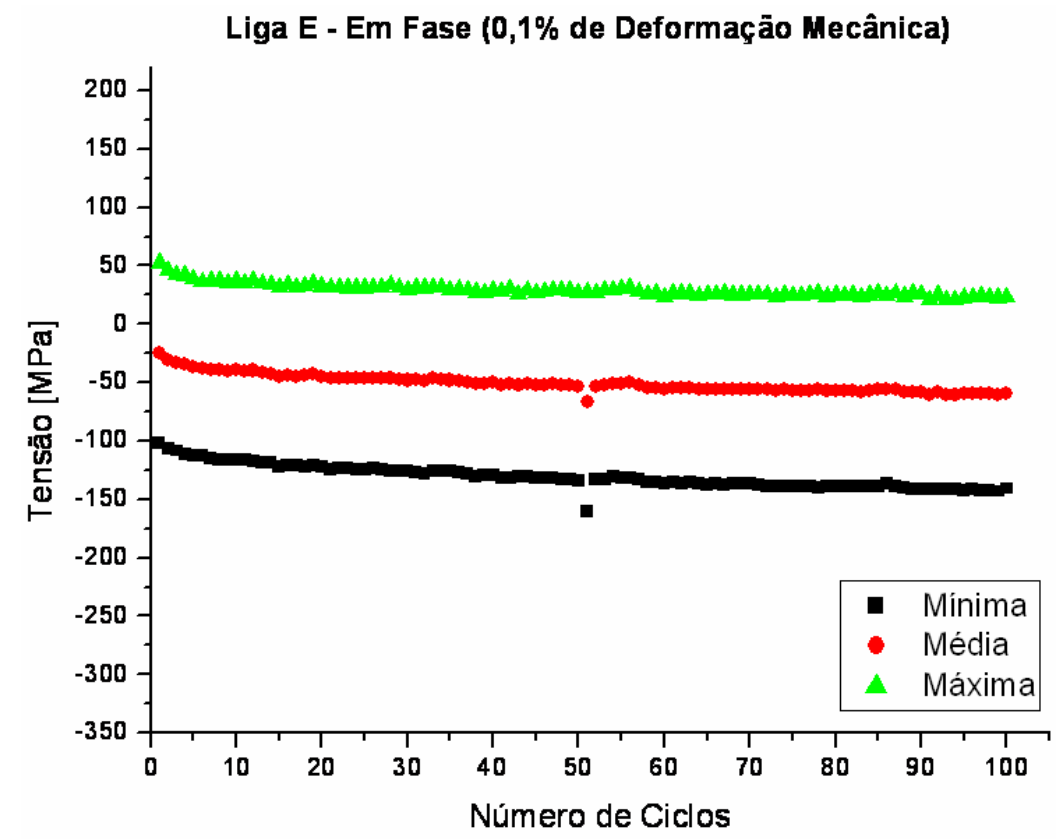

Figura AII.34 - Curvas Tensão em função do Número de Ciclos para a Liga E, ensaiada em fadiga termomecânica, em fase, sob amplitude de deformação mecânica de $0,1 \%$. 


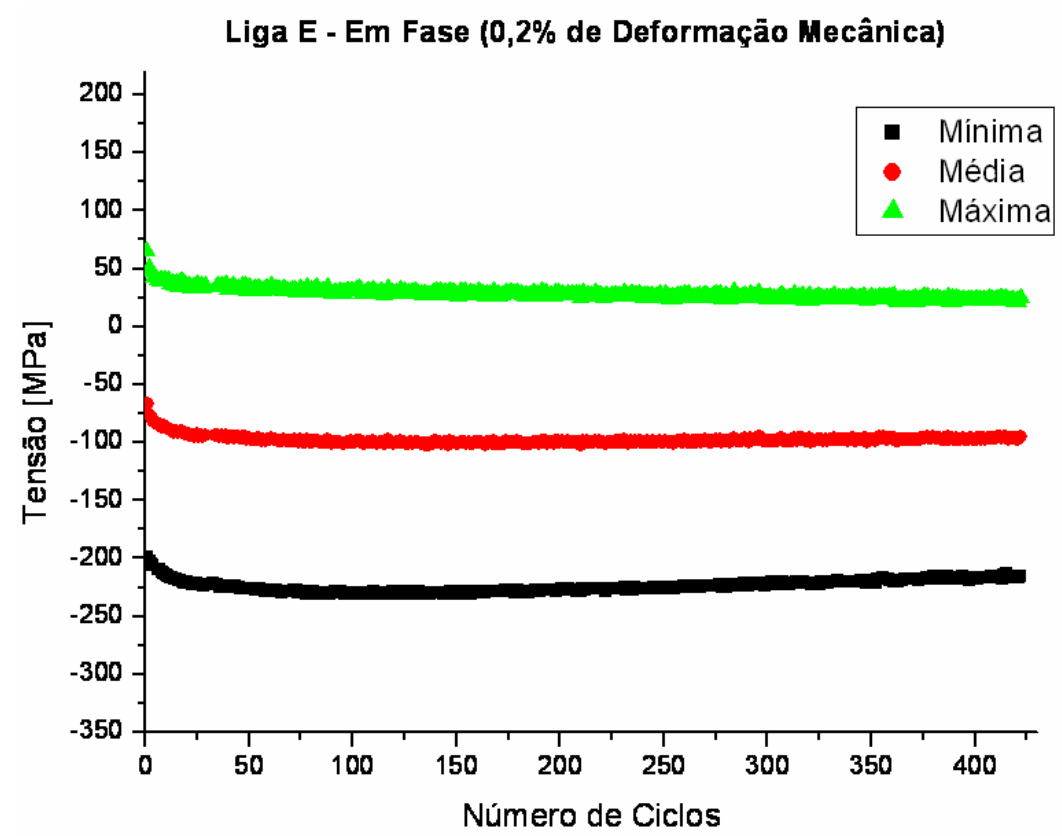

Figura AII.35 - Curvas Tensão em função do Número de Ciclos para a Liga E, ensaiada em fadiga termomecânica, em fase, sob amplitude de deformação mecânica de 0,2\%.

Liga E - Em Fase (0,3\% de Deformação Mecânica)

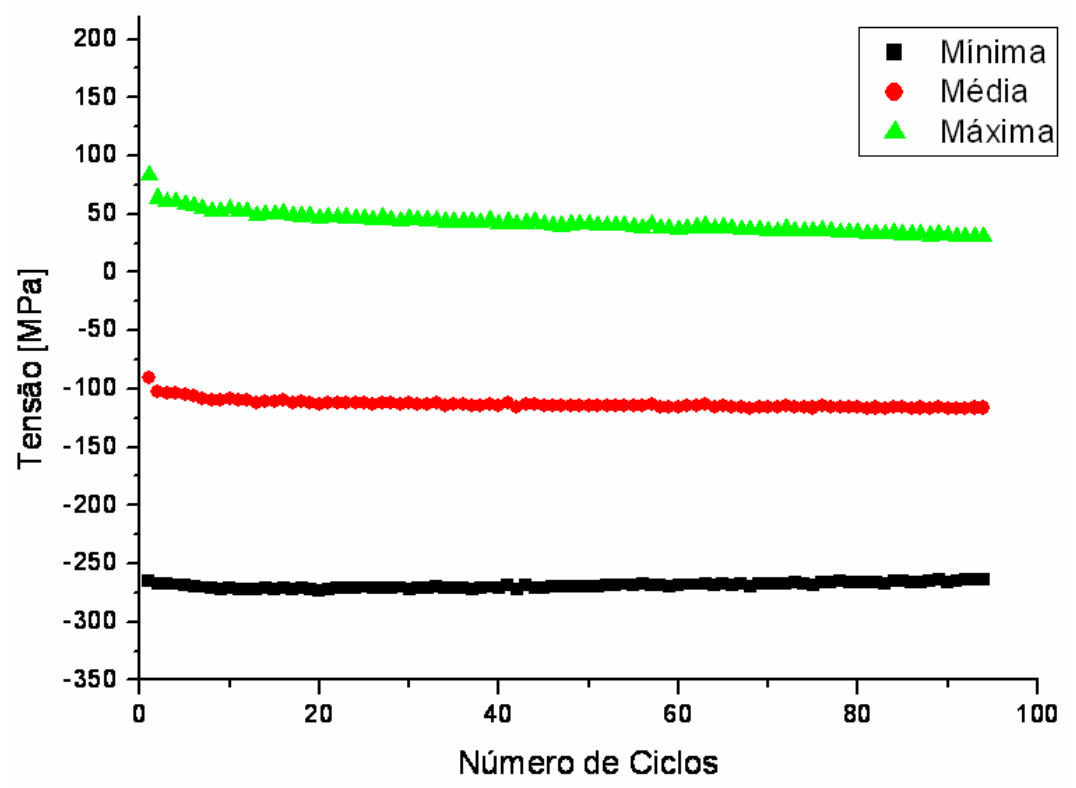

Figura AII.36 - Curvas Tensão em função do Número de Ciclos para a Liga E, ensaiada em fadiga termomecânica, em fase, sob amplitude de deformação mecânica de 0,3\%. 


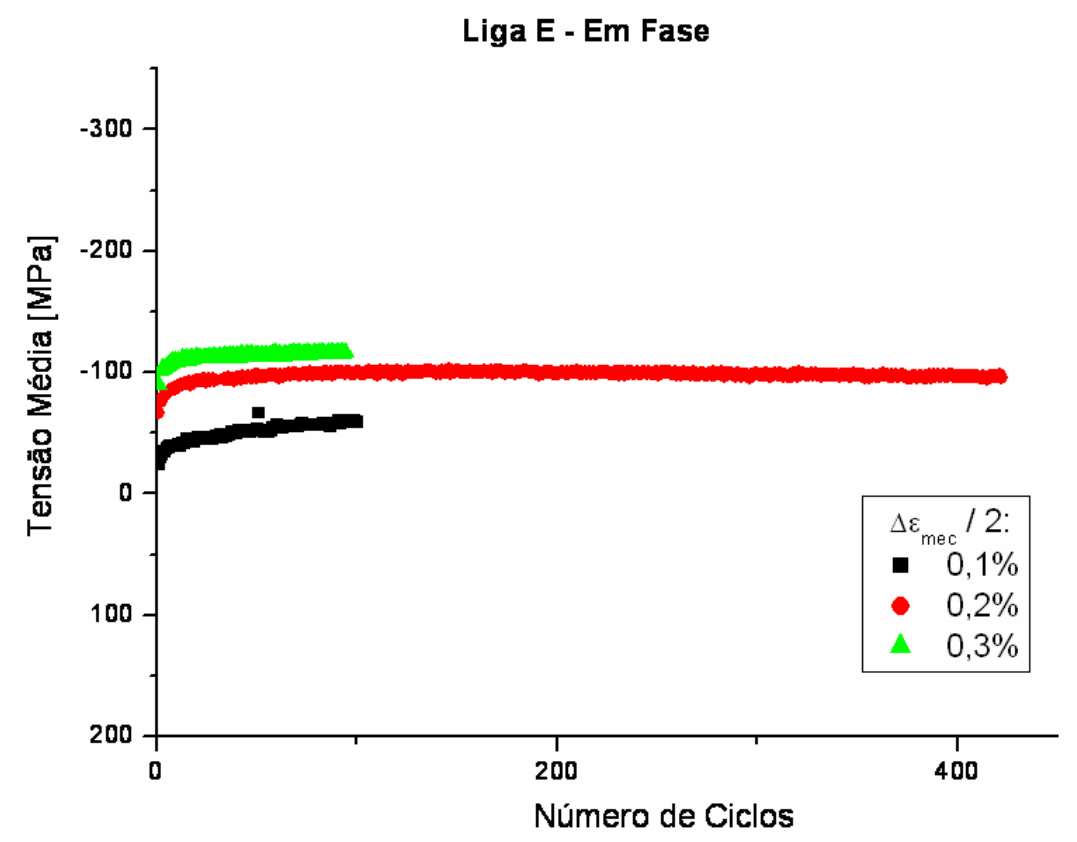

Figura AII.37 - Curvas Tensão em função do Número de Ciclos para a Liga E, em fase, comparando as quatro deformações mecânicas.

Liga E - Fora de Fase (0,1\% de Deformação Mecânica)

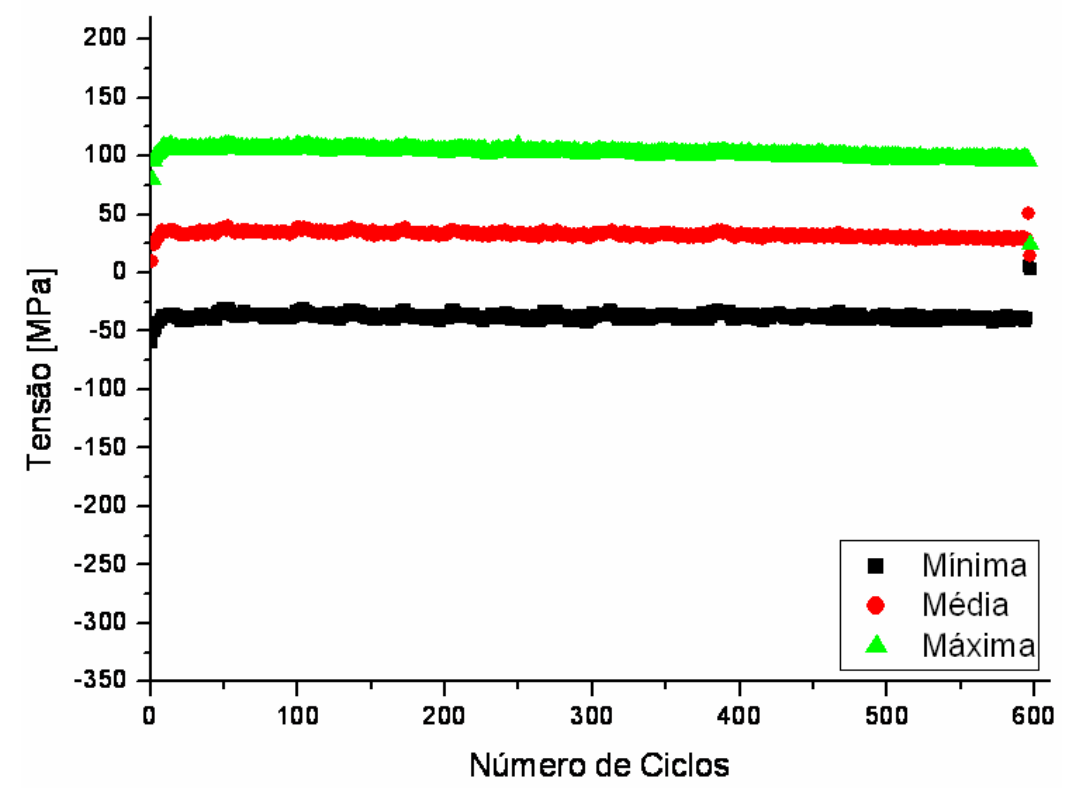

Figura AII.38 - Curvas Tensão em função do Número de Ciclos para a Liga E, ensaiada em fadiga termomecânica, fora de fase, sob amplitude de deformação mecânica de $0,1 \%$. 


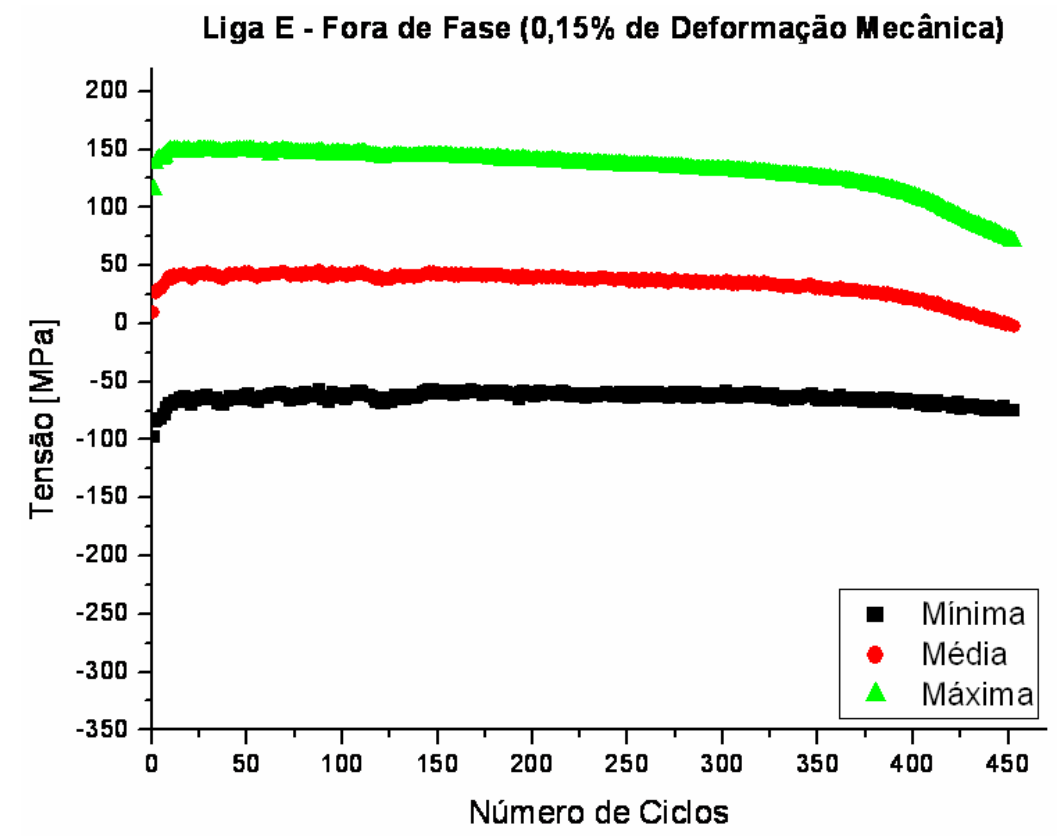

Figura AII.39 - Curvas Tensão em função do Número de Ciclos para a Liga E, ensaiada em fadiga termomecânica, fora de fase, sob amplitude de deformação mecânica de 0,15\%.

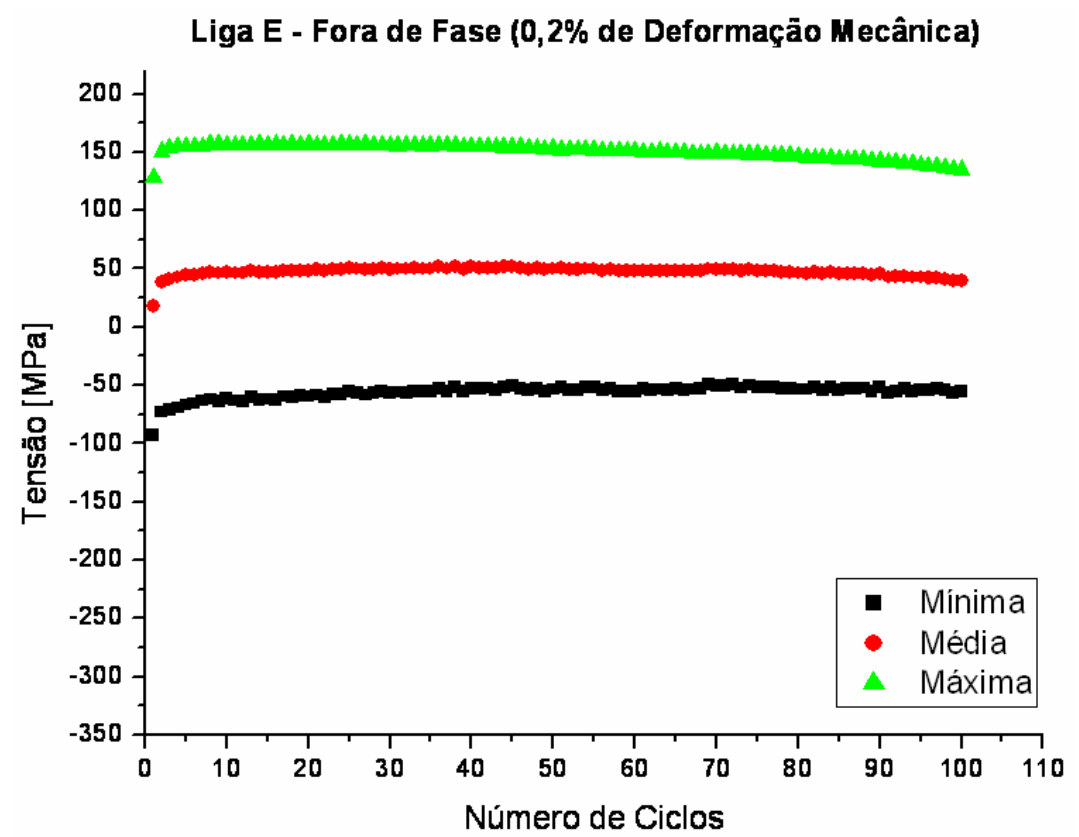

Figura AII.40 - Curvas Tensão em função do Número de Ciclos para a Liga E, ensaiada em fadiga termomecânica, fora de fase, sob amplitude de deformação mecânica de $0,2 \%$. 


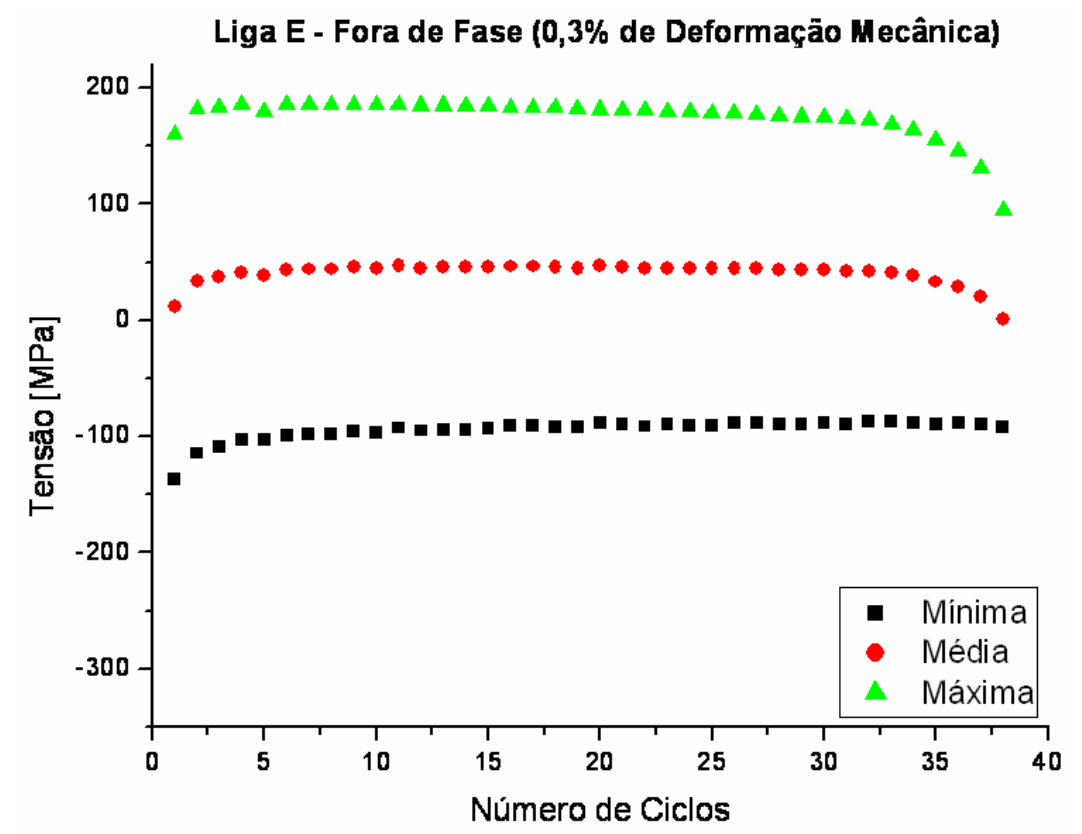

Figura AII.41 - Curvas Tensão em função do Número de Ciclos para a Liga E, ensaiada em fadiga termomecânica, fora de fase, sob amplitude de deformação mecânica de $0,3 \%$.

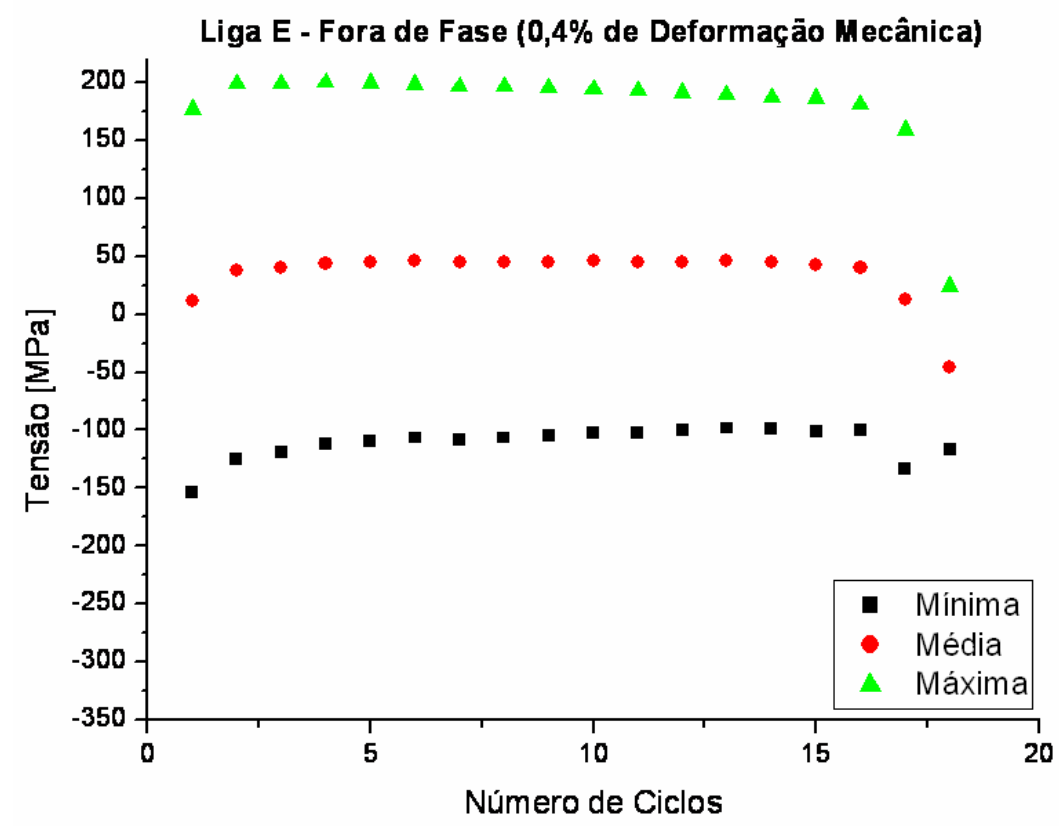

Figura AII.42 - Curvas Tensão em função do Número de Ciclos para a Liga E, ensaiada em fadiga termomecânica, fora de fase, sob amplitude de deformação mecânica de 0,4\%. 


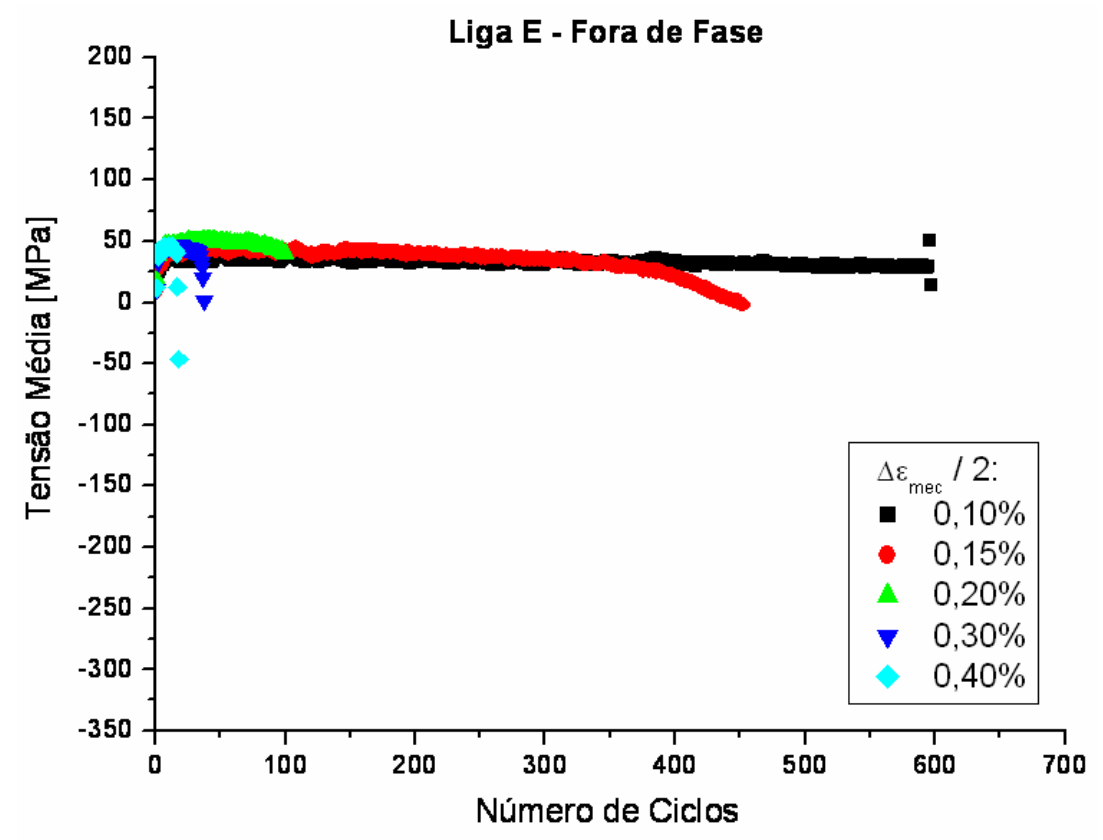

Figura AII.43 - Curvas Tensão em função do Número de Ciclos para a Liga E, fora de fase, comparando as cinco deformações mecânicas. 


\section{2) GRÁFICOS TENSÃO X DEFORMAÇÃO TOTAL}

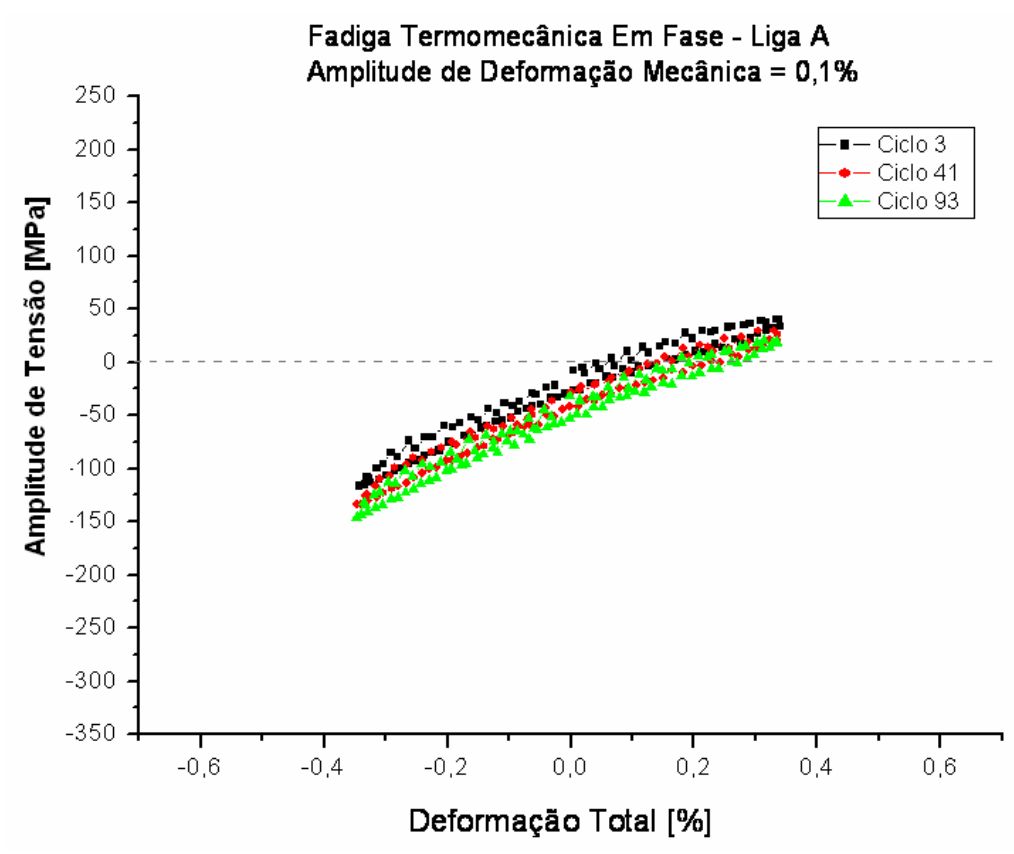

Figura AII.44 - Gráfico da Amplitude de Tensão em função da Amplitude de Deformação Total, para condição em fase da Liga A em amplitude de deformação mecânica de $0,1 \%$.

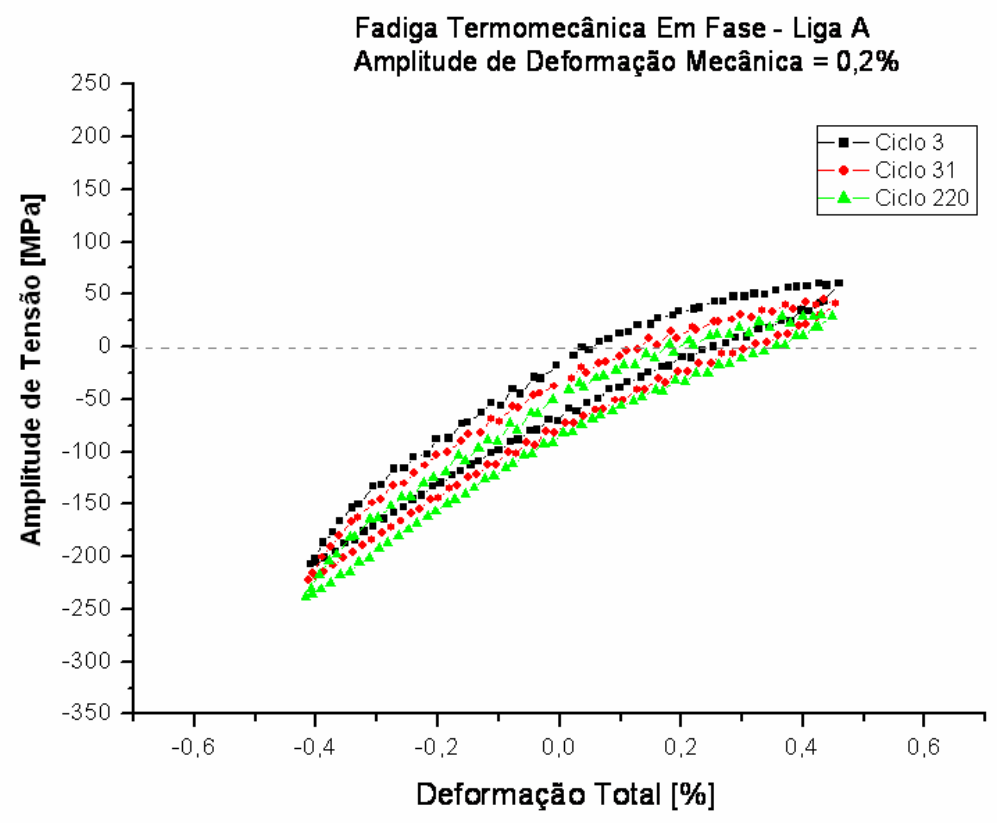

Figura AII.45 - Gráfico da Amplitude de Tensão em função da Amplitude de Deformação Total, para condição em fase da Liga A em amplitude de deformação mecânica de $0,2 \%$. 


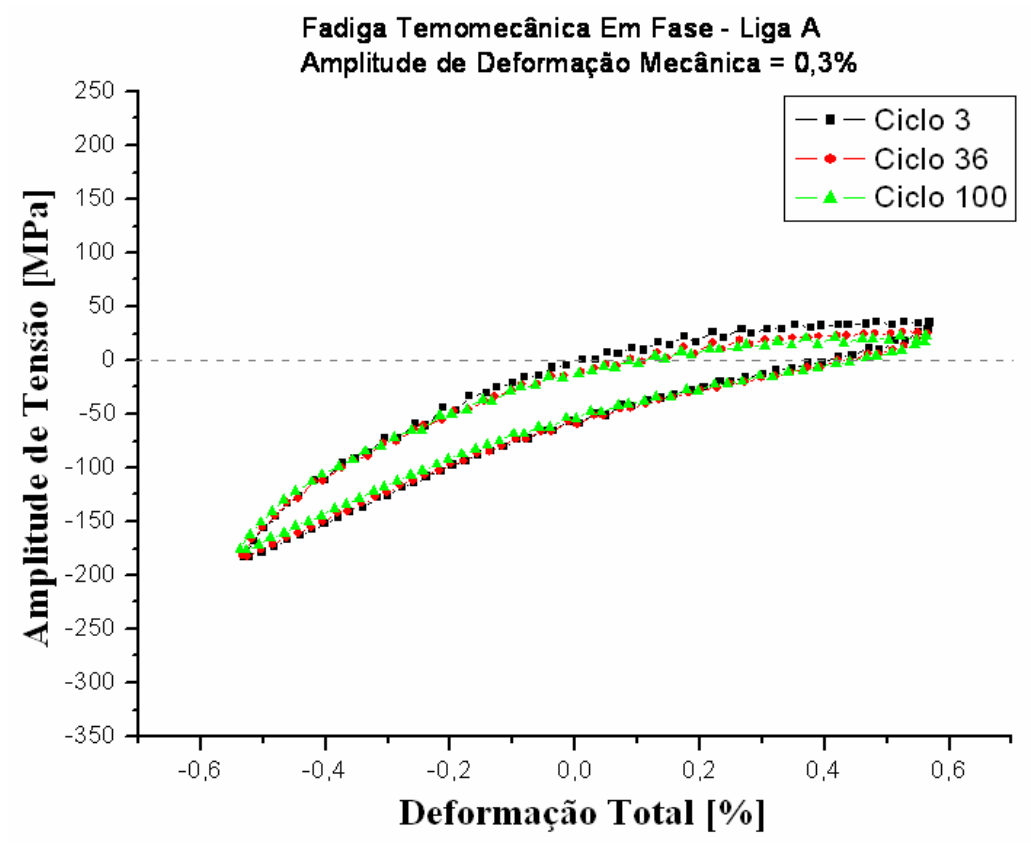

Figura AII.46 - Gráfico da Amplitude de Tensão em função da Amplitude de Deformação Total, para condição em fase da Liga A em amplitude de deformação mecânica de $0,3 \%$.

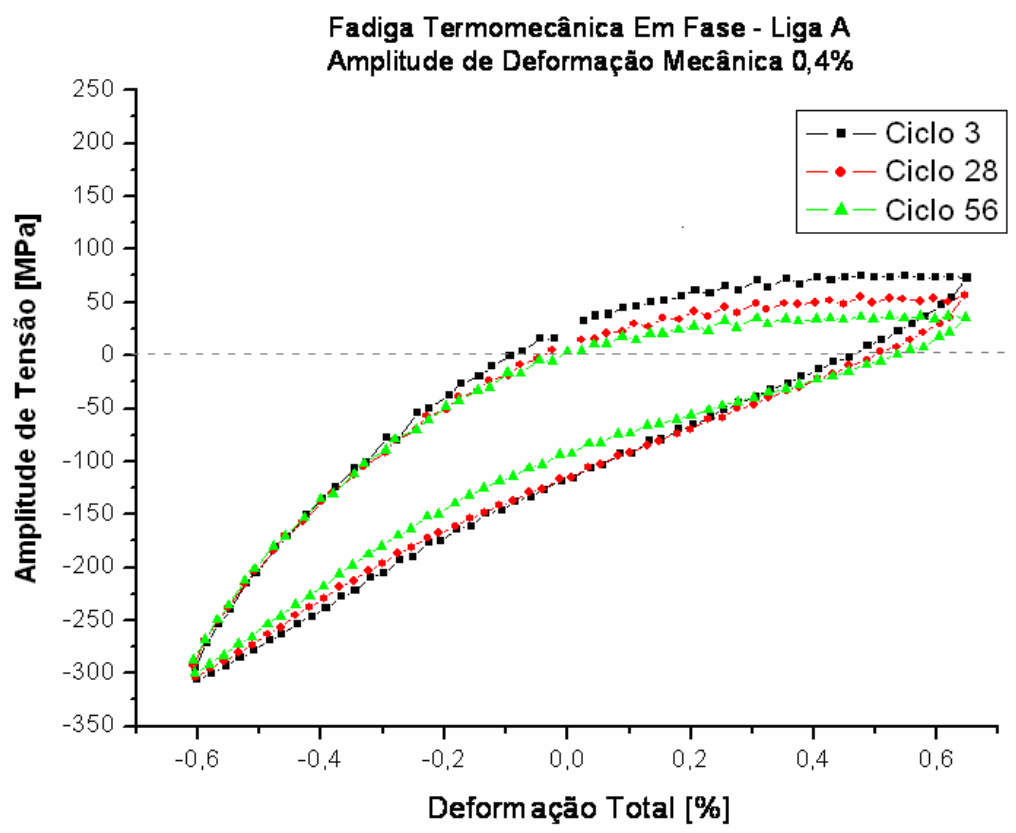

Figura AII.47 - Gráfico da Amplitude de Tensão em função da Amplitude de Deformação Total, para condição em fase da Liga A em amplitude de deformação mecânica de $0,4 \%$. 


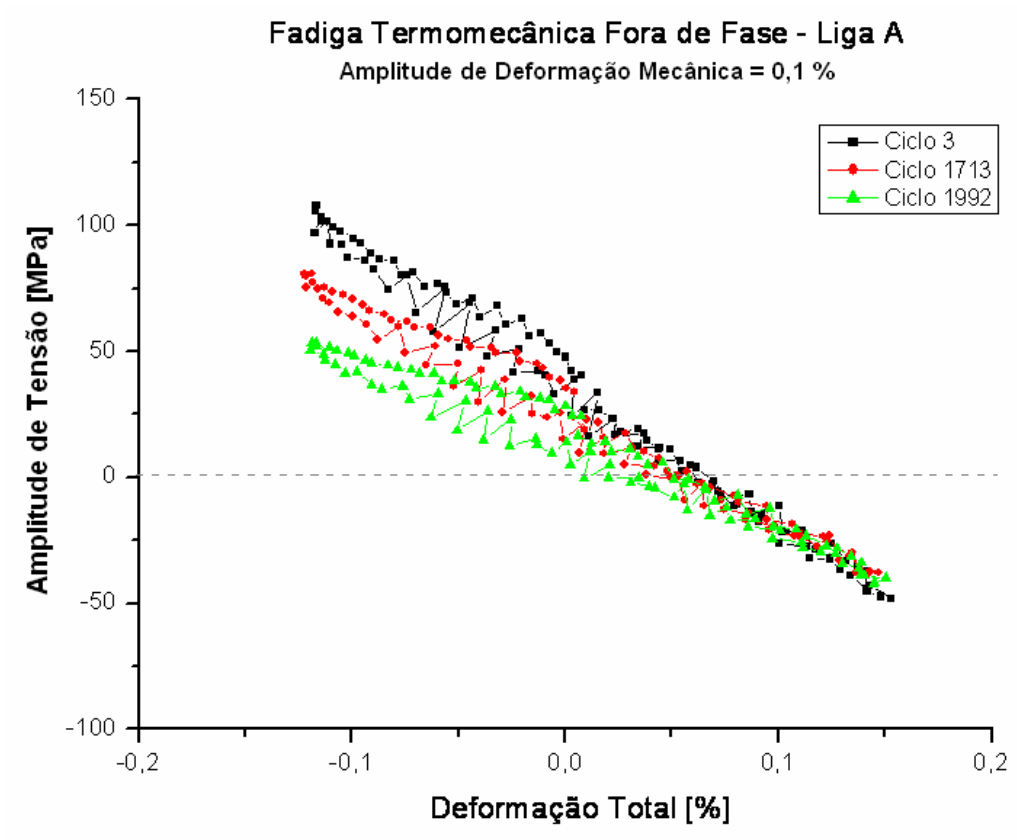

Figura AII.48 - Gráfico da Amplitude de Tensão em função da Amplitude de Deformação Total, para condição fora de fase da Liga A em amplitude de deformação mecânica de $0,1 \%$.

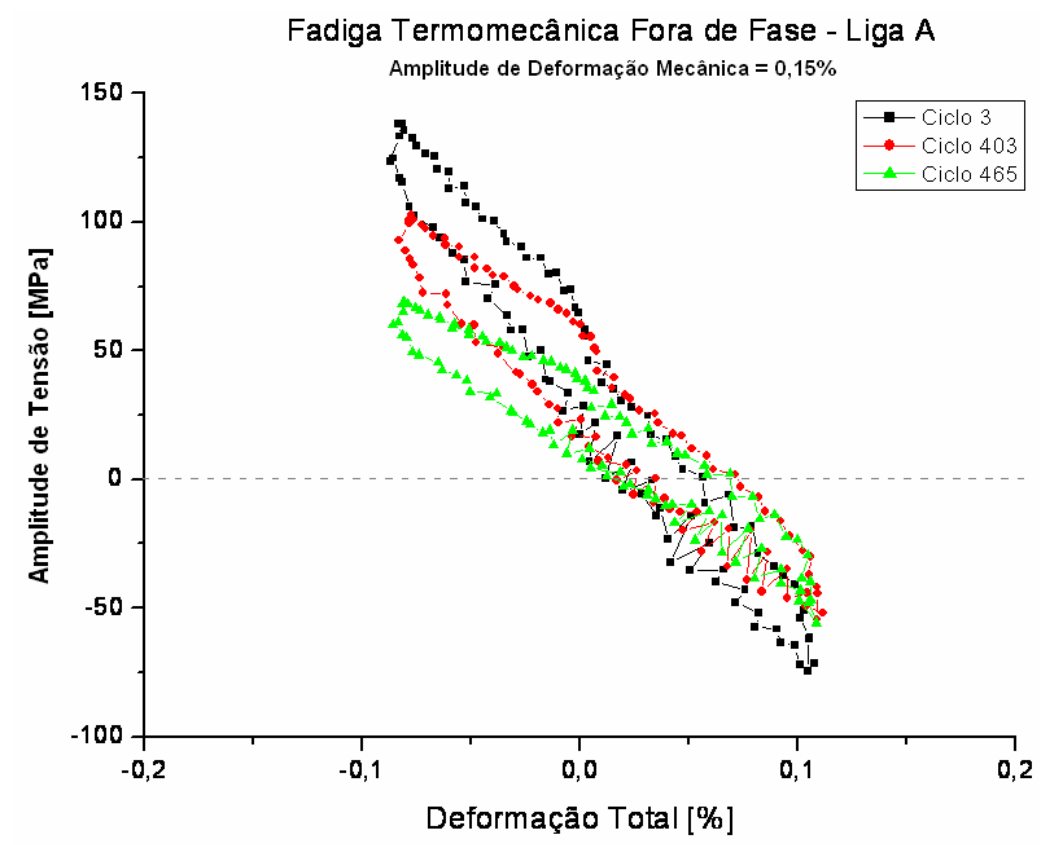

Figura AII.49 - Gráfico da Amplitude de Tensão em função da Amplitude de Deformação Total, para condição fora de fase da Liga A em amplitude de deformação mecânica de $0,15 \%$. 


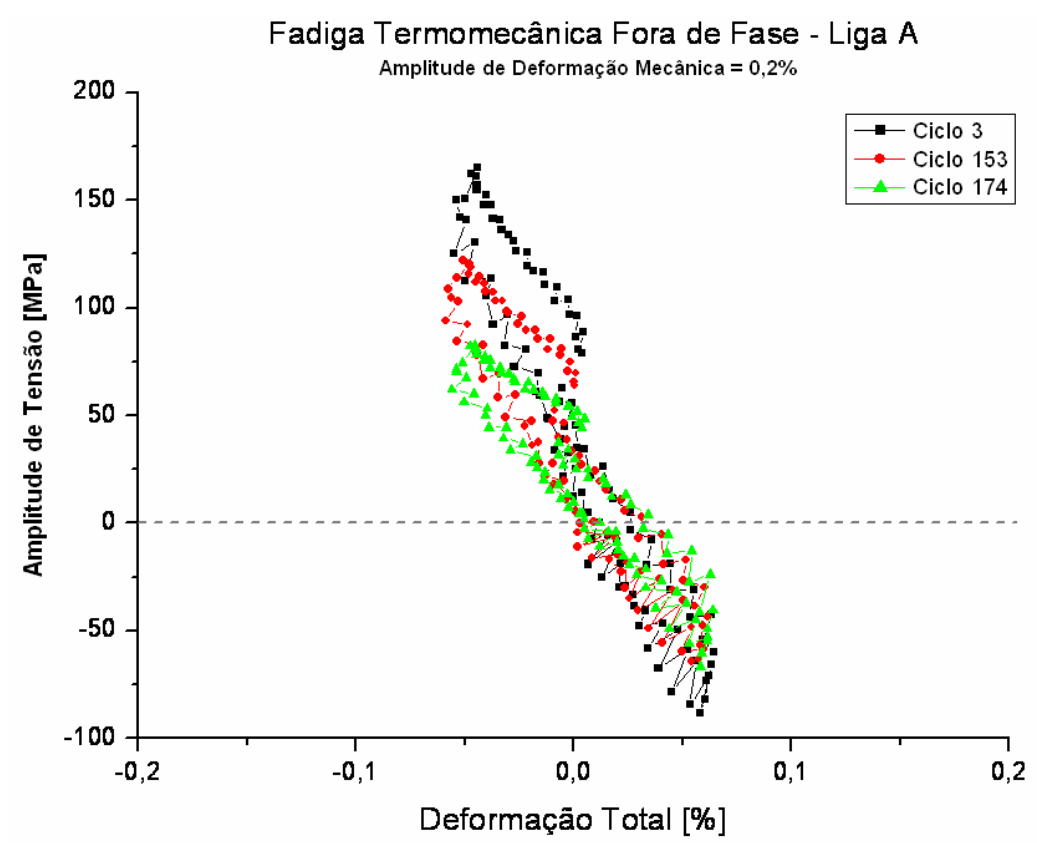

Figura AII.50 - Gráfico da Amplitude de Tensão em função da Amplitude de Deformação Total, para condição fora de fase da Liga A em amplitude de deformação mecânica de $0,2 \%$.

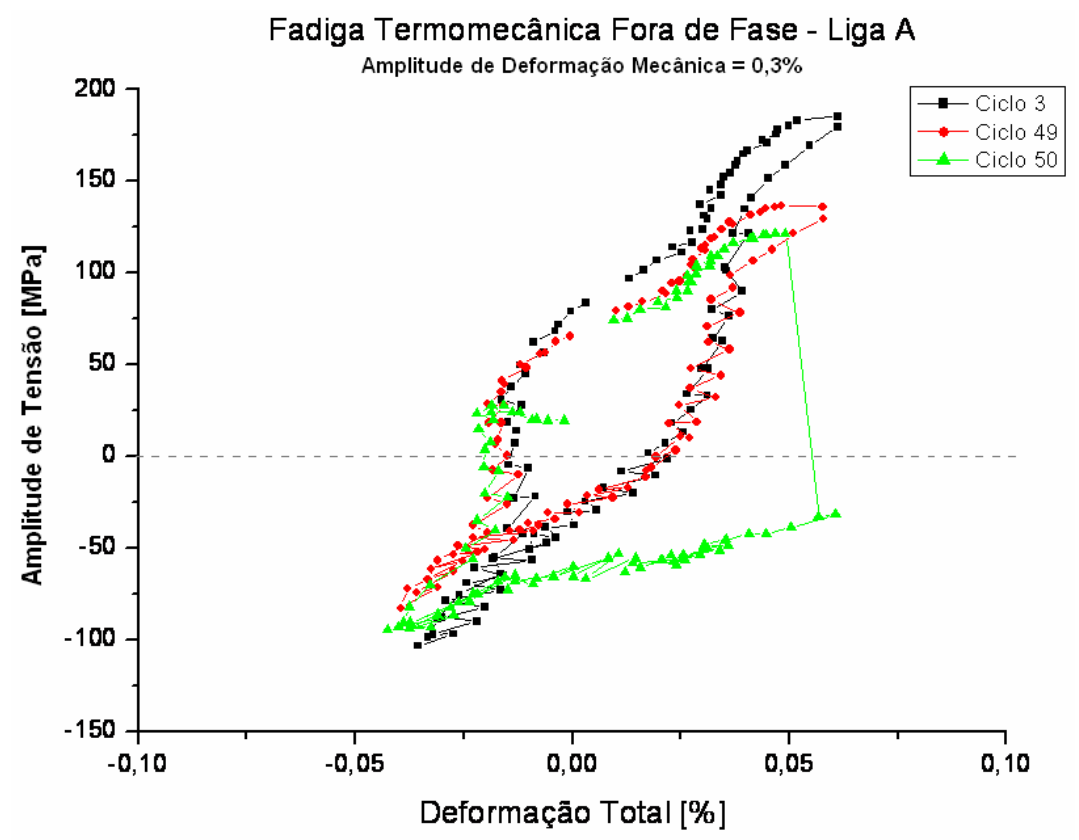

Figura AII.51 - Gráfico da Amplitude de Tensão em função da Amplitude de Deformação Total, para condição fora de fase da Liga A em amplitude de deformação mecânica de $0,3 \%$. 


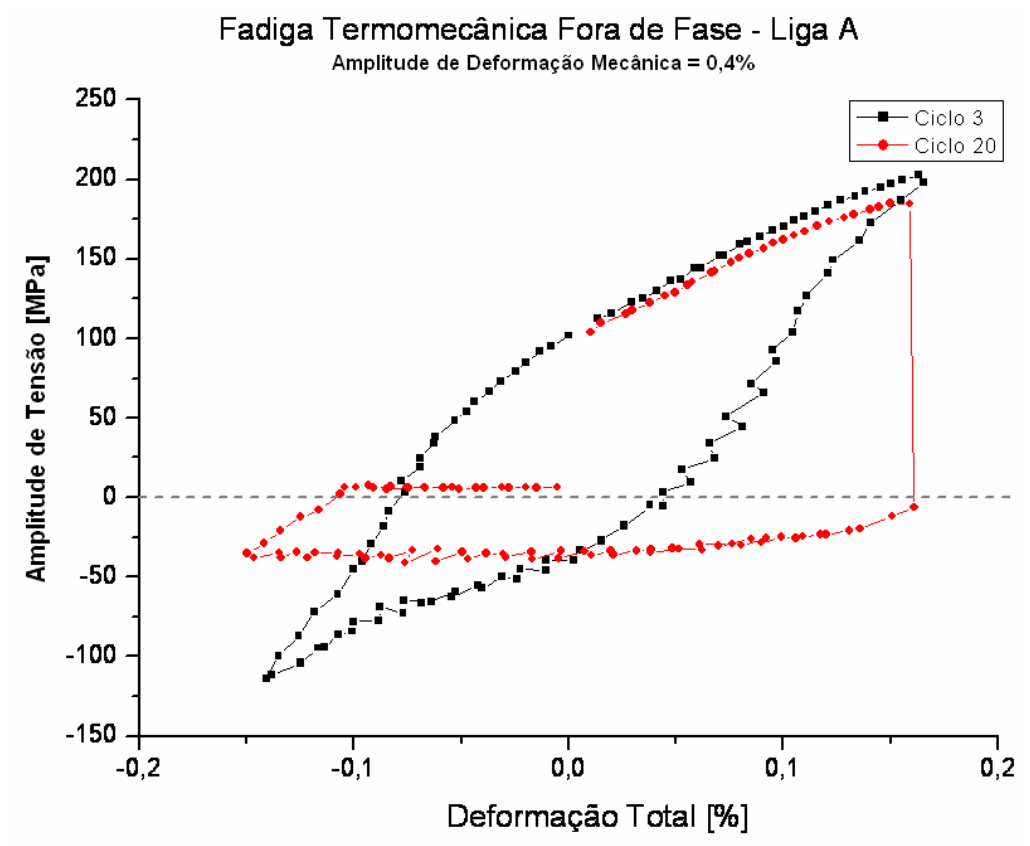

Figura AII.52 - Gráfico da Amplitude de Tensão em função da Amplitude de Deformação Total, para condição fora de fase da Liga A em amplitude de deformação mecânica de $0,4 \%$.

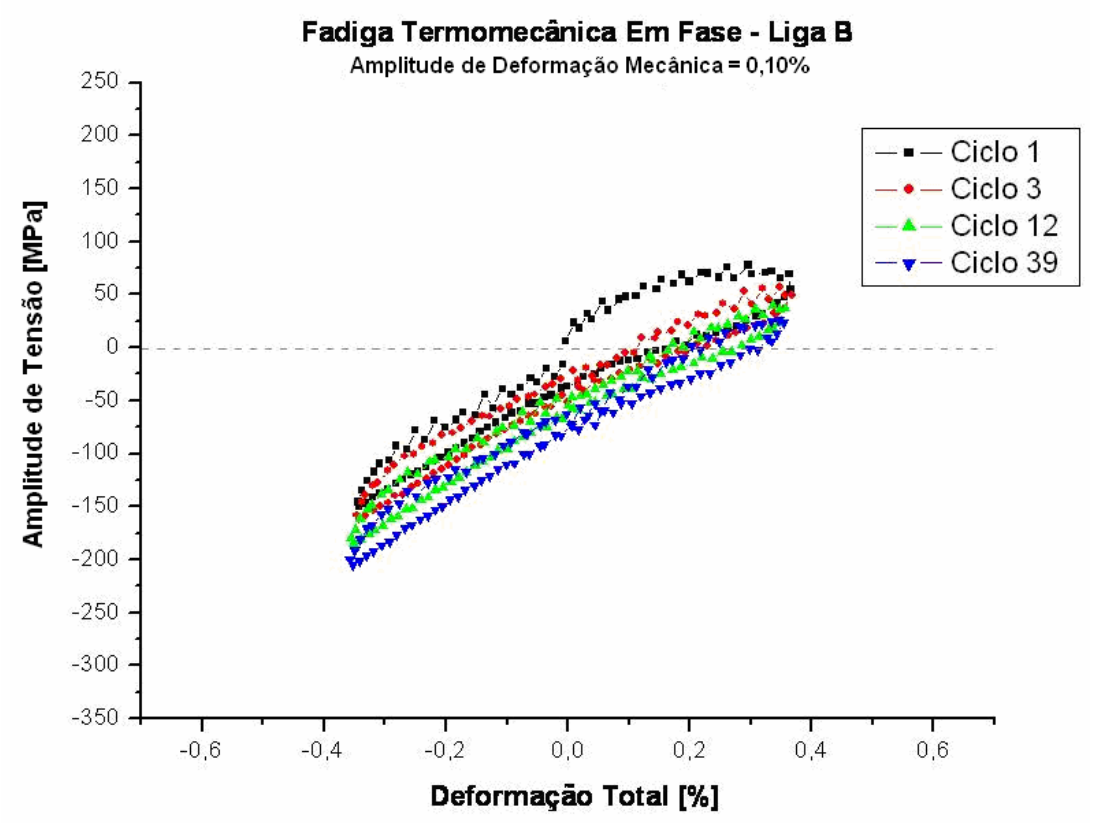

Figura AII.53 - Gráfico da Amplitude de Tensão em função da Amplitude de Deformação Total, para condição em fase da Liga B em amplitude de deformação mecânica de $0,1 \%$. 


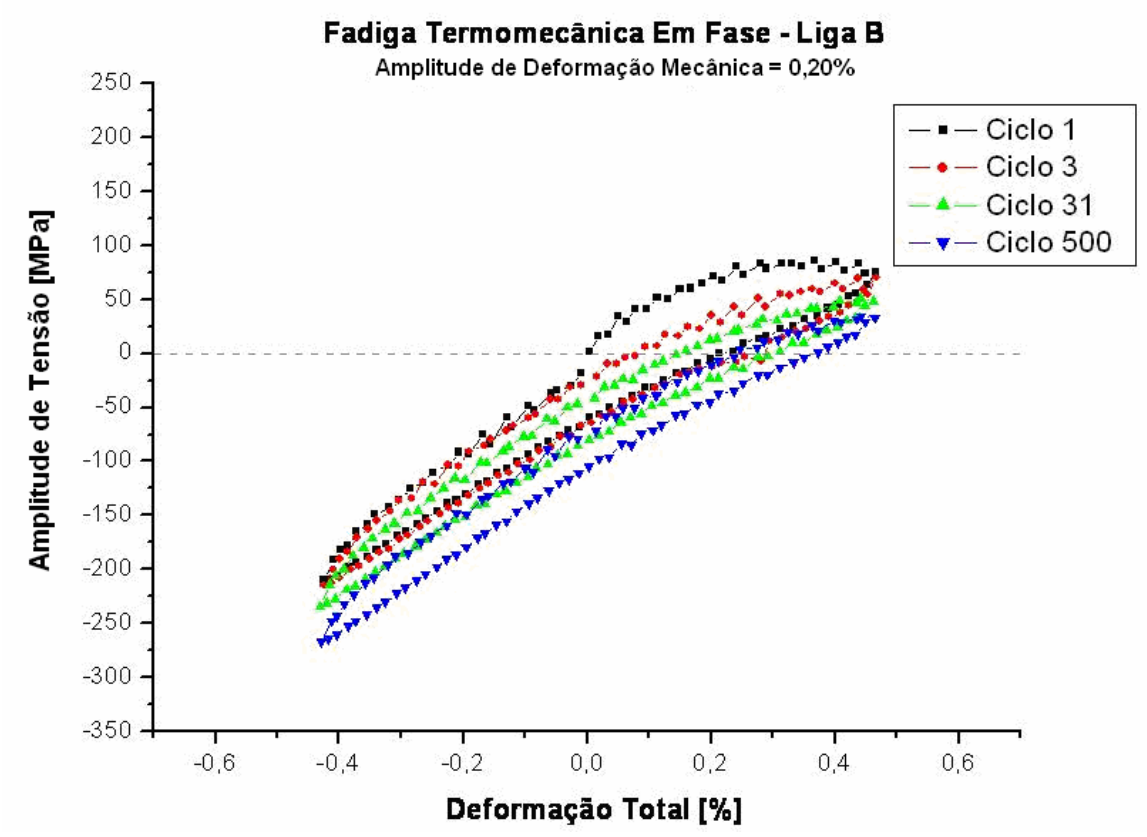

Figura AII.54 - Gráfico da Amplitude de Tensão em função da Amplitude de Deformação Total, para condição em fase da Liga B em amplitude de deformação mecânica de $0,2 \%$.

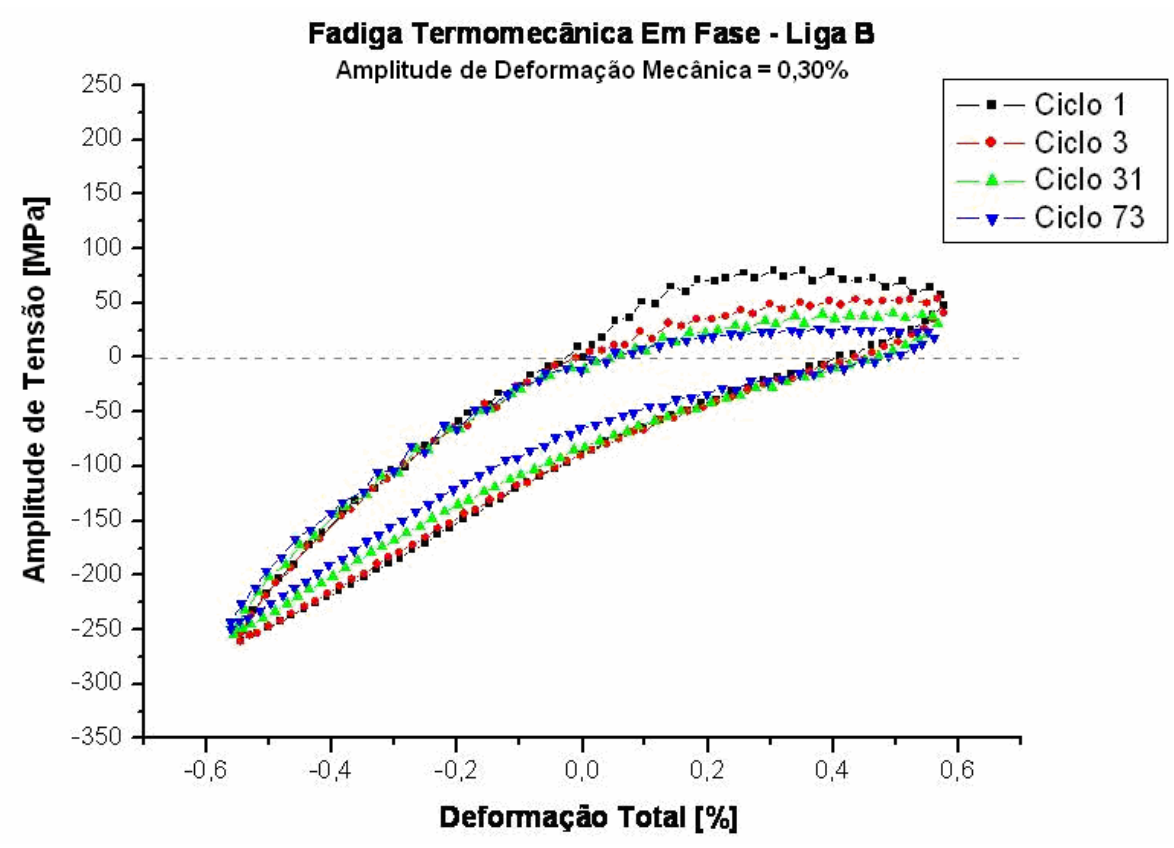

Figura AII.55 - Gráfico da Amplitude de Tensão em função da Amplitude de Deformação Total, para condição em fase da Liga B em amplitude de deformação mecânica de $0,3 \%$. 


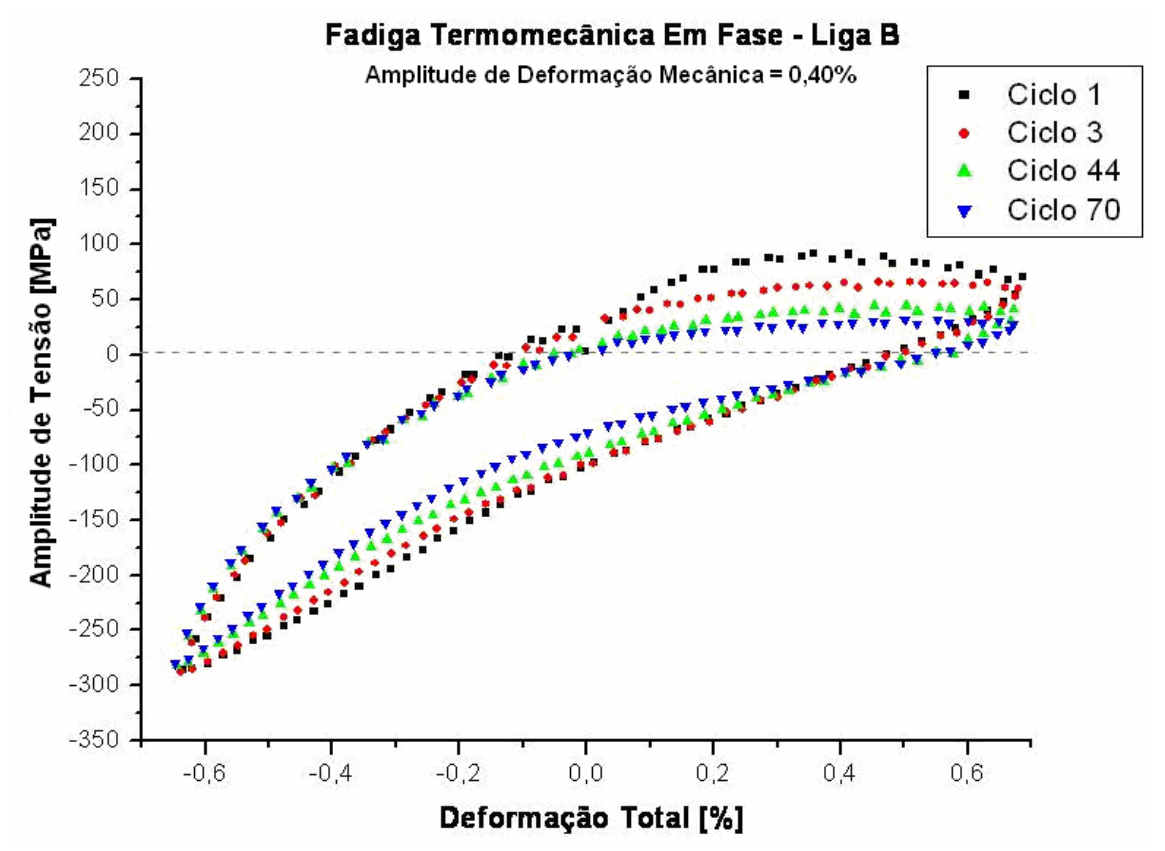

Figura AII.56- Gráfico da Amplitude de Tensão em função da Amplitude de Deformação Total, para condição em fase da Liga B em amplitude de deformação mecânica de $0,4 \%$.

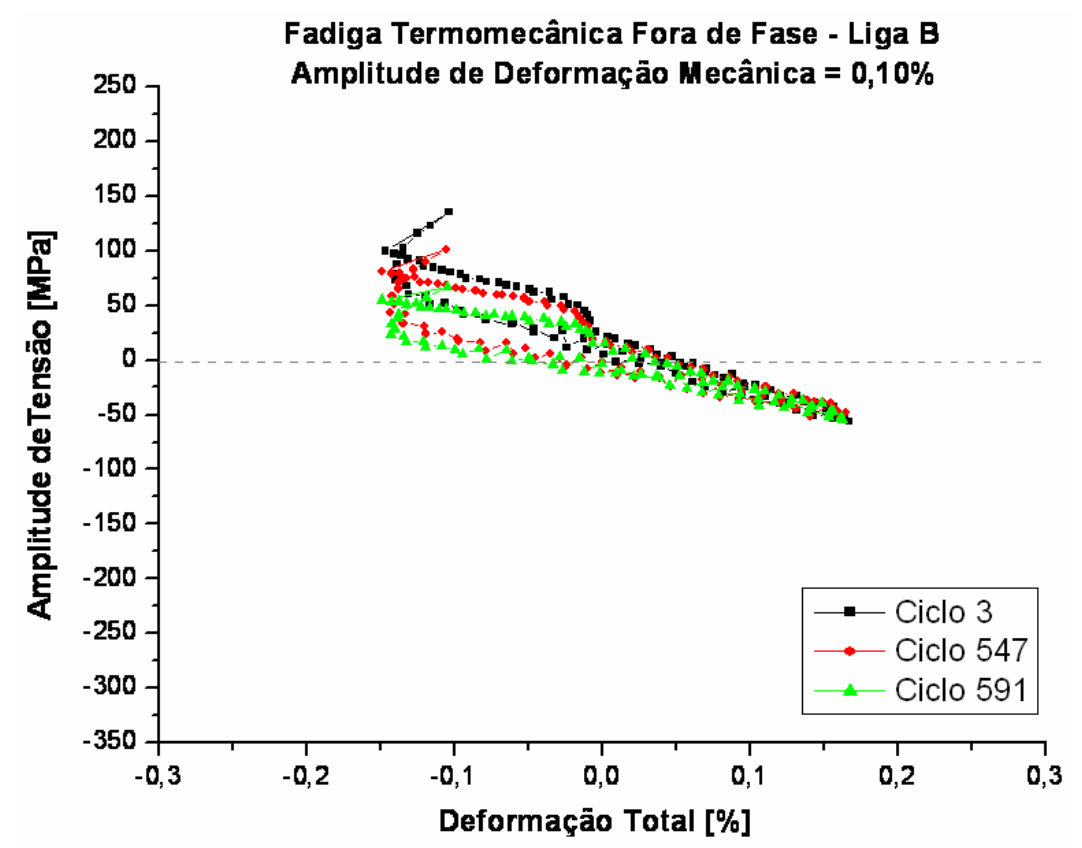

Figura AII.57 - Gráfico da Amplitude de Tensão em função da Amplitude de Deformação Total, para condição fora de fase da Liga B em amplitude de deformação mecânica de $0,1 \%$. 


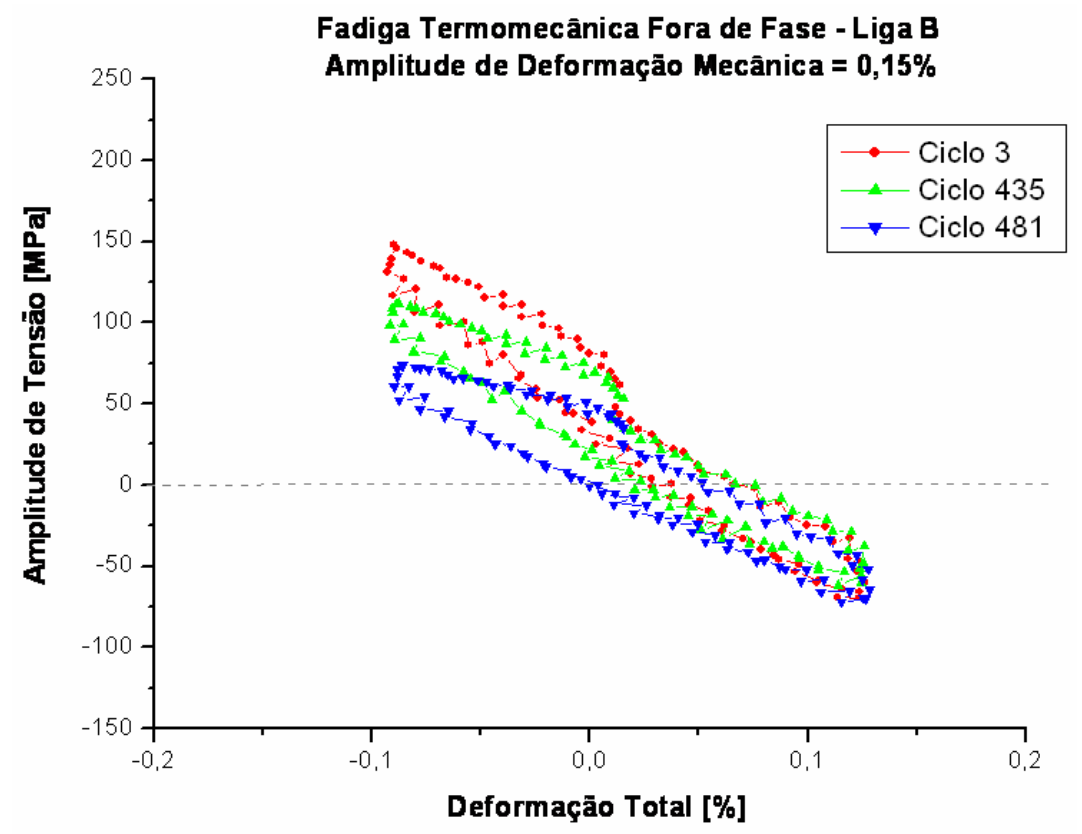

Figura AII.58 - Gráfico da Amplitude de Tensão em função da Amplitude de Deformação Total, para condição fora de fase da Liga B em amplitude de deformação mecânica de $0,15 \%$.

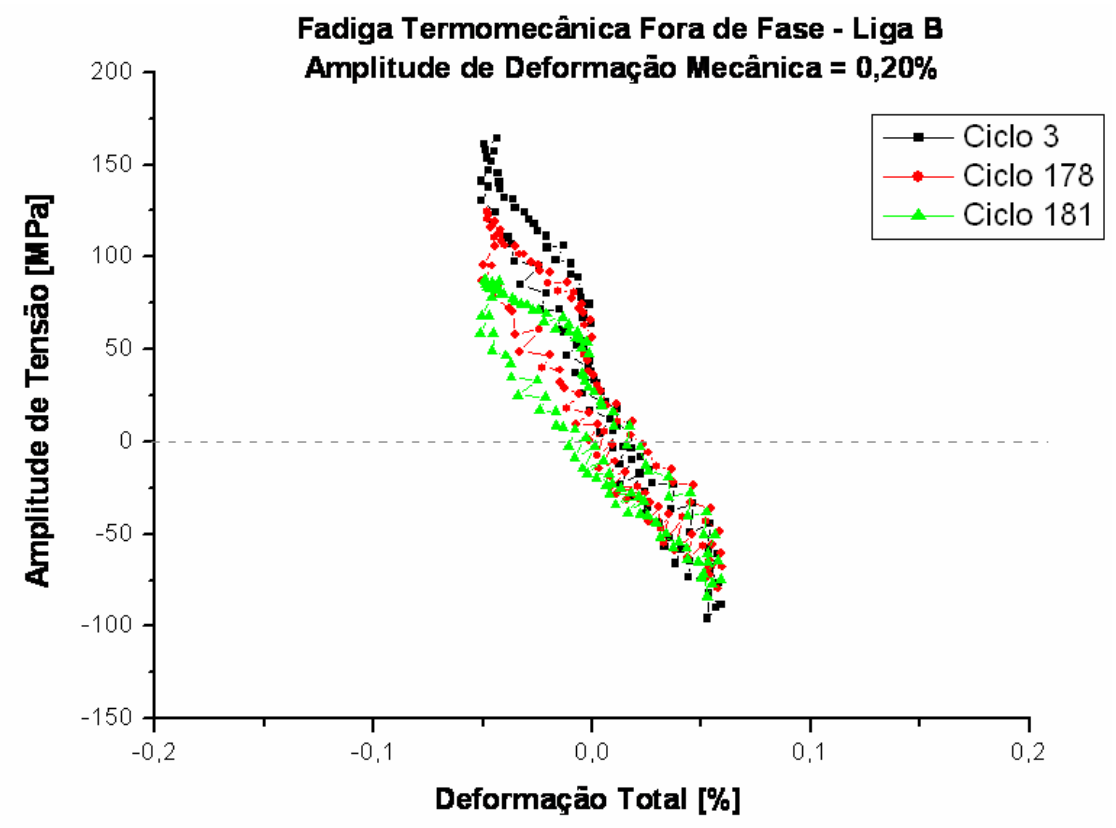

Figura AII.59 - Gráfico da Amplitude de Tensão em função da Amplitude de Deformação Total, para condição fora de fase da Liga B em amplitude de deformação mecânica de $0,2 \%$. 


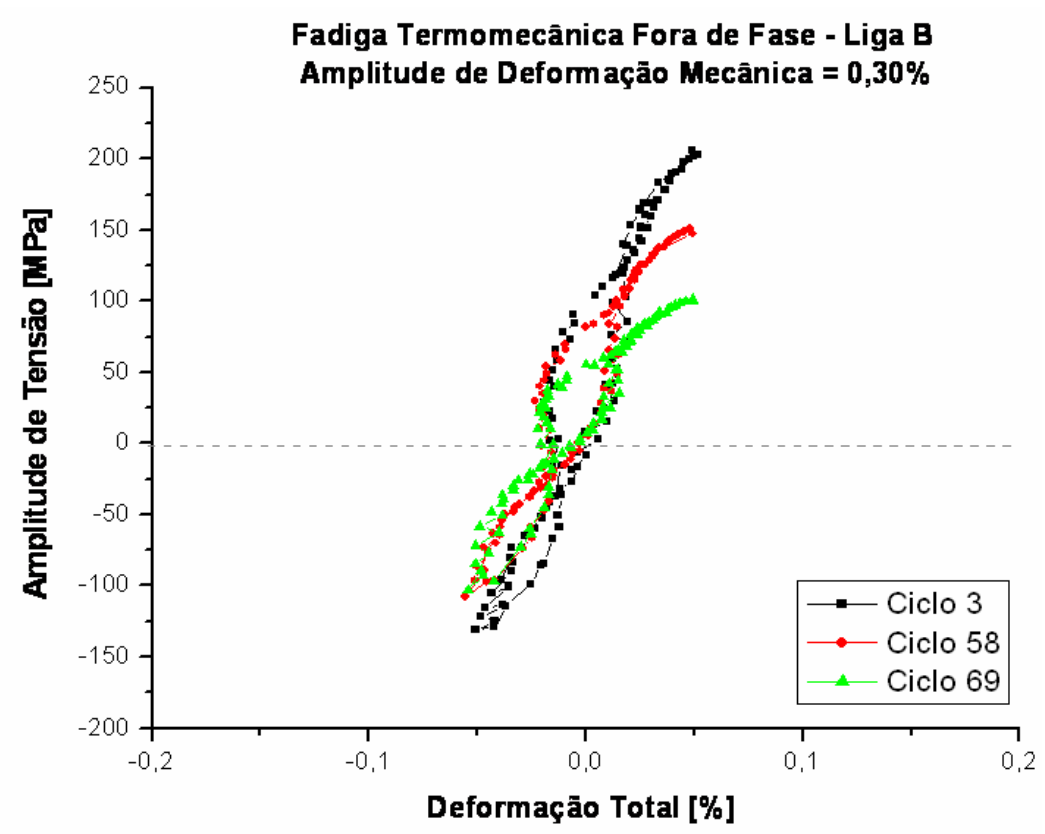

Figura AII.60 - Gráfico da Amplitude de Tensão em função da Amplitude de Deformação Total, para condição fora de fase da Liga B em amplitude de deformação mecânica de 0,3\%.

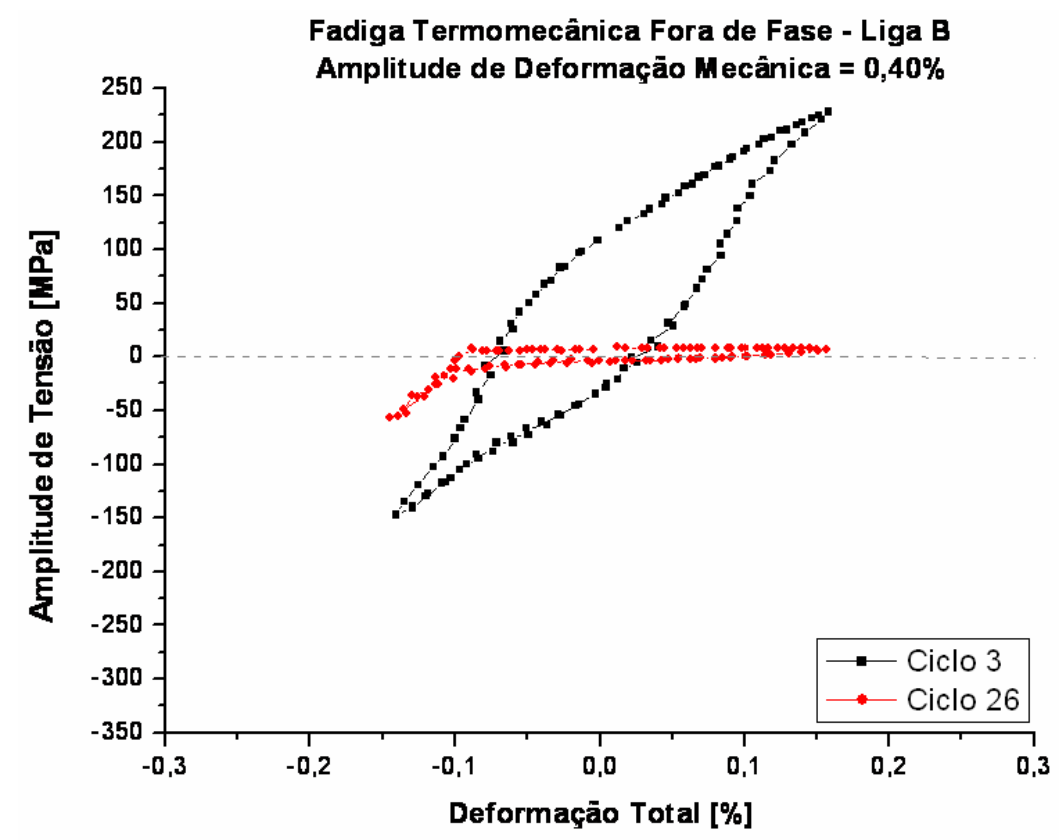

Figura AII.61 - Gráfico da Amplitude de Tensão em função da Amplitude de Deformação Total, para condição fora de fase da Liga B em amplitude de deformação mecânica de $0,4 \%$. 


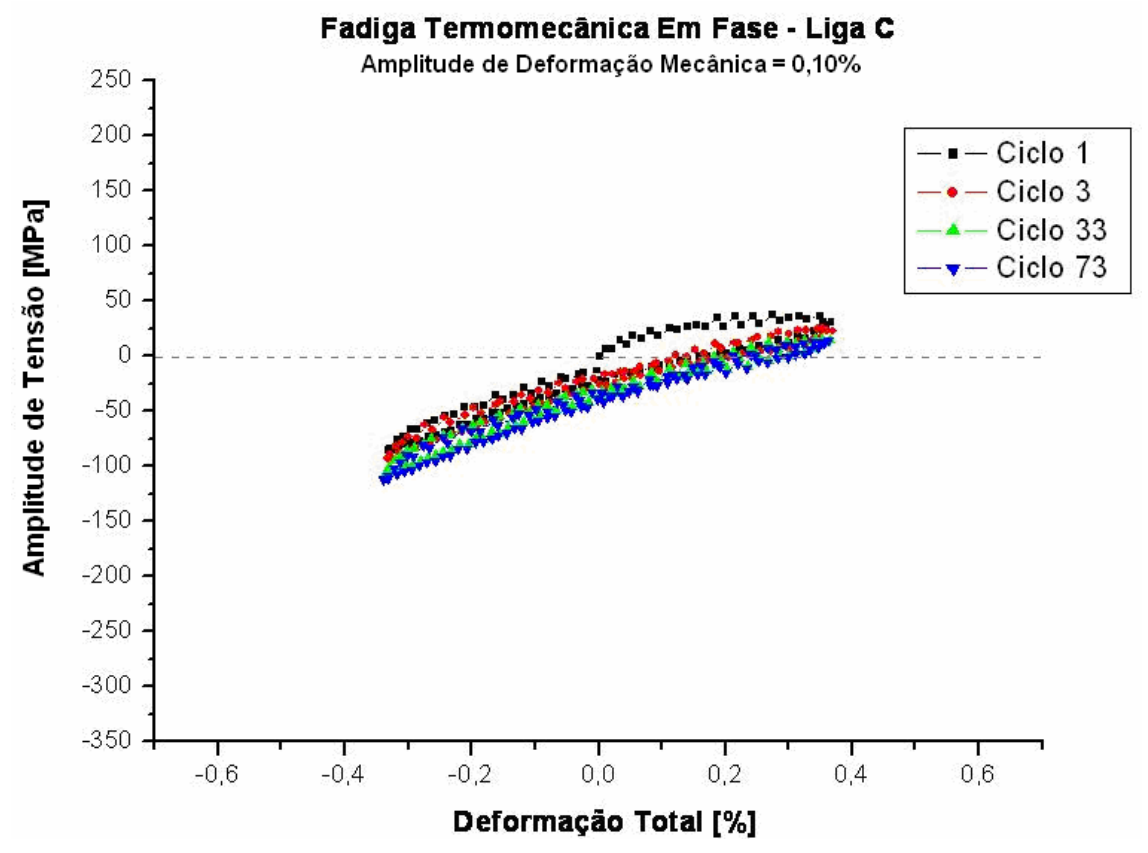

Figura AII.62 - Gráfico da Amplitude de Tensão em função da Amplitude de Deformação Total, para condição em fase da Liga $\mathrm{C}$ em amplitude de deformação mecânica de $0,1 \%$.

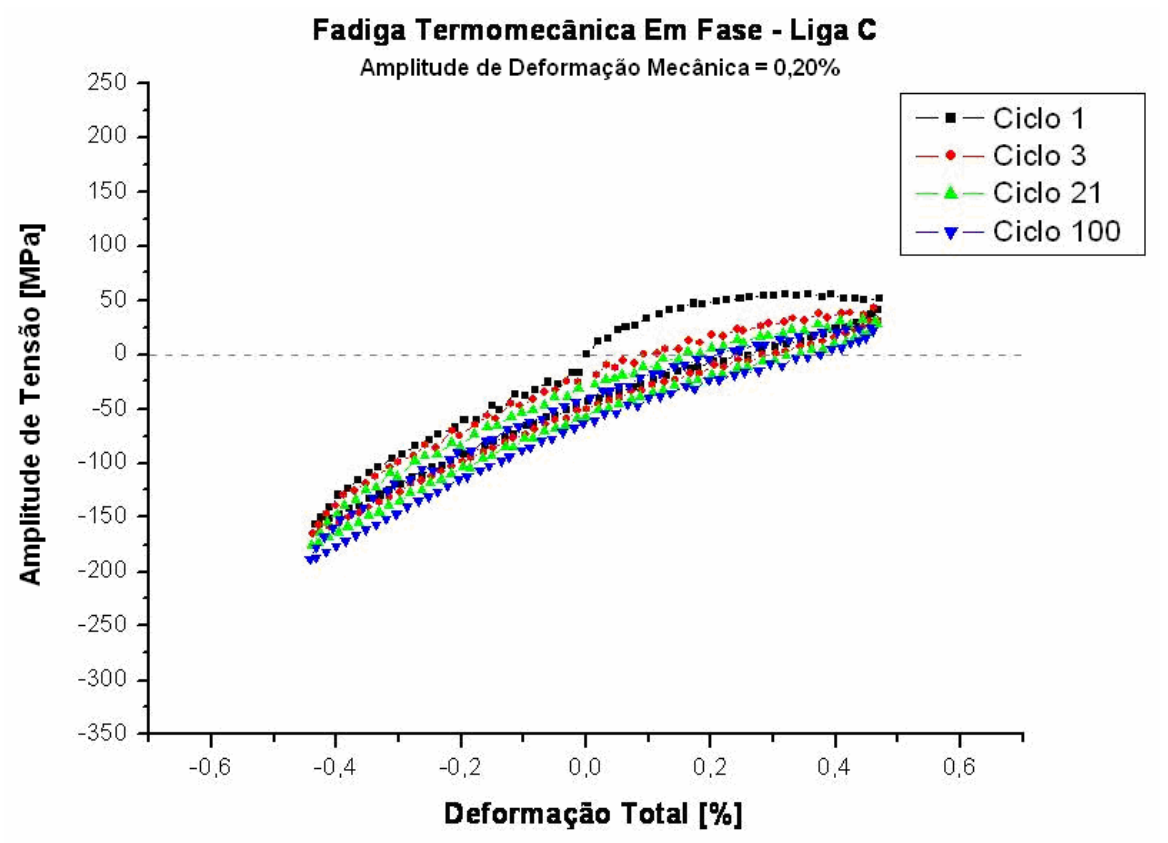

Figura AII.63 - Gráfico da Amplitude de Tensão em função da Amplitude de Deformação Total, para condição em fase da Liga $\mathrm{C}$ em amplitude de deformação mecânica de $0,2 \%$. 


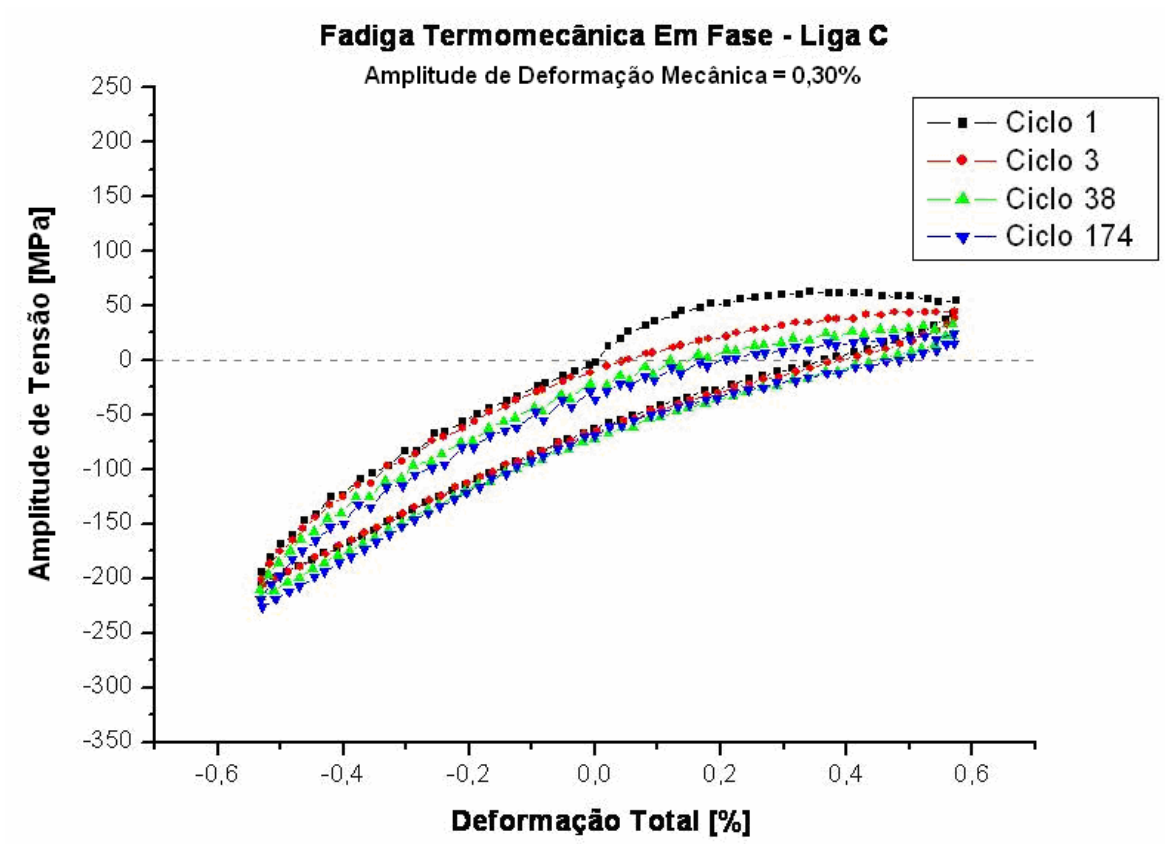

Figura AII.64 - Gráfico da Amplitude de Tensão em função da Amplitude de Deformação Total, para condição em fase da Liga $\mathrm{C}$ em amplitude de deformação mecânica de $0,3 \%$.

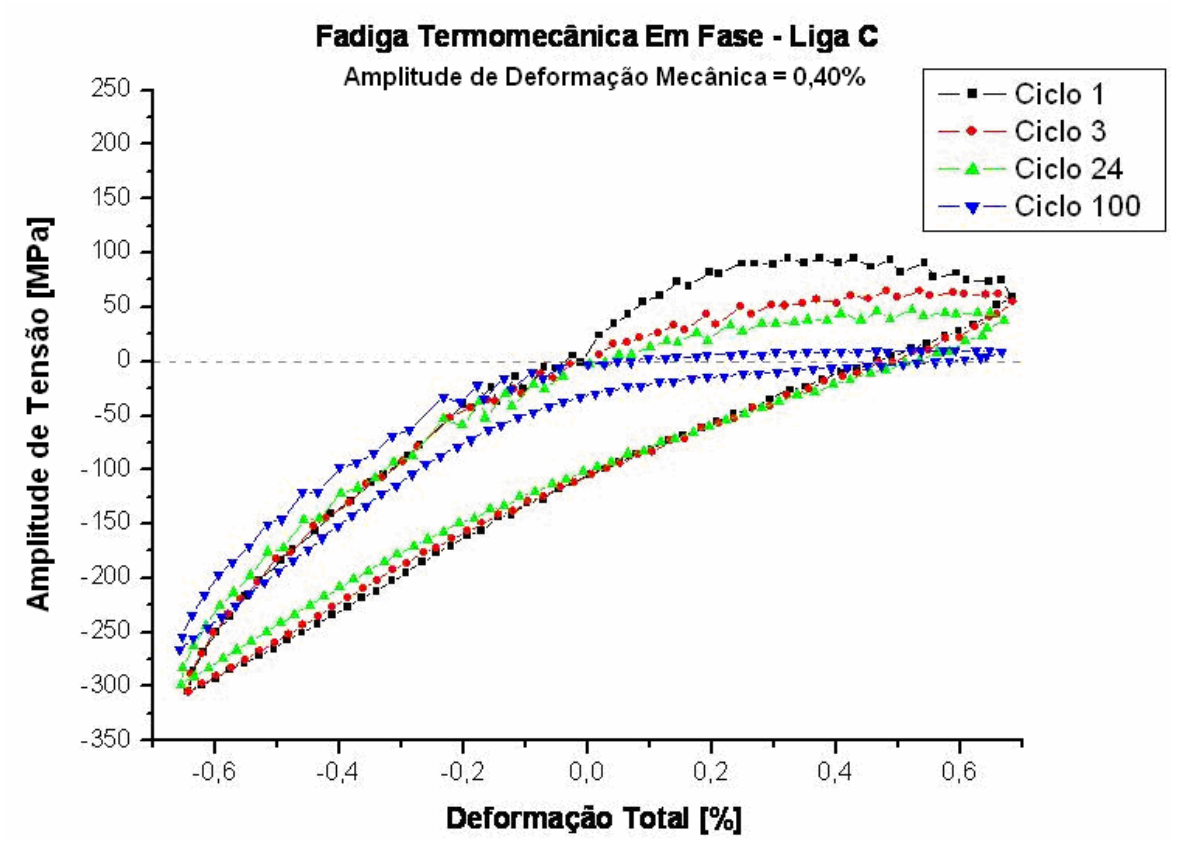

Figura AII.65 - Gráfico da Amplitude de Tensão em função da Amplitude de Deformação Total, para condição em fase da Liga C em amplitude de deformação mecânica de $0,4 \%$. 


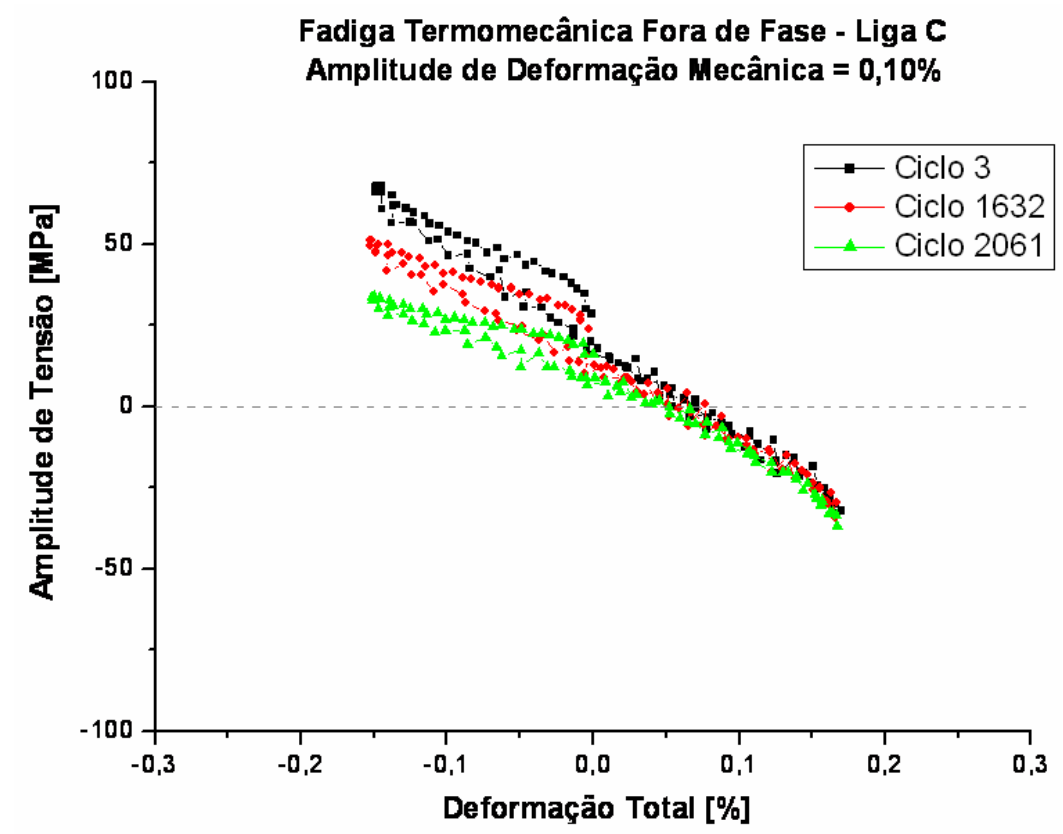

Figura AII.66 - Gráfico da Amplitude de Tensão em função da Amplitude de Deformação Total, para condição fora de fase da Liga C em amplitude de deformação mecânica de $0,1 \%$.

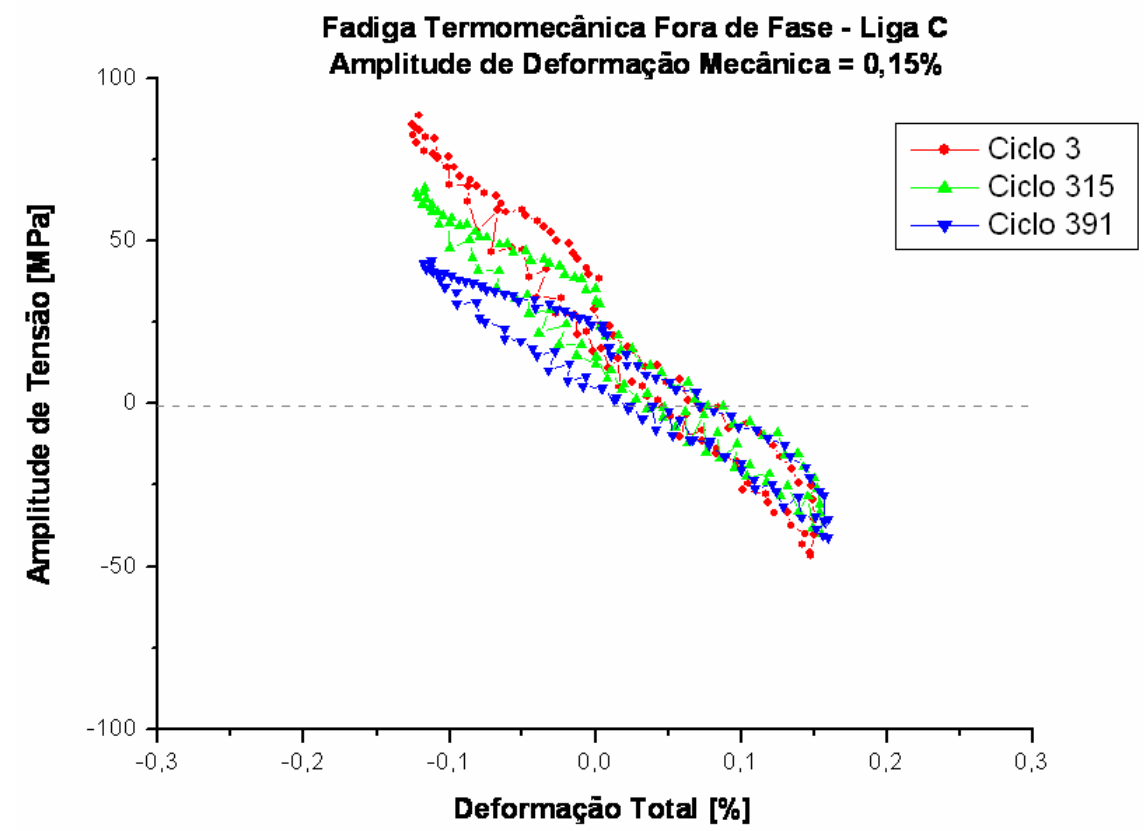

Figura AII.67 - Gráfico da Amplitude de Tensão em função da Amplitude de Deformação Total, para condição fora de fase da Liga $\mathrm{C}$ em amplitude de deformação mecânica de $0,15 \%$. 


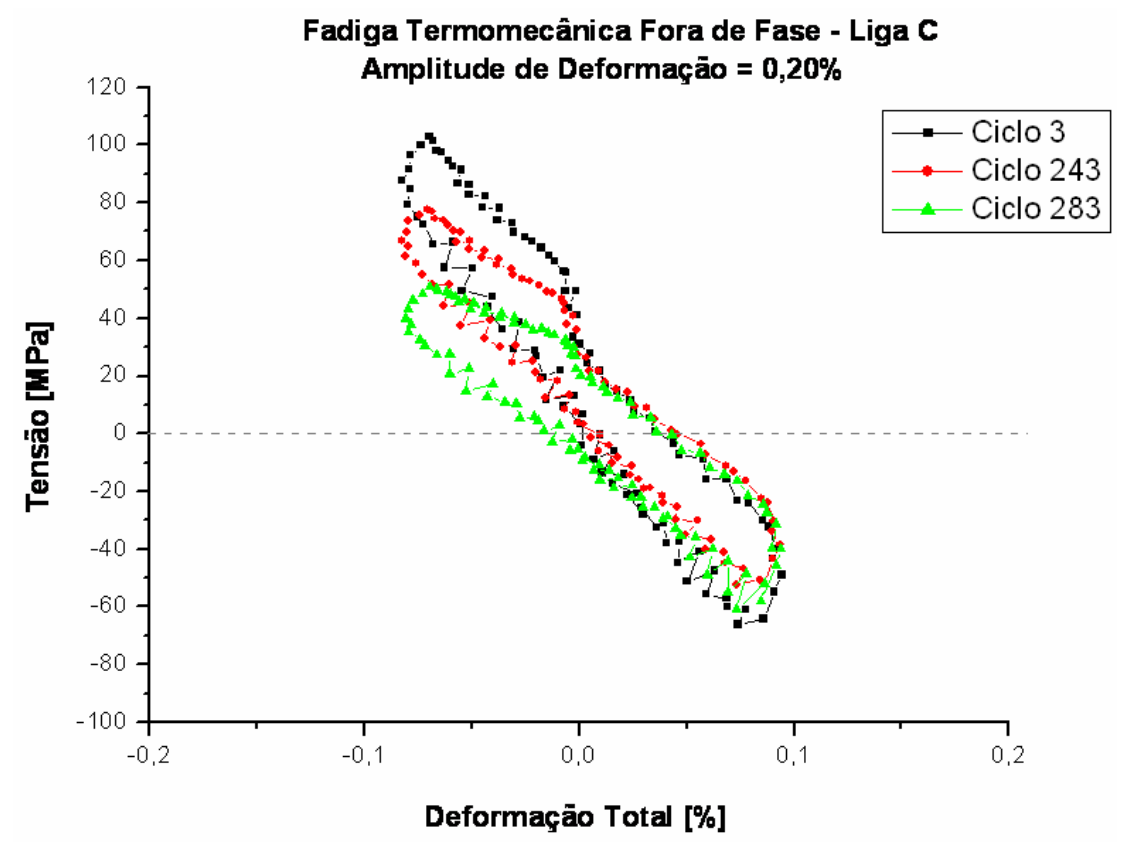

Figura AII.68 - Gráfico da Amplitude de Tensão em função da Amplitude de Deformação Total, para condição fora de fase da Liga C em amplitude de deformação mecânica de $0,2 \%$.

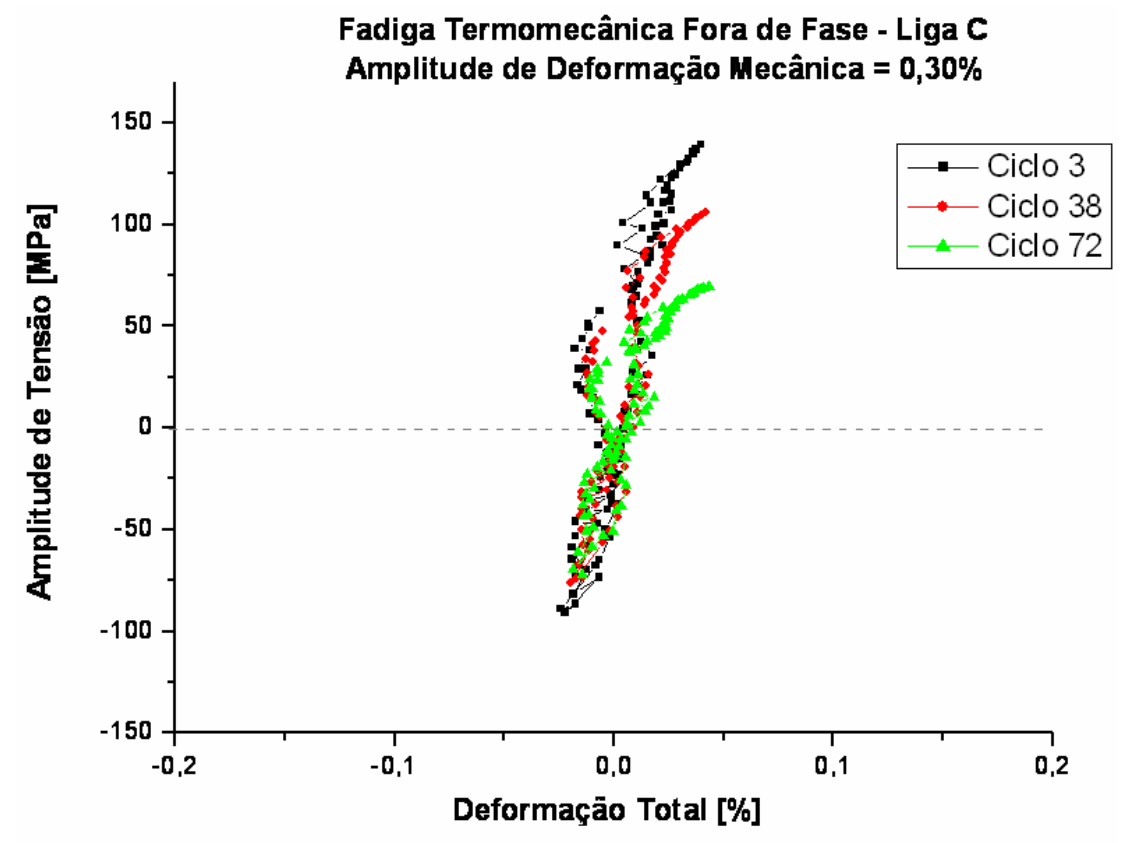

Figura AII.69 - Gráfico da Amplitude de Tensão em função da Amplitude de Deformação Total, para condição fora de fase da Liga C em amplitude de deformação mecânica de $0,3 \%$. 


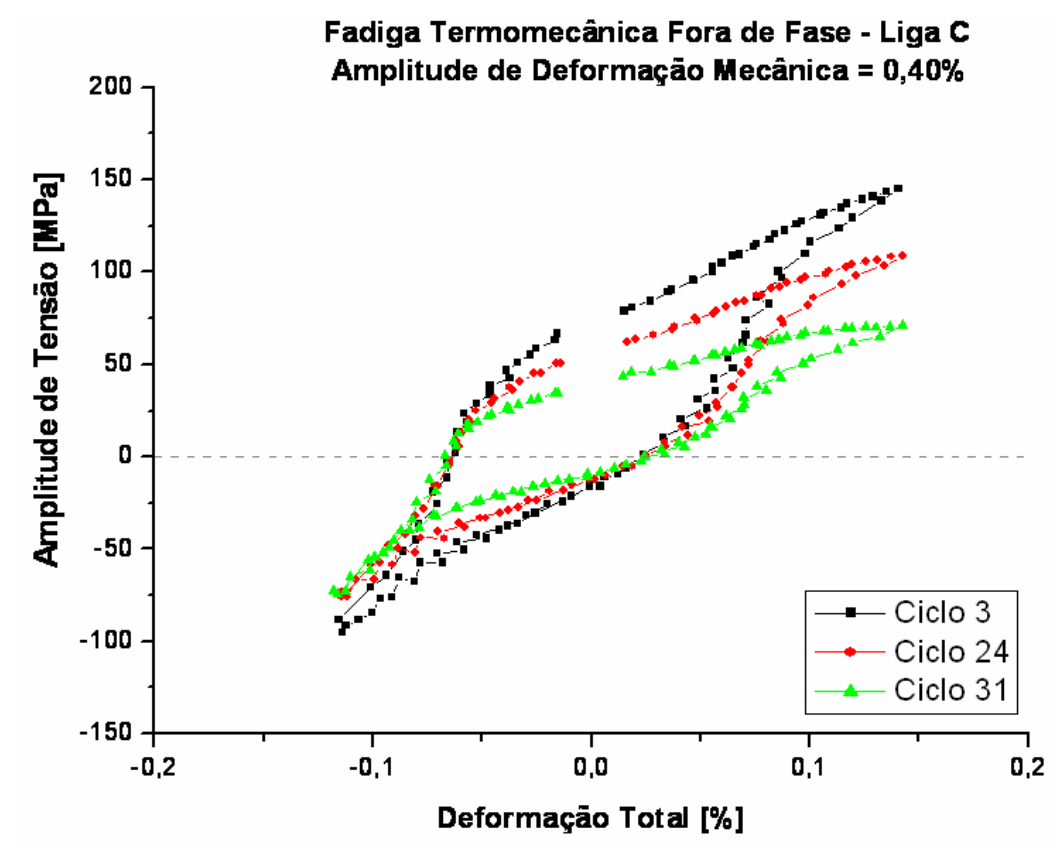

Figura AII.70 - Gráfico da Amplitude de Tensão em função da Amplitude de Deformação Total, para condição fora de fase da Liga C em amplitude de deformação mecânica de $0,4 \%$.

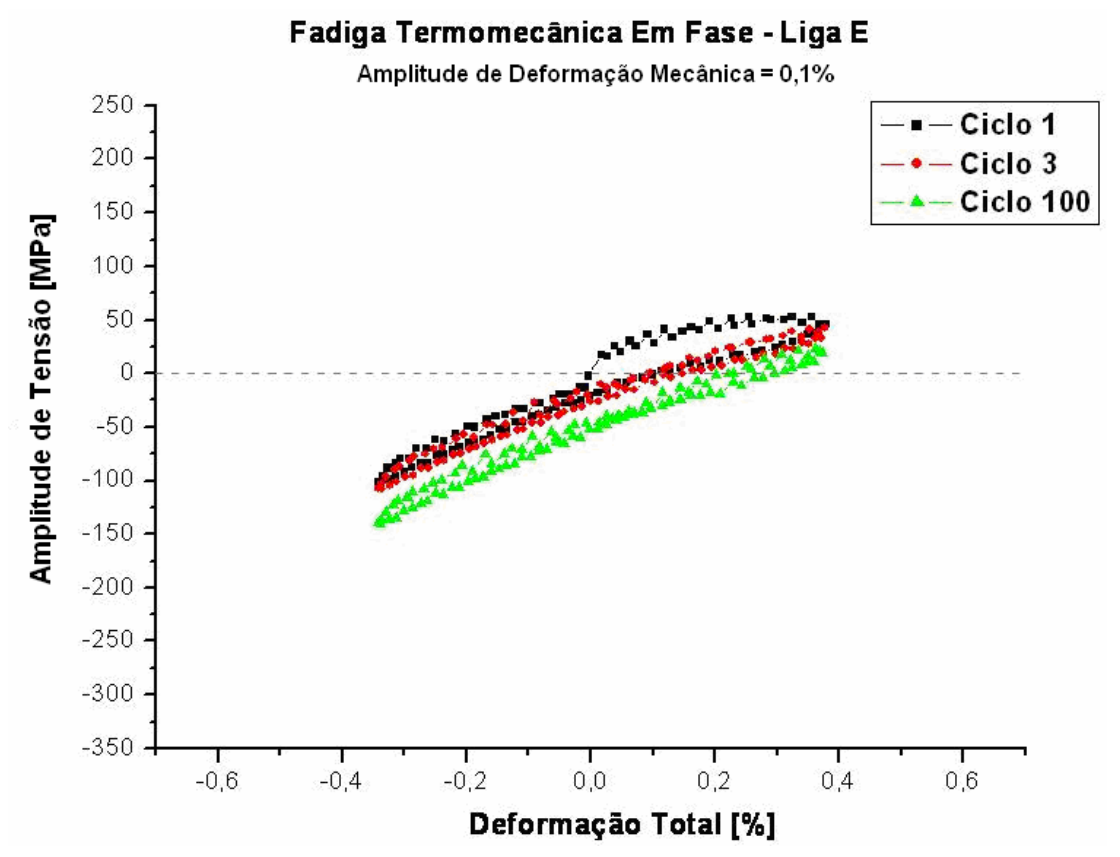

Figura AII.71 - Gráfico da Amplitude de Tensão em função da Amplitude de Deformação Total, para condição em fase da Liga E em amplitude de deformação mecânica de $0,1 \%$. 


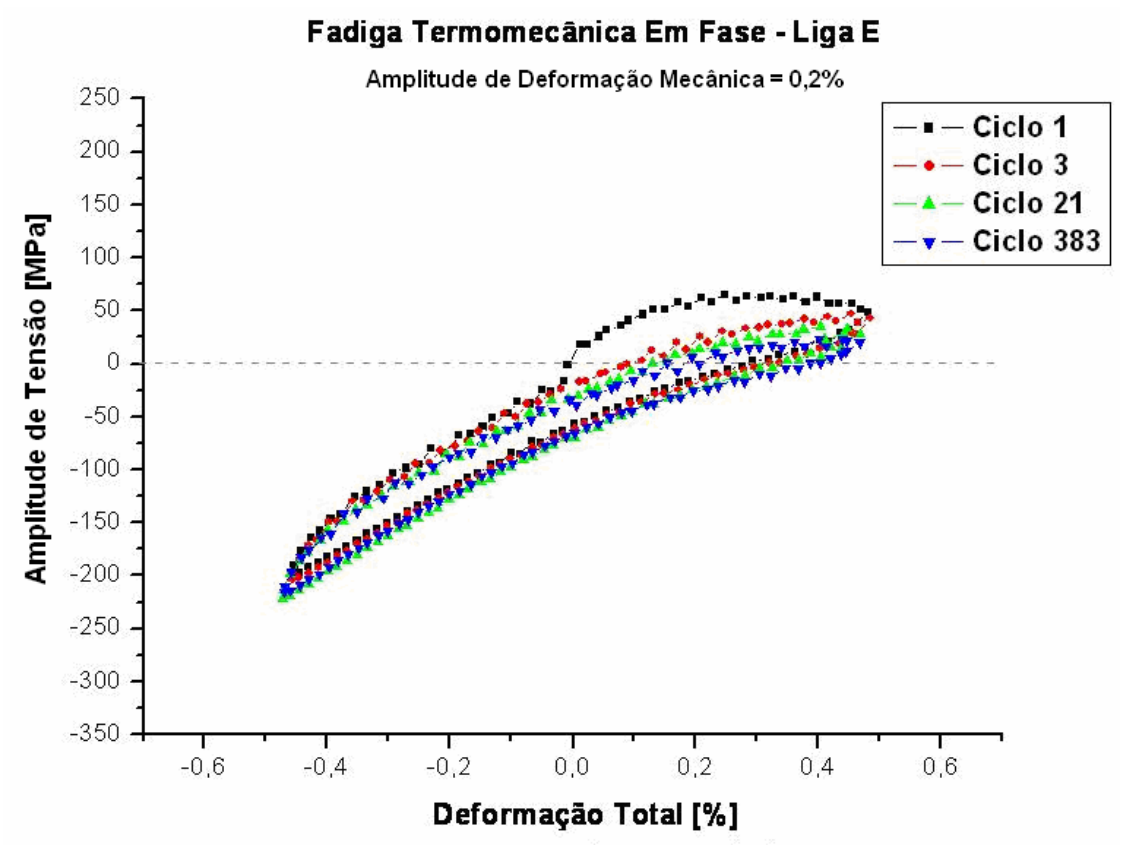

Figura AII.72 - Gráfico da Amplitude de Tensão em função da Amplitude de Deformação Total, para condição em fase da Liga E em amplitude de deformação mecânica de $0,2 \%$.

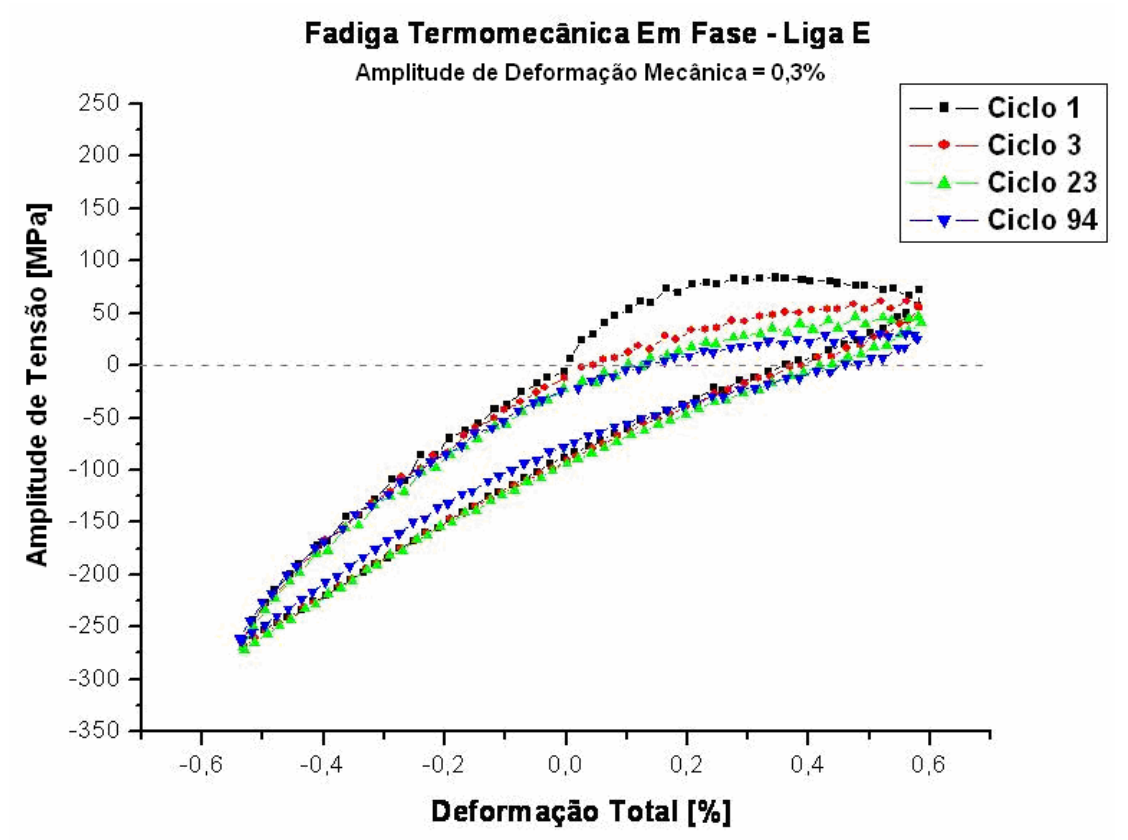

Figura AII.73 - Gráfico da Amplitude de Tensão em função da Amplitude de Deformação Total, para condição em fase da Liga E em amplitude de deformação mecânica de $0,3 \%$. 


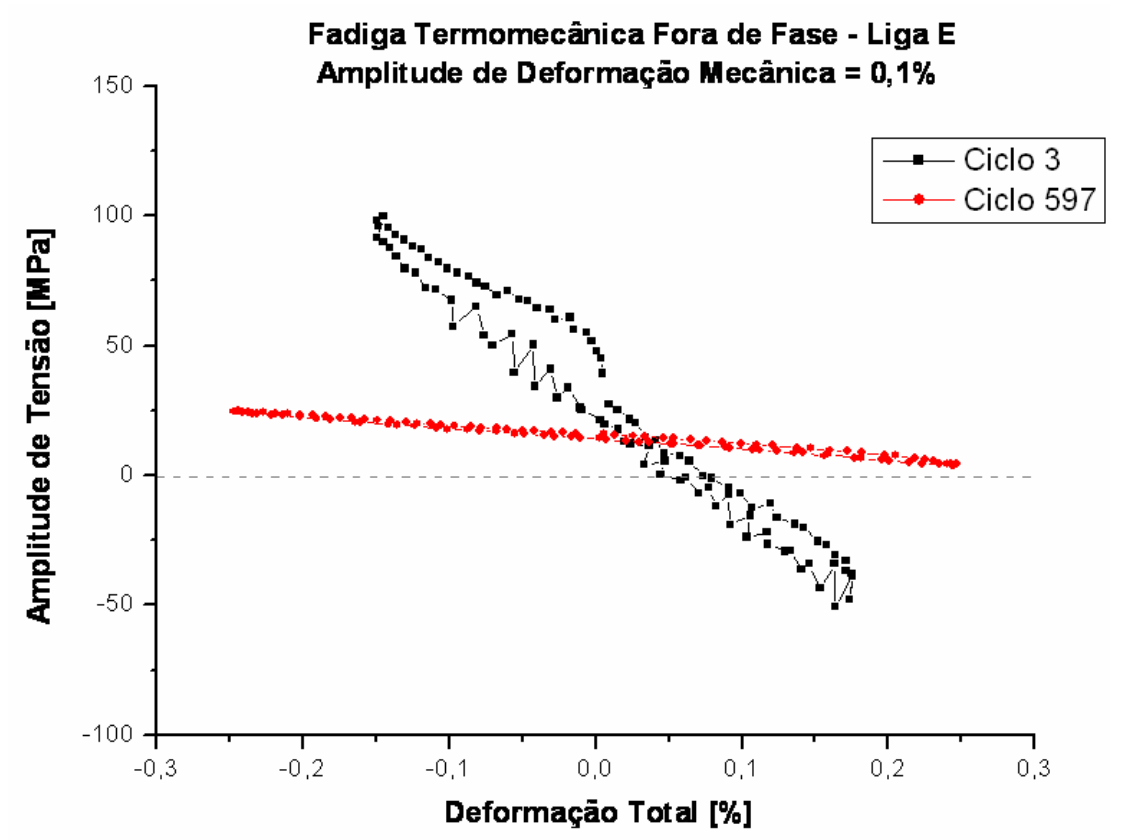

Figura AII.74 - Gráfico da Amplitude de Tensão em função da Amplitude de Deformação Total, para condição fora de fase da Liga E em amplitude de deformação mecânica de $0,1 \%$.

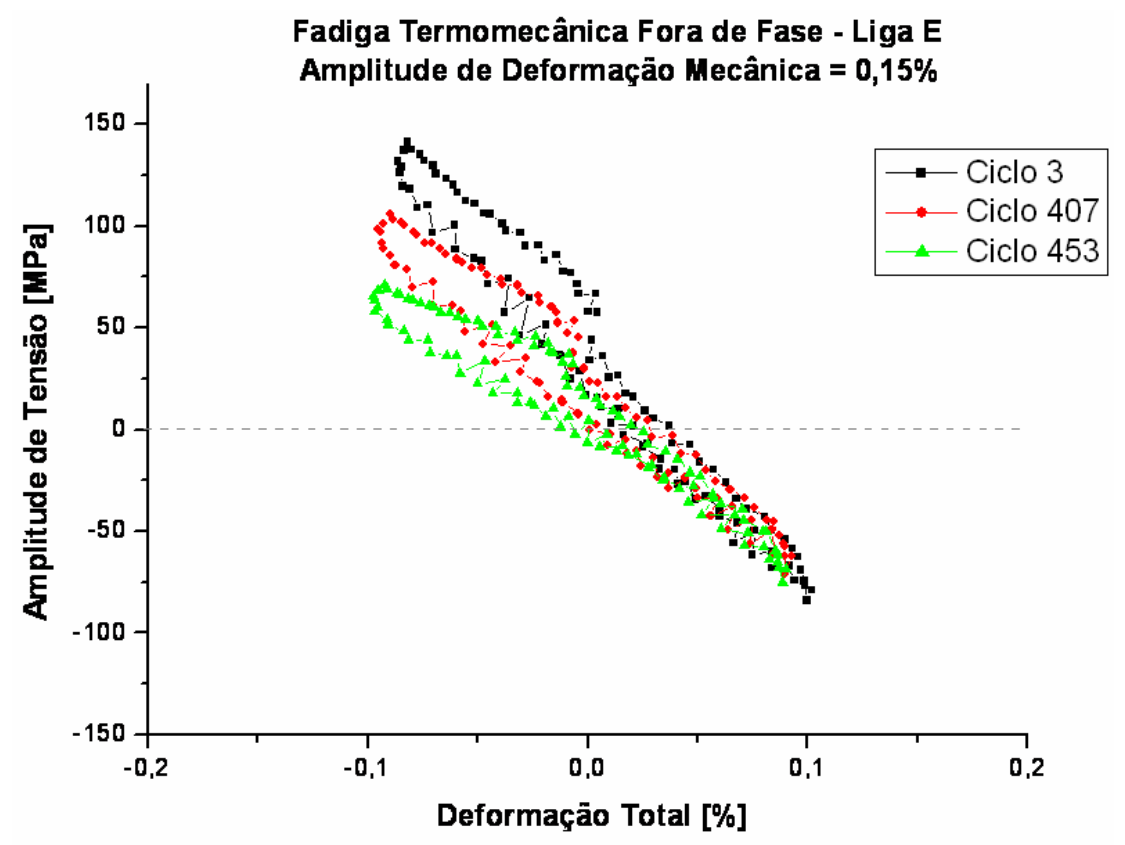

Figura AII.75- Gráfico da Amplitude de Tensão em função da Amplitude de Deformação Total, para condição fora de fase da Liga E em amplitude de deformação mecânica de $0,15 \%$. 


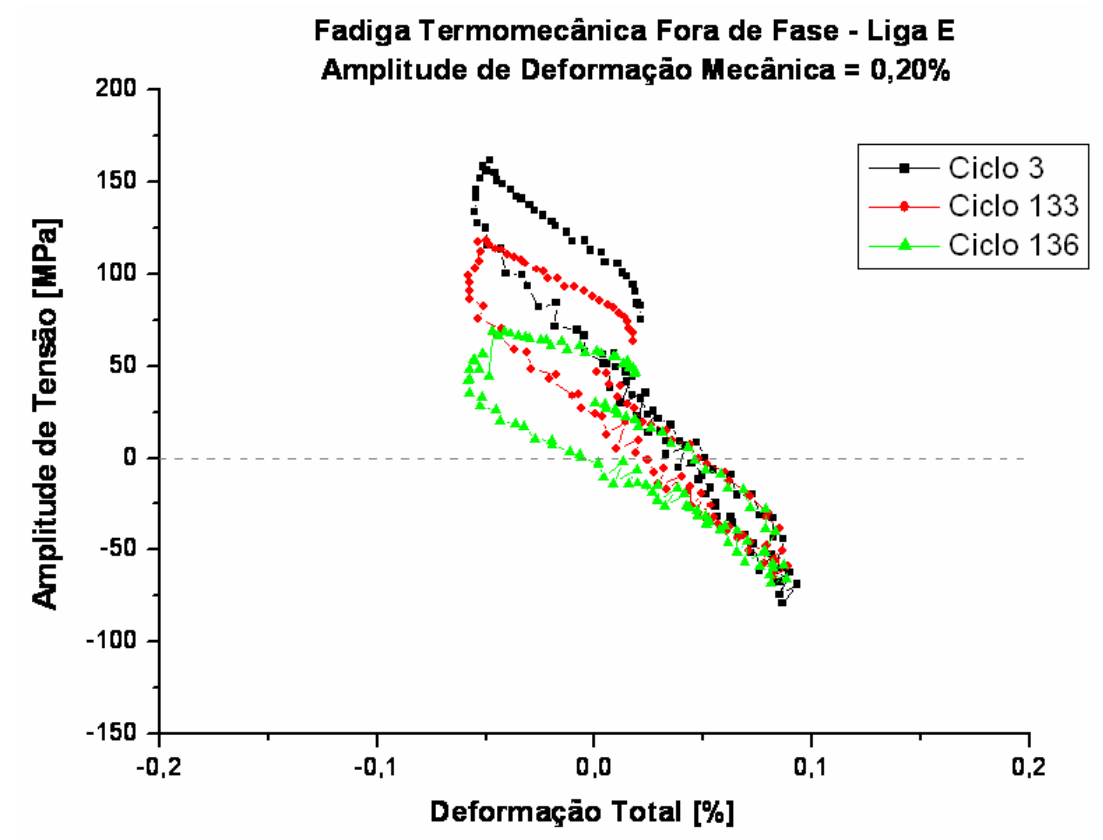

Figura AII.76 - Gráfico da Amplitude de Tensão em função da Amplitude de Deformação Total, para condição fora de fase da Liga E em amplitude de deformação mecânica de 0,2\%.

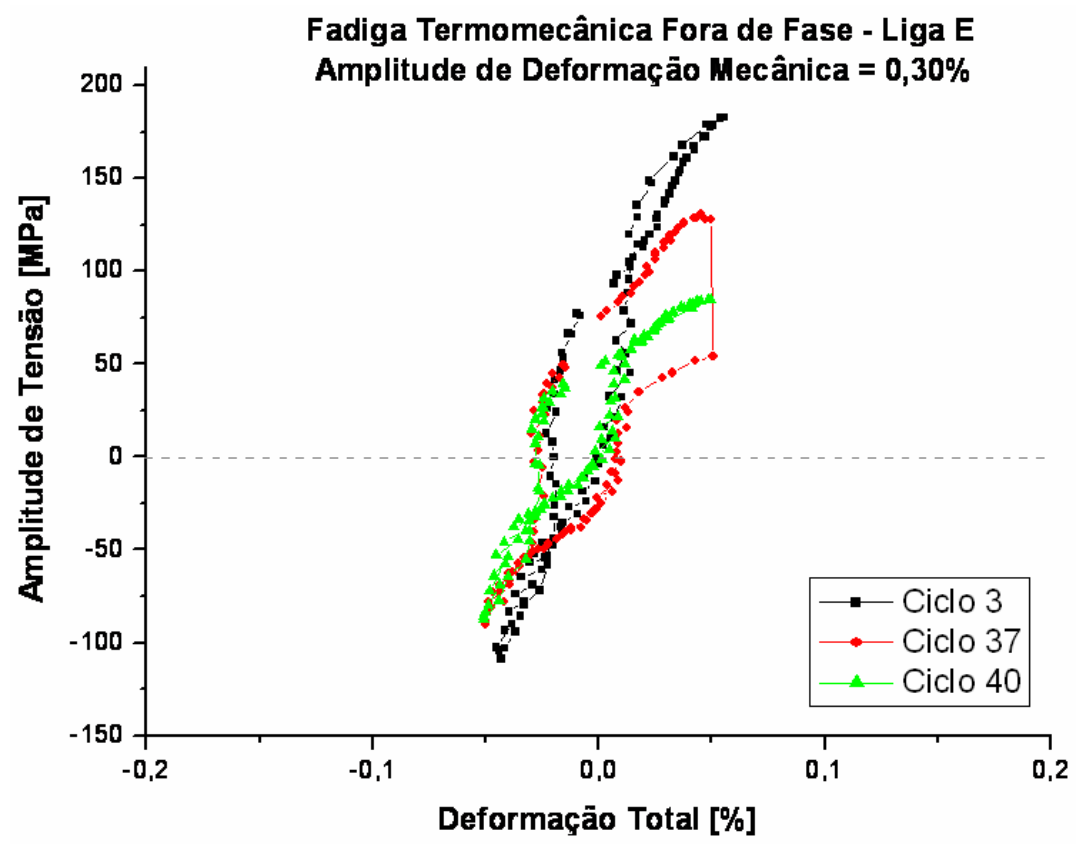

Figura AII.77 - Gráfico da Amplitude de Tensão em função da Amplitude de Deformação Total, para condição fora de fase da Liga E em amplitude de deformação mecânica de 0,3\%. 


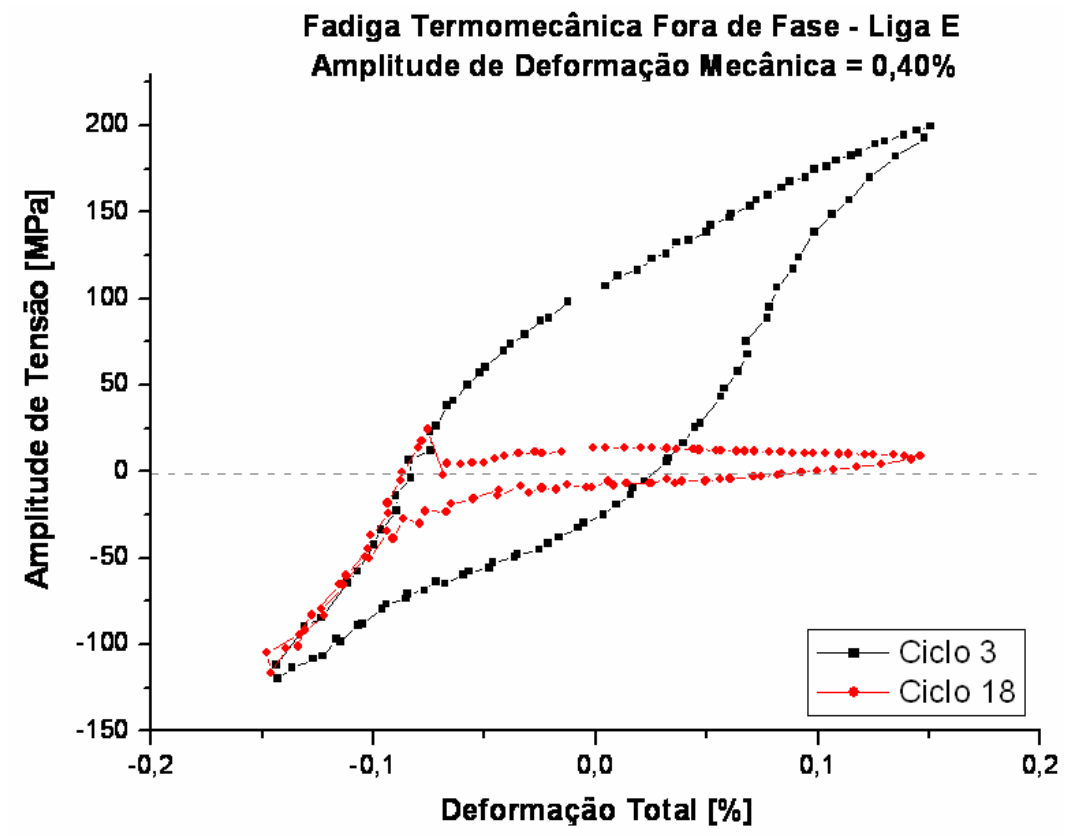

Figura AII.78 - Gráfico da Amplitude de Tensão em função da Amplitude de Deformação Total, para condição fora de fase da Liga E em amplitude de deformação mecânica de $0,4 \%$. 


\section{3) GRÁFICOS DEFORMAÇÃO MECÂNICA X TEMPERATURA}

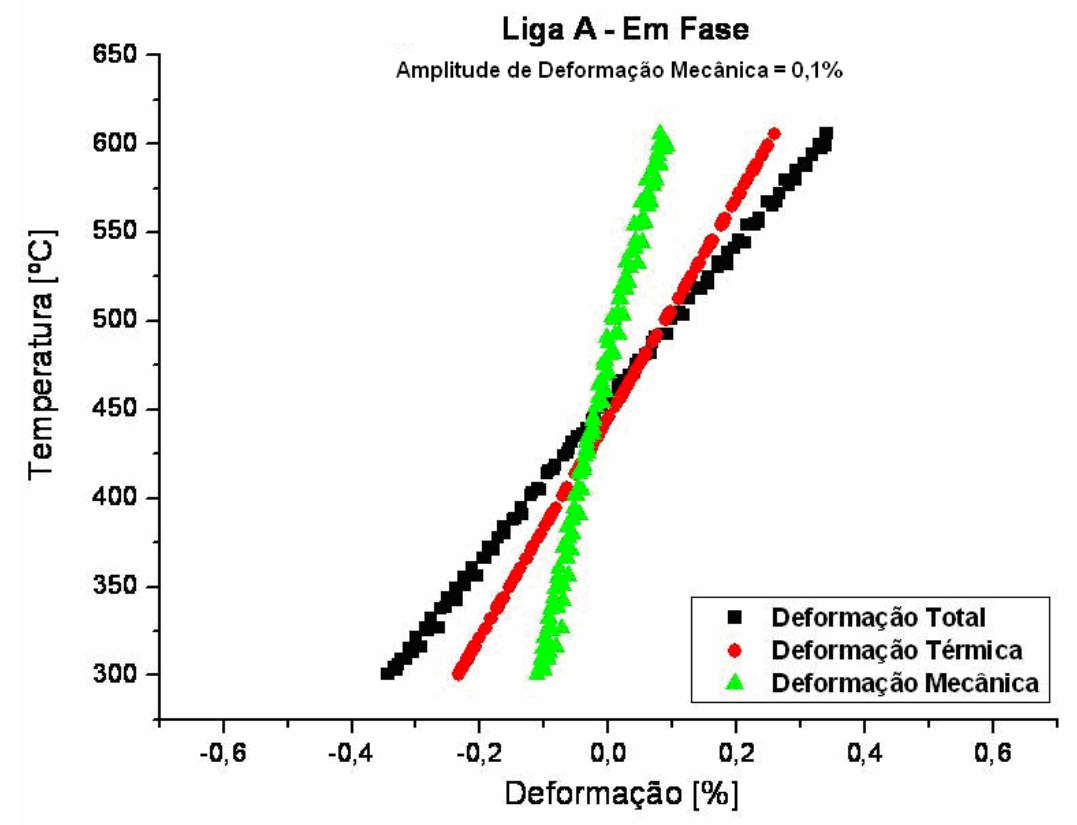

Figura AII.79 - Fadiga Termomecânica em fase (Liga A) - Gráfico da Deformação em função da Temperatura no ciclo 3, para Amplitude de Deformação Mecânica de 0,1\%

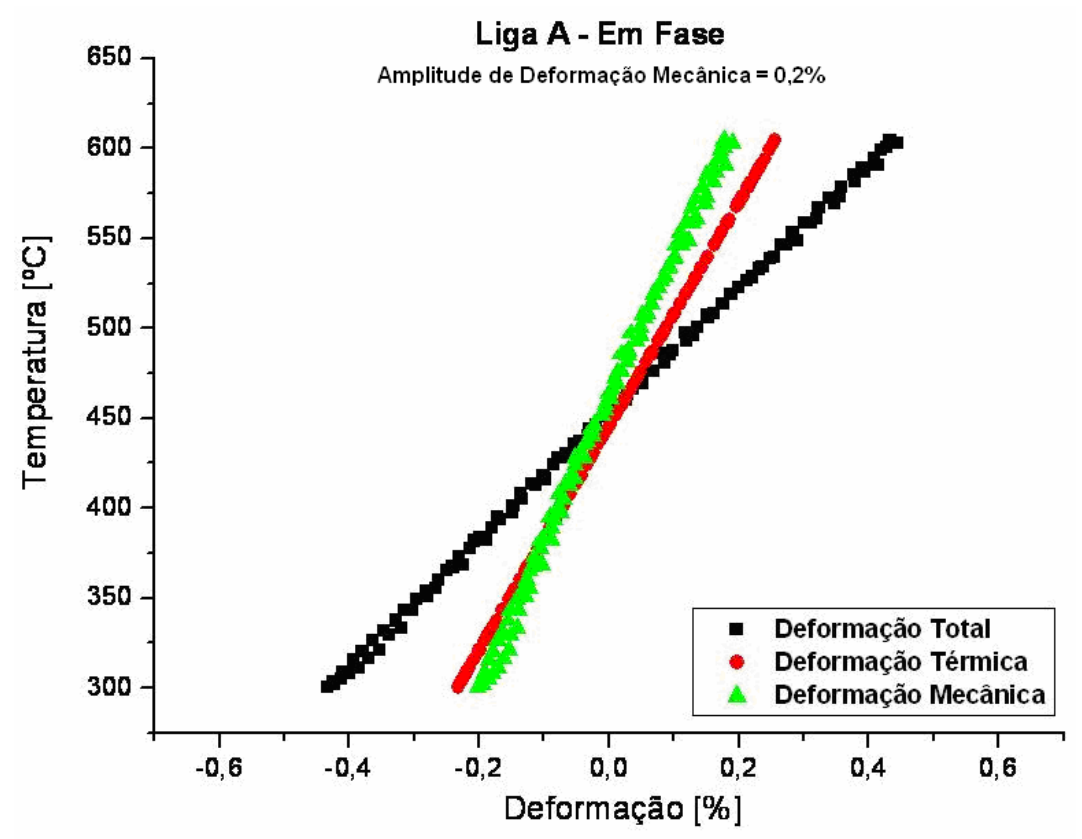

Figura AII.80 - Fadiga Termomecânica em fase (Liga A) - Gráfico da Deformação em função da Temperatura no ciclo 3, para Amplitude de Deformação Mecânica de 0,2\% 


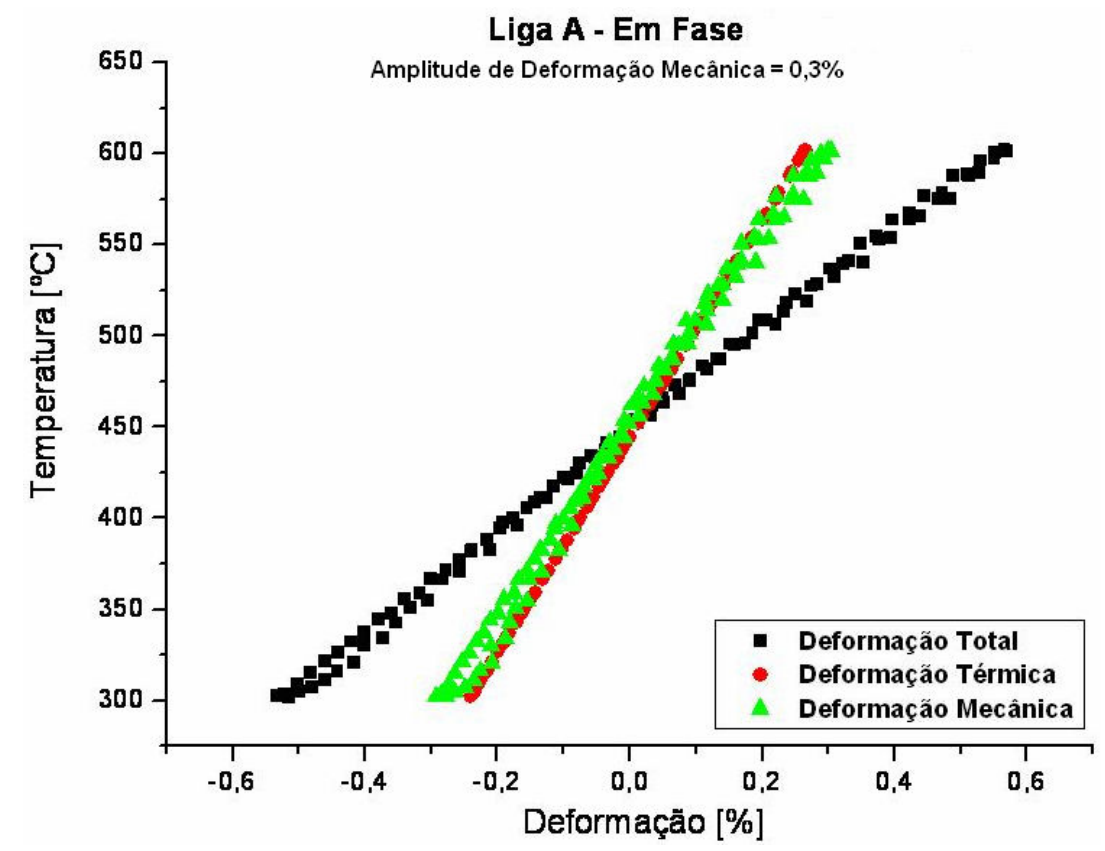

Figura AII.81 - Fadiga Termomecânica em fase (Liga A) - Gráfico da Deformação em função da Temperatura no ciclo 3, para Amplitude de Deformação Mecânica de 0,3\%

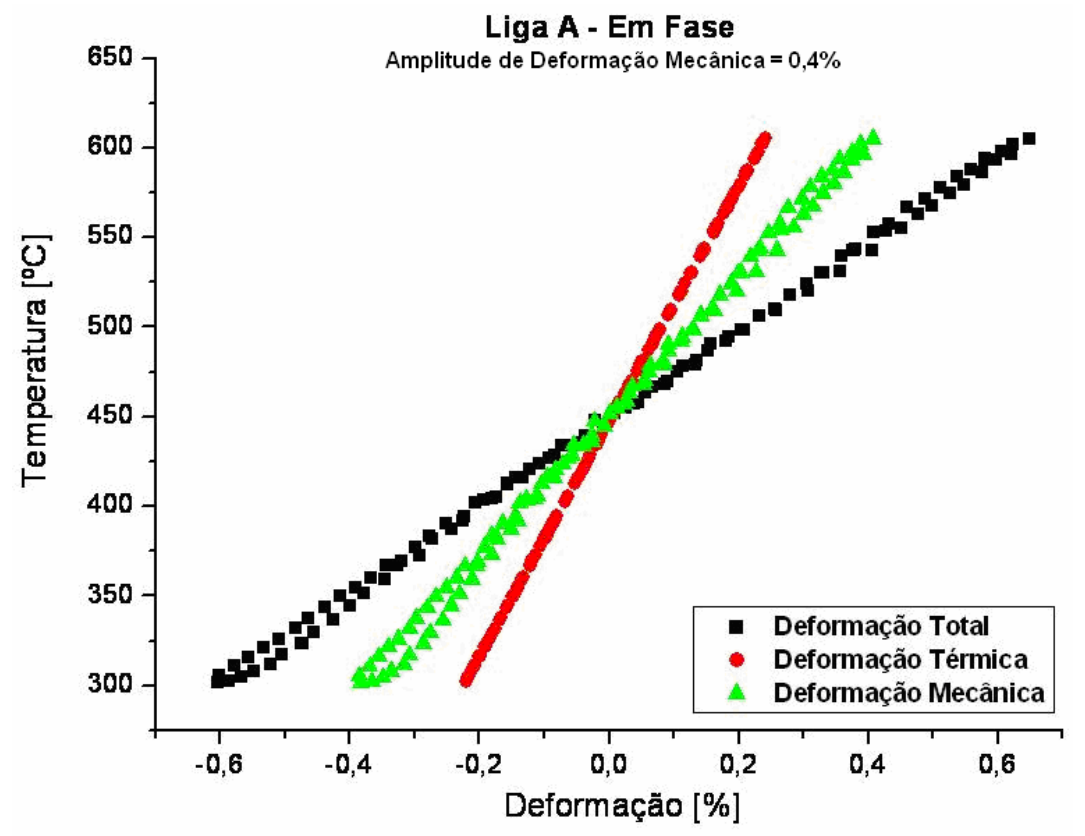

Figura AII.82 - Fadiga Termomecânica em fase (Liga A) - Gráfico da Deformação em função da Temperatura no ciclo 3, para Amplitude de Deformação Mecânica de 0,4\% 


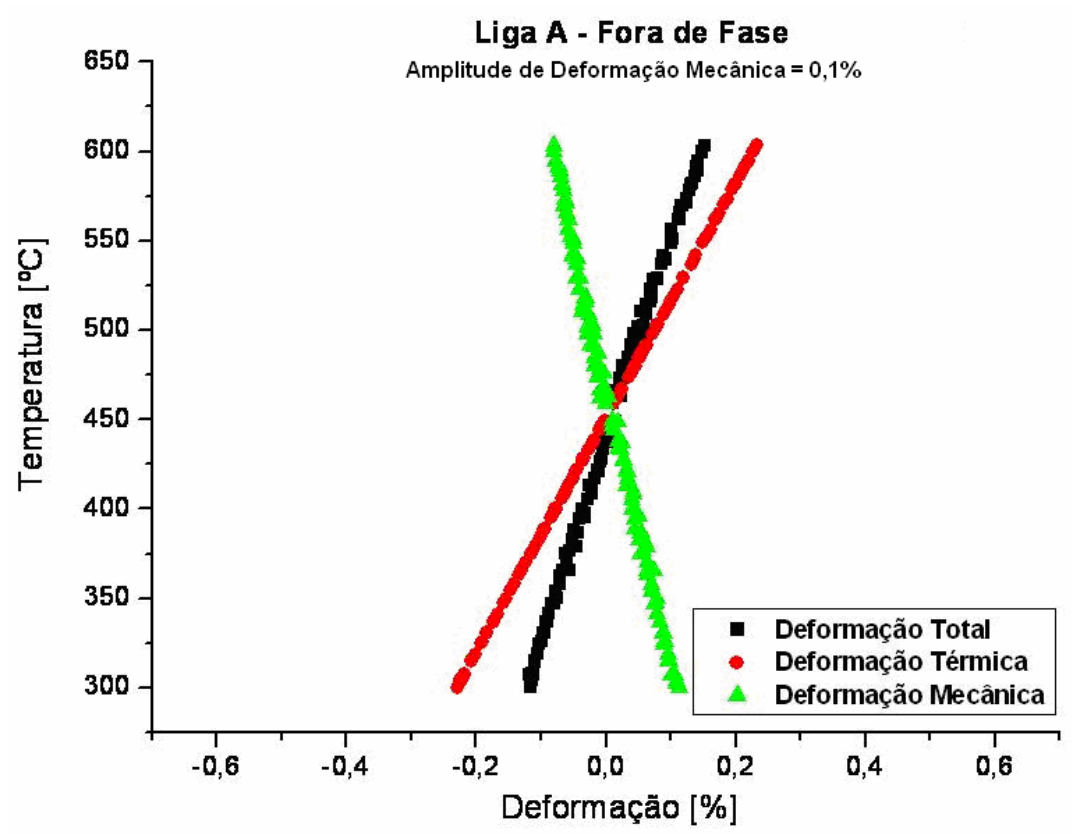

Figura AII.83 - Fadiga Termomecânica fora de fase fase (Liga A) - Gráfico da Deformação em função da Temperatura no ciclo 3, para Amplitude de Deformação Mecânica de 0,1\%

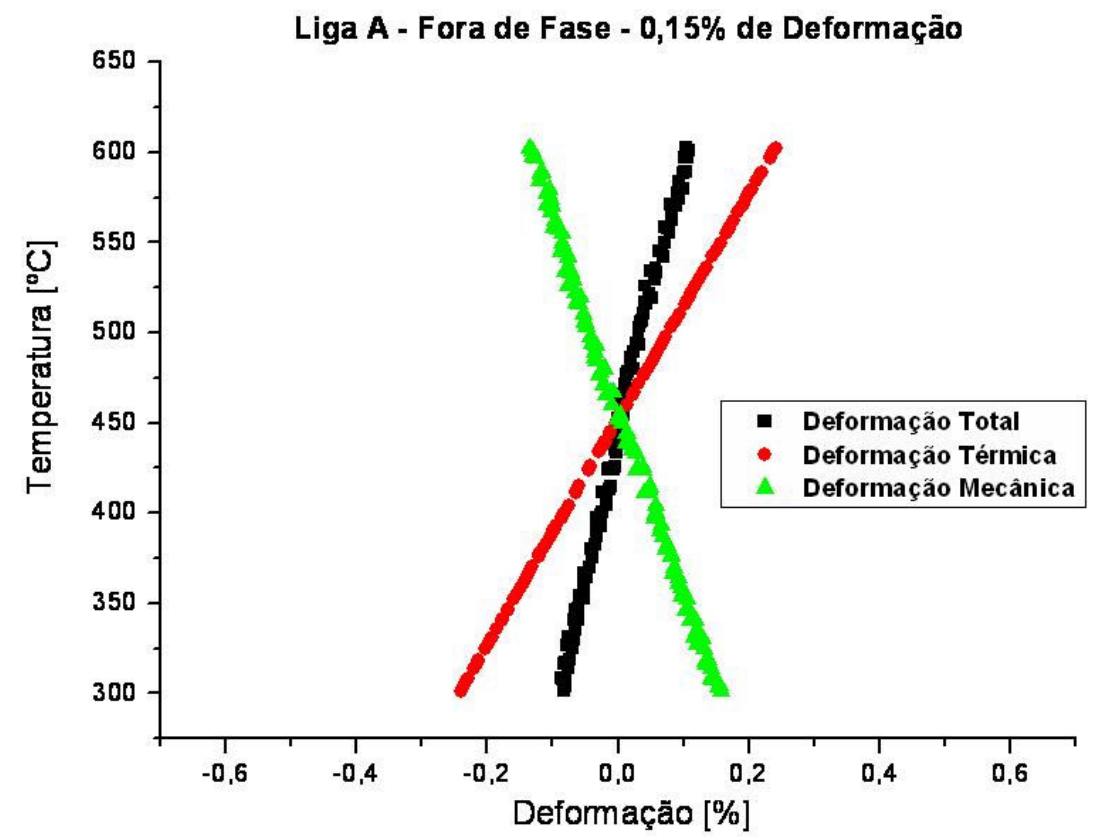

Figura AII.84 - Fadiga Termomecânica fora de fase fase (Liga A) - Gráfico da Deformação em função da Temperatura no ciclo 3, para Amplitude de Deformação Mecânica de 0,15\% 


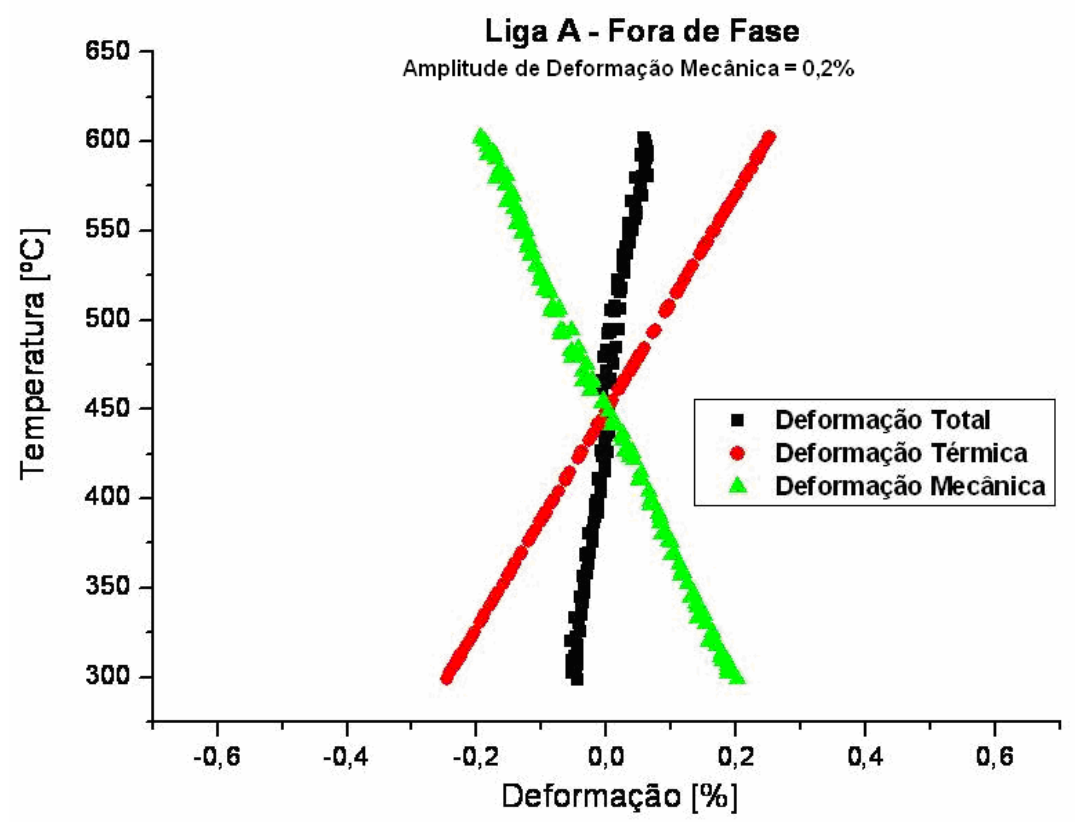

Figura AII.85 - Fadiga Termomecânica fora de fase fase (Liga A) - Gráfico da Deformação em função da Temperatura no ciclo 3, para Amplitude de Deformação Mecânica de 0,2\%

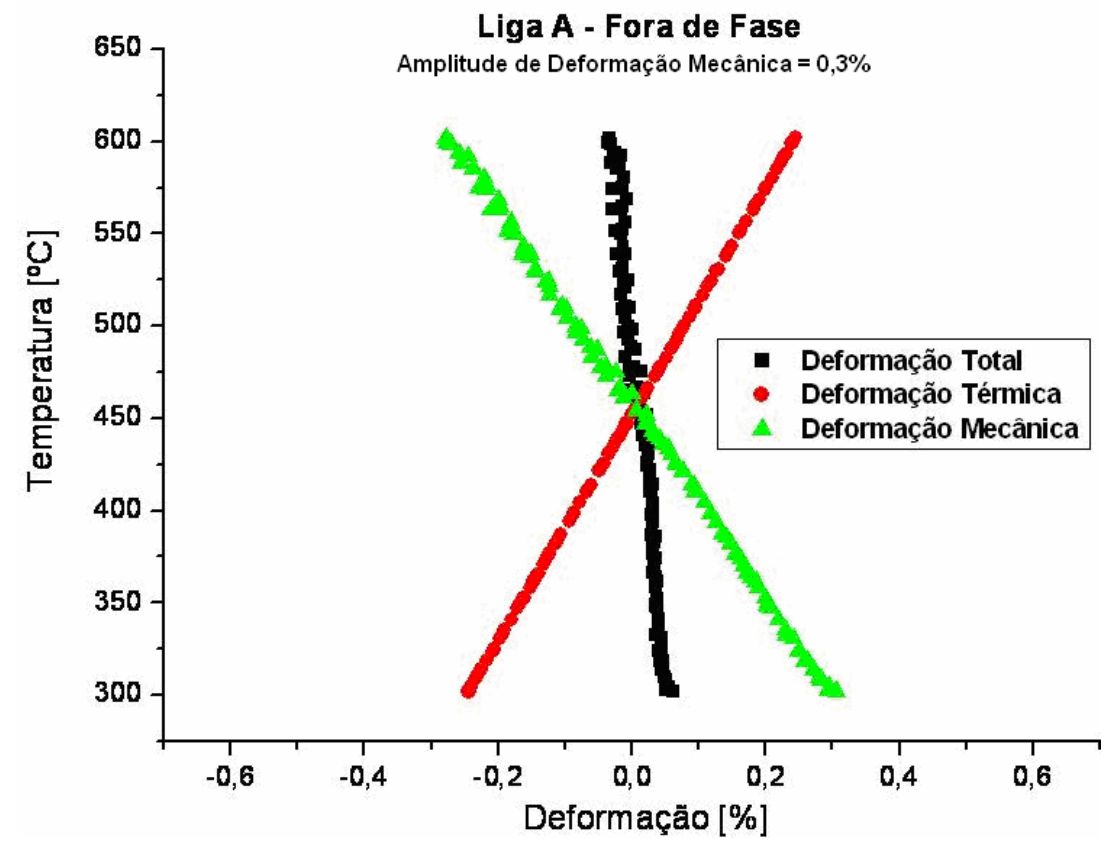

Figura AII.86 - Fadiga Termomecânica fora de fase fase (Liga A) - Gráfico da Deformação em função da Temperatura no ciclo 3, para Amplitude de Deformação Mecânica de 0,3\% 


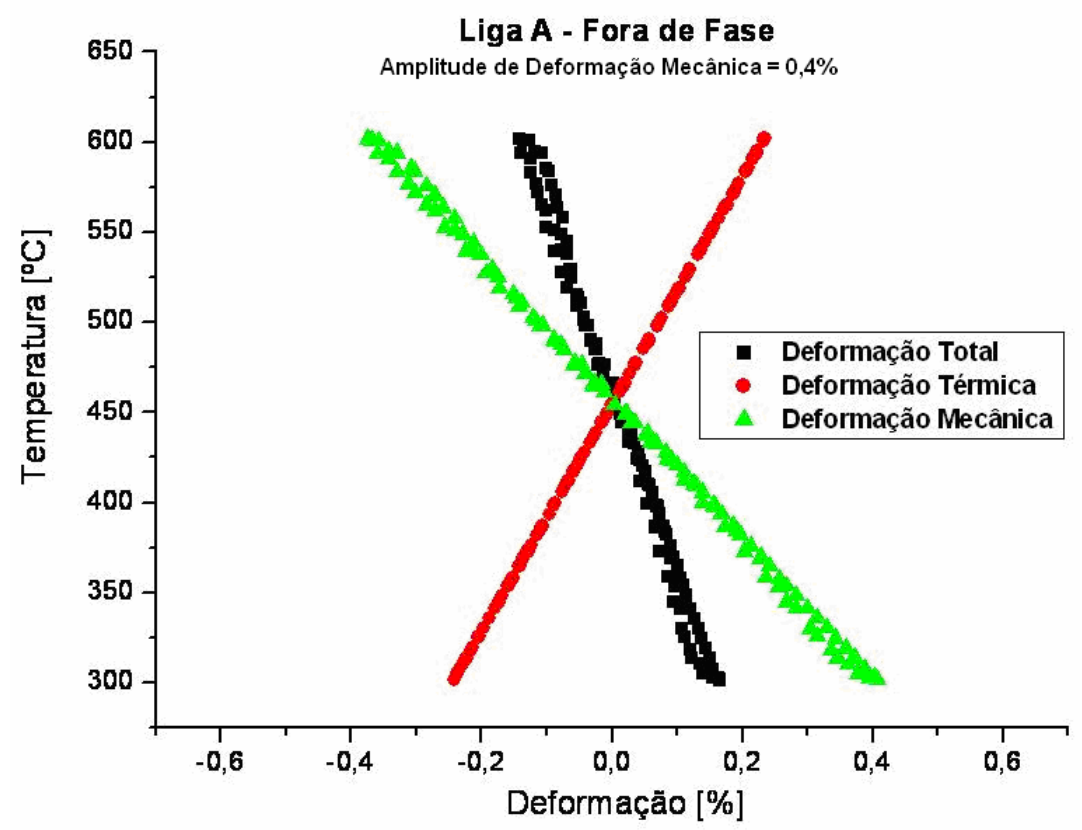

Figura AII.87 - Fadiga Termomecânica fora de fase fase (Liga A) - Gráfico da Deformação em função da Temperatura no ciclo 3, para Amplitude de Deformação Mecânica de 0,4\%

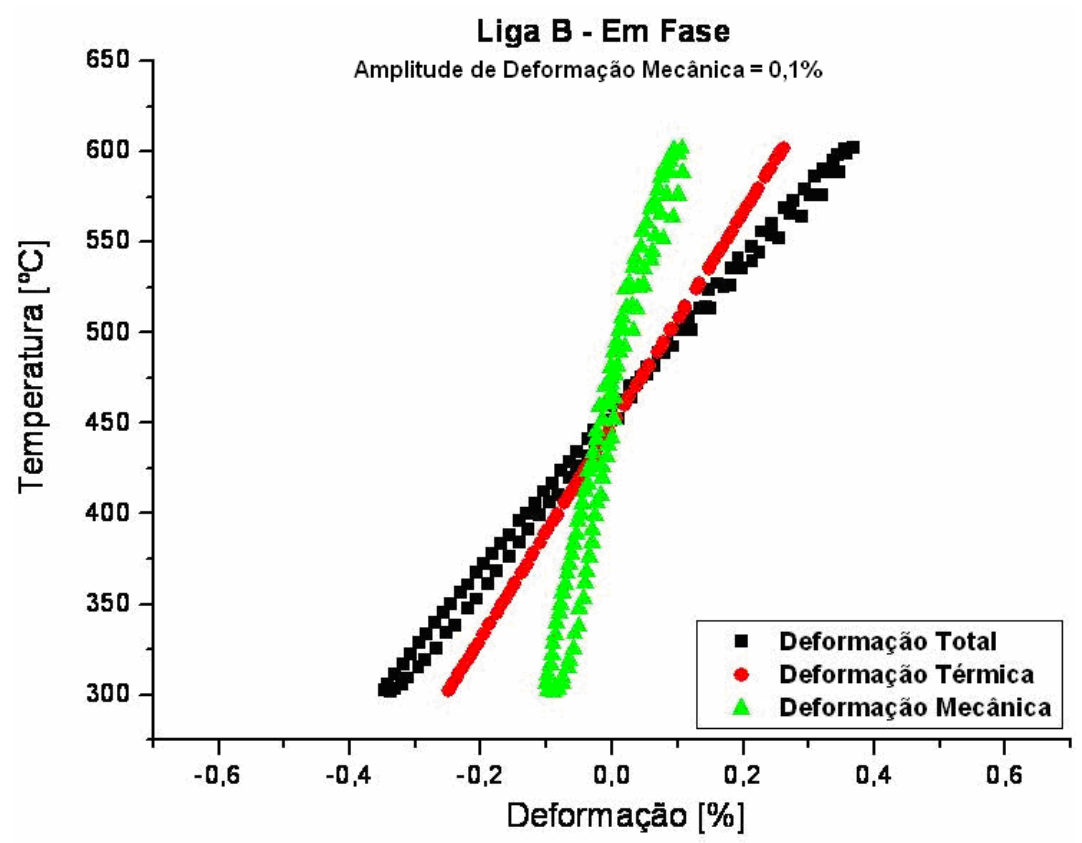

Figura AII.88 - Fadiga Termomecânica em fase (Liga B) - Gráfico da Deformação em função da Temperatura no ciclo 3, para Amplitude de Deformação Mecânica de 0,1\% 


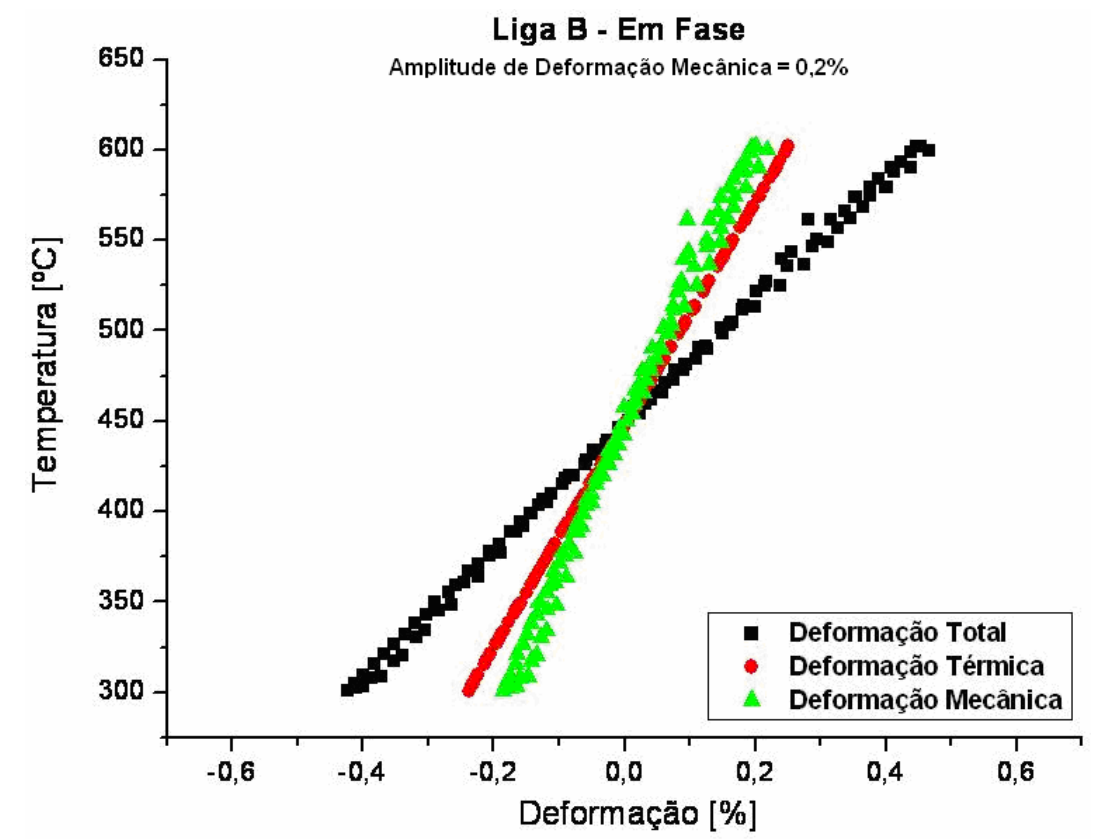

Figura AII.89 - Fadiga Termomecânica em fase (Liga B) - Gráfico da Deformação em função da Temperatura no ciclo 3, para Amplitude de Deformação Mecânica de 0,2\%

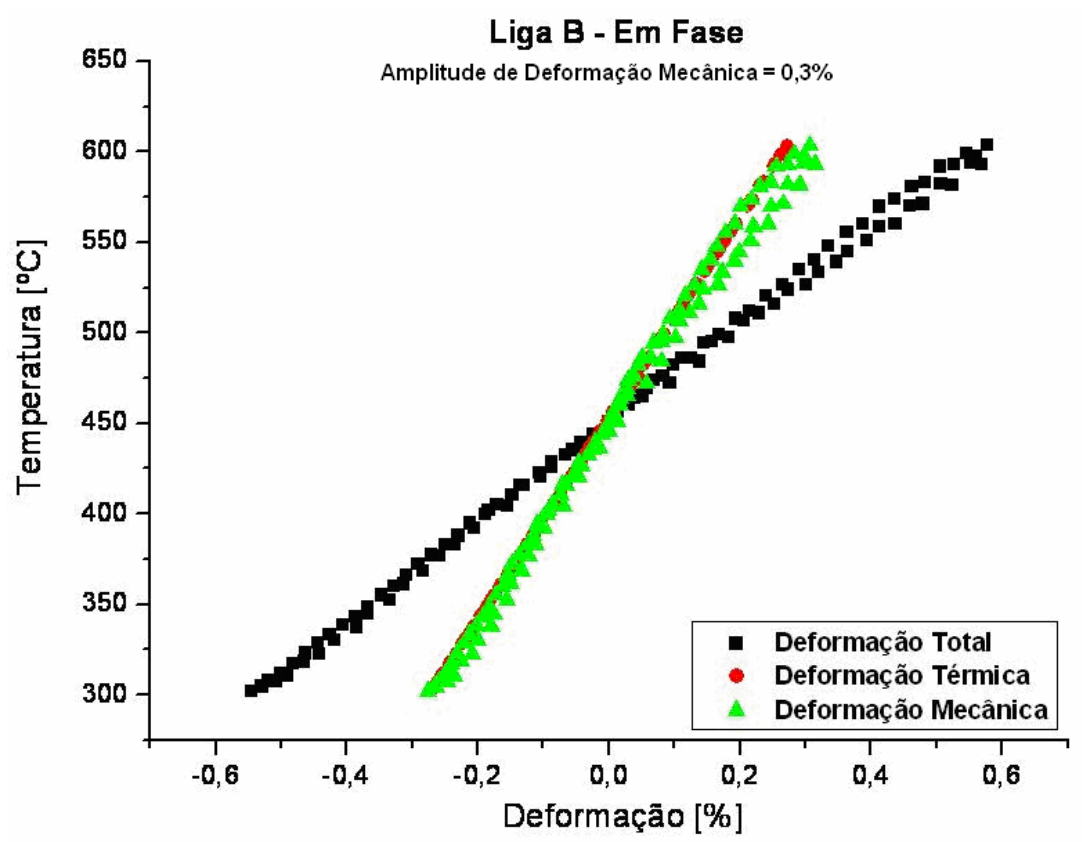

Figura AII.90 - Fadiga Termomecânica em fase (Liga B) - Gráfico da Deformação em função da Temperatura no ciclo 3, para Amplitude de Deformação Mecânica de 0,3\% 


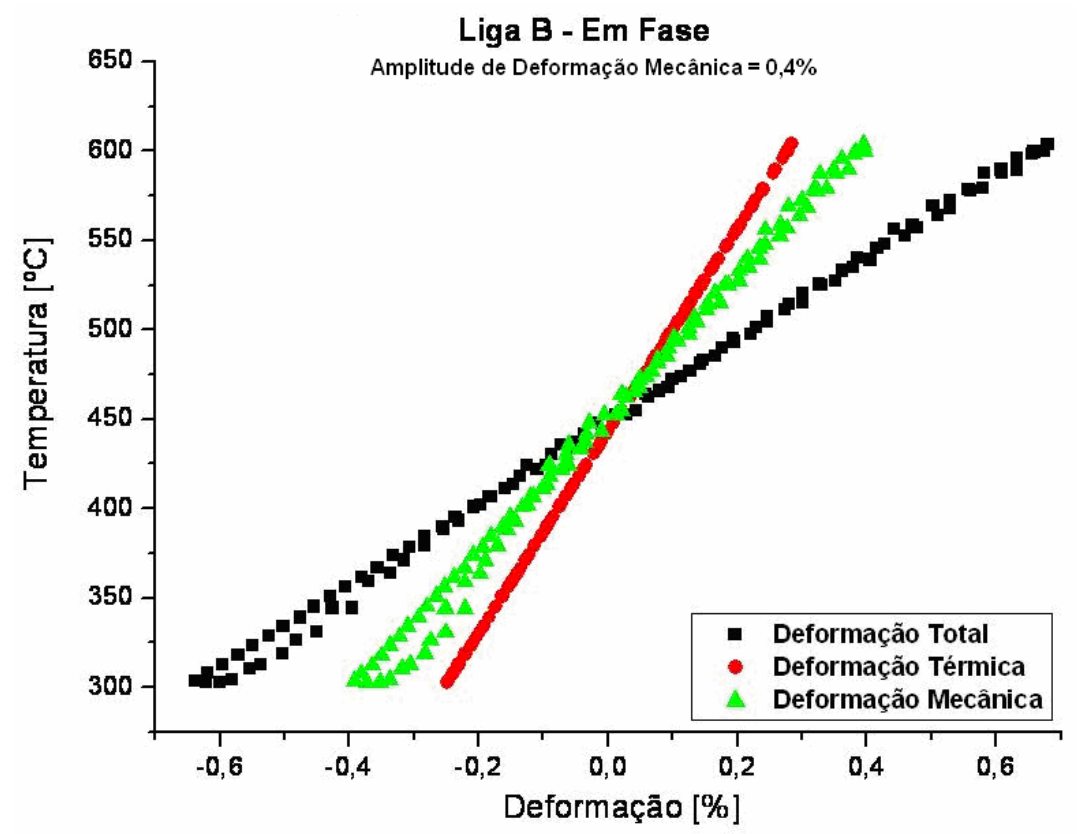

Figura AII.91 - Fadiga Termomecânica em fase (Liga B) - Gráfico da Deformação em função da Temperatura no ciclo 3, para Amplitude de Deformação Mecânica de 0,4\%

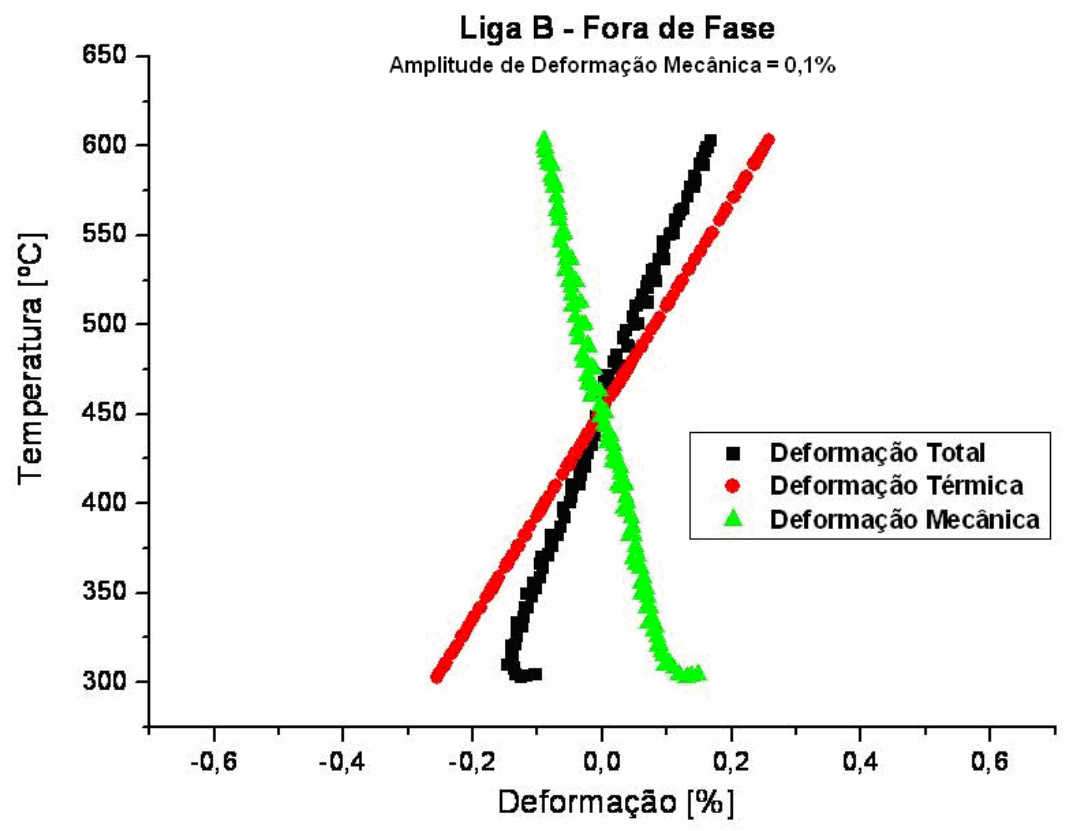

Figura AII.92 - Fadiga Termomecânica fora de fase (Liga B) - Gráfico da Deformação em função da Temperatura no ciclo 3, para Amplitude de Deformação Mecânica de 0,1\% 


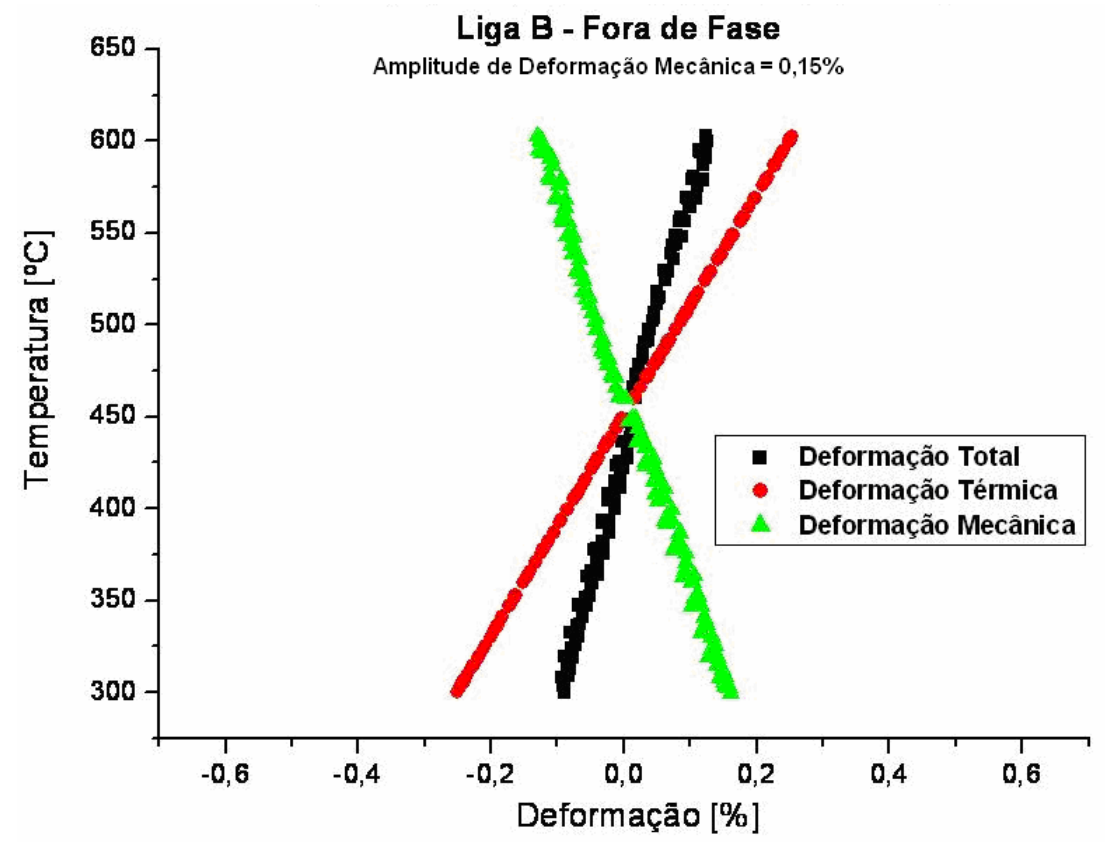

Figura AII.93 - Fadiga Termomecânica fora de fase (Liga B) - Gráfico da Deformação em função da Temperatura no ciclo 3, para Amplitude de Deformação Mecânica de 0,15\%.

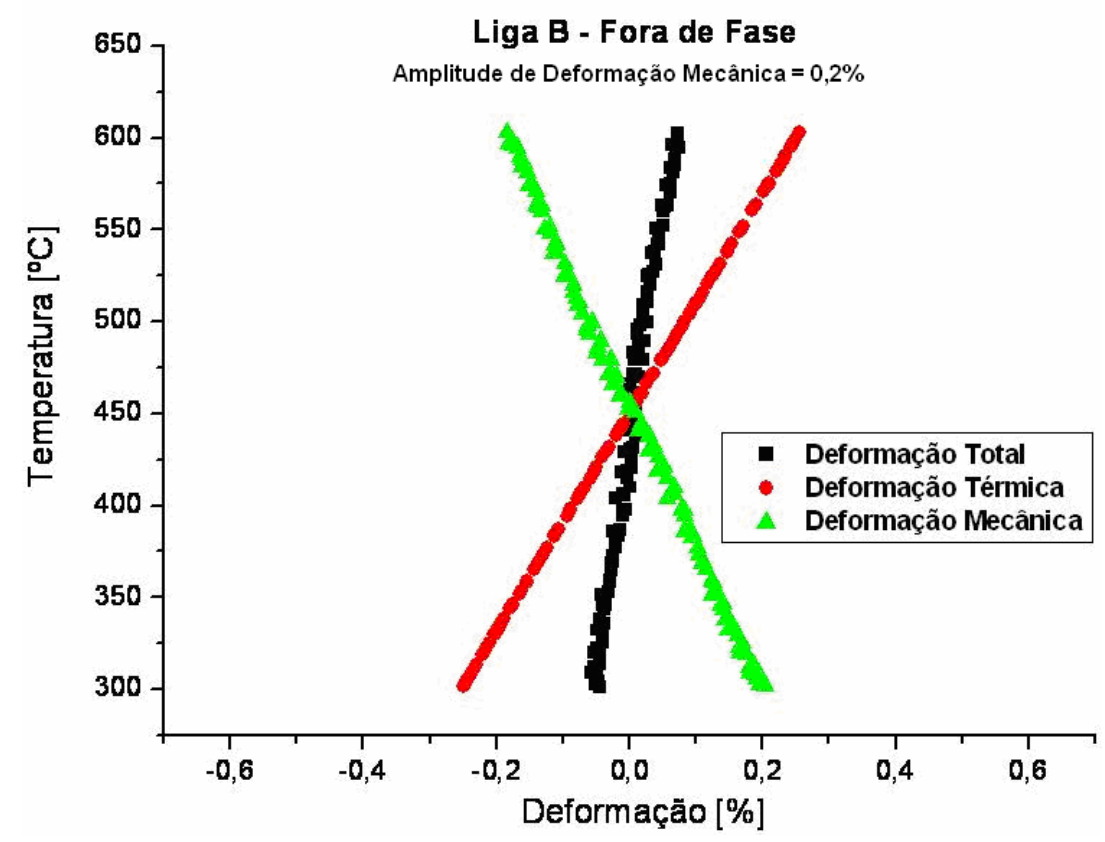

Figura AII.94 - Fadiga Termomecânica fora de fase (Liga B) - Gráfico da Deformação em função da Temperatura no ciclo 3, para Amplitude de Deformação Mecânica de 0,2\% 


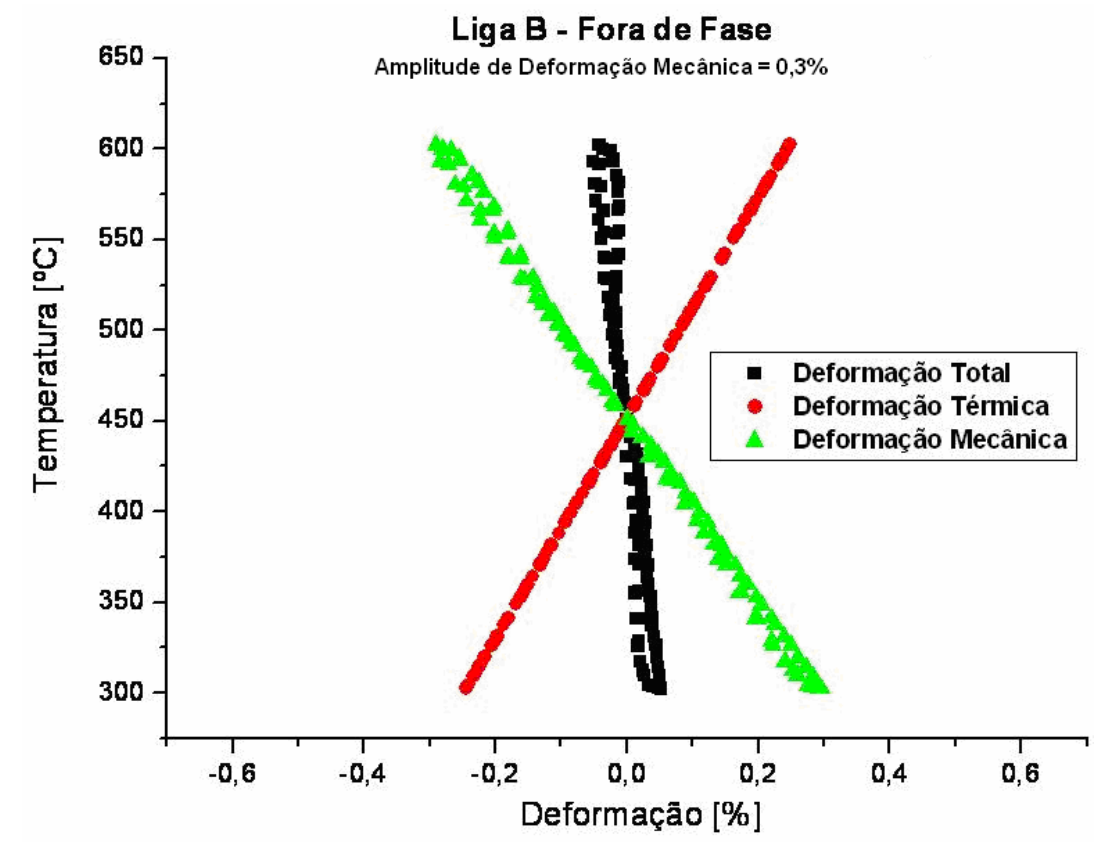

Figura AII.95 - Fadiga Termomecânica fora de fase (Liga B) - Gráfico da Deformação em função da Temperatura no ciclo 3, para Amplitude de Deformação Mecânica de 0,3\%

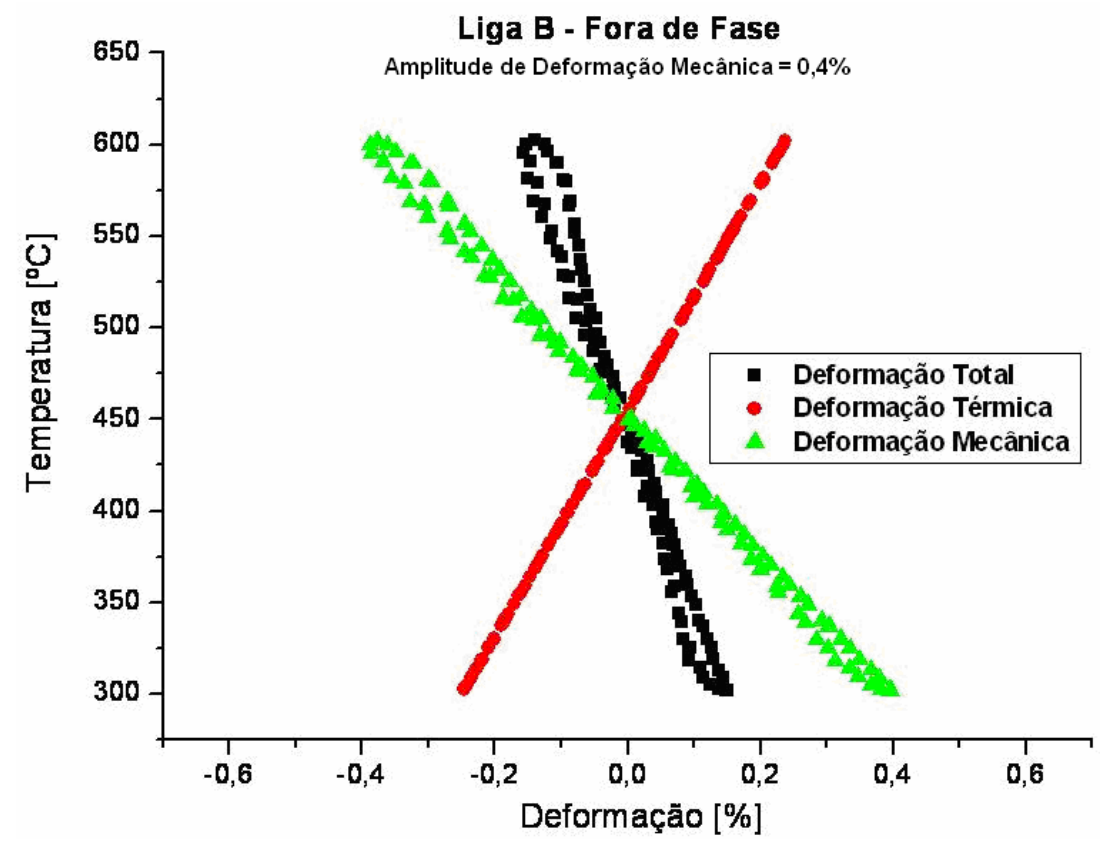

Figura AII.96 - Fadiga Termomecânica fora de fase (Liga B) - Gráfico da Deformação em função da Temperatura no ciclo 3, para Amplitude de Deformação Mecânica de 0,4\% 


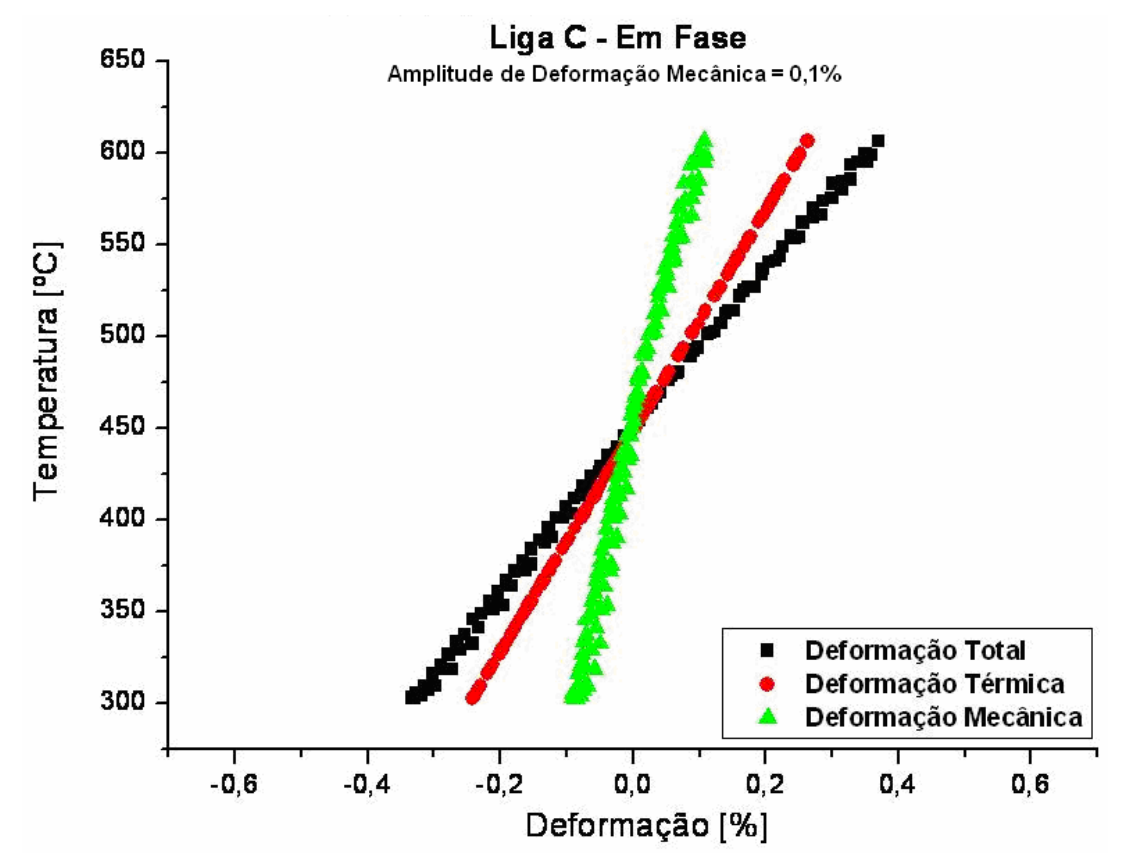

Figura AII.97 - Fadiga Termomecânica em fase (Liga C) - Gráfico da Deformação em função da Temperatura no ciclo 3, para Amplitude de Deformação Mecânica de 0,1\%

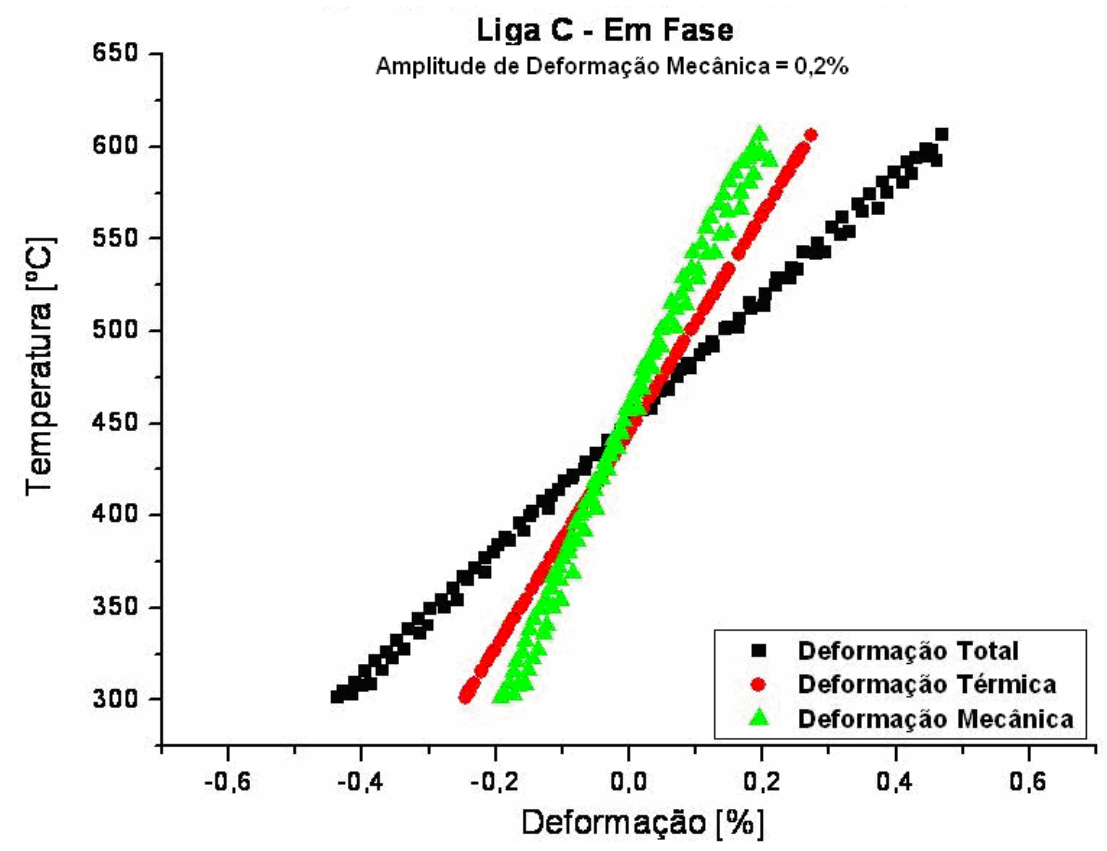

Figura AII.98 - Fadiga Termomecânica em fase (Liga C) - Gráfico da Deformação em função da Temperatura no ciclo 3, para Amplitude de Deformação Mecânica de 0,2\% 


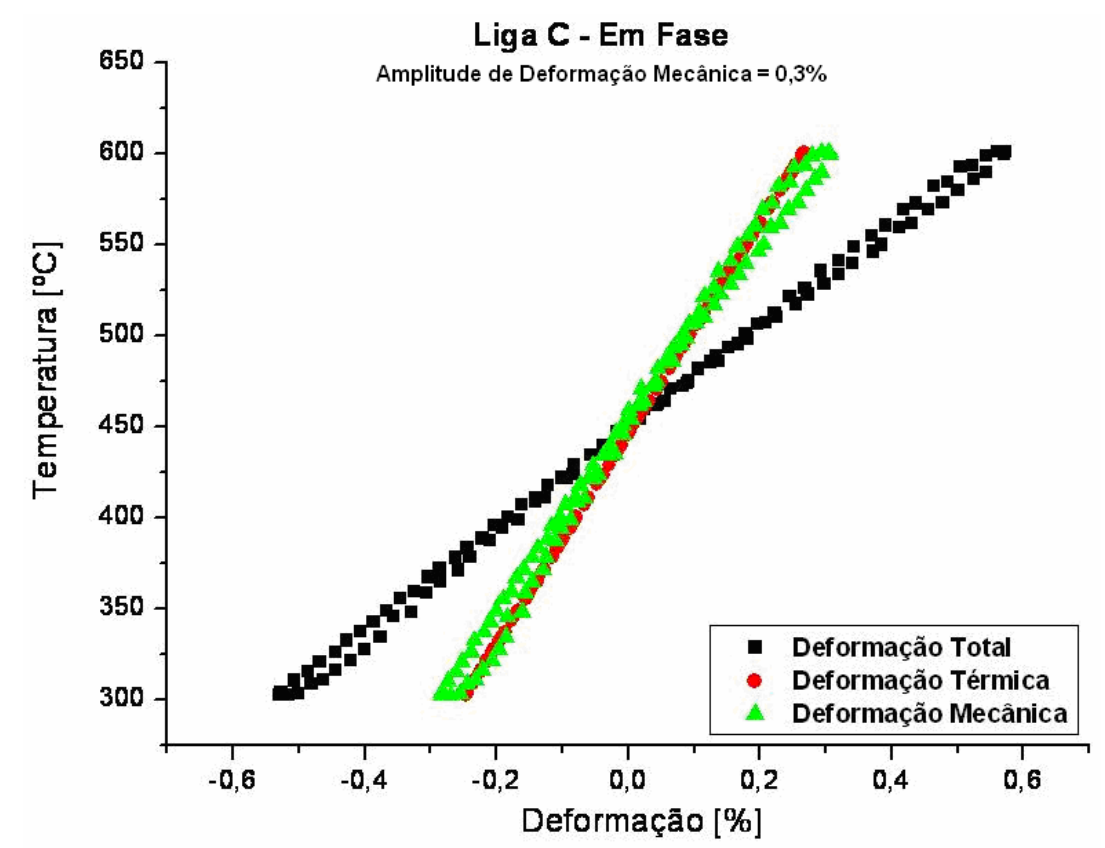

Figura AII.99 - Fadiga Termomecânica em fase (Liga C) - Gráfico da Deformação em função da Temperatura no ciclo 3, para Amplitude de Deformação Mecânica de 0,3\%

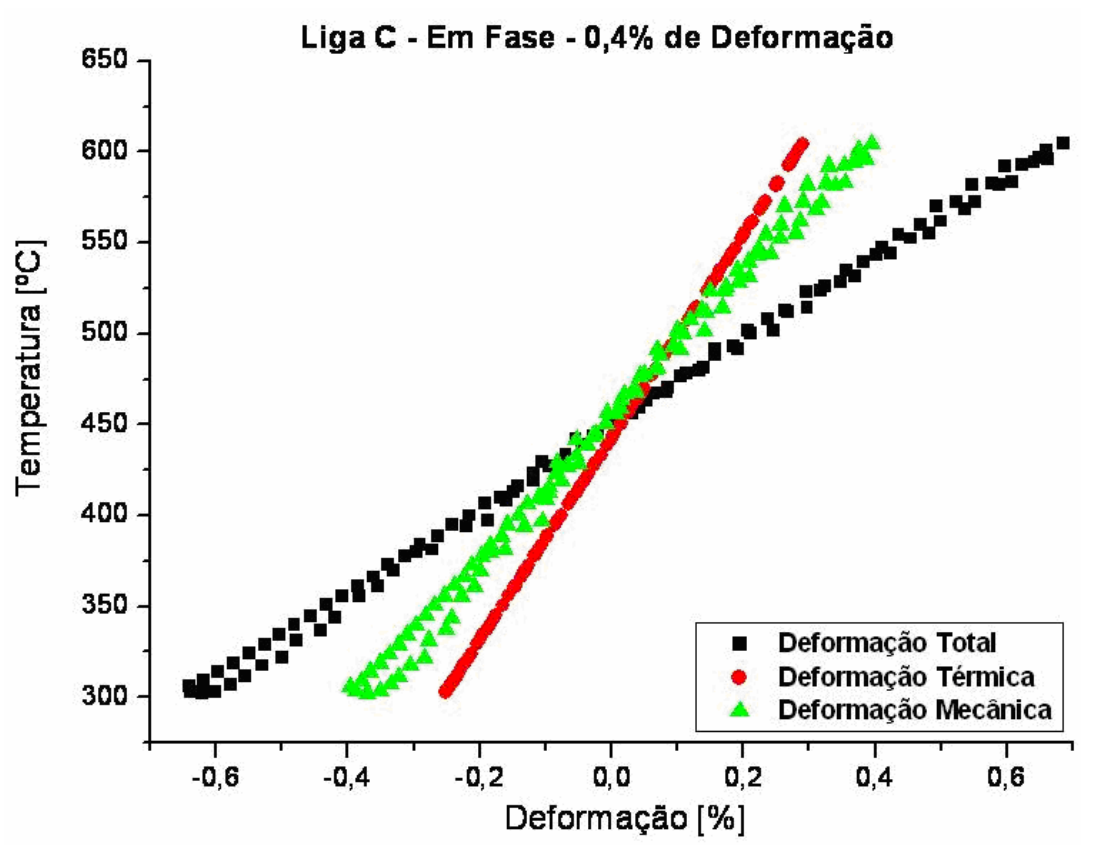

Figura AII.100 - Fadiga Termomecânica em fase (Liga C) - Gráfico da Deformação em função da Temperatura no ciclo 3, para Amplitude de Deformação Mecânica de 0,4\% 


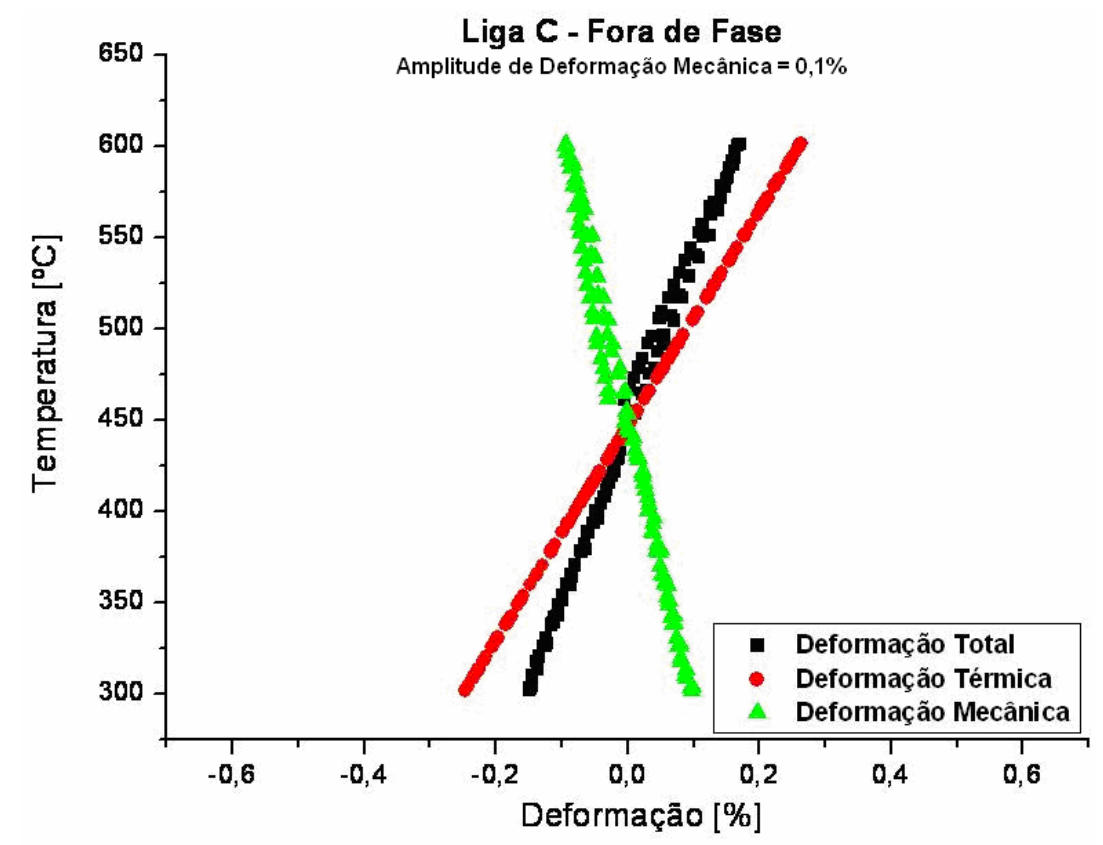

Figura AII.101 - Fadiga Termomecânica fora de fase (Liga C) - Gráfico da Deformação em função da Temperatura no ciclo 3, para Amplitude de Deformação Mecânica de 0,1\%.

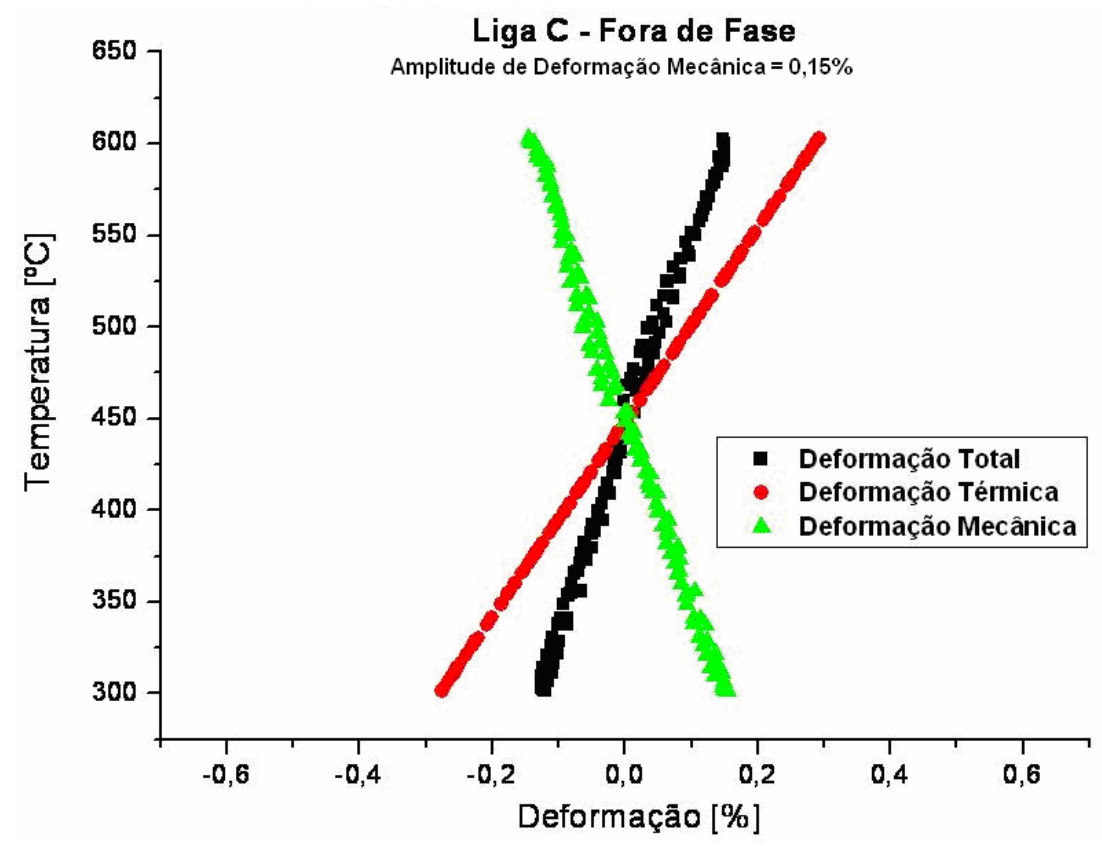

Figura AII.102 - Fadiga Termomecânica fora de fase (Liga C) - Gráfico da Deformação em função da Temperatura no ciclo 3, para Amplitude de Deformação Mecânica de 0,15\%. 


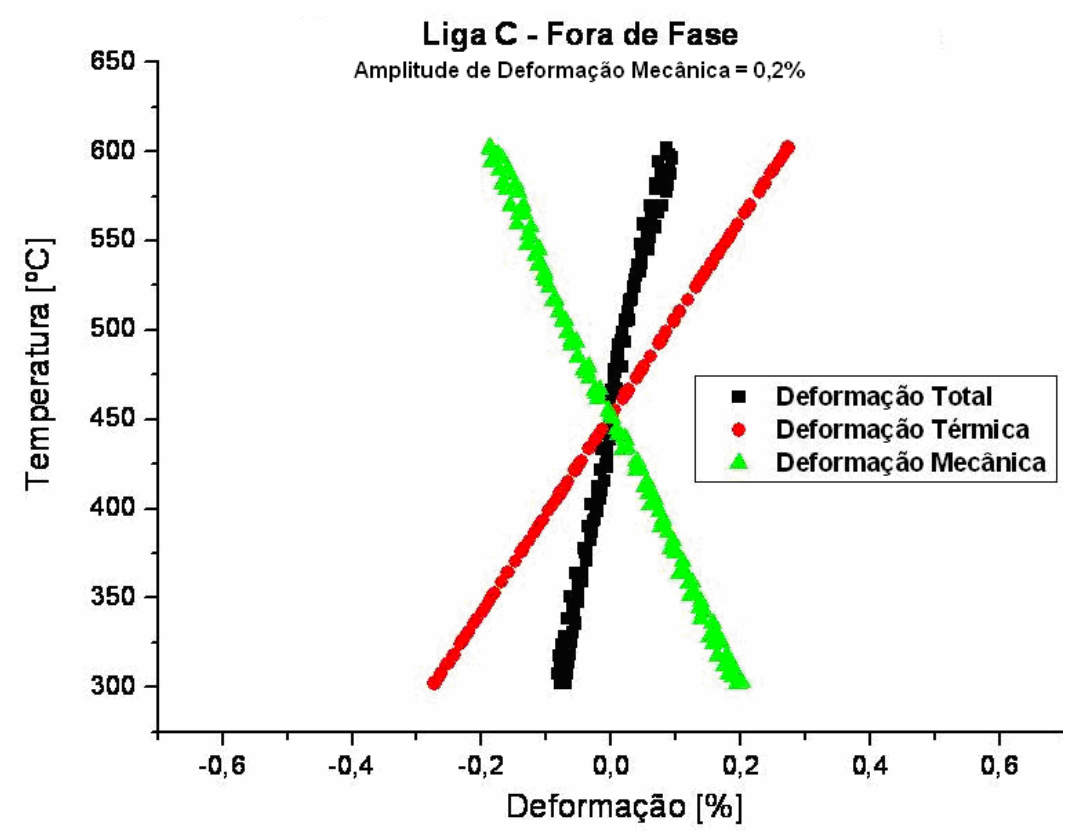

Figura AII.103 - Fadiga Termomecânica fora de fase (Liga C) - Gráfico da Deformação em função da Temperatura no ciclo 3, para Amplitude de Deformação Mecânica de 0,2\%.

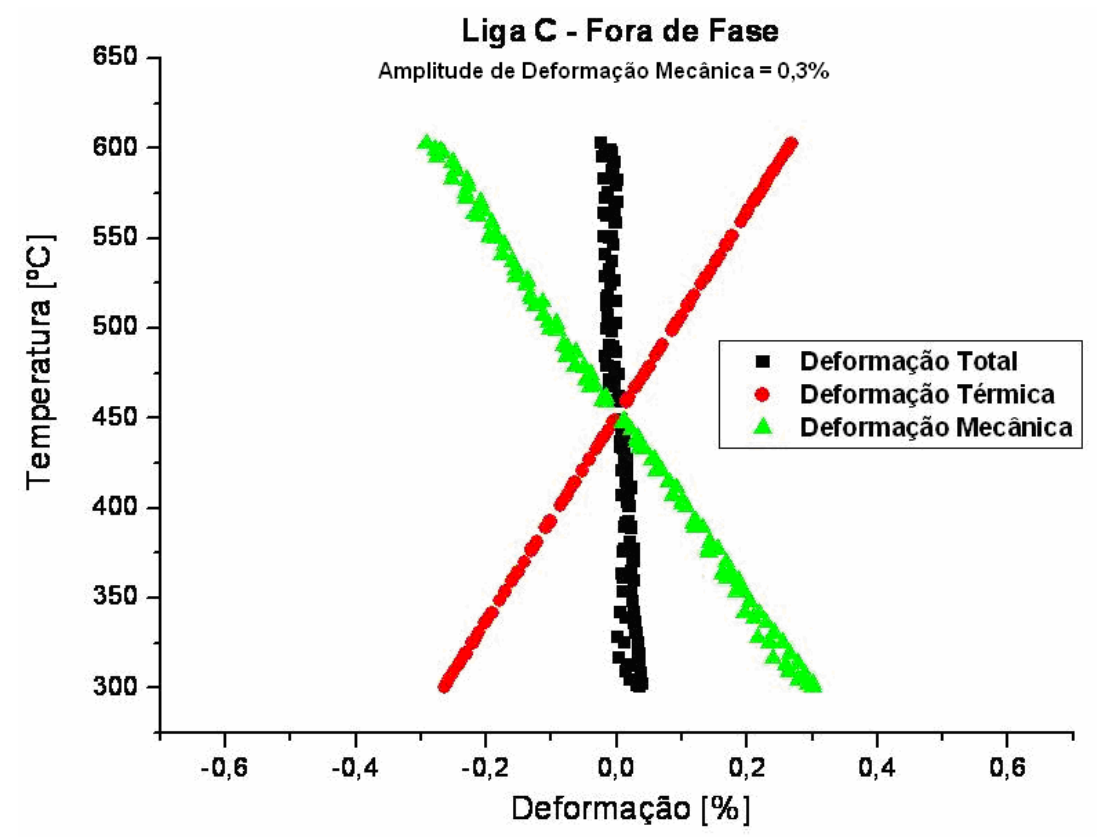

Figura AII.104 - Fadiga Termomecânica fora de fase (Liga C) - Gráfico da Deformação em função da Temperatura no ciclo 3, para Amplitude de Deformação Mecânica de 0,3\% 


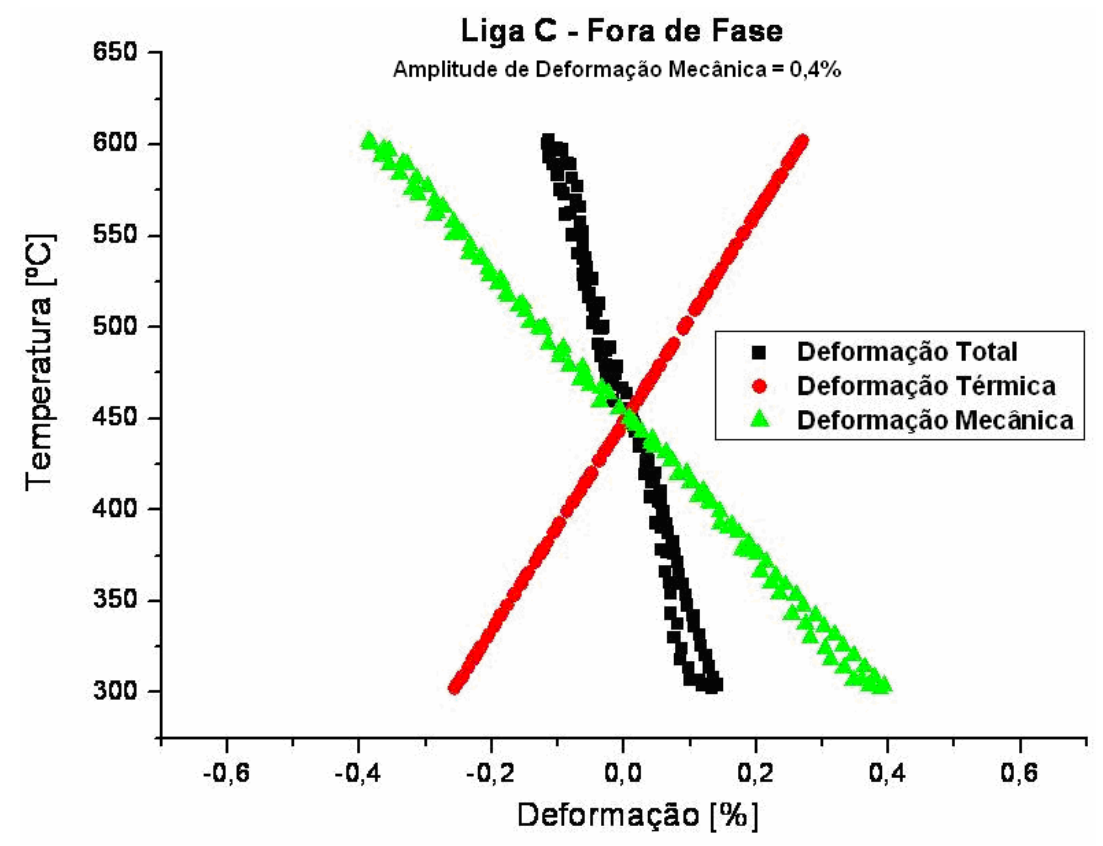

Figura AII.105 - Fadiga Termomecânica fora de fase (Liga C) - Gráfico da Deformação em função da Temperatura no ciclo 3, para Amplitude de Deformação Mecânica de 0,4\%

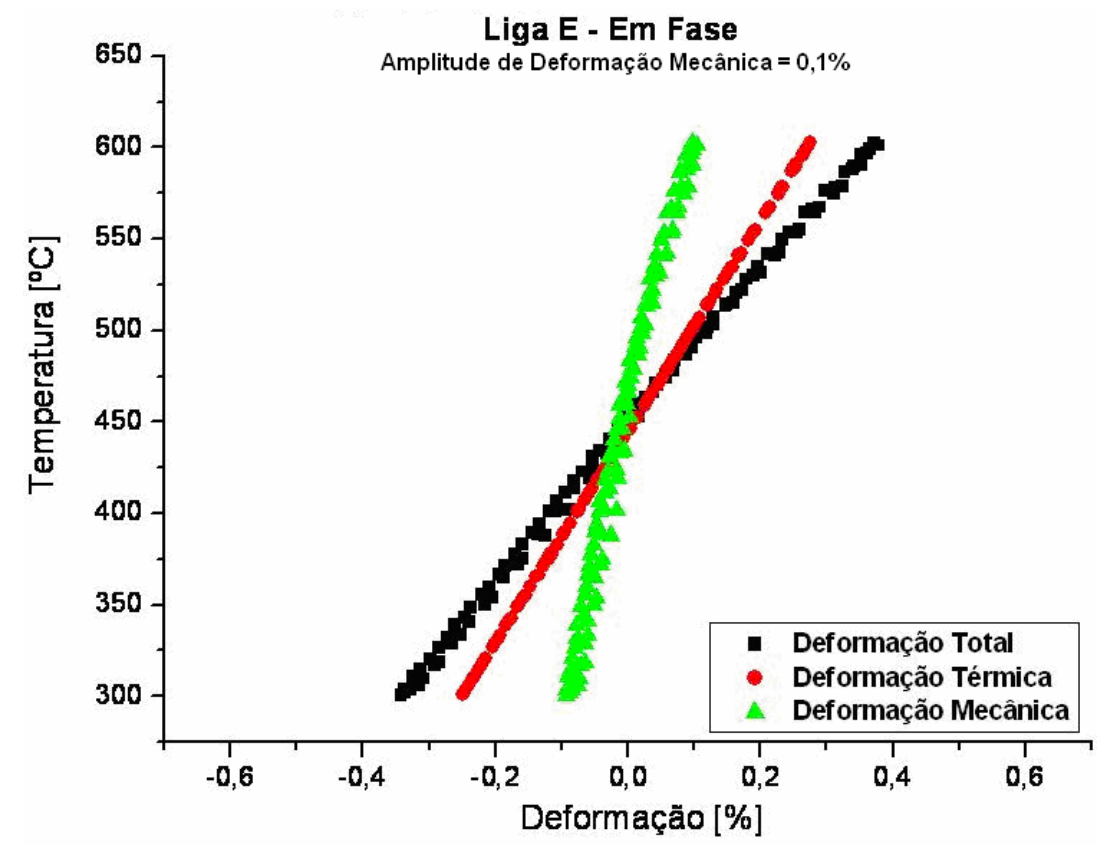

Figura AII.106 - Fadiga Termomecânica em fase (Liga E) - Gráfico da Deformação em função da Temperatura no ciclo 3, para Amplitude de Deformação Mecânica de 0,1\% 


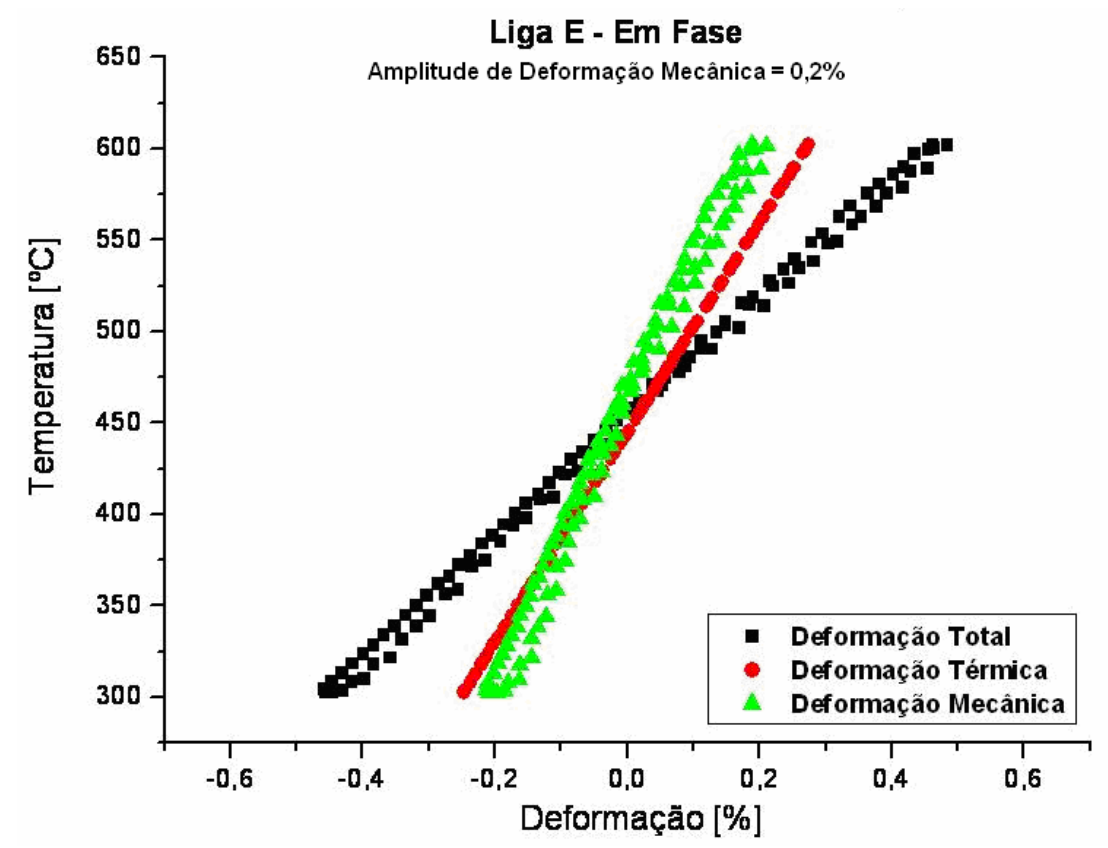

Figura AII.107 - Fadiga Termomecânica em fase (Liga E) - Gráfico da Deformação em função da Temperatura no ciclo 3, para Amplitude de Deformação Mecânica de 0,2\%

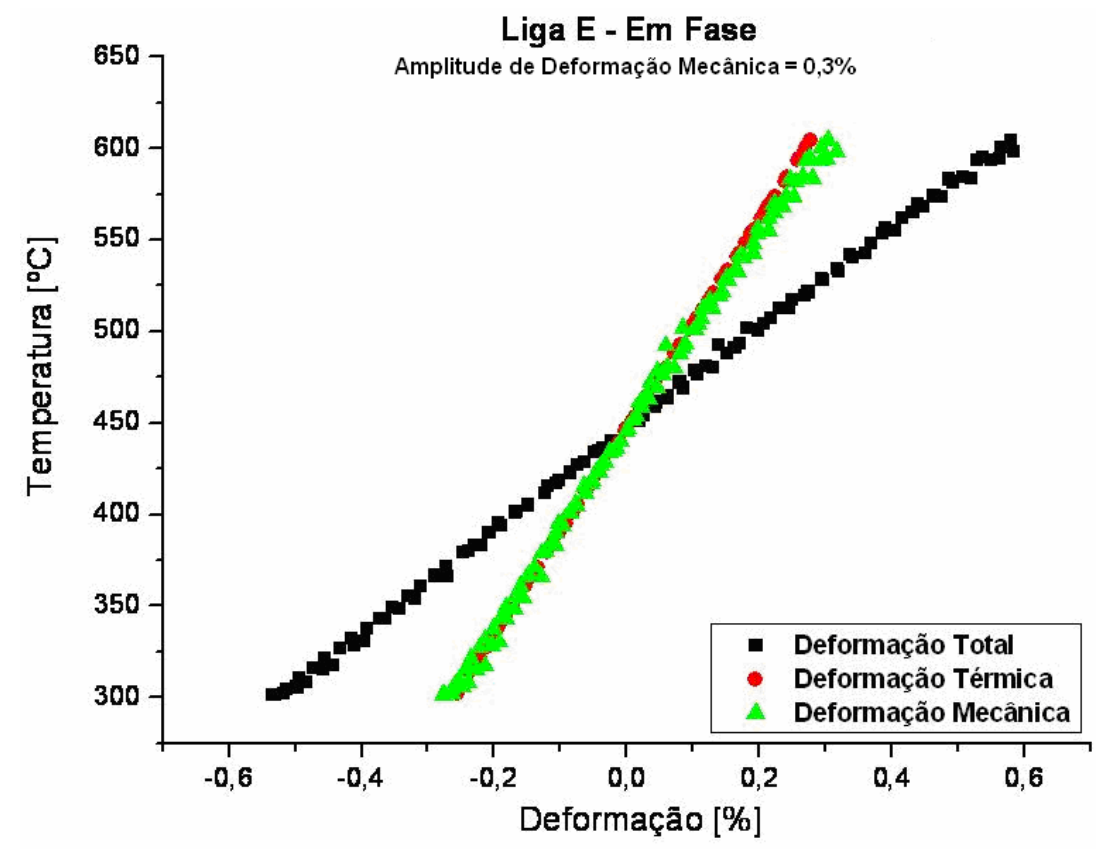

Figura AII.108 - Fadiga Termomecânica em fase (Liga E) - Gráfico da Deformação em função da Temperatura no ciclo 3, para Amplitude de Deformação Mecânica de 0,3\% 


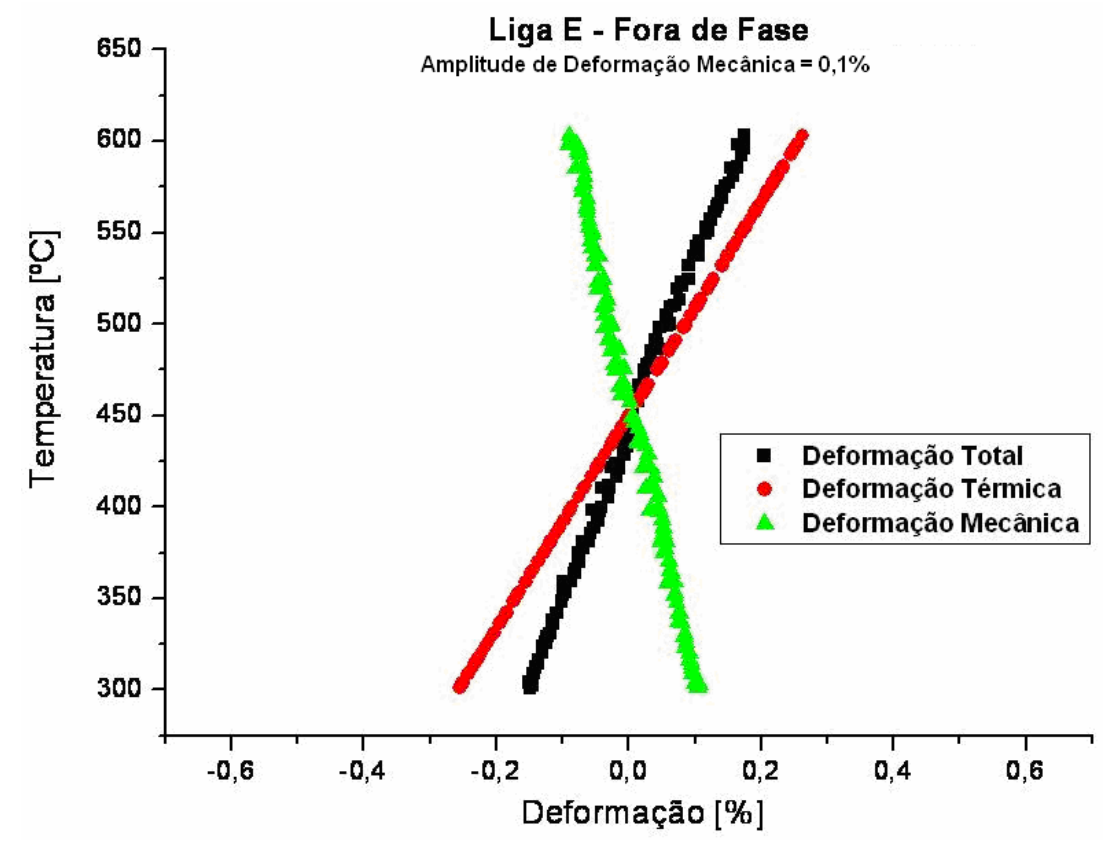

Figura AII.109 - Fadiga Termomecânica fora de fase (Liga E) - Gráfico da Deformação em função da Temperatura no ciclo 3, para Amplitude de Deformação Mecânica de 0,1\%

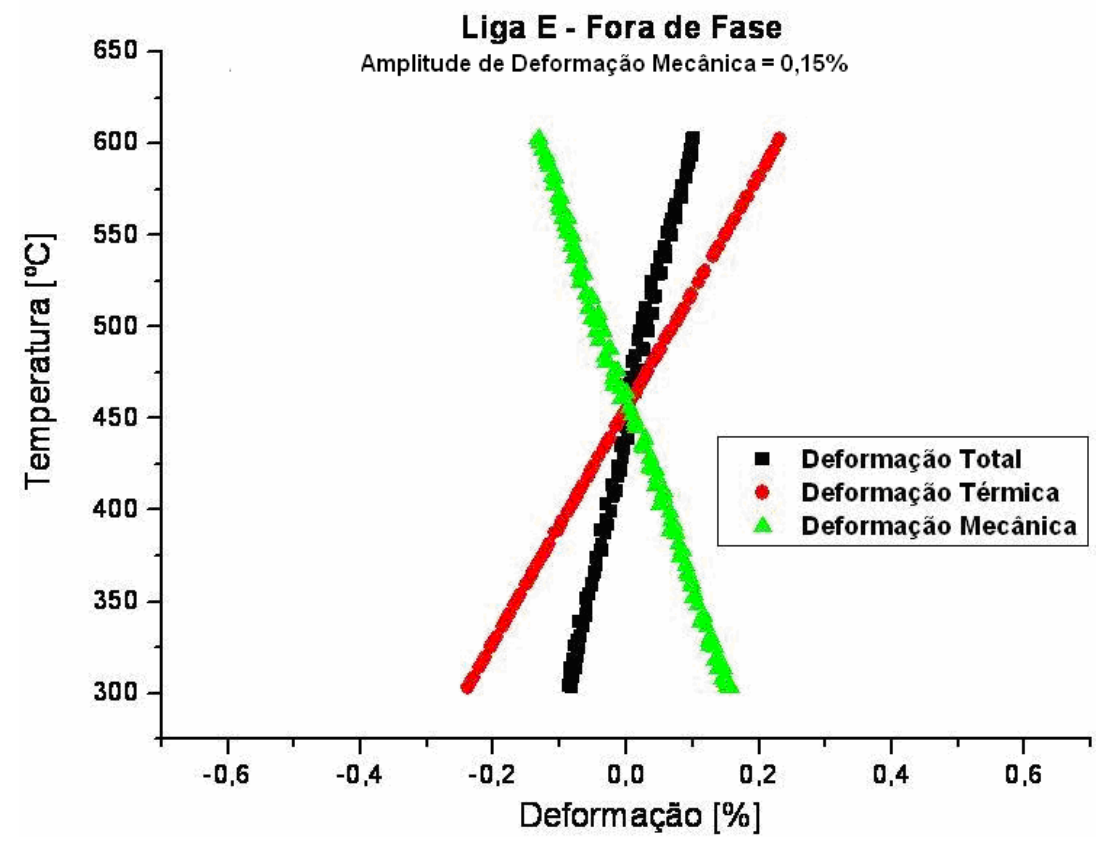

Figura AII.110 - Fadiga Termomecânica fora de fase (Liga E) - Gráfico da Deformação em função da Temperatura no ciclo 3, para Amplitude de Deformação Mecânica de 0,15\% 


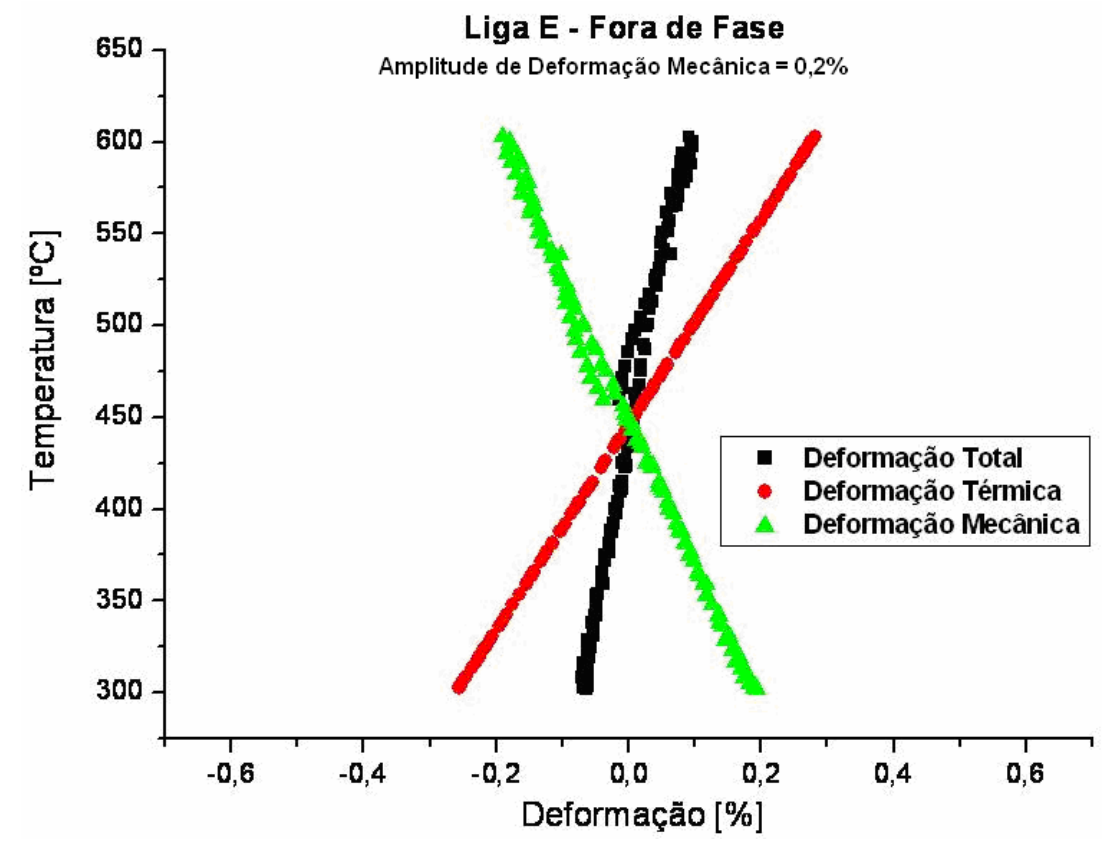

Figura AII.111 - Fadiga Termomecânica fora de fase (Liga E) - Gráfico da Deformação em função da Temperatura no ciclo 3, para Amplitude de Deformação Mecânica de 0,2\%

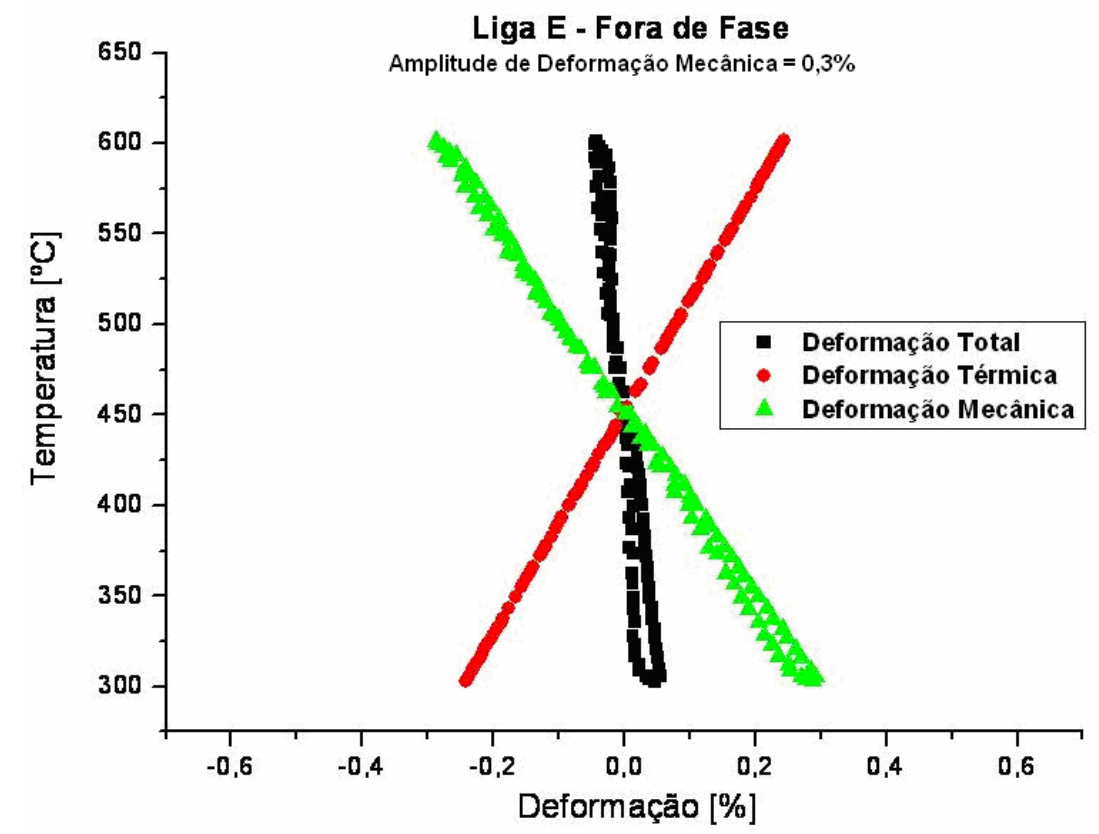

Figura AII.112 - Fadiga Termomecânica fora de fase (Liga E) - Gráfico da Deformação em função da Temperatura no ciclo 3, para Amplitude de Deformação Mecânica de 0,3\%. 


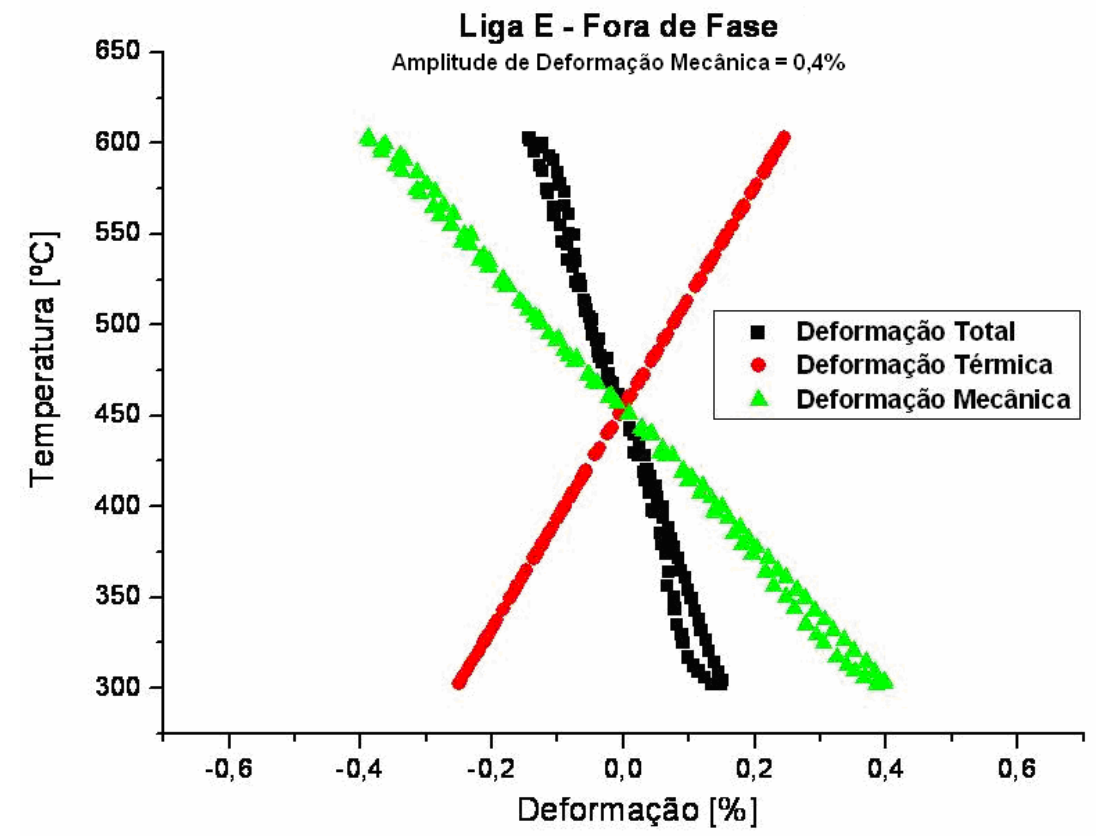

Figura AII.113 - Fadiga Termomecânica fora de fase (Liga E) - Gráfico da Deformação em função da Temperatura no ciclo 3, para Amplitude de Deformação Mecânica de $0,4 \%$. 
ANEXO III

ANÁLISE ESTATÍSTICA 


\section{Mètodo Estatístico t - student}

A análise estatística através do método $t-$ student $^{\left[{ }^{*}\right]}$ se deu sobre as medições da $\%$ de grafita na liga B para duas situações: uma no material não ensaiado e outra no ensaiado em fase para uma deformação mecânica de $0,1 \%$.

Tabela AIII.1 - Determinação do limite de confiança de 95\%.

\begin{tabular}{|c|c|c|c|c|}
\hline Situação & $\begin{array}{c}\text { Média } \\
\% \\
\text { grafita }\end{array}$ & Desvio.Padrão & Limite.Min.(95\%) & Limite Max.(95\%) \\
\hline Não ensaiado & $\mathbf{1 6 , 2 7}$ & $\mathbf{2 , 4 1}$ & 14,45 & 18,09 \\
\hline Ensaiado EF 0,1\% & $\mathbf{1 8 , 3 7}$ & $\mathbf{3 , 0 9}$ & 16,89 & 19,85 \\
\hline
\end{tabular}

Pode-se afirmar com 95\% de confiança que a média verdadeira está compreendida entre os valores máximo e mínimo calculados acima.

Tabela AIII.2 - Determinar se há diferença significativa entre os valores médios obtidos para um nível de significância de 5\%.

\begin{tabular}{|c|c|}
\hline Significância $(\mathrm{t})$ & $\mathbf{1 , 9 7}$ \\
\hline Validade $\left(\mathrm{t}_{0,95}\right)$ & $\mathbf{2 , 0 5}$ \\
\hline
\end{tabular}

Com base em um teste unilateral, no nível de significância de 0,05 (5\%), a diferença seria significativa se o valor de $t$ fosse superior a $t_{0,95}$, o qual para 28 graus de liberdade, é 2,05. Por conseguinte, conclui-se que não há diferença significativa.

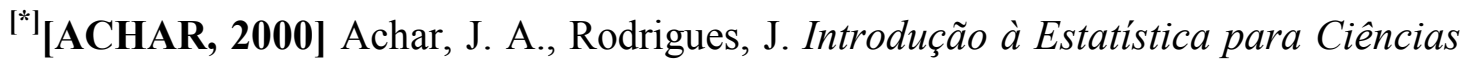
e Tecnologia, Instituto de Ciências Matemáticas e de Computação, USP, Campus de São Carlos, SP, p. 192, 2000 